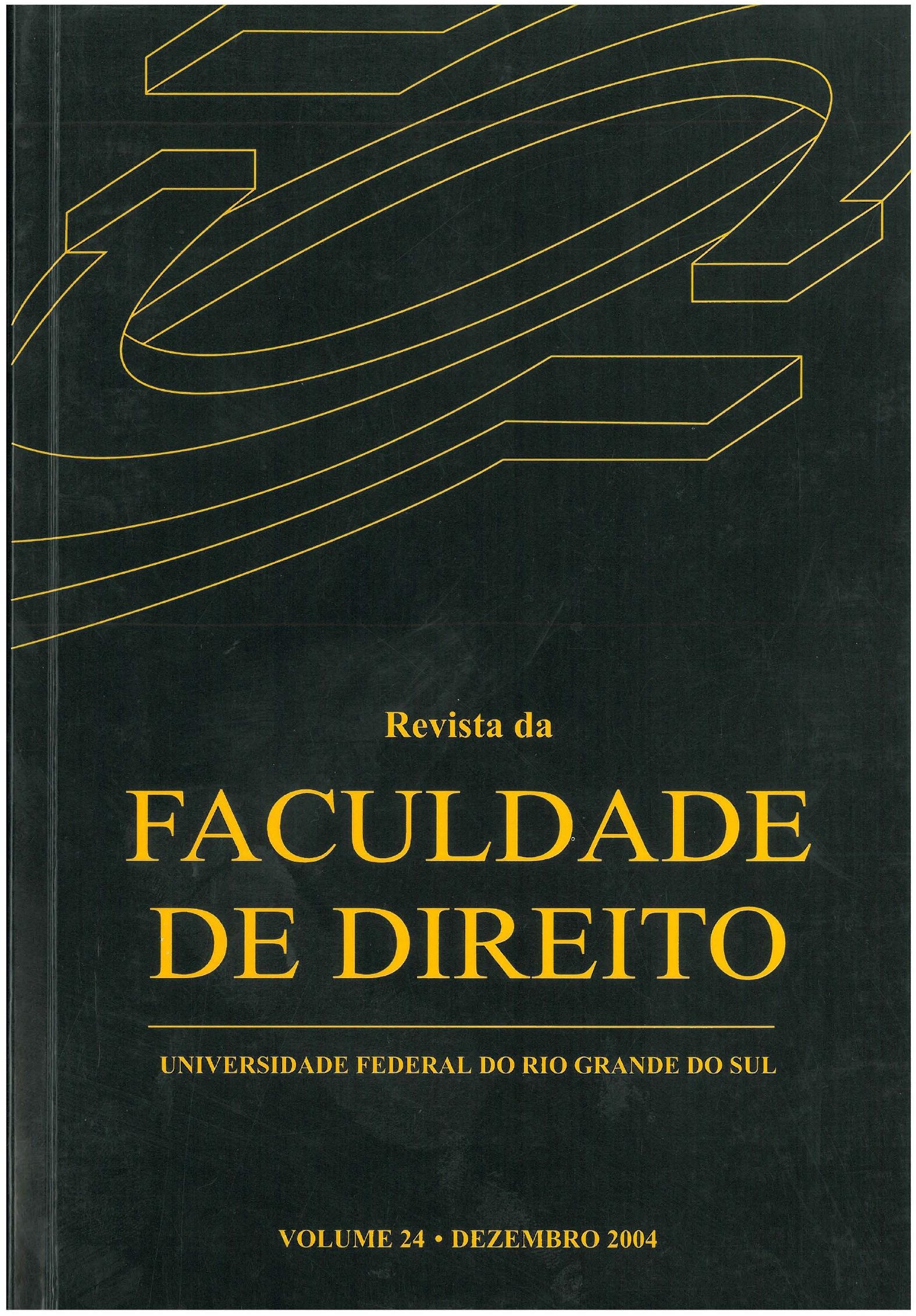


Revista da

\section{FACULDADE DE DIREITO}

UNIVERSIDADE FEDERAL DO RIO GRANDE DO SUL

Vol. 24 
UNIVERSIDADE FEDERAL DO RIO GRANDE DO SUL

Reitor: José Carlos Ferraz Hennemann - Vice-Reitor: Pedro Cezar Dutra Fonseca

FACULDADE DE DIREITO

Diretor: Plínio de Oliveira Corrêa • Vice-Diretor: Sérgio José Porto

Revista da Faculdade de Direito da Universidade Federal

do Rio Grande do Sul

Diretor: Carlos Silveira Noronha

Responsáveis técnicos:

Jornalista Blásio Hugo Hickmann - Reg. M.T.: 2.073

Bibliotecária Naila Touguinha Lomando - CRB - 10/711

\section{Conselho Editorial}

Ex-diretores:

Galeno Vellinho de Lacerda

Almiro Régis do Couto e Silva

José Sperb Sanseverino

Peter Walter Ashton

Eduardo Kroeff Machado Carrion

Professores titulares:

Carlos Alberto Álvaro de Oliveira

Carlos Silveira Noronha

Cezar Saldanha de Souza Júnior

Cláudia Lima Marques

Sérgio José Porto

Servidores técnico-administrativos:

Jornalista Blásio Hugo Hickmann

Bibliotecária Naila Touguinha Lomando
Professores doutores:

Carlos Freire Hofmeister

Carlos Klein Zanini

Cesar Viterbo Matos Santolin

Cláudio Fortunato Michelon Júnior

Glênio José Wasserstein Hekman

Humberto Bergmann Ávila

José Alcebíades de Oliveira Jr.

Juarez Freitas

Judith Hofmeister Martins-Costa

Luis Afonso Heck

Luiz Fernando Barzotto

Marco Fridolin Sommer Santos

Marta Lúcia Olivar Jimenez

Odone Sanguiné

Rui Portanova

Vera Maria Jacob de Fradera

Representação discente:

Acadêmico Sérgio Laguna Pereira

Faculdade de Direito - UFRGS

Av. João Pessoa, nº 80 - CEP 90.040*000

Porto Alegre/RS - Brasil

Tel: (51) 3316-3118/3316-3128/

3316-3555/3316-3464

e-mail: diretor@direito.ufrgs.br site: http://www.ufrgs.br 
Revista da

\section{FACULDADE DE DIREITO}

UNIVERSIDADE FEDERAL DO RIO GRANDE DO SUL

Vol. 24

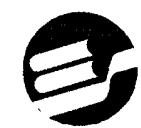




\section{Revista da Faculdade de Direito da Universidade Federal do Rio Grande do Sul \\ Diretor: Carlos Silveira Noronha}

Bibliotecária Responsável: Denise Mari de Andrade Souza - CRB 10/960

Revista da Faculdade de Direito da Universidade Federal do Rio Grande do

Sul. - V.24, dez.2004 - Porto Alegre: UFRGS, 2005 - v. - Continuação da:

Revista da Faculdade de Porto Alegre, publicada de 1949-1974.

Semestral

ISSN: 0104-6594

1.Direito: Periódicos. I. Universidade Federal do Rio Grande do Sul

CDD: 340

CDU:34(05)

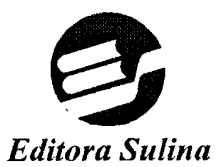

EDITORA MERIDIONAL LTDA.

Av. Osvaldo Aranha, 440 cj. 101

Cep: 90035-190 PortoAlegre-RS

Tel:(0xx51)3311-4082

Fax:(0xx51) 3264-4194

www.editorasulina.com.br

e-mail: sulina@editorasulina.com.br

Pede-se permuta $\cdot$ Se pide canje $\cdot$ We ask for exchange On demande de l'échange $\cdot$ Wir bitten um Austausch $\bullet$ Si richieri lo scambo 


\section{Sumário}

\section{Bruno Nubens Barbosa Miragem}

Do Direito Comercial ao Direito Empresarial. Formação histórica e tendências do Direito brasileiro

\section{Carlos Alberto Álvaro de Oliveira}

O problema da eficácia da sentença

\section{Carlos Menegat Filho}

Condições da ação no processo penal

\section{Carlos Silveira Noronha}

Revisitando a tutela do consumidor nos precedentes históricos

e no Direito pátrio

\section{Claudia Lima Marques}

Por um direito internacional de proteção dos consumidores:

sugestões para a nova lei de Introdução ao Código

Civil Brasileiro no que se refere à lei aplicável a

alguns contratos e acidentes de consumo

\section{Eduardo Kroeff Machado Carrion}

Direitos humanos e diversidade cultural

\section{Fabiane Segabinazi}

Uma análise da extradição no Direito brasileiro 


\section{Glênio José Wasserstein Hekman}

O contexto procedimental das ações diretas no

controle de constitucionalidade e a conversibilidade

das "jurisdições"

\section{James L. Bischoff}

A proteção internacional do patrimônio cultural

\section{José Guilherme Giacomuzzi}

A moralidade administrativa - história de um conceito

\section{José Néri da Silveira}

João Leitão de Abreu, o juiz e a política

\section{Maitê de Souza Schmitz}

Os impactos da existência de diversos mecanismos de solução de controvérsias na aplicação do Direito Internacional Ambiental

\section{Marco Fridolin Sommer Santos}

Relato de Emilio Betti sobre a visita à Universidade do

Rio Grande do Sul

\section{Patricia Azevedo da Silveira}

O dano extrapatrimonial, a crueldade contra os animais

e a dignidade da pessoa humana em face da autorização anual da caça amadorista no Rio Grande do Sul

Plínio de Oliveira Corrêa

Ney Messias e o ensino do processo penal 


\title{
Do Direito Comercial ao Direito Empresarial. Formação histórica e tendências do Direito brasileiro
}

\author{
Bruno Nubens Barbosa Miragem*
}

\section{INTRODUÇÃO}

O estudo da evolução histórica dos diferentes ramos da ciência jurídica é muitas vezes menosprezado, sob a falsa impressão de que tais conhecimentos, longe de serem indispensáveis ao exercício da atividade jurídica, constituem traços culturais adjetivos, ornamentos do conhecimento prático elementar necessário ao desempenho profissional. A origem dos institutos mais vale como capítulo a desconsiderar, seja pela aparente impossibilidade de utilização deste conhecimento, ou mesmo pelos obstáculos a desbravar no contato com estilos de linguagem e terminologias antigos. Neste contexto, impossível desconsiderar uma certa sensação de inutilidade do esforço a empreender, em face da revogação ou obsolescência de boa parte dos conteúdos examinados.

Tais considerações, válidas, por certo, para vários profissionais das carreiras jurídicas, não cabem ao verdadeiro cultor da ciência jurídica. Mais do que mero acúmulo de dados e ocorrências, penetrar sob as arcadas da história do direito significa descortinar a origem das modernidades atuais. Mais do que isso, trata-se de um ato de coragem investigar sob o manto das leis e dos códigos, a sua origem arcaica, que o tempo teve o condão de amadurecer e forjar a conformação dos institutos jurídicos na atualidade.

No caso do direito comercial, desafiar o gosto pela pesquisa histórica assume caráter ainda mais complexo. Convencer da importância de conhecimentos distantes frente ao dinamismo da economia e do tráfico comercial atual, soa aparentemente irrazoável. Inúmeras

\footnotetext{
* Professor de Direito Civil e Direito Econômico do Centro Universitário Ritter dos Reis/RS; professor convidado do Curso de Pós-Graduação em Regulação dos Serviços Públicos da UFRGS; especialista em Direito Internacional pela UFRGS; mestrando em Direito Privado pela UFRGS.
} 
razões levam a crer, entretanto, que um eventual desestímulo mais diz com o equívoco da abordagem do tema, do que com seu conteúdo. Ademais porque não se pode pretender observar o passado com a compreensão atual dos fenômenos da vida e do direito. Os que construíram aquelas verdades, o fizeram a partir das suas experiências de então. É tremenda a desigualdade do juízo que desconsidera a notória vantagem do observador moderno.

Da mesma forma, se há de reconhecer que nada existe senão a partir de uma origem. Esta, desnaturada ou não, diz com a identidade do que se conhece agora. Trilha um caminho repleto de influências de toda ordem, denunciando uma gênese elementar que se projeta no tempo. Daí a importância da evolução histórica do direito comercial brasileiro que ora se pretende indicar, para compreensão do estágio atual e suas tendências para o futuro.

\section{FORMAÇÃO HISTÓRICA DO DIREITO COMERCIAL}

Não é errado dizer que o direito comercial é tão antigo quanto o próprio comércio. Mais do que isso, é contemporâneo das primeiras relações interpessoais pacíficas da história, a partir das quais necessidades individuais determinaram a busca de sua satisfação e a consciência de que isoladamente os seres humanos não tinham como alcançá-la. A este tempo já se fazia necessário a elaboração de normas de conduta que viabilizassem um sistema rudimentar de intercâmbio de bens, a fim de satisfazer as necessidades das pessoas.

É possível identificar ao longo da história, um sem número de povos que tendiam à prática do comércio, desde os fenícios da Antigüidade, passando pelas civilizações grega e romana até chegarmos à Idade Média, quando uma Europa castigada pela miséria econômica inicia um processo de dinamização de suas relações de produção e descobre no comércio uma atividade legítima para aquisição, acumulação, conservação e multiplicação de riquezas. ${ }^{1}$ Neste ambiente pode se dizer que nasce o direito comercial originário dos modernos institutos de hoje.

\footnotetext{
' A influência cristã sobre Roma e, posteriormente sobre toda a Europa, faria o desenvolvimento do comércio enfrentar o desafio do desprezo da Igreja pela atividade mercantil - o que acaba gradativamente se desgastando, sem todavia deixar de gerar alguns problemas. Também de referir, relativamente à evolução do direito comercial na Alemanha, a importância da recepção do direito romano como estímulo à criação jurídica em geral. No dizer de Wieacker, esta recepção impusera novos princípios jurídicos nos quais se manifesta a progressiva racionalização da vida jurídica da baixa Idade Média. Traz o exemplo do artesanato, onde o princípio da subsistência fora substituído pelo desejo de lucro - o que já fazia parte da economia urbana (p. 113). Assinala todavia que, embora a recepção do direito romano tenha servido como estímulo à atividade criadora relativamente do direito em geral, as criações mais características do direito comercial não se desenvolveram a partir da romanística, inclusive nos países de sistema continental. (Wieacker, Franz. História do Direito Privado Moderno. 2. ed. Lisboa: Calouste Gulbenkian, 1980, p. 269).
} 
O direito comercial nasceu então para regular estas relações de comércio, inicialmente através das corporações, para em seguida expandir seu alcance no mesmo grau de alcance do desenvolvimento econômico, vindo a transformar-se em direito dos negócios, independente de maiores formalidades. ${ }^{2}$

A história do direito comercial neste sentido, inicia com o predomínio da idéia de direito dos comerciantes - construindo-se um conceito eminentemente subjetivo - para em seguida assistir-se a evolução desta impressão inicial.

Evoluindo os estudos através do tempo, a sistemática exclusivamente subjetiva é influenciada pela tendência objetivista, que procura dar primazia ao exame dos atos de comércio como núcleo do exame da disciplina comercial. Cesare Vivante, eminente comercialista italiano, vai afirmar que tal mudança conceitual partirá de uma ficção, ao considerar comerciante qualquer um que pratique atos de comércio, ou seja, atos que denotem o exercício da atividade mercantil. ${ }^{3}$

Atualmente, observa-se a retomada do antigo conceito subjetivo, vinculando-o ao conceito adjetivo e estabelecendo o direito comercial moderno como o que regula as relações jurídico-privadas no exercício das suas atividades típicas. ${ }^{4}$

As origens dos institutos do direito comercial se prendem, todavia, a diversas matrizes. Quanto à disciplina dos títulos de crédito, sua origem é identificada nas necessidades práticas dadas pelo tráfico monetário das cidades lombardas. Em relação às obrigações comerciais, o comércio entre as longínquas regiões de Flandres, Champanha, Alemanha central e outras feiras européias. ${ }^{5}$

2 A evolução terminológica culmina então, na indicação, já na segunda metade do século vinte, do direito empresarial, conceito que assume todavia um significado notadamente mais amplo, que trataremos adiante, referindo não apenas a prática comercial propriamente dita, mas a generalidade das matérias jurídicas que dizem com a atividade empresarial. No Brasil, veja-se: Requião, Rubens. Curso de Direito Comercial. 22. ed. $1^{\circ}$ v. São Paulo: Saraiva, 1995, p. 7.

\section{Vivante, Cesare. Tratato de Derecho Mercantil, v. 1. Madrid, 1932. p. 6.}

4 Carvalho de Mendonça, à época em que escreveu seu Tratado, já noticiava a opinião de Manara, sobre período anterior mesmo à colonização, para quem os elementos objetivo e subjetivo "não se concebiam um absolutamente distinto do outro: consideravam-se sempre reunidos, mas o elemento subjetivo não era muitas vezes mais do que um pressuposto ideal. A fusão dos dois elementos, em começo completa em todos os atos do comércio, em muitos se torna mais teórica e ideal do que efetiva. De fato era o elemento objetivo que imprimia a muitos atos o caráter comercial, desde que, em última análise, sobre a qualidade do ato se fixava a fição de ser o comerciante o autor." (Manara, Gli atti di commercio, $\mathrm{n}^{\circ}$ 8. apud: Carvalho de Mendonça, J. X. Tratado de Direito Comercial Brasileiro. v. I, Livro I. 3. ed. Rio de Janeiro: Freitas Bastos, 1937, p. 60).

5 Wieacker, op. cit., p. 269. 
O renascimento das cidades italianas após a desagregação do império de Carlos Magno e a independência de diversas repúblicas contribuiu, igualmente, de forma ímpar com a prosperidade comercial daquela região. Nota-se então, a propagação do comércio ao longo das margens do Mar Mediterrâneo, tornandose cidades como Amalfi, Veneza, Gênova, Pisa e Florença importantes empórios comerciais, que aproveitavam as cruzadas cristãs para estender esse comércio aos povos do Oriente. Destas cidades italianas surge a pioneira regulamentação comercial européia, de que é exemplo a tabla amalfitana, em Amalfi, o Constitutum usus e o Breve curiae maris, de Pisa, que vieram a colecionar os costumes mercantis da cidade reunidos no Breve consulum maris. Em Veneza, principal entreposto do comércio marítimo, surge o capitulare nauticum. E em Gênova, o mais importante tribunal de comércio italiano, a Rota
Genoveza, que formou o primeiro corpo de decisões (jurisprudência) da época. ${ }^{6}$

Nestas cidades, assim como por toda Europa, elemento fundamental da atividade comercial naquele tempo eram as denominadas corporações de oficio, associações de profissionais cuja filiação era pressuposto do exercício da atividade comercial. A admissão como membro destas corporações, de sua vez era dificultada por exigências diversas. Em primeiro lugar, o candidato a integrá-las deveria ser aprendiz do ofício, por período fixado no regulamento respectivo. Deste ascendia à condição de companheiro e daí a artifice propriamente dito. Esta passagem, todavia, não se dava sem desafios. ${ }^{7}$ Estas corporações espalharam-se por toda a Europa, sendo conhecidas na Alemanha, Inglaterra, França, Escandinávia e Países Baixos também como hansas. ${ }^{8} \mathrm{Na}$ França,

6 Conforme Ferreira, Waldemar Martins. Curso de Direito Comercial, v. I. São Paulo: Sales, Oliveira, Rocha \& Cia., 1927, p. 19 e ss.

7 Noticia Ferreira que no séc. XIV o companheiro deveria fazer a volta em todo o território francês - de cidade em cidade - para aperfeiçoar-se no seu ofício. Depois, deveria executar sua obra-prima (chef-d'oeuvre), que após submetida à apreciação dos jurados, the era dada a permissão para montar seu próprio estabelecimento. Op. cit., p. 27.

$8 \mathrm{~A}$ origem das hansas data de fins do séc. XII e início do séc. XIII. Formadas inicialmente por algumas cidades ao longo do Báltico e alemãs mais tarde se alastrariam pela França, Espanha e Inglaterra. Eram confederações de comerciantes cujo objetivo era a promoção do comércio, livrando-se dos óbices do sistema feudal. Seu apogeu se deu no séc. XV, quando dominaram o Báltico e o Mar do Norte, obtendo o privilégio de comerciar com diversos Estados da Europa, chegando mesmo a incentivarem uma guerra contra o Rei da Dinamarca pela conquista de novos mercados, celebrando na assembléia de Colônia (Alemanha), o ato de confederação de 77 cidades, estabelecendo-se as contribuições de cada uma. A liga hanseática sobreviveu, então, até o séc. XVII, reduzindo-se no final às mesmas cidades que the deram origem, vindo a perder seu prestígio. Delamare et Lê Poitvin. Traité de droit commercial, v. I, p. 28. apud: Carvalho de Mendonça, op. cit., p. 62. 
foram então suprimidas em 1776, em nome da liberdade de iniciativa. ${ }^{9}$

$\mathrm{O}$ direito das sociedades tem seu princípio nas companhias comerciais do séc. XVI, espécies assemelhadas às sociedades por ações, no período que antecede à formação do capitalismo na Europa ocidental. Desde o princípio, entretanto, nota-se a característica peculiar do direito comercial, da não submissão a fronteiras políticas nacionais, uma vezque, embora identificadas diferenças entre as diversas ordens jurídicas internas, tinham sua atividade vinculada a conexões comerciais inter-regionais. ${ }^{10}$

A tendência moderna do direito comercial indica uma retomada desta característica marcadamente internacional, bem como o reforço à crescente publicização dos seus conteúdos, como conseqüência da sua relação com a atividade econômica em geral e seu revestimento de interesse público, a ser defendido pelo Estado." Nota-se, todavia, que esta defesa estatal, longe dos moldes com os quais atuou no passado, inspira-se em novo paradigma, ${ }^{12}$ originário

9 Op. cit., p. 27.

10 Wieacker, op. cit., p. 269.

11 Conforme Franco, Vera Lúcia de Mello. Lições de Direito Comercial - Teoria geral do direito comercial. São Paulo: Maltese, 1993. p. 52-3. A respeito da intervenção estatal, contudo, a tendência de publicização, embora diga com a importância do Estado relativamente à normatização das relações que dizem com o direito comercial, tem como contraponto o fenômeno da internacionalização das relações econômicas fruto do processo que se convencionou chamar globalização. Daí que, se de um lado a intervenção estatal na ordem econômica surge como atividade de regulação econômica, de outro o dinamismo destas relações torna impossível uma antecipação de situações a regulamentar ou mesmo a pretensão de qualquer espécie de normatização com os prazos de validade do passado. 12 No nosso entender, o princípio da subsidiariedade vem prestar enorme contribuição na fixação dos limites entre os espaços público e privado na sociedade contemporânea. A respeito, a recente encíclica papal Centesimus annus, editada pelo Papa João Paulo II em 1991, que relendo a anterior encíclica Rerum novarum (1891), consigna: "La Rerum novarum se opone a la estatalización de los medios de producción, que reduciría a todo ciudadano a una 'pieza' en el engranaje de la máquina estatal. Con no menor decisión critica una concepción del Estado que deja la esfera de la economía totalmente fuera del propio campo de interés y de acción. Existe ciertamente una legítima esfera de autonomia de la actividad económica, donde no debe intervenir el Estado. A éste, sin embargo, le corresponde determinar el marco jurídico dentro del cual se desarrollan las relaciones económicas y salvaguardar asi las condiciones fundamentales de una economía libre, que presupone una cierta igualdad entre las partes, no sea que una de ellas supere talmente en poder a la otra que la pueda reducir prácticamente a esclavitud (...) Para conseguir estos fines el Estado debe participar directa o indirectamente. Indirectamente y según el principio de subsidiariedad, creando las condiciones favorables al libre ejercicio de la actividad económica, encauzada hacia una oferta abundante de oportunidades de trabajo y de fuentes de riqueza. Directamente y según el principio de solidariedad, poniendo, en defensa de los más débiles, algunos límites a la autonomía de las partes que deciden las condiciones de trabajo, y asegurando en todo caso un mínimo vital al trabajador en paro." 
das incompatibilidades entre a tendência de internacionalização e as velhas pretensões do dirigismo econômico, e mesmo deficiências do sistema político-

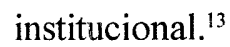

\section{ANTECEDENTES HISTÓRICOS DO DIREITO COMERCIAL BRASILEIRO}

No Brasil, o incremento da atividade comercial esteve vinculado de modo estreito com sua situação política, em especial, nos primórdios, às relações estabelecidas com Portugal. Durante a fase colonial da história brasileira, a dimensão do direito comercial estará vinculada, enfaticamente, à tradição jurídica portuguesa $^{14}$ e suas alterações ao longo dos anos. Quaisquer informações sobre o direito comercial neste período passam, obrigatoriamente, pelas ordenações portuguesas, parte da estrutura jurídica lusitana desde o século XV.

Primeiro as ordenações portuguesas editadas pelo rei Afonso V, por volta de 1447 (afonsinas), que tinha como sua principal matriz histórico-jurídica o direito romano do Corpus júris civilis justinianeu, e os decretais do Papa
Gregório XI. Contavam ainda com a subsidiariedade do direito canônico, que assumia sua preeminência nas matérias que envolviam o cometimento de pecado, conforme determinava o alvará de 12 de setembro de $1564 .{ }^{15}$

Em 1513, então, foram substituídas as antigas ordenações por uma nova iniciativa codificadora, as ordenações manuelinas, editadas pelo rei $\mathrm{D}$. Manuel. Estas, entretanto, em pouco modificaram as disposições da antiga legislação, mantendo-se sob a mesma inspiração romanística.

Em 1569, sob os ventos da contrareforma católica e a influência do Concílio de Trento, o rei Dom Sebastião editou nova compilação que reforçava princípios do direito canônico em desprestígio às ordinárias fontes romanas. Todavia, com a morte de $\mathrm{D}$. Manuel e o fim da dinastia de Avis, ascende ao trono o rei Felipe II. Este, desejoso do retorno da inspiração do direito romano sobre Portugal, edita em 1603 suas ordenações, as ordenações filipinas, que reconfirmadas pela Lei de 12 de agosto de $1643,{ }^{16}$ vigeriam no Brasil até após a independência política de 1822. Nestas ordenações, referia-se

13 Sobre a experiência político-jurídica brasileira, o clássico de Paim, Antônio. A querela do estatismo. Brasília: Senado Federal, 1998.

14 Como de resto o direito positivo em geral, do que Trigo de Loureiro vai notar como necessidade interpretativa das leis brasileiras a consideração da herança lusitana e sua influência. Loureiro, Trigo de. Instituições de direito civil brasileiro, 4. ed., v. 1 parágrafo XLVI. apud Carvalho de Mendonça, J. X. Tratado... Op. cit., p. 50.

15 Conforme Merêa, M. Resumo das lições de história do direito português, p. 115 e ss. apud Rao, Vicente. O direito e a vida dos direitos, v. 1. 4. ed. São Paulo: RT, 1997. p. 105. 16 Após a reconquista da independência de Portugal em relação à Espanha, com o fim da União Ibérica (1640). 
a matéria propriamente comercial nos livros terceiro e quarto, tratando-se, respectivamente, de direito processual e material, civil e comercial. ${ }^{17}$

O direito positivo vigente no período colonial permaneceu praticamente sem alterações após a codificação filipina. Todavia, a atividade de interpretação e integração das normas sofreu substanciais alterações ao longo do tempo, muito por conta da lei de 18 de agosto de 1769 , designada Lei da Boa Razão. Teve este diploma o condão de autorizar a invocação subsidiária de normas de direito estrangeiro das nações "de boa, depurada e sã iurisprudência". Esta lei, que de resto operou importante evolução do direito em geral, em relação à disciplina comercial tem marcada importância, uma vez que torna possível a influência direta do Código de Comércio Francês de 1807 e, mais tarde, das codificações espanhola (1829) e portuguesa (1833), lançando os sedimentos à construção do direito comercial pátrio. ${ }^{18}$

Sobre a codificação portuguesa de 1833 , aliás, de se notar a enorme contribuição de Ferreira Borges - conforme assinala Almeida Costa, para quem o ilustre comercialista contribui de modo definitivo no direito luso para a superação da concepção de direito comercial como direito de profissionais, em prol de uma concepção objetiva, favorecida a partir do advento da Revolução Francesa. ${ }^{19}$
Entretanto, em que pese a confessada inspiração da codificação portuguesa no direito comparado, especialmente nos códigos francês e espanhol, e no projeto do código italiano, notou-se uma certa complexidade nas definições e qualificações que estabeleceu, fruto do que se reconhece como um apego exagerado ao direito anterior. ${ }^{20}$

De outra parte, o Código português de 1833, do mesmo modo, foi vítima daquele que é o grande paradoxo do direito comercial, qual seja, o fato do direito vocacionado ao desenvolvimento da atividade mercantil, em regra tornarse obsoleto ou lacunoso por conta, exatamente, do progresso da atividade regulamentada, o que ele mesmo promove. Algumas décadas depois já abundavam em Portugal leis extravagantes, como a de sociedades anônimas (1867) ou de marcas e patentes (1883). Isto determinou a necessidade de elaborar-se novo Código, o que coube a Veiga Beirão, que veio a ser promulgado em 1888 .

\section{A INDEPENDÊNCIA E A ELABORAÇÃO DO CÓDIGO COMERCIAL}

O acontecimento histórico de maior repercussão na vida brasileira da primeira década do séc. XIX, pode se dizer,

17 Martins, Fran. Curso de Direito Comercial. 23. ed. Rio de Janeiro: Forense, 1999. p. 37. 18 Conforme Requião, op. cit., p. 15.

19 Almeida Costa, Mário Júlio de. História do direito português. 3. ed. Coimbra: Almedina, 2001, p. 422.

20 Idem, p. 423. 
influenciou decisivamente no desenvolvimento da economia e do comércio brasileiro e, em conseqüência, o direito comercial. A vinda das cortes portuguesas para o Brasil em 1808 - em fuga das tropas napoleônicas na Europa continental-significou benefícios de toda ordem. Politicamente, o Brasil foi elevado a Reino Unido de Portugal e Algarves, deixando sua condição legal de colônia. Sob a perspectiva econômica, significou, entre outros, a liberação do comércio marítimo através da Carta Régia de 28 de janeiro de 1808 (abertura dos portos às nações amigas), o fomento à atividade fabril e manufatureira, pelo Alvará de $1^{\circ}$ de abril, e a liberação do comércio e da indústria, do que decorre a criação da Real Junta de Comércio, Agricultura, Fábricas e Navegação, pelo
Alvará de 23 de agosto daquele ano. Também oportunizou a criação da primeira instituição bancária nacional (o Banco do Brasil), pelo Alvará de 12 de outubro, com o intuito de "promover a indústria nacional pelo giro e combinação dos capitais isolados". ${ }^{21}$

Sobrevindo a independência política em 1822, o novo império, através da lei de 20 de outubro de 1823 , determinou mantivessem as leis portuguesas vigentes em 25 de abril de 1821 e os atos subseqüentes de D. Pedro como Regente e, após Imperador do Brasil. Observa-se neste primeiro momento, a vigência de diplomas dos séculos XVII e XVIII relativamente à atividade comercial. ${ }^{22} \mathrm{Na}$ mesma época, o mais destacado dos comercialistas brasileiros, Silva Lisboa, ou Visconde do Cairu ${ }^{23}$

21 Finalidade expressano próprio alvará de criação, conforme Carvalho de Mendonça, op. cit., p. 76-77. 22 Como nota Carvalho de Mendonça, a recepção desta gama de normas comerciais tão díspares entre si, e separadas por longo tempo umas das outras, e todas daquele princípio do estado nacional brasileiro, acabou por fazer do direito comercial de então "envolto numa legislação pesada, sem orientação doutrinária ou pelo menos, sem lógica." Op. cit., p. 78-9. 23 Sobre o extraordinário papel deste estudioso do direito mercantil, veja-se, entre outros: Carvalho de Mendonça, op. cit., 82. Beviláqua, Clóvis. "Evolução jurídica do Brasil no segundo reinado." In. Revista Forense, $n^{\circ} 46$. p. 9. Mendes, Cândido. Prefácio à obra Princípios de direito mercantil, v. 1.p. X a XVIII. Ainda sobre Cairu, dentre os autores modernos, vejase a excelente introdução de Antônio Penalves Rocha em: Visconde do Cairu. Coleção Formadores do Brasil. São Paulo: Editora 34, 2001. O autor, com muita propriedade, além do papel acadêmico de Cairu, dá relevo à sua dimensão política, a partir de sua obra econômica, em que utilizou "parte do seu vocabulário e aparato conceitual para legitimar as mudanças em curso no Império português depois da abertura dos portos" (p. 36). Ao mesmo tempo, assinala a importância que o livre comércio assume para Cairu como instrumento de promoção da conciliação de classes (p. 40). De interesse também, notar a posição manifestada por Cairu em 1851, sobre a natureza degradante do ser humano e ao mesmo tempo antieconômica do trabalho escravo em artigo da revista "Guanabara", reproduzido na obra supracitada (p. 323-333). Outro grande jurista sempre citado foi Ferreira Borges a quem homenageia Carvalho de Mendonça, distinguindo os dois tratadistas pela enorme contribuição de desvincular o direito comercial do rígido sistema de direito romanístico, apresentando a doutrina italiana clássica, bem como nas contribuições do direito inglês e francês. Op. cit., p. 83 e ss. 
como posteriormente seria distinguido - recebeu a tarefa de elaborar a codificação comercial brasileira.

Em 1832, saindo o país dos tumultos da abdicação de Pedro I no ano anterior, as iniciativas para redação da codificação comercial se ampliaram, sendo designada comissão de comerciantes ${ }^{24}$ para realização da tarefa. Compreendeu o projeto a divisão da matéria em três partes, sendo a primeira relativa às pessoas do comércio (contratos e obrigações), a segunda sobre comércio marítimo e a terceira sobre as quedas. As fontes imediatas da elaboração do projeto observam-se na sua exposição de motịos, a qual indica sua inspiração, quanto à primeira parte, nas codificações francesa, espanhola e portuguesa, relacionando os motivos para o sensível afastamento em relação à legislação estrangeira nas demais partes. ${ }^{25}$

O projeto foi então enviado à Câmara dos Deputados em agosto de 1834. Após tramitação de quase 16 anos, ${ }^{26}$ em 25 de junho de 1850 foi promulgado, pela lei $\mathrm{n}^{\circ} 556$, o Código Comercial Brasileiro.

\subsection{Sistema do Código Comercial}

O projeto aprovado em 1850 se compunha de três partes e um título único. A primeira, intitulava-se Do comércio em geral; a segunda, Do comércio marítimo; a terceira, Das quebras. O título único, que não tardou em ser modificado tratava Da administração da justiça dos negócios e causas comerciais, subdividindo-se em dois capítulos: Dos tribunais e juizos comerciais; e Da ordem do juizo nas causas comerciais. ${ }^{27}$

Publicado o Código, cogitou-se imediatamente da elaboração da lei adjetiva que lhe viabilizasse a boa execução. Antes mesmo da promulgação do Código, uma comissão foi designada para elaborar tal legislação, que veio então a ser o regulamento publicado pelo decreto $\mathrm{n}^{\circ} 737$, de 25 de novembro de 1850 . $\mathrm{Na}$ mesma data, promulgou-se o decreto $\mathrm{n}^{\circ} 738$ regulamentando a atividade dos tribunais de comércio e o processo de quebras. ${ }^{28}$

24 Os membros da comissão eram: Antônio Paulino Limpo de Abreu ( $1^{\circ}$ presidente), José Antônio Lisboa, Inácio Ratton, Guilherme Midosi e Lourenço Westin. Posteriormente, José Clemente Pereira ( $2^{\circ}$ presidente). Conforme Requião, op. cit., 15.

25 Carvalho de Mendonça. op. cit., 92. Também: Ferreira, Waldemar. op. cit., p. 33 e ss.

26 Neste ínterim, todavia, diversas discussões se sucederam, como bem demonstra $o$ relatório do Ministro da Justiça, Aureliano Coutinho, em 1834, quando este solicita especial atenção dos deputados com as questões relativas à falência, tendo em vista os abusos e fraudes que se podiam detectar já à época, conforme afirma Carvalho de Mendonça, op. cit., p. 94, nota 1. Observa-se pois, que a questão do abuso e da fraude na prática falimentar conta com precedentes históricos bem marcados na tradição comercial brasileira.

27 Ferreira, p. 35.

28 Carvalho de Mendonça, op. cit., 100. 
$O$ regulamento $n^{\circ} 737$, longe de se restringir à lei de conteúdo meramente processual, introduziu preceitos que completaram a codificação, sendo considerado por Waldemar Ferreira, como "uma das melhores, senão a mais perfeita das leis brasileiras". ${ }^{29}$ A boa técnica do referido diploma pôde ser observada com o advento da República e sua adoção como referencial para as regras processuais e de organização da justiça. ${ }^{30}$

Em relação ao Código Comercial, há um certo consenso em admitir na obra de 1850 um monumento legislativo, que soube aproveitar-se das contribuições jurídicas de tradição estrangeira sem descaracterizar seu caráter nacional, atendendo aos traços da realidade local.

Pelo menos um defeito, entretanto, identifica Carvalho de Mendonça. Defeito este, aliás, corroborado pelo posterior regulamento $\mathrm{n}^{\circ} 737$. Nota o tratadista que, à justificativa de se afastar a jurisdição civil, então sujeita a um longo e demorado processo, foram designados como atos comerciais muitos atos nos quais não intervinham comerciantes - mesmo defeito já observado na codificação francesa. ${ }^{31}$ Estas críticas devem, todavia, ser relativizadas aos olhos de hoje. Primeiro, pelo caráter pioneiro do código comercial em relação às demais iniciativas codificadoras, o que de certo modo tornava possível uma certa flexibilidade. Em segundo lugar, pelo paradigma subjetivista adotado pela crítica, que a torna representativa de uma tendência importante na época, mas que hoje está longe de ser aceita integralmente.

A precedência da legislação comercial em relação à civil, entretanto, foi observada pelo próprio comercialista, como razão destas imprecisões teóricas. ${ }^{32}$ Assim, havia o anseio pela regulação de determinados fatos da vida, o que veio a ser correspondido pela inserção de certos institutos no âmbito da codificação comercial. ${ }^{33}$

\subsection{As leis comerciais até 1890}

A atividade legislativa de direito comercial, embora consagrada pela promulgação do Código em 1850, na verdade foi efetivamente inaugurada através de intensa produção de normas dirigidas à regulamentação das ativida-

\section{Ferreira, p. 36.}

30 Carvalho de Mendonça, p. 101.

31 Op. cit., p. 105.

32 Segundo Carvalho de Mendonça, "era natural que, no meio da esparsa, difusa e deficiente legislação civil, ele (direito comercial) exercesse extraordinário predomínio. Com efeito, passou a reger quase todas as relações da vida civil, quanto a obrigações e contratos." Op. cit., p. 109.

33 O exemplo utilizado pelo autor é o da hipoteca, inclusive criando o Código a controversa figura da hipoteca tácita. 
des do comércio. Além dos já mencionados decretos $n^{\circ} 737$ e 738 , nos quarenta anos que sucederam à promulgação do Código, diversos diplomas versaram, principalmente, sobre a regulamentação da atividade dos corretores, agentes de leilão, os tribunais de comércio, as exigências em relação às concordatas, entre outros temas.

Como é tradição do direito comercial, as normas positivas muitas vezes tiveram de regular necessidades da vida econômica, como por exemplo, as primeiras normas sobre bancos e sociedades (lei 1.083, de 22.08.1860 e diversos decretos), transferência de títulos públicos e de ações de companhias (Dec. 2.733, de 23.01.1861), e sobre o cheque (Dec. $n^{\circ}$ 2.694, de 17.11.1860)..$^{34}$ Observa-se, do mesmo modo, um acentuado número de leis tendo por condão a reforma das disposições do Código Comercial, dentre as quais avulta a retirada das disposições sobre hipoteca, sempre criticadas pela falta de pertinência à disciplina comercial. ${ }^{35}$

Também de grande repercussão a revogação dos dispositivos do Código Comercial que faziam necessário o juízo arbitral - anteriormente estabelecido como facultativo. As razões que levaram a este posicionamento, no mais das vezes, disseram com a falta de pouca valia a possibilidade de recurso judicial - para o qual necessariamente haveria de se comprovar defeito no procedimento capitaneado pelo árbitro. ${ }^{36}$

Digna de registro, ainda, a lei $\mathrm{n}^{\circ}$ 3.129 , de 14 de outubro de 1866 , que estabelecia o regime jurídico das invenções e descobertas, iniciativa pioneira de proteção da propriedade industrial no direito brasileiro.

Em relação ao direito societário, o ápice legislativo do período deve-se à lei $\mathrm{n}^{\circ} 3.150$, de 4 de novembro de 1881 . Esta lei, que foi submetida a intensa discussão parlamentar precedente à sua aprovação, ${ }^{37}$ e regulamentada pelo

$34 \mathrm{~A}$ indicação é de Carvalho de Mendonça, que comentando estas normas considera-as um desestímulo à livre iniciativa, à medida que o Estado instituía para si, série de prerrogativas especiais. Encontra-se nos dizeres de Tavares Bastos, a exata definição deste conjunto de normas, quando este diz que, com elas, o Estado praticamente estabeleceu que: "o comércio sou eu." (op. cit., p. 108-9).

35 Certamente a previsão no Código Comercial da matéria hipotecária foi uma das principais razões para sua crítica. A iniciativa de sua retirada deve-se ao Senador Nabuco de Araújo, através da lei $n^{\circ} 1.237$, de 24.09.1864, cujo texto foi adotado, na íntegra nos primeiros atos sobre hipoteca do governo republicano provisório.

36 Também em relação à lei $n^{\circ} 1.350$, de 14.09.1866, a iniciativa pertence a Nabuco de Araújo, que fará posteriormente, como membro do Ministério, sua regulamentação. Restabelecer, então, a faculdade da arbitragem, conforme previsto na Constituição de 1824 (art. 160). Conforme Nabuco, Joaquim. Um Estadista no Império, v. 1. 5. ed. Rio de Janeiro: Topbooks, 1997. p. 644. 37 Carvalho de Mendonça, p. 110-1. 
Decreto 8.821, de 30 de dezembro do mesmo ano, revogou as disposições do Código Comercial que faziam necessária a autorização estatal para a constituição e funcionamento das companhias de comércio. ${ }^{38}$ Neste sentido, instituiu-se a partir desta lei o sistema de livre criação das sociedades anônimas, espécie mais moderna de sua formação. ${ }^{39}$

\section{O DECRETO No 917 E A LEGISLAÇÃO COMERCIAL EXTRAVAGANTE}

Apesar das alterações do texto do Código Comercial, e da série de leis extravagantes que se seguiram à promulgação do diploma de 1850 , o passar do tempo reclamava uma reforma mais profunda do direito comercial brasileiro, em razão dos desafios da realidade econômica brasileira da segunda metade do século XIX.
Os decretos de 1860, como mencionamos, diziam respeito a providências em relação à emissão de títulos pelos bancos, casos de falências de instituições financeiras, sua criação e organização, assim como a regulação do mercado de títulos públicos (qualquer título que admitisse cotação).

Em 1864, por obra do senador Nabuco de Araújo, retirou-se do Código Comercial a matéria hipotecária, que passou a ser exclusivamente civil, ainda que alguns ou todos os credores fossem comerciantes.

Já em 1866, Nabuco de Araújo apresentava seu projeto de lei para o estabelecimento de um novo processo de falências, cuja justificativa é importante documento para conferir-se o estado de ânimo geral em relação às normas de 1850 neste particular. Escreve o então ministro da Justiça, que "há quatorze anos o nosso comércio

38 Observa-se nesta lei a influência das disposições inglesas a respeito, sobretudo nos pontos principais, preferindo a contribuição insular da doutrina francesa (posteriormente a lei francesa de 23 de maio de 1863). Assim, opta por não fixar um valor mínimo do capital social e das ações. Todavia, opta o projeto por permitir que as sociedades tivessem por objeto os seguros e operações bancárias, no que vai contrariar a lei inglesa de 1858. Outras disposições determinavam que as ações destas sociedades seriam nominativas até o pagamento integral de dois quintos do seu valor, depois do que poderiam ser negociadas. E, para a constituição definitiva da sociedade, estabelecia a necessidade de subscrição de todo o capital, estando um quinto deste efetivamente depositado. Ressalte-se, entretanto, que este projeto sofreu intensa oposição - principalmente no Conselho de Estado - o que determinou sua alteração substancial. Conforme Nabuco, Joaquim, op. cit., p. 647.

39 Tavares Borba resume os diferentes sistemas de formação da sociedade anônima nos sistemas de privilégio, vigente do direito medieval ao século XVIII. Depois, o sistema de autorização governamental (revogado no Brasil pela lei de 1866). Por último, o sistema de livre criação, no qual a formação da sociedade se submete a meras providências burocráticas junto ao Registro de Comércio (Tavares Borba, J. Edwaldo. Direito societário. $5^{\text {a }}$ ed. Rio de Janeiro: Renovar, 1999. p. 104). 
acolheu esperançoso a legislação de 1850. O tempo, porém, veio demonstrar que não era senão ilusória a proteção que o Código prometia aos credores. Com efeito, o nosso processo das falencias, lento, complicado, dispendioso, importa sempre a ruína do falido e o sacrificio do credor." ${ }^{\prime 40}$

Neste espírito, a reforma do Código tornou-se uma questão de tempo. À mesma época, observe-se, acontecimentos da vida econômica acabaram por gerar a sensação de urgência da reforma da legislação comercial. ${ }^{41}$

Em 1875, após diversas modificações, os tribunais do comércio são extintos. Lei $2.262 / 75$, unificando o processo judicial civil e comercial. Em 1882 a criação de sociedades anônimas deixou de depender de autorização do Estado. Já a lei $\mathrm{n}^{\circ} 2.821$, de 1881 , e após, o decreto 10.165 , de 1889 , eliminaram a possibilidade da falência das S.As., preferindo-lhes a figura da liquidação forçada. ${ }^{42}$ Ainda em 1888 , a lei $\mathrm{n}^{\circ} 3.065$ admitiu figura da chamada concordata por abandono.

Em 24 de outubro de 1890, publicase o decreto $n^{\circ} 917$, cujo texto fora da lavra dos comercialistas Carlos de Carvalho e Macedo Soares, e que acabou por ser recebido, num primeiro momento, como importante instrumento de flexibilização do instituto da falência. Cria-se, então, o instituto da concordata preventiva, que teria por condão oferecer a oportunidade de recuperação da sociedade em dificuldades, ao invés da sua mera extinção. Sinale-se, todavia, que as disposições do referido diploma não se aplicariam às sociedades anônimas, que permaneceriam reguladas quanto à matéria, pela lei 3.150 , de 1882 , sob o instituto da liquidação forçada.

Não tardou, contudo, para que a experiência da vida mercantil acabasse por suscitar uma série de críticas ao novo regime falimentar. Sobretudo, relacionadas ao abuso com que se passou a lançar mão das moratórias sob a égide da recuperação do negócio. Apesar das críticas, a reforma introduzida pelo decreto $n^{\circ} 917$ acabou por se consolidar, em razão da evolução inegável que representou para a disciplina falimentar, mais relevante do que as eventuais imperfeições poderiam desqualificar o novo instituto. Foi completada em diversos de seus aspectos pelo decreto $n^{\circ} 2.024$, editado em $1908{ }^{43}$

40 Nabuco, Joaquim. Um estadista... op. cit., p. 645 e ss.

41 Dentre as quais se aponta a falência da Casa Mauá e a sucessão de crises no sistema bancário e industrial na segunda metade do séc. XIX.

42 Carvalho de Mendonça considerará que esta terminologia é uma espécie de simulação. Op. cit., p. 116.

43 Este decreto, aliás, da lavra de Carvalho de Mendonça. Segundo Requião, Curso..., op. cit., p. 16. 
De 1908 também, é o decreto $\mathrm{n}^{\circ} 2.044$ que, dispondo sobre títulos de crédito, estabelece as normas sobre as letras de câmbio e notas promissórias, ajustando o direito cambiário brasileiro, segundo afirma Requião, às mais modernas conquistas da ciência. ${ }^{44}$

Deve-se citar também, como da maior importância para o direito comercial brasileiro, a ação da jurisprudência na última década do século XIX, sobretudo nos litígios advindos da crise econômica causada pela política do encilhamento, levada a cabo pelo governo federal. Teve a virtude, sobretudo, de completar questões não atacadas pela legislação, acabando por influenciar e inspirar futuras reformas legislativas.

\section{TENTATIVAS DE REFORMA DO CÓdIGO COMERCIAL}

À evidência - pelo que já se narrou sobre a evolução do direito comercial brasileiro, e que constitui característica do direito comercial universal - a relação de tensão entre o caráter de permanência da regulamentação legislativa, e a natureza dinâmica do mundo dos negócios se observa com maior intensidade no direito comercial do que em qualquer outra esfera do direito.

A própria idéia de codificação do direito comercial, neste sentido, tem um conteúdo muito mais flexível do que a concepção observada pela tradição civilista do sistema romano-canônico. De certo modo, como será visto a seguir, as modernas teorias codificadoras do século $\mathrm{XX}$ incorporam muitos aspectos já consagrados pela experiência jurídica do direito comercial, sobretudo no que diz com o afastamento da idéia de regulação total, dentre as funções reconhecidas a um Código. A atual evolução das teorias codificadoras, e mesmo da idéia de decodificação, conecta-se com pressupostos há muito observados pelos comercialistas, sobretudo no que diz com a agilidade da vida de relações diante da morosidade dos processos legislativos. A própria origem do direito comercial é representativa da inversão do fenômeno legislativo típico, tendo sido as primeiras normas comerciais instituídas pelos próprios sujeitos da relação regulamentada, que somente $a$ posteriori mereceu a atenção do Estado.

E mesmo esta incorporação diz mais com realidades extrínsecas ao próprio direito do que propriamente com a condição para sua eficácia. Afinal, antes de direito estatal, o direito comercial foi o direito dos comerciantes, e a atividade destes diz não só com a criação do direito, mas também, e principalmente, com sua aplicação às relações jurídicoprivadas correspondentes, como garantia de estabilidade dos negócios.

Sabe-se, entretanto, que a consolidação do Estado nacional a partir da

44 Idem. 
Idade Moderna, teve como uma de suas principais características o monopólio da jurisdição sob a guarda do Estado, derivando daí a necessária submissão da atividade comercial aos comandos legislativos estatais.

No Brasil, editado o Código Comercial de 1850, logo em seguida surgiram os reclames pela sua atualização e adequação "às novas realidades da atividade mercantil". Estas novas realidades, antes de um fenômeno eventual, eram em verdade uma constante histórica, originadas no avanço tecnológico contínuo observado a partir de fins do século XVIII e ainda hoje sem qualquer perspectiva de interrupção. Max Weber, em sua obra maior, identificou com precisão que para nenhum fenômeno econômico fundamental é imprescindível, do ponto de vista teórico, a garantia estatal do direito. ${ }^{45}$

No direito comercial, tais avanços . no campo do desenvolvimento econômico demonstrarão a falta de agilidade do Estado na regulação das relações deles advindas, seja por questões subjetivas como os conflitos de conteúdo moral que ensejavam, ${ }^{46}$ seja diante da incapacidade originária de prever seus desdobramentos futuros ou da ínsita morosidade do procedimento de produção legislativa.

A reforma do Código pela legislação da segunda metade do século XIX, que culminou com o decreto ${ }^{\circ} 917$, de 1890 , longe de adequar a codificação comercial à modernidade das relações econômicas, acabou assinalando a inadequação das normas remanescentes do texto original, determinando a própria superação das disposições resultantes da iniciativa reformadora.

Daí que, madura a idéia da necessidade de um novo Código Comercial, é editada a lei 2.378 , de 04 de janeiro de 1911, autorizando o governo a mandar organizar os anteprojetos de reforma das codificações penal e comercial. Em relação a esta última, tarefa coube ao professor Inglez de Souza. ${ }^{47} \mathrm{Um}$ dos grandes comercialistas da época, dedicou-se à tarefa durante todo o ano de 1911, acabando por apresentar seu trabalho em abril do ano seguinte..$^{48}$ Nesta oportunidade,

45 Weber, Max. Economia y sociedad. 2. ed. $11^{\mathrm{a}}$ reimp. México: Fondo de Cultura Económica, 1997.p. 271.

46 Sobre o enfrentamento da questão moral, obrigatórias as reflexões de Weber, Max. $A$ ética protestante do capitalismo. São Paulo: Ed. Pioneira, 1967. Também o relato sobre a experiência inglesa: Moore Jr., Barrington. Aspectos morais do crescimento econômico. Rio de Janeiro: Record, 1999; e Macfarlane, Alan. A cultura do capitalismo. Rio de Janeiro: Jorge Zahar Ed., 1987.

47 Considerado um dos maiores comercialistas brasileiros de então, Herculano Marques Inglez de Souza era professor da Faculdade Nacional do Rio de Janeiro.

48 Para uma pormenorizada análise do projeto de Inglez de Souza, veja-se Ferreira, Waldemar. op. cit., p. 39 e ss. 
entretanto, surpreendeu ao apresentar ao invés de apenas um anteprojeto para o qual fora designado, um segundo texto, colecionando emendas que o transformava em código do direito privado, unificando as normas jurídicas civis e comerciais sob o artigo do mesmo diploma legislativo. Este segundo projeto, embora balizado pela idéia de unificação do direito privado-que de resto contava com importantes defensores nos meios jurídicos nacional e estrangeiro - foi prontamente afastado pelo Senado.

Sobre as razões dessa rejeição, podemos apontar duas. De um lado, a resistência de parte significativa do meio jurídico brasileiro à idéia de unificação, o que inviabilizava o debate teórico que preservasse a essência do anteprojeto. De outro lado, uma questão de ordem prática, já que tramitava em últimas providências o projeto do Código Civil, da lavra de Clóvis Beviláquia. Este tinha sido objeto de intensos debates no parlamento, sobretudo por conta das objeções que lhe indicou Rui Barbosa, bem como a polêmica lingüística deste com o professor Levi Carneiro. Aceitarse àquela época o anteprojeto de código unificado de Inglez de Souza seria desperdiçar o trabalho de mais de uma década, em torno do projeto de Código Civil, finalmente sancionado em 01 de janeiro de 1916.

Assim, prosseguiu a tramitação do anteprojeto de código comercial do ilustre comercialista, que após sucessivas alterações - suprimindo-se todo o texto original relativo às falências e ao direito marítimo - foi aprovado pelo Senado em 1927, a partir do que iniciou sua tramitação na Câmara dos Deputados. ${ }^{49}$ A ocorrência da Revolução de 1930, todavia, concentrou as atenções do parlamento sobre outras questões, levando o projeto a ter sua tramitação interrompida.

Nova iniciativa de confecção de um novo código comercial se dá então, em 1936, sob a coordenação do professor Waldemar Ferreira, nomeado relatorgeral da Comissão Parlamentar encarregada de redigir o anteprojeto. Todavia, mais uma vez os eventos políticos se colocam como óbice ao trabalho parlamentar e, em 1937, com a instituição do Estado Novo e conseqüente fechamento do Congresso Nacional, os trabalhos são interrompidos peremptoriamente.

Sobrevindo a redemocratização do país, em 1949, o então ministro da Justiça, comercialista gaúcho, Adroaldo Mesquita da Costa, designa o desembargador Florêncio de Abreu para que redija o esboço de um novo código comercial. Este projeto foi então apresentado à Câmara dos Deputados, prevendo somente a modificação de dispositivos do Código relativos à sua primeira parte, não se posicionando a respeito das demais. Posteriormente,

49 Sobre as fases de tramitação do projeto no Senado, veja-se: Carvalho de Mendonça, op. cit., p. 122 e ss. 
projetos tratando da reforma das duas outras partes do Código foram apresentados, nenhum deles tendo logrado, contudo, a continuidade na sua tramitação.

\section{EVOLUÇÃO E PERSPECTIVAS DA UNIFICAÇÃO DO DIREITO PRIVADO}

Em paralelo às iniciativas reformadoras da codificação comercial, tomava vulto a idéia de unificação do direito privado. A um tempo combatida por inúmeros civilistas e comercialistas, as idéias que, no direito brasileiro encontraram eco primeiro com Teixeira de Freitas, surgem como reação à dicotomia aparente entre público-privado, bem como uma iniciativa simplificadora do direito positivo, procurando sistematizar ordenamento uno de direito privado a partir da predominância de uma ou outra matéria, civil ou comercial.

Do ponto de vista histórico, a discussão que inicialmente se pautou na autonomia do direito comercial em relação à disciplina civil, evoluiu para a idéia de conveniência da unificação: em um só corpo legal o direito das obrigações, esparsamente tratado em ambas as codificações de direito privado. Neste sentido, argumentavam os entusiastas da unificação que esta acabaria por gerar enormes vantagens do ponto de vista prático, dentre as quais, a eliminação da controvérsia eventual sobre o direito aplicável. ${ }^{50}$ Vivante, como já se afirmou, também defende na primeira fase de sua produção científica, a unificação. $\mathrm{E}$, relacionando os motivos deste seu entendimento, arrola a dificuldade na aplicação de normas comerciais derivadas de direito consuetudinário (costumes estes produzidos pelos próprios comerciantes a quem se deseja regular) e as dificuldades em se apontar o direito aplicável ao caso concreto. ${ }^{51}$ Estas posições o autor italiano já havia antecipado em aula na Universidade de Bolonha, em fins do século XIX, indicando ainda as desvantagens evidentes causadas pela faculdade outorgada aos juízes de decidir sobre o caráter civil ou comercial de uma dada relação na qual estivesse presente ato não disposto em lei como comercial. Do mesmo modo, observa-se o prejuízo do desenvolvimento científico do direito comercial em razão de um direito comercial com autonomia legislativa, a causar caracterizações doutrinárias impróprias, o que faz com que, a cada nova regra obrigacional, fale-se em contrato sui generis. ${ }^{52}$

O desafio da elaboração do projeto do Código Comercial italiano, todavia,

50 Gella, Augustín Vicente y. Introducción al derecho mercantil comparado. 3. ed. Barcelona: Labor, 1941.p. 15-6.

51 Vivante, Cesare. Trattato di diritto commerciale, v. I. 5. ed., 1922. p. 11.

52 Conforme Requião, op. cit., p. 18. 
fez com que Vivante revisse seu posicionamento, passando a considerar a unificação do direito privado como hipótese de grave prejuízo para o direito comercial, tanto pelas diferenças metodológicas entre um e outro ramo, quanto pelo caráter dinâmico da disciplina comercial em relação à civil. Ademais, certas preferências lógicas do direito comercial, como a proteção do portador de boa-fé na disciplina dos títulos de crédito, acabariam por comprometer as conseqüências do direito unificado. ${ }^{53}$

No Brasil, entretanto, a perspectiva da unificação do direito das obrigações é almejada há algum tempo. A iniciativa pioneira neste sentido é o anteprojeto do Código de Obrigações, apresentado por comissão de juristas em 1941, mas que não chegou sequer a tramitar no Congresso Nacional. ${ }^{54}$ A grande polêmica que surge dali em diante, então, refere-se à objeção proposta por comercialistas contrários à unificação, afirmando que o pressuposto para tanto teria de ser, obrigatoriamente, a extensão do instituto da falência também para as sociedades civis. ${ }^{55}$

Nova iniciativa então se observa em meados da década de 60 , quando o governo forma "comissão de notáveis" para elaboração de novo anteprojeto de
Código de Obrigações. Este anteprojeto, apresentado em 1965, em que uma das três partes em que se dividia o Código correspondia à sociedade e ao exercício da atividade comercial, teve sua produção indicada ao professor Sylvio Marcondes. Por determinação do governo da época, o anteprojeto de Código das Obrigações não teve promovida sua tramitação finalizada no Congresso Nacional, sendo retirado para maiores estudos.

Então, tendo sido indicada nova "comissão de notáveis" para a redação de um novo Código Civil, o professor Sylvio Marcondes novamente foi indicado para a confecção da parte relativa ao direito da empresa, tarefa que tinha desempenhado em relação ao anteprojeto anterior.

O conhecido projeto $\mathrm{n}^{\circ} 634-\mathrm{B}$, de 1975 , então, foi o germe do atual Código Civil Brasileiro, lei $\mathrm{n}^{\circ} 10.406$, de 10 de janeiro de 2002, após extensa tramitação legislativa. Primeiro, na Câmara dos Deputados, onde permaneceu de 1975 a 1984. Depois, no Senado Federal, de 1984 a 1998, para em seguida retornar à Câmara dos Deputados, onde foi aprovado em fins de 2001 , sendo promulgado pelo Presidente da República em 10 de janeiro de 2002, e vigente no Brasil

53 Requião, op. cit., p. 19.

54 Integravam esta comissão os juristas Orozimbo Nonato, Philadelpho Azevedo e Hanemann Guimarães.

55 A respeito da falência civil, veja-se: Guimarães, Hanemann. "A falência civil". In: Revista Forense, ${ }^{\circ}$ 85. São Paulo: Ed. Forense, janeiro de 1941, p. 581. 
desde 11 de janeiro de 2003, após vacatio legis de um ano (art. 2.044).

\section{O DIREITO EMPRESARIAL E O NOVO CÓDIGO CIVIL}

A designação tradicional do ramo do direito que tem por objeto a regulação de direitos e interesses dos que exercem atividades de produção e circulação de bens e serviços com finalidade econômica, que se convencionou referir como direito comercial, sofre desde algum tempo, críticas quanto à sua óbvia limitação terminológica. Direito comercial era denominação típica das etapas em que o desenvolvimento econômico tinha na atividade do comércio praticamente a sua razão de ser.

O desenvolvimento econômico ao longo dos séculos que nos separam dos primórdios da atividade comercial na Europa fizeram surgir um sem número de atividades características de iniciativa econômica, como indústrias, serviços e mesmo, nos tempos atuais, a chamada economia digital, cujos fundamentos não permitem classificálos na consagrada concepção de atividade comercial. A finalidade lucrativa, neste sentir, avança para além das atividades produtivas, a que de modo convencional se determinava a incidência do direito comercial.

E para atualizar o direito frente a tais fenômenos econômicos é que se buscou cunhar nova expressão, que favorecesse a ampliação do setores da vida de relações contidas no objeto deste ramo do direito. Consagrou-se na doutrina, então, a partir do advento da teoria da empresa do direito italiano, a designação direito empresarial.

Conforme assinala Fábio Ulhôa Coelho, entretanto, a atualização da denominação da disciplina, a adoção da teoria da empresa, ou mesmo sua integração a diplomas legislativos típicos de direito civil, não servem por si, para determinar a unificação do direito privado. Comprova esta sua percepção, conforme ele mesmo demonstra, o fato de que no direito italiano, passados sessenta anos da unificação legislativa, direito civil e direito empresarial mantêmse como disciplinas autônomas. ${ }^{56}$

O novo Código Civil Brasileiro de 2002 , entretanto, vai dispor sobre matéria de direito empresarial no seu Livro II da Parte Especial, do Direito da Empresa. Entretanto, no que é pertinente ao direito comercial, o novo Código Civil avança para consequiências muito mais sensíveis do que se pode pressupor.

O modelo do novo Código, como demonstra Judith Martins-Costa, no esteio das lições do próprio Miguel Reale, é concebido como eixo central do sistema de direito privado, ao tempo em que não perde de vista a necessidade de abertura e mobilidade do sistema para os influxos da realidade 
social e de um projeto de permanência futura, natural a qualquer legislação. ${ }^{57}$

No que toca à unificação das obrigações civis e comerciais, realizada pelo Código Civil de 2002, observa com perfeição Norberto Mac-Donald, que, embora se observe a influência de direito comparado, de uma série de países de civil law sobre as coordenadas essenciais do Código, a unidade do direito obrigacional é tributada, fundamentalmente ao direito italiano, em que o fenômeno se observou no Código de $1942 .{ }^{58}$

Todavia, identifica-se neste particular que, embora a unificação das obrigações tenha determinado às normas do novo Código a regulação de novos contratos como os de comissão (arts. 693 a 709), de agência e distribuição (arts. 710 a 721), corretagem (arts. 722 a 729), transporte (arts. 730 a 756), ou mesmo sobre os títulos de crédito (arts. 887 a 926), a par da legislação extravagante remanescente, deixa de contemplar contratos tipicamente afetos ao direito empresarial, como os contratos bancários $^{59}$ e financeiros, a franquia empresarial, o know-how e outros tantos. Evidentemente que tais ausências não se dão exclusivamente por suposta deficiência do código ou esquecimento do legislador. Setor típico da iniciativa criativa do homem com o objetivo de maximização do lucro, a atividade empresarial por si não é própria às restrições legais representadas pela consagração dos chamados contratos típicos. Assim como tantos contratos comerciais já conhecidos foram excluídos do âmbito de regulação do novo Código Civil, de se esperar que outros tantos, resultado da criatividade dos empresários e demais agentes econômicos ainda surjam, e sejam regulados além das normas gerais sobre contratos do Código (arts. 421 a 480), pelos aspectos específicos que os caracterizem.

Outras críticas se percebem também em relação à já mencionada disciplina dos títulos de crédito no novo Código Civil. Segundo demonstra MacDonald, noticiando a crítica de Fábio Comparatto, certa dificuldade deverá perceber-se na prática, em face do conceito genérico de título de crédito estabelecido no Código, sobretudo no que diz com a confusão que seu texto

57 Martins-Costa, Judith. "O novo Código civil brasileiro: em busca da ética da situação". In: Martins-Costa, Judith; Branco, Gerson Luiz Carlos. Diretrizes teóricas do novo Código Civil Brasileiro. São Paulo: Saraiva, 2002, p. 87-160.

58 Mac-Donald, Norberto. "O projeto de Código Civil e o direito comercial". In: Revista da Faculdade de Direito da UFRGS, $\mathrm{n}^{\circ}$ 16, Porto Alegre, 1999, p. 142-143.

59 Em relação aos contratos bancários lembra Mac-Donald que os mesmos foram parte do anteprojeto, sendo excluídos ao longo da tramitação legislativa pelas impropriedades apontadas, dentre outros, por Fábio Konder Comparatto. Op. cit., p. 144. 
favorece entre título de crédito inominado (que parece criar), título de crédito impróprio, ou simples comprovante de legitimação. ${ }^{60}$ Omissões são identificadas também em relação a uma das características essenciais dos títulos de crédito, que dizem com a inoponibilidade das exceções a terceiros de boa-fé. ${ }^{61}$

Do mesmo modo, embora não diga diretamente com uma falta do legislador do Código, mas muito mais com o paradoxo de desenvolvimento do direito empresarial, ao qual já nos referimos, e que faz de suas normas progressivamente desatualizadas em face do avanço e incremento das relações econômicas que elas mesmas propugnam, outra questão limite do tratamento jurídico dos títulos de crédito é a desmaterialização ${ }^{62}$ das relações que tradicionalmente são representadas a partir da utilização de meios eletrônicos de transferência de fundos. Este fenômeno, aliás, já está sendo tratado em legislação específica, que consagra atuação de autoridades de certificação eletrônica e regulamentação da movimentação de recursos por meio eletrônico. ${ }^{63}$
Finalmente, no que toca ao direito de empresa propriamente dito, consagrado no Livro II do Código Civil de 2002, é de se observar que se concentra a norma em estabelecer os conceitos centrais do direito empresarial, antes objeto da parte primeira do Código Comercial de 1850 (revogado pelo art. 2.045 da lei nova). Neste sentido, o fio condutor apresentado pelo novo Código é afirmado pelo conceito de empresário presente no art. 966, que refere: "Considera-se empresário quem exerce profissionalmente atividade econômica organizada para a produção ou circulação de bens e serviços". Ao mesmo tempo, exclui o parágrafo único do mesmo artigo, do conceito de empresário, "quem exerce profissão intelectual, de natureza científica, literária ou artística, ainda com o concurso de auxiliares e colaboradores, salvo se o exercício da profissão constituir elemento de empresa".

A definição legal do novo Código, a nosso ver, além de delimitar o espectro subjetivo de incidência das suas normas, tem alcance para além do direito

60 Op. cit., p. 146.

61 Idem, p. 147.

62 Embora utilizada por diversos autores quanto a uma série de aspectos da sociedade pós-moderna, para os efeitos do presente estudo tomamos a expressão das considerações do prof. Norberto Mac-Donald sobre o tema. Op. cit., p. 148.

63 No Brasil, a legislação e atuação do ITI, Instituto Nacional de Tecnologia da Informação, vinculado à Casa Civil da Presidência da República, medida provisória 2002-2, de 24 de agosto de 2002 , bem como o decreto ${ }^{\circ} 3.872$, de 18 de julho de 2001 . 
empresarial, permitindo inclusive solver indagações, por via interpretativa, de outros ramos do direito privado, como o direito do consumidor. ${ }^{64}$

No que toca à sociedade empresária, note-se que o novo Código desfez confusão própria das normas de 1916 quanto à utilização dos termos sociedade e associação. Enquanto esta ficou adstrita à identificação das pessoas jurídicas de fins não-econômicos, aquela distingue as pessoas jurídicas de fins econômicos, do que são espécies as sociedades simples e as sociedades empresárias, estas com fins econômicos e sujeitas ao registro próprio (art. 984), condição de sua existência jurídica (art. 985). Hentz, de sua parte, anota que dentre as sociedades nãopersonificadas, porque não sujeitas a registro, além das sociedades em comum tem-se as sociedades em conta de participação (arts. 991 a 996) ${ }^{65}$

Quanto ao registro, aliás, são diversas as questões levantadas na doutrina especializada, sobre a opção legislativa do novo Código, sobretudo em relação à previsão da denominada sociedade em comum (art. 986 et seq.), não personificada, a qual é regulada pela nova lei. Segundo aponta Mac-Donald, a exigência do registro, não só como condição para personificação, mas também para o regular funcionamento das sociedades comerciais, evidencia-se ao considerar-se as conseqüencias atuais da falta de registro (...). ${ }^{66}$ A questão que surge é se estas sociedades não inscritas, pelo sistema do novo Código, estariam ou não submetidas às conseqüências e sanções próprias advindas da falta de registro.

Neste contexto, a previsão apartada da cooperativa como espécie distinta da sociedade empresária mereceu algum questionamento quanto à sua adequação. Assim, por exemplo, o entendimento de Luiz Antônio Hentz, para quem sua natureza jurídica originária, como sociedade de pessoas, de caráter civil, conforme a lei $n^{\circ} 5.764 /$ 71 , perde sua razão diante dos atuais contornos impressos na lei nova, a identificá-la como forma de empresa,

64 No direito do consumidor é conhecida a divergência doutrinária em torno da interpretação do art. $2^{\circ}$ do Código de Defesa do Consumidor (Lei $\mathrm{n}^{\circ} 8.078 / 90$ ), que definiu o sujeito consumidor. No caso, dois entendimentos, dos chamados finalistas (que defendem interpretação mais restritiva do conceito legal) e dos maximilistas (que defendem sua ampliação), relativamente à aplicação das normas de proteção do consumidor poderão utilizar-se da definição de empresário estabelecida no art. 966 do novo Código Civil para excluí-lo, o caso concreto, da proteção das normas do $\mathrm{CDC}$, remetendo-o à norma subjetiva do Código Civil.

65 Hentz, Luiz Antônio Soares. Direito de empresa no Código Civil de 2002. 2. ed. São Paulo: Editora Juarez Oliveira, 2003, p. 39-40.

66 Mac-Donald, op. cit., p. 156. 
no que aliás remontaria à própria origem do instituto, através da lei ${ }^{\circ} 1.637 / 07.67$

De outra parte, observa-se que o Código, em matéria pertinente às sociedades empresárias e às pessoas jurídicas em geral, acolhe a já consagrada teoria da desconsideração da personalidade jurídica (disregard doctrine), que no Brasil foi introduzida pioneiramente pelo direito empresarial, através da lição de Rubens Requião. ${ }^{68}$

$\mathrm{O}$ art. 50 do novo Código dispõe: Em caso de abuso da personalidade iurídica, caracterizado pelo desvio de finalidade, ou pela confusão patrimorial, pode o juiz decidir, a requerimento da parte, ou do Ministério Público quando lhe couber intervir no processo, que os efeitos de certas determinadas relações de obrigações sejam estendidas aos bens particulares dos administradores ou sócios da pessoa jurídica.

Nota-se dentre os traços fundamentais deste instituto inovador do direito privado, ${ }^{69}$ de larga utilização jurisprudencial mesmo anterior à codificação, dois aspectos centrais. Primeiro, de que sua identificação deverá observar a ocorrência de desvio de finalidade ou confusão patrimonial, cuja prova deverá ser demonstrada, assim como concede prerrogativa ao juiz para providência invalidante tópica, relativamente a certas e determinadas relações de obrigações, as quais deverão, por óbvio, guardar relação com um dos elementos caracterizadores do abuso. ${ }^{70}$

Daí porque se pode concluir que o atual fenômeno de incorporação das normas de direito empresarial pelo novo Código Civil, embora tenham o condão de determinar uma significativa transformação desta disciplina jurídica em razão do conteúdo das normas em vigor, não servem para afetar de qualquer modo sua autonomia. Até porque, em face da opção legislativa do novo Código, a matéria de direito empresarial ultrapassa as tênues fronteiras da codificação para afirmar seus institutos fundamentais em uma infinidade de leis extravagantes - cujo

67 Hentz, Direito de empresa..., op. cit., p. 142-143.

68 Requião, Rubens. "Abuso do direito e fraude através da personalidade jurídica (disregard doctrine)". In: Aspectos modernos de direito comercial. São Paulo: Saraiva, 1977, p. 67.

69 De se ressaltar, contudo que pioneiramente foi consagrado no art. 28 do Código de Defesa do Consumidor (lei 8.078/90) quando, em detrimento do consumidor, houve abuso do direito, excesso de poder, infração da lei, fato ou ato ilícito ou violação dos estatutos ou contrato social.

70 A respeito veja-se o instigante estudo do professor Norberto Mac-Donald. "Pessoa jurídica: questões clássicas e atuais. Abuso - Sociedade unipessoal - Contratualismo". In: Revista da Faculdade de Direito da UFRGS, $\mathrm{n}^{\circ} 22$. Porto Alegre, setembro/2002, p. 300-376, em especial 360-371. 
exemplo recorrente, por sua importância reconhecida, é a lei $n^{\circ} 6.404 / 74$, que regula as sociedades anônimas.

Assim, superado o debate sobre a autonomia do direito empresarial, questão de maior significado diz respeito às tendências atuais desta disciplina jurídica, o que se deve reconhecer a partir das exigências que o próprio desenvolvimento da atividade econômica na sociedade pós-industrial passa a determinar.

\section{AS TENDÊNCIAS ATUAIS DO DIREITO EMPRESARIAL}

Como poucos ramos do direito as disciplinas jurídicas de direito privado refletem direta e rapidamente, transformações da realidade sobre as quais suas normas devem incidir. Assim é com o direito civil, em que as normas sobre família, propriedade ou mesmo os limites da autonomia privada refletem, em cada tempo, as condicionantes sociais, políticas e culturais de uma determinada sociedade. Assim também o direito empresarial, em que o que já denominamos paradoxo do desenvolvimento faz com que suas normas, continentes de um telos específico de otimização do lucro nas relações típicas que regulam, vejam-se permanentemente superadas pela criatividade e desenvoltura negocial que elas próprias estimulam. Este paradoxo, característico do caráter dinâmico do direito empresarial, é uma das razões principais da sua reconhecida inadequação às codificações. ${ }^{71}$

No caso do direito empresarial, dado o seu conteúdo marcadamente econômico, é de se considerar nas últimas décadas, o advento do que Manual Castells convencionou denominar capitalismo informacional, cujas características essenciais são determinadas por três processos independentes, sinais desta nova era. São eles: a) a revolução da tecnologia da informação, b) a crise econômica do capitalismo e do estatismo, e conseqüente reestruturação de ambos; e c) o apogeu de movimentos sociais culturais como direitos humanos, feminismo e ambientalismo. ${ }^{72}$ Esta nova circunstância histórica global determina para organização da apropriação e exploração da riqueza processos completamente novos de organização. Estes determinam conseqüências que vão da redefinição

71 Assim: Ascarelli, Túlio. "A idéia de Código no direito privado e a tarefa da interpretação". In: Problemas das sociedades anonimas e direito comparado. São Paulo: Saraiva, 1969, p. 61. No mesmo sentido: Lucca, Newton de. "A atividade empresarial no âmbito do projeto de Código Civil". In: Direito empresarial contemporâneo. São Paulo: Juarez Oliveira, 2000, p. 47 et seq.

72 Castells, Manuel. A era da informação: Economia, sociedade e cultura-Fim de milênio. v. 3. São Paulo: Paze Terra, 1999, p. 412. 
das relações entre a iniciativa econômica do Estado e dos particulares, como a própria reestruturação dos modos de atuação econômica da iniciativa privada.

No que toca com fenômenos típicos de regulamentação pelo direito empresarial, a sociedade empresária e a atividade empresarial são os fenômenos mais conhecidos destas novas tendências do direito empresarial. Segundo demonstra minuciosamente Castells, no que toca à atividade produtiva, esta deixa de se concentrar no fenômeno da produção em massa, fundamentada em ganhos de produtividade através de economias de escala, para se definir segundo um modelo de produção flexível, tanto em relação aos produtos (diferenciação dos produtos para distintos consumidores), quanto em relação aos processos de produção propriamente ditos. ${ }^{73}$

De outra parte, fenômeno sensível do novo cenário econômico mundial, de reflexos imediatos nas formulações de direito empresarial, é a formação de redes entre empresas, de caráter multidirecional, colocado em prática por empresas de pequeno e médio porte, $\mathrm{e}$ o modelo de licenciamento e subcontratação de produção sob o controle de uma grande corporação. ${ }^{74}$
Além disso, a nova noção de alianças estratégicas entre sociedades empresárias, ${ }^{75}$ que determinam a formulação de contratos específicos (como o joint-venture, por exemplo), assim como novas formas de contratação de alianças estratégicas em que o objeto de contratação é marca ou designação de apelo publicitário, bem como um determinado processo de produção (franquia empresarial), faz com que as fórmulas clássicas de direito empresarial submetam-se à permanente revisão.

Nesta esteira, apenas para complementar estas sucintas observações, também estão o atual valor de medição de riqueza e o conceito contemporâneo de bem economicamente avaliável. Avulta hoje, sabidamente, a cotação dos chamados bens imateriais, que muitas vezes consistem simplesmente em informações sobre processos, sem uma materialidade ou elementos convencionais que possam lhe determinar um valor, o qual será determinado, muitas vezes, exclusivamente pela concepção arbitrária dos agentes do mercado.

Este panorama permite identificarse em relação ao direito empresarial brasileiro, no mesmo sentido do direito comparado, algumas tendências bastante sensíveis, quais sejam: $a$

73 Castells, Manuel. A era da informação: Economia, sociedade e cultura-Sociedade em rede, v. 1. São Paulo: Paze Terra, 1999, p. 175-176.

74 Idem, p. 181.

75 Ibidem, p. 183-184. 
flexibilização; a internacionalização; a desmaterialização; e o reforço da confiança.

\subsection{Flexibilização}

No que se refere à primeira tendência está o que denominamos de flexibilização do direito empresarial. Trata-se de uma tendência que decorre diretamente da necessidade de atualização veloz do instrumental jurídico de regulamentação da atividade empresarial (paradoxo do desenvolvimento). Em regra, tanto a iniciativa legislativa, quanto a própria compreensão pelo aplicador do direito sobre a evolução dinâmica da atividade empresarial, não permite que ambos, direito e atividade empresária se desenvolvam na mesma velocidade. Este fato, evidentemente, faz com que muitas vezes, as exigências formais da regulamentação jurídica representem custos ou mesmo fatores desfavoráveis ao desenvolvimento da atividade econômica.

Por esta razão, a flexibilização das relações jurídicas interempresariais é uma tendência bastante notada, tanto no Brasil quanto em direito comparado. Internamente, um exemplo típico desta nova flexibilidade é o instituto da arbitragem, previsto no direito brasileiro da lei $\mathrm{n}^{\circ} 9.307$, de 23 de setembro de 1996, pelo qual é reconhecida a possibilidade de fuga da jurisdição estatal (júris dictio, dizer o direito) para decisão sobre o litígio entre particulares, a partir do pronunciamento do árbitro privado. Flexibiliza-se a jurisdição necessária do Estado, legado da Idade Moderna, para se reconhecer aos particulares competência ${ }^{76}$ para decisão sobre litígios entre si. Trata-se, pois, da determinação do aplicador do direito através de convenção das partes, de uma justiça convencional, cujo procedimento de conhecimento e decisão do litígio se dá por regras acordadas ou mesmo costumeiras.

Um segundo fenômeno característico desta tendência flexível, vinculado igualmente ao reforço da autonomia privada dos empresários, é a possibilidade de escolha da lei aplicável aos contratos internacionais. Esta possibilidade, em regra limitada pelas exigências de ordem pública (típicas do direito internacional privado) vai encontrar sua sede característica nos contratos internacionais, que para além disto, desde algum tempo dispõem com naturalidade sobre cláusulas de foro e convenções sobre usos e costumes reconhecidos na sua execução.

\subsection{Internacionalização}

O direito empresarial acentua sua dimensão internacional, à medida que a atividade empresarial assume

76 Competência, tomada no lapidar conceito do prof. Ruy Cirne Lima, como "a medida de poder que a ordem jurídica assina a uma pessoa determinada" (Principios de direito administrativo. São Paulo: RT, 1987, p. 139). 
repercussão global. A tendência de internacionalização do direito empresarial acompanha, neste sentir, a influência recíproca dos mercados nacionais, definindo os principais fatores econômicos. Os contratos empresariais são cada vez mais contratos entre sociedades empresárias de distintos países, tendo como objeto a importação e exportação de bens e serviços, ou ainda, a transferência de tecnologia. As sociedades empresárias assumem cada vez mais o caráter de corporações transnacionais, com diversos centros de interesse, e submetidas a distintos ordenamentos jurídicos. As normas sobre direito empresarial e econômico cada vez mais são objeto de negociação em organismos internacionais multilaterais, como a Organização Mundial de Comércio, ou de cooperação e integração econômica, como o MERCOSUL ou a União Européia. ${ }^{77}$

Neste sentido, a dimensão internacional do direito empresarial traz consigo uma segunda característica auxiliar, de uniformização ${ }^{78}$ dos diferentes ordenamentos jurídicos sobre a forma de organização do capital e garantias de estabilidade para o investimento internacional. A disciplina de organização do capital diz especificamente com o objeto do direito empresarial, enquanto o que identificamos como garantias de estabilidade passa a estar afeto de modo próprio ao direito econômico, em suas variáveis de defesa da concorrência e regulação de determinados setores do mercado.

De outra parte, a atividade empresarial, também em relação ao mercado de produção e consumo de bens e serviços, observa esta tendência de internacionalização, fruto do afamado fenômeno da globalização dos mercados. Tais circunstâncias determinam, primeiro, uma interação permanente entre distintas ordens jurídicas, ao tempo que promovem a construção gradual de normas internacionais comuns sobre estas transações afetas ao direito empresarial, como é o caso, por exemplo, da Convenção das Nações Unidas sobre os Contratos de Compra e Venda Internacional de Mercadorias (Convenção de Viena de 1980), ${ }^{79}$ ou

77 Esplêndida reflexão sobre o tema é a do mestre francês François Rigaux. A lei dos juizes. Trad. Edmir Missio. São Paulo: Martins Fontes, 2000, em especial p.8 et seq.

78 Assim, veja-se: Barreto Filho, Fernando Paulo de Mello. O tratamento nacional dos investimentos estrangeiros. Brasília: Instituto Rio Branco, 1999. Segundo o autor, nesta matéria a construção de regras internacionais para produção de relativa estabilidade quanto à matéria, é recente, datando de princípio da década de 1970, p. 38.

79 A respeito, veja-se, dentre outros: Martins-Costa, Judith. "Os princípios informadores do contrato de compra e venda na Convenção de Viena de 1980". In: Contratos Internacionais e Direito Econômico no MERCOSUL. São Paulo, Editora LTr, 1996, p. 163187. No mesmo sentido: Grebler, Eduardo. "O contrato de venda internacional de mercadorias". In: Revista Forense, vol. 319. Rio de Janeiro: Forense, 1992, p. 310-317. 
do Acordo sobre os Aspectos dos Direitos de Propriedade Intelectual Relacionados com o Comércio (Acordo TRIPS), ${ }^{80}$ regulando questões relativas à propriedade intelectual e criando direitos e obrigações para os Estados-membros.

\subsection{Desmaterialização}

Uma terceira tendência bastante sensível no direito empresarial é a da sua desmaterialização no que diz com as atividades típicas de empresa, como o comércio, e os meios de representação da riqueza, sejam os títulos de crédito ou as transações financeiras em geral, interempresariais ou de consumo. Assiste-se, deste modo, ao crescente retomar de instrumentos eletrônicos de conservação e transferência de recursos financeiros, que desde algum tempo, afirmam o desnível entre a quantidade de moeda física e aquela objeto de representação eletrônica.

Do mesmo modo, algumas operações de crédito, para as quais o direito tradicionalmente havia previsto a figura dos títulos de crédito, em face de sua realização por meio eletrônico, terminam por perder as características próprias de cartularidade e autonomia, tão prezadas pelo direito comercial clássico.

No que tange às profundas alterações no campo da compra e venda de bens e serviços, esta tendência de desmaterialização é notada pelo advento do comércio eletrônico que, se de um lado determina um novo meio para realização de negócios, cujo objeto em regra será material (aquisição de produtos materiais pela internet), de outro permite igualmente que toda a relação tipicamente comercial tenha sua formação e execução por meio eletrônico (a aquisição de um software através da internet, é o exemplo mais utilizado).

Tais circunstâncias promovem a discussão de novas questões afetas a esta espécie de relação, como a noção de estabelecimento comercial, de formação e execução do contrato, e outras tantas examinadas pela doutrina especializada em direito privado.

Ao mesmo tempo, reforçam a necessidade de mecanismos que assegurem a autenticidade dos sujeitos, dos processos de manifestação da vontade e do conteúdo dos negócios celebrados por meio eletrônico. Trata-se de instrumentos jurídicos de reação à esta tendência de desmaterialização, a fim de preservar a segurança e a autenticidade, como é o caso, por exemplo, do processo de certificação digital.

\subsection{Reforço da confiança}

Por fim, a quarta tendência atual que identificamos em relação ao direito empresarial é o que denominamos reforço da confiança. Confiança esta, tomada em seu sentido jurídico, mas cuja

80 Incorporado ao direito interno brasileiro através do decreto legislativo $\mathrm{n}^{\circ} 30$ de 15.12 .94 e regulado pelo decreto $\mathrm{n}^{\circ} 1.355$ de 30.12 .94 . 
repercussão avança para os mais distintos campos da ação humana. Carlos Alberto Ghersi refere que na atualidade a confiança representa significativas projeções para a economia, e novos enfoques determinam como dela depende, em grande medida, a eficiência econômica ${ }^{81}$

A confiança como instituto jurídico, tem sua origem no direito alemão (Treu und Glauben), intimamente vinculada à noção de boa-fé objetiva presente no parágrafo 242 do BGB, de 1900 . No direito brasileiro, a primeira disposição legislativa prevendo a boa-fé objetiva se observa exatamente no art. 131, primeira parte, do Código Comercial, de 1850, que dispunha, sobre a interpretação do contrato comercial, que esta deveria ter por base a inteligência simples e adequada, que for mais conforme à boa-fé, e ao verdadeiro espirito e natureza do contrato, deverá sempre prevalecer à rigorosa e restrita significação das palavras.

Entretanto, sua aplicação jurisprudencial poucas vezes respeitou o caráter objetivo do dever determinado pela disposição legal, o que se vai consolidar apenas ao longo do século $\mathrm{XX}$, a partir do esforço de definição conceitual da boa-fé pela doutrina civilista, e sua adoção pela jurisprudência, já na década de 1980 . Sob o aspecto legislativo, a boa-fé objetiva como norma surgiu então no Código de Defesa do Consumidor ${ }^{82}$ de 1990, e no Código Civil de 2002. ${ }^{83}$

Em termos dogmáticos, a unificação das obrigações civis e comerciais, e o reconhecimento da boa-fé como princípio geral do direito dos contratos, previsto no art. 422 do novo Código Civil, determina às obrigações típicas de direito empresarial a observação do conteúdo objetivo dos valores de fidelidade e confiança, exigências geralmente vigentes de justiça ${ }^{84}$

Nas obrigações de natureza empresarial, a tendência de valorização da confiança observa-se em dois planos. De um lado, como reação à tendência de flexibilização, como necessidade conseqüente do reconhecimento de standards com força jurídica e aceitação pelos indivíduos envolvidos. De outro, como espécie de garantia necessária à velocidade atual dos negócios, que estimulam, no âmbito jurídico, a elevação da importância dos usos e

81 Ghersi, Carlos Alberto. Contratos interempresarios. Buenos Aires: Astrea, 2001, p. 126. 82 A respeito veja-se: Marques, Cláudia Lima. Contratos no Código de Defesa do Consumidor. 4. ed. São Paulo: RT, 2002, p. 232 et seq.

83 Sobre a boa-fé no direito civil, veja-se: Martins-Costa, Judith. "A boa-fé como modelo (uma aplicação da teoria dos modelos de Miguel Reale)". In: Diretrizes teóricas..., op. cit., p. 188-221.

84 Conforme a lição de Karl Larenz. Derecho de obligaciones, tomo I. Madrid: Editorial Revista de Derecho Privado, 1958, p. 142-143. 
costumes como fonte das obrigações e, neste sentido, a proteção das expectativas legítimas geradas a partir do respeito aos mesmos.

O reforço da confiança consistirá no reconhecimento, pelo direito empresarial, de efeitos jurídicos próprios às expectativas legítimas $\mathrm{e}$ aos deveres oriundos da boa-fé, matriz valorativa do direito privado, consagrada internamente no novo Código Civil, bem como pelo retorno dos usos e costumes comerciais como fonte do direito, recuperando seu papel eclipsado, eventualmente, pelas aspirações de regulação exaustiva do século vinte.

$\mathrm{O}$ direito empresarial brasileiro avança, deste modo, na aproximação dos fenômenos que regula, caracterizando-se como elemento promotor do desenvolvimento econômico, ao tempo em que estabelece, no plano interno e internacional, normas para estabilidade dos investimentos e organização da iniciativa econômica na sua dimensão privada. 


\section{O problema da eficácia da sentença ${ }^{*}$}

\section{Carlos Alberto Álvaro de Oliveira ${ }^{* *}$}

1. Problema delicado que tem sobremaneira ocupado a atenção dos processualistas, principalmente nos últimos tempos, diz respeito à questão da eficácia da sentença no processo de conhecimento, às vezes situado exclusivamente no campo do direito processual, outras vezes no domínio do direito material, sem que até agora se tivesse logrado, pelo menos na minha ótica, uma solução satisfatória. Esse interesse tem sido redobrado, principalmente, em vista da tomada de consciência de que para o processualista dos dias atuais não basta apenas elaborar conceitos (tarefa útil, não há dúvida), mas de que é preciso elaborálos levando em conta a efetividade do instrumento jurisdicional.

No presente ensaio, busca-se, em primeiro lugar, determinar o estado atual do problema (itens 2 e 3 ); num segundo momento, examinar com espírito crítico as teorias correntes sobre o assunto (itens 4 e 5) e, finalmente, reelaborar uma concepção mais afim às exigências do dia (item 6).

2. Na doutrina brasileira, exsurgem claramente duas posições a respeito do tema.

O entendimento tradicional vincula a eficácia da sentença à espécie de tutela jurisdicional concedida à parte, adotando a usual classificação ternária das sentenças em declaratórias (positivas ou negativas), constitutivas (positivas ou negativas) e condenatórias.

Para Humberto Theodoro Junior, por exemplo, "A classificação realmente importante das sentenças (considerando tanto a decisão do juiz singular como o acórdão dos tribunais)

\footnotetext{
"Ensaio destinado a integrar livro em homenagem a Giuseppe Tarzia.

"* Professor titular da Faculdade de Direito da UFRGS; doutor em Direito.
} 
é a que leva em conta a natureza do bem jurídico visado pelo julgamento, ou seja, a espécie de tutela jurisdicional concedida à parte." Dentro dessa perspectiva, classifica ele as sentenças em condenatórias, constitutivas e declaratórias. Já as sentenças mandamentais e executivas, - como comandos a serem cumpridos dentro do mesmo processo em que a sentença foi proferida - não são essencialmente diversas das três categorias clássicas: "Tanto as que se dizem executivas como as mandamentais realizam a essência das condenatórias, isto é, declaram a situação jurídica dos litigantes e ordenam uma prestação de uma parte em favor da outra. A forma de realizar processualmente essa prestação, isto é, de executá-la, é que diverge. A diferença reside, pois, na execução e respectivo procedimento. Sendo assim, não há razão para atribuir uma natureza diferente a tais sentenças."'

Cândido Rangel Dinamarco, embora com certos temperamentos, também compartilha desse modo de pensar.

Ressalta que a classificação das ações, cara à doutrina clássica do processo civil, segundo a espécie de sentença que se pede no exercício de cada uma delas, tem o mérito de ser puramente processual, evitando os critérios herdados da tradição romana e impregnados de elementos inerentes ao direito subjetivo afirmado pelo autor (real, pessoal, etc.). Diz, também, mostrar-se mais coerente com a moderna visão do processo civil classificar as demandas, como concretas iniciativas de pedir a tutela jurisdicional. ${ }^{2}$ A classificação é ternária: sentenças declaratórias, constitutivas e condenatórias. As mandamentais integrariam a classe das condenatórias: "A sentença mandamental é título para a execução forçada, tanto quanto a condenação ordinária - e portanto é também uma condenação. A diferença está no conteúdo da sanção imposta em seu segundo momento, na qual se exacerba o fator comando, ou mandamento [...] O comando contido em tais sentenças é de tal intensidade, que autoriza o juiz, ainda no processo de conhecimento e sem necessidade de propositura ou instalação do executivo, a desencadear medidas destinadas a proporcionar ao vencedor a efetiva satisfação de seu direito."3 Adiante reforça esse entendimento: “[...] não se trata de uma quarta categoria sentencial, ao lado da

1 THEODORO JÚNIOR, Humberto. Curso de Direito Processual Civil. 39. ed. Rio de Janeiro: Forense, 2003, v. 1, n' 497 , p. 468-469, n 499 , p. 470.

2 DINAMARCO, Cândido Rangel. Instituições de Direito Processual Civil. 2. ed. São Paulo, Malheiros, 2002, v. 3, n 894, p. 204-205.

3 DINAMARCO, Instituições..., nº 919, p. 242-243. 
meramente declaratória, da condenatória e da constitutiva. Por sua estrutura, função e eficácia, as sentenças mandamentais compartilham da natureza condenatória, sem embargo do reforço de eficácia que lhes outorga a lei." ${ }^{\prime 4}$

Nada obstante, admite Cândido Rangel Dinamarco a subclasse das sentenças executivas lato sensu, quando a sentença condenatória comportar execução no mesmo processo em que foi proferida, sem necessidade de ser instaurado formalmente o processo executivo. Para o jurista, esses casos são raros e excepcionais no sistema e só existem na medida em que o direito positivo os permita especificamente, como nas ações de despejo, nas possessórias, nas desapropriações imobiliárias e poucas outras. ${ }^{5}$

3. A outra corrente origina-se das idéias elaboradas por Pontes de Miranda, depois retomadas e desenvolvidas por Ovídio A. Baptista da Silva.

Sustenta Pontes de Miranda, em primeiro lugar, que a eficácia da sentença está umbilicalmente vinculada à ação exercida. Significativamente ao falar de ação, sem aspas (portanto, no significado de ação de direito material que lhe empresta), afirma que "A ação, que supõe haver-se transgredido a norma, constitui outro plus e tende, não à prestação, mas a efeito jurídico específico." Adiante repisa: "Enquanto o direito subjetivo e a pretensão tendem à prestação, a ação supõe combatividade e, pois, tende, não à prestação, mas a efeito jurídico específico." Nessa perspectiva, "O conceito de ação, a classificação das ações por sua eficácia, tudo isso consulta o direito material, porque o fim precípuo do processo é a realização do direito objetivo. Na própria classificação das ações e das sentenças, o direito processual tem de atender à eficácia das ações segundo o direito material. A margem de liberdade que se lhe deixa é pequena, mas existe." ${ }^{\prime}$

Para Pontes de Miranda, "As ações ou são declarativas (note-se que as relações jurídicas de que são conteúdo direitos e pretensões, ou de que direitos ou pretensões derivam, antes de tudo existem); ou são constitutivas (positivas ou negativas; isto é, geradoras ou modificativas, ou extintivas); ou são condenatórias; ou são mandamentais; ou são executivas", ${ }^{9}$ pois, as

4 Ibidem, n919, p. 245.

5 Ibidem, n 920, p. 245-246.

6 PONTES DEMIRANDA. Tratado das Ações. São Paulo: Revista dos Tribunais, 1970, v. 1, p. 33.

7 Ibidem, p. 93.

8 Ibidem, p. 126.

9 Ibidem, p. 117. 
classificações de ações de que usaram os juristas europeus estão superadas. Assim,

a classificação binária como a classificação ternária (ação declaratória, ação constitutiva, ação condenatória) não resistem às críticas e concorreram para confusões enormes que ainda hoje estalam nos espiritos de alguns juristas, como também não viam que uma coisa é força de sentença (eficácia preponderante) e outra a eficácia imediata ou mediata, sem sefalar nas duas menores, com que se completa a constante da eficácia das ações e das sentenças. ${ }^{10}$

Consoante Pontes de Miranda, a classificação correta é a quinária, com as seguintes notas distintivas: a) "A ação declarativa é ação a respeito de ser ou não-ser a relação jurídica"; b) "De regra, a ação constitutiva prendese à pretensão constitutiva, res deducta, quando se exerce a pretensão à tutela jurídica. Quando a ação constitutiva é ligada ao direito, imediatamente, não há, no plano da res in iudicium deducta, pretensão constitutiva (há-a, no plano do direito subjetivo à tutela jurídica, que é a especialização, pelo exercício da pretensão à tutela jurídica em pretensão constitutiva)"; c) "A ação de condenação supõe que aquele ou aqueles, a quem ela se dirige tenham obrado contra direito, que tenham causado dano e mereçam, por isso, ser condenados (con-damnare)"; d) "A ação mandamental prende-se a atos que o juiz ou outra autoridade deve mandar que se pratique. $O$ juiz expede o mandado, porque o autor tem pretensão ao mandamento e, exercendo a pretensão à tutela jurídica, propôs a ação mandamental"; e) "A ação executiva é aquela pela qual se passa para a esfera jurídica de alguém o que nela devia estar, e não está."

$\mathrm{Na}$ mesma esteira posiciona-se Ovídio A. Baptista da Silva: "Reafirmando, pois, o que já ficou dito, podemos distinguir bem as duas formas de agir e, portanto, as duas espécies

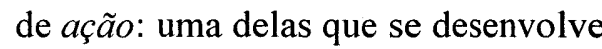
no plano do direito material e corresponde ao agir contra o obrigado para a realização do direito, independentemente de sua colaboração; a outra, dirigida contra o Estado, para que ele provocado pelo interessado (autor), exerça a atividade jurisdicional a que se obrigou e preste a respectiva tutela, dando resposta adequada ao pedido. A primeira espécie de ação tem como pressuposto um direito material preexistente de que é titular aquele que age; esta, a "ação" processual, por força há de estar igualmente fundada num direito anterior. Também ela, como qualquer outra atividade lícita, deve corresponder a um direito exigível (= pretensão), sob pena

10 Ibidem, p. 118.

11 PONTES DE MIRANDA, Tratado das..., p. 118-122. 
de configurar o puro arbítrio e a violência." Mais adiante afirma que "Aquele que age (exerce ação) no plano do processo absolutamente não pode prescindir da atividade do Estado para a realização do direito do autor à jurisdição. Ao contrário, o exercício da "ação", aqui, é tanto o agir quanto o exigir que o Estado aja, prestando tutela jurídica."12

Em tema de classificação das ações, pondera ainda o jurista:

Quando pretendemos classificar o ato jurisdicional típico - decisões e sentenças, tanto do "processo de conhecimento" quanto do processo de execução por créditos -, teremos de examinar e ordenar o produto desta atividade estatal conforme os efeitos que cada um deles produz no mundo jurídico, de acordo com o respectivo verbo por meio do qual o ato sentencial reflete a ação de direito material correspondente, contida na demanda, de que a decisão judicial de procedência é conseqüência necessária.

Levando em conta esse critério, divide as sentenças em declaratórias, constitutivas, condenatórias, executivas e mandamentais, "conforme a pretensão material do autor vitorioso seja dirigida a obter a simples declaração de existência ou inexistência de uma determinada relação jurídica; ou tenha por fim sua constituição, modificação ou extinção; ou colime a simples condenação do demandado a cumprir uma obrigação; ou finalmente tenha por objeto obter, desde logo, a realização do direito litigioso no processo de conhecimento, mediante um ato de execução praticado pelo juízo, ou através de um simples mandado ou ordem que o magistrado emita, como porção do conteúdo do ato sentencial."13 Mais adiante, acentua: "Quando se diz que as ações - e as respectivas sentenças de procedencia - podem ser declaratórias, constitutivas ou condenatórias, está-se a indicar ações de direito material afirmadas existentes, na correspondente petição inicial, e que na perspectiva da relação jurídica processual concreta onde elas se apresentam não serão mais do que simples hipóteses de trabalho com que o magistrado se depara" (grifos do original) ${ }^{14}$

4. Claro está que mostra-se insuficiente a vinculação a fatores unicamente processuais. Com razão, pondera Ovídio A. Baptista da Silva, que a "ação" processual una e abstrata não pode ter conteúdo declaratório, constitutivo ou condenatório, sem tornar-se "azioni della tradizione

12 SILVA, Ovídio A. Baptista da. Curso de Processo Civil. 5. ed. rev. e atual. São Paulo: Revista dos Tribunais, 2000, v. 1, p. 92-93.

13 Ibidem, v. 1, p. 112.

14 SILVA, Curso..., v. 1, p. 160. 
civilistica" e prossegue afirmando que "O prodígio de alguma coisa que, não tendo substância, por ser igual a si mesma, e a todos indistintamente concedida, possa ser declaratória, constitutiva ou condenatória, é uma contradição que não chega a ofender a racionalidade dos juristas que lidam com processo." 15

Por outro ângulo visual, a idéia da ação abstrata parece não levar na devida conta que as diversas formas procedimentais reagem também sobre a ação, o agir em juízo, determinando poderes, faculdades e ônus diversos: um só ato é comum a todo o tipo de ação (decorrente do poder abstrato de colocar em andamento o procedimento), mas os outros atos posteriores podem ter dimensão diversa, em razão do objeto do processo, da forma, etc. ${ }^{16} \mathrm{E}$ isso porque não parece possível afastar a ligação com o direito material, em virtude da ínsita instrumentalidade que a função jurisdicional exerce em relação a este, a que servem a ação e o processo, por meio do exercício dos poderes, faculdades e ônus titulados pelas partes.

Todo o processo está impregnado do direito material. Como bem ressalta Fazzalari, o autor alega fatos, mas não qualquer "episódio da vida" e sim fatos que, enquadrando-se no esquema de uma norma, geram determinadas conseqüências jurídicas, deduzindo assim os fatos constitutivos da situação jurídica (substancial) preexistente, e antes de tudo, a situação fática concreta da qual deriva a posição de proeminência em relação ao bem, vale dizer o direito subjetivo (substancial). Trata-se é claro de direito afirmado, que logo passa a ser objeto da controvérsia e termina por se apresentar (na hipótese da sentença de acolhimento) como realidade declarada. ${ }^{17}$ Outro ponto de confluência é o pedido imediato, que contém a especificação da tutela jurisdicional pretendida (declarar, condenar, constituir, mandar, executar), estreitamente vinculada ao direito material. A própria lesão afirmada pelo autor, que conduz à insatisfação de uma situação material protegida e evidencia o interesse na tutela jurisdicional reclamada, diz respeito ao direito material.

Tudo isso demonstra não ser possível emprestar à eficácia da sentença um caráter puramente processual.

5. Por outro lado, tampouco satisfaz a invocação ao conceito equívoco de ação de direito material.

A esse respeito Pontes de Miranda tece as seguintes considerações:

15 SILVA, Ovídio A. Baptista da. Jurisdição e Execução na tradição romano-canônica. São Paulo: Revista dos Tribunais, 1996, p. 179.

16 Assim, FAZZALARI, Elio. Note in tema di diritto e processo. Milano: Giuffrè, 1953, p. 151 , nota 129 .

17 Ibidem, p. 122-123. 
O exercer pretensão, ou ação, ou exceção, que se contém no direito, é exercer o direito. A alguns poderes correspondem ações para se realizarem ou serem 'declarados'. Aqui está um dos pontos mais relevantes da Teoria Geral do Direito: em todo direito, pretensão, ação ou exceção, tem-se como incluido o elemento poder de revelar-se, se alguém obsta ou dificulta ou nega a revelabilidade. Esse poder de revelar-se é actio e corresponde ao conteúdo favorável da sentença quando se exerce a pretensão à tutela jurídica. ${ }^{18}$

A ação (de direito material) é inflamação do direito ou da pretensão. ${ }^{19}$ Por sua vez, "A 'ação' "é outro grau em que já se confere a alguém, autor, titular da ação (nota: ação de direito material), o reclamar, através ou por meio de ato, a verificação, a atuação da lei". ${ }^{20}$ A "ação" exerce-se junto com a ação. ${ }^{21}$

Quando se afirma que "a ação (de direito material) é inflamação do direito ou da pretensão", logo surgem à lembrança as idéias de Savigny, que via a ação de direito material como emanação (Ausfluss) do próprio direito material, confundindo-se com a eficácia deste. Para tanto distinguia ele entre os direitos em si (Rechten an sich), os direitos lesionados (verletzten Rechten) e os direitos em estado de defesa (im Zustand der Vertheidigung), ${ }^{22}$ todos aspectos do direito material. Ao inserir a ação no plano do direito material, tal modo de visualizar o problema deixa obviamente de levar em conta a necessária separação entre os planos do direito material e processual.

Ora, se não é possível afirmar a existência do direito antes do contraditório, muito menos se poderá admitir a "ação material" já no início da demanda. Sua existência só poderá ser averiguada no final do processo, com o trânsito em julgado da sentença, quando então se confundirá com a eficácia da própria sentença.

Para salvar essa evidente contradição, Pontes de Miranda sustenta que o direito à pretensão à tutela jurídica (rectius: pretensão à outorga de justiça) de modo nenhum é pretensão à sentença favorável: $:^{23}$

Se, em vez de se alcançar, com trânsito em julgado, sentença favorável, por ser julgada improcedente a ação (= propôs-

18 PONTES DE MIRANDA, Tratado das..., p., 67.

19 PONTES DE MIRANDA, Tratado das..., p. 116.

20 Ibidem, p. 277.

21 Ibidem, p. 94-95, 110.

22 SAVIGNY. System des heutigen römischen Rechts. Berlin, 1841, v. 5, p. 1-2, §§ 204-205.

23 PONTES DE MIRANDA. Comentários ao Código de Processo Civil. Rio de Janeiro, Forense, 1974, v. 1, p. XXXIV. 
se ação que o demandante não tinha), declara-se a inexistência da ação. Uma vez que o autor não tinha a ação, exerceu pretensão à tutela jurídica, exerceu a pretensão ao remédio iurídico processual, porque não podia esperar sentença favorável quanto à ação de que se supunha ser titular. ${ }^{24}$

A explicação não satisfaz, porque ao mesmo tempo em que se reconhece que o demandante não tinha ação (de direito material) afirma-se que a ação foi exercida pela "ação". Não se pode exercer o que não se tem, é o óbvio.

Ovídio A. Baptista da Silva, por sua vez, concebe a ação de direito material, inerente a todo o direito, como "um agir do titular do direito para sua realização, independentemente da vontade ou do comportamento do obrigado" (grifos do original). ${ }^{25} \mathrm{Em}$ outra passagem, conceitua-a "como o agir próprio de cada direito, capaz independentemente de qualquer participação ativa do obrigado - de realizar inteiramente o respectivo direito". ${ }^{26}$ Acentua, também, que

a realização coativa do direito, com absoluta prescindência da vontade ou da colaboração do obrigado, que se consegue através da jurisdição, é rigorosamente a mesma ação de direito material, ou seja, o mesmo agir para a realização inerente a todo o direito, com a única diferença que, proibida a autotutela privada, a efetivação do direito se dá através da ação dos órgãos estatais. Portanto, longe de haver supressão ou substituição, da ação de direito material, o que em verdade ocorreu foi uma duplicação de ações: uma dirigida contra o obrigado, outra endereçada contra o Estado, para que este, uma vez certificada a existência do direito, o realize coativamente praticando a mesma atividade de que fora impedido seu titular" (grifos do original).27

Apesar da assertiva, casos há em que se torna indispensável a participação ativa do obrigado, o que retira validade ao conceito, ou pelo menos à generalidade que se lhe pretende atribuir. Assim ocorre, por exemplo, como admite Ovídio A. Baptista da Silva, no ato de dar posse ao servidor público, o que inviabilizaria a realização direta, por parte do juiz, do direito reconhecido na sentença. ${ }^{28}$ Ainda, para ser coerente com as idéias que defende, o jurista passou a negar também a existência da ação condenatória, pois o agir realizador da pretensão será a ação de execução, no caso execução obrigacional. ${ }^{29}$ Ressalta

24 Ibidem, p. XLIII-XLIV.

25 SILVA, Curso...., v. 1, p. 80.

26 Ibidem, v. 2, p. 354-355.

27 SILVA, Curso..., v. 2, p. 84-85.

28 Ibidem, v. 2, p. 354-355.

29 Ibidem, v.2, p. 204. 
aí a fragilidade da teoria, pois é inegável que, mesmo na ausência da ação de direito material nessas hipóteses, a sentença (condenatória ou mandamental) continuaria mantendo toda eficácia que lhe é própria.

Por outro lado, não se constata a pretendida duplicação de ações em certas demandas constitutivas, positivas ou negativas, despidas de pretensão material, a exemplo da demanda de divórcio, de anulação de casamento e de interdição. Da mesma forma, impensável a duplicação de ações no que concerne à pretensão declaratória, pois o titular do direito não pode agir por si mesmo para sua realização com ou sem vontade do obrigado: a declaração do próprio interessado de seu próprio direito seria um flatus vocis, tornando-se indispensável a certificação que exsurge da autoridade estatal, com o exercício da jurisdição e o acolhimento da demanda.

Aliás, aliar o conceito de ação de direito material à titularidade do direito ("um agir do titular do direito") já denuncia um certo comprometimento com as teorias imanentistas da ação (Savigny), embora sempre negado.
Uma vez posto em discussão o direito, não se pode ainda falar em sujeito que dele seja titular, mas apenas de pretendente a esse reconhecimento, que poderá ou não ocorrer, dependendo da sorte da sentença.

Além disso, a imanência do direito material, que estaria presente em todas as ações de direito material (observo tratar-se da própria eficácia do direito material), induz a pensar numa concepção intimamente vinculada ao direito justicial material civil de James Goldschmidt (também ele concretista, não se esqueça). Esse direito, integrado pelas normas que regulam a tutela jurisdicional e pelas próprias normas de direito privado, seria totalmente distinto deste último, e entendido não como regulador da conduta dos particulares, mas do juízo e da atividade do juiz. Para o grande jurista alemão, as normas de direito privado se endereçariam ao particular e, ao mesmo tempo, ao juiz, que deveria lhes garantir a atuação, ou, o que resulta no mesmo, regulariam tanto a conduta do particular quanto a sanção que é imposta pelo Estado. ${ }^{30}$ Nessa visão, o direito privado material e o direito justicial material seriam

30 GOLDSCHMIDT, James. Zivilprozessrecht. 2. ed. Berlin, 1932, Aalen, Scientia Verlag, $1969, \S 2,3$, p. 5 (na trad. espanhola de Leonardo Prieto Castro, Barcelona, Labor, 1936, p. 8): "Pode-se compreender o direito como um conjunto de imperativos aos sujeitos de direito e também como medidas de aplicação para o juiz. Esta última concepção é adequada ao direito justicial e também ao direito processual civil. Desse ponto de vista, as regras jurídicas servem como normas inibitórias ou permissivas, de uma determinada conduta por parte dos particulares, e ainda como padrão para uma sentença jurisdicional com determinado conteúdo." 
apenas dois lados de um único e mesmo domínio jurídico. ${ }^{31}$ Mais importante ainda, assim como Savigny trata a acionabilidade como uma questão de direito material, Goldschmidt também atribui à acionabilidade justicial civil um significado material, vinculando-a ao direito material. ${ }^{32}$ Sintomaticamente, a inserção do fenômeno processual no direito material torna o conceito de ação de Goldschmidt semelhante àquele da actio de Savigny. ${ }^{33}$

Como se vê, a concepção de Goldschmidt sujeita-se às censuras, por demais conhecidas, que são efetuadas às idéias de Savigny. Ademais, não padece dúvida de que as normas reguladoras do processo, geralmente de direito público, dirigidas especialmente à função jurisdicional, não se preocupam diretamente com o direito material pretendido, e ao mesmo tempo o sujeito da conduta prevista na norma de direito material certamente não é o órgão judicial. ${ }^{34}$

A mesma crítica pode ser endereçada ao conceito de ação de direito material, que é um agir derivado do direito material (normas dirigidas ao particular), e que mesmo assim seria exercido no processo por meio do órgão judicial, juntamente com a "ação" processual. A idéia de uma norma de conduta que contenha dentro de si o mecanismo de sua própria realização judicial, acaso violada, de modo nenhum

31 GOLDSCHMIDT, James. Über Begriff und Bedeutung des materiellen Ziviljustizrechts (primeiro dos ensaios denominados Zwei Beiträge zum materiellen Ziviljustizrecht). In: FESTGABE für Heinrich Brünner, München, Leipzig: Duncker, Humblot, 1914, p. 109-138, esp. p. 123.

32 GOLDSCHMIDT, Zivilprozessrecht, § 12, 3, p. 52, trad. p. 96: “A ação processual, como objeto concreto do processo (o meritum causae) é um direito justicial de caráter material, não de caráter processual".

33 Observação de KOLLMANN, Andreas. Begriffs- und Problemgeschichte des Verhältnisses von formellem und materiellem Recht. Berlin, Duncker, Humblot, 1996, p. 598.

34 FAZZALARI, Note in tema..., p. 49, criticando o já mencionado pensamento de Goldschmidt, observa com razão que toda atividade, prevista e valorizada em abstrato na norma, tem o seu próprio sujeito, também indicado na norma. Da constância dessa indicação abstrata e típica, chega-se à conclusão de que toda norma concerne a uma certa categoria de sujeitos (aqueles que venham a se encontrar, concretamente, nas condições descritas na norma), a qual pode também coincidir, mas nem sempre e necessariamente coincide com a generalidade dos sujeitos. Nesses termos, se poderá então concluir que existem normas que indicam como sujeito das condutas nelas descritas e valorizadas o juiz; outras, que indicam os particulares; outras ainda, que indicam o legislador, a administração pública e assim por diante. Daí ser impossível sustentar que a norma de direito privado se dirija ao particular e, ao mesmo tempo, ao juiz que deve garantir sua observância; entender, assim, que a norma de qua regule, ao mesmo tempo, a conduta e a sanção. 
se afina com o ordenamento jurídico brasileiro, que distingue claramente $o$ plano do direito material e o plano do direito processual. É como admitir a existência de uma norma de primeiro grau que, ao mesmo tempo, fosse de segundo grau. ${ }^{35}$

Não bastasse isso, não se vê como possa o juiz agir materialmente (exercer ação de direito material, diriam Pontes de Miranda e Ovídio A. Baptista da Silva) de modo paralelo à ação processual: o que ele faz é desempenhar os atos de seu ofício, mediante o exercício dos poderes que lhe são conferidos por regras de direito público, totalmente distintas das regras de direito privado. Só depois de tomada a decisão (seja antecipatória, seja a própria sentença de mérito) é que o juiz pode em tese interferir no mundo sensível, agindo, mas aí já se trata do resultado da tutela jurisdicional, da própria eficácia da sentença. Antes disso, como é óbvio, não teria havido ação de direito material. Mesmo assim, esse agir do juiz não pode ser equiparado, pura e simplesmente, ao agir do particular, dada a natureza diferenciada da tutela jurisdicional e a forma substitutiva de que se reveste, destinada a reconstruir a realidade fora do processo e não apenas a reproduzi-la.
6. Estabelecido não se assentar a eficácia da sentença apenas em considerações de ordem processual e muito menos se confundir com a ação de direito material, mostra-se indispensável ir mais fundo no exame do problema.

Deve-se atentar em que o direito material constitui a matéria prima com que irá trabalhar o juiz, mas sob uma luz necessariamente diversa. $O$ resultado desse trabalho, que é a tutela jurisdicional, refletida na eficácia da sentença, já não apresenta o direito material em estado puro, mas transformado, em outro nível qualitativo. O provimento jurisdicional, embora certamente se apóie no direito material, apresenta outra força, outra eficácia, e com aquele não se confunde, porque, além de constituir resultado de trabalho de reconstrução e até de criação por parte do órgão judicial, exibe o selo da autoridade estatal, proferida a decisão com as garantias do devido processo legal. Tanto é assim que declarar, condenar, constituir, executar ou mandar são verbos que não constam do repertório do direito material. Este fala em indenizar, em resolver contrato, em renúncia de direito, etc. De notar, aliás, que mesmo a autotutela, que seria a ação de direito material em estado puro,

35 Como bem explicita BOBBIO, Norberto. Norme Primarie e Norme Secondarie. In: STUDI per una Teoria Generale del Diritto. Torino: Giappichelli, 1970, p. 196, em complementação ao pensamento de Santi Romano, os numerosos mecanismos ou engrenagens, os coligamentos de autoridade e força, que produzem, modificam, aplicam e garantem as normas jurídicas constituem também eles normas, exatamente as normas de segundo grau. 
não se equivale, como é óbvio, à tutela jurisdicional, porque ainda sujeita a futura e eventual revisão judicial, despida que é do selo da autoridade estatal, realizada de forma parcializada pelo próprio interessado, sem as garantias do devido processo legal.

Nesse contexto, a eficácia se apresenta apenas como uma forma da tutela jurisdicional, outorgada a quem tenha razão, seja o autor, seja o réu (sentença declaratória negativa). ${ }^{36}$

Por outro lado, a distinção entre as diversas espécies de tutela jurisdicional não é arbitrária.

Deve-se atender, essencialmente, aos princípios da efetividade ${ }^{37}$ e da segurança (este derivado do próprio
Estado de Direito e representado pelo conceito de "devido processo legal"), ambos com matriz constitucional, e ainda à situação jurídica substancial afirmada. Esses princípios informadores é que determinam as espécies possíveis de tutela jurisdicional in abstracto.

Concretamente, a tutela vai depender ainda do pedido formulado pelo autor e das exceções de direito material suscitadas pelo demandado, assim como da configuração (constitucional, material e processual) específica de cada ordenamento jurídico, que constituem todavia elementos externos ao conceito abstrato. Em razão do princípio dispositivo, mostra-se possível a existência de espécies

36 Em outra perspectiva, observa acertadamente YARSHELL, Flávio Luiz., Tutela Jurisdicional Específica nas obrigações de Declaração de Vontade. São Paulo: Malheiros, 1993 , p. 19, que mesmo se pensando em tutela exclusivamente como proteção, ainda assim ela terá estado evidentemente presente em face do vencido na exata medida em que o Estado lhe assegurou, através do exercício da função jurisdicional e do devido processo legal, a resolução do conflito segundo regras pré-estabelecidas e garantidoras de sua participação (procedimento em contraditório) no resultado final da decisão, decisão essa prolatada por julgador cuja imparcialidade vem, inclusive, revestida de inafastáveis garantias de modo a impedir a supremacia do mais forte sobre o mais fraco.

37 Embora já seja um lugar comum, mantém toda a atualidade a consideração fundamental de CHIOVENDA, Giuseppe. Della azione nascente dal contratto preliminare. In: SAGGI di diritto processuale civile. Roma: Foro Italiano, 1930, v. 1, p. 110, no sentido de que "il processo deve dare per quanto è possibile praticamente a chi ha un diritto tutto quello $\mathrm{e}$ proprio quello ch'egli ha diritto di conseguire." MARINONI, Luiz Guilherme Tutela Inibitória (individual e coletiva). 3. ed. São Paulo: Revista dos Tribunais, 2003, p. 449, embora defendendo posição diversa, acentua que a tutela jurisdicional deve ser classificada a partir do que efetivamente faz para atender ao direito material, e não apenas em razão da espécie do efeito jurídico declarado, ressaltando que a preocupação deve se centrar com o resultado que o processo deve proporcionar para que a tutela seja efetivamente prestada ao jurisdicionado. A respeito da efetividade e sua moldura constitucional, as magníficas observações de GUERRA, Marcelo Lima. Execução Indireta. São Paulo: Revista dos Tribunais, 1998, p. 48-54. 
diversas de demandas e de sentenças para uma mesma relação de direito material. Como exemplo pode ser apontada a possibilidade de declaração da relação jurídica, mesmo tendo ocorrido a violação do direito, permitida no art. $4^{\circ}$, parágrafo único, do CPC. A violação do direito, em tese, poderia dar lugar também a demanda mandamental, condenatória ou executiva. Nem por isso, pode-se afirmar, em face das considerações já desenvolvidas, que a classificação das sentenças (ternária ou quinária) constitua um fenômeno puramente processual. ${ }^{38}$

Presentes essas coordenadas, deve ser dada preferência à tutela que conceda a maior efetividade possível. Ao ângulo visual da segurança, importa fundamentalmente possa o direito de defesa do demandado ser exercido de maneira adequada. ${ }^{39}$ A situação jurídica substancial afirmada não deve impedir, outrossim, a eficácia pretendida.

Veja-se, por exemplo, a questão das obrigações de dar dinheiro. Em tal hipótese, a tutela condenatória é a mais adequada, visto que a futura execução por meios sub-rogatórios, por ela proporcionada, em regra é a mais efetiva.

O campo propício ao emprego da tutela mandamental é o dos direitos absolutos, porque estes fazem surgir o dever negativo de abstenção, de não invadir a esfera jurídica alheia, de alterum non laedere. ${ }^{40}$

Inexiste, porém, qualquer razão, como bem pondera Luiz Guilherme Marinoni, ${ }^{41}$ para se estabelecer uma relação necessária entre direitos absolutos e sentença mandamental. Também as obrigações de fazer e não fazer podem ser objeto de tutela mandamental. Mesmo no que concerne aos direitos relativos se reconhece hoje o dever de abstenção: todos os direitos são relativos em relação ao objeto e absolutos no que concerne a sua inviolabilidade (oponibilidade) por parte dos sujeitos do ordenamento. A distinçã̃o está na forma como podem ser realizados ou exigidos: os absolutos realizam seu conteúdo independen-

38 Como preconizam, v.g., ROSENBERG; SCHWAB. Zivilprozessrecht. 12. ed. München: Beck, 1977, §93, 3, p. 478.

39 Às vezes, impõe-se ao juiz a ponderação entre esses dois valores, como sucede com a tutela de urgência, mas a observação é realizada apenas de passagem, porque este estudo está centrado nas eficácias decorrentes da sentença no processo de conhecimento. 40 MARINONI, Tutela.., p. 415.

41 Ibidem, p. 418. TALAMINI, Eduardo. Tutela Relativa aos Deveres de Fazer e de Não Fazer. São Paulo: Revista dos Tribunais, 2001, p. 125-127, com base em amplo estudo da doutrina do direito civil, relativiza a distinção entre deveres e obrigações, preconizando acertadamente a aplicação do art. 461 do CPC tanto aos deveres quanto às obrigações de fazer e não fazer. 
temente da colaboração alheia; os relativos, na relação com outros sujeitos, cujo comportamento é instrumental para sua realização. ${ }^{42} \mathrm{~A}$ explicação é válida em parte, porque nas obrigações de fazer não está em causa o dever de abstenção. Aqui, a tutela mandamental encontra justificativa no princípio da efetividade.

De qualquer modo, a questão foi grandemente facilitada no direito brasileiro, em razão do novo tratamento do cumprimento das obrigações de fazer ou não fazer operado pelo art. 461 do CPC e especialmente, quanto ao ponto, por seu $\S 1^{\circ}$ (Lei 8.952, de 13.12.1994). Por essa norma, deu-se a inversão do princípio Nemo praecise poteste cogi ad factum (ninguém pode precisamente ser coagido a fazer alguma coisa): "A obrigação somente se converterá em perdas e danos se o autor o requerer ou se impossível a tutela específica ou a obtenção do resultado prático correspondente."Afastou-se, assim, a leitura equivocada dos glosadores, privilegiando-se, do ponto de vista do direito material, o respeito à força do negócio jurídico ou do contrato, banidos é claro os meios que violentem a pessoa ou a dignidade do devedor, permitindo-se o constrangimento indireto.

Se a obrigação de fazer é personalíssima, só realizável pelo obrigado (e.g., prestação de obra de arte ou científica), ou se foi convencionado no negócio jurídico que o cumprimento não seria específico, mostra-se adequada a tutela condenatória. $\mathrm{Na}$ obrigação de fazer fungível, que por hipótese pode ser prestada por terceiro às custas do obrigado, $\mathrm{o}$ autor pode escolher entre a sentença condenatória e a mandamental. Esse o sentido da multa estabelecida pelo art. 287 do CPC (redação de acordo com a Lei 10.444, de 7.5.2002). ${ }^{43}$

A tutela declaratória só pode se relacionar com a declaração da existência ou inexistência de uma relação jurídica (excepcionalmente: falsidade de documento). A declaração de um mero fato ou do alcance de uma norma jurídica abstratamente considerada, hipóteses em que não se verifica incidência concreta da norma jurídica sobre o suporte fático, comprometeria a garantia de ampla defesa do demandado, seja porque um mesmo fato pode ser relevante para inúmeros e diversos efeitos jurídicos, seja porque a norma geral e abstrata pode ser aplicada numa série indefinida de situações concretas. ${ }^{44}$

A tutela executiva lato sensu diz respeito apenas à agressão ao próprio patrimônio do autor - linha divisória entre tutela executiva lato sensu e a

42 Cf. COMPORTI, Marco. Diritti reali in generale, p. 26-27, apud MARINONI, op. cit., p. 417 .

43 MARINONI, Tutela..., p. 460-462, com base especialmente no princípio da efetividade. 44 PISANI, Andrea Proto. Appunti sulla Giustizia Civile. Bari: Cacucci, 1982, p. 92-94. 
tutela condenatória (Pontes de Miranda) - porque a agressão de patrimônio alheio requer, por hipótese, maiores possibilidades de defesa (princípio da segurança).

A tutela mandamental, embora atue como a executiva lato sensu, por meio de emissão de ordens do juiz, desta se diferencia porque age sobre a vontade da parte e não sobre o seu patrimônio. Assim o exige a situação jurídica substancial porque a natureza da obrigação não recomenda, dentro da idéia da maior efetividade possível, o emprego da tutela condenatória. ${ }^{45}$

Realmente, tanto a tutela executiva lato sensu quanto a mandamental atendem ao princípio da maior efetividade possível. Basta pensar em relação a esta última que o resultado específico não poderia ser obtido mediante a simples condenação, porquanto conduziria apenas à obtenção do equivalente em dinheiro, com o emprego dos meios sub-rogatórios de execução.

De outro lado, não parece adequado confundi-las com a tutela condenatória sob o argumento de que esta também contém ordem de prestação, variando apenas a forma de realização. ${ }^{46} \mathrm{E}$ isso porque a sentença condenatória não contém ordem de cumprimento da prestação, mas somente juízo de reprovação. Trata-se apenas de exortação ao cumprimento da obrigação, tanto é assim que o descumprimento não está sujeito a qualquer sanção penal ou civil.

Pretende-se, ainda, como já foi ressaltado no início deste ensaio, que a sentença mandamental constitui título para a execução forçada, tanto quanto a condenação ordinária - e assim é também uma condenação, só se diferenciando no conteúdo da sanção imposta em seu segundo momento, na qual se exacerba o fator comando, ou mandamento. ${ }^{47}$ Todavia, a diferença está no próprio conteúdo da sentença, porque os dois verbos mandar e condenar são totalmente distintos, com conseqüências jurídicas distintas: o mandamento atua sobre a vontade do demandado, por meios de coerção, a condenação tende a atuar sobre o patrimônio, em outro processo futuro (efeito executivo da condenação), mediante meios sub-rogatórios. Ora, segundo a melhor doutrina, na primeira hipótese não se trata de verdadeira execução, porque a satisfação do credor é obtida com' a colaboração do devedor, constrangido a cumprir sua obrigação para evitar males maiores. ${ }^{48}$

45 De modo diverso, entende MARINONI, op. cit., p. 398, que o critério que permite definir a mandamentalidade é puramente processual.

46 É a posição de THEODORO JúNIOR, Curso..., v. 1, nº 497, p. 468-469, nº 499, p. 470, já mencionada ao início deste trabalho.

47 DINAMARCO, Instituições..., n 919, p. 242-243.

48 Cf., por exemplo, LIEBMAN, Enrico Tullio. Processo de Execução. 3. ed.. São Paulo, Saraiva, $n^{\circ} 3$, p. 6. 
Cumpre ainda sublinhar que as cinco espécies de tutela (declaratória, condenatória, constitutiva, mandamental e executiva lato sensu) constituem todas, fenômenos jurídicos, mas é preciso considerar que as sentenças declaratórias e constitutivas satisfazem por si mesmas a pretensão processual, sem necessidade de qualquer ato material futuro; a condenatória fica a meio caminho, criando apenas as condições jurídicas, com a constituição do título executivo, para que tal possa ocorrer em processo autônomo e

\section{REFERÊNCIAS}

BOBBIO, Norberto. Norme Primarie e Norme Secondarie. In: STUDI per una Teoria Generale del Diritto. Torino: Giappichelli, 1970.

CHIOVENDA, Giuseppe. Della azione nascente dal contratto preliminare. In: SAGGI di diritto processuale civile. Roma: Foro Italiano, 1930. v. 1

DINAMARCO, Cândido Rangel. Instituições de Direito Processual Civil. 2. ed. São Paulo, Malheiros, 2002. v. 3.

FAZZALARI, Elio. Note in tema di diritto e processo. Milano: Giuffrè, 1953.

GOLDSCHMIDT, James. Über Begriff und Bedeutung des materiellen Ziviljustizrechts (primeiro dos ensaios denominados Zwei Beiträge zum materiellen Ziviljustizrecht). In: FESTGABE für independente, dito de execução; as duas últimas satisfazem no mesmo processo, por meio de atos materiais, realizados depois da sentença, aptos a produzir alterações no mundo fático.

Finalmente, em se cuidando de tutela mandamental ou executiva lato sensu, o ofício jurisdicional só se considera cumprido e acabado com a realização do direito reconhecido na sentença. $\mathrm{O}$ art. 463 do CPC implica apenas veto a que depois de publicada a sentença de mérito possa o juiz alterá-la.

Heinrich Brünner, München, Leipzig: Duncker, Humblot, 1914.

. Zivilprozessrecht. 2. ed. Berlin, 1932.

GUERRA, Marcelo Lima. Execução Indireta. São Paulo: Revista dos Tribunais, 1998.

KOLLMANN, Andreas. Begriffs- und Problemgeschichte des Verhältnisses von formellem und materiellem Recht. Berlin, Duncker, Humblot, 1996.

LIEBMAN, Enrico Tullio. Processo de Execução. 3. ed. São Paulo, Saraiva.

PISANI, Andrea Proto. Appunti sulla Giustizia Civile. Bari: Cacucci, 1982.

PONTES DE MIRANDA. Comentários ao Código de Processo Civil. Rio de Janeiro, Forense, 1974. v. 1. 
- Tratado das Ações. São Paulo: Revista dos Tribunais, 1970. v. 1. ROSENBERG; SCHWAB. Zivilprozessrecht. 12. ed. München:Beck, 1977.

SAVIGNY. System des heutigen römischen Rechts. Berlin, 1841.

SILVA, Ovídio A. Baptista da. Curso de Processo Civil. 4. ed. São Paulo: Revista dos Tribunais, 2000.v. 1, v. 2. . Jurisdição e Execução na tradição romano-canônica. São Paulo: Revista dos Tribunais, 1996.
TALAMINI, Eduardo. Tutela Relativa aos Deveres de Fazer e de Não Fazer. São Paulo: Revista dos Tribunais, 2001.

THEODORO JÚNIOR, Humberto. Curso de Direito Processual Civil. 39. ed. Rio de Janeiro: Forense, 2003. v. 1.

YARSHELL, Flávio Luiz. Tutela Jurisdicional Especifica nas obrigações de Declaração de Vontade! São Paulo: Malheiros, 1993. 



\title{
Condições da ação no processo penal
}

\author{
Carlos Menegat Filho*
}

Segundo a doutrina de Liebman, a qual influenciou a dogmática processual brasileira, são estas as condições da ação: a possibilidade jurídica do pedido, o interesse em agir e a legitimação para a causa.

Discute-se se elas abarcariam o mérito da ação ou não. Embora alguns juristas possam defender essa tese, ela não nos parece correta, pois, ao estudarmos as condições da ação, supõe-se que, mesmo estando presentes aquelas condições, ainda é necessário um segundo momento, ou seja, um julgamento, de procedência ou não do pedido, produzindo a coisa julgada material.

Portanto, a inexistência de condições da ação terá como consequiência a carência da ação, mas que todavia não produzirá coisa julgada material, podendo, pois, ser novamente proposta se for completado o elemento da ação faltante. Pelo exposto, não podemos colocar as condições da ação como fazendo parte do mérito, já que este tem em sua base a coisa julgada.

Assim, onde deveríamos inseri-las? Pensamos que o seu lugar ideal seria entre os pressupostos processuais e $o$ mérito propriamente dito, numa categoria intermediária, podendo então ter tratamento diferenciado, consistindo na existência da procedibilidade do processo, bem como na inexistência de coisa julgada material.

No exame da verificação das condições da ação, afloram duas teorias doutrinárias: a) que o exame da ação deva ser feito à luz da realidade dos fatos e b) que esse exame deva ser feito à luz das alegações do autor, tão somente.

No que tange à segunda posição divergimos frontalmente, eis que as

* Professor de Ciências Penais na Faculdade de Direito da UFRGS. 
afirmações constantes da peça inicial e que dão origem ao processo devem ser consideradas como meras afirmações de direito. Assim, a existência ou não das condições da ação devem ser analisadas à verdade dos autos, como um todo e não somente nas alegações do autor.

Nessa mesma linha de raciocínio, destaca Ada Pellegrini Grinover: "Não é possível rotular a mesma circunstância, ora como condição de admissibilidade da ação, ora como mérito, justificando as decisões de uma ou de outra forma, consoante o momento procedimental em que forem proferidos. Não acolhemos a teoria da prespectazzione: as condições da ação não resultam da simples alegação do autor, mas da verdadeira situação trazida a julgamento".

Ao darmos essa visão panorâmica e geral nas. condições da ação no processo, podemos trabalhar melhor os seus elementos, mais especificamente no processo penal, pois sua natureza diverge, em alguns pontos, do processo civil. E notaremos essas diferenças na própria classificação dos elementos das condições da ação, já que o processo penal não segue os três elementos clássicos da teoria de Liebman, ou seja:

a) Possibilidade jurídica do pedido;

b) Interesse em agir;

c) Legitimação para a causa.
Contudo, é preciso avaliar um quarto elemento: a justa causa.

Então, urge que analisemos mais precisamente esses elementos:

\section{POSSIBILIDADE JURÍDICA DO PEDIDO}

A idéia da possibilidade jurídica do pedido como condição da ação se deve a Liebman, que com esse termo pretendeu conceituar a idéia de possibilidade em abstrato do provimento solicitado. No Direito Penal, a aplicação da própria lei obedece ao princípio da legalidade, ou seja: "Não há crime sem lei anterior que o defina. Não há pena sem prévia cominação legal".

Logo, para aplicar-se uma pena privativa de liberdade, a conduta do autor tem que estar tipificada como crime, quer definindo a conduta, quer impondo a sansão penal e, previamente, impondo uma pena. Sem essas condições seria impossível iniciar-se uma ação penal. Imaginemos um promotor de justiça iniciar uma ação penal denunciando alguém por clonagem de seres vivos. Ora, se tal fato não está previsto no CP como crime, há absoluta impossibilidade de sua existência.

Da mesma forma se considera como impossibilidade jurídica do pedido, a ação proposta com falta do ato prévio. Assim, a ação penal pública condicionada exige a representação da vítima ou

1 GRINOVER, Ada Pellegrini. As condições da ação penal. São Paulo: Bushatsky, 1997, p. 126. 
a requisição do ministro da Justiça, pois sem esses elementos faltarão condições à ação, já que inexiste possibilidade jurídica do pedido, não podendo ter prosseguimento a ação penal.

\section{INTERESSE EM AGIR}

Quanto ao "interesse em agir", assim se referia Chiovenda: "sem a intervenção dos órgãos disciplinadores o autor sofreria um dano injusto."2 Liebman assim pontificava: "Consiste no interesse de obter o provimento demandado". ${ }^{3}$

Podemos resumir, então, o interesse de agir em necessidade e adequação do provimento solicitado. Na lição do eminente jurista José Maria Rosa Tesheiner em sua valiosa obra Elementos para uma Teoria Geral do Processo, ${ }^{4}$ aponta o "interesse em agir" como necessidade para obter através do processo a proteção do interesse substancial, pressupondo, por conseqüência, a lesão desse interesse e a idoneidade do provimento solicitado.

Segue o mestre: "Às vezes não é tanto a necessidade quanto a utilidade que se encontra na base do interesse de agir. Pode ocorrer, por exemplo, que o poder executivo, embora podendo emitir e executar ato administrativo, prefira, por motivos políticos solicitar o provimento jurisdicional como tem mandado de reintegração de posse em terras públicas invadidas. Não há necessidade, mas utilidade, e esta basta para que se componha o interesse em agir".

No processo penal, o interesse em agir encontra-se no momento em que é ofertada a própria ação, pois não é possível impor uma sanção pènal sem o devido processo penal. Cabe aqui lembrar o ensinamento de Ada Pellegrini Grinover de que "no interesse de agir não deve tratar a do direito material alegado (pedido idôneo amparado em provas) já que são distintos o direito de ação e o direito material."'s

\section{LEGITIMAÇÃO PARA A CAUSA}

A ação só pode ser exercida pelos seus titulares, pois eles é que são as pessoas legítimas a proporem a ação (legitimação ativa) contra outros (legitimação passiva). Então vemos que existem duas legitimações: a passiva e a ativa. E quem são essas pessoas legítimas? No dizer do professor

2 CHIOVENDA, Giuseppe. Instituições de direito processual civil. São Paulo: Saraiva, [s.d.], v. 1, p 181, 1365.

3 LIEBMAN, Enrico Túlio, Manual de direito processual civil . [s.n.t.], v. 1.

4 TESHEINER, José Maria Rosa. Elementos para uma teoria geral do processo. São Paulo: Saraiva, 1993.

5 GRINOVER, As Condições... 
Tourinho Filho, ${ }^{6}$ são aquelas que são titulares de uma situação jurídica material.

No processo penal, a titularidade se dará pela lei ou a titularidade é vista em face do conflito de interesses e não do direito que se pretende reconhecer, ou seja, quando o interesse maior for o público, a ação penal será pública e o titular o MP; quando for privado, o interesse maior será privado e então o - titular será o ofendido ou seus representantes.

A legitimação passiva, por sua vez, obriga que o réu seja também legitimado para a ação, isto é, deve ele poder receber a ação penal que é proposta. Assim, não haveria legitimação para a causa de uma ação penal de roubo proposta pelo Ministério Público, em que o réu fosse menor de dezoito anos.

\section{JUSTA CAUSA}

Este é o quarto elemento das condições da ação penal. O Processo Penal apresenta esse elemento que não faz parte da doutrina do Processo Cível pela própria natureza jurídica do Processo Penal. O Direito Penal é visto como a ultima ratio, sendo que o Processo Penal já representa uma forma de penalidade, pois desde o início da ação penal até o julgamento desta, o réu, sujeito passivo na relação processual penal, será exposto a execração pública até provar a sua inocência, podendo chegar à condenação e, como conseqüência, perder um dos direitos básicos do ser humano, que é a liberdade, o direito de ir, vir, ficar e permanecer, sendo muitas vezes, colocado em cárceres que destroem a integridade física e psíquica do homem, fazendo com que a re-socialização do indivíduo e sua recuperação para viver em sociedade, que é um dos objetos na execução penal, se torne letra morta.

Por isso é que se reveste de importância o processo penal, mormente no que tange às condições da ação, pois a simples instauração do processo como já vimos pelas suas conseqüências, atinge a dignidade humana. Não podemos admitir que qualquer fato permita essas conseqüências que abordamos. A ação penal, portanto, só deve ser desencadeada com fatos inequívocos, ou seja, elementos que permitam concluir pelo fumus boni juris, sem o qual não existirá justa causa, não podendo desencadear a ação penal.

Mas o que é a justa causa? São provas mínimas que devem estar presentes quando do oferecimento da ação penal.

E que provas são essas? Prova da materialidade e indícios suficientes da autoria, pois sem essas provas não poderá ser instaurado o Processo Penal, face à evidência da coação ilegal. (648, I do CPP).

6 TOURINHO FILHO, Fernando da Costa. Manual do processo penal. São Paulo: Saraiva, 2001, p. 136. 
A prova da materialidade é aquela que demonstra a consumação do crime, admitindo-se a forma indireta.

Exemplificando: a materialidade num homicídio é o auto de necropsia; a de lesões corporais graves é o auto de corpo de delito. Tais provas, nesses delitos, devem necessariamente estar presentes no oferecimento da denúncia.

E se não existirem tais provas? Deve, então, ser feito de maneira indireta. Por exemplo, através de testemunhas que viram o homicídio ou as lesões corporais. Esse tipo de prova, inclusive, está previsto no art. 158 do CPP.

Então, seja de forma direta ou indireta ela deve vir aos autos. O que não pode acontecer é a falta de prova de materialidade. Exemplo: todas as pessoas numa certa comunidade acham que foi determinada pessoa que cometeu um homicídio, só que o corpo da vítima nunca foi achado e nem teve testemunhas presenciais para realizar o auto de necropsia indireto; assim, não é possível instaurar a ação penal por falta de justa causa no que tange à materialidade.

Mas não basta a materialidade, deve haver indícios suficientes de autoria.

E quando há indícios suficientes de autoria? Bem, nesse caso, existe um critério subjetivo do juiz; todavia, podemos afirmar que são aquelas provas mínimas que apontam o acusado como sendo o autor do crime imputado.

Desta forma, não basta apenas termos a prova da materialidade. Exemplo: o auto de necropsia. É necessário que tenhamos elementos mínimos (seja testemunhal, pericial ou quaisquer outras provas admitidas em direito) que apontem para o acusado como sendo o autor do crime.

É importante ressaltar que a justa causa (prova da materialidade e indícios suficientes de autoria) não diz respeito ao mérito. $O$ juiz não está antecipando qualquer tipo de julgamento, ele apenas está fazendo um juízo de admissibilidade, ou seja, observando se esse requisito se encontra na proposição da ação para que possa ser recebida e processada.

Podemos, então, colocar a justa causa como elemento, independente dos demais da teoria clássica, apresentada por Liebman, em virtude da natureza do objeto do Processo Penal.

Senão vejamos:

Admitamos que Alfredo, Promotor de Justiça na primeira vara do Tribunal do Júri de Porto Alegre-RS, tenha uma discussão áspera com Luiz, o advogado, na saída do fórum. Então, Alfredo resolve "denunciar" Luiz por um suposto homicídio doloso, descrevendo todas as circunstâncias, conforme art. 41 do CPP, sem, no entanto, demonstrar a materialidade ou indícios de autoria, entregando, mesmo assim, a denúncia.

No presente caso podemos, em tese, vislumbrar:

a) Há possibilidade jurídica do pedido, já que o homicídio está previsto no art. $121, \S 1^{\circ}$ do CP.

b) O interesse em agir está implícito na própria ação penal, presente o seu 
interesse no provimento jurisdicional, já que em tese um crime praticado e em não se vislumbrando excludente, deve ser punido.

c) A legitimação também está presente aqui - pelo representante do MP, no caso uma ação penal pública incondicionada.

Portanto, se analisarmos apenas pela ótica da teoria clássica, o juiz deveria, em tese, receber a denúncia proposta e citar o réu para se defender,

\section{REFERÊNCIAS}

CHIOVENDA, Giuseppe. Institulações de direito processual civil. São Paulo: Saraiva, [s.d.]. v. 1.

GRINOVER, Ada Pellegrini. As condições da ação penal. São Paulo: Bushatsky, 1997. o que evidentemente seria um absurdo. Por isso defendemos a existência do quarto elemento, que é a justa causa existente no processo penal, tendo em vista as suas peculiaridades.

No presente caso, não estariam contidas as condições da ação, justamente pela falta de justa causa, não podendo o magistrado receber a denúncia e dar início à ação penal, porque, caso o fizesse, estaria incorrendo em coação ilegal.

LIEBMAN, Enrico Túlio, Manual de direito processual civil . [s.n.t.]. v. 1. TESHEINER, José Maria Rosa. Elementos para uma teoria geral do processo. São Paulo: Saraiva, 1993. TOURINHO FILHO, Fernando da Costa. Manual do processo penal. São Paulo: Saraiva, 2001. 


\title{
Revisitando a tutela do consumidor nos precedentes históricos e no Direito pátrio
}

\author{
Carlos Silveira Noronha*
}

\section{DOS PRECEDENTES HISTÓRICOS}

No concerto histórico-universal os bens de consumo e serviços sempre estiveram presentes na vida do ser humano, como exigência necessária, material, fisiológica, psicológica e hedonística da humanidade, no endereço à satisfação de suas necessidades. Pode-se conceber a presença da relação de consumo e dos seus elementos compositivos (fornecedor-consumidor - produto de consumo) nos mais recônditos tempos da ancestralidade, ainda que nas origens imemoriais da pessoa humana se pudesse confundir a individualidade do produtor com a do consumidor, como se pode supor dos relatos bíblicos do Gênesis, quando o
Criador impôs a Adão a sentença divina "ganharás o pão com o suor do teu rosto".

Essa realidade não escapou à percepção dos espíritos mais agudos da Antigüidade Clássica, pois se sabe que, em época áurea da cultura romana (século I a.C.), propusera Cícero fosse assegurada garantia ao comprador de mercadoria eivada de vício oculto, adquirida em razão de anúncio ou apregoação de qualidades não verdadeiras, à instância do vendedor, ${ }^{1}$ podendo aí configurar-se a fonte mais remota dos vícios redibitórios.

No direito moderno, a tutela do consumidor acelerou-se a partir do epílogo do anterior e início do presente século, sob o influxo da chamada Revolução Industrial. Os mecanismos

\footnotetext{
* Professor titular de Direito Civil da Faculdade de Direito da UFRGS; especialista, mestre e doutor em Direito pela USP.

1 Cícero, De officiis, 3.17.76, in Oeuvres complètes de Cicéron, Paris, Ed. Garnier, s.d.
} 
criados para a sua proteção espraiamse por três grandes sistemas: o da common law o da civil law e o socialista. Este último, no entanto, não oferece maior interesse para as comunidades do mundo ocidental, por estar sujeito a modelos econômicos e políticos bem diversos.

As primeiras experiências modernas situam-se efetivamente na família dos sistemas da common law, através de construções da jurisprudência, com base na equity, inicialmente no sistema inglês e posteriormente no sistema norteamericano, onde podem ser destacados os casos Longmeid v. Holliday, em 1851, e Donoghue v. Stevenson, em 1932, cujas sentenças foram proferidas pela House of Lords, na Inglaterra, bem como os casos Thomas $v$. Winchester, em 1852, e Mac Pherson v. Buick Motor Co., em 1916, nos Estados Unidos, em tema de responsabilidade do fabricante pelo fato do produto. Nessas hipóteses, os tribunais prolatores das sentenças, amparandose num dever geral de diligência (duty of care) que o fabricante devia ter perante terceiros, no processo de fabricação e distribuição dos seus produtos, superaram o princípio do privity of contract, que havia sido consagrado no caso Winterbottom $v$. Wright, julgado em 1842. ${ }^{2} \mathrm{No}$ âmbito da reparação no sistema norte-americano, o mecanismo mais utilizado é a class action, originária do direito inglês e introduzida no direito estadunidense com a Federal Equity Rule 38, de 1912 , onde atingiu maior relevância a partir da Regra 23 das Federal Rules of Civil Procedure, de 1938. As mais importantes eram a true class action, a hybrid class action e a spurious class action, que sofrem adaptações para utilização nos tribunais estaduais. ${ }^{3}$

No direito europeu-continental, a tutela do consumidor nasceu com maior vigor na França, onde, ao abordar a doutrina dos contratos, Saleilles invocava, em 1901, a necessidade de maior proteção do aderente, diante do desprestígio do princípio da autonomia da vontade, em razão da disparidade de forças entre as partes nos contratos de adesão. ${ }^{4}$ Foi ali que também nasceu, no contexto do sistema de direitos caracterizador da família civil law, o primeiro diploma positivo para proteger o consumidor - a lei de $1^{\circ}$ de agosto de 1905 -, que visava reprimir todos os embustes sobre a qualidade, quantidade, origem e distorções no preço dos

2 Luiz Gastão Paes de Barros Leães, A responsabilidade do fabricante pelo fato do produto, São Paulo, Saraiva, 1987, p. 29-47.

3 José Rogério Cruz e Tucci, "Class action" |e mandado de segurança coletivo, São Paulo, Saraiva, 1990, p. 11-2.

4 Carlos Alberto Bittar, Os contratos de adesão e a defesa do consumidor, RTJESO, 122:26-38. 
produtos, praticados por fabricantes ou comerciantes inescrupulosos. ${ }^{5}$

A França, como não tivesse, então, codificação específica sobre o assunto, desde o início do século vinha editando um elenco de importantes diplomas legislativos com o objetivo de enfrentar as relações de consumo. Tais são as Ordonnances n. 45-1483 e 45-1484, de 30 de junho de 1945, que estabelecem regras sobre a fixação do preço das mercadorias; a Loi Royer, n. 73-1193, de 27 de dezembro de 1973, que instituiu as ações coletivas; as Leis Scrivener n. 78-22 e 78-23, de 10 de janeiro de 1978, que proscreveram as cláusulas abusivas nos contratos, e muitas outras. ${ }^{6} \mathrm{Na}$ atualidade tem a França seu Code de la consommation, editado com a Lei n. 93-949, de 26.07.1993.

Outros países, como a Suécia com o seu Consumer Ombudsman, de 1969, a República Federal Alemã, com a $A G B$-Gesetz, de 9 de dezembro de 1976 , a primeira lei a proscrever as cláusulas abusivas; Portugal, com a sua Lei de Defesa do Consumidor (Lei $n$. 29/81, de 22-8-1981); a Espanha, com a sua Ley General para Defensa de los Consumidores y Usuarios, n. 26/ 84, de 19 de julho de 1984; e, finalmente, as Diretivas da Comunidade Econômica Européia para a disciplina das relações de consumo nos países que a integram, completam o elenco normativo acerca da proteção do consumidor no Velho Continente.

$\mathrm{Na}$ América Latina, o México foi o primeiro Estado a editar diploma legal pertinente ao assunto, o qual se acha consubstanciado na Lei Federal de Proteção ao Consumidor, de 5 de fevereiro de $1976 .{ }^{7}$

No Brasil, a proteção do consumidor apresenta-se como tema novo, quase contemporâneo aos nossos dias. Efetivamente, só a partir da Revolução de 1930 começa a despertar a consciência nacional no sentido de abandonar o liberalismo político, econômico e jurídico fundado na igualdade formal dos postulados iluminísticos, que desde muito já haviam olvidado o outro postulado, o da fraternidade, evocado pela Revolução Francesa. E essa tomada de consciência, a par da insatisfatória evolução cultural, social e política,

\footnotetext{
5 Bernard Bouloc, La loi de 1905 en tant qu'instrument de la sécurité des consommateurs, in Sécurité des consommateurs et responsabilité du fait des produits défecteux (Colloque des 6 et 7 novembre 1986, organisé par le Centre de Droit des Obligations de l'Université de Paris I, Pantheon Sorbonne), dir. Jacques Ghestin, Paris, LGDJ/R. Pichon et R. DurantAuzias, 1987, p. 13.
}

6 Philippe Malinvaud, La protection du consommateur en droit français, Revista de Direito Comparado Luso-Brasileiro, Rio de Janeiro, Forense, 5:41-58, 1986.

7 Carlos Alberto Bittar, Direitos do consumidor, Rio de Janeiro, Forense Universitária, 1990, n. 7, p. 11-4. 
tornou-se ainda mais penosa diante da intervenção do Estado no conflito mundial de 1939-1945, que trouxe sérios transtornos à sua economia e desenvolvimento em todos os setores da vida nacional. No contexto econômico, teve o povo que enfrentar e não raro se submeter ao recrudescimento de um capitalismo anterior a 1939 , senão a 1914, dominado por grandes grupos empresariais integrados entre si, formando monopólios ou oligopólios impositores dos preços ao consumidor, de modo que a concorrência resultava apenas aparente, com real subversão desse princípio basilar da chamada economia de mercado. ${ }^{8}$

Tais acontecimentos, aliados aos estágios intermitentes de instabilidade política por que passou o País nesse período pós-guerra, fizeram com que a conscientização do povo quanto à satisfação de suas necessidades em direção a uma melhor qualidade de vida enfrentasse obstáculos muito sérios.

\section{DA TUTELA DA RELAÇÃO DE CONSUMO, EM GERAL}

O vocábulo tutela, traduz a idéia de amparo, proteção, defesa, apoio e guarda, em sentido genérico. Sua origem etimológica está na palavra homógrafa do nominativo latino tutela, tendo sido usada na acepção jurídica por Cícero, em Pro Caecina. E, com tal semântica, trasladou-se para a linguagem jurídica moderna, passando a significar, neste ramo do conhecimento científico, a proteção que a ordem jurídica se propõe a conferir às pessoas, aos bens e às relações que dela venham a necessitar para se resguardar das ameaças de lesão dos seus direitos ou para se recuperar de lesões efetivamente sofridas.

$\mathrm{Na}$ verdade, há na relação de consumo, como em outros setores da ordem jurídica, uma bipolarização da tutela, que se opera em dois planos: $n o$ plano do direito material e no plano da jurisdição.

\subsection{Da tutela do consumidor no plano do direito material}

De notar, inicialmente, que a noção de direito individual vem cedendo espaço à noção de direito social em decorrência da elevação deste último à categoria de direito de segunda geração, pertencente à escala dos direitos fundamentais, notadamente em face do surgimento da concepção de Estado Social (Welfare state), nos tempos modernos. Assim, a partir do segundo quartel do século $X X$, vêm se destacando do direito subjetivo individual clássico os chamados direitos supraindividuais (difusos e coletivos).

Diante de tal perspectiva, para analisar os mecanismos de tutela do

8 Sobre o assunto, v. Luiz Otávio de Oliveira Amaral, História e fundamentos do direito do consumidor, RT, 648:31-45. 
consumidor no plano do direito material, dividimo-la em dois setores: o legislativo e o administrativo.

\subsubsection{Dos mecanismos legislativos}

A tutela dos direitos do consumidor no Brasil, no âmbito legislativo, constitui tema deveras recente, não obstante tenham surgido a partir do segundo quartel do século recém findo algumas leis que, embora visando a proteção a outros segmentos da vida social e econômica, tenham ensejado uma tutela indireta às relações de consumo. No modelo legislativo, sem dúvida, reside a fonte normativa para os demais tipos de tutela aos direitos do consumidor, como de resto o seria para qualquer outra atividade. Aqui se manifesta essencialmente a função do Estado-legislador.

A primeira dentre as leis desse tipo pode-se identificar no Código Civil de 1916, com a disciplina dos vícios redibitórios (arts. 1.101 a 1.106), instituição essa de características nitidamente clássicas que vinha cuidando da qualidade do produto mediante a mesma ótica, instituída desde o sistema romano, onde adquiriu suas características atuais. Apesar disso e se não estivesse inserto em sistema jurídico dominado pelo relativismo contratual estabelecido no artigo 928 do Código Civil de 1916, e pela teoria da culpa estatuída no artigo 159 , o instituto poderia ter oferecido melhor tutela aos interesses do consumidor, como ocorreu na França com a action en garantie de vices cachés, de que trata o artigo 1.648 do Code Civil, o qual, com os suprimentos introduzidos pela jurisprudência, vinha dando efetiva proteção aos ditos interesses, como informa Mazeau, in Leçons, tome trezième, p. 808-812, Ed. Monchresten, 1966. Atualmente o tema está regulado pelo Code de la consommation (Lei n. 93949, de 26.07.1993). Mas, no panorama nacional, a ação redibitória limitava-se a alguns alargamentos do prazo decadencial curtíssimo do então artigo $178, \S 2^{\circ}$, do Código anterior, pela ação dos tribunais. Nada mais além disso.

Entre nós, outras leis de cunho protetivo da população têm sido editadas. Começaram com a Lei da Usura (Dec. n. 22.626/33), limitativa da taxa de juros e das cláusulas penais, mas os juros passaram, para as instituições financeiras, a ser liberados ao talante do Conselho Monetário Nacional, instituição pública de características liberais, criada pela Lei da Reforma Bancária (art. $3^{\circ}$ da lei n. 4.595/64), com apoio na súmula 596 do Supremo Tribunal Federal. Seguem-se o decreto-lei n. 869/38, que define e penaliza os crimes contra a economia popular e abusos do poder econômico; a chamada Lei da Economia Popular (lei n. 1.521/51), ampliando o diploma anterior; a Lei de Repressão ao Poder Econômico (lei n. 4.137/62), que cria o Conselho Administrativo de Defesa Econômica - CADE, para a repressão do abuso e regular a concorrência. 
Toda essa gama de diplomas legislativos dirigiu-se para a disciplina normativa de outros segmentos setoriais da economia e da comunidade. E, não obstante tivesse por escopo a melhoria da qualidade da vida nacional, não ofereceu senão tutela indireta ou reflexa aos direitos do consumidor.

Em termos de legislação protetiva indireta, mister se faz referir, por fim, a teoria do abuso de direito, originária da jurisprudência francesa, que não foi acolhida pelo Código Civil pátrio de 1916, uma vez que na época ainda não se havia firmado uma proteção mais efetiva do consumidor, devido à prevalência ainda muito forte do direito subjetivo individual clássico. O novo Código Civil, certamente inspirado no art. 334 do Código português, cuida do abuso de direito no art. 187 , cuja redação é a seguinte: Também comete ato ilícito o titular de um direito que, ao exercêlo, excede manifestamente os limites impostos pelo seu fim econômico ou social, pela boa-fé ou pelos bons costumes. Entendem alguns civilistas, entre os quais o saudoso Prof. Carlos Alberto Bittar, que há lesões de direitos do consumidor nas quais se caracteriza o abuso de direito, razão por que resultaria aplicável essa disposição do direito pátrio, para salvaguarda do mesmo. ${ }^{9}$

Tal proteção só passou a ser encarada com maior seriedade no Brasil a partir do último quartel do século passado e mais precisamente nos primeiros albores da década de $80, \mathrm{com}$ a legitimação do Ministério Público para a propositura da ação civil pública (LC n.40/81) e a completa disciplina desta pela lei n. 7.347/85, bem como através do decreto n. $91.469 / 85$, editado concomitantemente à mesma lei, criando o Conselho Nacional de Defesa do Consumidor - CNDC, para a formação e condução da política nacional de defesa do consumidor. Mas, a par desta última providência de natureza legislativa, visando estruturar uma consciência nacional de proteção ao consumidor, e ainda que a lei da ação civil pública estendesse sua disciplina a esse mister, como integrante dos chamados interesses difusos, carecia ainda a comunidade nacional de normatização política fundamental e de um estatuto específico para cuidar das relações de consumo.

A primeira carência foi substancialmente suprida pela Carta Política de 1988 (arts. $5^{\circ}$, XXXII, e 170, V; disposições constitucionais transitórias, art. 48), que integrou o Brasil no concerto das nações mais preocupadas com a tutela do consumidor, cujos cuidados com o mister se projetam ainda que timidamente, desde o início do século anterior. Parece não restar dúvida de que o legislador constituinte foi sensível à recomendação da $\mathrm{ONU}$, na Resolução n. 39/248, de 10 de abril

9 Carlos Alberto Bittar, Os contratos de adesão e o sancionamento de cláusulas abusivas, RT, 648:17-20; Responsabilidade civil, Forense Universitária, 1989, n. 47, p. 54-5. 
de 1985, ao recomendar que Os governos devem desenvolver, reforçar ou manter uma política de proteção ao consumidor; e em outra passagem: Os governos devem prover ou manter uma infra-estrutura adequada para desenvolver, implementar e orientar a política de proteção ao consumidor.

A segunda recomendação materializou-se, com muita ênfase e efetividade entre nós, com a edição do Código de Defesa do Consumidor (lei n. 8.078, de 11-9-1990), contendo ampla disciplina quanto aos direitos gerais e básicos do consumidor, relação de consumo, proteção contratual, responsabilidade civil do fornecedor, estilos de publicidade, defesa administrativa e processual.

\subsubsection{Dos mecanismos administrativos}

Aqui, a função do Estadoadministrador, atividade primária, que se consubstancia no poder-dever de gestão da coisa pública, como munus publicum que lhe é próprio, independentemente de provocação do súdito interessado. ${ }^{10}$ Nesse sentido, pode-se mais uma vez invocar a frase já tantas vezes repetida de que administrar é aplicar a lei de oficio."
Como ocorreu na França, desde os primórdios do século passado, a primeira preocupação do Estado em tema de proteção ao consumidor deve ser de conteúdo pedagógico, no sentido de informá-lo e educá-lo para enfrentar a batalha do consumo, satisfazendo as suas necessidades dirigidas para uma melhor qualidade de vida e precavendose contra os males do consumismo e contra os desequilíbrios contratuais tão freqüentes nas relações de consumo. Esses princípios, propostos por John Kennedy perante o Congresso dos Estados Unidos em 1962, foram admitidos pela Comissão de Direitos Humanos das Nações Unidas, em sua $29^{a}$ Sessão, realizada em Genebra, em 1973, como direitos fundamentais e universais do consumidor. ${ }^{12}$ De tão grande relevância são consideradas a informação e a educação dos consumidores em Portugal e Espanha, de tal modo que nas suas leis específicas introduziram esse tema como matéria obrigatória em programas oficiais de ensino público (art. $8^{\circ}$ da lei portuguesa n. $29 / 81$ e art. 18 , n. 2, da lei espanhola n. 26/84). E, nos Estados Unidos, desde há algum tempo, são ministrados programas educacionais para treinamento de pessoal especializado na

10 Rodolfo de Camargo Mancuso, Comentários ao Código de Proteção do Consumidor, São Paulo, Saraiva, 1991, p. 271-2.

11 Cf. Miguel Seabra Fagundes, em sua conhecida monografia $O$ controle dos atos administrativos pelo Poder Judiciário.

12 Luiz Otávio de Oliveira Amaral, História e fundamentos do direito do consumidor, $R T$, 648:32. 
matéria consumer affair, bem como para educar e orientar o consumidor, pelo Consumer's Education Office.

Outros organismos de proteção ao consumidor têm surgido no concerto internacional. Dentre tais, podem ser arrolados, a título de exemplificação: a Carta do Consumidor; a Federal Trade Commission, órgão máximo do sistema federal; a Food and Drug Administration; o Attorney General e a Commission criada pelo Federal Consumer Product Safeties Acts, nos Estados Unidos; Ombudsman do consumidor, na Suécia e em outros países escandinavos; o Institut National de la Consommation, na França; o Instituto National del Consumidor, no México; a Prokuratura nos ordenamentos socialistas; o Instituto Nacional de Defesa do Consumidor, em Portugal; o Instituto Nacional del Consumo, na Espanha, etc.

No Brasil, o primeiro diploma diretamente destinado à tutela administrativa e também de natureza pedagógica no que diz com a atividade e relações de consumo é o decreto $n$. 9.469/85, editado coevamente à lei da Ação Civil Pública e alterado pelo decreto n. 94.508/87. O primeiro desses diplomas normativos criou o Conselho Nacional de Defesa do Consumidor CNDC, como órgão de assessoria à Presidência da República, para a formulação e condução da política nacional de defesa do consumidor, com competência específica para promover e incentivar medidas e campanhas de formação e informação do consumidor, quanto à escolha do produto adequado à satisfação de suas necessidades e compatível com a sua capacidade econômica, visando extrair da relação de consumo os melhores benefícios possíveis, disposição essa hoje presente também na lei específica ( $\operatorname{art} .4^{\circ}, \mathrm{IV}$, do Código de Defesa do Consumidor).

Objetivava ainda o diploma legal referido a formulação de uma política global de consumo, a criação, a transformação e a coordenação dos órgãos fiscalizadores em todos os níveis da esfera administrativa, celebrar convênios com entidades nacionais e estrangeiras dedicadas à defesa do consumidor; solicitar a abertura de inquérito policial à Polícia Federal, representar perante o Ministério Público a ocorrência de lesões aos direitos do consumidor e outras atribuições várias. O referido órgão foi atingido pela Reforma Administrativa no âmbito federal, sendo substituído por outro.

$\mathrm{Na}$ esfera administrativa do Governo da União convivem cerca de trinta e dois órgãos dedicados direta ou indiretamente à tutela dos interesses do consumidor, de modo a se constatar, às vezes, verdadeiro tumulto administrativo ou paralelismo burocrático capaz de entravar a dinâmica dos serviços. Dentre os principais órgãos podem ser mencionados o Departamento Nacional de Defesa do Consumidor, o Conselho Administrativo de Defesa Econômica (CADE), a Associação Brasileira de Normas Técnicas, o Conselho Nacional 
de Metrologia, Normalização e Qualidade Industrial (Conmetro), a Superintendência Nacional do Abastecimento (SUNAB), a Companhia Brasileira de Alimentos (Cobal), etc.

$\mathrm{Na}$ esfera estadual, predominam geralmente os PROCONs, podendo ser criados outros órgãos protetivos dos consumidores locais, segundo estabeleçam os critérios políticos de cada unidade federada.

Restam ser mencionadas as associações de consumidores, como entidades, agora incentivadas pela lei atual (arts. $4^{\circ}$, II, $a$, e $5^{\circ}, \mathrm{V}$, do Código de Defesa do Consumidor), que poderão constituir-se sob o modelo de associações civis, na forma da lei civil (arts. 53 a 61, do Código Civil atual), mediante registro de seus atos constitutivos no Ofício do Registro Civil das Pessoas Jurídicas.

\section{DOS MECANISMOS NO ÂMBITO DO PODER JUDICIÁRIO PARA A TUTELA DO CONSUMIDOR}

Aqui se manifesta a função do Estado-juiz, mediante a qual se instituem os mais completos e eficazes instrumentos de tutela dos interesses ou direitos do consumidor, exercidos pelo Poder Judiciário. Essa é a clássica divisão de funções públicas do Estado, de legislar, de administrar e de judicar, espraia-se pelas diversas sedes da codificação especial. Nesta última função, o Estado não age esponta- neamente como nas demais, uma vez que a atuação jurisdicional está sujeita ao princípio geral ne procedat iudex ex officio, consagrado no ordenamento processual geral (art. $2^{\circ}$ do CPC).

Outra singularidade a ser ressaltada é que na codificação especial dá-se predominante relevo à defesa coletiva do consumidor, como salienta enfaticamente o art. 81 e seu parágrafo único, certamente por compreender o legislador que a defesa dos direitos individuais do consumidor, envolvendo conflitos intersubjetivos (v.g., Tício versus Caio), já se encontra naturalmente regulada pela lei geral, o Código de Processo Civil, e em certas leis extravagantes, como as referentes às locações de imóveis urbanos (lei n. 8.245/91), aos alimentos (lei n. 5.478/68), aos direitos autorais (lei n. 5.988/73), à proteção da criança e do adolescente, denominada Estatuto da Criança e do Adolescente (lei n. 8.069/90) e outras.

A doutrina prevalente no Código de Defesa do Consumidor funda-se nitidamente na idéia de coletivização da defesa dos direitos que contemporaneamente vem suplantando a concepção individual fundada no direito subjetivo. Manifestações dessa tendência, que abundam nos sistemas jurídicos alienígenas, também já se vinham esboçando no direito pátrio, como sóe acontecer com as experiências da ação popular (lei n. 4.717/ 65); da ação civil pública (lei n. 7.347/ 85); das ações coletivas, tais como o dissídio coletivo (arts. 856 e 857 da 
CLT); e da ação de cumprimento (art. 872, parágrafo único, da CLT), na área trabalhista, exercidas pelo sindicato; do mandado de segurança coletivo (art. $5^{\circ}$, LXX, da CF); e do mandado de injunção (art. $5^{\circ}$, LXXI, da CF).

Em tema de mecanismos judiciários, para implementar a efetiva tutela dos direitos do consumidor, caberia ao legislador nacional a escolha de uma entre três opções: criar modelo próprio, filiar-se ao modelo romano-germânico ou ao sistema da common law, já que o outro sistema, o socialista, tem menor identidade jurídica, social e política com o nosso.

O modelo da common law, que envolve o sistema inglês e o norteamericano, ampara-se fundamentalmente na equity, com antecedentes no Bill of Peace do século XVII. Transfunde-se na relator action da experiência inglesa e australiana e na class action do modelo norteamericano, extensíveis também a outros interesses difusos que não os do consumidor. Funda-se em sistema de ações, que, embora peculiar à família common law, é habitualmente representado pelo aforismo construído pelos romanistas ubi actio, ibi ius.

O paradigma europeu-continental, fundado em sistema de direitos e não de ações, que se expressa pelo aforismo ubi ius, ibi actio, é fonte do nosso sistema e por isso com ele guarda maior identidade.

Na elaboração do Código de Defesa do Consumidor, o legislador não criou nem modelo próprio, nem modelo novo. Preferiu recolher as experiências ora do sistema europeu-continental, ora do norte-americano. Assim é que as três ações coletivas de que trata o art. 81, parágrafo único, do Código pátrio assemelham-se, em sua estrutura, à action civile colletive do sistema francês, criada com a Lei Royer (lei n. 73-1193, de 27-12-1973), e à ação coletiva do sistema alemão.

Por outro lado, no que diz com o tipo de tutela produzida, assemelhamse as nossas ações à class action norte-americana. Com efeito, a ação coletiva para a defesa dos interesses difusos (inc. I do art. 81) assemelha-se à true class action; a mesma ação para a defesa de interesses coletivos (inc. II) assemelha-se à hybrid class action; e a ação do mesmo tipo para a tutela dos direitos individuais homogêneos (inc. III) assemelha-se à spurious class action. ${ }^{13}$

Aqui não se pode deixar de registrar que, enquanto nos Estados Unidos a class action pode ser proposta por um ou mais membros da classe, independentemente da organização do grupo

13 Sobre o assunto, v. José Rogério Cruz e Tucci, Class action, cit., p.21; Ada Pellegrini Grinover, A tutela jurisdicional dos interesses difusos no direito comparado, in A tutela dos interesses difusos, São Paulo, Max Limonad, 1984, p. 79-80; Pierre Godé, Dictionnaire juridique - consommation, Paris, Dalloz, 1983, p. 18-21. 
como pessoa jurídica, bastando a prova do interesse comum apreciada livremente pelo juiz, as ações coletivas dos sistemas alemão, francês e brasileiro só podem ser promovidas por associações de consumidores juridicamente constituídas ou pelas pessoas do direito público indicadas no art. 82.

\subsection{Do acesso do consumidor à justiça}

Não obstante os postulados ou princípios do livre acesso aos órgãos judiciários, da inafastabilidade do processo judicial para o deslinde dos litígios, do devido processo legal e da gratuidade de justiça aos necessitados, consagrados genérica ou especificamente na Carta Política brasileira (art. $5^{\circ}$ ), nem sempre os consumidores conseguem chegar às portas dos tribunais para obter a tutela dos seus direitos.

O enfoque da expressão hoje tão em voga acesso à Justiça ${ }^{14}$ supõe a persecução de um duplo escopo, que se consubstancia no acesso aos procedimentos adequados à vindicação dos direitos e na solução das desavenças sob os auspícios do Estado. $\mathrm{O}$ primeiro constitui indubitavelmente pressuposto do segundo, que se identifica na justa solução dos litígios, um dos escopos político-sociais do Welfare
State. Assim, o acesso ao Poder Judiciário diz prioritariamente com o primeiro objetivo, mas, ao persegui-lo, não se pode perder de vista o segundo, que é o desiderato final.

Esse primeiro passo para o alcance do deslinde do litígio é que deve ser indistintamente franqueado à população do Estado, na qual se insere o indimensionável contingente dos consumidores e para os quais o acesso $\grave{a}$ Justiça constitui direito básico (art. $6^{\circ}$, VII, do CDC).

O projeto de acesso à Justiça deve estar armado de mecanismos capazes de superar as dificuldades naturais e ínsitas à própria individualidade do consumidor, qual a de ser solitário, sempre desarmado de poder político e econômico e bloqueado por fatores psicológicos que lhe tolhem a iniciativa. Esses fatores negativos podem ser ainda agravados por carências culturais ou por desconhecimento técnico de problemas com os produtos indispensáveis à sua sobrevivência, de modo a infundirem no espírito do consumidor verdadeiro sentimento de inferioridade em relação ao produtor.

Além desses, há ainda que se atentar para as questões do desinteresse do pleito pela exigüidade da lesão, os "mistérios" do processo na ótica laica, a lentidão da Justiça, que

14 Sobre o tema "acesso à justiça", v. Mauro Cappelletti e Bryant Garth, Acesso à justiça, trad. Port. de Ellen Gracie Northfleet, Porto Alegre, Sérgio A. Fabris, Editor, 1988, passim; Stiglitz, Contratos por adhesión, cláusulas abusivas y protección al consumidor, Buenos Aires, Depalma, 1985, p. 251-65. 
ainda não se desvencilhou completamente das amarras do princípio dispositivo imperante nos séculos XVIII e XIX, bem como a escassez de recursos econômicos para o enfrentamento das despesas forenses.

O laissez-faire que caracterizou o vasto período individualista dos últimos séculos vem sendo superado, com maior velocidade no pós-guerra 19391945, a partir dos novos conceitos acerca dos direitos humanos e do reconhecimento da sobrelevação dos direitos sociais em relação aos individuais, que se encontram inscritos em todas as declarações de direitos e nos pórticos das Cartas Políticas, dentre as quais não se pode deixar de referir a francesa de 1946 e a brasileira de 1988.

$\mathrm{O}$ direito de acesso à Justiça modernamente erige-se em fenômeno sócio-político que se coloca como pressuposto necessário à universalização da tutela jurisdicional, a que o Estado moderno persegue e que está presente não só nas preocupações dos cientistas políticos, mas também nas proposições dos processualistas. ${ }^{15}$

O enfoque de tais preocupações há muito deixou de ser exclusivo do direito individual, centrado no direito subjetivo clássico, para alcançar os direitos ou interesses difusos e coletivos. Nessa idéia de coletivização do acesso à
Justiça incluem-se os direitos do consumidor, de tal modo que os entraves com que este se deparava, para a efetivação desses direitos, vêm sendo amenizados mediante a criação de novos mecanismos postos à sua disposição, tais como a gratuidade de justiça, a instituição de órgãos judiciários mais dinâmicos como os Juizados Especiais (lei n. 9.099/95); a flexibilidade dos procedimentos; a legitimação ativa de associações de consumidores; a inversão do ônus da prova; o redimensionamento do instituto da coisa julgada, etc.

Mas todos esses fatores concebidos pela doutrina em geral para superar as ditas dificuldades do consumidor no pleito dos seus direitos, poderão, no Brasil, lamentavelmente esbarrar nos formidáveis problemas que o Estado enfrenta com a administração da Justiça, cuja organização e praxes judiciárias se encontram secularmente plantadas, sem melhorias capazes de acompanhar a evolução dos tempos, com seus estilos, modismos, vícios e cacoetes cartoriais, de tal modo a causar certo cansaço, justificável desânimo, senão ameaçadora desesperança para as pessoas mais desarmadas de poder exercitarem seus direitos.

Não basta o puro e simples acesso à Justiça e a instituição de ações

$15 \mathrm{O}$ fenômeno diz estreitamente com a efetividade do processo. Sobre o assunto, v. Cândido Rangel Dinamarco, $A$ instrumentalidade do processo, n. 36.1, 36.2 e 36.3, p. 391 434; v. também Adolfo Gelsi Bidart, Proceso y época de cambio, Revista de Estudios Procesuales, Rosario, Centro de Estudios Procesuales de Rosario, 1974, v. 19. 
típicas e as outras tantas reformulações realizadas pelo Código de Defesa do Consumidor, mas é preciso também que se criem juízos rápidos, aumentando o número de juizados especiais ao lado de um esforço global de conscientização dos espíritos para que se assimile a necessidade de atuação célere da Justiça, como a última trincheira onde se albergam as esperanças do homem comum.

Exemplos inequívocos dessa predisposição de espíritos hão de ser colhidos no continente europeu, já no início do presente século. Informa-nos Adolf Wach, com a sua autoridade, que na Alemanha, logo após a edição da $Z P O$, cerca de $30 \%$ dos processos perante os tribunais de primeira instância, os Amtsgerichte e os Landsgerichte, duraram menos de três meses; quase $60 \%$ com solução em menos de seis meses; e quase $10 \%$ resolvidos em menos de um ano. ${ }^{16}$

Fenômeno semelhante ocorreu na Áustria, após a entrada em vigor do Código de F. Klein, em 1898. Segundo a mesma fonte, cerca de $40 \%$ dos processos foram solucionados em menos de um mês, mais de $50 \%$ em torno de seis meses, e em prazo superior a um ano apenas uma percentagem entre $0,4 \%$ e $1,2 \% .^{17}$

Esses fatos deveram-se à estreita adequação da organização judiciária dos dois referidos Estados, que consagrava a colegialidade dos seus tribunais para fazer atuar o processo oral e concentrado, admitido nas suas respectivas codificações processuais.

No Brasil, o problema da morosidade forense vem sendo, ainda que modestamente, solucionado através de dois expedientes governamentais de ordem legislativa que já contam com previsão legal expressa: a criação de novos juizados especiais e de varas especializadas, além dos já existentes, para solucionar litígios de consumo, para o que já existe autorização constitucional que institui a competência genérica, da União, dos Estados e dos Territórios, para a criação de juizados especiais, providos por juízes togados e leigos, competentes para a conciliação, julgamento e execução de causas cíveis de menor complexidade.

Quanto aos primeiros, já existe bom número em funcionamento na Justiça dos Estados e também na Justiça Federal, com resultados muito satisfatórios. Tantos outros quantos necessários podem ser criados pela União, Estados e Distritos Federal, cujo procedimento deve orientar-se pelos canais da oralidade, da simplicidade, da informalidade, da economia, da celeridade e da conciliação das partes desavindas, segundo as expressas disposições da lei especial (art. $2^{\circ}$, da lei n. 9.099, de 26.09.1995).

16 Mauro Cappelletti, Procédure orale et procédure écrite, Milano, Giuffre, 1971, p. 60 e 62. 17 Mauro Cappelletti, Procédure, cit., p. 63. 
Em tal tipo de procedimento, o juiz poderá contar com a colaboração de conciliadores e juizes leigos, ${ }^{18}$ (lei $n$. $9.099 / 95$, arts. $5^{\circ}, 6^{\circ}$ e $7^{\circ}$ ), no qual estão praticamente contemplados todos os mecanismos de que dispunham os Códigos da Áustria e da Alemanha, no início do século, e que os levaram aos sucessos acima relatados.

A Constituição atual (art. 98, I) permite que tais órgãos sejam singulares ou coletivos, competentes para a conciliação das partes e que atuem mediante o procedimento oral e sumário, rematando por adotar o princípio do único grau de jurisdição para o julgamento de recursos, caso em que o Juízo deverá ser necessariamente colegiado na forma disposta no artigo $41, \S 1^{\circ}$, da lei . 9.099/95.

Com tais providências, que já estão sendo tomadas pelas autoridades responsáveis, vem o Código de Defesa do Consumidor obtendo razoáveis condições de aplicabilidade e alcançando os escopos para os quais foi criado.

\subsection{Dos mecanismos típicos e atípicos de tutela jurisdicional do consumidor}

Para tutelar os direitos ou interesses do consumidor, o legislador especial foi colher elementos nos paradigmas oferecidos pelos ordenamentos jurídicos vinculados às famílias civil law e common law, elaborando, nesse mister, um verdadeiro trabalho de síntese em que conjugou os modelos do sistema romano-germânico, retirados especialmente das experiências francesa e alemã, com os do sistema anglo-americano, notadamente extraídos deste último modelo, como já foi referido acima (item 3.1).

Passemos, pois, à análise particularizada dos mecanismos jurisdicionais coletivos e individuais adequados para tutelar os interesses ou direitos dos consumidores na área do processo civil.

\subsubsection{Da tutela coletiva}

No âmbito do processo de conhecimento, criou o legislador cinco ações coletivas em prol da proteção do consumidor que podem ser consideradas ações típicas. Tais são as três ações coletivas do art. 81, parágrafo único, I, II e III, a ação de responsabilidade civil do fornecedor de produtos e serviços dos arts. 101 e 102, todos do Código de Proteção e Defesa do Consumidor, e a ação civil pública disciplinada pela lei n. 7.347/85.

A ação civil coletiva, de que trata o art. 81, parágrafo único, I, criada à semelhança da true class action norteamericana, constitui ação típica, destinada à tutela dos interesses ou direitos difusos, como tais entendidos os de natureza transindividual ou metaindividual, indivisíveis, de que

18 Cândido Rangel Dinamarco, Manual das pequenas causas, São Paulo, Revista dos Tribunais, 1986, n.5-9, p. 9-11. 
sejam titulares pessoas indeterminadas e indetermináveis, ligadas por circunstância de fato.

A tutela produzida por este tipo de mecanismo processual é de caráter inibitório da materialização da ação danosa do demandado, quando esta ainda não se tiver iniciado, ou da sua suspensão, quando parte do resultado danoso já se tiver produzido. Porém, no caso de seu objeto constituir o cumprimento de obrigação de fazer ou não fazer, dois outros tipos de tutela podem-se produzir segundo as hipóteses veiculadas pelo art. 84 e seus $\S \S 1^{\circ} \mathrm{e}$ $2^{\circ}:$ a) a tutela será reparatória, quando se cuidar de obrigação personalíssima e o juiz impuser ao obrigado o cumprimento da prestação in natura, ou, na impossibilidade desta, a sua conversão em perdas e danos, ou, quando não for personalíssima, o seu cumprimento através de terceiro, às custas do obrigado; b) a tutela será sancionatória, no caso do cumprimento da prestação pelo equivalente ser cumulado com a pena pecuniária (astreintes) prevista nos arts. $287 \mathrm{e}$ 644-645 do Código de Processo Civil.

A eficácia erga omnes, que the atribui a lei (art. 103, I, do CDC), projeta-se por amplo espectro, em face da indimensionável multiplicidade de sujeitos que venham a ter seus interesses protegidos. Consulta, pois, um dado subjetivo. Tem, no entanto, sua ampliação subjetiva máxima obviamente limitada à totalidade da população estatal, pelo simples fato de que a jurisdição só é eficaz, em regra, aos súditos do Estado e aos estrangeiros que contingencialmente gozem da sua proteção. Por outro lado, a limitação mínima da sua abrangência diz com um dado objetivo, pois restará subordinada a uma circunstância de fato espacial que dimensionará o prejuízo que determinado produto ou serviço venha a causar à saúde, ao bem-estar, etc., da população de certa cidade, ou região, ou país.

Este o sentido do efeito erga omnes de que se ocupa o art. 103, I, e que se opera secundum eventum litis pela circunstância de que, no caso de improcedência da ação, por insuficiência de prova, pode ela ser renovada por qualquer interessado, mediante nova prova. Esta é uma conotação excepcional, criada pela lei especial, que distoa da eficácia da coisa julgada, no processo comum.

A ação civil coletiva de que trata o art. 81, parágrafo único II, criada à semelhança da hybrid class action norte-americana, é outra ação típica que se dirige à proteção dos interesses ou direitos coletivos, definidos legalmente como tais os transindividuais de natureza indivisível, de que seja titular grupo, categoria ou classe de pessoas ligadas entre si ou com a parte contrária por relação jurídica base.

A tutela por esta produzida não difere, por sua natureza, da anterior, pois é também meramente inibitória do ato antijurídico, se o prejuízo ao direito do consumidor ainda não se tiver materializado. 
Porém, nas hipóteses reguladas pelo art. 84 e $\S \S 1^{\circ}$ e $2^{\circ}$, a ação civil coletiva, neste passo analisada, produzirá tutela do tipo reparatório, ou, ainda, tutela sancionatória, nos mesmos casos examinados acima, para a ação coletiva na defesa de direitos ou interesses difusos. Aqui, como na hipótese anteriormente tratada, a aplicação da sanção ao demandado, sob a modalidade de astreintes, poderá ser feita ex officio pelo juiz, quando for relevante o fundamento da demanda e houver justificado receio de ineficácia do provimento final (art. 84, $\S \S 3^{\circ} \mathrm{e} 4^{\circ}$ do $(D C)$, casos em que a lei especial derrogou o princípio da iniciativa particular do ne procedat iudex ex officio, a que está sujeita essa providência perante a lei processual comum (arts. $2^{\circ}$ e 287 do CPC).

A eficácia ultra partes proclamada pelo Código de Defesa do Consumidor (art. 103, II) para este tipo de tutela jurisdicional, transcende aos intervenientes na demanda judicial, mas limita-se ao grupo, categoria ou classe de indivíduos abrangidos pela relação iurídica base que os vincula entre si, ativa ou passivamente, podendo-se espelhar tal perspectiva na hipótese, $v$. g., do fornecimento de produtos ou serviços, cujas relações de consumo estejam subordinadas a certas condições estipuladas em convenção coletiva de consumo firmada entre entidades representativas de fornecedores e consumidores, a teor do art. 107 do Código de Defesa do Consumidor.
Não há outros dados objetivos para limitá-la, senão os contornos territoriais em que exerce a jurisdição estatal e o elemento qualitativo do prejuízo dos consumidores por ela alcançados.

A ação civil coletiva, de que trata o art. 81, parágrafo único, III, criada à semelhança da spurious class action, a terceira ação típica, destina-se à proteção dos chamados interesses ou direitos individuais homogêneos, como tais entendidos os que têm origem comum. Os direitos lesados não se enquadram entre os difusos, nem os seus titulares estão vinculados entre si por uma relação jurídica básica, podendo, por isso, ser identificados à medida que ingressam no feito, como litisconsortes, em decorrência da ciência do processo especial pela publicação de edital no órgão oficial ou pelos meios de comunicação social praticados entre os consumidores (art. 94 do CDC).

Neste caso, a tutela dos direitos ou interesses do consumidor é essencialmente reparatória, quando se cuidar da indenização de danos patrimoniais sofridos individualmente pelo consumidor. Mas poderá ser de natureza sancionatória, quando se tratar da proteção de direitos ou interesses tuteláveis pela ação civil pública de que trata a Lei n. 7.347/85 (art. 99 e parágrafo único do $\mathrm{CDC}$ ), ou quando decorrer um ano da sentença condenatória sem que haja habilitação de interessados em número compatível com a gravidade do dano (art. 100 e parágrafo único do $\mathrm{CDC}$ ). Nestes dois 
últimos casos, o valor da indenização não se destinará diretamente aos prejudicados, mas será recolhido ao Fundo criado pela Lei n. 7.347/85 e regulamentado pelo Decreto n. $92.302 /$ 86 , conforme dispõem os arts. 99 e 100 e seus respectivos parágrafos únicos do Código de Defesa do Consumidor.

No caso de procedência da ação proposta, a sentença produzirá efeitos erga omnes, para beneficiar todas as vítimas e seus sucessores (art. 103, III do $\mathrm{CDC}$ ), mesmo que não tenham participado do processo. Porém, se a ação for julgada improcedente, os interessados que não se tenham integrado ao processo especial, como litisconsortes, poderão intentar ação de indenização a título individual $\left(\operatorname{art.} 103, \S 2^{\circ}\right.$ ).

A última ação de conhecimento, típica, prevista pelo Código de Proteção e Defesa do Consumidor, é a ação de responsabilidade civil contra o fornecedor de produtos e serviços, fundada genericamente na regra do art. $6^{\circ}$, VI, e especificamente na dos arts. $101 \mathrm{e}$ 102, que pode ser individual ou coletiva. Constitui o mecanismo processual adequado a ensejar o ressarcimento dos prejuízos sofridos pelo consumidor contra o fornecedor e os demais coresponsáveis pelo fato do produto e do serviço (arts. 12 a 17 do CDC), ocorrendo tal responsabilidade independentemente de culpa, salvo os casos indicados no $\S 3^{\circ}$ do artigo 12 .

$\mathrm{O}$ legislador omitiu-se quanto à regulamentação da ação de responsabilidade do produtor pelos vícios de qualidade ou de quantidade do produto ou do serviço, também chamados vícios de inadequação, que os tornem inadequados ao uso e consumo (arts. 18 a 23). Apesar disso, a lacuna poderá ser suprida pelos instrumentos processuais atípicos oferecidos pela lei processual comum, aplicável subsidiariamente, segundo o artigo 90, do CDC, de que trataremos logo a seguir, como também em face da amplitude da regra do art. 83, ao dispor que "para a defesa dos direitos e interesses protegidos por este Código são admissiveis todas as espécies de ações capazes de propiciar sua adequada e efetiva tutela". Ademais, poderá a jurisprudência, mediante construção própria, oferecer seus suprimentos, ao se defrontar com a aplicação dinâmica desse microssistema.

Tais ações têm sua origem em construções magistrais da jurisprudência anglo-saxônica, fundadas no dever de diligência do fabricante (duty of care), e da jurisprudência alemã, fundadas na culpa organizativa da empresa (Organisationsverschuld), tendo como caso padrão a sentença do Supremo Tribunal alemão (Bundesgerichtshof), no famoso caso da "peste dos frangos" (Hühnerpest Urteil), quando o tema da responsabilidade civil do fabricante adquiriu maioridade no direito tedesco. No sistema anglo-saxônico, há precedentes firmes, no âmbito do direito inglês, a partir do caso Longmeid v. Holliday, em 1851, mas a evolução jurisprudencial 
culminou com a sentença proferida pela House of Lords, no caso Donoghue v. Stevenson, em 1932, enquanto, no campo do direito norte-americano, são conhecidos os casos Thomas $v$. Winchester, em 1852, este como leading case, e Mac Pherson v. Buick Motor Co., em 1916, dentre os principais. ${ }^{19}$

A ação de responsabilidade civil é de natureza ressarcitória, razão por que produz tutela essencialmente reparatória.

Por fim, a última ação típica é a ação civil pública regulada pela lei $\mathrm{n}$. $7.347 / 85$. Embora ela não integre o elenco dos arts. 81 e 101 do Código de Defesa do Consumidor, endereça-se à defesa de determinados direitos ou interesses do consumidor, não só em razão da remissão feita pelo art. 90 dessa codificação especial, como também por força de disposição expressa contida no art. $1^{\circ}$, II da lei $n$. $7.347 / 85$, que a disciplina.

Parece não restar dúvida de que a ação civil pública pode ser utilizada, além dos casos específicos para os quais está diretamente vocacionada (art. $1^{\circ}$, I, III e IV da lei n. 7.347/85), também para a defesa dos interesses ou direitos difusos e coletivos do consumidor, seja em razão da remissão feita pelo art. 90 do CDC, seja por força da disposição expressa contida no art. $1^{\circ}$, II, daquela lei especial. É que esses direitos ou interesses do consumidor são por natureza metaindividuais e dizem respeito, os difusos, ao interesse geral, pertinentes à coletividade inteira em que o prejuízo de um implica oneração de todos, indivisivelmente, ${ }^{20}$ ou dizem, os coletivos, com o interesse comum, também indivisível, de uma parcela ponderável da comunidade, caracterizada por um mínimo de organização, pela afetação a um grupo determinado ou determinável e que se encontrem atrelados por um vínculo iurídico base. ${ }^{21}$

A assertiva ainda se embasa no fato de que a tutela que se produz na atividade jurisdicional para a defesa dos interesses difusos e coletivos do consumidor é de natureza inibitória, impeditiva ou sustadora do fato ou ato danoso à coletividade, e a eventual tutela reparatória das perdas e danos decorrentes da impossibilidade do cumprimento da prestação específica (art. 84 e parágrafos do CDC), deve ser recolhida ao fundo criado pela lei $n$. 7.347/85 (art. 13), em face da aplicação

19 Neste sentido consultem-se os estudos magníficos de Luiz Gastão Paes de Barros Leães em sua tese intitulada $A$ responsabilidade do fabricante pelo fato do produto, cit., p. 31-82. 20 José Carlos Barbosa Moreira, A legitimação para defesa dos interesses difusos no direito brasileiro, in Temas de direito processual, terceira série, São Paulo, Saraiva, 1984, p. 183-92.

21 Rodolfo de Camargo Mancuso, Interesses difusos; conceito e legitimação para agir, São Paulo, Revista dos Tribunais, 1988, p. 44-5. 
subsidiária dessa lei especial aos interesses e direitos do consumidor, como dispõe o citado artigo 90 da lei consumerista, remissão essa estrategicamente colocada pelo legislador ao final do capítulo I, do título III que disciplina as defesas de interesses difusos e coletivos contidos na relação de consumo.

Tais conotações têm o condão de conformar a defesa desses dois tipos de interesses do consumidor à vocação da ação civil pública. A opção entre esta e as ações coletivas dos incisos I e II do art. 81 do CDC dependerá, na aplicação casuística dessa codificação, das contingências de fato que a hipótese apresentar, escolhendo-se dentre tais instrumentos o que parecer mais adequado| à proteção reclamada, segundo se infere da regra do art. 83 desse microssistema.

Não parece estar a ação civil pública vocacionada para a defesa dos interesses individuais homogêneos, onde a tutela pretendida é primordialmente reparatória, salvo nas hipóteses, certamente raras, de pretensões fundadas em obrigações de fazer ou não fazer, em que a tutela é sancionatória na primeira e inibitória na segunda.

Com maiores razões, a ação civil pública não é instrumento hábil para ação de responsabilidade civil contra o fornecedor de produtos e serviços de que cuida o art. 101, por ser essencialmente ressarcitória, não se coadunando com o desiderato final daquela que reverte para o fundo do artigo 13, da lei n. 7.347/85. Não parece incompatível, porém, com a ação cominatória contra o Poder Público de que trata o artigo 102, da lei consumerista.

A eficácia da sentença na ação civil pública, que é secundum eventum litis, será erga omnes, salvo se julgada improcedente por deficiência de provas (art. 18 da lei n. 7.347/85, c/c o art. 103, I, do CDC), mas será ultra partes, limitada ao grupo, categoria ou classe, exceto na hipótese antes aventada.

\subsubsection{Da tutela individual}

$\mathrm{Na}$ defesa dos interesses ou direitos do consumidor os mecanismos processuais utilizados são, em regra, coletivos. As ações coletivas caracterizam-se subjetivamente pela maior potencialidade de proteção desses interesses por englobar os legitimados ativos referidos no artigo 82 , e, objetivamente, pela maior ou menor coletivização ou fluidez do bem da vida pretendido pelos titulares desses interesses tutelados. São, assim, as ações coletivas, mais adequadas para o mister, porque suprem as insufi-ciências de ordem econômica, cultural e psíquica do consumidor individual e do seu minúsculo interesse no contraste com o aparato técnico e o suporte econômico dos outros sujeitos que se postam no outro pólo da relação de consumo: o fabricante, o produtor ou o comerciante.

$\mathrm{Na}$ gama dos mecanismos típicos para a tutela do consumidor, resta a possibilidade de ser individual a ação 
de responsabilidade pelo fato do produto contra o fornecedor de produtos e serviços, de que trata o artigo 101 e incisos, em face da alternativa oferecida pelo artigo 81. Pode a mesma ação ser meramente individual, quando promovida por qualquer consumidor isoladamente, ou individual plúrima, quando promovida por grupo informal de consumidores individuais, em litisconsórcio ativo facultativo, que pode ser inicial ou ulterior, segundo o cúmulo subjetivo se forme $a b$ initio ou venha a constituir-se após a instauração do processo. Essa a única defesa individual típica, em tema de proteção do consumidor, prevista no art. 81 do CDC.

No entanto, há uma plêiade de tutelas individuais atípicas que são colocadas à disposição do consumidor através do processo comum regulado pelo Código do Processo Civil, por força mesmo do disposto no art. 83 da lei consumerista, que diz o óbvio, porquanto é princípio geral que toda a conduta humana é permitida se não expressamente vedada por lei, conforme dispõe o artigo $5^{\circ}$, II, da Constituição.

De qualquer modo, o legislador houve por bem assim dispor, o que significa dizer que o consumidor poderá também dispor de todos os instrumentos definidos no processo comum para a tutela dos seus direitos, podendo valerse do processo comum ordinário ou sumário (CPC, art. 272), que no caso couber, a teor do artigo 90 da lei consumerista. São as ações atípicas que vêm completar o elenco de mecanismos processuais ao alcance do consumidor.

Há no processo pátrio, além dos mecanismos pertinentes ao procedimento comum, um outro de procedimento especial, chamado Juizado Especial, já referido item 3.1 supra, criado pela lei n. 9.099/95, que implementa outro modo de proceder capaz de empreender grande rapidez na solução de certos conflitos de natureza patrimonial que se enquadrem no conceito de causas de menor complexidade, a teor do artigo 98, I, da Constituição Federal, cuja aferição se realiza ratione materiae e ratione valoris.

As causas que se resolvem através desse procedimento especial podem ensejar aos que a ele recorrem uma tutela condenatória decorrente de sentença condenatória, cujo valor não exceda a quarenta (40) vezes o salário mínimo; que julgar as causas enumeradas no artigo 275, II, do CPC; a ação de despejo para uso próprio; e as ações prossessórias sobre bens imóveis de valor não superior a 40 salários mínimos; e bem assim as execuções dos seus julgados e as de títulos extrajudiciais de valor até 40 salários mínimos, segundo dispõe o artigo $3^{\circ}$, da mencionada lei n. 9.099/95.

O processo obedece à preocupação da lei especial, centrada na economia e na celeridade, mas esses resultados se obtêm pelo procedimento oral e de seus afluentes ou princípios satélites, como os da imediatidade, concentração e irrecorribilidade das interlocutórias em 
separado, conforme a pregação de Chiovenda. ${ }^{22}$

O que se percebe, todavia, da análise conjunta das duas leis especiais, o Código de Defesa do Consumidor e a Lei dos Juizados Especiais é que este último procedimento especial não se ajusta às ações coletivas, mas tãosomente às ações individuais para a defesa do consumidor.

Além dessas, poderá ainda o consumidor dispor de outra ação atípica para o sistema pátrio, mas muito em voga nos sistemas de proteção ao consumidor dos países pertencentes à Comunidade Econômica Européia, que através de sua Carta do Consumidor recomenda aos Estados-Membros que a integram que instituam o juizo arbitral como mecanismo processual hábil para resolver os litígios entre fornecedores e consumidores. ${ }^{23} \mathrm{Tal}$ mecanismo pode ser instituído entre nós, mediante introdução de cláusula compromissória nas convenções coletivas de consumo previstas no art. 107, do CDC. Embora seja um modo para solução dos litígios pouco usado no Brasil, nada obsta que se constitua o iuizo arbitral mais um mecanismo atípico em defesa dos direitos do consumidor, que no sistema pátrio está regulado pela lei n. 9.307/96.

\subsubsection{Da tutela preventiva}

Além das tutelas definitivas conferidas pela lei especial e pela legislação comum para a defesa de interesses ou direitos do consumidor acima examinadas, a codificação de consumo contempla alguns procedimentos preparatórios e assecuratórios desses direitos.

A medida já contemplada pela lei da Ação Civil Pública (art. $8^{\circ}, \S 1^{\circ}$ ), é o inquérito civil, a cargo do Ministério Público, que o preside, na forma do artigo 90, do CDC. Também previsto no art. $51, \S 4^{\circ}$, da codificação consumerista que o Ministério Público poderá exercer controle sobre cláusulas abusivas, a requerimento do consumidor, providência que o legislador foi buscar no sistema francês, onde essas disposições contratuais são controladas por um órgão administrativo, a Commission de Clauses Abusives, criada por uma das Leis Scrivener, o art. 35 da lei n. 78-23, de 10 de janeiro de 1978, regulamentada pelo decreto $\mathrm{n}$. $78-464$, de 24 de março de $1978 .{ }^{24}$

O $\S 3^{\circ}$ do art. 51 do Código de Defesa do Consumidor foi vetado pelo Poder Executivo sob o argumento de que o dispositivo agredia os perfis constitucionais que reservam ao Poder Judiciário o controle geral dos atos

22 Cândido Rangel Dinamarco, Manual, cit., passim.

23 Pierre Godé, Dictionnaire, cit., p. 38-9; Carlos Ferreira de Almeida, Os direitos dos consumidores, Coimbra, Livr. Almedina, 1982, p. 35-9.

24 Sobre o assunto, v. Pierre Godé, Dictionnaire, cit., p. 83-6. 
jurídicos (art. $5^{\circ}, \mathrm{XXXV}$, da CF), bem como de que as atribuições do Ministério Público são fixadas em lei complementar, não podendo a lei ordinária fazê-lo. O veto foi mantido.

É de se registrar, todavia, que o impedimento para a instauração do inquérito civil só prevalece quanto ao controle pelo parquet das cláusulas abusivas, pois continua o mesmo órgão habilitado a instaurá-lo visando a defesa de outros direitos do consumidor, em face da referência expressa que o art. 90 do Código de Defesa do Consumidor faz ao mesmo inquérito e à remissão à lei n. $7.347 / 85$, cujos arts. $1^{\circ}, \mathrm{IV}, 8^{\circ}$ e $9^{\circ}$ disciplinam essa providência a cargo do Ministério Público.

É o inquérito civil uma providência preparatória para a propositura das ações civis coletivas, visando o resguardo de interesses difusos e coletivos dos consumidores, cuja atribuição ao Ministério o foi com muito acerto e coerência, uma vez que é o Parquet, além de órgão independente na fiscalização do cumprimento das leis em geral, também o principal legitimado ativo para promover judicialmente os mecanismos de defesa do consumidor. Constitui tutela preventiva típica.

O Código de Defesa do Consumidor instituiu ainda outras medidas preventivas típicas, tais como a busca e apreensão, a remoção de coisas e pessoas, o desfazimento de obra e o impedimento de atividade nociva, para assegurar o sucesso do processo principal (art. $84, \S 5^{\circ}$ ). A tutela preventiva, nesses casos, é essencialmente assecuratória. Além disso, a codificação autoriza o juiz a conceder liminarmente a tutela postulada pelo consumidor, sempre que, sendo relevante o fundamento da demanda, houver justificado receio de se tornar ineficaz a sentença final (art. 84, $\S 3^{\circ}$ ), caso em que a tutela toma o caráter de antecipatória.

Por fim, em tema de tutela preventiva, possui ainda o ordenamento processual brasileiro um sistema de medidas cautelares nominadas (arts. 813 a 851 do CPC) e inominadas (art. 798 do (PC), que poderão ser utilizadas para a defesa do consumidor, como tutelas atípicas.

\subsubsection{Das condições de exercício da tutela jurisdicional}

Salvo as poucas normas que introduzem modificações parciais nos institutos da legitimação ativa, intervenção de terceiros, litisconsórcio, contraditório, despesas processuais, ônus da prova e coisa julgada, não contém o novo Código de Defesa do Consumidor disciplina processual própria para regular o procedimento dos mecanismos jurisdicionais que criou para a proteção do consumidor, de modo que praticamente toda a matéria pertinente ao setor está subordinada à legislação processual comum, através do Código de Processo Civil, para o qual remete a própria lei especial como encontra-se disposto no artigo 90 do CDC. 
Deste modo, ditos mecanismos estão sujeitos, no que não for expressa a referida lei especial, aos requisitos exigidos para a regularidade do processo e aos pertinentes ao exercício do direito (ou poder) de ação, vale dizer, aos pressupostos processuais e às condições da ação (art. 267, IV e VI, do CPC) e a outros modos e estilos procedimentais a que se subordina a prática do processo comum.

\subsubsection{Da legitimação dos entes coletivos}

Quanto à legitimação ativa, que implementa para o processo civil pátrio, uma das condições da ação, a lei especial possui disciplina própria, adotando-se legitimação extraordinária, mediante a qual ficam autorizados o órgão do Ministério Público, as pessoas jurídicas de natureza política e de existência necessária (União, Estado, Municípios, Distrito Federal), as pessoas jurídicas de natureza administrativa pública direta e indireta, bem como as pessoas jurídicas de direito privado (associações de consumidores) a promover, na qualidade de autores, os mecanismos processuais chamados ações coletivas (art. 82 do CDC). A melhor doutrina tem-na classificação de legitimação concorrente ou disjuntiva. ${ }^{25}$

No processo civil comum, a legitimação ordinária é a curial, na qual legitimado ativo para desencadear o processo é o próprio sujeito que se afirma titular do direito a respeito do qual postula a tutela estatal, de modo a haver coincidência entre o titular do direito afirmado e o titular ou autor da ação judicial.

O Código de Defesa do Consumidor, seguindo a tradição das legislações da espécie no concerto do mundo ocidental, notadamente a dos sistemas francês, alemão, português, espanhol e italiano, optou pela legitimação extraordinária, que caracteriza o fenômeno da substituição processual. Esta significa o exercício do direito (ou poder) de ação, em nome próprio, por quem não é titular do direito afirmado e a respeito do qual é pedida a tutela estatal. E por ser extraordinário tal tipo de legitimação, só existe por expressa determinação legal, que, para a defesa das relações de consumo, está no art. 82 da codificação especial.

\subsubsection{Da intervenção de terceiros}

No que diz com a intervenção de terceiros, está vedada a denunciação da lide, que é obrigatória pela lei processual comum (art. 70, III, do CPC), nas ações de regresso do comerciante co-responsável pelo fato do produto, contra os outros coresponsáveis pela indenização ao consumidor, que são o fabricante, o

25 Entre nós, José Carlos Barbosa Moreira, A legitimação para defesa dos interesses difusos no direito, in Temas, cit., p. 183-92. 
produtor, o construtor e o importador (arts. 12, 13 e 88 do CDC). Dita ação de regresso pode ser ajuizada em processo autônomo, facultando-se ao titular do direito de regresso o procedimento nos próprios autos da ação de responsabilidade civil (art. 88).

A denunciação da lide ao Instituto de Resseguros do Brasil está vedada na ação de responsabilidade civil que o consumidor vier a mover contra o fornecedor de produtos ou serviços, quando este houver contratado o seguro adequado para cobrir eventuais prejuízos decorrentes da atividade explorada (art. 101).

Quanto ao chamamento ao processo (art. 101, II) e ao litisconsórcio (arts. 94 e 103, $\S 2^{\circ}$ ) admitidos pela lei especial, não há singularidades a registrar, uma vez que não distoam dos princípios da lei processual comum (CPC, arts. 46-49 e 77-80) que os define e regula exaustivamente. É mister, porém, se registre a impropriedade dos argumentos jurídicos para justificar o veto ao litisconsórcio facultativo entre os órgãos do Ministério Público da União, Estados e Distrito Federal, admitido no $\S 2^{\circ}$ do art. 82 , porquanto o instituto do litisconsórcio é regulado por lei ordinária, no caso a lei processual civil comum, e não por lei complementar. Além disso, a própria Constituição Federal (art. 129, III) outorga legitimação ao Ministério Público para promover a ação civil pública, que é mecanismo processual adequado à tutela dos interesses difusos e coletivos do consumidor, na qualidade de autor, posição processual que abrange, absorve ou se confunde com a de litisconsorte. Assim, a autorização para o Parquet assumir a posição de litisconsorte em ditas ações já está expressa na Constituição, o que até dispensaria a referência feita no art. 82, $\S 2^{\circ}$, do Código de Defesa do Consumidor. De tal sorte, as razões jurídicas suscitadas pelo Poder Executivo para a sustentação do veto são, no mínimo, questionáveis.

No que pertine à vedação ao Instituto de Resseguros do Brasil de integrar o contraditório (art. 101, II, do $\mathrm{CDC}$ ), registra-se equívoco do legislador, ao proscrever, por lei especial sujeita ao rito ordinário do processo legislativo, o exercício de postulado constitucional universalmente contemplado nos sistemas processuais, nas Cartas Políticas dos Estados modernos e expressamente assegurado, como garantia fundamental, pelo art. $5^{\circ}, \mathrm{LV}$, da atual Constituição brasileira. É, pois, manifesta a inconstitucionalidade do dispositivo legal referido, que próbe ao Instituto de Resseguros do Brasil integrar o contraditório, podendo esta ser alegada perante o Poder Judiciário pelo sistema difuso (art. 97 da CF) ou pelo concentrado (arts. 102, I a, e 129, IV, da CF).

\subsubsection{Das despesas processuais}

Quanto às despesas processuais, a lei especial dispensa o adiantamento delas pelo autor nas ações coletivas e seu pagamento pelo autor vencido, no 
caso de improcedência da ação, salvo hipótese de comprovada má-fé (art. 87 do CDC). No caso de litigância de máfé, respondem solidariamente pelo décuplo das custas e honorários advocatícios a associação autora e os diretores responsáveis pela propositura da ação, independentemente da responsabilidade por perdas e danos, conforme dispõe o artigo 87, parágrafo único da dita lei especial.

\subsubsection{Do ônus da prova e sua inversão}

Classicamente, o ônus da prova ou dever de provar funda-se na passagem do Digesto segundo a qual ei incumbit probatio qui dicit, non qui negat (D 22.3.2).

No incomensurável campo da responsabilidade civil, tema que, por sua grandeza, modernamente exerce invulgar influência no âmbito do direito obrigacional, o onus da prova, ou carga probatória, segundo a preferência dos ordenamentos de origem hispânica, trilha simetricamente os mesmos caminhos percorridos por aquele setor da ordem jurídica.

Com efeito, a teoria clássica sobre a responsabilidade civil sempre se amparou nos postulados da liberdade e da igualdade, que, revigorados enfaticamente com o evento sócio-políticojurídico da Revolução Francesa, tiveram efetiva influência nas relações jurídicas, porquanto o outro postulado, o da fraternidade, foi desde logo esquecido.

A liberdade, na concepção dos inspiradores do sistema, irradiava-se dinamicamente sob o influxo de três princípios cardeais: o da autonomia da vontade, o do efeito relativo dos contratos e o da responsabilidade subjetiva, decorrente da culpa.

Com base no primeiro, a autonomia da vontade, abria-se para o contratante uma tríplice perspectiva: contratar ou deixar de fazê-lo, escolher com quem contratar e estabelecer o conteúdo das obrigações assumidas. Para os consumidores, a experiência vinha demonstrando que os desníveis econômicos e sociais entre ele e o fornecedor não the permitiam exercer em sua plenitude a manifestação autônoma da vontade, devido ao maior aparato de poder de barganha conferido a este em detrimento daqueles.

No que diz com o efeito relativo, expresso no aforismo latino res inter alios acta ou pela forma anglo-saxônica privity of contract, a teoria clássica vinha demonstrando que a vontade própria era fonte fundamental das obrigações, de modo que os efeitos dos contratos deviam restringir-se às partes intervenientes, norma que estava presente na lei civil brasileira de 1916 (art. 928 do Código Civil), dito princípio criava embaraços à relação de consumo que se insere numa cadeia plurissubjetiva formada por fabricante, fornecedor, importador, comerciante, restando o consumidor como o último elo da cadeia e, em razão disso, impotente para reclamar o descumprimento do contrato contra 
outro sujeito que não seja o que com ele contratou. O dispositivo pertinente ao efeito relativo não foi repristinado na vigente codificação civil, que contempla com muita ênfase a função social do contrato, expressa no artigo 421 e, ainda, no artigo 2.035, parágrafo único. Além disso, estabelece regras especiais a respeito dos contratos de adesão, nos artigos 423 e 424 , recomendando interpretação mais favorável ao aderente, quando nesses contratos houver cláusulas ambíguas ou contraditórias e bem assim eivando de nulidade cláusulas que estipulam renúncia antecipada do aderente. Amplia, assim, a nova codificação civil as disposições pertinentes ao assunto, contidas no artigo 51 do CDC.

O terceiro aspecto da teoria liberal é que a aferição da responsabilidade civil do contratante restava submetida ao pressuposto da culpa. Este requisito, em tema de relações de consumo, poderia tornar-se injusto ou até iníquo, pelas dificuldades da prova de culpa do fornecedor, em razão da disparidade de armas com que conta o consumidor para enfrentar a parte mais forte. No entanto, diante de tais dificuldades do consumidor, o CDC adotou a teoria da culpa presumida do fabricante, produtor ou fornecedor, no artigo 12 , dessa codificação especial.

O outro grande postulado da teoria liberal, que se posta ao lado da liberdade, é o da igualdade. Embora este se ampare em indiscutível imperativo humanístico, há que se distinguir entre igualdade formal e igualdade real. Aquela, que se encontra enunciada e proclamada pelo princípio liberal, não encontra equivalência na última, que se abriga na posição econômica desfrutada pelas partes. Assim, das condições econômicas mais frágeis do consumidor resulta a desigualdade entre ele e o fornecedor, economicamente mais forte.

Essas desigualdades, que se vinham verificando a partir da metade do século XIX para cá, restaram por infundir na consciência dos juízes, doutrinadores e, finalmente, dos legisladores a idéia de restabelecer a igualdade real nos contratos, substituindo o contrato liberal pelo contrato social. E, para que isso fosse factível, evolui-se da tradicional teoria da culpa da presunção de culpa com nexo casual, a que se chamou teoria objetiva ou do risco, agora proclamada no artigo 12 do CDC, não obstante a tomada de outras transformações na área contratual, inclusive com o desaguamento desta teoria intermediária na do risco exarcebado, que é observada nas atividades nucleares, nas quais é desconsiderado inclusive o nexo casual. ${ }^{26}$

Outra providência para assegurar

26 Carlos Alberto Bittar, Responsabilidade civil, cit., n. 23-33, p. 29-42;

Responsabilidade civil nas atividades nucleares, São Paulo, Revista dos Tribunais, 1985 , n. 21-30, p. 146-222. 
essa técnica de amenização da teoria clássica, adotou-se, dentre outros engenhos já referidos, o da inversão do ônus da prova. ${ }^{27}$

A primeira manifestação no contexto do direito comparado, a respeito da inversão do ônus da prova, operou-se no campo da jurisprudência. E foram os tribunais americanos, desde 1916, mediante uma consciência de injustiça sugerida pela interpretação restrita do princípio da culpa, que passaram a admitir a amenização deste com base no entendimento de que devia ser alargada a idéia do dever geral de cuidados dos empresários com os produtos de seu fabrico, colocados no mercado (reasonable care), e de informação sobre seu uso (duty of warn).

Tal concepção teve início em 1916, com o caso Mac Pherson v. Buich Motor Co., nos Estados Unidos. Seguiu-se com o caso Donoghue $v$. Stevenson, na Inglaterra, em 1932; com uma decisão do Supremo Tribunal italiano, de 1964; e com a sentença do Supremo Tribunal alemão (Bundesgerichtshof) no famoso caso sobre a "peste dos frangos" (Hühnerpest Urteil), considerado o leading case no direito tedesco sobre o assunto. ${ }^{28}$

$\mathrm{Na}$ Espanha, onde os tribunais também já vinham construindo a aplicação do princípio em favor do litigante mais franco, foi a inversão do ônus da prova expressamente contemplada no art. $1^{\circ}$, letra $c, \S 8^{\circ}$, da "ley General para la Defensa de los Consumidores y Usuarios" (ley 19 julio 1984, 26/84), que dispõe: Las cláusulas, condiciones o estipulaciones que, com carácter general, se apliquen a la oferta, promoción o venta de productos o servicios, incluidos los que faciliten las Administraciones públicas y las Entidades y Empresas de ellas dependientes, deberán cimplir los seguientes requisitos: ... c) Buena fe y iusto equilibrio de las contraprestaciones lo que, entre otras cosas, excluye: $\ldots 8^{\circ}$ La inversión de la carga de la prueba em prejuicio del consumidor o usuario.

A lei portuguesa (lei n. 29/81, de 228-1961), denominada Lei de Defesa do Consumidor, omitiu-se não só acerca da responsabilidade objetiva do fornecedor como também quanto ao ônus da prova, o que nos leva a concluir que a matéria ainda se situa em campos da teoria clássica, isto é, a responsabilidade do produtor é a subjetiva, ${ }^{29}$ naquele sistema.

No Brasil, já de algum tempo para cá, especialmente após a década de 30

27 Carlos Alberto Bittar, Responsabilidade civil, cit., n. 24, p. 31-2.

28 Carlos Ferreira de Almeida, Os direitos, cit., n. 34-36, p. 134-9; Luiz Gastão Paes de Barros Leães, A responsabilidade, cit., p. 36, 42 e 67; Alpa e Bessone, $L a$ responsabilità del produtore, Milano, Giuffrè, 1987, p.113 es.

29 Carlos Ferreira de Almeida, Os direitos, cit., p. 134, nota 154. 
do século recém findo, quando começaram a esboçar-se as primeiras escaramuças dos direitos sociais em nossa Pátria, passou a doutrina a propor timidamente a adoção de um temperamento da responsabilidade subjetiva, adotada pelo Código Civil, visando reequilibrar certas relações jurídicas contratuais ou extracontratuais onde um dos sujeitos se apresentasse como personagem mais fraco. A esse propósito doutrinal seguiu-se um acolhimento da jurisprudência e posteriormente da legislação para casos esporádicos. Tais eram as hipóteses de acidentes do trabalho, no campo da infortunística; dos acidentes ferroviários; dos acidentes resultantes de certas atividades perigosas, especialmente os decorrentes de atividades nucleares, onde há a máxima exarcerbação da responsabilidade, com desconsideração inclusive do nexo causal.

Para obviar a reparação dos danos decorrentes dessas atividades, a jurisprudência passou a admitir a presunção de culpa do agente da atividade ou do serviço, em razão do risco por este assumido ao colocá-lo à disposição do público. E assim o primeiro passo para reequilibrar as situações descompassadas pela disparidade de forças e obter a plena responsabilidade e reparação do prejuízo era a inversão do ônus da prova.

Tal doutrina sensibilizou, em termos amplos, o legislador constituinte de 1988, ao alargar sobremodo, quiça exage- radamente, os direitos sociais, de modo a desequilibrar os contrapesos dos pratos da balança para o outro pólo, em detrimento da justiça contratual o que pressagiamos, oxalá não aconteça. Nessa linha, introduziu-se amparo amplo às atividades de consumo em geral, com significativa tutela à pessoa do consumidor.

E, com a edição do Código de Defesa do Consumidor, através da lei n. 8.078 , de 11 de setembro de 1990 em vigor a partir de 11 de março de 1991, instituiu o legislador a inversão do ônus da prova, qualificando-a como direito básico do consumidor, no art. $6^{\circ}$, VIII, da codificação.

Vê-se, pela redação do dispositivo legal, que a inversão do onus probandi não constitui princípio absoluto que deva ser aplicado na generalidade dos casos e sem exceção. É, sem dúvida, um princípio que se encontra relativizado por condicionamentos a serem aferidos no caso concreto, mediante prudente critério judicial, quando a alegação do consumidor for verossimil, ou quando for ele considerado hipossuficiente, diga-se, litigante mais fraco, segundo as regras ordinárias da experiência.

Em várias outras passagens da codificação o princípio encontra-se direta ou indiretamente admitido, tal como acontece nos textos do artigo 12 , $\S 3^{\circ}$; no do artigo 14 , caput e $\S 3^{\circ}$; nos artigos 23 e 38; e também no artigo 51, inciso VI. 


\section{Por um direito internacional de proteção dos consumidores: sugestões para a nova lei de introdução ao Código Civil brasileiro no que se refere à lei aplicável a alguns contratos e acidentes de consumo*}

\section{Claudia Lima Marques**}

\section{INTRODUÇÃO}

Este artigo é uma homenagem a José Francisco Rezek, "credor do incondicional reconhecimento de todos aqueles estudiosos do Direito Interna- cional." O grande jurista e professor brasileiro, Francisco Rezek, que com seus ensinamentos, cortesia e extrema competência, honra nosso país e nossas Universidades, ao prefaciar um livro sobre Proteção do consumidor no

\footnotetext{
* A autora agradece ao dr. Jean Michel-Arrighi, renomado consumerista e diretor jurídico da OEA, Washington, pelo honroso convite para ministrar o curso na OEA em 2000, origem destas observações sobre a CIDIP e ao dr. Ricardo Morishita, diretor do CPDC/MJ, pelo convite para colaborar com o CT7 do Mercosul e em sugestões à LICC. Artigo já publicado no livro em homenagem à Francisco Rezek Direito Internacional, org. Wagner Menezes, Ed. UNIJUÍ, Ijuí, 2004, Anais do $2^{\circ}$ Congresso de Direito Internacional, 25-28 de agosto de 2004, org. PUC/PR, Curitiba.

** Professora titular de Direito Internacional Privado da Universidade Federal do Rio Grande do Sul, doutora em Direito pela Universidade de Heidelberg, Alemanha; mestre em Direito Civil e Direito Internacional Privado pela Universidade de Tübingen e Especialista em Integração Européia pelo Europa-Institut, Saarbrücken, Alemanha; ex-presidente do Instituto Brasileiro de Política e Direito do Consumidor; vice-presidente da Association Internationale de Droit de la Consommation, Bruxelas.

1 Permito-me aqui usar o elogio que o próprio homenageado utilizou para honrar os estudos de Pontes de Miranda, "credor do incondicional reconhecimento dos estudiosos do tema", REZEK, José Francisco. A nacionalidade à luz da obra de Pontes de Miranda. Revista Forense, Rio de Janeiro, v. 74, n. 263, jul./set. 1978, p. 15.
} 
Mercosul e na União Européia, destacou as diferenças que a efetividade do Direito, em cada uma das sociedades nacionais, exige. ${ }^{2}$ Segundo o mestre, a simples importação de normas de países principais do Direito Comparado, ${ }^{3}$ não é suficiente: o exame deve ser profundo, de convergências e de divergências, para alcançar-se a efetividade da norma proposta ou aceita. Assim é com o delicado tema da necessidade de proteção especial dos consumidores, em suas relações (contratuais ou extracontratuais) internacionais.

Igualdade é o tratamento igual dos iguais e diferente daqueles que - por circunstâncias externas, especialidade profissional ou falta de informação e situação econômica e fática - diferentes são. ${ }^{4}$ Como ensina o nosso homenageado, também este ramo do Direito, tradicionalmente, conhece normas especiais para que os agentes privados atinjam esta esperada igualdade. ${ }^{5}$

Relembra ainda o mestre Rezek, que as relações internacionais devem seguir as linhas estabelecidas e o espírito delineado pela Constituição. ${ }^{6}$ Efetivamente, há que se considerar que a Constituição democrática de 1988 incluiu dois mandamentos ou Gebote imperativos de distinção e de proteção dos interesses dos consumidores por normas especiais: no art. 48 dos Atos e Disposições Transitórias mandou elaborar um Código de Defesa do Consumidor, com normas especiais a atravessar todos os ramos do direito

2 REZEK, José Francisco. Prefácio. In: Fellous, Beyla Esther, Proteção do consumidor no Mercosul e na União Européia, São Paulo: Revista dos Tribunais, 2004, p. 11-12.

3 REZEK, José Francisco, Le droit international de la nationalité. Recueil des Cours, v. 198, 1986-1987, p. 341.

4 A igualdade é uma das grandes meta-narrativas da modernidade (Brilmayer, Lea. Postmodernism in American Choice of Law. In: LIBER Memorialis François Laurent. Bruxel, 1989, p. 702 e 705), mas a pós-modernidade tende a destacar o que há de "diferente" e "privilegiador" nestes novos direitos humanos (veja os ensinamentos de Erik Jayme (JAYME, Erik. Identité culturelle et intégration: Le droit internationale privé postmoderne. Recueil des Cours, Haye, n. 2, 1995, p. 33 et seq.), permitindo a desigualdade formal para atingir a igualdade material. No caso, as normas nacionais sobre proteção do consumidor, como o CDC ou Lei 8.078/90, asseguram-se direitos ao consumidor para alcançar a igualdade material dos desiguais, garantem-se direitos de escolha, reflexão, informação e transparência para proteger sua abalada liberdade ou autonomia de vontade dos consumidores nos contratos (art. 4,6, 18 a 54 do CDC) e o direito de prevenção de danos e de indenização integral em caso de acidentes de consumo (art. 8 a 17 do CDC).

5 Veja neste sentido o belo artigo do homenageado, Rezek, José Francisco, Aspectos elementares do Estatuto da Igualdade, in Boletim do Ministério da Justiça, Lisboa, n. 277, p. 5-12, jun. 1978.

6 REZEK, José Francisco. As relaç̃es internacionais na Constituição da primeira República. Revista Arquivos do Ministério da.Justiça, v; 30, n. 126, jun. 1973, p. 107 et seq. 
que importassem para a proteção deste sujeito vulnerável (direito civil, direito penal, direito administrativo, direito processual civil e penal e, porque não, direito internacional privado!), assim como, o art. $5^{\circ}$, inciso XXXI esclareceu que a proteção deste sujeito econômico alcança nível de direito fundamental (liberdade e garantia fundamental $)^{7}$ no ordenamento jurídico brasileiro: O Estado promoverá, na forma da lei, a defesa do consumidor.

Assim, se relações privadas de consumo assumem hoje também um crescente caráter internacional, devem preocupar os jus-privatistas internacionais. Em outras palavras, num mundo de crescentes áreas de complexidade, rapidez e globalização, ${ }^{8}$ há um crescimento na importância do Direito Internacional Privado ou dos conflitos de leis no espaço também em relação aos consumidores, atores leigos deste mercado internacional, ${ }^{9}$ cuja porta de entrada pode ser o simples computador $^{10}$ (televisão, fax, a tela do palmtop ou mesmo do telefone celular), ${ }^{1} \mid$ pode ser a evolução da globalização, ${ }^{12}$ o

$7 \mathrm{Na}$ expressão de Alexy, estes direitos asseguram/garantem/estimulam a efetivação da Dignidade do Homem, sua Liberdade e Igualdade ("...was die Verwirklichung von Menschenwürde, Freiheit und Gleichheit fordert"), ALEXY, Robert. Theorie der Grundrechte, Suhrkamp. Frankfurt, 1996, p.15.

8 Aceitarei aqui a definição de globalização feita por CASTELLS, Manuel. End of millennium: the information age: Economy, Society and culture,. Oxford: Blackwell, 1998, v. 3, p. 1: " $[\ldots]$ this is indeed a time of change a technological revolution, centered around information, has transformed the way we think, we produce, we consume, we trade, we manage, we communicate, we live, we die, we make war, and we make love. A dynamic global economy has been constituted around the planet, linking up valuable people and activities from all over world, while switching off from the networks of power and wealth, people and territories dubbed as irrelevant from the perspective of dominant interests..."

9 Veja Marques, Cláudia. A insuficiente proteção do consumidor nas normas de direito internacional privado: da necessidade de uma Convenção Interamericana (CIDIP) sobre a lei aplicável a alguns contratos e relações de consumo. Revista dos Tribunais, São Paulo, v. 90 , n. 788 , p. 11-56, jun. 2001, que utilizarei como base para muitas observações aqui repetidas.

10 Sobre o tema veja a interessante análise do jus-filósofo argentino Ciúro Caldani, Miguel Angel. La debilidad del consumidor en la sociedad de consumo. Investigación y Docencia, Rosario, n. 28, 1997, p. 33 et seq.

11 Veja também a juíza brasileira Fernanda Moron (A internet e o direito. Revista Consulex, mar. 1997, p. 64): "Como se vê, na medida que as relações que surgem pela Internet transcendem fronteiras, maior necessidade teremos de recorrer a regras do Direito Internacional, ramo jurídico que com certeza apresentará sensível crescimento.."

12 Sobre os problemas e a trivialização da expressão "globalização", veja a análise lúcida de Porto, Ronaldo. Globalização e Direito do Consumidor. Revista de Direito do Consumidor, São Paulo, n. 32, [s.d.], p. 45. 
crescente turismo, as áreas de livre comércio e processos de integração, ${ }^{13}$ como o Mercosul ${ }^{14}$ ou a futura ALCA (Parte I) ${ }^{15}$

Sem dúvida, como ensina Francisco Rezek, ${ }^{16}$ é pela mão do Direito Internacional Público que o Direito Internacional Privado pode conseguir a maior efetividade, propondo, por exemplo, um tratado de proteção dos consumidores. Tendo tido a honra de ministrar aulas no Curso de Direito Internacional da OEA-Organização dos Estados Americanos, em agosto de 2000, sobre "A proteção do consumidor: aspectos de direito privado regional e geral", ${ }^{17}$ onde concluí pela necessidade e oportunidade de elaborarmos na região uma Convenção Interamericana de Direito Internacional Privado (CIDIP) para a proteção do consumidor turista e do consumidor que contrata à distância, em especial no crescente comércio eletrônico, considero que esta lição do mestre foi honrada. ${ }^{18}$ Agora, gostaria de trazer os resultados deste curso para o âmbito interno do direito brasileiro, pois afinal as convenções têm uma dinâmica própria e aplicam-se apenas a alguns Estados, e se desejamos uma proteção ampla e efetiva dos consumidores devemos propor também a inclusão de normas específicas de proteção deste sujeito de direitos fundamentais também em nossa futura Lei de Introdução ao Código Civil (Parte II).

Note-se, ainda que a importância e atualidade do tema estão dadas no Brasil pela falta de sugestões específicas de defesa do consumidor nos projetos em trâmite hoje para acompanhar a entrada em vigor do novo Código Civil (Lei

13 Veja sobre o tema, Perin Júnior, Ecio. A globalização e o direito do consumidor. Barueri: Manole, 2003, p. 45 et seq.

14 Sobre o tema, duas obras específicas, Fellous, Beyla Esther. Proteção do consumidor no Mercosul e na União Européia. São Paulo: Revista dos Tribunais, 2004 e Batisti, Leonir. Direito do consumidor para o Mercosul. Curitiba: Juruá, 1998.

15 Comentando o tema sob a ótica brasileira, veja Marques, Claudia Lima. A proteção do consumidor de produtos e serviços estrangeiros no Brasil: primeiras observações sobre os contratos à distância no comércio eletrônico. Revista de Direito do Consumidor, São Paulo, v. 41, p. 39-80, jan./mar. 2002, Some recent developments in Private International Law in Brazil. Japanese Yearbook of Private International Law, Tóquio, v. 4, 13-50, 2002. 16 Veja a importância dos tratados na evolução do Direito, in Rezek, José Francisco. Direito internacional público: curso elementar. 9. ed. São Paulo: Saraiva, 2002, p.11 et seq.

17 A íntegra do Curso foi publicada pela OEA, em Washington, veja Marques, Claúdia Lima. A proteção do consumidor: aspectos de direito privado regional e geral. In: Curso de Derecho Internacional-OEA/CIJ. Washington: OEA, 2001, p. 657-780.

18 Rezek, Francisco. A insuficiente proteção do consumidor nas normas de Direito Internacional Privado - Da necessidade de uma Convenção Interamericana (CIDIP) sobre a lei aplicável a alguns contratos e relações de consumo. Revista dos Tribunais, São Paulo, v. 90, n. 788, p. 11-56, jun. 2001. 
10.406/2003). ${ }^{19}$ Neste sentido, concluise facilmente que as normas de Direito Internacional Privado no país estão defasadas e mister refletir em como nós, consumeristas e jus-privatistas, aceitando o desafio do homenageado, podemos ajudar a elevar a efetividade de nossas normas para a proteção dos mais fracos. Vejamos.

\section{A INSUFICIÊNCIA DAS REGRAS DE DIREITO INTERNACIONAL PRIVADO BRASILEIRO E O FENÔMENO DO CONSUMO INTERNACIONAL}

Efetivamente, se, algum tempo atrás, a proteção do consumidor era um tema de direito interno, eis que a atuação da maioria das pessoas restringia-se ao território do seu país, uma relação típica nacional, sem qualquer elemento de internacionalidade,$^{20}$ hoje a realidade regional e nacional é diversa. Com a abertura dos mercados a produtos e serviços estrangeiros, com a crescente integração econômica, a regionalização do comércio, as facilidades de transporte, o turismo em massa, o crescimento das telecomunicações, da conexão em rede de computadores, do comércio eletrônico, não há como negar que o consumo já extrapola as fronteiras nacionais. ${ }^{21}$ Os bens estrangeiros estão nos supermercados, os serviços são oferecidos por fornecedores com sede no exterior no telemarketing, através da televisão, do rádio, da internet, da publicidade massificada no dia-a-dia da maioria dos cidadãos de nossas metrópoles. ${ }^{22}$ Não é mais necessário

19 Veja PL 243/2002, PL 87/97, PL 4.905/95, PL 4.782/90, PL 377/89 sobre as modificações na LICC. Outro bom exemplo é que dos 80 PLs apensados ao Projeto de Lei 1825/91 de atualização do CDC, apenas três (PL 884/95, PL 2646/96 e PL 2893/97) tratam de temas de consumo internacional e isto no que se refere à informação prestada ao consumidor, tema já tratado pelo art. 31 do CDC.

20 Assim ensina Hoffman, Bernd Von. Über den Schutz des Schächeren bei internationalen Schuldvertragen, RabelsZ, n. 38, 1974, p. 401, explicando que nos casos excepcionais se podia usar a cláusula de ordem pública para proteger este "mais fraco" em seus contratos/ acidente/turismo internacional.

21 Assim também observam os mestres uruguaios Hargain, Daniel; Mihali, Gabriel. Circulación de bienes en el Mercosur. Montevidéu: Júlio César Faira, 1998, p. 504.

22 Assim concordam Benjamin, Antônio Herman de V. Consumer protection in lessdeveloped countries: the latin american experience. In CONSUMER law in the global economy. Asgate: Brookfield, USA, 1996, p. 50 e Reich, Norbert. Consumerism and citizenship in the Information Society-The case of eletronic contracting, In: Consumer law in the information society. Haia: Kluwer, 2001, p. 163 et seq. Veja Marques, Claudia Lima (Org.). Estudos sobre a proteção no Brasil e no Mercosul. Porto Alegre: Livraria do Advogado, 1994 e Marques, Claudia Lima. El código brasileño de defensa del consumidor y el Mercosur. In MERCOSUR: perspectivas desde el derecho privado. Buenos Aires: Editorial Universidad, 1996, p. 199-226. 
viajar, ser um consumidor-ativo, um consumidor turista, deslocar-se para ser um consumidor, que contrata de forma internacional ou se relaciona com fornecedores de outros países. ${ }^{23}$ As próprias formas de produção e montagem hoje são internacionais, os contatos internacionais de consumo e o turismo massificaram-se. ${ }^{24} \mathrm{O}$ fenômeno do consumidorpassivo internacional e o do consumidor-ativo internacional já chegou ao Brasil. Consumir de forma internacional é típico de nossa época. O serviço ou produto estrangeiro é status, é bem simbólico na atual cultura de consumo; ${ }^{25}$ o turismo, as viagens, o ser consumidorativo de forma internacional faz parte da procura pós-moderna dos prazeres, do lazer individual, da realização dos sonhos e do imaginário, é uma distinção social cada vez mais importante. ${ }^{26}$

Como sempre afirmamos, o direito do consumidor tem uma vocação internacional, ${ }^{27} \mathrm{e}$, em nenhum outro setor do direito privado, os modelos e as inspirações estrangeiras e supranacionais estiveram tão presentes. Em teoria, o consumidor não deve ser prejudicado, seja sob o plano da segurança, da qualidade, da garantia ou do acesso à justiça somente porque adquire produto ou utiliza serviço proveniente de um outro país ou fornecido por empresa com sede no exterior. ${ }^{28}$ Em teoria, o consumidor turista, o viajante, aquele que adquire produtos e serviços em outro país deve poder contar com uma proteção mínima aos seus interesses, assim como aquele que assistindo publicidade de fabricante

23 A distinção entre consumidor-ativo (que se desloca de um país para outro) e consumidorpassivo (que recebe a informação, que contrata em seu país, sem deslocamento físico) é muito utilizada na Alemanha e será aqui seguida para facilitar a exposição. Veja, por todos, usando a expressão JAYME, Erik; Kohler, Christian, Europäisches kollisionsrecht 1999Die Abendstunde der Staatsverträge. IPRAX, 1999, p. 404.

24 Assim Benjamin, Antonio Herman de V. O transporte aéreo e o Código de Defesa do consumidor. Revista AJURIS, Porto Alegre, março 1998, v. 2 edição especial, p. 499 et seq. Veja também MARQUES, Cláudia Lima. A responsabilidade do transportador aéreo pelo fato do serviço e o Código de Defesa do Consumidor - Antinomia entre norma do CDC e de leis especiais. Revista Direito do Consumidor, São Paulo, v. 3 p. 155-197, 1992.

25 Aqui estamos seguindo os ensinamentos de Featherstone, Mike. Cultura de consumo e pós-modernismo, São Paulo: Studio Nobel, 1995, p. 31.

26 Assim Ibidem, p. 31.

27Veja Bourgoignie, Thierry. Eléments pour une théorie du droit de la consommation, CDC-Story Sciencia, Bruxelas, 1988, p. 215 et seq.

28 Marques, Cláudia Lima. Regulamento comum de defesa do consumidor do Mercosul: primeiras observações sobre o Mercosul como legislador da proteção do consumidor. Revista Direito do Consumidor, São Paulo, v. 23-24, [s.d.], p. 79 e também, no mesmo sentido no Mercosul, Stiglitz, Gabriel. El derecho del consumidor en Argentina y en el Mercosur. Derecho del Consumidor, v. 6, 1995, p. 20. 
localizado em outro país, resolve contratar à distância. Houve uma substancial mudança na estrutura do mercado, ${ }^{29}$ uma globalização também das relações privadas de consumo, ${ }^{30}$ que põe à luz as falhas do mercado ${ }^{31}$ e os limites da noção fictícia de "soberania" do consumidor no mercado atual. ${ }^{32}$ A sua posição é cada vez mais fraca ou vulnerável e o desequilíbrio das relações de consumo é intrínseco, ${ }^{33}$ necessitando efetiva tutela e positiva intervenção dos Estados e dos organismos internacionais legitimados para tal. ${ }^{34}$

A pergunta é se o nosso ordenamento jurídico está preparado para esta internacionalização das relações de consumo. Há grande especificidade nestas relações jurídicas internacionais, que, se bem representam apenas uma parcela do comércio internacional, têm um potencial econômico e político importantíssimo. A realidade é que, nas
Américas, as leis nacionais de proteção dos consumidores, de direito civil e de direito comercial, e as normas gerais raramente possuem normas de direito internacional privado especiais para a tutela efetiva dos contratantes mais fracos, das vítimas dos acidentes com produtos e serviços defeituosos, dos turistas, dos que recebem a publicidade, o marketing agressivo e emocional de nossos tempos, enfim, dos consumidores domiciliados ou nacionais destes países. A norma nacional de Direito Internacional Privado (aqui denominado DIPr.) geralmente é antiga ${ }^{35}$ a única atualização veio através das conferências interamericanas de Direito Internacional Privado (CIDIPs), organizadas no seio da OEA. As CIDIPs, porém, nenhuma conexão mais favorável impuseram especificamente sobre a proteção do consumidor.

Incontroverso é que a proteção deste agente econômico mais fraco, ${ }^{36}$

29 Cf. Botana García, Gema; Ruiz Muñoz, Miguel (Coord.). Curso sobre protección jurídica de los consumidores. Madrid: Ciencias Juridicas, 1999, p. 8.

30 Veja, por todos, Ghersi, Carlos Alberto. Postmodernidad. [s.n.t.], p. 139 et seq.

31 Assim Bourgoinie, Élements, p. 64 et seq.

32Assim Botana, op. cit., p. 8 e Bourgoinie, Élements, p. 64.

33 Calais-Auloy, Jean, Droit de la consommation. 3.ed.. Paris: Dalloz, 1992, p. 1, considera que este desequilíbrio sempre existiu, apenas agora está qualificado de tal forma que é um dos objetivos sociais de nosso tempo, proteger o consumidor em posição estruturalmente mais fraca.

34 Marques, El código brasileño, p. 199 , também Botana Garcia; Ruiz Muñoz, Curso sobre..., p. 8 menciona a atual "degradación de la posición del consumidor".

35 Exceção feita aos EUA e Venezuela, veja Parra-Aranguren, Gonzalo, Curso general de derecho internacional privado: problemas selectos. Caracas: Fundación Fernando Parra Aranguren, 1991, p.51 et seq.

36 Assim Benjamin, Antônio Herman. El código brasileño de protección del consumidor. In: Politica y derecho del consumo. Bogotá: El Navegante, 1998, p. 480. 
geralmente pessoa física não profissional, que age, contrata ou negocia no mercado de consumo o fornecimento de produtos e serviços sem fins lucrativos e fora de sua atividade profissional principal, interessa hoje ao Direito Internacional Privado, como comprova o Protocolo de Santa Maria de 1998 no Mercosul e ao Direito Internacional Privado geral, como demonstrou o projeto de 1980 da Convenção de $\mathrm{Haia}^{37}$ e a Convenção Européia de Roma de 1980.

Pergunta-se, aqui, se os esforços até agora realizados foram suficientes ou devem ser renovados. As normas nacionais deveriam ser suficientes para proteger o consumidor no novo mercado sem fronteiras, ao mesmo tempo em que não devem ser usadas pelos países como novas barreiras à livre circulação de produtos e de serviços dos países integrados ou que pertencem a uma zona de livre comércio ou união aduaneira, como a NAFTA, a ALCA e o Mercosul. ${ }^{38}$ Note-se, porém, que as normas nacionais, reguladoras do comércio internacional, assim como o direito uniforme do comércio internacional ou a denominada lex mercatoria, geralmente não se preocupam em proteger o consumidor, ${ }^{39}$ ao contrário tentam excluir estes contratos de seu campo de aplicação. ${ }^{40}$

Na Europa, desde a década de 1970, os doutrinadores propugnam a necessidade do Direito Internacional Privado voltar-se para a proteção dos mais fracos, especialmente dos consu-

37 Veja Mehren, Arthur Von. Law applicable to certain consumer sales: texts adopted by the fourteenth session and explanatory report. Haia: Bureau Permanent de la Conférence, 1982, p. 6, que explica como este projeto de convenção visava complementar a Convenção de Haia de 1955 sobre lei aplicável à venda internacional de mercadorias, o que nunca chegou a acontecer, pois o referido projeto, findo em 1980, nunca chegou a ser aprovado, superado que foi pela própria Convenção de Roma da CEE, assinada naquele mesmo ano com seu famoso art. $5^{\circ}$ sobre o mesmo tema.

38 Assim Krämer, Ludwig. La CEE et la protection du consommateur. Bruxelles, 1988, p. 377. Veja também o nosso artigo, Marques, op.cit., p. 199 et seq.

39 Assim Botana Garcia; Ruiz Muñoz, op. cit. p. 21, citando os princípios de UNIDROIT sobre os contratos comerciais internacionais e a Convenção de Viena sobre compra e venda internacional de mercadorias de 1980.

40 O exemplo mais importante são as normas uniformizadoras da Convenção da ONU sobre Compra e Venda de mercadorias de 1980, conhecida como Convenção de Viena de 1980 , que em seu art. $2^{\circ}$ e e art. $5^{\circ}$, procuram evitar a aplicação destas normas do comércio internacional aos contratos com consumidores-leigos. Veja sobre o tema Hargain; Mihali, Circulación..., p. 506 e GARRO, Alejandro Miguel; Zuppi, Alberto Luis. Compraventa internacional de mercaderías. Buenos Aires: La Rocca, 1990, p. 81. 
midores, ${ }^{41}$ incluindo novos elementos de conexão mais flexíveis e adaptados à tutela do vulnerável nestas situações privadas internacionais, face à falência das ditas conexões "neutras" e rígidas, mais adaptáveis ao relacionamento entre iguais ou pelo menos entre profissionais, comerciantes. ${ }^{42}$ Estas normas especiais de DIPr. seriam necessárias até que a harmonização das normas materiais de defesa do consumidor, pelo menos nos temas principais da internacionalização então vivida, acontecesse na Europa ${ }^{43}$

Com as devidas adaptações, parece-me que exatamente este momento histórico está se repetindo no espaço interamericano. O sistema interamericano está claramente aberto para o comércio internacional e a regionalização, mas ainda possui um ordenamento jurídico lacunoso e insuficiente para proteger os agentes econômicos mais fracos de seu mercado, os consumidores. Uma evolução seria necessária.

Neste sentido, unindo-me aos doutrinadores uruguaios e argentinos, ${ }^{44}$ que me precederam nestes estudos sobre a proteção do consumidor em situações internacionais, aproveitei o convite do Comitê Jurídico Interamericano para sugerir a elaboração de uma Convenção Especializada de Direito Internacional Privado sobre proteção do consumidor em duas situações específicas, a do consumidor-turista, especialmente aquele que se utiliza do sistema de multipropriedade ou time-sharing, e a do consumidor que contrata à distância, seja por meios tradicionais ou por novos meios eletrônicos. Inspiro-me na atual doutrina européia, a qual continua indicando que o tema da proteção do consumidor é básico para os mercados globalizados, ${ }^{45}$ é a

41 Ficaram famosos os trabalhos de Zweigert, Neuhaus e Lando, sugerindo o primeiro que o DIPr. incluisse valores sociais e, o segundo, que se abandonasse a autonomia de vontade nos contratos entre contratantes fracos e fortes, como os de consumo e o terceiro, pragmaticamente, que passasse o DIPr. a escolher como conexão o domicílio do contratante mais fraco, veja também o estudo de Hoffmann, Bernd Von. Über den Schutz des Schächeren bei internationalen Schuldvertragen. RabelsZ, n. 38, p. 396-420, 1974., p. 398 et seq. e de Kropholler, Jan. Das kollisionsrechtliche System des Schutzes der schwächeren Vertragspartei. RabelsZ, n. 42, p. 634-661, 1978, p. 634 et seq.

42Assim Ibidem, p. 636.

43Assim manifesta-se, denominando a ordem jurídica alemã da época de "lacunosa e insegura para os contratantes mais fracos", Ibidem, p. 635.

44 Mencione-se aqui especialmente os estudos aqui citados de Boggiano, Dromi e Toniollo, na Argentina, Arrighi e os autores Hirgain/Mihali, no Uruguai.

45Assim a exposição forte e crítica de Junker, Abbo. Von Citoyen zum Consommateur: Entwicklung des internationalen Verbraucherschutzrechts. IPRAX, 1998, p. 67 et seq., afirmando que o consumidor é o "citoyen", o cidadão político europeu do futuro. Junker inspira-se em trabalho semelhante de Westphalen, Von. Vom Citoyen über den Bourgeois zum Consommateur. ZIP, 1995, p. 1643, veja Junker, op. cit., p. 67. 
maneira de harmonizar os interesses do mercado com os anseios de respeito aos novos direitos humanos em tempos pósmodernos, de individualismo crescente e de integração econômica cada vez mais desenvolvida. ${ }^{46}$ Esta sugestão de CIDIP não deve aqui ser repetida, logo, cabe agora estudar quais as sugestões para a LICC brasileira.

\section{A) A especificidade do consumo internacional e a Lei de Introdução ao Código Civil (LICC/1942)}

Repita-se aqui, em parte, nosso estudo para a elaboração da CIDIP. Inicialmente, mister estabelecer claramente quais são as especificidades das relações de consumo internacionais se comparadas às relações comerciais internacionais. Certo é que no comércio internacional também há a barreira da língua, a barreira da falta de informações, as normas e costumes dife- rentes, as dificuldades e a insegurança na entrega e no pagamento, as dificuldades na garantia, no nível qualidade e no serviço pós-venda ${ }^{47}$ mas estas dificuldades qualificam-se quando o parceiro contratual é um leigo, um consumidor. ${ }^{48} \mathrm{~A}$ primeira das especificidades do consumo internacional é, pois, o desequilíbrio intrínseco informativo e de especialização entre os parceiros contratuais internacionais face ao status leigo e vulnerável do parceiro-consumidor. ${ }^{49} \mathrm{O}$ comércio internacional, as relações de compra e venda ou de prestação de serviços entre pessoas com sede em países diferentes, geralmente ocorre entre pessoas jurídicas ou profissionais, comerciantes e empresários, logo, especialistas e profissionais para poderem se movimentar no cenário dos negócios internacionais. No consumo internacional não é esta a realidade. O parceiro-consumidor é atraído ou por métodos agressivos de marketing (por

46 Esta análise pós-moderna é uma homenagem ao mestre orientador de Doutorado, prof. dr. dr.h.c. Erik Jayme, da Universidade de Heidelberg, que em seu brilhante curso de Haia lançou sua teoria dos reflexos da pós-modernidade no direito. Veja Jayme, Identité..., p. 33 et seq.

47 Sobre as dificuldades do comércio internacional veja Feldstein de Cárdenas, Sara. Contratos internacionais. Buenos Aires: Abeledo-Perrot, 1995, p. 60 et seq. e Moura Ramos, Rui Manuel; Soares, Maria Angela Bento. Contratos internacionais. Coimbra: Almedina, 1986, p. 9 et seq. Chega-se a advogar, pela sua especificidade mesmo a existência de um direito do comércio internacional, veja Jadaud, Bernard; Plaisant, Robert. Droit du commerce international. Paris: Dalloz, 1991, p. 1.

48 Assim COMISSÃO EUROPÉIA. Guía del consumidor europeo en el mercado único. Bruxelas: Comisión Europea, 1995, p. 15-16.

49 Veja sobre a vulnerabilidade do consumidor, Marques, Cláudia. Contratos no código de defesa do consumidor. São Paulo: Revista dos Tribunais, 1999, p. 140 et seq. 
exemplo, telemarketing, teleshopping, vendas emocionais de time-sharing para turistas) ou por preços reduzidos (descontos, redução nos tributos, envio gratuito, etc.), pelo senso de aventura (por jogos, apostas, prêmios), ou por sua própria ignorância quanto às dificuldades nas transações transnacionais (parco conhecimento da língua para entender a oferta ou a publicidade, mito da qualidade superior dos produtos importados, produtos-novidade, desconhecidos em países emergentes, pela falta de conselhos jurídicos ou de um departamento jurídico para a negociação, confiança que a marca terá serviços pós-venda em seu país, etc.). As regras do comércio internacional, as regras de direito internacional privado, em geral, estão construídas sobre a base do profissionalismo e especialidade dos parceiros envolvidos, ${ }^{50}$ a proteger quem vende, quem fornece o produto e o serviço, não daquele que apenas paga (comprador, recebedor do serviço, "consumidor").

Outra especificidade do consumo internacional é a sua falta de "continuidade" ou sua "descontinuidade". Os atos de comércio caracterizam-se pela repetição e mesmo os contratos internacionais tendem a abrir mercados e relações bastante cooperativas e duradouras. Os contratos de consumo internacionais, ao contrário, são geralmente de troca, não possuem longa duração, nem se beneficiam do sistema financeiro internacional ou transferem tecnologia no sentido estrito da palavra. ${ }^{51}$ Por exemplo, ser turista é um fenômeno pontual e sazonal, comprar à distância de um fornecedor da Califórnia (EUA) um determinado soft ware ou livro também é um fenômeno eventual e descontínuo. As regras do comércio internacional, as regras de direito internacional privado, em geral, estão construídas sobre a base da confiança e da continuidade, do crescer de relações: aquele que compra internacionalmente, voltará a comprar se a "execução" for adequada, há que se proteger aquele que vende, aquele que envia sem muitas garantias e sem conhecer seu cliente propriedade sua

50 Neste sentido destaque a decisão do STF não considerando "consumo" relações de importação de matéria prima entre dois comerciantes, SENTENÇA ESTRANGEIRA CONTESTADA n ${ }^{\circ}$ 5.847-1, acórdão promulgado em 01.12.1999, Rel. Min. Maurício Corrêa. Veja meus comentários a esta decisão do STF, junto com Turkienicz, Eduardo. Comentários ao acórdão do STF no caso Teka vs. Aiglon : em defesa da teoria finalista de interpretação do art. $2^{\circ}$ do CDC. Revista Direito do Consumidor, São Paulo, v. 36, 2000, p. 221 et seq.

51 Rara exceção seria o contrato de time-sharing ou multipropriedade, que é uma relação duradoura, se bem que fluída, por vezes nacional ou internacional (com círculos de trocas), veja sobre assunto o mestre brasileiro, Tepedino, Gustavo. Multipropriedade imobiliária. São Paulo: Saraiva, 1993 e meu artigo, Marques, Cláudia Lima, Contratos de time-sharing no Brasil e a proteção dos consumidores: crítica ao direito civil em tempos pós-modernos. Revista Direito do Consumidor, São Paulo, v. 22, p. 64-86, 1997. 
para país distante. No consumo internacional, a prioridade se inverte, o comprador não é um comerciante, não é expert, é, ao contrário, leigo, compra pelo preço, pelas qualidades apregoadas, confia em uma, muitas vezes, inexistente proteção legal e assume enormes riscos ao viabilizar o número de seu cartão de crédito.

As outras especificidades são o pequeno valor, a massificação e a difícil re-execução. O consumo internacional é hoje um fenômeno de massas, basta pensar o turismo sazonal, o timesharing, com seus círculos de trocas internacionais, os pacotes turísticos para grandes festas, os transportes aéreos, os cruzeiros marítimos, etc. ${ }^{52}$ Individualmente considerado o contrato internacional de consumo tem, porém, pequeno valor, seja para a economia de um país ou de um fornecedor. Este pequeno valor dificulta em muito o acesso à justiça, faz com que a lide fique reprimida, dificulta que o consumidor assuma gastos exagerados, seja para reclamar, para procurar novamente o fornecedor, para fazer valer sua garantia, etc. O consumo internacional ainda possui uma última especificidade, que lhe é comum com os serviços em geral, sua re-execução, em caso de frustração das expectativas do contra- tante consumidor é bastante dificultosa. Em caso de turismo, reeditar algo, uma excursão, dias de férias em praia poluída, recuperar o conforto de um hotel em país distante e assim por diante, é tarefa quase impossível e a resposta será apenas econômica, com as perdas e danos respectivas. Em matéria de contratos à distância, a eventualidade da perda de tempo, da perda de uma chance e de acontecerem danos morais anexos à má-execução do contrato internacional de consumo também são quase uma constante, o melhor é prevenir os danos e minimizá-los, ou a resposta será apenas econômica, com as perdas e danos respectivos.

Destaque-se, por fim, que há um forte componente político-econômico nas regras de proteção nacional e internacional dos consumidores, pois se um país exportador mantém um alto nível de proteção de seus consumidores aumenta a qualidade de seus produtos, que encontrarão maior aceitação internacional. Se um país turístico, aumenta o grau de proteção dos turistas e facilita o seu acesso à Justiça, garante melhores condições ao turismo e facilita o desenvolvimento deste importante setor econômico. Em outras palavras, regras sobre o direito do consumidor interessam à competitividade do mercado

52 A doutrina européia alerta desde a década de 80 e, especialmente na década de 90 , que o turismo de massa é um dos setores econômicos que mais cresce na União Européia e que a defesa do consumidor se faz necessária até mesmo como instrumento harmonizador da concorrência, veja, por todos, com estatísticas sobre o crescimento do setor turístico, Lete Achirica, Javier. El contrato de multipropriedad y la protección de los consumidores. Barcelona: Cedec, 1997, p. 32-34. 
interno e à competitividade internacional, assim como contribuem à criação de um mercado interno com concorrência leal e à realização das políticas governamentais. ${ }^{53}$

A tendência é a elaboração de regras nacionais, muitas consideradas de ordem pública internacional, ${ }^{54}$ lois de police ou leis de aplicação imediata, ${ }^{55}$ assim como a aproximação, harmonização das regras nacionais, que asseguram a proteção do consumidor, nos organismos internacionais dedicados à integração econômica, como a União Européia (UE) e o Mercosul.

B) Da necessidade de regras especiais de Direito Internacional Privado para a proteção dos consumidores também no Brasil

\section{Por um Direito Internacional} Privado com valores sociais $e$ função de harmonia regional

Os autores clássicos brasileiros conceituavam Direito Internacional Privado, na esteira de Pillet e da teoria francesa, como "a ciência que tem por objeto a regulação jurídica das relações internacionais de ordem privada" 56 ou as "relações de ordem privada da sociedade internacional", ${ }^{57}$ cujo objeto não seria apenas o estudo dos conflitos de leis no espaço, ${ }^{58}$ mas também os conflitos de jurisdição, os problemas de nacionalidade, condição jurídica do estrangeiro e direito adquirido. Particularmente, aceito a limitação do objeto do DIPr. proposta pelos autores italianos e alemães ${ }^{59}$ e neste trabalho considerarei Direito Internacional Privado as

53 Assim também Ghersi, Carlos Alberto, Razones y fundamentos para la integración regional. In: Ghersi, Carlos Alberto (Coord.). Mercosur: perspectivas desde el derecho privado. 1993 , p. 30 et seq.

54Veja Bucher, Andreas. L'ordre public et le but social de lois en droit international privé. Recueil des Cours, Haia, v. 2, n. 239, 1993, p. 60-69.

55 Veja sobre o art. 18 Lei de Dir. Internacional Privado suíça, Bucher, op. cit., p. 39.

56 Esta a definição de Fulgêncio, Tito, Synthesis de Direito Internacional Privado, Ed. Freitas Bastos, Rio de Janeiro, 1937, p. 5.

57 Esta a expressão de Bevilaqua, Clóvis, Princípios Elementares de Direito Internacional Privado, Ed. Histórica, Ed. Rio, 1988, p. 11.

58 Assim Rodrigo Octavio, Rodrigo, Direito Internacional Privado-Parte Geral, Ed. Freitas Bastos, Rio de Janeiro, 1942, p. 19, confessando que esta é a parte principal da disciplina, mas não a única, que segundo ele incluiria ainda a condição jurídica dos estrangeiros e o respeito aos direitos adquiridos, p. 20.

59 Kegel, Gerhard, Internationales Privatrecht, 6.ed., Beck, Munique, 1987, p. 3, Kropholler, Jan, Internationales Privatrecht, J. C. B. Mohr, Tübingen, 1990(Citado Kropolher/IPR), p. 1 e von Bar, Christian, Internationales Privatrecht-vol.II,BT, Beck, Munique, 1991, p. 1. 
regras, normas, o desenvolvimento jurisprudencial e os princípios tendentes a indicar uma lei aplicável aos casos privados com conexão com mais de uma ordem jurídica, solucionando apenas indiretamente os chamados conflitos de leis no espaço, assim como todas as normas (materiais, de ajuda, qualificadoras e de aplicação imediata) que intervêm ou ajudam (Hilsfnormen) neste procedimento. ${ }^{60}$ Os temas auxiliares para a solução destes conflitos de leis no espaço serão tratados aqui como matérias "irmãs" do DIPr. e, hoje praticamente e pragmaticamente nele contidas, como o Direito Processual Civil Internacional ou Processo Civil Internacional. Mas só poderei mencionar alguns dos esforços para a determinação de uma jurisdição especial para o consumidor e de facilidades no reconhecimento e execução de sentenças, bem como esforços para uma maior cooperação jurisdicional internacional neste tema, pois merecem um estudo epecial e monográfico, que expandirei este trabalho em demasia.

Da mesma forma, parece-me necessário esclarecer que aceitaremos aqui a teoria do Direito Internacional Privado pós-moderno de meu mestre de Heidelberg, prof, dr. dr. h.c. mult. Erik Jayme, para o qual o DIPr. é um instrumento de harmonia e paz nas relações hoje globalizadas. ${ }^{61} \mathrm{O}$ DIPr. pós-moderno conseguiria equilibrar e representar ao mesmo tempo as forças contraditórias sociais e econômicas de nossa época, do individualismo pósmoderno de uma identidade cultural exacerbada, à força irresistível da aproximação e regionalização econômica, de espaços supranacionais de integração e de um livre comércio globalizado. A proteção do consumidor se insere neste contexto como válvula de escape dos conflitos pós-modernos, pois representa juridicamente a garantia de um standard mínimo de segurança e adequação dos serviços e produtos, nacionais ou importados, comercializados nos mercados abertos de hoje. Representa, politicamente, um comprometimento com a lealdade do mercado, assegurada em visão macro pelo direito da concorrência e em visão micro, mas hoje cada vez mais coletiva e difusa, pelo direito do consumidor. Por fim, socialmente, procura equilibrar o revival da autonomia da vontade, da concentração no papel do indivíduo a determinar soberanamente suas relações privadas, econômicas e de consumo, e o revival dos direitos humanos, uma vez, que receber proteção do Estado é direito fundamental dos cidadãos de muitos países, e o direito do consumidor é direito humano de nova geração. ${ }^{62}$

\section{Veja art. $3^{\circ} \mathrm{da}$ EGBGB alemã.}

61 Assim os belíssimos ensinamentos de Jayme, Cours, p.56 e seg.

62 Jayme, Cours, p. 49. 
Se, como ensina Jayme, ${ }^{63}$ o DIPr. é um dos ramos mais sensíveis às mudanças sociais, políticas e jurídicas do final do século, pois evita conflitos ideológicos e valorações negativas quanto aos direitos nacionais, permitindo indicar soluções (materialmente e jusprivatisticamente) justas para os conflitos privados internacionais sem impedir ou afetar o curso do comércio internacional e do liberalismo econômico, inserir normas de respeito aos direitos do indivíduo neste DIPr. do futuro, não só minimiza os riscos de adoção de soluções radicais, pela insatisfação quanto à Justiça material nas relações internacionais, como também preenche uma lacuna da lex mercatoria ao estabelecer um standard internacional de garantia de efetividade de direitos para o parceiro mais fraco no comércio internacional, o consumidor, agente econômico leigo. Evita-se assim que a lacuna seja preenchida, pois, através de um novo territorialismo nacional radical.

Interessante notar que se os países sempre conseguiram um consenso sobre a necessidade de evoluir e garantir, com normas imperativas ou com normas narrativas (soft law), as bases do comércio internacional de mercadorias e serviços entre comerciantes ou profissionais, não houve até agora grande preocupação em evoluir as normas de DIPr. de proteção do consumidor-pessoa física, atuando fora de sua atividade profissional, como destinatário final de serviços e produtos para fins pessoais ou familiares. ${ }^{64}$ Fora os esforços da projetada Convenção de Haia em 1980 e as Convenções européias, o tema tem sido pouco debatido nas Américas como veremos. ${ }^{65}$ Se uma explicação pode ser tentada para esta lacuna consciente da lex mercatoria mundial, parece-me ser a de que os países desenvolvidos já possuem mecanismos jurídicos e de DIPr. suficientes para a aplicação de suas regras de defesa do consumidor, garantindo assim uma proteção efetiva de seus cidadãos também nas relações de consumo internacional.

Ao mesmo tempo, não há grande interesse ou necessidade de estender este mesmo standard para consumi-

63 Veja Jayme, Cours, p. 129 e seg.

64 Veja sobre o tema Arrighi, Jean Michel. La Proteccion de los Consumidores y el Mercosur, in: Revista Direito do Consumidor, São Paulo, vol. 2 (1992), p. 126 e seg.

65 Assim Toniollo, Javier Alberto. La protección internacional del consumidor - Reflexiones desde la perspectiva del Derecho Internacional Privado Argentino, in Revista de Derecho del Mercosur, ano 2, nr. 6, diciembre de 1998, p. 96, comentado o projeto de Haia. Veja também o mencionado relatório e projeto de VON MEHREN, Rapport explicatif-Loi applicable à certaines ventes aux consommateurs, in Actes et Documents de la Quatorzième session (1996), tome II, Ventes aux consommateurs, Buerau Permanent de la Conférence de la Haye, La Haye, 1982, p. 6 e seg. 
dores fora da região ou consumidores dos países de segundo e terceiro mundo, hoje países emergentes. Desenvolve-se então o mito, entre países emergentes, que um standard alto de proteção do consumidor representaria barreira ao livre comércio, ${ }^{66}$ desenvolvendo assim novos mercados para a colocação de produtos e serviços já proibidos em outros países ou ainda em fase de testes quanto aos seus riscos. Evita-se também que as indústrias locais dos países emergentes invistam no desenvolvimento de um standard internacional adequado de proteção do consumidor (e meio ambiente), de forma a impedir indiretamente que estas indústrias possam exportar seus produtos e serviços e participar mais ativamente (e concorrencialmente) do mercado internacional. Reverter este quadro, é problema de política internacional, mas o Direito pode contribuir preenchendo esta lacuna da maneira mais neutra e menos conflitual possível, que é, por ironia, o Direito Internacional Privado, com suas normas indiretas (ou de método conflitual) protetivas dos consumidores, com claro objetivo material (e não juridicamente neutro). ${ }^{67}$

Em resumo neste trabalho, propomos uma utilização atualizada do DIPr., preenchendo estas normas com valores sociais que oportunizarão a harmonia de relações internacionais necessária em nosso tempo; um DIPr. de solução material dos complexos conflitos pós-modernos que agora envolvem direitos humanos e limites constitucionais, ${ }^{68}$ um DIPr. "narrativo" 69 que vise, que "discurse" ao mesmo

66 Sobre a incorreção deste mito, veja meu artigo O Código de Defesa do Consumidor e o Mercosul, in Revista Direito do Consumidor, vol. 8 , p. 43 e seg.

67 Sobre a crise do DIPr., veja o curso de Kegel em Haia, citado por Nishitani, Yuko, Mancini und die Parteiautonomie im Internationalen Privatrecht, Universitätsverlag C.Winter, Heidelberg, 2000, p. 283.

68 Refiro-me ao Double Coding na interpretação das normas atuais, que não são mais intrinsecamente neutras, mas trazem em si a proteção dos valores constitucionais, especialmente os direitos humanos reconhecidos na ordem jurídica internacional, por Convenções de Direito Internacional Público. Veja Jayme, Cours, p. 36.

69 Adoto aqui a teoria de Jayme sobre normas narrativas (Jayme, Cours, p. 247), destacando que qualquer proposta de Convenção internacional e o texto daí oriundo tem hoje um efeito ao menos narrativo, de demonstrar os problemas e os caminhos, de narrar objetivos e princípios, mesmo que seja apenas como fonte de inspiração, mesmo que estas normas nunca cheguem a ter vigência, seus esforços, como os da Convenção de Haia de 1980, demonstram a existência de necessidades e forçam a procura - nacional, regional ou universal - de soluções. Veja sobre a necessidade de proteção internacional do consumidor os estudos de von Hoffman, Kropholler, nas Américas, de Boggiano, e mais recentemente de BRÖCKER e TONIOLLO, todos citados neste trabalho. 
tempo promova a "discussão," 70 que efetive a necessária proteção dos mais fracos nos mercados internacionalizados dos dias de hoje. ${ }^{71}$

Como prega Kropholler, em seu famoso artigo de 1978 sobre a proteção da parte mais fraca através do Direito Internacional Privado, ${ }^{72}$ é necessário evoluir para um DIPr. impregnado de valores sociais. Parece-me o momento para passar a considerar também nas normas de DIPr., como ensina Fausto Pocar, ${ }^{73}$ este valor: a proteção do mais fraco na sociedade de consumo e de informação, o consumidor.

Segundo Brilmayer os valores tradicionais do DIPr., tais como a previsibilidade da lei aplicável e o desencorajamento do forum shopping são análogos aos valores processuais, e não às conexões territoriais, pois não encontram seu fundamento em preferências materiais de cada país. ${ }^{74}$ Desenvolvendo um pouco mais este pensamento crítico da autora norteamericana, poderíamos afirmar, com Jayme, ${ }^{75}$ que as novas normas de DIPr. de proteção do consumidor, pelo menos as oriundas da União Européia têm finalidade material. Isto é, estas normas de DIPr. encontram seu fundamento nas preferências materiais e na decisão governamental supranacional de estender o standard europeu de proteção aos agentes econômicos mais fracos e de forma efetiva em toda a região, a todos os seus cidadãos e residentes.

Apesar de à primeira vista "nacionalista" (ou pós-nacionalista) esta opção material não me parece errada, pois em verdade o DIPr. continua à procura de uma legitimação material

70 Veja sobre o tema Müller, Friedrich, Direito-Linguagem-Violência, Ed. Sérgio Fabris, Porto Alegre, 1995, p. 17 e seg. Veja Habermas, Jürgen, Legitimation Crisis, Beacon Press, Boston, 1999,p. 68 e seg. e meu trabalho, A crise cientifica do Direito na pós-modernidade e seus reflexos na pesquisa, artigo publicado na Revista Arquivos do Ministério da Justiça, Brasília, ano 50, número 189, jan/junho 1998, p. 49 e seg., com extensa bibliografia sobre os efeitos descontrutores no Direito dos discursos da pós-modernidade.

71 Sobre a necessidade de tomada de posição da doutrina, veja incisivo, Arrighi, p. 126-127. 72 Kropholler, p. 655.

73 Veja seu curso de referência, Pocar, Fausto. La protection de la partie faible en droit internationl privé. Rec. Acad. La Haye, 1984, V, p. 339 et s.

74 Brilmayer, Lea, Conflits of Law, 2.ed, Little, Brown and Co., Boston, 1995, p. 178: "Traditional choice of law values such as predicability and the discouragement of forum-shopping are very closely analogous to procedural values. Unlike territorial scope decisions that derive from substantive preferences, however, they are typically not a product of specific domestic substantive rule, but apply across a wide range of substantive areas."

75 Assim manifestou-se sobre o fim material das normas de DIPr. oriundas da União Européia, Jayme (in Hommelhoff/Jayme/Mangold (Ed.), Binnermarkt-Internationales Privatrecht und Rechtsvergleichung (1995), p.35), apud Junker, p. 74, nota 132. 
para as suas opções de qual a lei a ser aplicada. Sendo assim, parece-me perfeitamente razoável que as conexões escolhidas pelo DIPr. para proteger o consumidor tenham como finalidade a proteção da parte mais fraca (von Hoffman), de seus direitos fundamentais (Jayme) e a justiça substancial no caso concreto (Zweigert). ${ }^{76}$

Doutrinadores norte-americanos de DIPr. destacam que o ideal de igualdade tem origem constitucional (The equal protection clause), ${ }^{77} \mathrm{o}$ que significa um limite para as normas de DIPr.: não devem elas de forma unfair discriminar, criar privilégios e imunidades, devem ser razoáveis e ter uma clara base social e política. ${ }^{78}$ Hoje, também podemos considerar este mandamento universal, mandamento de procura da igualdade entre as pessoas físicas de uma sociedade (o destacado por Jayme, revival dos direitos humanos na pósmodernidade): ${ }^{79}$ como um dos objetivos do DIPr., à procura da harmonia de decisões, ${ }^{80}$ da solução justa para os interesses envolvidos e para os direitos fundamentais envolvidos na relação de consumo. O DIPr. seria então mais um instrumento de proteção dos mais fracos e de realização da Justiça nestas sociedades internacionalizadas, integradas ou globalizadas.

Note-se que também em matéria de concorrência leal houve uma clara evolução em DIPr. As normas nacionais protetoras de concorrência leal atingiram forte grau de extraterritorialidade. ${ }^{81}$ Assim como os tratados europeus, ${ }^{82}$ também a tradicional conexão da lex loci delicti commissi passou a ser interpretada de forma flexível, seja como lugar da conduta concorrencial abusiva (place of wrongful conduct), seja o lugar do impacto (place of impact or relevant market), e até mesmo em ilícitos complexos passou o lugar da tomada de decisão da empresa a ser considerado, ${ }^{83}$ visando sempre

76 Assim concorda Toniollo, p. 99 citando De Vischer.

77 Herzog, Peter E., Constitucional Limits on Choice of Law, Recueil des Cours, 1992, III, t. 229, Nijhoff, Dordrecht, 1993, p. 285.

78 Herzog, p. 287.

79 Jayme, Cours, p. 167 e seg.

80 Assim Boggiano, Antonio, The Contribution of the Hague Conference to the Development of Private International Law in Latin America. Universality and genius loci, in Recueil des Cours, 1992, II, t. 233, Nijhoff, Dordrecht, 1993, p. 138.

81 Assim conclui, examinando o $\S 98,2,1$ GWB alemã, Martinek, Michael, Das internationale Kartellprivatrecht, Verlag Recht und Wirtschaft, Heidelberg, 1987, p.94.

82 Casella, Paulo Borba, Comunidade Européia e seu Ordenamento Jurídico, São Paulo, Ltr, 1994, p.430.

83 Sobre o tema e esta evolução em flexibilidade, veja DYER, Recueil, p. 413 e seg. 
a Justiça do DIPr. no caso concreto

e uma maior harmonia de decisões, ${ }^{84}$ em matéria contratual e extra-contratual.

Por fim, considere-se que em tempos de fragmentação pós-moderna, as regras de DIPr. devem concentrarse apenas em alguns temas, logo, assegurar também uma proteção em temas ou fragmentada. Devem ser regras flexíveis ou pelo menos alternativas para que o princípio do favorecimento do consumidor possa realizar-se. Segundo Jayme, o DIPr. pós-moderno deve privilegiar ao mesmo tempo os valores individuais, deixando que cada mercado de certa forma decida o que é melhor para seus consumidores. ${ }^{85}$ Esta fragmentação e flexibilização será tentada aqui através da concentração em dois temas, nos quais, parece-me, a proteção nacional do consumidor será sempre insuficiente e lacunosa, mesmo nos países de primeiro mundo, e onde a unificação de normas de DIPr. ${ }^{80}$ será oportuna também para o comércio internacional, ao criar maior segurança, previsibilidade para os profissionais e harmonia nas decisões, quais sejam alguns aspectos da proteção do turista e da proteção do consumidor no comércio internacional à distância ou através de meios eletrônicos.

\section{As conexões atuais das normas de conflito tradicionais e sua inadequação para a proteção do consumidor}

Segundo ensina Kropholler, ${ }^{87}$ é necessário elaborar normas específicas de DIPr. para a proteção dos consumidores leigos ou não profissionais, pois as conexões hoje existentes para regular o comércio internacional todas têm como base um equilíbrio estrutural de forças ou de interesses profissionais entre os agentes (ambos profissionais) envolvidos. Estas conexões, seja a autonomia da vontade (escolha da lei que regerá o contrato pelas partes, no contrato ou após), o local da execução (geralmente o local de execução da prestação característica, sempre prestada pelo profissional em caso de contrato de consumo internacional), ou do local de conclusão do contrato (conectando o contrato com a ordem jurídica do país do ofertante, em contratos à distância, sempre também o ofertante), não são adpatadas para os contratos de consumo, pois este equilíbrio estrutural inexiste nos contratos internacionais concluídos com consumidores leigos.

Segundo bem relembra Jayme, o momento atual é de prevalência de

84 Martinek, p. 96 .

85 Veja Jayme, Cours, p. 129 e seg.

86 Sobre os aspectos positivos e negativos da unificação do DIPr. através de Tratados, veja NEUHAUS, Paul Heinrich e Kropholler, Jan, Rechtsvereinheitlichung Rechstverbesserung?, in RabelsZ 45 (1981), p. 73 e seg.

87 Kropholler, p. 398 e seg. 
normas materiais em casos internacionais, reduzindo a importância do processo civil internacional tradicional. ${ }^{88}$ Tempos de uma maior possibilidade de determinação própria pelo indivíduo (Selbstbestimmung) em direito material, ${ }^{89}$ de novas técnicas nas convenções internacionais tentando harmonizar as diferenças culturais e de desenvolvimento através da cooperação judicial e respeito às normas imperativas locais, ${ }^{90}$ tentando respeitar os direitos humanos envolvidos no caso, ${ }^{91}$ o que significa, face à revolução tecnológica atual, uma nova prevalência pela residência habitual do consumidor como novo elemento de conexão para determinar a lei aplicável ao comércio internacional de conumo e novo critério para determinar a competência do foro. ${ }^{92}$ Aqui está, segundo o grande mestre de Heidelberg, o futuro do DIPr., a Jutiça do DIPr.

Alcançar objetivos materiais através de normas de DIPr. não parece propor um problema metodológico no DIPr. das Américas. Segundo muitos autores, há uma certa tradição de territorialismo na América Latina ${ }^{93}$ e também nos Estados Unidos, ${ }^{94}$ havendo claro privilégio hoje da aplicação da lex fori. Esta solução simplista da aplicação da lex fori sempre que relação de consumo ou relação considerada de ordem pública (internacional) é clássica, porém, não parece oportuna ou suficiente nos dias de hoje. ${ }^{95}$

88 Assim Jayme, Erik, Zum Jahrtausendwechsel: Das Kollisionsrecht zwischen Postmoderne und Futurismus, in IPRAX-Praxis des Internationalen Privat- und Verfahrensrechts, 2000, p. 169.

89 Jayme, IPRAX 2000, p. 170.

90 Assim Jayme, IPRAX 2000, p. 168.

91 Assim Jayme, IPRAX 2000, p. 171, citando os casos de decisão judicial na Alemanha sobre o desastre de Tschernobyl, em que o "local do delito" foi considerado o território alemão onde a "nuvem radiotiva" causou danos, que devem ser indenizados pela empresa russa e, também, os casos sobre comércio eletrônico, em que estão sendo considerados competentes os foros do local de "distribuição" da informação por internet, logo, do local onde está o consumidor.

92 Jayme, IPRAX 2000, p. 171.

93 Veja sobre as diferentes influências políticas e jurídicas para o territorialismo típico do DIPr. dos países da América Latina, Samtleben, Juergen, Menschheitsglück und Gesetzgebungsexport- Zu Jeremy Benthams Wirkung in Lateinamerika, in RabelsZ 50 (1986), p. 475. Veja também ARAÚJO, Nádia de, Contratos Internacionais - Autonomia da Vontade, Mercosul e Convenções Internacionais, $2^{\mathrm{a}}$ ed.,Ed. Renovar, Rio de Janeiro, 2000, p. 145 e seg.

94 Assim Richman, William M. e Reynolds, William L., Understanding Conflict of Laws2.ed., Times Mirror Books, USA, 1995, p. 230.

95 Assim também Kropholler, p. 635. 
Esta solução territorialista não é oportuna, pois não promove a harmonia de decisões e acaba por aumentar as tensões entre o comércio internacional, cada vez mais uniformizado e protegido, e as legislações nacionais ou regionais, que deixam desamparados seus consumidores, especialmente em países do terceiro mundo, possibilitando o abuso e o uso de standards fortemente diferenciados a criar, como afirma Gabriel Stiglitz, um consumidor de "resíduos", situação não sustentável a longo prazo. Esta solução territorialista não é suficiente, pois deixa sempre desamparados parte dos consumidores nacionais, pois nunca é suficiente para proteger o consumidor turista, nem protege eficazmente o consumidor atual, que contrata internacionalmente por telefone, cabo ou internet, sem precisa consciência de que lei se aplica a esta relação ou quais exatamente são seus direitos e garantias materiais, seus privilégios (ou não) de foro. De outro lado, há que se aprender com o ensinamento da Corte Européia, de tolerância e igualdade implícita dos ordenamentos jurídicos, das leis protetivas dos consumidores, principalmente entre Estados que participam de uma integração econômica e legislam sobre o standard mínimo. ${ }^{96}$ Assim como relembrar que muitas vezes a lei do outro país pode assegurar mais direitos ao consumidor do que a lei local..$^{97}$ Mister, pois, tentarmos usar todas as técnicas de flexibilidade, de abertura atual do DIPr. e ao mesmo tempo, as técnicas clássicas de segurança e limitada alternatividade para legitimar a melhor solução para o caso concreto privado internacional de consumo.

Esta mistura entre o atual DIPr. pós-moderno, posterior à American Revolution, ${ }^{98}$ e com valores sociais

96 Sobre o tema veja Bröcker, Marion, Verbraucherschutz im Europäischen Kollisionsrecht, Peter Lang, Frankfurt am Main, 1998, p. 107. Segundo a autora, a corte começou a estabelecer esta linha de igualdade valorativa (Gleichwertigkeit) das normas nacionais de proteção dos consumidores e de dever do Estado membro da União Européia de tolerância em relação à aplicação do direito "estrangeiro" de um país outro membro da União Européia justamente no caso Cassis de Dijon, BRÖCKER, p. 107.

97 Assim relembra Boggiano, Antonio, International Standard Contracts, Recueil des Cours, 1981, I, t. 170, Nijhoff, Dordrecht, 1982,p. 138, pleiteando a aplicação da lei mais favorável ao consumidor.

98 Segundo Erik Jayme (Jayme, Cours, p. 44), uma das tendências do direito internacional privado pós-moderno ou atual seria a materialização das regras de conflito de leis e aplicação reiterada da lex fori. Após a chamada "american revolution", movimento doutrinário e jurisprudencial ocorrido nos Estados Unidos na década de 1960, que repensou o método e a idéia de justiça no direito internacional privado, as regras de conflito de leis teriam superado seu automatismo e simples posição instrumental de indicação de uma lei material para resolver "diretamente" o conflito, passando agora a interessar-se pela solução concreta ou direta (material) do caso. 
claros, deve ser construída examinando o positivo e o negativo das conexões hoje existentes. Assim, por exemplo, se a autonomia de vontade das partes é hoje considerada o mais importante elemento de conexão no comércio internacional entre empresários, ${ }^{99}$ encontra ela um limite no que se refere às relações de consumo. Como ensina Neuhaus, a possibilidade de escolha da lei pelas partes, a autonomia da vontade em DIPr., perde seu sentido, se passa a ser instrumento de domínio dos mais fracos pelos mais fortes. ${ }^{100}$ Examinando a Convenção de Haia e a CIDIP IV, o mestre argentino Boggiano ${ }^{101}$ propôs para a proteção dos consumidores uma regra de limitada autonomia: a escolha das partes só prevaleceria se fosse esta a melhor lei, a lei mais favorável para o consumidor, devendo em caso contrário, aplicar-se a lei do domicílio do consumidor. Prevaleceriam como limites gerais à autonomia de vontade as normas de ordem pública internacional e as normas de polícia (art. 1208 CCArg.). ${ }^{102}$

A experiência européia é em sentido inverso, preferindo a Convenção de Roma indicar a preferência das normas imperativas do foro (art. $\left.7^{\circ}\right)^{103}$ e só depois uma norma especial limitadora - e em muito - da autonomia da vontade. A tendência autônoma internacional, porém, é de prestigiar a autonomia da vontade na escolha da lei aplicável aos contratos, mesmo que, por questões de política e de ordem pública, esta escolha seja limitada. ${ }^{104}$ A razão parece estar com Mancini, que, pleiteando a autonomia da vontade em DIPr., encontrava suporte desta justa-

99 De Boer, Ted. M., Facultative Choice of Law - The procedural status of choice-of-law rules and foreign Law, Recueil des Cours, 1996, t. 257, Nijhoff, The Hague, 1997, p. 300.

100 No original: "Die Parteiautonomie verliert ihren Sinn - ebenso wie die materiellrechtliche Vertragsfreiheit-, wenn sie zur Hersschaft des Stäerkeren über den Schwächeren wird.", Neuhaus, Die Grundbegriffe des IPR, 1962, p. 172 apud von Hoffmann, p. 396.

101 Veja, por todos, Boggiano, em seu texto The Contribuition, p. 138 e 139.

102 Boggiano, The Contribuition, p. 137.

103 Convenção de Roma de 1980- "Artigo $7^{\circ}$ - Disposições imperativas - 1. Ao aplicar-se, por força da presente Convenção, a lei de um determinado país, pode ser dada prevalência às disposições imperativas da lei de outro país com o qual a situação apresente uma conexão estreita se, e na medida em que, de acordo com o direito deste último país, essas disposições sejam aplicóveis, qualquer que seja a lei reguladora do contrato. Para se decidir se deve ser dada prevalência a estas disposições imperativas, ter-se-á em conta a sua natureza e o seu objecto, bem como as conseqüências que resultariam da sua aplicação ou da sua não aplicação. 2. $O$ disposto na presente Convenção não pode prejudicar a aplicação das regras do país do foro que regulem imperativamente o caso concreto, independentemente da lei aplicável ao contrato.

104 Assim a lei suíça de 1987, veja, em geral Nishitani, p. 291 e seg. 
mente no direito material, na liberdade (material) do indivíduo de vincular-se a um contrato que lhe seja justo e útil, estabelecer suas cláusulas e escolher a lei que será aplicada. ${ }^{105}$ Se hoje o DIPr. possui bases próprias para a escolha de elemento de conexão da autonomia da vontade, ${ }^{106}$ Neuhaus ${ }^{107}$ propõe que se inverta a idéia de Mancini: se as partes têm autonomia material de vontade, pode haver autonomia de vontade em DIPr., mas se as partes não têm verdadeira autonomia de vontade materialmente, porque uma parte é mais forte estruturalmente (como o profissional fornecedor que redige e determina $100 \%$ dos contratos internacionais de consumo) e outra mais fraca (o consumidor, leigo ou vulnerável que normalmente conclui contratos nacionais e somente, em algumas hipóteses, concluí contratos internacionais, às vezes sem mesmo se dar conta destas circunstâncias, então, não serve a autonomia de vontade como conexão principal do DIPr. Nestes casos, se não há verdadeira liberdade material, não pode haver verdadeira liberdade em DIPr. ou incentivaremos a escolha da lei mais favorável à (e pela) parte mais forte.

A posição de Boggiano, de uma limitada autonomia da vontade, estabelece em verdade uma conexão a "favor do consumidor", que pode ser interessante para a evolução do DIPr. da região. Certo é que os juízes brasileiros têm pouca tradição com normas alternativas abertas, mas a alternatividade limitada é um dos instrumentos mais usados hoje para garantir resultados materiais eqüitativos. ${ }^{108}$ A técnica de elaborar normas alternativas, indicando o fim material ou de favorecimento desejado, é mesmo denominada pela doutrina de Princípio do Favorecimento (Günstigkeitsprinzip) e são conhecidas as regras alternativas que levam ao favor negotii, favor matrimonii, favor legitimitatis, etc. ${ }^{109}$ A dificuldade com a regra proposta por Bogianno é a ainda ampla possibilidade de escolha da lei, o que significará grande trabalho para o juiz competente em verificar se aplicada a lei escolhida

105 Assim ensina Nishitani, p. 216 e pode-se ler nas perdidas aulas de Mancini, recuperadas e reproduzidas, em italiano, pela professora de Sendai, Nishitani, p. 378 e seg.

106 Assim Nishitani, p. 318.

107 Assim Nishitani, p. 318 citando a frase de Neuhaus: "Nur und überall dort, wo die erste [materiellrechtlicher Freiheit] besteht, ist auch die zweite [kollisionsrechtlicher Freiheit] angebracht." [Neuhaus, Die Grundbegriffe des IPR, 1962, p. 257] Assim também von Hoffmann, p. 396, citando Neuhaus.

108 Assim Kropholler, IPR, p. 120 (§ 20 II). Como esclare Nishitani, p. 283 estes novos métodos do DIPr. continental são conseqüência direta da American Conflicts Revolution emDIPr.

109 Assim ensina Kropholler, IPR, p. 120 a 122. 
seria esta melhor que a aplicação material das outras leis em contato com o consumidor.

Semelhante sugestão alternativa, mas mais limitada, fez Toniollo, defendendo que ao aplicar as regras argentinas o juiz procurasse uma harmonização com o mandamento de proteção do consumidor e permitisse ao consumidor (não ao juiz) escolher entre a aplicação da lei da residência habitual (art. 1209,1210,1212,1213 CCArg.), lex loci celebrationis (art. 1205 CCArg.) ou lex loci executionis, conforme a que fosse mais favorável a suas pretensões. ${ }^{110}$ Esta solução alternativa também é interessante, pois permite a escolha da lei mais próxima a esta relação de consumo, segundo a visão do consumidor. De outro lado, quanto maior a possibilidade de escolha do consumidor, menor a previsibilidade da lei a ser aplicável para o fornecedor, o que pode - se muito estendido - acabar prejudicando o comércio.

Note-se que Kropholler já considerava, em 1978, a determinação da lei mais favorável ao consumidor uma tarefa bastante difícil para os juízes, pois o uso desta conexão aberta, típica do atual Restatement dos Estados Unidos, pressupunha a comparação do resultado material da aplicação hipotética das várias leis envolvidas no caso, para só então determinar aquela mais favorável aos interesses do consumidor, e que seria aplicável. ${ }^{111}$ De outro lado, o hoje consagrado autor alemão, considerava que a progressiva harmonização das normas materiais a ser realizada pela Comunidade Européia iria diminuir a necessidade de normas especiais de DIPr., as quais, porém, continuariam necessárias em relações privadas envolvendo países terceiros, não euroupeus. ${ }^{12}$ Hoje, sabe-se que a evolução na harmonização das normas materiais apenas especifica a tarefa do DIPr. como instrumento de maior integração e não substitui estas normas, ${ }^{113}$ como comprovam as novas normas de DIPr. das Diretivas, da revisão da Convenção de Roma e mesmo do Direito autônomo alemão, que modificou o art. 29 da EGBGB de proteção do consumidor para incluir especificamente uma regra de preferência das leis materiais em alguns contratos (art. 29a EGBGB). ${ }^{114}$

110 Toniollo, p. 99: "Las elecciones alternativas son un adecuado instrumento de protección desde que permitan dejar de lado las legislaciones menos favorables, promoviendo teleologías."

111 Kropholler, p. 657.

112KrophollerR, p. 657.

113Assim também Toniollo, p. 108.

114A lei sobre contratação à distância com consumidores, aprovada em 13 de abril de 2000, introduziu este novo (e polêmico) art. 29a EGBGB, que entrou em vigor em $1^{\circ}$ de julho de 2000 (conforme noticia IPRAX, 2000, 3, p. [248] VI. Sobre os estudos de modificação do art. 29 para incluir o art. 29a na EGBGB, veja Staudinger, p. 414 e seg. O texto encontra-se também in IPRAX, 1999, 4, p. [304]VII. 
Correto, está, porém, Boggiano ao afirmar que as conexões rígidas fornecem para os nacionais apenas uma "segurança ilusória"," 115 pois hoje ninguém desconhece os fenômenos do forum shopping, das soluções alternativas de controvérsias e da desistência do consumidor de litigar internacionalmente (demanda reprimida). É assim pouco provável que, continuando o Brasil, no art. $9^{\circ}$ da LICC/ 1942, com conexões rígidas para os contratos de consumo, estas demandas venham a acontecer e ser solucionadas pelo juiz local. O DIPr. deve evoluir também em matéria de proteção do consumidor. Alerte-se que as normas que visam a proteção do consumidor são sempre representativas de um interesse estatal, regras imperativas. Desta natureza imperativa devem ser também as regras de DIPr. sugeridas. Em outras palavras, aqui não se está em uma matéria onde prevalece o interesse privado e comercial, onde a autonomia da vontade poderá decidir até mesmo a natureza da norma de DIPr., se obrigatória ou facultativa (facultative choice of law). ${ }^{116}$ Pela própria natureza desequilibrada da relação privada objeto das normas regionais propostas, o DIPr. para a proteção do consumidor aqui proposto deve ser um DIPr. imperativo e cogente para todos.

Mister superar as conexões tradicionais para proteger o contratante mais fraco. Por exemplo, a regra do favor offerentis, quanto à forma, e a conexão na residência do ofertante em contratos entre ausentes, conhecida no direito brasileiro, também são inadequadas para os desafios do comércio com consumidores e sua proteção nos dias de hoje. No caso de contratos ou relações de consumo, o ofertante é sempre o fornecedor (veja art. 30 Lei 8.078/90 brasileira), mesmo se fictamente denomina-se o contrato de adesão ou as condições gerais contratuais de "proposta" colocada a aceitação dos consumidores. Sabe-se que é o fornecedor que redige e determina tal "proposta", logo, tais formulários e a própria publicidade realizada pelo fornecedor ou profissional, determinam que a oferta de consumo seja, hoje, sempre realizada pelo fornecedor. ${ }^{17}$

Esta realidade faz com que as normas brasileiras atuais do art. $9^{\circ} \S 2^{\circ}$ da $\mathrm{LICC} / 42$ e art. $9^{\circ} \S 1^{\circ} \mathrm{LICC} / 42$

115 Assim Boggiano, The Contribuition, p. 134: "the illusion of rigid conflict rules". 116 Sobre o tema do DIPr. facultativo veja o curso de Haia de DE BOER, p. 235 e seg., em especial, p. 303 e seg.

117 No caso brasileiro, o CDC,Lei 8.078/90, determina expressamente que a oferta é sempre do fornecedor ou profissional ex vi lege nos art. 30, 34, 35 e 48. Veja meus comentários, in Contratos, p. 288 e seg. 
estejam superadas. ${ }^{118} \mathrm{O} \S 2^{\circ}$ do art. $9^{\circ}$ dispõe que a obrigação resultante do contrato reputa-se constituída no lugar onde residir o proponente, determinando assim a aplicação da lei do lugar de residência do fornecedor para reger os contratos entre ausentes, mesmo os de consumo. Necessário, pois, superar esta regra e escolher, para os contratos de consumo, diferentemente dos contratos internacionais comerciais uma conexão mais favorável ao consumidor, como a do art. $5^{\circ}$ da Convenção de Roma de 1980, que dá preferência à lei do país onde o consumidor tem sua residência habitual como conexão rígida (art. $5^{\circ}, 3$ Convenção de Roma de 1980), se não há expressa manifestação da vontade.

Este mesmo art. $5^{\circ}$ da Convenção de Roma de $1980^{119}$ determina que a eleição de uma lei para reger o contrato de consumo, isto é, a conexão na autonomia da vontade, não poderá excluir a aplicação das normas e leis imperativas de proteção do país de residência habitual do consumidor, se $a$ ) a oferta, publicidade ou algum ato de conclusão do contrato aconteceu neste país (por exemplo, a publicidade para um cruzeiro marítimo organizado na Argentina é feita na televisão aberta ou a cabo brasileira); b) se o fornecedor ou um seu representante receber a reserva ou realizar a contratação no país de residência habitual do consumidor (por exemplo, os contratos de multipropriedade no Uruguai, Punta del Este, com consumidores residentes no Brasil são celebrados no Brasil por representantes autônomos, que convidam os

118 O texto atual da LICC/42 é: "Art. $9^{\circ}$ - Para qualificar e reger as obrigações, aplicarse-á a lei do país em que se constituírem. $\S 1^{\circ}$. Destinando-se a obrigação a ser executada no Brasil e dependendo de forma essencial, será esta observada, admitidas as peculiaridades da lei estrangeira quanto aos requisitos extrínsecos do ato. $\S 2^{\circ}-A$ obrigação resultante do contrato reputa-se constituída no lugar onde residir o proponente."

119 O texto do artigo é: "Artigo $5^{\circ}$ - Contratos celebrados por consumidores - 1. Opresente artigo aplica-se aos contratos que tenham por objecto o fornecimento de bens móveis corpóreos ou de serviços a uma pessoa, o "consumidor», para uma finalidade que pode considerar-se estranha à sua actividade profissional, bem como aos contratos destinados ao financiamento desse fornecimento. 2. Sem prejuizo do disposto no artigo $3^{\circ}$, a escolha pelas partes da lei aplicável não pode ter como conseqüência privar o consumidor privado da protecção que lhe garantem as disposições imperativas da lei do país em que tenha a sua residência habitual: - se a celebração do contrato tiver sido precedida, nesse pais, de uma proposta que lhe foi especialmente dirigida ou de anúncio publicitário, e se o consumidor tiver executado nesse país todos os actos necessários à celebração do contrato, ou - se a outra parte ou o respectivo representante tiver recebido o pedido do consumidor nesse país, ou - se o contrato consistir numa venda de mercadorias e o consumidor, se tenha deslocado desse país a um outro país e aí tenha feito o pedido, desde que a viagem tenha sido organizada pelo vendedor com o objectivo de incitar o consumidor a comprar." 
consumidores para coquetéis e reuniões, lhe oferecem prêmios e vantagens, onde o empreendimento será explicado e a proposta assinada, assim como o pagamento futuro através de boletos de cartão de crédito que serão assinados também naquelas reuniões de venda em solo brasileiro); c) quando se tratar de venda de produtos e o consumidor viajar para adquirir estes produtos, mas a viagem for organizada pelo fornecedor com esta finalidade de contratação (por exemplo, excursões organizadas para adquirir produtos em uma zona franca ou em uma determinada fábrica no exterior), como esclarece o art. $5^{\circ}, 2$ da Convenção de Roma de 1980 sobre a lei aplicável às relações obrigacionais oriundas de contratos. ${ }^{120}$ No caso brasileiro, a melhor conexão rígida seria a do domicílio, entendido como residência habitual, a exemplo do art. $3^{\circ}$ do Protocolo de Santa Maria (Mercosul) ${ }^{121}$ ou da tradição das CIDIPs ${ }^{122}$ e suas normas materiais uniformes. ${ }^{123}$

Segundo Kropholler, as normas de proteção especiais de proteção dos consumidores, como agentes mais fracos no comércio internacional, deveriam seguir o seguinte método: respeitar a aplicação das normas imperativas (em alemão, Sonderregelung für zwingende Normen), ${ }^{124}$ elaborar normas por tipos contratuais ou temas, ${ }^{125}$ usar normas

120 Jayme, Erik e Hausamann, Rainer, Internationales Privat- und Verfahrensrecht, Beck Verlag, Munique, 1998, p. 116.

121 Araújo, Nádia, Marques, Frederico Magalhães e Reis, Márcio, Código do MercosulTratados e Legislação, Ed. Renovar, Rio de Janeiro, 1998, p. 161.

122 Segundo Siqueiros, José Luis, Contribucion de las CIDIP-I, II y III al Desarrollo del Derecho Internacional Privado, XIII Curso de Derecho Internacional, Secretaria General, OEA, 1987, p. 170. Esta foi uma das grandes contribuições das CIDIPS ao determinar que o domicílio interamericano aproximava-se da figura da residência habitual em voga na Europa, veja também CIDIP-II-1979- Convenção sobre o domicílio das pessoas físicas.

123 Como ensina Opperti Badan, Estado Actual del Derecho International Privado en el Sistema Interamericano, IX Curso de Derecho Internacional, vol. I, Secretaria General,OEA, 1983, nr. 2.7, a principal inovação da CIDIP-II sobre domicílio das pessoas físicas de 1979 foi a utilização de normas materiais uniformes. Segundo Almeida, Ricardo Ramalho, A convenção Interamericana sobre domicílio das pessoas fisicas em direito internacional privado, in Casella, Paulo Borba e Araujo, Nádia (Coord.), Integração Jurídica Interamericana- As Convenções Interamericanas de Direito Internacional Privado (CIDIPs) e o Direito Brasileiro, Ltr, São Paulo, 1998, as normas da referida CIDIP-II não são "substanciais", mas sim "qualificadoras", p. 217, ocorre que, na tradição germânica (veja Kropholler, p. 80, Kegel, IPR, 35, Steindorf, Ernst, Sachnormen im internationalen Privatrecht, Vittorio Klostermann, Frankfurt am Main, 1958, p. 30), as normas materiais de ajuda (Hilfsnormen), são consideradas normas materiais de DIPr (materielles Sonderrecht), logo, concordamos com a opinião do mestre uruguaio Opperti, Curso OEA, nr. 2.7.

124 Kropholler, op. cit., p. 648.

125 Ibidem, p. 655. 
bilaterais clássicas, ${ }^{126}$ optar por elementos de conexão objetivos, e, no caso dos contratos de consumo, optar por outra conexão do que a da prestação característica, ${ }^{127}$ dando preferência a conexões da esfera contratual do mais fraco (Recht der Vertragsphäre des Schwächeren), assim como limitar a autonomia da vontade ou possibilidade de escolha da lei por parte do fornecedor, comerciante ou parte contratual mais forte, ${ }^{128}$ e impor correções com cláusulas de ordem pública ${ }^{129}$ e cláusula escapatória, ${ }^{130} \mathrm{a}$ exemplo da atual lei suíça. Parece-me mais positivo utilizar o método da Convenção de Roma de 1980, de combinação entre a preferência das regras de aplicação imediata do foro (como o novo art. 29a EGBGB), com uma cada vez mais limitada possibilidade de escolha da lei.

Quanto às conexões tutelares, parece-me preferível no momento seguir o modelo do Mercosul, usado no Protocolo de Santa Maria específico de relações de consumo, e propor conexões rígidas para reger os contratos de consumo específicos, propondo uma regra alternativa limitada, a escolha do juiz da lei "favor consumidor", na regra geral para contratos de consumo. Assim, não resta muito espaço para a autonomia da vontade, neste primeiro momento, até mesmo para diferenciar da CIDIP V de 1994 e para estar atento às tendências protecionistas norte-americanas e tendências limitadoras atuais da experiência européia.

Kropholler termina sua análise afirmando que normas de DIPr. clássicas, com roupagem atual, poderiam servir para proteger o contratante mais fraco, que o DIPr. continental europeu poderia (e deveria) incluir valores e esta dimensão social, este era um mandamento (Gebote) de seu tempo. ${ }^{131}$ Concordando com esta afirmação e tomando em conta a visão pósmoderna do DIPr., segundo os ensinamentos de Erik Jayme, parece-me que hoje este é o mandamento ou Gebote para o Brasil, daí nossas sugestões na Parte II deste trabalho. Resta, porém, examinar os tratados regionais e verificar se são suficientes para a proteção dos consumidores.

126 Ibidem, p. 657 e 660.

127 Ibidem, p. 656.

128 Ibidem, p. 656.

129 Ibidem, p. 655.

130 Ibidem, p. 657.

131 Note-se que Kropholler, p. 660 , defende que a conexão mais estreita, determinada imperativamente por normas clássicas de DIPr. pode proteger eficazmente o consumidor, o contratante mais fraco, uma vez que as normas clássicas do DIPr. com roupagem atual podem absorver esta dimensão social de proteção dos mais fracos: "Das IPR Savignyscher Prägung nimmt die sozialen Gebote der Zeit in sich auf'. 


\section{A insuficiente proteção do} consumidor em DIPr. na LICC e nas convenções gerais sobre comércio de mercadorias

No Mercosul, a doutrina sempre alertou que, face às diferenças de nível de proteção nacional entre os quatro países, não poderia ser adotado o sistema de origem, ou se deixaria desprotegidos os consumidores dos países destinatários. ${ }^{132}$ A opção da Resolução do Grupo Mercado Comum n. 126/ 94, ${ }^{133}$ aprovada em 16 de dezembro de 1994, foi exatamente neste sentido, ao impor a regra do mercado de comercialização, no que respeita as normas aplicáveis de proteção dos consumidores, até que os esforços de harmonização legislativa dessem resultado positivo. ${ }^{134}$ Trata-se de norma específica de direito internacional privado unificado, visando a defesa do consumidor, ao determinar - indiretamente - qual a lei aplicável em caso de conflitos de consumo e ao impor a regra do país de destino: os produtos e serviços que circulam livremente no
Mercosul devem respeitar a lei do país onde serão comercializados, lei do mercado de destino, quanto à defesa do consumidor. Tal regra fixa assim um campo de aplicação espacial e territorial das normas nacionais de direito do consumidor $^{135}$ e recusa a regra européia de aplicação das leis do país de origem do produto ou serviço.

Se de um lado temos uma evolução bastante razoável na proteção material do consumidor por sua lei nacional, o mesmo não se pode dizer em matéria de proteção especial através do DIPr. Poderia se pensar que, como as normas nacionais de proteção dos consumidores são geralmente consideradas nos países como sendo de ordem pública internacional, lois de police ou normas imperativas do tipo "lei de aplicação imediata", não haveria necessidade de legislar sobre o tema: o consumidor domiciliado ou nacional de um país estaria sempre protegido pela aplicação provável destas normas. A conclusão não é suficiente, pois apresenta duas falhas:

1) Deixa o consumidor turista sem

132 Veja Dromi, p. 365. Assim também sempre propôs Stiglitz, El derecho del consumidor en Argentina y en el Mercosur, publicado na Argentina, La Ley,19/5/95 e no Brasil, in: Direito do Consumidor, vol. 6, p. 20.

133 MERCOSUL/GMC/RES. 126/94, in: Boletim de Integração Latino-Americana, 15, p. 133. 134 Resolución 126/94 GMC/Mercosur- "Art 2. Hasta que sea aprobado un Reglamento común para la defensa del consumidor en el Mercosur, cada Estado Parte aplicará su legislación de defensa del consumidor y reglamentos técnicos pertinentes, a los productos y servicios comercializados en su territorio."

135 Veja também Ciuro Caldani, Miguel Angel, Hacia la proteccion equilibrada del consumidor en el Derecho Internacional privado, in Investigación y docencia, 18, 1991, Rosario, p. 50. 
proteção quando retorna ao seu país, pois sua proteção pressuporia a extraterritorialidade destas leis, cuja característica é justamente a territorialidade. O consumidor turista nacional só estaria protegido quando o juiz nacional fosse aplicar justamente a lex fori a estas relações internacionais. ${ }^{136}$ Note-se, porém, que a maioria dos elementos de conexão hoje existentes nos países interamericanos é ou da autonomia da vontade em contratos internacionais, ou do lugar da execução ou do lugar de residência do proponente. Todas estas conexões mais comuns levarão à aplicação da lei estrangeira em relações contratuais com consumidores nacionais, pois é o fornecedor estrangeiro que redige os contratos concluídos com turistas, por exemplo, e inclui a cláusula de eleição da "sua" lei, também o lugar da execução é o da prestação caracterís- tica, que sempre é do fornecedor ou de país terceiro, por exemplo no comércio eletrônico de consumo, uma vez que o consumidor apenas paga o produto ou serviço. Hoje, também, ofertante é o profissional fornecedor, não mais os consumidores. ${ }^{137}$

2) Deixa o consumidor sem proteção, quando o foro provável de sua demanda for em país estrangeiro, por exemplo, quando contrata à distância ou por comércio eletrônico. Isto porque, não é cèrto que as normas imperativas ou de ordem pública do país de domicílio do consumidor serão aplicadas (se não houver uma Convenção Internacional específica) pelo juiz ou juízo arbitral do outro país, como comprovaram exaustivos estudos da jurisprudência do primeiro mundo. ${ }^{138}$

Interessante observar que à exceção dos Estados Unidos ${ }^{139}$ e Canadá, raras são as normas nacionais

136 Veja Resp. 63.981-SP, cujo relator foi o min. Sálvio de Figueiredo, foi decidido em 4 de maio de 2000. Veja meus comentários no artigo Normas, in Revista de Direito Privado 4, p. 85 e seg.

137 Veja que a prestação característica não foi considerada oportuna, nem mesmo para inclusão na CIDIP V, assim Noodt, Taquela, Maria Blanca, Convención interamericana sobre Derecho aplicable a los contractos internationales, in El Derecho internacional privado interamericano en el umbral del siglo XXI, Diego Fernandez Arroyo (Org.) Ed. Eurolex, Madri, 1997, p. 104.

138 Após exaustivo exame do direito e da jurisprudência alemã, chegou à conclusão de que não há obrigação alguma do juiz alemão de usar as normas imperativas de terceiros países, somente as normas imperativas dos países membros da UE devem ser respeitadas, face ao art. $7^{\circ}$, I da Convenção de Roma de 1980, assim BECKER, Michael, Zwingendes Eingriffsrecht in der Urteilsanerkennung, in RabelsZ 60 (1996), p. 737.

139 Veja art. 3.545 sobre products liability e art. 3.547 sobre conventional obligations da nova lei da Louisiana, Lei 923 de 1991 (publicada na íntegra in IPRAX 1993, p. 56 e seg), in Kropholler, Jan, Krüger, Hilmar, Riering, Wofgang, Samtleben, Jürgen, Siehr, Kurt, Aussereuropäische IPR-Gesetze, Max-Planck-Insitut, Hamburg, 1999, p. 1002 e seg. 
de Direito Internacional Privado que se voltam especificamente para a proteção dos consumidores nos países Americanos. Quanto ao DIPr. do Quebec, positivado no Código Civil de 1991, interessante observar sua atualização metodológica, porque prevê várias normas abertas (art. 3076), o conhecimento de leis imperativas de outro Estado (art. 3079), uma ordem pública estrita pela incompatibilidade do resultado prático da aplicação da lei estrangeira (art. 3081) e uma cláusula escapatória geral (art. 3082). ${ }^{140}$ Assim como possui uma regra específica para os contratos de consumo (art. 3117), ${ }^{141}$ permitindo a autonomia de vontade, mas considerando obrigatórias as normas imperativas do foro, em idênticas circunstâncias que o art. $5^{\circ} \mathrm{da}$ Convenção de Roma e indicando, na falta de escolha, a lei da residência do consumidor como aplicável.

O Código Civil do Quebec possui regra específica também para acidentes envolvendo produtos (art. 3128), prevendo que a vítima (não se menciona a expressão consumidor) poderá escolher entre a lei do Estado em que o fabricante do produto tem seu estabele- cimento ou sua residência e a lei do Estado onde o bem foi adquirido, além de considerar as suas normas de DIPr. imperativas para qualquer dano sofrido no Quebec ou resultante de matéria prima oriunda do Quebec (art. 3129).

Por exemplo, a lei de proteção ao consumidor da Venezuela é de $1995 .{ }^{142}$ A nova lei venezuelana de Direito Internacional Privado é posterior e data de 1998, mas, em seus 64 artigos, nada menciona especificamente sobre proteção do consumidor, apesar de várias vezes mencionar os princípios generales del Derecho Comercial Internacional. Mesmo assim, a nova lei venezuelana traz normas atualizadas sobre a aplicação das normas imperativas nacionais (art. 10), sobre a conexão eqüitativa para o caso concreto (art. $7^{\circ}$ ) e, especialmente, traz uma norma de favor vítima em caso de acidentes ou atos ilícitos, o que pode beneficiar os consumidores (art. 32). ${ }^{143}$

Nos países membros do Mercosul, a situação não é melhor. No Paraguai, a lei de defesa do consumidor é de $1998,{ }^{144}$ já o Código Civil de 1985 nada menciona sobre consumidores e, em matéria contratual, indica aplicável a lei

140 Veja texto in Dolinger, Jacob, e Tibúrcio, Carmen, Vade-Mécum de Direito Internacional Privado, Ed. Renovar, Rio de Janeiro, 1994, p. 297-298.

141 Veja texto in Dolinger, Vade Mecum, p. 297-298.

142 Publicada na íntegra, no Brasil, in Revista Direito do Consumidor, vol. 26(1998), p. 307-327. 143 Veja Decreto 36.511, de 6 de agosto de 1998, in Kropholler/Krüger/Riering/Samtleben/ Siehr, p. 958-995.

144 Ley 1.334, 27 de outubro de 1998, a ser publicada na íntegra. Revista Direito do Consumidor, vol. 30 (1999), p. 247-255. 
do lugar da execução da obrigação (art. 17). ${ }^{145}$ No Uruguai, sua lei de defesa do consumidor é de 1999, ${ }^{146}$ seu Código Civil de 1868, modificado em 1994, indica aplicável para relações obrigacionais a lei do lugar da execução (art. 2.399) e os Tratados de Montevidéu de 1889. ${ }^{147}$

Já no Brasil, as normas brasileiras de DIPr. são rígidas e antigas, também nada mencionam sobre consumidor e prevêem apenas uma ampla regra sobre ordem pública (art. 17 da Lei de Introdução ao Código Civil Brasileiro, LICC/42). Em matéria contratual, apesar dos esforços da doutrina; as normas atuais praticamente impossibilitam a autonomia de vontade em matéria de contratos. ${ }^{148}$ Aplicável neste caso é a lex loci celebrationis (art. 9० caput da LICC/42: "Para qualificar e reger as obrigações, aplicar-se-á a lei do país em que se constituirem"). A norma do art. $9^{\circ} \S 1^{\circ}$ LICC/42 impõe uma aplicação cumulativa de lei brasileira quanto à forma, em caso de execução no Brasil. A norma do art. $9^{\circ} \S 2^{\circ}$ da LICC/42 é usada para identificar o lugar da proposta em contratos entre ausentes ou à distância, como a maioria dos contratos internacionais nos dias de hoje. Segundo o $\S 2^{\circ}$ do art. $9^{\circ}$, a obrigação resultante do contrato reputa-se constituida no lugar onde residir o proponente, determinando assim a aplicação da lei do lugar de residência do fornecedor para reger os contratos entre ausentes, mesmo os de consumo, como os contratos concluídos por computador, no comércio eletrônico de consumo, ou nos contratos de timesharing ou multipropriedade. Em matéria de acidentes com produtos e serviços defeituosos a regra aplicável também é a do art. $9^{\circ}$, agora interpretada como lex loci delicti, lei do lugar em que foi cometido o ato ilícito ou lei do lugar em que aconteceu o dano e suas conseqüências. ${ }^{149}$

A doutrina argentina sempre propôs normas especiais mais protetivas para

145 Kropholler/Krüger/Riering/Samtleben/Siehr, p. 638.

146 Ley 17.189, de 20 de setembro de 1999, publicada na íntegra. Revista Direito do Consumidor, vol. 33 (2000), p. 262-270.

147 Kropholler/Krüger/Riering/Samtleben/Siehr, p. 910.

148 Ver, por todos, Araújo, p. 108. Sobre a controvérsia da autonomia da vontade no Brasil e em vários países da América Latina e a contribuição dada pela CIDIP e pelas Convenções de Haia, veja Boggiano, The Contribuition, p. 132 e seg.

149 Sobre esta versão brasileira da teoria da ubiqüidade alemã e as críticas da doutrina a estas conexões rígidas, veja Marques, Claudia Lima, Novos rumos do Direito Internacional Privado quanto às obrigações resultantes de atos ilícitos (em especial de acidentes de trânsito), in Revista dos Tribunais, São Paulo, vol. 629 (mar/1988), p. 72 e seg. 
as relações de consumo, especialmente para os contratos de adesão. ${ }^{150}$ Quanto ao âmbito contratual, que mais nos interessa, as normas nacionais ou autônomas de DIPr. argentino encontram-se nos art. 1205 a 1214 do Código Civil e não há normas especiais para a proteção dos consumidores, mas o novo mandamento constitucional deve "iluminar" a aplicação destas normas. ${ }^{151}$ Os artigos 1209 e 1210 prevêem a aplicação da lex loci executiones e da lex loci celebrationes, mas a doutrina alerta que, em uma visão tradicional, a primeira conexão vai indicar aplicável geralmente a lei do fornecedor, aquele que realizou a prestação principal característica, isto é, a prestação não vinculada ao pagamento de dinheiro realizado pelo consumidor, cons- tituindo "injustificado privilégio" ao fornecedor. ${ }^{152}$ A segunda conexão beneficia a aplicação da lei do lugar de "assinatura" dos contratos, levando muitas vezes à aplicação da lex fori argentina, mas deixa sem proteção o consumidor turista e aquele que contrata à distância ou por meios eletrônicos, situações cada vez mais comuns nos dias de hoje. ${ }^{153}$ A doutrina propõe então que o consumidor possa eleger entre a ley del lugar de adquisisión del producto, que seria especialmente importante nos dois casos mencionados, e uma conexão para a lei mais favorável ao consumidor, assim como a elaboração de normas semelhantes ao art. $5^{\circ}$ da Convenção de Roma de $1980 .{ }^{154}$ Já quanto aos atos ilícitos frente aos consumidores, a conexão tradicional é também na Argentina a lex loci delicti (art. 43 do Tratado de Montevidéu de 1940), entendida como lei do lugar do ato delituoso (lex loci actus), mas já sofre severas críticas e sugere-se que, em relações de consumo, possa-se usar a lei da residência habitual de quem sofreu o dano, em solução semelhante à Convenção de Haia de 1973. ${ }^{155}$ Parte da doutrina propõe que o consumidor vítima possa eleger entre a lei do lugar do estabelecimento principal da pessoa a quem vai se atribuir a responsabilidade e a lei do lugar de aquisição do produto. ${ }^{156}$

Se a legislação nacional ainda é falha neste setor, na doutrina do DIPr.,

150 Assim o famosos curso de Haia de Boggiano, International, p. 55 e The Contribuition, p. 134 e seg.

151 Toniollo, p. 98.

152 Assim Toniollo, p. 100.

153 Assim alerta também, Toniollo, p. 102.

154 Toniollo, p. 101, 102 e 107.

155 Toniollo, p. 108 e 110.

156 Sugestão de Toniollo, p. 110. 
cada vez mais o tema da proteção dos consumidores é incluído como matéria de nova concentração do Direito Internacional Privado. ${ }^{157}$ A doutrina é praticamente unânime na necessidade de proteção especial do consumidor também em relações de consumo internacionais e na decisão regional a favor do consumidor. A autonomia de vontades é regra não oportuna se uma das partes é mais fraca, como no caso de contratos concluídos com consumidores. ${ }^{158}$ Propõe-se assim uma harmonização das regras de DIPr. através do Mercosul ${ }^{159}$ e de outros organismos internacionais. ${ }^{160}$ Também em processo civil internacional os desafios da globalização e regionalização da economia estão a requerer uma reposta efetiva de proteção dos mais fracos com jurisdições privilegiadas e soluções alternativas de controvérsias.

Importa-nos aqui relembrar que as grandes convenções sobre comércio internacional sempre procuraram excluir do campo de aplicação de suas normas os contratos concluídos com consumidores para uso doméstico, familiar ou não profissional. ${ }^{161}$ Assim a Convenção de Haia ${ }^{162}$ sobre a lei aplicável aos contratos de compra e venda internacional de 1986 (art. $2^{\circ}$, lit.c e $5^{\circ}$, lit. d) $)^{163}$ ou a Convenção da ONU sobre Compra e Venda de Mercadorias de 1980, conhecida como Convenção de Viena de $1980^{164}$ (art. $2^{\circ}$, a e

157 Boggiano, The Contribuition, p. 139, Toniollo, p. 94 e seg., Marques, Cláudia Lima, Direitos do Consumidor no Mercosul : Algumas sugestões frente ao impasse, in Revista Direito do Consumidor, São Paulo, vol. 32 (1999), p. 16 e seg. Já Brilmayer, p. 174, inclui tópico "The postulate of Consumer Sovereignity" não para tratar da proteção do consumidor, mas para realizar analogia à soberania de decisões dos estados de quais politicas (policy) ou interesses protegerão em DIPr, seguindo a linha do Law and Economics.

158 Veja Boggiano, International, p. 55 e seg. e Boggiano, The Contribuition, p. 138.

159 Veja por todos Toniollo, p. 97.

160 Boggiano, The Contribuition, p. 138, trabalha com a possibilidade de uma manifestação geral através da Conferância de Haia ou regional, através da OEA.

161 Assim Hargain/Mihali, p. 506.

162 Trata-se de uma atualização da Convenção de 1955. Veja sobre a pequena aceitação destas Convenções entre os Estados, mas de sua enorme importância como modelo legislativo, in Araújo, p. 124 e seg.

163 No original: "Art.2. The Convention does not apply to: ....c) sales of goods bought for personal, family or household use; it does, however, apply if the seller at the time of the conclusion of the contract neither knew nor ought to have known that the goods were bought for any such use. Art. 5. The Convention does not determine the law applicable to ...d) the effect of the sale in respect of any person other than the parties."

164 Veja sobre a importância e a aceitação desta Convenção também entre Estados das Américas, Araújo, p. 127 e seg. 
art. $\left.5^{\circ}\right) .{ }^{165}$ Seja para evitar conflitos com leis nacionais consideradas de ordem pública internacional, ${ }^{166}$ seja porque as diferenças na proteção dos consumidores sempre pesaram a favor dos países industrializados e exportadores do primeiro mundo. ${ }^{167} \mathrm{~A}$ verdade é que o tema nunca foi tratado diretamente nas convenções ${ }^{168}$ que unificaram as normas materiais, nem em uma lei modelo, do UNIDROIT ou UNCITRAL, ${ }^{169}$ nem foi objeto de uma CIDIP ou de uma Convenção de Haia. ${ }^{170}$ Apenas as Resoluções da ONU tiveram influência inspiradora nas legislações nacionais.

O tratamento jurídico de relações entre iguais não pode ser igual ao tratamento jurídico de relações entre diferentes, entre profissionais e leigos,

165 No original o art. $2^{\circ}$ da Convenção de Viena de 1980 dispõe: "Esta convenção não se aplica às vendas: a) de mercadorias adquiridas para uso pessoal, familiar ou doméstico, salvo se o vendedor, antes ou no momento da celebração do contrato, não soubesse nem devesse saber que as mercadorias eram adquiridas para tal uso".

166 Assim manifestam-se Garro/Zuppi, p. 81: "La razón principal de excluir la venta a consumidores del ámbito de aplicación ha sido de evitar un eventual conflicto entre las normas de la Convención y las leyes de orden público de protección al consumidor. La legislación especial de protección al consumidor ha sido incorporada en estos últimos años a numerosos ordenamentos jurídicos, inclusive en algunos países de América Latina, como México." Assim também Hargain/Mihali, p. 507.

167 Assim Hoffmann, p. 396, Kropholler, p. 636, Botana, p. 9 e Hargain/Mihali, p. 506, citando opinião de Lible.

168 Teriam ratificado a Convenção, até 1995, os seguintes países interamericanos, Argentina, Chile, Ecuador, Canadá, Cuba, México e Estados Unidos, e assinado, Venezuela. Veja Schlechtriem, Peter, Internationales UN-Kaufrecht, J.C.Mohr, Tübingen, 1996, p. 225-226 ou para dados atualizados: www.un.org/Depts/Treaaty/bible/Part_I_E/X_/X_10.html.

169 A lei modelo da UNCITRAL (que efetivamente se dedica ao comércio internacional) versando sobre comércio eletrônico expressamente informa não afastar as normas tutelares e parece querer excluir os contratos de consumo através de meios informáticos de seu campo de aplicação com o texto: “Art. 1. Ámbito de aplicación - La presente Ley* será aplicable a todo tipo de información en forma de mesaje de datos utilizada en el contexto de actividades comerciales. ${ }^{*}$ La presente ley no deroga ninguna norma jurídica destinada a la protección del consumidor."

170 Mencione-se o projeto de Haia de 1980. Veja Von Mehren, Arthur, Law applicable to certain consumer sales, Texts adopted by the Fourteenth Session and Explanatory Report, Ed. Bureau Permanent de la Conférence, Haia, 1982, p. 6. Este projeto de convenção visava complementar a Convenção de Haia de 1955 sobre lei aplicável à venda internacional de mercadorias, mas isto nunca chegou a acontecer, pois o referido projeto, findo em 1980, não foi aprovado, superado que foi pela própria Convenção de Roma da CEE, assinada naquele mesmo ano, com seu art. $5^{\circ}$ sobre o mesmo tema. 
entre fortes e fracos. Esta foi justamente a idéia central do Projeto de Haia de 1980, que foi superado pelas convenções européias e as modificações internas nos países industrializados, mas não no espaço interamericano. ${ }^{171} \mathrm{~A}$ experiência européia de mais de 40 anos de harmonização de normas materiais e unificação de normas de DIPr. e do art. $2^{\circ}$ da Convenção de Viena de 1980 , nos faz concluir que tanto regionalmente, como universalmente, a proteção do consumidor sempre foi tema a separar-se do comércio internacional normal e a tratar-se em DIPr. com conexões mais seguras, previsíveis e positivas para o agente mais fraco. Concluo, portanto, pela oportunidade de se elaborar norma epecial sobre o tema.

\section{SUGESTÕES PARA A NOVA LEI DE INTRODUÇÃO AO CÓDIGO CIVIL BRASILEIRO NO QUE SE REFERE À LEI APLICÁVEL A ALGUNS CONTRATOS E
ACIDENTES DE CONSUMO}

Efetivamente, conhece o Direito Internacional Privado brasileiro as denominadas "normas de aplicação imediata", espécie das normas imperativas, que perseguindo um resultado material de Justiça do Direito Internacional Privado, aplicam-se aos casos pluriconectados de forma "direta" antes mesmo da norma indireta, da norma de conflito que indicaria uma lei para regular materialmente o caso concreto. ${ }^{172}$ A pergunta é se todas as normas de

171 Note-se que as conexões previstas pelo projeto de Haia de 1980 foram: a autonomia da vontade (art. $6^{\circ}$, frase 1), mas a lei escolhida pelas partes não poderia privar o consumidor da proteção que lhe asseguram as normas imperativas do país de sua residência habitual (art. $6^{\circ}$, frase 2 do projeto), as condições relativas à existência, à validade e à forma do consentimento seriam regidas pela lei do país de residência habitual do consumidor no momento da declaração. (art. $6^{\circ}, 4$ frase), na falta de escolha pelas partes, a lei aplicável seria a lei do país de residência habitual do consumidor (art. $7^{\circ}$ do projeto), a capacidade das partes e os efeitos dos contratos não seriam regidos pela lex contractus e sim tratados como questões independentes (art. $9^{\circ}$ ) e a reserva de ordem pública, veja Von Mehren, Arthur, Law applicable to certain consumer sales, Texts adopted by the Fourteenth Session and Explanatory Report, Ed. Bureau Permanent de la Conférence, Haia, 1982, p. 2 e 3. A definição de consumidor (art. $2^{\circ}$ ) e as exclusões (art. $4^{\circ}$ e $5^{\circ}$ ) do projeto não são hoje, porém, atuais, mesmo assim em um exame mais detido do projeto de 1980 encontramos muitos dos elementos até hoje desejáveis em matéria de proteção efetiva dos consumidores em DIPr.

172 Assim Marques dos Santos, António. As normas de Aplicação imediata no Direito Internacional Privado - Esboço de uma Teoria Geral- vol. I, Coleccão de Teses, Ed. Almedina,Coimbra, 1991, p. 11. Veja também Schwander, Ivo, Lois d'application immédiate, Sonderanknüpfung, IPR-Sachnormen und andere Ausnahmen von der gewöhnlichen Anknüpfung im internationalen Privatrecht, Schulthess, Zurique, 1975, p. 132-184. 
defesa do consumidor, por exemplo, as presentes no Código de Defesa do Consumidor, que é norma de ordem pública interna (ex $v i$ art. $1^{\circ}$ da Lei 8.078/90) seriam normas de aplicação imediata, a afastar o exame do atual art. $9^{\circ} \mathrm{da} \mathrm{LICC} / 42$ ou se deveríamos sugerir normas especiais de proteção dos consumidores em DIPr. Vejamos.

\section{Consumidor, o agente} esquecido na LICC: leis de aplicação imediata ou necessidade de uma norma especial para a proteção contratual dos consumidores

A globalização, a aproximação dos mercados, a integração de mercados, a abertura para produtos e serviços estrangeiros, a internacionalidade das relações privadas são, segundo doutrina atual, os grandes desafios do direito do consumidor. ${ }^{173}$ Segundo as palavras lúcidas de Jean-Michel Arrighi o consumidor, nesta aproximação de mercados, é, também nas leis nacionais, o "protagonista olvidado". ${ }^{174}$

As chamadas "leis de aplicação imediata", na definição clássica de
Franceskakis, são leis ou regras "cuja observação é necessária para a salvaguarda da organização política, social ou econômica de um país."175 Esta técnica de regulação direta do Direito Internacional Privado, de identificar algumas leis ou normas internas, que por sua importância e íntimo contato com os interesses governamentais ou a ordem pública de um país, devem ser seguidas por todos e em todas as relações privadas com contatos fortes com aquele país, ${ }^{176}$ Estas normas aplicam-se imediatamente para nacionais e estrangeiros e para todas as relações privadas, sem necessidade de antes passar pelo método de DIPr. de indicação de uma lei aplicável. Em outras palavras, esta lei "de aplicação imediata" ou lei de "polícia" tem pretensões de aplicação genérica e extraterritorial sempre, não importando se são leis de direito privado ou público, uma vez que positivam fortes interesses de organização da sociedade estatal.

Como a chamada lei de aplicação imediata é direta ou resolve o conflito diretamente, sua aceitação e identificação hierárquica dentro do DIPr. é

173 Assim também Macedo Júnior, p. 45 e 53.

174 Arrighi, p. 126.

175 No original: "don't l'observation est nécessaire pour la sauvegarde de l'organisation politique, sociale ou économique du pays.", citado por Bucher, p. 39. Veja art. $7^{\circ}$, alinea 2 da Convenção de Roma da UE sobre lei aplicável às obrigações contratuais de 1980. Tais normas se aplicam diretamente. Veja sobre o art. 18 Lei de Dir. Internacional Privado suíça, Bucher, p. 39.

176 Veja detalhes no Cap. 6, que escrevi para o livro, Derecho Internacional Privado de los Estados del Mercosur, Org. Diego Fernandez Arroyo, Zavalia, Buenos Aires, 2003, p. 300 e seg. 
uma técnica (por sinal cada vez mais usada) de "materialização" das novas regras de conflitos de leis. ${ }^{177}$ Este fenômeno geralmente é conhecido pela expressão francesa lois d'application immédiate, popularizadas pelos estudos do grande professor grego Franceskakis desde 1958, apesar do estudo muito semelhante do italiano De Nova (norme sostanziali autolimitate, norme di applicazione necessaria), datar de 1959. ${ }^{178}$ A segunda expressão francesa, lois de police ou leis de polícia, também ficou mais conhecida do que a expressão alemã, a significar leis obrigatórias, zwingende Normen (na expressão de Savigny: Gesetzen von streng positiver, zwingender Natur). ${ }^{179}$

Assim, por exemplo, o art. $3^{\circ}$ do Código de Defesa do Consumidor inclui como fornecedor submetido às normas imperativas do CDC toda pessoa fisica ou juridica, pública ou privada, nacional ou estrangeira, bem como os entes despersonalizados, que desenvolvam atividade de produção, montagem, criação, construção, transformação, importação, exportação, distribuição ou comercialização de produtos ou prestação de serviço. Mencionados expressamente também no art. 12 do CDC estão os fabricantes, produtores e construtores estrangeiros e o importador de produtos estrangeiros. É interessante relembrar que as normas do CDC são de ordem pública interna (art. $1^{\circ}$ ), e que os artigos $2^{\circ}$ e $3^{\circ}$ do Código de Defesa do Consumidor denotam sua aplicação a todos os consumidores finais, nacionais ou estrangeiros (independente de sua nacionalidade ou domicílio) e fornecedores, nacionais e estrangeiros. Assim, dispõe o CDC, em espírito de inclusão semelhante ao do revogado art. $3^{\circ}$ do Código Civil de $1917,{ }^{180}$ e com espírito de real proteção do vulnerável, sem mencionar a nacionalidade ou o domicílio dos agentes: art. $2^{\circ}$ Consumidor é toda pessoa fisica ou jurídica que adquire ou utiliza produtos ou serviços como destinatário final. Parágrafo único. Equipara-se a consumidor a coletividade de pessoas, ainda que indetermináveis, que haja intervindo nas

177 Jayme, Hague Cours, 1995, p. 44.

178 Assim Marques dos Santos, António. As Normas de Aplicação Imediata no Direito Internacional Privado - Esboço de uma Teoria Geral- vol. I, Coleção de Teses, Ed. Almedina, Coimbra, 1991, p. 11 e seg.

179 Veja, por todos, Schwander, Ivo, Lois d'application immédiate, Sonderanknüpfung, IPR-Sachnormen und andere Ausnahmen von der gewöhnlichen Anknüpfung im internationalen Privatrecht, Schulthess, Zurique, 1975, p. 132 a 184.

$180 \mathrm{O}$ art. $3^{\circ}$ do $\mathrm{CCBr}$. atual dispõe: "A lei não distingue entre nacionais e estrangeiros quanto à aquisição e ao gozo dos direitos civis." Infelizmente este artigo não foi repetido pelo novo Código Civil brasileiro aprovado em 10.01.2002. 
relações de consumo. $\mathrm{E}$ o art. 29 complementa: Para os fins deste capitulo e do seguinte, equiparamse aos consumidores todas as pessoas determináveis ou não, expostas às práticas nele previstas. Em matéria extracontratual, a inclusão - para proteção - de todos os consumidores, contratantes ou não, é clara, no art. 17, no capítulo referente à responsabilidade pelo fato do produto ou serviço: art. 17. Para os efeitos desta seção, equiparamse aos consumidores todas as vítimas do evento.

Todos estes artigos bem denotam a "vontade" do Código de Defesa do Consumidor em aplicar-se também a casos de consumo internacional ocorridos no mercado brasileiro ou com os consumidores que protege. Pareceme, pois, em uma primeira análise, tratar-se de uma lei de aplicação imediata. ${ }^{181}$ Efetivamente, parte da doutrina defende que o Código de Defesa do Consumidor deve se aplicar a todos os contratos do consumidor com contatos suficientes ao Brasil, enquanto uma regra imperativa internacional ou lois d'application immediate. ${ }^{182} \mathrm{O}$ Código de Defesa do Consumidor deve fornecer padrões mínimos (e imperativos) à proteção de consumidores-passivos em todos os contratos à distância, contratos negociados no Brasil por nacionais ou estrangeiros ou quando o marketing ou a oferta forem feitos no Brasil, inclusive nos contratos com fornecedores com sede no exterior, ${ }^{183}$ como impõem o Unfair Contract Terms Act de 1977 do Reino Unido, ou a lei alemã (art. 29a da EGBGB), ${ }^{184}$ ou a lei portuguesa de 1985 (art. 33). ${ }^{185}$

Assim, se a conclusão do contrato for precedida por um convite ou indução ao negócio dirigido a ele ou genérico

181 Examinando as leis alemãs de proteção ao consumidor e o novo art. 29a da Lei de Introdução ao Código Civil alemão (EGBGB), conclui no mesmo sentido Reich/Nordausen, p. 95 a 99.

182 Veja meu artigo CIDIP e Reich/Nordhausen, p. 159 e seg.

183 Assim também sugere Lorenzetti, Comercio eletrónico, p. 256 para a Argentina.

184 Winter relembra também que as normas sobre seguros e proteção dos consumidores são imperativas na Alemanha, Winter, p. 1.461.

185 Como ensina Pierre Mayer, p. 521 estas são leis de aplicação imediata que determinam expressamente seu campo de aplicação, impondo sua aplicação a todos os contratos de consumo, se o consumidor tem nestes países a sua residência habitual e realizou todos os atos de conclusão do contrato sem sair do país (Consumidor passivo). Veja como o consumidor passivo no comércio eletrônico é protegido também nos Estados Unidos, nas leis de Ohio, Virginia e Wasington e na lei suíça, in Kronke, Herbert, Applicable Law in Torts and Contracts in Cyberspace, in Internet- Which Court Decides? Which Law Applies, Boele-Woelki, Katharina e Kessedjian, Catherine, Kluwer Law International, 1998, p. 82 e 83. 
por meio da publicidade, ${ }^{186}$ e o consumidor realizou no Brasil todas as medidas necessárias de sua parte para a conclusão do contrato (aceitação válida), a lei brasileira possui contatos mais próximos e deve se aplicar ao contrato internacional de consumo, de forma a favorecer o contratante mais fraco. Deve ser um risco profissional do fornecedor, o qual se utiliza destas tecnologias novas e deste tipo de marketing à distância, o eventual uso das normas imperativas ou de aplicação imediata do país do domicílio ou residência habitual do consumidor, onde a oferta à distância resultou em contratação. ${ }^{187}$ Segundo a doutrina francesa, a proteção dos contratantes mais fracos é melhor realizada se as normas tutelares nacionais são consideradas "leis de aplicação imediata". ${ }^{188}$ A doutrina estrangeira conclui que esta é a prática da maioria dos países do primeiro mundo. ${ }^{189}$ Esta teoria parece ser compartilhada pela jurisprudência do STJ.

O caso de líder em matéria de produtos e serviços estrangeiros e do CDC como standard mínimo de proteção dos consumidores tem origem no STJ. Trata-se de um caso envolvendo um turista brasileiro (consumidor ativo), que retorna ao mercado brasileiro após a compra de uma filmadora com vício. Nesta decisão de líder, o STJ responsabilizou a filial brasileira pela garantia do produto adquirido nos EUA (distribuído pela matriz no Japão e produzido possivelmente na Indonésia ou China), da marca Panasonic, tudo segundo o Código Brasileiro de Direito do Consumidor, considerado "lei de aplicação imediata".

O REsp. 63.981-SP, cujo relator foi

186 A simples publicidade online, com efeitos no país, já pode violar as normas imperativas do direito do consumidor, como comprova a decisão do Tribunal de Frankfurt (OLG Frankfurt), de 31.05.2001, envolvendo publicidade de farmácia holandesa oferecendo medicamento proibido na Alemana. Veja ZIP 2001, p. 1164 a 1168.

187 Assim as conclusões do $5^{\circ}$ Congresso Brasileiro de Direito do Consumidor, in Revista Direito do Consumidor, vol. 33, p. 265: : "11. As normas do CDC, como expressamente consignado em seu artigo $1^{\circ}$, são de "ordem pública e de interesse social", entre a ordem pública local e a ordem pública estrangeira o juiz deve preferir a ordem pública de seu pais; as disposições do CDC, por serem normas de ordem pública, não podem deixar de ser aplicadas às relações de consumo que envolvem consumidores residentes no território nacional, ressalvada a aplicação cumulativa da legislação estrangeira mais favorável. (aprovada por unanimidade)". Veja também FERNANDES, Antônio Joaquim, "Responsabilidade do provedor de Internet", in Revista Direito do Consumidor, vol. 26, p.49.

188 Assim conclui o grande professor de DIPr. francês, Pierre MAYER, p. 531.

189 Veja, por todos, KRONKE, p. 82, e JUNKER, RIW 1999, p. 815. Assim conclui até mesmo o advogado da Microsoft,. em seu Curso de Haia de 2001, SMITH, p. 330 mesmo protestando contra esta prática e pedindo que a internet seja regulada de forma mínima. 
o min. Sálvio de Figueiredo Teixeira, foi decidido em 4 de maio de 2000, com a seguinte ementa:

DIREITO DOCONSUMIDOR. FILMADORA. DEFEITO DA MERCADORIA. RESPONSABILIDADE DA EMPRESA NACIONAL DA MESMA MARCA (PANASONIC). ECONOMIA GLOBALIZADA. PROPAGANDA. PROTEÇÃO AOCONSUMIDOR. PECULIARIDADE DA ESPÉCIE. SITUAÇÕES A PONDERAR NOS CASOS CONCRETOS. NULIDADEDOACÓRDÃO ESTADUAL REJEITADA, PORQUE SUFICIENTEMENTE FUNDAMENTADO. RECURSO CONHECIDO E PROVIDO NO MÉRITO, POR MAIORIA. I - Se a economia globalizada não mais tem fronteiras rigidas e estimula e favorece a livre concorrência, imprescindivel que as leis de proteção ao consumidor ganhem maior expressão em sua exegese, na busca do equilibrio que deve reger as relações jurídicas, dimensionando-se, inclusive, o fator risco, inerente à competitividade do comércio e dos negócios mercantis, sobretudo, quando em escala internacional, em que presentes empresas poderosas, multinacionais, com filiais em vários paises, sem falar nas vendas hoje efetuadas pelo processo tecnológico da informática e no forte mercado consumidor que representa o nosso país. II - O mercado consumidor, não há como negar, vê-se hoje 'bombardeado' diuturnamente por intensa e hábil propaganda, a induzir a aquisição de produtos, notadamente os sofisticados de procedência estrangeira, levando em linha de conta diversos fatores, dentre os quais, e com relevo, a respeitabilidade da marca. III - Se empresas nacionais se beneficiam de marcas mundialmente conhecidas, incumbe-lhes responder também pelas deficiências dos produtos que anunciam $e$ comercializam, não sendo razoável destinar-se ao consumidor as conseqüencias negativas dos negócios envolvendo objetos defeituosos. ${ }^{190}$

Como se observa, se em caso envolvendo turista brasileiro, cuja única conexão com o Brasil era o domicílio do consumidor, o CDC foi aplicado, parece-me provável que o STJ deverá considerar o CDC também "lei de aplicação imediata" em Direito Internacional Privado nos demais casos, em especial quando o consumidor passivo contratar no comércio à distância, aplicando o $\mathrm{CDC}$, antes do art. $9^{\circ}$ da LICC/42.

A solução do STJ foi a mesma da União Européia, que considera as Diretivas de proteção do consumidor como "imperativas", ${ }^{191}$ aplicando-as

190 DJ 20.11.2000, na íntegra, em sua primeira versão, in RDC 35, p. 270 e seg.

191 Assim, como conclusão geral, Bröcker, Marion, Verbraucherschutz im Europäischen Kollisionsrecht. Peter Lang, Frankfurt am Main, 1998, p. 138 e Junker, IPRAX 1998, p. 74. Também Jayme, IPRAX 1999, p. 412. Assim as Diretivas impõem, por exemplo, a Diretiva 1999/44/CE sobre garantias: "art. $7^{\circ}$ (2) Os Estados membros tomarão as medidas necessárias para que o consumidor não perca a proteção assegurada por esta Diretiva, quando o direito de um Estado terceiro é escolhido para regular o contrato, desde que o contrato possua um vínculo estreito com o território de um Estado Parte (da E. U.) " in RDC 38/313. 
sempre como standards mínimos de proteção dos consumidores europeus, sempre que a lei aplicável é de país fora da zona. A conclusão é de que os interesses de proteção do agente mais vulnerável superam os de harmonia das decisões, melhor seria regular o tema em norma especial na Lei de Introdução ao Código Civil, a exemplo dos artigos 29 e 29 a da lei alemã ${ }^{192}$ e do direito francês.

A Lei de Introdução ao BGB alemã (EGBGB) já conhecia uma norma especial para consumidores, o criticado art. 29 EGBGB, inspirado no art. $5^{\circ} \mathrm{da}$ Convenção de Roma de 1980, mas que já era considerado complicado e pouco "sólido" pela doutrina alemã. ${ }^{193}$ O novo art. 29a da EGBGB é ainda mais complexo e mais difícil, como se verifica, no que passo a traduzir livremente:

Art. 29a EGBGB. (1) Se a lei escolhida para regular um contrato não é de um Estado-membro da UE ou do Espaço Econômico Europeu, são também aplicáveis as normas das leis que incorporaram Diretivas de proteção dos consumidores (leis de proteção do consumidor sobre Condições Gerais Contratuais, a Lei de Contratos à Distância e de Time-sharing), quando o contrato tenha um vínculo estreito com um ou mais países da União Européia (EU) ou do Espaço Econômico Europeu (EEE); (2) Um vinculo estreito existe quando: (1) O contrato seja feito em virtude de uma oferta pública, publicidade ou atos negociais semelhantes realizados em um dos Estados da UE ou EEE. (2). A outraparte contratante, quando declarou a sua vontade ou aceitou a oferta, tenha domicilio nos paises da UE ou EEE. (3) A lei sobre time-sharing é aplicável ao contrato, regido por uma lei de um país não membro da UE ou EEE, quando o imóvel localize-se em um Estado da UE ou EEE. (4) Diretivas de proteção do consumidor no sentido deste artigo são: 1. Diretiva 93/13/CEE, sobre cláusulas abusivas; 2. Diretiva 94/47/ CEE, sobre time-sharing 3. Diretiva 97/ $7 / C E$, sobre contratos à distância. ${ }^{194}$

Em resumo, caso a norma indicada aplicável pelo DIPr. alemão for a de um país em que as diretivas de proteção do consumidor (normas materiais) não se aplicam, elas serão consideradas de ordem pública internacional e de aplicação imperativa (mandatory) ou obrigatória, cumulando-se como um patamar mínimo de proteção à lei aplicável ao contrato, tudo para a proteção do consumidor europeu. Também a França introduziu no Código de consumo uma regra de DIPr. (art. L. 121-20-6 do

192 Winter relembra que também as normas sobre seguros e proteção dos consumidores são imperativas na Alemanha, Winter, p. 1461.

193 Assim se manifestou Junker, citando Christian von Bar, in IPRAX 1998, p. 68.

194 Texto original em alemão, livremente traduzido, publicado in IPRAX 1999, p. [304] VII e in BGBL. Teil $1 \mathrm{n}^{\circ}$ 8/29, Juni 2000, p. 901. 
Code de la Consommation), ${ }^{195}$ alcançando o mesmo resultado de aplicação imperativa das diretivas de proteção dos consumidores.

Parte da doutrina brasileira, em especial a voltada para o comércio eletrônico, considera esta aplicação direta do Código de Defesa do Consumidor demasiadamente extensiva e defende a aplicação das regras tradicionais nacionais de conflitos de lei. ${ }^{196}$ Apoiando a solução da LICC de 1942 e a aplicação da lei do fornecedor (ou porque propõe o contrato - art. $9^{\circ}, \S 2^{\circ}$ LICC -, ou porque escolhe a sua lei no contrato autonomia da vontade em DIPr., ou porque tem a conexão mais estreita ao realizar a prestação característica - lei do lugar da execução), consideram estes autores que é risco do consumidor fazer uma transação à distância internacional e a aplicação da lei mais favorável ao fornecedor é uma consequiência aceitável. ${ }^{197}$

Já a doutrina consumerista geralmente desconhece a teoria das leis de aplicação imediata em DIPr. e defende - de lege ferenda - a aplicação da lei local do domicílio ou a residência do consumidor, se a oferta for feita no Brasil $^{198}$ ou que as normas do CDC são de ordem pública internacional. ${ }^{199}$ Dada máxima vênia a este esforço louvável de proteção dos contratantes mais fracos, o uso excessivo da ordre public international, ${ }^{200}$ se bem que comum

195 A regra do Code de la Consommation é o art. L. 121-20-6, com a seguinte redação: "Lorsque les parties ont choisi la loi d'un État non membre de la Communauté européenne pour régir le contrat, le juge devant lequel est invoquée cette loi est tenu d'en écarter l'application au profit des dispositions plus protectrices de la loi de la résidence habituelle du consommateur assurant la transposition de la directive 97/7/CE du Parlement européen et du Conseil du 20 mai 1997 concernant la protection des consommateurs en matière de contrats à distance, lorsque cette résidence est situé dans un Etat membre."

196 Cf. Greco, 2000, p. 50.

197 Veja. Greco, 2000, p. 50 e Benevides de Carvalho, p. 108.

198 Assim Lucon, Paulo Henrique dos Santos. "Competência no comércio e no ato ilícito eletrônico, in DeLucca e Simão, Direito e Internet- Aspectos Jurídicos Relevantes, São Paulo, Edipro, 2000, p. 351 a 370, p. 354-355.

199 Assim Martins Castro, Luiz Fernando. O comércio eletrônico e a Defesa do Consumidor no Direito Brasileiro e no Mercosul, in Internet e Direito- Reflexões doutrinárias, Roberto Rodrigues da Silva Júnior (Coord.), Ed. Lumen Juris, Rio de Janeiro, 2001, p. 138 e 139, veja também conclusão independente do Congresso de Minas 2000, in RDC 35, p.265.

200 Esta é uma teoria francesa do início do século XX: "les lois d'intérêt général qui s'imposent toujours à son observation sur le territoire où elles ont été édictées. Nous comprendrons ces dernières sous le nom de lois d'ordre public international." Assim André Weiss apud Anderegg, Kirsten, Ausländische Eingriffsnormen im internationalen Vertragsrecht, Ed. Mohr, Tübingen, 1989, p. 9. Sobre Código de Bustamante, veja Samtleben, Jürgen. Derecho Internacional Privado en América Latina- Teoría y Práctica del Código Bustamante, Ed. Depalma, vol. I, Buenos Aires, 1963, p. 270. 
nos países latino-americanos (veja-se o Código de Bustamante), traz sérias perturbações ao sistema de DIPr. ${ }^{201} \mathrm{O}$ resultado seria de que qualquer lei estrangeira indicada aplicável em qualquer questão de consumo passaria a ofender a nossa ordem pública internacional (art. 17 LICC), simples-mente por não ser igual à lei brasileira, descaracterizando a ordem pública em DIPr. como uma exceção ao sistema, em que se aplica a lex fori (no caso, a lei brasileira) face ao resultado concreto da aplicação da lei estrangeira, o qual, este sim, ofenderia os pilares e valores básicos de nosso ordenamento jurídico. Esta solução radical e genérica só pode ser aceita se considerarmos que as regras materiais do CDC seriam (algumas) de ordem pública interna-cional por se caracterizarem ou positivarem direitos fundamentais (art. $4^{\circ}$ do Código de Bustamante). Sendo assim, parece-me que o melhor é atualizar as nossas regras de DIPr. em uma nova LICC.

Neste sentido, proponho como norma especial de proteção do consumidor a seguinte redação para um artigo 9bis a ser incluído na LICC/42 ou para compor um eventual novo projeto de lei:

Art. $9^{\circ}$ bis. Os contratos e as transações envolvendo consumidores, especialmente os contratados à distância, por meios eletrônicos, de telecomunicações ou por telefone, estando o consumidor em seu país de domicílio, serão regidos pela lei deste pais ou pela lei mais favorável ao consumidor, escolhida entre as partes, se for a lei do lugar da celebração do contrato, lei do lugar da execução do contrato, da prestação característica ou lei do domicílio ou sede do fornecedor de produtos e serviços.

$\S 1^{\circ}$. Aos contratos celebrados pelo consumidor, estando ele fora de seu pais de domicilio, será aplicada a lei escolhida pelas partes, dentre a lei do lugar de celebração do contrato, a lei do lugar da execução ou a lei do domicilio do consumidor.

$\S 2^{\circ}$. Em todos os casos, aplicar-se-ão necessariamente as normas do pais do foro que tenham caráter imperativo, na proteção do consumidor.

$\S 3^{\circ}$. Tendo sido a contratação precedida de qualquer atividade negocial, de marketing, do fornecedor ou de seus representantes, em especial envio de publicidade, correspondência, e-mails, prêmios, convite, manutenção de filial ou representantes de demais atividades voltadas para o fornecimento de produtos e serviços, a atração de clientela no país de domicilio do consumidor, aplicar-se-á necessariamente as normas imperativas deste pais, na proteção do consumidor, cumulativamente às normas imperativas do foro e à lei aplicável ao contrato ou à relação de consumo.

\section{Os acidentes envolvendo pro-} dutos e serviços defeituosos e a necessidade de uma norma especial sobre lei aplicável aos acidentes de consumo, um foro privilegiado da vítima e uma norma especial de ordem pública

Segundo os autores argentinos, há

201 Assim também conclui, Pierre Mayer, p. 531. 
um DIPr. do Mercosul. ${ }^{202}$ Já, autores uruguaios $^{203}$ e brasileiros preferem destacar as normas como sendo de Processo Civil Internacional. ${ }^{204}$ Certo é que o Protocolo de San Luis, de 1996, regula o foro e a lei aplicável à responsabilidade civil por acidentes de trânsito, logo, traz normas de DIPr., enquanto os demais tratados tratam efetivamente de processo e de normas auxiliares ao DIPr. ${ }^{205}$

No âmbito do Mercosul, pois, temos o Protocolo sobre Matéria de Responsabilidade Civil Emergente de Acidentes de Trânsito entre os EstadosPartes do Mercosul, assinado em San Luis, em 25 de agosto de 1996, o qual estabelece "o direito aplicável e a jurisdição internacionalmente competente em casos de responsabilidade civil emergente de acidentes de trânsito ocorridos no território de um EstadoParte, nos quais participem, ou dos quais resultem atingidas, pessoas domiciliadas em outro Estado-Parte" (art. $1^{\circ}$ ). Este protocolo foi saudado pela doutrina como necessário, ${ }^{206}$ e suas normas, mais flexíveis que as atuais normas nacionais, como adequadas. ${ }^{207}$ As normas do referido protocolo estabelecem a aplicação da lex loci delicti commissi e determinam exceções para as regras com vínculos mais estritos, respeitadas as regras imperativas do lugar do acidente. $\mathrm{O}$ Protocolo não regula casos de conumo, mas pode servir de modelo à nossa sugestão e assim dispõe:

Art. $3^{\circ}$. La responsabilidad civil por accidentes de tránsito se regulará por el derecho interno del Estado Parte en cuyo territorio se produjo el accidente.

Si en el accidente participen o resulten afectadas únicamente personas domiciliadas en otro Estado Parte, el mismo se regulará por el derecho interno de éste último.

Art. $5^{\circ}$. Cualquiera fuere el derecho aplicable a la responsabilidad, serán tenidas en cuenta las regras de circulación y seguridad en vigor en el lugar y en el momento del accidente. ${ }^{208}$

No âmbito do Mercosul, em 1996, também foi assinado um protocolo específico sobre jurisdição para o

202 Assim Klor, p. 229 e seg.; e Fernandez Arroyo, p. 42.

203 Assim Hargain/Mihali, p. 537 e seg.

204 Assim Pabst, IPRAX, 1999, p. 76, que cita opiniões de Araújo, Almeida, Martins, Borba Casella e Pabst, p. 31. Veja meu artigo na Revista do UNIDROIT.

205 Esta também é a opinião de Samtleben, em seu artigo publicado in RabelsZ, 63 (1999), p. 1 e seg.

206 Assim Fernandez Arroyo, p. 43.

207 Veja meu artigo sobre o tema, em que há sugestão de normas para o Brasil, que foram levadas para a Reunião de Ministros, Revista dos Tribunais, vol. 629 (mar/1988), p. 89-92. 208 Texto reproduzido de Araújo/Marques/Reis, p. 155-156. 
consumidor que ficou conhecido como "Protocolo de Santa Maria", cidade brasileira onde foi negociado, que traz um foro especial privilegiado para o consumidor e que poderia ser utilizado em caso de acidentes de consumo. No CDC há atualmente um foro privilegiado para o consumidor, em seu art. 101, inciso I da Lei 8.078/90. Dúvida há se o STF abandonará sua preferência pelos art. 88 e 89 do CPC em prol do foro privilegiado do consumidor do art. 101, I do CDc, daí a importância de uma norma epecial sobre o tema, em convenção ou na reforma do CPC.

Efetivamente são estas as tendências internacionais em matéria de acidentes de consumo: assegurar um foro privilegiado aos consumidores, aplicar a teoria da ubiqüidade em matéria de acidentes de consumo (indicando ou a lei do lugar do ato ou tentativa de delito, lex loci delicti commissi, ou lei do lugar onde os efeitos do delito ou acidente fizeram-se sentir), indicar a lei do domicílio ou residência do consumidor ( $§ 40,2$ EGBGB) ou a sua cumulação com a lei do mercado em que o bem foi vendido ou mesmo cláusulas escapatórias e normas de favor consumidor. ${ }^{209}$

Especialmente em matéria de riscos novos da tecnologia ou biotecnologia, como os OGMs ou trangênicos, mister relembrar a existência da Convenção de Haia de outubro de 1973 sobre responsabilidade pelo fato do produto. ${ }^{210}$ A convenção é flexível o suficiente e representaria um avanço considerável se pudesse o Brasil a ela aderir ou ratificá-la, conforme o caso. ${ }^{211}$ A convenção traz a responsabilidade de toda a cadeia de fornecedores, inclusive distribuidores e importadores $\left(\operatorname{art.} 3^{\circ}\right.$ ), conhece a noção de vício da informação ou falha na informação sobre os riscos e ingredientes dos produtos (art. $1^{\circ}$ ) e inclui os produtos agrícolas e naturais $\left(\operatorname{art.} 2^{\circ}\right) .^{212}$ A Convenção de Haia de 1973 indica como aplicável (art. $4^{\circ}, 5^{\circ}$ e $6^{\circ}$ ) a lei do país onde ocorreu ou deveria ocorrer o dano (lex loci delicti) ou a lei do país de residência habitual das pessoas vítimas. ${ }^{213}$ A tendência mundial é de ter regras especiais sobre os delitos de

209 Veja Kadner Graziano, Thomas. Europäisches Internationales Deliktsrecht, Mohr, Tübingen, 2003, p. 67 e seg.

210 Wandt, p. 58 ss.

211 Veja Lima Marques, Claudia. Novos rumos do Direito internacional privado quanto às obrigações resultantes de atos ilícitos, in Revista dos Tribunais (São Paulo), vol. 629 (mar. 1988), p. 72-92.

212 Veja Conférence de La Haye de droit internationale privé, Actes et documents de la douzième session - 2 au 21 octobre 1972, Tome III - Responsabilité du fait des produits, Ed. Bureau Permanent de la Conférence, La Haye, 1974, p. 246-250.

213 Veja Freitag, Robert, Der Einfluss des Europäischen Gemeinschaftsrechts auf das internationale Produkthaftungsrecht, Mohr, Tübingen, 2000, p. 171ss. 
consumo, que podem ser catastróficos ou não, individuais ou coletivos, utilizando a lei do lugar de aquisição ou lei do mercado de origem (lex originis), ou a lei mais favorável ao consumidor, o que pode ser muito importante no futuro, com os novos danos ainda não identificados. ${ }^{214}$

Acidentes e delitos de consumo são temas muito ligados à exceção de ordem pública e aos direitos fundamentais dos cidadãos. Qualidade e segurança, de produtos e serviços oferecidos no mercado, é hoje um dos anseios de dignidade da pessoa humana. Sendo assim, cabe lembrar a importância que a LICC, tenha clara uma norma sobre a chamada ordem pública positiva, ou os efeitos protetivos dos direitos fundamentais também em DIPr. Assim também a tradicional exceção de ordem pública tem um claro fim social e de proteção, não só do sistema do DIPr, mas também, nos países da família de direito continental-europeu, das políticas públicas ou objetivos de harmonia social interna. ${ }^{215}$ Minha sugestão seria incluir um parágrafo único no atual art. 17 da LICC, que fortemente influenciado pelo art. $6^{\circ} \mathrm{da}$ EGBGB e retirando as menções desnecessárias à soberania nacional e aos bons costumes, assim ficaria redigido:

Art. 17. As leis, atos e sentenças de outro pais, bem como quaisquer declarações de vontade, não terão eficácia no Brasil quando ofenderem a ordem pública.

$\S$ único. A norma estrangeira indicada não terá eficácia quando o resultado da aplicação desta for incompativel com os princípios fundamentais do direito brasileiro especialmente com os direitos fundamentais.

E, por fim, para regular a contento os acidentes de consumo, ${ }^{216}$ mister sugerir uma regra especial para estes delitos ou atos ilícitos envolvendo consumidores, sem prejuízo do disposto nos art. 12, 13 e 14 do CDC. A redação poderia ser esta:

Art. $9^{\circ}$ Para reger as obrigações resultantes de atos ilicitos, acidentes de consumo ou da responsabilidade pelo fato do produto ou serviço de consumo será aplicável, em princípio, a lei do lugar onde o ato ocorreu ou aconteceu a tentativa ou, em caso de omissão, devia ter ocorrido o fato. Excepcionalmente, será aplicável a lei do lugar onde os efeitos se fizeram sentir, caso este lugar coincida com o lugar do foro.

$\S 1^{\circ}$ Caso nenhuma das partes possua seu domicilio ou sede no país onde o acidente ocorreu ou seus efeitos se fizeram sentir, poderão as partes, no processo, escolher o Direito a ser aplicado entre o direito do foro, do domicilio ou residencia habitual comum, do lugar do registro dos veículos ou lugar do ato ou do

214 Kadner Graziano, p. 78.

215 Bucher, p. 60 e eg.

216 Veja meu artigo in RT 629, p. 89 e seg. 
mercado de comercialização do produto ou serviço.

$\S 2^{\circ}$ Caso as partes não exerçam o direito de escolha previsto no parágrafo primeiro e, possuindo as partes seu domicílio ou residência habitual no mesmo país, será a lei deste país a aplicável.

$\S 3^{\circ}$ As leis indicadas aplicáveis não excluem a aplicação das normas imperativas previstas pela lei do lugar do ato ilícito.

\section{CONCLUSÃO}

Concluímos, pois, este estudo em homenagem ao prof. dr. José Francisco Rezek, da UnB, convencidos da necessidade e da oportunidade da academia brasileira sugerir hoje novas normas especiais de Direito Internacional Privado para a proteção contratual e extracontratual dos consumidores, a serem incorporadas na LICC, justamente agora que - com a aprovação do novo Código Civil - estuda-se a sua modificação (projeto de Lei 243/2002).

A minha singela sugestão seria a seguinte:

Art. $9^{\circ} \mathrm{bis}$. Os contratos e as transações envolvendo consumidores, especialmente os contratados à distância, por meios eletrônicos, de telecomunicações ou por telefone, estando o consumidor em seu pais de domicílio, serão regidos pela lei deste país ou pela lei mais favorável ao consumidor, escolhida entre as partes, se for a lei do lugar da celebração do contrato, lei do lugar da execução do contrato, da prestação característica ou lei do domicilio ou sede do fornecedor de produtos e serviços.

$\S 1^{\circ}$ Aos contratos celebrados pelo consumidor, estando ele fora de seu país de domicilio, será aplicada a lei escolhida pelas partes, dentre a lei do lugar de celebração do contrato, a lei do lugar da execução ou a lei do domicílio do consumidor.

$\S 2^{\circ}$ Em todos os casos, aplicar-se-ão necessariamente as normas do país do foro que tenham caráter imperativo, na proteção do consumidor.

$\S 3^{\circ}$ Tendo sido a contratação precedida de qualquer atividade negocial, de marketing, do fornecedor ou de seus representantes, em especial envio de publicidade, correspondência, e-mails, prêmios, convite, manutenção de filial ou representantes de demais atividades voltadas para o fornecimento de produtos e serviços, a atração de clientela no país de domicílio do consumidor, aplicar-se-ão necessariamente as normas imperativas deste país, na proteção do consumidor, cumulativamente às normas imperativas do foro e à lei aplicável ao contrato ou à relação de consumo.

Art. $9^{\circ}$ ter. Para reger as obrigações resultantes de atos ilicitos, acidentes de consumo ou da responsabilidade pelo fato do produto ou serviço de consumo será aplicável, em princípio, a lei do lugar onde o ato ocorreu ou aconteceu a tentativa ou, em caso de omissão, devia ter ocorrido o fato. Excepcionalmente, será aplicável a lei do lugar onde os lefeitos se fizeram sentir, caso este lugar coincida com o lugar do foro.

$\S 1^{\circ}$ Caso nenhuma das partes possua seu domicílio ou sede no país onde o acidente ocorreu ou seus efeitos se fizeram sentir, poderão as partes, no processo, escolher o Direito a ser 
aplicado entre o direito do foro, do domicílio ou residencia habitual comum, do lugar do registro dos veículos ou lugar do ato ou do mercado de comercialização do produto ou serviço.

$\S 2{ }^{\circ}$ Caso as partes não exerçam o direito de escolha previsto no parágrafo primeiro e, possuindo as partes seu domicílio ou residência habitual no mesmo país, será a lei deste país a aplicável.

$\S 3^{\circ}$ As leis indicadas aplicáveis não excluem a aplicação das normas imperativas previstas pela lei do lugar do ato ilícito.

Art. 17 - As leis, atos e sentenças de outro país, bem como quaisquer declarações de vontade, não terão eficácia no Brasil quando ofenderem a ordem pública.

$\S$ único. A norma estrangeira indicada não terá eficácia quando o resultado da aplicação desta for incompativel com os principios fundamentais do direito brasileiro especialmente com os direitos fundamentais.

Como se observa, a sugestão não inclui os aspectos de processo civil internacional para não duplicar os esforços atualmente realizados no UNIDROIT $^{217}$ e na Convenção de Haia, ${ }^{218}$ mas norma semelhante às previstas no Protocolo de Santa Maria poderiam ser incluídas ou na nova LICC ou no CPC brasileiro.

Igualmente, se assim tiver por bem o legislador, pode ser incluída uma cláusula escapatória, semelhante a que sugeri para a nova CIDIP sobre proteção do consumidor:

Art. ....A lei indicada como aplicável pode excepcionalmente não ser utilizada pelo juiz, se, tendo em vista todas as circunstâncias do caso, a conexão com a lei indicada aplicável mostrar-se superficial e o caso encontrar-se muito mais vinculado estreitamente a outra lei, mais favorável ao consumidor.

Neste sentido, pedindo desculpas ao mestre pela singeleza das sugestões aqui realizadas, que espero sejam construtivas, reafirmo minha viva admiração intelectual pela sua sólida obra, a qual foi decisiva para a evolução do Direito Internacional brasileiro. Maio de 2004.

217 Veja sobre o texto já existente, Projet de Principes relatifs à la procédure transnationale, in Uniform Law Review/ Revue de droit uniforme (UNIDROIT), 1119 e seg. ou no site www.unidroit.org, comentário de Ferrand, Frédérique "Les 'principes' relatifs à la procédure civile transnationale sont-ils autosuffisants? De la nécessité ou non de les assortir de 'règles' dans le projet ALI/Unidroit', in Uniform Law Review/ Revue de droit uniforme (UNIDROIT), 2001, p. 995 e seg. e meu artigo, Procédure civile internationale et Mercosur : pour un dialogue des règles universelles et régionales, p. 465 e seg..

218 Veja site www.hcch.net. 



\title{
Direitos humanos e diversidade cultural $^{*}$
}

\author{
Eduardo Kroeff Machado Carrion ${ }^{\star \star}$
}

Minha exposição tem por objeto Direitos Humanos e Diversidade Cultural. Entretanto, a reflexão sobre esse tema deve inserir-se, tal como definido pela coordenação do projeto Tribunos da Cidadania, em um contexto mais abrangente, que diz respeito a Preconceito e Tolerância e também à Igualdade e Celebração da Diferença. Assim, não tratarei imediatamente do ponto especifico. Retomarei antes algumas observações sobre o conceito de igualdade e a problemática da diferença. A começar, o conceito de igualdade.

\section{IGUALDADE E DIFERENÇA ${ }^{1}$}

Com razão, atribuímos geralmente um valor positivo à idéia de igualdade. Opõe-se ela à discriminação, opõe-se ao preconceito, opõe-se mesmo à violência. Opõe-se mesmo à violência porque, exatamente, a discriminação, o preconceito, a desigualdade fomentam a violência. Nesse sentido, a idéia de igualdade opõe-se também à violência, não só à discriminação e ao preconceito. Mais ainda: geralmente, no pensamento clássico, a idéia de justiça significa,

\footnotetext{
* O presente texto resulta de palestra proferida para a EDHUCA - Escola de Direitos Humanos e Cidadania, dentro do projeto Tribunos da Cidadania da Faculdade de Direito da UFPel em convênio com a Secretaria de Estado dos Direitos Humanos, do Ministério da Justiça, com o apoio institucional da UNESCO, Pelotas, 10/11/2001. Mantive o estilo coloquial originário.

** Ex-diretor e professor titular de Direito Constitucional da Faculdade de Direito da UFRGS. 1 Retomo aqui alguns pontos tratados em trabalho anterior: (CARRION, Eduardo Kroeff. Igualdade, preconceito e violência. In: adquiridos e outros estudos. Porto Alegre: Síntese, 2000. Reforma constitucional e direitos
} 
substancial ou fundamentalmente também, a de igualdade. Justiça como igualdade. Assim, a idéia de igualdade adquiriu um sentido significativamente positivo na nossa cultura. Entretanto, muitas vezes ela representou ou ainda representa um valor claramente negativo. Já na Grécia Antiga, encontramos um discurso em defesa da desigualdade. Em um dos diálogos de Platão, um dos personagens, Cálicles, expressa basicamente o seguinte: a idéia de igualdade é a bandeira dos fracos que querem com a lei conter os fortes. Temos aqui a idéia de igualdade como algo essencialmente negativo porque não possibilita que os fortes sejam fortes e não ajuda a que os fracos continuem fracos. Temos aqui um discurso extremamente preconceituoso e conservador. Seria uma espécie de "darwinismo social". Darwin falou em seleção natural, a evolução das espécies dependendo de uma seleção natural. Importar a idéia de seleção natural para o mundo social, para a esfera da convivência entre pessoas humanas, torna-se extremamente preconceituoso e conservador. Significa em última análise afirmar que os fortes devem sempre se sobrepor aos fracos porque os fortes são fortes e os fracos são fracos. Essa proposta, portanto, já encontramos expressa em um dos diálogos de Platão, que utiliza o personagem para expor um tipo de discurso disseminado na época, um discurso conservador e preconceituoso, de defesa da desigualdade e de crítica à idéia de igualdade, concluindo finalmente que a desigualdade seria natural e a igualdade, artificial. Em outros termos, a lei seria artificial porque pretenderia transtornar a relação natural entre fortes e fracos. Vemos aqui uma crítica à idéia de igualdade. É também o discurso do neoliberalismo que já está presente nesse personagem de um dos diálogos de Platão, Cálicles. Nesse sentido, não há nenhuma novidade no neoliberalismo. O neoliberalismo é finalmente um discurso requentado das elites, dos discursos das elites que já vêm desde a Antigüidade, passando por esse personagem de um dos diálogos de Platão chamado Cálicles. Vemos, assim, a crítica à idéia de igualdade. Uma crítica conservadora à idéia de igualdade. Podemos também formular uma crítica à idéia de igualdade numa outra perspectiva. Referi-me, inicialmente, ao aspecto positivo da idéia de igualdade para depois mostrar a crítica conservadora à idéia de igualdade. Mas podemos também articular uma crítica progressista à idéia de igualdade. Uma crítica progressista da idéia de igualdade na perspectiva da ampliação do processo civilizatório e da construção do futuro. Aqui, tratar-se-á da crítica à mera e simples igualdade formal e da defesa de algo mais, algo além da igualdade formal, que seria a igualdade material. Tratar-se-á finalmente do discurso que surge ou em grande parte se concretiza com o chamado Estado Social, após a $1^{\mathrm{a}}$ Guerra Mundial e sobretudo após a $2^{\mathrm{a}}$ Guerra Mundial. Estado Social esse marcado pela 
implementação e pela efetivação de políticas sociais caracterizadas como políticas compensatórias, de abrandamento das desigualdades materiais. Reconheceu-se que não bastava juridicamente afirmar ou simplesmente afirmar num texto constitucional ou na legislação infraconstitucional que todos eram iguais em direitos, sendo ainda necessário encontrar os instrumentos para a organização e a efetivação dessa igualdade. Reconheceu-se, por exemplo, que não bastava simplesmente atribuir a igualdade formal do direito de voto ao cidadão se ao mesmo tempo se mantinham e se reproduziam gritantes desigualdades econômicas, sociais, culturais, de tal forma que o voto de alguns se multiplicava e se potencializava, negando ou descaracterizando assim aquela igualdade formal inicialmente afirmada. Daí, a necessidade de o Estado Social implementar políticas sociais que compensem ou abrandem essas desigualdades materiais. Essa crítica à idéia de igualdade no sentido da crítica à mera igualdade formal representa a defesa de um passo a mais na idéia de igualdade. Significa a tentativa de trânsito de uma igualdade meramente formal para uma igualdade efetivamente material. Não diz propriamente respeito a uma crítica global à idéia de igualdade, como no discurso anterior, o discurso do Cálicles ou do neoliberalismo, mas concerne a uma crítica às insuficiências da igualdade formal e à luta por sua complementação ou sua superação como igualdade material.
Entretanto, o discurso da igualdade não pode servir de pretexto ou de justificativa para esquecermo-nos da necessidade do reconhecimento da diferença. Não há incompatibilidade entre igualdade e diferença, isso que gostaria de acentuar. Quando se fala em igualdade e diferença, que não se entenda como sugestão de que eventualmente haja algum problema ou conflito inevitável entre igualdade e diferença. Reconheço que possa haver, por momentos, no discurso da igualdade, não em todo o discurso da igualdade, mas em um certo discurso da igualdade, uma aproximação desse certo discurso da igualdade com a idéia de discriminação e de preconceito. Porque esse certo discurso da igualdade, assim como o discurso da intolerância e do preconceito, pode significar um discurso da intolerância e do preconceito com relação a diferença. Reconheço que se possa equivocadamente entender a igualdade como algo oposto ou contrário à diferença. Então, minha crítica a esse certo discurso da igualdade. Embora me pareça que devamos resgatar a idéia de igualdade, não só a igualdade meramente jurídica e formal, mas também a igualdade real, fazer mesmo a apologia da igualdade, não podemos de forma alguma entender a idéia igualdade como um desconhecimento da diferença. Não só a idéia de igualdade não se opõe à diferença, mas, mais ainda, a idéia de igualdade justifica-se num certo sentido a partir da diferença. Se os indivíduos fossem idênticos não 
se justificaria a idéia de igualdade. Exatamente porque os indivíduos não são idênticos é que se torna pertinente a idéia de igualdade. Então, vejam: a idéia de igualdade é antes de tudo uma decorrência da diferença do que uma contraposição à diferença. Se os indivíduos fossem idênticos não haveria propriamente espaço para a reivindicação da igualdade. Exatamente porque os indivíduos são diferentes torna-se pertinente a idéia de igualdade. Há diferenças de classe, diferenças de cultura, diferenças de etnia, diferenças de gênero, inúmeras diferenças, e, por causa dessas diferenças, torna-se pertinente a idéia de igualdade. Assim, a idéia de igualdade se funda na diferença, para resgatar o que há de rico na diferença e afastar o que há de discriminatório na diferença. A idéia de igualdade não existe se não houver a diferença. Se houvesse apenas identidade, a idéia de igualdade não seria nem pertinente nem razoável. Em outros termos, a idéia de igualdade não se funda em uma presumida identidade entre os indivíduos, mas no fato de sua real diversidade, de sua efetiva diferença.

A diversidade é um motor fundamental da evolução. Os geneticistas, os especialistas em biologia, sobretudo em biologia evolutiva, que estudam a evolução natural, têm cada vez mais chamado a atenção para a importância do chamado polimorfismo genético no processo evolutivo. A evolução natural, ao invés de uniformizadora, tem-se revelado diversificante. Ao invés de unificar, ele tende a diversificar. Em outros termos, o processo evolutivo não é um processo que vá uniformizando as espécies, mas sim diversificando as espécies, enriquecendo a existência e a vida. Polimorfismo genético traduz exatamente isso: expressão que significa muitos, poli, ao contrário de único ou de um. Por um lado, poli, muitos ao invés de único ou de um; por outro, morfismo, de forma; quer dizer, finalmente, multiplicidade de formas. Multiplicidade de formas enriquecedora no processo evolutivo. Temos um meio ambiente diversificado. Se também houver diversificação na evolução das espécies, seguramente existirão melhores condições de responder às pressões e aos desafios de um meio ambiente diversificado. Se o processo evolutivo fosse uniformizador, provavelmente nós não teríamos as mesmas condições de sobrevivência na Terra. Exatamente porque o processo evolutivo revela-se diversificador é que nós sobrevivemos em face de um meio ambiente igualmente diversificado. A diversidade possibilita que a humanidade melhor sobreviva porque possui ela assim condições de dar respostas múltiplas a um meio ambiente diversificado. A inter-relação de espécies, de caracteres e de características distintas é que possibilitou em grande parte à humanidade a sobrevivência e o processo civilizatório, sua permanência e continuidade. Para tal, e simplesmente com relação à evolução 
biológica, o polimorfismo genético procura chamar a atenção. Quando, entretanto, damos o salto da evolução biológica para a evolução cultural, tornase muito mais importante a diversidade e a diferença. Graças à diferença é que nós conseguimos dar respostas múltiplas e, finalmente, eficazes. Hoje, para um mesmo desafio da humanidade, não damos necessariamente uma única e simples resposta. Se fôssemos todos iguais, provavelmente daríamos uma única e simples resposta. Exatamente porque somos diferentes, poderemos dar para um mesmo desafio da humanidade múltiplas respostas, com maior probabilidade de acerto. Seguramente, a probabilidade de acerto numa única e simples resposta é muito menor do que a probabilidade de acerto em múltiplas respostas. Graças à essa diversidade, diversidade de características, diversidade de respostas, é que temos razoavelmente evoluído. Sempre com riscos, com riscos de retrocessos, é verdade. Novamente, as respostas únicas, que procuram dividir a humanidade entre o certo e o errado, são respostas uniformizadoras que colocam em risco a própria trajetória da humanidade. Contra isso, temos de nos rebelar. Encontrar respostas na afirmação da diversidade que é o pressuposto da idéia de igualdade.

Feitas essas considerações iniciais, gostaria de tratar mais pontualmente da problemática dos direitos humanos nesse contexto.

\section{DIREITOS HUMANOS: UNIVERSALISMO $\mathbf{X}$ RELATIVISMO}

De forma sumária, podemos dizer que toda construção dos direitos humanos, direitos humanos universais, que se traduzem nos textos legais e, sobretudo, nos textos constitucionais, expressou em grande parte uma construção do mundo ocidental. É inequívoco isto, embora suas raízes estejam na Antigüidade clássica. A questão dos direitos humanos já surge, de forma precária é verdade, na experiência grega clássica, mas se fortalece com o Estoicismo, corrente filosófica que, em grande parte, preparou a emergência do Cristianismo, onde a problemática da liberdade individual talvez tenha sido explorada e refletida de forma mais enfática. O Estoicismo que foi uma importante corrente filosófica durante o helenismo, não mais na fase áurea da Grécia Antiga, mas em uma fase de expansão da cultura grega. O Estoicismo que em grande parte preparou a revolução cultural representada pelo Cristianismo, que também enfatiza a idéia de liberdade individual. Mas, mais recentemente, no mundo moderno, a base da afirmação dos direitos humanos encontra-se na liberdade religiosa. Daí, a importância também da reforma protestante e da afirmação da liberdade religiosa em alguns estados europeus. Da liberdade religiosa podemos deduzir, por extensão, inúmeras liberdades: a 
liberdade de consciência, a liberdade de cátedra, a liberdade de ensino, a liberdade de comunicação, a liberdade de reunião, a liberdade de manifestação, finalmente até mesmo a liberdade de organização sindical e a liberdade de organização partidária. A liberdade religiosa significou uma importante mudança cultural, quebrando o monopólio do pensamento religioso hegemônico ou predominante. Antes, o pensamento diferente era considerado diabólico e, portanto, imediatamente condenado. Afinal, representava uma crítica à ortodoxia da religião oficial. Então, afirmar a liberdade religiosa nesse contexto representou uma verdadeira revolução intelectual. Significou a quebra do monopólio ideológico por parte da Igreja Católica dominante. Foi também uma afirmação da diversidade. Dela podemos deduzir, como já foi dito, inúmeras liberdades modernas. É o que afirma um grande jurista, Jellinek, para quem a base da afirmação dos direitos humanos modernos foi a liberdade religiosa. A partir daí, tivemos uma longa construção dos direitos humanos, inclusive a tentativa de superar a mera igualdade formal e construir a efetiva igualdade material.

A idéia que nós ocidentais temos da universalidade dos direitos humanos, a idéia que temos de direitos humanos universais é, efetivamente, uma idéia universal? Nossa idéia de universalidade ou o que nós entendemos por direitos humanos universais é a mesma idéia de universalidade ou é o mesmo que entendem por direitos humanos universais outras culturas, como a cultura islâmica ou a cultura africana? Não há finalmente distintas interpretações da idéia de universalidade dos direitos humanos? Não há distintas compreensões do que sejam direitos humanos universais? Esta é uma reflexão que estamos enfrentando não só no campo da antropologia, que é uma ciência que estuda as diversidades culturais, mas também no campo do direito, sem falar em outras áreas. Hoje, observamos o surgimento de declarações africanas dos direitos humanos, declarações asiáticas dos direitos humanos e outras com suas especificidades e suas particularidades. Por exemplo, as cartas africanas dos direitos humanos têm uma compreensão um pouco distinta das cartas ocidentais dos direitos humanos. Há uma certa ênfase, nas cartas africanas dos direitos humanos, nos direitos coletivos em detrimento dos direitos individuais. $\mathrm{Na}$ cultura ocidental, priorizamos sobretudo os direitos individuais em detrimento dos direitos coletivos. Na Grécia Antiga, havia igualmente um reforço da idéia do que nós denominaríamos hoje de direitos coletivos em detrimento dos direitos individuais. Praticamente, não houve na Grécia Antiga uma construção da idéia de direitos individuais. Isto ocorrerá posteriormente, como já foi dito, com o Estoicismo. Mas, na filosofia clássica grega, não há propriamente uma perspectiva de direitos individuais 
e sim de direitos políticos, de direitos coletivos. Temos, assim, compreensões diferentes, diversificadas, da própria idéia do que sejam direitos humanos, presumivelmente universais. Há, assim, o risco de nós, como cultura ocidental, entendermos nossa universalidade como a única universalidade possível e verdadeira. Da mesma forma, entendermos a universalidade dos outros como uma parcialidade. Esse, o risco do etnocentrismo cultural que, no fundo, expressa um eurocentrismo cultural ou um ocidentalcentrismo cultural ou até mesmo um americanocentrismo cultural. Facilmente, compreendemos e avaliamos o outro, o diferente, a partir simplesmente de nossos referenciais e paradigmas, presumidos universais. Assim como no ato amoroso quando, muitas vezes, ao invés de instituir-se como diálogo, transforma-se em monólogo. Quando procuro encontrar no outro a projeção do meu eu. Então, na realidade, estou estabelecendo um diálogo comigo mesmo. Dialogo no outro o que existe de eu no outro e não o que existe de outro no outro, o diálogo transformando-se portanto em monólogo. Temos de subverter essa relação, que é uma relação, em grande parte, egoísta ou solipsística e de não compreensão da diferença. $\mathrm{Na}$ realidade, tenho finalmente de reconhecer no outro o que ele tem de outro e não simplesmente o que ele tem de mim nele. O risco, portanto, de lermos outras culturas a partir dos nossos parâmetros, das nossas características e dos nossos sincronismos sem perceber o que existe de sincronismos, de características e de parâmetros distintos e diversificados nas outras culturas. Quer dizer, ler as outras culturas e suas particularidades e diferenças a partir dos nossos critérios uniformizadores. O mundo ocidental tem de ter a sensibilidade da compreensão das diferenças culturais. Por que refirome sobretudo ao mundo ocidental? Porque é um mundo hegemônico.

Há também e seguramente outro risco, um risco num certo sentido oposto: o de sermos então seduzidos pelo relativismo cultural. Todas as culturas seriam finalmente equivalentes ou iguais. Porque, em sendo diferentes, sem termos possíveis de comparação, todas as culturas seriam equivalentes ou iguais. Posso, porém, em nome da diversidade cultural, justificar processos sociais que são processos sociais extremamente aviltantes, que desconhecem, inclusive, a diferença? Hajam vista, por exemplo, as condições das liberdades públicas em alguns países teocráticos, bem como a condição da mulher. Vejase, da mesma forma, algumas práticas existentes em alguns países africanos como a da infibulação que se caracteriza pela ablação do clitóris e pela sutura dos órgãos genitais femininos, em nome de hábitos religiosos ou culturais. Podemos em nome da diversidade cultural aceitar tais práticas? Podemos, em nome da diversidade cultural, aceitar regimes autocráticos e autoritários? Finalmente, são equivalentes nossas conquistas 
democráticas no mundo ocidental e as conquistas ou atrasos com relação ao processo civilizatório em outros horizontes culturais? Por sermos ocidentais, estamos sempre sujeitos à condenação, já que o mundo ocidental é dominante e dominador, nossas conquistas democráticas tendo o sinal inevitável e necessário da negatividade? Estou fazendo essas interrogações para problematizar. Poderia ter algumas respostas, mas não quero dizer que minha resposta seja a resposta universal ou verdadeira. Penso, entretanto, que temos de reconhecer que há sim um processo civilizatório. $\mathrm{O}$ que ocorreu, circunstancialmente, no mundo ocidental? Aqui, volto à idéia de liberdade religiosa. O mundo ocidental, primeiro do que outros, conseguiu laicizar o poder político, isto é, secularizar o poder político. Alcançou diferenciar poder político e poder religioso. Conseguiu resgatar ou instaurar a idéia de poder civil. Resultou de um processo histórico, propiciado, é verdade, pela superação do feudalismo e a emergência do capitalismo e da grande indústria, que foi a base da construção da sociedade democrática e dos direitos contemporâneos. Que, aliás, não são direitos e não são conquistas que possam ser monopolizadas pelo mundo ocidental. São direitos e conquistas universais. Há outras culturas que, até por interesse do mundo ocidental, ficaram inclusive cristalizadas em uma visão teocrática. $\mathrm{O}$ mundo ocidental, os países hegemônicos, ao conquistarem, por exemplo, o mundo africano ou o mundo oriental, mantiveram no poder oligarquias autoritárias e corruptas. Isso fomentou, até por reação, fundamentalismos religiosos. Ao lado do fundamentalismo radical, que vai se traduzir muitas vezes em terrorismo, temos também um fundamentalismo conservador que, com a colaboração ou a conivência do mundo ocidental, não propiciou uma efetiva democratização dessas sociedades. Ora, o mundo islâmico - estou dando a título de exemplo o mundo islâmico em decorrência dos episódios recentes que estamos presenciando -, o mundo islâmico foi de uma exuberância inquestionável. Durante a Idade Média, talvez não seja temerário dizer, esteve por momentos muito à frente do mundo ocidental. É verdade que na Idade Média, presenciamos, desde o século XII, a eclosão das universidades no mundo ocidental. Mas o mundo islâmico resgatou em grande parte a cultura grega clássica. Os avanços nas áreas da reflexão filosófica, da construção poética, das descobertas científicas foram consideráveis. A partir do século XVI, do século XVII, houve uma certa paralisia. Foi quando começou o colonialismo europeu e ocidental. Depois da $1^{\text {a }}$ Guerra Mundial, houve interesse em manter oligarquias atrasadas e autoritárias em função de interesses geopolíticos e econômicos estratégicos. De qualquer forma, temos de entender as conquistas do mundo ocidental, em termos de liberdades e de 
reconhecimento da diferença, como conquistas da humanidade. Não são conquistas exclusivamente ocidentais. São conquistas do processo civilizatório. Então, reconhecer a diferença não significa, necessariamente, tornar todas as culturas equivalentes ou iguais. Temos de, ao mesmo tempo, reconhecer que há um processo civilizatório. Um processo de construção democrática, de ampliação de horizontes democráticos e de conquistas populares.

Como compatibilizar a idéia de universalidade com a idéia de diversidade? Creio que através da perspectiva de um universalismo plural.

Para concluir, gostaria ainda de acrescentar a seguinte reflexão: em que pese todos esses episódios que presenciamos hoje, se formos fazer a leitura da história, veremos que muitas vezes as sociedades avançam, retrocedem, mas que finalmente progridem. Volto a insistir: há um processo civilizatório. Assim como houve uma evolução biológica, demos um salto para uma evolução cultural extremamente rica e diversificada, muito mais rica e diversificada do que a evolução biológica. Ela, a evolução humana, tem a capacidade da transcendência, entre outras coisas. Pois bem, não há como desacreditar deste potencial do processo civilizatório. Finalizo, lembrando um momento da nossa existência como humanidade. Tentemos imaginar o quadro há mais de dez ou quinze mil anos atrás, quando o homem vivia nas cavernas.
A capacidade tecnológica do homem era mínima, reduzida. O homem não tinha a capacidade de acumular riquezas, produzindo basicamente para o seu sustento diário. Ele vivia a duras penas e com dificuldades. Por isso mesmo, não havia ainda a instituição da escravidão, que só passa a economicamente justificar-se - não estou dizendo a moralmente justificarse - quando o homem consegue produzir além da sua necessidade diária de sobrevivência, quando o homem consegue acumular riquezas. Nesse momento a que me refiro, o homem mal conseguia sobreviver. $O$ avanço tecnológico era mínimo. Homem esse com uma baixa expectativa de vida. Pois bem, esse homem, quando foi ensinar seu companheiro de jornada a como caçar o bisão, foi capaz de deixar registrado nas paredes das grutas de Altamira e tantas outras uma verdadeira obra de arte, numa espécie, por assim dizer, de assalto aos céus, transcendendo seu miserável cotidiano. A capacidade de, numa circunstância extremamente desfavorável, fazer uma obra de arte. Ora, se esse homem teve essa capacidade, não somos nós hoje que vamos desacreditar da utopia e do processo civilizatório.

\section{DISCRIMINAÇÃO POSITIVA}

(RESPOSTA À QUESTÃo)

Com relação à idéia da discriminação positiva, acho que ela resgata em grande parte a perspectiva 
da idéia de igualdade. Quando me referi ao trânsito da igualdade meramente formal para uma igualdade real, emerge ou insere-se a perspectiva da discriminação positiva. $O$ direito moderno, $o$ direito que surge a partir do início ou meados do século passado, tentou ser, em grande parte, um direito compensatório. Veja-se o caso do direito do trabalho. A realidade inicial ou a circunstância originária era a de desigualdade de fato entre patrão e empregado. Se superponho a uma desigualdade de fato uma mera igualdade jurídica, estarei fortalecendo a desigualdade material. Então, o que fez o direito do trabalho? Tentou ser um direito compensatório, de proteção ao empregado com relação ao poder absoluto inicial do empregador. Temos já aí uma discriminação positiva. $\mathrm{Na}$ experiência do direito, desde o início do século passado, ou mesmo o final do século retrasado, a idéia de uma discriminação positiva foi pouco a pouco incorporada na legislação. Mas, mais recentemente, houve passos acentuados nessa perspectiva. Por exemplo, nossa Constituição. Ela prevê uma discriminação positiva para os portadores de deficiência física. Temos aqui, claramente, uma desigualdade física. Então, os portadores de deficiência física são constitucionalmente beneficiados por uma discriminação positiva. A questão torna-se um pouco mais problemática com relação a outras desigualdades, como de gênero ou, em termos de acesso ao ensino, sobretudo o ensino universitário público, entre integrantes de classes abastadas e membros de classes populares. A questão passa então a ser um pouco mais problemática. Parece-me que a discriminação positiva nas hipóteses que envolvem diferenças culturais, num sentido amplo, não tanto físicas, como os portadores de deficiência física, pode justificar-se como instrumento transitório. De qualquer forma, temos de examinar cada hipótese com muito cuidado. Discute-se muito com relação ao ingresso nas universidades públicas. Não sei se medidas compensatórias teriam grandes resultados. Porque a universidade caracteriza-se por ser uma instituição de ensino. É verdade, a escola, desde o ensino fundamental, divide, discrimina. É distinto aprender numa escola pública ou numa escola privada, sobretudo numa escola privada de elite. Numa escola pública, no centro da cidade ou numa escola pública de periferia. Então, desde o ensino fundamental a escola discrimina, em termos de classe. $O$ pobre recebe um ensino mais deficiente, o filho da elite, um ensino mais qualificado. Além disso, o filho da elite terá um contexto familiar muito mais enriquecedor, sob o ponto de vista cultural. Demais, terá melhores condições econômicas de realizar cursos complementares. Estabelece-se assim uma desigualdade gritante na disputa por uma vaga pública no vestibular. Mas até que ponto resolve o problema procurar igualar depois no ingresso ao ensino superior? Será esse 
o caminho? Não criará uma nova discriminação, interna ao ensino superior. Temos seguramente de denunciar essa discriminação, essa diferença que a educação escolar estabelece desde o ensino fundamental, e de criar mecanismos de qualificação da escola pública. Temos, portanto, de examinar com cuidado cada situação. Quotas dentro dos partidos para as mulheres, talvez se justifiquem como medida transitória. Mas não podem ter como resultado uma maior discriminação. Como melhor compensar essa marginalização das mulheres na atividade sindical, na atividade partidária? Não existem soluções prontas e acabadas. Podemos até definir um padrão, mas que talvez não se adapte a todas as situações. Em certos casos, justifica-se plenamente a discriminação positiva. O próprio Supremo Tribunal Federal tem reconhecido isso. Justifica-se muitas vezes uma discriminação positiva, nem que seja provisoriamente.

\section{UNIVERSALISMO PLURAL}

(RESPOSTA À QUESTÃO)

Com relação ao universalismo plural, acho que seria, antes de tudo, a afirmação da universalidade. Quando se afirma a universalidade, independe de acreditarmos ou não em uma natureza humana pronta e acabada, constituída desde os primórdios dos tempos. Numa visão religiosa ou teológica, por exemplo, poderíamos dizer que, desde os primódios dos tempos, o homem é feito à imagem e semelhança de Deus. Em outros termos, partiríamos de uma predefinição da natureza humana, facilmente concluindo pela afirmação da universalidade. Seja a partir desse ponto de vista, seja a partir de um outro ponto de vista, segundo o qual não encontramos uma natureza humana predefinida, mas há de qualquer maneira uma construção histórica da natureza humana, a humanidade constituindo-se, o homem constituindose no processo, em ambos os casos conclui-se pela afirmação da universalidade, pelo reconhecimento de conquistas universais. Ou porque a universalidade corresponde a uma natureza predefinida, ou porque os conteúdos dessa universalidade foram socialmente construídos, historicamente constituídos. Entendo, portanto, que se impõe finalmente a afirmação da universalidade. A verdadeira questão é como estabelecer o diálogo da universalidade com as diversidades e com as parcialidades. Veja-se o caso da infibulação. Na perspectiva de um universalismo plural, plural sim, mas universalismo de toda maneira, não há como valorizar essa prática, que é uma prática de desvalorização da mulher, que é uma prática de mutilação, não podendo ser valorizada em nome da diversidade cultural, por melhor que se procure explicar suas raízes ou razões culturais. Temos de reconhecer, sim, os avanços da cultura ocidental que efetivamente existem, antes de tudo a 
laicização do poder político, a secularização do poder político, distinguindo o que é política do que é religião. A política não é religião, se não vira inquisição, como lembrava Albert Camus. Na política transformada em religião, o adversário político não é simplesmente um adversário político, mas um inimigo da religião, merecendo as penas do inferno. Contra ele, tudo vale, o assassinato, a tortura, não importa. Como se fez aqui, durante o regime autoritário. Não precisa se tratar necessariamente de uma religião clássica ou histórica, pode ser uma religião laica. Tal como a doutrina da segurança nacional durante o regime autoritário. Forma também de entender a política como religião. Isso muitas vezes é reproduzido na vida partidária mesmo em situações democráticas. A visão do certo e do errado. Maneira igualmente de tornar religiosa a atividade política. Isso é muito característico em algumas culturas. Sociedades teocráticas em que não há liberdades públicas efetivas, onde emergem fundamentalismos. As liberdades públicas são sempre um contraponto ao poder, poder econômico, poder social, poder político ou poder ideológico. Para construir a democracia, temos que nos contrapor ao poder em todas suas modalidades. Não vou dizer que nas sociedades teocráticas ocorra o mesmo que na Idade Média no mundo ocidental, mas elas revelam alguns elementos análogos. As práticas atrasadas inserem-se muitas vezes nesse contexto de fundamentalismos religiosos, de autocracias. Assim, não podemos, em nome da diversidade cultural, em nome do respeito à diferença, valorizar tais práticas. Devemos formular a crítica. Como, entretanto, atuar na perspectiva de um universalismo plural? Também não adianta conquistar e impor uma ordem, que será a ordem dos dominadores. Como enfrentar a situação? Creio que o diálogo e a pressão internacionais são importantes. Devemos também saber assimilar o que existe de virtudes e qualidades, de perspectivas diferentes, de potencialidades novas em outras culturas. Veja-se o caso das culturas orientais tão ricas em inúmeros aspectos. Por exemplo, as religiões que predominam no mundo ocidental são muito mais racionais, o que é uma virtude, mas também revela limites; o cristianismo, o catolicismo tem todo um aparato teológico, praticamente uma filosofia teológica. É o racionalismo próprio do mundo ocidental. As religiões do mundo oriental trabalham muito mais a questão da sensibilidade e outras facetas que talvez as religiões do mundo ocidental têm, circunstancialmente, relativizado. Há seguramente muito a aprender. Volto então a insistir na idéia de polimorfismo genético, agora como polimorfismo cultural, como diversidade cultural a colaborar para o processo civilizatório. 


\title{
Uma análise da extradição no Direito brasileiro
}

\author{
Fabiane Segabinazi ${ }^{\star}$
}

\section{INTRODUÇÃO}

O direito internacional visa a paz e a harmonia social na coletividade mundial e para bem desempenhar seu desiderato, utiliza-se de regras de convivência e de cooperação entre as diversas nações.

Quando um indivíduo nacional de um país comete um crime e evade-se para os domínios de outro a fim de esquivarse de responsabilidade judicial surge a necessidade de cooperação entre esses países envolvidos para recompor o equilíbrio social então quebrado, reconduzindo o indivíduo para que arque com sua responsabilidade judicial e social, onde e para quem de direito.
A esse pedido e consentimento de entrega do indivíduo chamamos extradição.

A palavra extradição tem origem no latim ex-traditione (ex: fora; traditione: entrega; entrega fora das fronteiras), significando traditio extra territorium. No passado, as palavras delito, remissio e intercum eram utilizadas para designar a entrega de criminosos.

Extradição é o instituto pelo qual "o governo de uma nação pede ao de outra que lhe entregue certo indivíduo que se homiziou no seu território por haver praticado um crime no país de onde saiu, a fim de que, perante a sua justiça, seja julgado ou cumpra a pena que lhe foi imposta".'

\footnotetext{
* Professora de Direito Civil e Processual Civil na Universidade da Região da CampanhaURCAMP, Alegrete e São Gabriel. Especialista em Direito Internacional Público, Privado e Direito da Integração pela Universidade Federal do Rio Grande do Sul - UFRGS. Especialista em Educação pela Universidade da Região da Campanha - URCAMP.

1 NUNES, Pedro. Dicionário de Tecnologia Jurídica. 12. ed. Rio de Janeiro: Freitas Bastos, $1994,954 \mathrm{p}$.
} 
Nos dizeres do insigne jurista Hildebrando Accioly ressaltando a subjetividade do instituto: "é o ato mediante o qual um Estado entrega a outro individuo acusado de haver cometido crime de certa gravidade ou que já se ache condenado por aquele, pós haver se certificado de que os direitos humanos do extraditando serão garantidos". 2

Está fundada no interesse recíproco das nações visando a punibilidade dos delitos, com base no princípio moderno do auxílio mútuo que deve existir entre os Estados. ${ }^{3}$

A Convenção sobre a Condição dos Estrangeiros assinada pelos Estados Americanos por ocasião da $6^{\mathrm{a}}$ Conferência Interamericana em Havana-1928, determina em seu artigo $1^{\circ}$ que "os Estados têm o direito de estabelecer, por meio de leis, as condições de entrada e residência dos estrangeiros nos seus territórios".

$\mathrm{Na}$ República Federativa do Brasil, inserto no artigo 22, XV da Constituição Federal $^{4}$ temos que a União mantém sua competência para legislar sobre a entrada e expulsão de estrangeiros e, portanto, para conceder e manter a permanência destes em solo pátrio. Outrossim, prevê a Carta Maior em seu artigo $5^{\circ}, \mathrm{XV}$ que "é livre a locomoção no território nacional em tempo de paz, podendo qualquer pessoa, nos termos da lei| [grifo nosso], nele entrar, permanecer ou dele sair com seus bens". A lei que regulamenta a citada livre locomoção é o Estatuto do Estrangeiro. $^{5}$

Destarte aqueles estrangeiros que por qualquer motivo não se adequarem às referidas condições estipuladas, seja de entrada seja de permanência no país estarão sujeitos a sua retirada compulsória através da expulsão por cometimento de atos prejudiciais ao Estado, extradição por cometimento de crime em outro Estado e por este ser requerida sua entrega, ou deportação pela entrada ou permanência ilegal no país, dependendo então da espécie de prescrição legal desacatada.

Em resumo diferem-se os três institutos por ser a extradição a saída compulsória, de estrangeiro ou nacional naturalizado em razão de pedido de outro Estado por estar o sujeito sendo

2 ACCIOLY, Hildebrando; NASCIMENTO E SILVA, G.E. Manual de direito internacional público. 14. ed. São Paulo: Saraiva, 2000, 364 p.

3 "Extradición es el acto en cuya virtud un estado hace entrega, a requerimiento de outro, de un individuo inculpado, para su julgamiento o condena." QUINTA, Lúcio M. Moreno; SHAW, Carlos M. B. Derecho Internacional Público. Aires: Libreria del Colégio, 1950; p. 157. 4 Caberá exclusivamente ao presidente da República resolver sobre a conveniência e oportunidade da expulsão ou de sua revogação. A medida expulsória ou a sua revogação far-se-á por decreto.

5 Lein 6.815/80, art. 57. 
acusado ou já condenado pela prática de crime no país requerente. A exclusão ocorre por iniciativa de outro Estado. Já a expulsão e a deportação consistem na retirada compulsória de estrangeiro do território nacional por iniciativa local, sendo a expulsão ato discricionário do governo brasileiro diante do cometimento pelo indivíduo alienígena de atos entendidos como nocivos à segurança e à tranqüilidade da nação. A medida de deportação, por sua vez, tem como escopo a proteção do Estado com a exclusão compulsória do estrangeiro que no país adentrou ou permaneceu à revelia das exigências para tal conduta.

Com a evolução natural do mundo reunido cada vez mais em blocos se faz necessário o uso de uma forma eficaz para o combate de crimes que acompanham essa evolução global. Neste contexto, a extradição tem se mostrado eficiente instrumento de cooperação internacional no combate à impunibilidade de criminosos que buscam furtar-se das malhas da lei simplesmente ultrapassando fronteiras geográficas. Por essa razão justificase o interesse no estudo desse instituto, que é próprio do direito internacional, mas que está inserido no direito interno, de todos os países.
Essa análise será feita em duas partes. A primeira trata dos fundamentos da extradição no direito brasileiro, apresentando um estudo dos seus fundamentos internacionais e nacionais, a segunda trata da concessão da extradição no direito brasileiro explanando os requisitos formais, bem como os requisitos materiais, todos constantes da lei $n^{\circ} 6.815 / 80$.

\section{OS FUNDAMENTOS DA EXTRADIÇÃO NO DIREITO BRASILEIRO}

O instituto da extradição é um dos mecanismos jurídicos destinados a promover a paz social, portanto seu fundamento geral está na cooperação solidariedade que deve reinar entre todos os membros da comunidade internacional, os quais têm necessidade de reprimir os atos delituosos, visando com esse intercâmbio de relações promover o equilíbrio social nos Estados. ${ }^{6}$

As primeiras idéias sobre a extradição no direito brasileiro datam do século XIX - década de 1820 - quando o Brasil celebrou vários tratados em matéria extradicional, como com a Alemanha, França, Inglaterra, Portugal e Rússia, que permitiam a extradição por crimes como rebelião do vassalo

\footnotetext{
6 Essa intenção é manifesta em todos os preâmbulos de tratados de extradição firmados pelo Brasil, dentre os quais citamos com os Estados Unidos da América: "Os Estados Unidos do Brasil e os Estados Unidos da América, desejando tornar mais eficaz a cooperação dos respectivos países na repressão ao crime, resolvem celebrar Tratado de Extradição e, para esse fim, nomearam os seguintes Plenipotenciários."
} 
contra o seu senhor, a deslealdade, a perfídia, a traição, a produção de dinheiro falso além de outros delitos que contrariavam as normas de ordem sóciocultural da época. O primeiro pedido de extradição dirigido ao Brasil data de quatro de março de 1845 , de procedência da França, com desfecho ignorado. O ato era puramente administrativo, o poder judiciário não intervinha, o governo prendia e entregava o extraditando.

Foi a circular de quatro de fevereiro do ano de 1847 que estabeleceu os princípios e as considerações gerais de entrega de criminosos refugiados no Brasil, prevendo as condições que seguem:

a) Quando os crimes pelos quais se reclamar a extradição tiverem sido cometidos no território do governo reclamante, e este oferecer ou se prestar à reciprocidade; b) Quando pela gravidade e habitual frequiência forem capazes de pôr em risco a moral e a segurança dos povos, tais como os de roubo, assassínio, moeda falsa, falsificações e alguns outros; c) Quando estiverem provados de maneira que as leis do Brasil justifiquem a prisão e acusação, como se o crime tivesse sido nele cometido; d) Quando o suspeito ou criminoso for reclamado pelo ministro da nação em que tiver lugar o delito e, e) Se o mesmo indivíduo for criminoso em mais de um Estado e for reclamada sua entrega em cujo território tiver sido cometido o mais grave delito.

A circular de 1847 foi revogada pelo Barão de Cairu e exarada nova circular em dez de agosto de 1848. A importância da circular de 1847 está no fato de ter sido baseado nela que o Brasil celebrou muitos tratados e declarações de reciprocidade.

Já no início do Século XX em 1906 o poder judiciário passou a se posicionar de forma ativa nos processos de extradição, contestando a competência do Poder Executivo na concessão dos pedidos extradicionais, não só baseados em tratados internacionais, mas apenas em acordos de reciprocidade de tratamento, e assim abandonou a postura de neutralidade para avocar-se a competência para a concessão dos pedidos.

A primeira lei de extradição do País foi a de $n^{\circ} 2.416$ de 28 de junho de 1911 . Posteriormente surgiu o decreto-lei $\mathrm{n}^{\circ}$ 394, de 28.4.1938, que vigorou até 1969 e assim sucederam-se os decretos e leis até a vigência do Estatuto do Estrangeiro - lei $n^{\circ} 6.815 / 1980$ que define a situação jurídica do estrangeiro no Brasil e criou o Conselho Nacional de Imigração, alterada pela lei n ${ }^{\circ} 6.964$ / 1981 , e regulamentada pelo decreto $\mathrm{n}^{\circ} 86.715 / 1981$.

\section{Fundamento internacional}

A Declaração Universal dos Direitos do Homem, no seu artigo XI manifesta que "todo homem acusado de um ato delituoso tem o direito de ser presumido inocente até que a sua culpabilidade tenha sido provada de acordo com a lei, em julgamento público no qual the tenham sido 
asseguradas todas as garantias necessárias à sua defesa".

No caso específico da extradição, a lei $n^{\circ} 6.815 / 1980$, art. 76 , prevê que seja fundada em tratado ou reciprocidade, que será tratada a seguir. ${ }^{7}$ Nos dizeres da renomada Gilda Russomano os tratados de extradição são: Acordos celebrados entre Estados, através dos quais eles estabelecem regras para a entrega recíproca dos delinqüentes que tenham praticado o delito no território de um deles e se refugiado dentro das fronteiras do outro. ${ }^{8}$

Geralmente a concessão da extradição de um indivíduo é praticada de conformidade com um tratado que pode ser bilateral ou multilateral, assinado pelos Estados envolvidos, no qual se estabeleça que na conformidade de certos pressupostos, dar-se-á a entrega do indivíduo requisitado. Apresentam seu fundamento nos princípios do pacta sunt servanda, que é um dos princípios constitucionais da sociedade internacional, e do pacta tertiis nec nocent prosunt, já que têm efeitos contra terceiros.
Silbert apresenta algumas características primordiais para estes tratados, a saber:

a) "Precisam as condições e as formalidades da extradição, evitando dúvidas e incertezas"; b) "Protegem os Estados fracos das pressões, muitas vezes injustificadas, dos Estados fortes"; c) "Constituem medida preventiva do delito pela advertência que fazem aos criminosos eventuais, lembramo-nos de que, dificilmente se poderão refugiar na impunidade ou escapar às conseqüências de seus atos". 9

Terão efeito vinculatório para os contratantes e o tratado mais recente revogará o mais antigo firmado pelas partes, além disso, seu teor consiste, via de regra, em estipular os pressupostos legais para a extradição, como o delito ser tipificado em ambas as legislações internas dos Estados contratantes, a enumeração dos crimes que justificam o pedido. Mas a maioria dos internacionalistas entende que deve ser subentendido que a enumeração dos delitos é puramente exemplificativa, não

\footnotetext{
7 Acto judicial transcendente, la extradición solo procede mediante tratado sobre la matéria entre estado requirente y estado requerido. La cortesia o la reciprocidad motivan a veces, la extradición (comitas gentium ad reciprocicam utilitatem) lo cual no la convierte en obligacion jurídica. (Quintana, Lucio Moreno e Carlos M.B. Shaw. Derecho Internacional Publico. Ediciones Libreria del Colégio. Buenos Aires; 1950, p. 157).

8 TAGLIANI, Camila Carneiro. A extradição no ordenamento juridico brasileiro. São Paulo: Memória Jurídica. 2002. p. 42-43.

9 Citado por Gilda Russomano in A Extradição no Direito Internacional e no Direito Brasileiro. 3. ed.; SP: Revista dos Tribunais, 1981.
} 
excluindo outros crimes, ${ }^{10}$ os requisitos de ordem formal que devem instruir o pedido, e.g. os documentos probatórios da existência de um processo criminal em andamento ou sentença condenatória," que o crime não tenha cunho político em ambos os Estados; que a pena imposta seja superior a um ano de prisão, bem como a estipulação das regras para a solução de quaisquer litígios decorrentes do tratado, e.g. o art. 19 do Tratado entre Brasil e Argentina: Todas as divergências entre as Altas Partes Contratantes, relativas à interpretação ou execução deste Tratado, se decidirão pelos meios pacíficos reconhecidos no Direito internacional.

No que concerne a eficácia, o STF já decidiu' ${ }^{12}$ que os tratados de extradição têm aplicação imediata, independentemente de o crime em que se funda a extradição ser anterior a ele, salvo disposição expressa em contrário.

A extradição na América Latina é abordada em vários tratados internacionais multilaterais, como a Convenção sobre Extradição - Montevidéu, 1932 - que modificou o Código de Bustamante - 1928 e o Tratado de Direito Penal Internacional (Montevidéu -
1940). Além destes existem a Convenção de Haia e de Tóquio para combate à pirataria séria e o Acordo de Extradição entre os Estados partes do Mercosul, a República da Bolívia e a República do Chile, firmado em 20 de novembro de 1998.

O Brasil é signatário de vários tratados bilaterais para extradição que têm sido efetivamente aplicados. A ausência de tratado de extradição entre o Estado de refúgio e o que solicita a entrega do delinqüente não será motivo suficiente para a denegação do pedido. Nessa situação utilizar-se-á o mecanismo da reciprocidade.

A reciprocidade é definida como a permissão do Estado em admitir a execução de sentenças estrangeiras, se o país de onde provêm admitir execução das decisões nacionais ou uma declaração segundo a qual, ocorrendo crime análogo no país requerido, o país requerente se compromete a conceder a extradição solicitada.

Segundo o mestre Francisco Rezek, as declarações de reciprocidade, em matéria de extradição, tendem a instituir entre Estados uma relação jurídica diversa da relação convencional. O vínculo da

10 e. g.: o artigo 13 do código penal uruguaio que permite a extradição por crimes não previstos expressamente no tratado existente: La extradición puede otorgar-se u ofrecerse aún por delitos no contemplados en los tratados, siempre que no existiera prohibición en ellos.

11 Tratado de extradição firmado pelo Brasil e pela Suíça: "O pedido de extradição será feito por via diplomática."

12 STF - Pleno Extradição nº 759 - Itália; Rel. Min. Moreira Alves, decisão 9/12/1999. 
reciprocidade não é um tratado bilateral sui-generis, como já se viu insinuar. ${ }^{13}$

A reciprocidade foi utilizada pela legislação brasileira desde os primórdios do instituto com a Circular de 4 de fevereiro de 1847 que teve grande importância para o desenvolvimento do mecanismo da extradição porque estabeleceu os princípios e as condições gerais para a entrega de extraditandos pelo Brasil, dentre elas a previsão de reciprocidade: Quando os crimes pelos quais se reclamar a extradição tiverem sido cometidos no território do governo reclamante, e este oferecer ou se prestar à reciprocidade. A partir dessa Circular o Brasil celebrou vários tratados bilaterais e declarações de reciprocidade, destacando-se os tratados de 1851 com o Uruguai, 1853 com o Peru, 1855 com o Equador, 1857 com Portugal e com a Argentina.

A reciprocidade opera stricto sensu, consistindo no pedido de um Estado a outro a entrega de um nacional seu ou não que esteja no mínimo sendo acusado do cometimento de um crime comum nos seus domínios, prometendo acolher, no futuro, pedidos que transitem em sentido inverso. Assim a reciprocidade não compreende condições especiais na sua feição, como a exposição de certas exceções a delitos ou outros requisitos normais à extradição, pois se assim fosse teríamos um tratado bilateral de extradição e não um compromisso de reciprocidade. Esse deve ser o mais puro e direto possível.

A relação que se estabelece entre dois Estados por força do sistema de reciprocidade difere da que caracteriza os tratados bilaterais. Estes devem possuir forma escrita, elementos de natureza contratual e têm duração indefinida, já o elo da reciprocidade dispensa textos escritos, sendo mesmo incorpóreos, têm origem em um fato concreto (a necessidade de um pedido de extradição) e materializam-se através de nota diplomática. ${ }^{14} \mathrm{O}$ compromisso tem efeito de criar obrigação entre as partes. É uma liberalidade estabelecer reciprocidade ou não com outro Estado, mas uma vez acordado gera obrigações. Dessa forma, o dever de garantir adequado exame jurídico à demanda da outra parte refoge ao terreno da pura cortesia internacional, bem assim ao domínio do direito interno. Descumprir esse dever é incidir em ilícito internacional. Neste caso buscase a aplicação do Direito das Gentes, que protege com eficiência o compromisso de reciprocidade.

Existem muitos pedidos de extradições autorizadas pelo Brasil com

13 Direito dos Tratados. São Paulo: Saraiva, p. 168.

14 Quando se cuida de estabelecer o vínculo de reciprocidade, uma nota diplomática contendo a promessa de igual tratamento acompanha o pedido concreto de extradição. 
fundamento em compromisso de reciprocidade. ${ }^{15}$

\section{Fundamento nacional}

No âmbito do Direito Pátrio a extradição tem fundamento na Constituição e em leis esparsas.

A extradição alicerçada no espírito de cooperação mútua entre os povos para repressão ao crime tem seus fundamentos legais de ordem internacional, tratado e declaração de reciprocidade, conforme já foi visto e os fundamentos nacionais, no ordenamento jurídico brasileiro, tema que abordaremos neste capítulo.

A nacionalidade é o vínculo jurídicopolítico que liga o indivíduo ao Estado. Desde as primeiras práticas da extradição na história brasileira sua fonte preponderante eram os tratados internacionais, mas atualmente temos sua cominação na Constituição Federal e leis esparsas.

Para o deferimento do pedido de extradição de estrangeiro ao Brasil o Estado requerente deve fundar seu pedido nas hipóteses constitucionais (requisitos materiais: art. $5^{\circ} \mathrm{LI} \mathrm{e} \mathrm{LII)} \mathrm{e}$ nas normas legais esparsas (requisitos formais: Estatuto do Estrangeiro, Lei Federal $n^{\circ} 6.964 / 81$ e Regimento Interno do Supremo Tribunal Federal).

A extradição se divide em duas espécies: ativa, aquela requerida pelo Brasil a outros Estados soberanos e a passiva, que é a que se requer ao Brasil por outro Estado.

Os requisitos e restrições constitucionais e esparsas na legislação ordinária incidem somente nos pedidos de extradição passiva, ou seja, quando o Brasil é o país requerido - incitado a entregar criminosos.

15 Pedido de Extradição n 272-4 - República Federal da Áustria, República Popular da Polônia e República da Alemanha. Rel.: Min. Vítor Nunes Leal. Extradição. O deferimento ou recusa da extradição é direito inerente à soberania. A efetivação, pelo governo, da entrega do extraditando, autorizada pelo STF, depende de direito internacional convencional. Reciprocidade. É fonte reconhecida do direito extradicional. Extr. 232 (1961), Extr. 288 (1962), Extr. 251 (1963). A Constituição de 1967 art. 83, VIII, não exige referendum do Congresso para aceitação da oferta do Estado requerente. A lei brasileira autoriza o governo a oferecer reciprocidade.

Pedido de extradição ${ }^{\circ} 347$ - Itália. Relator: Min. Djaci Falcão. Pedido de extradição sob promessa de reciprocidade de tratamento. Mandato di cattura, medida cautelare coercitiva, que equivale à prisão preventiva prevista na legislação brasileira. Imputação dos crimes de corrupção ativa e truta qualificada. Tipicidade penal incontroversa

Pedido de extradição n 378 - República da Áustria. Relator: Min. Xavier de Albuquerque. Extradição. Crimes patrimoniais imputados a um casal. Narrativa que só deixa caracterizada, de modo aceitável, a conduta delituosa do varão (esteleionato sob a forma de venda de coisa alheia como própria). Prazo de diligência observado. Pedido parcialmente deferido. Relatório: Garantindo reciprocidade de tratamento, o Governo da República da Áustria pede a execução. 
O artigo $5^{\circ}$, LI e LII da Carta Magna disciplina a extração. Está, portanto inserta dentre as garantias fundamentais da pessoa.

É possível se depreender dos incisos retro mencionados que a Constituição Federal prevê tratamento diferenciado aos brasileiros natos, naturalizados e aos estrangeiros a respeito da extradição. Vejamos:

- O brasileiro nato nunca será extraditado;

- O brasileiro naturalizado somente será extraditado em dois casos: por crime comum, praticado antes da naturalização ou quando da participação comprovada em tráfico ilícito de entorpecentes e drogas afins, na forma da lei, independentemente do momento do fato, não importa se foi antes ou depois da naturalização.

É absoluta a inextradibilidade de cidadão brasileiro nato assim como a maioria das legislações internacionais contemporâneas. Todavia grande parte da literatura jurídica internacional atual é favorável à extradição de nacionais. Poucos Estados, no entanto, a concedem, e quando o fazem é submetida à condição de reciprocidade como os Estados Unidos da América, a Grã-Bretanha e a Itália. ${ }^{16}$

A respeito da discussão sobre a inextradibilidade de nacionais é válido ressaltar a ponderação do eminente Hildebrando Accioly: "Os Estados devem proteção a seus nacionais e, por conseguinte, têm a obrigação de lhes garantir uma justiça imparcial; ora, essa imparcialidade pode faltar aos juízes estrangeiros. Os Estados não devem abdicar parcela alguma e sua soberania," e a entrega de um nacional a uma justiça estrangeira constitui uma espécie de renúncia a direitos inerentes à soberania. Todo indivíduo tem o direito de viver no território sob a proteção do Estado de que é nacional, e, portanto, seria injusto afastá-lo contra a vontade. Esses argumentos podem ser facilmente rebatidos. Primeiro de tudo, a proteção devida pelo Estado aos seus nacionais não pode ser entendida de maneira que impeça o comparecimento destes perante juízes estrangeiros". ${ }^{17}$

Defensores da extradição de nacionais argumentam ainda que o princípio da territorialidade da lei penal, pelo qual o julgamento do criminoso compete ao país que teve sua norma penal infringida. Esta argumentação é fundada na questão prática da dificuldade da produção de provas em Estado diverso daquele onde houve o cometimento do fato delituoso. Filiamse a esta corrente, países como o Uruguai, a Colômbia, a Grã-Betranha e os Estados Unidos.

160 princípio da não extradição de nacionais não é recente, remonta ao séc. XII, e resulta do dever de proteção do Estado aos seus cidadãos.

17 Extraído da revista Informação Legislativa a.19, n. 76/out/dez., 1982, p. 73. 
O Brasil não extradita brasileiros natos sendo relativa essa regra quanto aos naturalizados.

A naturalização, que para muitos é um ato de soberania do Estado e, portanto, de natureza política e de total discricionariedade, é o meio tradicional de aquisição derivada da nacionalidade brasileira. A Constituição Federal prevê dois parâmetros para a concessão do pedido quanto aos naturalizados: a) a época da naturalização e, b) a natureza do crime cometido.

a) Será extraditado brasileiro naturalizado, em caso de crime comum, praticado antes da naturalização.

Todas as Constituições brasileiras até 1946 faziam distinção entre brasileiros natos e naturalizados. A de 1988 trouxe clara distinção para os efeitos da extradição. A aquisição da nacionalidade brasileira após o cometimento de crime comum tem por efeito a nulidade do ato de naturalização, em razão da presunção de que a naturalização só foi pedida com o desiderato de impedir a aplicação da pena prevista para o crime. Neste sentido a doutrina de Pontes de Miranda ao esclarecer que: pedida a extradição do estrangeiro, isto é, do naturalizado brasileiro, por fato anterior à naturalização, a extradição pode ser concedida, se a naturalização não podia ser deferida (nulidade com efeito ex tunc), porquanto que o tivesse sido. ${ }^{18}$

b) Será extraditado brasileiro naturalizado, comprovado seu envolvimento em tráfico ilícito de entorpecentes e drogas afins, independentemente do momento da prática desse crime ter sido antes ou depois da naturalização. ${ }^{19}$

Assim, se para quaisquer outros crimes exige a Constituição o fator anterioridade da naturalização, para a proteção do Estado brasileiro, no caso do tráfico de entorpecentes e drogas afins, devido a sua gravidade e mobilização da comunidade internacional para seu refreamento, não vale o elemento tempo de naturalização para refugiar-se no solo pátrio o meliante. Neste sentido esta redação constitucional objetiva combater com maior rigor o crime de tráfico, que tem se alastrado por todo o mundo de forma veloz e eficaz. Porém, este dispositivo não é suficientemente aplicável, eis que, na forma da lei pressupõe que a legislação ordinária deverá regulamentar a forma de aplicação da norma constitucional. Isto significa que o artigo $5^{\circ}, \mathrm{LI} d a$ CF/88 não é auto-aplicável. Além disso, não existe legislação ordinária regulamentando esta situação. ${ }^{20}$

18 Comentários a Constituição de 1967, t.5, p. 258.

19 MORAIS, Alexandre de. In Direito Constitucional; 12. ed. São Paulo: 2002, p. 114.

20 Op. cit. p. 14. CARNEIRO, Camila T. in A Extradição no Ordenamento Jurídico Brasileiro. São Paulo: Memória Jurídica, 2002, p. 57. 
A aplicação desse inciso encontra dificuldades na prática. O ordenamento brasileiro adota o sistema da contencionalidade limitada no qual não cabe ao Estado requerido analisar o mérito do processo que ensejou o pedido de extradição, cabendo apenas analisar o aspecto formal. Ora, a Constituição Federal fala em "comprovado envolvimento" no ilícito de tráfico de entorpecentes e "na forma da lei", são exigências de caráter excepcional, e não formais.

Destarte, não havendo permissão para análise do mérito e inexistindo lei regulamentadora para o inciso torna-se difícil sua aplicação. Para solucionar esta problemática o Supremo admite a extradição nos casos em tela, se o pedido vier instruído com provas de envolvimento do extraditando em crime de tráfico de drogas, com sentença condenatória transitada em julgado.

O entendimento do Supremo Tribunal Federal sobre a extradição por crime político é o seguinte: é de repelirse, no caso concreto, a existência de crime político, dado que não é demonstrada a destinação de atentar, efetiva ou potencialmente, contra a soberania nacional e a estrutura política. ${ }^{21} \mathrm{De}$ acordo com este raciocínio lógico, o português que goza de todos os direitos do brasileiro naturalizado, conforme 0 parágrafo $1^{\circ}$ do artigo 12 da $\mathrm{CF} / 88$, poderá ser extraditado como brasileiro naturalizado. Todavia é resguardado por certas prerrogativas decorrentes de tratado bilateral firmado entre a pátria brasileira ePortugal-Decreto Legislativo $n^{\circ} 70.391 /$ 72 o qual restringe a possibilidade de cidadão português equiparado ser extraditado somente para Portugal.

Várias foram as normas infraconstitucionais que regulamentaram a extradição até as vigentes de hoje.

Em 1808, com a vinda da família real portuguesa para o Brasil e a abertura dos portos brasileiros ao comércio houve um aumento substancial no fluxo de estrangeiros entrando no país; assim, surgiu a necessidade de uma norma a tratar da extradição: a Circular de 4 de fevereiro de 1847 , expedida pelo Ministério dos Negócios Estrangeiros, chefiado pelo Barão de Cairu, sendo o primeiro documento brasileiro sobre o instituto e continha regras gerais para a entrega de estrangeiro por crime cometido no exterior.

Em 1848, 10 de agosto, o mesmo Barão de Cairu exarou nova circular sobre a extradição, revogando a de 1847. Todavia, como o documento de 1848 não atendeu as necessidades existentes, a circular de 1847 foi repristinada, tendo vigência até $1911 \mathrm{com}$ a publicação da lei $n^{\circ} 2.416(28 / 06)$, caracterizada pela permissão da extradição de nacionais brasileiros (artigo $1^{\circ}$ ).

Já a lei $\mathrm{n}^{\circ} 2.416$ foi revogada pelo decreto-lei $n^{\circ} 394$ de 28 de abril de 1938 que veio a proibir a extradição

21 STF $2^{\text {a }}$ t.-HC no 73.452/RJ - Rel. Min. Maurício Correa, Diário da Justiça - Seção I, 27 / junho 1997, p. 30.226 . 
de brasileiros natos, sob o princípio da proteção que o Estado deve conceder aos seus nacionais. Este decreto-lei foi revogado pelo de $n^{\circ} 941$ - Estatuto do Estrangeiro, datado de 13 de outubro de 1969, revogando integralmente a legislação editada de 1938 , no que concerne à extradição. A lei $n^{\circ} 6.815$, de 19 de agosto de 1980, revogou o Estatuto de 1969, passando a disciplinar a matéria de extradição no Brasil.

O Brasil é signatário de vários tratados internacionais para extradição - como o Código de Bustamante, concluído na $6^{\mathrm{a}}$ Conferência PanAmericana de Direito Privado, no ano de 1928 - contendo 38 artigos sobre o instituto; a Convenção Interamericana sobre Extradição, firmada em Caracas no ano de 1981. No âmbito do Mercosul, não há ainda regulamentação específica sobre a extradição; em vigência apenas o Protocolo de Assistência Jurídica Mútua em Assuntos Penais do Mercosul.

Assim, além dos protocolos internacionais, são normas infraconstitucionais em vigência no país em matéria de extradição e Estatuto do Estrangeiro - lei $\mathrm{n}^{\circ} 6.815 / 80$, artigo 91 e seguintes; a lei federal $n^{\circ} 6.964 / 81$ e o Regimento interno do Supremo Tribunal Federal, artigos 207 a 214.

\section{A CONCESSÃO DA EXTRADIÇÃO NO DIREITO BRASILEIRO}

A extradição - instrumento de garantia da ordem social na comunidade internacional - ainda apresenta discussão a respeito de sua natureza jurídica. Entendem alguns juristas que se trata de um ato administrativo discricionário do governo, sem garantia jurisdicional para o extraditando, e outros, que é ato de natureza jurisdicional entre o Estado requerente e o extraditando, procedimento que finaliza com sentença vinculadora para o Estado requerido.

No Brasil, assim como na Itália, adota-se o sistema misto, no sentido de que o processo extradicional é um ato de governo, mas subordinado a uma garantia jurisdicional em favor do extraditando.

A Constituição Federal brasileira prevê em seu artigo 102, I "g", que a competência originária para processar e julgar pedido de extradição é resguardada à cúpula maior do poder judiciário brasileiro, o Supremo Tribunal Federal:

Artigo 102 - Compete ao SFT, precipuamente, a guarda da Constituição, cabendo-lhe:

I - processar e julgar, originariamente:

" $g$ " - a extradição solicitada por Estado estrangeiro.

Em que pese ser a extraditio no Brasil um procedimento bifásico, que tem seu início em mãos do poder executivo e processo e julgamento nos domínios do poder judiciário, é cabível um estudo mais aprofundado acerca de sua competência e procedimento. É o que examinaremos a seguir. 


\section{A) Condições formais}

1. Da competência do Supremo Tribunal Federal

Sendo que a Constituição Federal confere a competência para análise da legalidade e procedência do pedido extradicional à mais alta corte do poder judiciário, é nele - Supremo Tribunal Federal - que se exercem todos os trâmites legais em relação à extradição. ${ }^{22}$

Assim dispõe o artigo 83 da lei vigente que:

Art. 83 - Nenhuma extradição será concedida sem prévio pronunciamento do plenário do Supremo Tribunal Federal sobre sua legalidade e procedência, não cabendo recurso da decisão.

Além deste, determinam a competência originária do STF os artigos 102, I, "g" da Constituição Federal (já citado) e o artigo 207 do Regimento Interno do STF:

Art. 207 - Não se concederá extradição sem o prévio pronun- ciamento do STF sobre a legalidade e a procedência do pedido, observada a legislação vigente.

Uma leitura sumária dos dispositivos legais supracitados pode conduzir a interpretação equivocada de que a Corte Suprema brasileira possui poderes absolutos para analisar todos os aspectos do pedido de extradição. Todavia tais poderes são, em verdade limitados à análise das circunstâncias legais e formais do pedido, vedada a análise do mérito do fato ensejador. É o que denominamos contencionalidade limitada.

É o sistema de competência judiciária, desde que quem concede a extradição não é o poder judiciário, mas sim executivo, e ao judiciário compete apenas dizer da legalidade do pedido.

Nos dizeres de José Francisco Rezek explicando o artigo 85, parágrafo $1^{\circ}$ do Estatuto do Estrangeiro, a defesa do extraditando não pode adentrar o mérito da acusação: ela será impertinente em tudo quanto não diga respeito à sua identidade, à instrução do pedido ou à ilegalidade da extradição à luz da

22 A prática internacional sobre essa matéria não é uniforme. O sistema francês tem caráter essencialmente político e deixa a extradição ao arbítrio do poder executivo, sem nenhuma garantia jurisdicional em favor do extraditando. A intervenção, requerida pelo Conselho de Estado e pela autoridade judicial tem caráter meramente consultivo. Por outro lado, os sistemas inglês e norte-americano revestem-se de caráter de procedimento jurisdicional, no qual o Estado requerente e a pessoa extraditanda são partes, e a sentença pertinente não poderá ser executada enquanto não passar em julgado. $O$ sistema belga-holandês, de caráter jurisdicional, faculta ampla liberdade aos interessados. 
lei específica. ${ }^{23}$ Neste sentido é vasta a jurisprudência do $\mathrm{STF}^{24}$

Destarte será o Supremo proibido de apreciar o mérito no processo de extradição passiva brasileira.

O procedimento do pedido de extradição com base em processo penal em curso ou sentença condenatória é feito pelo governo do Estado requerente através da via diplomática e endereçado ao presidente da república - chefe do poder executivo - que é a autoridade com autorização constitucional para manter relações com Estados estrangeiros (art. 84, VII CF). Essa negociação tem, portanto, caráter intergovernamental. ${ }^{25}$

A lei brasileira dispõe que ninguém será extraditado sem que o processo seja analisado pelo poder judiciário, porém, o Supremo Tribunal Federal não concede a extradição, mas sim, autoriza o executivo a fazê-lo. ${ }^{26}$ Salienta-se que no caso de denegação do pedido, o Estado requerente não poderá repeti-lo fundado no mesmo fato, conforme prevê o art. $88 \mathrm{da}$ Lei $\mathrm{n}^{\circ} 6.815 /$ 80 . Uma vez decidido pela procedência da entrega do extraditando, será o fato comunicado por via do Ministério das Relações Exteriores ao Estado requerente que então disporá de um prazo peremptório de sessenta dias (salvo disposição distinta em tratado), para resgatá-lo do território brasileiro, sob pena de livrar-se solto o extraditando.

Os requisitos formais e materiais apreciados pelo Supremo para a

23 Op.cit. p.7, in Direito Internacional Público - Curso Elementar. São Paulo: Saraiva, 1998, n. 118, p. 202.

24 Extradição n ${ }^{\circ} 659-2$. Rel. Min. Marco Aurélio. Extradição - Matéria de defesa - Inexistência de configuração do crime imputado. Na apreciação do pedido de extradição descabe o exercício de crivo relativamente à procedência, ou não, da imputação formalizada no Estado requerente. Cumpre tão só verificar a observância dos requisitos previstos no artigo 88 da Lei $\mathrm{n}^{\circ} 6.815 / 80 \mathrm{e}$ a inexistência de qualquer dos óbices revelados no artigo 77 do citado diploma. (DJ de 15.03.1996).

25 Extradição. Pressuposto. Competência. 1. É pressuposto essencial da extradição que seja ela requerida por Governo de país estrangeiro. Pedido não conhecido, visto que formulado por autoridade judiciária estrangeira. O pedido é encaminhado para o STF que providenciará a prisão preventiva, conforme exigência do art. 81 do Estatuto do Estrangeiro, do extraditando decretada pelo Ministro Relator, que ficará prevento para a condução do processo extradicional. Preso o extraditando, tem início o processo que possui caráter especial, sem dilação probatória, pois incumbe ao Estado requerente o dever de instruir o processo, apresentando prova pré-constituída de natureza documental essencial em face aos requisitos constitucionais. Os documentos instrutórios do pedido constam no art. 80 da Lei $n^{\circ} 6.815 / 80$ e específica no art. $85, \S 2^{\circ}$ que não estando 0 processo devidamente instruído, o tribunal poderá converter o feito em diligências para suprir as provas.

26 Op.cit. p. 14, CARNEIRO, Camila T. in A Extradição no Orndenamento Jurídico Brasileiro. São Paulo: Memória Jurídica, 2002, p. 81. 
concessão do pedido são os constantes na Lei $n^{\circ} 6.815 / 80$, art. 77 , por critério de exclusão, já que mencionam as circunstâncias em que não se deferirá a extradição, a saber:

I - se tratar de brasileiro, salvo se a aquisição dessa nacionalidade verificar-se após o fato que motivar o pedido;

II - o fato que motivar o pedido não for considerado crime no Brasil ou no Estado requerente;

III - o Brasil for competente, segundo suas leis, para julgar o crime imputado ao extraditando;

IV - a lei brasileira impuser ao crime a pena de prisão igual ou inferior a um ano;

$V$ - o extraditando estiver a responder a processo ou já houver sido condenado ou absolvido no Brasil pelo mesmo fato em que se fundar o pedido;

$V I$ - estiver extinta a punibilidade pela prescrição segundo a lei brasileira ou a do Estado requerente;

VII - o fato constituir crime político;

$e$,
VIII - o extraditando houver de responder, no Estado requerente, perante tribunal ou juizo de exceção.

Devido à importância desses requisitos legais para a concessão da extradição analisaremos a seguir sua interpretação e aplicação pelo Supremo Tribunal Federal.

\section{B) Condições materiais}

Passaremos a examinar cada uma das regras materiais estabelecidas na legislação infraconstitucional para a concessão do envio.

\section{Da competência brasileira para o julgamento do crime}

Inculta no art. 77, III do Estatuto do Estrangeiro está a vedação da concessão da extradição nos casos em que o Brasil for competente, segundo suas leis, para julgar o crime imputado ao extraditando.

Conforme a interpretação do dispositivo o Brasil concederá a extradição quando configurar competência penal exclusiva da justiça do Estado requerente para processar e julgar o fato, do qual decorre incompetência do Brasil. Assim se a legislação pátria prevê que o Brasil tem competência privativa para julgar o crime que deu origem ao pedido extradicional, este será denegado, e se a competência para julgamento for concorrente entre o Brasil e o país requerente e o 
extraditando já estiver sendo processado no Brasil, não será concedida a extradição. ${ }^{27}$

Se o contrário ocorrer, o conjunto de provas que instruiu o pedido de extradição servirá para instruir o processo que aqui deva ter curso no foro criminal, conforme assevera Rezek que informa também que o Supremo vem abrandando o rigor da regra, $\mathrm{e}$ preferindo conceder a extradição hotadamente a de tráfico de drogas quando não se tenha ainda instaurado no Brasil algum processo pelos mesmos fatos, ainda que lhes pareça aplicável, em princípio, nossa lei penal. ${ }^{28}$

No que concerne à competência concorrente a interpretação do Supremo é de que mesmo existindo competência relativa do Brasil para o processo e julgamento do fato se aqui não houver um inquérito policial ou processo penal em andamento será deferida a extradição.

\section{Da vedação do Juízo de} Exceção

É regra no direito das gentes não se utilizar tribunal ou juízo de exceção para processar e julgar criminosos. Todavia já se vislumbrou esta prática no século XX após a Segunda Guerra Mundial, no final da década de 1940, com os tribunais na cidade alemã de Nuremberg, para processar e julgar os crimes de guerra e contra a humanidade cometidos pelo $3^{\circ}$ Reich, durante a Grande Guerra. A maioria dos condenados na época que em defesa argumentaram a nulidade dos julgamentos devido à sua natureza excepcional, já que foi instituído pós factum, lograram êxito.

O Direito das Gentes um de cujos princípios é o respeito aos direitos humanos não admite juízo de exceção e o Estatuto do Estrangeiro em seu art. 77, VIII, traz expressa a vedação da

27 Op.cit. p. 14, CARNEIRO, Camila T. in A Extradição no Orndenamento Jurídico Brasileiro. São Paulo: Memória Jurídica, 2002, p. 73.

28 Op.cit. REZEK, José Francisco. in Direito Internacional Público. São Paulo: Saraiva, 1998,410 p. Extradição n ${ }^{\circ}$ 695-9. Rel. Min. Celso de Mello. Extradição - Tráfico de drogas - Exportação de cocaína do Brasil para a Itália - Concurso de jurisdições penais - Ausência de inquérito policial, ou de processo penal no Brasil, possibilidade de efetivação da entrega extradicional - Discussão de matéria probatória e alegação de inocência do extraditando - Inadmissibilidade - Sistema de Contecionalidade Limitada - Pedido deferido. (DJ 02.02.1997). Extradição. Mandado de prisão. Integralidade. Competência concorrente da Justiça do Estado requerente. Documentação. Estatuto do Estrangeiro: Lei ${ }^{\circ} 6.815 / 80$, modificada pela Lei $n^{\circ} 6.964 / 81$. Extraditando casado com brasileira e com filhos brasileiros. Súmula 421 . Não procede, no caso, a objeção à competência exclusiva da Justiça brasileira para o processo criminal, não só pelo princípio da universalidade, por se tratar de associação para tráfico internacional de entorpecentes, com atuação, no caso, no Brasil e na Alemanha, mas, também, por se imputar ao extraditando a incusão em território alemão para o mesmo fim. Hipótese, ademais, em que não há processo criminal nem mesmo inquérito policial, instaurado no Brasil, sobre os mesmos fatos. Precedentes do STF. 
extradição requerida ao Brasil quando o extraditando houver de responder, no Estado requerente, perante tribunal ou juízo de exceção. Essa vedação para a análise da Suprema Corte é absoluta. $A$ apreciação| nesta hipótese não é sobre um crime, nele analisado caráter político ou comum. Trata-se de submeter a juízo a autoridade judiciária que um Estado soberano investiu no poder decisório, havendo-a, conforme o caso, por irregular ou por excepcional..$^{29}$

O posicionamento do Supremo é pela não extradição nestes casos. Todavia, contrariando a regra, foi concedida a extraditio na histórica decisão de $n^{\circ} 347$ de 1977 . Pedido de extradição da Itália, apontada e reconhecida pelo Procurador da República brasileiro, como tribunal de exceção. O Procurador da República na época era o eminente Francisco Rezek que assim se manifestou sobre o caso: $O$ princípio de efeito útil, elementar em hermenêutica jurídica, prescreve, desde logo, a idéia simplista de que juizo de exceção seja aquele precipuamente destinado ao processo e julgamento de crimes politicos. Quando assim fosse, ter-seia o legislador contentado com a relação do inciso VII, capaz de cobrir o seu duplo propósito. Se o rol condicionante se estende até um inciso VIII, versando de modo autônomo a excepcionalidade do juizo, é porque esta se presume possivel também em presença de delitos comuns. Aquele mesmo principio hermenêutico, agora associado ao da compreensão sistemática da lei, manda que se condene, na matéria em exame, uma restrição excessiva do conceito de tribunal excepcional. ${ }^{30}$

A posição atual adotada pelo Supremo é pela denegação do pedido extradicional havendo a posterior submissão do alienígena a juízo de exceção. ${ }^{31}$

29 Op.cit. p. 7. REZEK, José Francisco. in Direito Internacional Público. São Paulo: Saraiva, 1998, p. 205.

30 Revista de Informação Legislativa, a.21, n. 83 jul/set., 1984, p. 100-101.

31 Extradição n ${ }^{\circ} 417$ - República Argentina. Relator: Min. Oscar Correia. Extradição - Lei de anistia do pais requerente inaplicável à hipótese, não atingindo o extraditando. Prevalência dos crimes comuns sobre o político, aplicando-se os $\S \S 1^{\circ} \mathrm{a} 3^{\circ}$ do art. $77 \mathrm{da} \mathrm{Lei} n^{\circ} 6.815 / 80$, de exclusiva apreciação da Corte: fatos que caracterizam, em princípio, terrorismo, sabotagem, seqüestro de pessoas, propaganda de guerra e processos violentos de subversão da ordem. Alegação improcedente de submissão a juízos de exceção. Exclusão dos delitos relativos a: liderança de movimento político, porte de armas e explosivos, e uso de documentos falsos; bem como ressalvado que não poderão ser impostas ao extraditando penas superiores a trinta anos de prisão, o máximo, em relação a cada crime. Extradição deferida com as ressalvas enunciadas. 


\section{Do caráter penal do delito}

A terceira condição para a concessão da extradição pelo Brasil concerne à natureza do delito, que deve ser penal comum, não se admitindo os crimes de cunho político, de opinião, ${ }^{32}$ de imprensa, religiosos ou militares. $\mathrm{O}$ delito político é conforme Luiz Alberto Araújo e Regis Prado, todo ato lesivo à ordem político-jurídica interna ou externa do Estado. Objetiva ele predominantemente destruir, modificar ou subverter a ordem política institucionalizada unidade orgânica do Estado.

A Lei $n^{\circ} 6.815 / 80$, no art. 77 , VII prevê que não se concederá a extradição quando o fato constituir crime político.

Luis Jimenez de Asua divide o delito político em três espécies: a) delitos puros são os que se dirigem contra a forma e a organização política de um Estado; b) delitos complexos são os que lesionam ao mesmo tempo a ordem política e o direito comum, como o homicídio de um chefe de Estado ou de governo; c) delitos conexos à delinqüência política, no sentido de meio a fim, ou conexos para o objetivo de insurreição política, realizados pelos mesmos motivos políticos. Por outro lado, alguns autores falam em delitos puramente políticos e delitos relativos, ou mistos. Estes últimos são crimes comuns dominados por motivação política. ${ }^{33}$
Antes do século XIX os criminosos políticos não encontravam refúgio, além fronteiras. A mudança dessa situação foi uma conquista dos juristas daquele século, acolhida posteriormente pelo Instituto de Direito Internacional, na sessão de Oxford, de 1980, e depois pelo Código de Bustamante.

Gilda Russomano, citada por Luis Ivani Araújo, ressalta que se vem colocar certas infrações em que a finalidade política ou o motivo político se encontram mesclados à prática de atos violadores do direito comum. Assim, segue Amorim Araújo, manifestando que os delitos conexos, em que se verifica a existência simultânea de duas infrações: uma política e outra comum, unidas por um laço de conexidade, e os complexos, isto é, os que embora ferindo, a um só tempo, a ordem política e o direito comum constituem ato único e inseparável em seus elementos. ${ }^{34}$

As legislações modernas na sua quase totalidade adotam o princípio da inextraditabilidade do criminoso político. Em 1977, o Projeto da Convenção Interamericana sobre Extradição, aprovado, pelo Comitê Jurídico Interamericano, estabeleceu que a extradição não procede: Cuando con arreglo a la calificación del Estado requerido se trate de delitos políticos, o de delitos conexos. La circunstancia

32 Conforme art. $5^{\circ}, \mathrm{LII}, \mathrm{CF} / 88$.

33 Revista de Informação Legislativa, a.19, n.76, out/dez., 1982, p. 79.

34 in Curso de Direito Internacional Público, 5.ed. Rio de Janeiro: Forense, 1987, p. 357. 
de que la víctima del hecho punible de que se trata ejerciera funciones políticas no justifica por si sola que dicho delito sea calificado como político (art. II, parágrafo $4^{\circ}$ ). A matéria é ainda hoje controvertida na doutrina por conseqüência da competência do Supremo para analisar e determinar se o delito é ou não de natureza política. ${ }^{35}$

Sobre a matéria o Supremo Tribunal Federal tem se posicionado no sentido da análise da preponderância do caráter político do delito, denegando o envio quando se tratar de crimes complexos. ${ }^{36}$

\section{Da nacionalidade do extraditando}

Como já foi analisado anteriormente no capítulo sobre o fundamento nacional para a extradição baseada na Constituição Federal, é vedada, conforme art. 77, I do Estatuto do Estrangeiro a extradição quando se tratar de brasileiro, salvo se a aquisição dessa nacionalidade verificar-se após o fato que motivar o pedido.

Assim, o brasileiro nato nunca será extraditado; a exceção para o envio ocorre nos casos de brasileiro naturalizado, pendente análise da época da naturalização (que deve ter ocorrido após o fato motivador do pedido de extradição) ou independentemente de data da naturalização, em função da espécie de crime cometido - tráfico ilícito de entorpecentes e drogas afins. A interpretação do STF sobre a matéria é vista na Extradição no 541 (RTJ 149/ 428), cujo relator foi o Min. Sepúlveda Pertense, valendo ressaltar trecho específico da ementa:

Ao princípio geral de inextraditabilidade do brasileiro, incluido o naturalizado, a Constituição admitiu, no art. $5^{\circ}, L I$, duas exceções: a primeira, de eficácia plena e aplicabilidade imediata, se a naturalização é posterior ao crime comum pelo qual procurado; a segunda, no caso de naturalização anterior ao fato, se cuida de tráfico de entorpecentes: ai, porém, admitida, não como a de qualquer estrangeiro, mas sim na forma da lei e por comprovado envolvimento no crime: a essas exigências de caráter

\footnotetext{
35 Ver art. 77, § 2 Estatuto do Estrangeiro. Assim foi no caso da Extradição $\mathrm{n}^{\circ} 417$, de Eduardo Firminich à Argentina, em 1984 (RTJ 111/13).

36 Extradição no 524 - Paraguai. Rel. Min. Celso de Mello. Extradição passiva - natureza do processo extradicional - limitação jurídica dos poderes do STF - inextraditabilidade por delitos políticos - compromisso constitucional do Estado brasileiro - asilo político extradição política disfarça - inocorrência - deficiência na formulação do pedido de extraição - inobservância do Estatuto Estrangeiro e do tratado de extradição Brasil/Paraguai incerteza quanto à adequada descrição dos fatos delituosos - ônus processual a cargo do estado requerente-descumprimento - indeferimento do pedido. (DJU 08.03.1991).
} 
excepcional não basta a concorrência dos requisitos formais de toda extradição, quais sejam, a dúplice incriminação do fato imputado e o juizo estrangeiro sobre a seriedade da suspeita.

\section{Da dupla tipicidade}

Além dos requisitos já estudados prevê o artigo 77, II, conforme o critério de exclusão, que não se concederá a extradição se o fato que motivar o pedido não for considerado crime no Brasil ou no Estado requerente.

É uma garantia essencial ao direito de liberdade que o fato ensejador da extradição deva ser tipificado como crime por ambas as leis em confronto, para que seja procedida a extradição pelo Brasil. Como informa o insigne professor Francisco Rezek pouco importam as variações terminológicas, e irreleva, até mesmo, a eventualidade de que o Estado requerente o classifique na categoria intermediária dos delitos. ${ }^{37}$

Neste sentido é manifestada a interpretação do Supremo Tribunal Federal: Revela-se essencial, para a exata aferição do respeito ao postulado da dupla incriminação, que os fatos atribuídos ao extraditando - não obstante a incoincidência de sua designação formal - revistam-se de tipicidade penal e sejam igualmente puníveis tanto pelo ordenamento jurídico doméstico quanto pelo sistema de direito positivo do Estado requerente. Precedente: RTJ 133/1075. ${ }^{38}$

O requisito da dupla incriminação ou tipicidade também conhecido como princípio da identidade admite a entrega de extraditando que esteja respondendo a processo ou já condenado por contravenção penal no Brasil (art. 90 do Estatuto do Estrangeiro). Todavia será negado pedido de Estado estrangeiro, se apesar de ser crime no ordena-mento jurídico estrangeiro, for tipificado como contravenção no Brasil. ${ }^{39}$

A legislação pátria analisa não só a tipicidade da conduta como também os demais elementos do crime como a culpabilidade e punibilidade. Neste caso, o STF denegaria, e.g., a extradição de menor de 18 anos reclamado por homicídio pela Argentina ou pelos Estados Unidos. Porque os três sistemas penais tipificam o ato de matar alguém. Todavia pelas provas que instruem o pedido perceberiam os julgadores que o ato concreto carece, perante nossa legislação penal interna,

37 Op.cit. p. 7, in Direito Internacional Público - Curso Elementar, p. 203.

38 Informativo do STF - Brasília, n. 22, 4 a 8 de março de 1996.

39 Neste sentido: extradição no 753 - Estados Unidos. Rel. Moreia Alves, Diário da Justiça-seção I, 26 nov. de 1999, p. 83. 
do requisito da punibilidade, sendo denegado o envio. ${ }^{40}$

A interpretação do Supremo é cristalina em indeferir extradição passiva quando o fato motivador do pedido não configurar crime em ambos os Estados, no requerente e no Brasil. $^{41}$

\section{Da gravidade do delito}

A extradição, como instituto baseado na cooperação internacional para o fim de reprimir a impunibilidade com a devolução do delinqüente a jurisdição de direito para processá-lo e julgá-lo só se justifica por crime de certa gravidade e não se aplica a simples contravenções. É o que espelha o artigo 77 em seu inciso IV: Não se concederá a extradição quando: a lei brasileira impuser ao crime a pena de prisão igual ou inferior a um ano.

Em que pese a simples leitura desse dispositivo depreende-se que são excluídos das hipóteses de extradição os delitos a que a lei brasileira impuser as penas de multa ou restritivas de direitos por entender que estas só se aplicam a crimes com menor gravidade e a exclusão compulsória de um indivíduo do país somente se procederá por motivos graves, segundo os princípios do direito pátrio, acata a determinação da sessão de 1880, em Oxford, do Instituto de Direito Internacional, ao afirmar que "a extradição, sendo sempre medida grave, só se deve aplicar a infrações de certa importância".

Explicita ainda o Estatuto do Estrangeiro que não basta tratar-se de crime com pena privativa de liberdade; esta pena cominada - abstrata, deverá ser de no mínimo um ano, o que exclui do rol dos crimes sujeitos a extradição delitos como: lesão corporal, rixa, calúnia, constrangimento ilegal, maus tratos... Esta determinação está na maioria dos tratados firmados pelo Brasil sobre o tema: Assim, com a mesma redação supra citada e constante no artigo II, temos tratado de extradição entre o Brasil e Venezuela (1940); Colômbia (1940); Bélgica (1957); Estados Unidos (1965) este no artigo III e Argentina (1968) no artigo II, exigindo pena de dois anos ou mais de prisão, entre outros tratados.

40 A lei argentina também exige a dupla incriminação, tendo-a como princípio da identidade de norma: No procede extradición si el hecho inculpado al individuo no constituye, a la vez, delito, según la legislación de ambos estados, requirente y requerido.

41 Extradição n ${ }^{\circ} 687$ - Reino da Espanha. Rel. Min. Maurício Correa. Extradição - Tratado entre a República Federativa do Brasil e o Reino da Espanha - Crime de Peculato. Fundandose o pedido em Tratado de Extradição firmado entre a República Federativa do Brasil e o Reino da Espanha, em 02.02.1988 e promulgado pelo Decreto no 99.340 , de 22.06.1990, está assim atendido o requisito autorizativo da medida, previsto no art. 76 da Lei 6.815/80. $\mathrm{O}$ delito de peculato, definido na legislação penal espanhola, configura crime previsto no Brasil (art. 312 do CP) (DJU 21.02.1997). 
A Suprema Corte tem se manifestado no sentido de acatar essa determinação do Estatuto do Estrangeiro. ${ }^{42}$

\section{Do princípio do non bis in idem}

A expressão latina non bis in idem, significa não duas vezes pela mesma coisa. Trata-se de axioma jurídico, em virtude do qual ninguém pode responder, pela segunda vez, sobre o mesmo fato, já julgado, ou ser duplamente punido pelo mesmo delito. ${ }^{43}$

Neste sentido é prevista vedação da extradição-art. $77, \mathrm{~V}$ da Lei $\mathrm{n}^{\circ} 6.815 / 80$ - quando o extraditando estiver a responder a processo ou já houver sido condenado ou absolvido no Brasil pelo mesmo fato em que fundar o pedido. Sendo o Brasil Estado requerido em processo de extradição não será outorgado o pedido se o ilícito penal a motivar a extradição já estiver sendo processado ou já tenha sido julgado pelo poder judiciário no Brasil, pois estar-seia infringindo um preceito fundamental do direito penal e dos direitos humanos caso fosse imposto a um indivíduo responder judicialmente mais de uma vez pelo mesmo fato.

Este princípio aplicado pela legislação pátria está presente em vários tratados de extradição feitos pelo Brasil, dentre eles com a Venezuela
(1940), Colômbia (1940), Bélgica (1957), Argentina (1968) em todos no inciso III, acrescentando a denegação da extradição também nos casos de anistia ou indulto em qualquer dos Estados, requerente ou requerido e com os Estados Unidos (1965) no artigo $5^{\circ}$, II, especificando que não será concedida a extradição em qualquer das seguintes circunstâncias - II: quando o indivíduo cuja entrega já tenha sido julgado ou, ao tempo do pedido, esteja sendo processado no Estado requerido, pelo crime ou delito que ocasionou o pedido de extradição. A Comunidade Européia também segue o princípio, conforme determina a Resolução da Assembléia da República $n^{\circ}$ 22/95: Convenção entre os Estados membros das Comunidades européias sobre a Aplicação do Princípio do ne bis in idem, em seu art. $1^{\circ}$ : Quem tiver sido definitivamente julgado num Estado membro não pode, pelos mesmos fatos, ser perseguido num outro Estado membro, desde que, em caso de condenação, a sanção tenha sido cumprida, esteja efetivamente em curso de execução ou já não possa ser executada segundo as leis do Estado da condenação.

O Supremo Tribunal Federal tem se manifestado sobre a matéria com acato literal da previsão legal do Estatuto do

42 Extradição no 308 - Estados Unidos. Rel. Min. Eloy da Rocha. Extradição. Solicitação que satisfaz aos requisitos legais. Condenação por crime a que se aplica, na lei brasileira, pena de prisão superior a um ano. Extradição concedida (1971).

43 NUNES, Pedro. in Dicionário de Tecnologia Jurídica. 12. ed. Rio de Janeiro: Freitas Bastos, 1994, p. 605. 
Estrangeiro, para vedar a possibilidade de dupla responsabilização do sujeito pelo mesmo fato delituoso. ${ }^{44}$

\section{Da prescrição do crime}

A prescrição como forma da perda do ius puniendi do Estado pelo decurso do tempo fixado em lei é presente também no processo extradicional dentre os pressupostos relativos ao fato imputado ao extraditando, prevista no art. 77, VI, da Lei $n^{\circ}$ 6.815/80: Não se concederá a extradição quando extinta a punibilidade pela prescrição segundo a lei brasileira ou a do Estado requerente.

A legislação Argentina também prevê o requisito da imprescritibilidade para a concessão da extradição: $L a$ conducta que configura el delito objeto de extradición, como es obvio, no debe estar prescripta según los cânones legales del Estado requirente, cuyo extremo es consagrado en forma expressa en el art.
19, num. 4, conforme Bermudez, in La Extradición, p. 206.

É cristalino o dispositivo legal ao permitir a concessão do pedido diante da inocorrência de prescrição da pretensão punitiva ou executória, seja pelas leis brasileiras, seja pela lei do Estado estrangeiro requerente. Importante ressaltar que a prescrição deve ser perquirida, separadamente, primeiro quanto à legislação pátria, e após, quanto à legislação do Estado requerente.

Verificada a incidência da prescrição e extinta a punibilidade do infrator, a Suprema Corte brasileira tem se posicionado da seguinte maneira: ou indefere o pedido de extradição ou julgao prejudicado. Neste sentido tem se manifestado o Supremo Tribunal Federal. ${ }^{45}$

\section{CONCLUSÃO}

As fronteiras do mundo estão desaparecendo. Os Estados estão cada

44 Extradição no 664-9 - Espanha. Rel. Maurício Correa. Extradição. Tráfico de Entorpecentes. Condenação no Brasil e na Espanha por crimes autônomos. Tratado de Extradição Brasil - Espanha de 02.02.1988, promulgado pelo Decreto n 99.340, de 1990. Aplicação. Prescrição extraditando com cônjuge e filho no Brasil. 3. Não há óbice para o deferimento da extradição se a condenação sofrida no Brasil tem por base fato diverso daquele que se funda o pedido do Estado Requerente. (art. 77, V, da Lei 6.815/80).

45 Extradição n ${ }^{\circ}$ 560. Reino da Bélgica. Rel. Min. Moreira Alves. Extradição, Prisão e Prescrição. Julgando pedido de extradição formulado pelo governo da Bélgica o Tribunal afastou a alegação de prescrição da pretensão executória deduzida com fundamento na legislação belga, por entender que a prisão do extraditando, mesmo tendo sido efetuada no Brasil para fins de extradição, é causa interruptiva da prescrição, o art. 96 do Código Penal da Bélgica (o trânsito em julgado da sentença penal condenatória - termo inicial do prazo - ocorrera em 15.12.90 e o réu foi preso no Brasil em 22.03.95) (27.03.96). 
vez mais próximos em conseqüência do progresso tecnológico, dos meios de comunicação até poucas décadas passadas inimagináveis como a internet e com os interesses direcionados para o desenvolvimento comum para sobrevivência de todos os povos através das comunidades de Estados, como a Comunidade Européia e o Mercosul.

Neste contexto de globalização aumentam além das vantagens advindas da integração, os malefícios que a mesma proporciona, como a facilidade de fuga além fronteiras de delinqüentes a fim de furtarem-se de responder por seus atos a quem de direito.

Destarte a extradição, como mecanismo de cooperação internacional para reprimir tais tentativas furtivas, é essencial em sua finalidade, nos tempos em que vivemos. Trata-se de um ato de soberania efetivado com a entrega de um indivíduo a um país que o requeira para que nele seja processado ou cumpra pena por delito comum que the foi imputado.

No presente estudo de cunho bibliográfico e jurisprudencial foram tecidas considerações gerais sobre a matéria bem como abordado o seu fundamento jurídico, que no âmbito do direito internacional deve ser baseado em tratado internacional bi ou multilateral, com efeito vinculatório para os contratantes, prevendo as condições gerais e as específicas para o procedimento e apresentando estes tratados o escopo de proteger os Estados fracos das pressões, muitas vezes injusti- ficadas, dos Estados fortes e constituir medida preventiva do delito pela advertência que fazem aos criminosos eventuais. Viu-se que na falta de tratados pode-se substanciar a extraditio em compromisso de reciprocidade entre o Estado requerente e o requerido, constituindo em promessa de que ocorrendo crime análogo no país requerido o país requerente se comprometa a conceder a extradição solicitada. No que concerne aos fundamentos nacionais do pedido foram analisados os dispositivos constitucionais a respeito que determinam que o brasileiro nato nunca será extraditado e quanto ao naturalizado a Constituição Federal prevê sua concessão pendente análise dos requisitos do tempo de naturalização e da espécie de delito praticado. Todavia além das determinações constitucionais regem a matéria leis esparsas que foram ao longo do tempo aprimorando-se até o atual Estatuto do Estrangeiro - Lei ${ }^{\circ} 6.815 /$ 80 e a Lei Federal $n^{\circ} 6.964 / 81$.

Numa segunda parte do estudo foi examinada a competência para o processo e julgamento da extradição que é do Supremo Tribunal Federal, no Brasil, em que pese ser um processo de natureza mista: administrativo, com pedido e entrega feitos de governo a governo e, judiciário, com o exame e autorização pela Suprema Corte do poder judiciário.

Outrossim, foi vista a interpretação e aplicação dada pelo Supremo Tribunal Federal quanto aos requisitos formais e 
materiais exigidos para a extradição constantes da Lei $n^{\circ} 6.815 / 80$, que obedecem a critério de exclusão. Nestes termos não se concederá a extradição além da já mencionada nacionalidade brasileira, quando não houver dupla tipicidade do fato motivador do pedido, quando for o caso de competência brasileira para julgar o crime. Só haverá extradição por crime de certa gravidade, pois esta constitui-se em ato drástico de retirada compulsória de indivíduo do país e não se presta para delitos menores, como as contravenções; o Brasil segue o princípio do non bis in idem - o extraditando não responderá duas vezes em Estado diverso e no Brasil pelo mesmo fato; prescrito o crime motivador do pedido em algum dos Estados, não será a extradição concedida devido à extinção da punibilidade. Outrossim, crimes políticos e de opinião, religiosos e militares estão fora do rol dos passíveis de extradição, e vedação em caso de responder o extraditando a juízo ou tribunal de exceção.

Assim foi cumprido o propósito deste estudo de analisar alguns aspectos deste importante instituto que é de direito internacional, mas se encontra regulado no direito interno de todos os países. 



\title{
O contexto procedimental das ações diretas no controle de constitucionalidade e a conversibilidade das "jurisdições"
}

\author{
Glênio José Wasserstein Hekman*
}

\section{INTRODUÇÃO}

O objetivo deste trabalho é trazer à discussão a necessidade de reavaliar conceitos que são importados do direito processual clássico para o processo constitucional que, se de um lado homogenizam este, ordinarizando-o, de outro, revelam-se incapazes de fazer frente às novas exigências da sociedade brasileira, em constante mutação. Carecendo de disciplina própria, organizada em estatuto processual que consolide princípios e normas, o processo constitucional transforma-se em algo místico, inacessível, reduzido e miscigenado que é às velhas fórmulas privatistas de processo, a confundir, ainda mais, sua função e finalidade. Daí que, a experiência jurídica costuma "costurar" tais conceitos, com ares de definitividade quando, em verdade, eles podem e devem sofrer a crítica para se saber até que ponto são flexíveis e adaptáveis à nova realidade (como conceitos abertos), ou se a dogmática processual contemporânea não foi concebida para prospectar além de sua postura conservadora, apresentando dificuldades de espaço para a discussão dessa relevante temática. É o que veremos!

\section{ORDINARIZAÇÃO DO PROCESSO}

Não há dúvidas que o processo constitucional deva merecer um tratamento disciplinatório-normativo especial para, dessarte, afastar-se do

\footnotetext{
* Professor de Direito da Univeridade Luterana do Brasil/ULBRA e da Universidade Federal do Rio Grande do Sul/UFRGS, Advogado, Mestre em Direito do Estado pela UFRGS e Doutor em Direito do Estado pela Universidade de São Paulo/USP.
} 
domínio dogmático do processo civil comum. De fato, a tentativa de explicar o processo constitucional a partir da influência clássica e remansosa que sofre daquele, deixa a desejar, já que pressiona o jurista a operar com institutos que se revelam inadequados pela diversidade de vertentes, a conciliar conceitos e procurar o equilíbrio de princípios eventualmente interexcludentes, tendentes a produzir eficácia incompleta ou duvidosa, ainda mais quando se lhe transporta uma visão privatista e individualista desses institutos, sem atentar que, de há muito, fruto da multiplicidade e complexidade das relações inter-humanas, os interesses individuais passam a ser coletivos, na medida em que a lesão ou ameaça de lesão a direito de um indivíduo indica a lesão ou ameaça de lesão a direito de toda a coletividade. ${ }^{1}$ Adroaldo Furtado Fabrício analisa o fenômeno experimentado pelo Direito, principalmente nas últimas décadas, $\mathrm{e}$ afirma não ser um despropósito que cada vez mais se fale acerca da publicização do Direito Privado, "no sentido de que a carga de interesse público envolvido nas relações do Direito dito "Privado" tende a crescer constantemente,"'2 a exigir, em correspondência, "uma impostação mais publicística do processo, inclusive do processo "civil", que na verdade é, para o nosso sistema, todo processo nãopenal." ${ }^{3}$ Por uma questão racional, os interesses coletivos devem ter primazia sobre o individual (disponível), já que o homem vive em sociedade, embora, é certo, deva existir um núcleo intangível na esfera da personalidade individual, para que o próprio homem possa se desenvolver na sociedade. Não é possível crer, no entanto, a não ser num sistema de méritos e deméritos, que somente um ou alguns indivíduos possam usufruir dos efeitos da norma jurídica, através do processo, ao passo que o restante coletivo fica relegado a um segundo plano, de acordo com a conveniência da política vigente ("como

1 Nesse sentido, Vitalino Canas observa que: "o direito processual constitucional não pode deixar de ser um direito processual autônomo, regido por princípios próprios, necessariamente pouco fungíveis com os dos processos jurisdicionais típicos. Estes últimos têm por fim resolver lides ou conflitos intersubjetivos de interesses que se manifestem em concreto. E se não se quiser ficar preso no conceito, porventura demasiado rígido, de lide, pelo menos terá de se reconhecer que nesses processos vêm sempre envolvidos interesses subjectivos" (CANAS, Vitalino. Os processos de fiscalização da constitucionalidade e da legalidade pelo Tribunal Constitucional: natureza e principios estruturantes. Coimbra: Coimbra, 1986, p. 87).

2 FABRÍCIO, Adroaldo Furtado. As novas necessidades do processo civil e os poderes do juiz. Estudos Jurídicos, v. 25, n. 64, p. 57-63, maio/ago. 1992. p. 61.

3 Ibidem, p. 62. 
se o processo não fosse instrumento eminentemente social. ${ }^{\prime 4} \mathrm{Se}$ a isonomia legal significa tratar desigualmente os desiguais na justa medida desta desigualdade, há um princípio que deve ser observado para que esta afirmação tenha sentido e possa ser efetivada: o da igualdade de oportunidades. Assim, de um berço comum, os indivíduos passam a se desenvolver, segundo as suas capacidades intrínsecas, e o sistema de méritos e deméritos, nessa convenção, torna-se justo, ou pelo menos, racionalmente aceitável. Mas isso, evidentemente, não é o que ocorre, até porque, a história nos ilustra, a concentração do poder, por qualquer que seja a forma pela qual ele se revele, pressupõe a desigualdade social. Esta desigualdade precisa ser amenizada, e não é sem razão que os Estados modernos tenham sua preocupação voltada para esse aspecto, como o Brasil que, em sua Carta Constitucional de 1988, o tem como objetivo fundamental (art. $3^{\circ} \mathrm{daCF} / 88$ ). Cumpre ao Estado, portanto, criar instrumentos de acesso à justiça para aqueles que, vítimas da desigualdade social, são excluídos da eficácia normativa individual, consequiência de um processo "privado-elitista", mas que encerra, em seu bojo, questão de interesse geral. Assim, não só para a efetivação dos direitos previstos na Constituição, mas na defesa de seus princípios, ação, processo e jurisdição são conceitos que devem ser permanentemente discutidos e atualizados, sob pena de aprisionar os operadores do direito, tornando-os incapazes de enfrentar os desafios que as novas relações impõem ao mundo jurídico.

De acordo com Rodolfo Mancuso, "os interesses metaindividuais (difusos, coletivos, individuais homogêneos) estão hoje alçados ao nível constitucional (CF, arts. 127 e 129, III)". Além disso, leis especiais compõem um sistema integrado, no sentido de possibilitar "uma tutela adequada e efetiva desses interesses, que de outra forma não teriam acesso à justiça em modo apropriado, já que o CPC, sendo um corpo de normas de origem romanística, está voltado para a solução de conflitos intersubjetivos, de tipo Tício versus Caio."

O Estado, portanto, procura equalizar as diferenças oferecendo meios de tutela coletiva, abrangendo aqueles que, por um motivo ou outro, estariam afastados do acesso à justiça.

No entanto, no que tange ao controle de constitucionalidade, é

\section{Ibidem.p. 63.}

5 MANCUSO, Rodolfo de Camargo. Manual do consumidor em juizo. 2.ed. São Paulo: Saraiva. 1998. p. 4.

6 Ibidem, p. 5. 
possível verificar que o mesmo ainda espelha desigualdade social, notadamente na modalidade do controle concreto de normas, quando a questão constitucional posta em exame rende apenas dividendos inter-partes, obrigando a coletividade a promover ações individuais para buscar os mesmos efeitos, nem sempre obtidos, dando margem à insegurança jurídica.

Assim, de fato, tais inconvenientes são superados pela modalidade de controle em tese.

\section{PODER JUDICIÁRIO E A NATUREZA DE SUA ATUAÇÃO}

Cabe aqui registrar, no entanto, que o contexto procedimental das ações diretas no controle de constitucionalidade, a partir de sua origem, tem como cenário de fundo a idéia de que o controle, na jurisdição constitucional, se desenvolve precipuamente para assegurar a coerência do sistema normativo e somente secundariamente, ou por conseqüência, para proteger eventuais lesões ocasionadas pela lei ou ato normativo às posições subjetivas constitucionalmente garantidas. Qual é, no entanto, a natureza da atuação do Poder Judiciário neste contexto?

$\mathrm{Na}$ obra Jurisdição e competência, Athos Gusmão Carneiro afirma que a "Constituição Federal atribui ao Poder Judiciário, mais especificamente ao Supremo Tribunal Federal, o exercício, embora sob vestes jurisdicionais, de uma atividade legislativa, porque não vinculada à aplicação do direito a um caso concreto." Refere ele às hipóteses então previstas de ação direta;

7 CARNEIRO, Athos Gusmão. Jurisdição e competência. 2. ed., São Paulo: Saraiva, 1983, p. 16. Na doutrina italiana, conforme se pode perceber da leitura de Mauro Cappelletti (Pronunce di rigetto nel processo costituzionale delle libertà e cosa giudicata. Rivista di Diritto Processuale, Padova, v. 11, n. 1, p. 135-166, 1956.), há a posição adotada por Calamandrei que reconhece a natureza legislativa da função exercida pela Corte constitucional, notadamente ante a eficácia erga omnes da pronúncia. Por outro lado, afirma que a doutrina dominante italiana, assim como aquela dos países de língua alemã, defende a jurisdicionalidade da função atribuída à Corte, podendo-se notar, em CARNELUTTI E ALLORIO apud CAPPELLETTI, op. cit. p. 138), ser característica essencial e imprescindível dos provimentos "jurisdicionais", aquela de criar a coisa julgada substancial. No entanto, Cappelletti não concorda com a posição dominante. Segundo ele, o que distingue a jurisdição das outras "funções" é um elemento puramente formal, modal, isto é como se posicionam os sujeitos da relação processual considerada, e não pelo resultado da atividade exercitada, razão pela qual prefere o critério da "terzietà", característica particularmente evidenciada no juízo constitucional, quando exercita o poder de decidir sobre a questão que lhe é submetida (CAPPELLETTI, op. cit. p. 140-141). Até porque, não reconhece a formação de coisa julgada na sentença de rejeição da inconstitucionalidade, pelo fato de a questão poder voltar a ser decidida, mais tarde, por fundamento diverso. 
uma para declarar a inconstitucionalidade (visando excluir a eficácia da lei ou ato normativo impugnado), outra, para firmar interpretação, em tese, de lei ou ato normativo federal ou estadual, sem provocar a sua nulidade ou cassação (equivalendo ou funcionando de modo materialmente idêntico, a decisão do Supremo, a uma lei declaratória ou interpretativa). Esse controle genérico antecipase ao conflito concreto de interesses por meio de ações preventivas e saneadoras.

Galeno Lacerda, na mesma linha, ao comentar as inovações então introduzidas pela Emenda Constitucional $\mathrm{n}^{\circ} 7$, de 13.4 .77 , no que tange à interpretação, em tese, foi categórico em dizer que, o Supremo Tribunal Federal passa a atuar de forma legiferante, ao se confundir jurisdição e legislação, em razão da coisa julgada que torna a exegese vinculativa, posto que a "hermenêutica se consolida em obrigatória e imutável." se introduzam novas disposições à lei existente.

A confusão de funções, nessa perspectiva, não aparece de forma clara na obra de Edson Prata, que ressalta apenas dúvidas quanto a separar funções administrativas das judiciárias, notadamente no campo da jurisdição voluntária. Assim, para o citado autor:

Pela função legislativa, o Estado elabora as normas gerais e abstratas com o objetivo de regular a atividade das pessoas e dos órgãos públicos. É essencialmente criadora, e criadora do próprio direito.

A função jurisdicional, ao revés, objetiva atuar a norma legal nos casos concretos que lhe são submetidos, distribuindo justiça aos requerentes. Declara a lei, o direito ao caso concreto. A lei criada pelo Poder Legislativo é seu principal material de trabalho. Obriga-se a declará-la, salvo quando se reveste de inconstitucionalidade, caso em que também a própria inconstitucionalidade é declarada, deixando a lei, conseqüentemente, de ser cumprida. ${ }^{9}$

De qualquer sorte, é possível imaginar, na atuação jurisdicional, atos judicialiformes que, se não visam diretamente a aplicação do direito ao caso concreto, o fazem indiretamente, criando-lhe acessos ou afastando entraves para este objetivo.

\section{O PROCESSO OBJETIVO E JURISDIÇÃO}

É corrente, na doutrina e jurisprudência nacionais mais recentes,

8 LACERDA, Galeno. Comentários ao código de processo civil: lei n. ${ }^{\circ}$ 5.869, de 11.01.73. Rio de Janeiro: Forense, 1981. v.8, t.1.p. 77-78.

9 PRATA, Edson. Jurisdição voluntária, São Paulo: Leud, 1979, p. 111. 
que as ações diretas inauguram autêntico processo objetivo. ${ }^{10} \mathrm{~A}$ dúvida que resta, portanto, é saber se essas ações instituem processos clássicos de jurisdição contenciosa ou se, na realidade, instituem "procedimentos judicialiformes", que partem da jurisdição voluntária ${ }^{11} \mathrm{e}$, posteriormente, se convertem, pela transmutação da espécie, posto que a jurisdição é una (poder indivisível), em face dos efeitos que visa a atingir.

Em que pese as numerosas críticas contra a expressão "jurisdição voluntária", indicando que esta, de acordo com
Zamora, Lopes da Costa e Mortara, não seria nem voluntária nem jurisdição (apenas administração pública de interesses privados), ${ }^{12}$ certo é que sem o domínio de certeza em torno da temática, volta e meia ressurge e com força, a sustentação da jurisdicionalidade dos atos nela inseridos, havendo ainda quem a enxergue como uma atividade mista, eis que substancialmente administrativa e formalmente jurisdicional. ${ }^{13}$

Como bem refere Maria Luiza Ahrends Maraninchi, "a atuação jurisdicional não pode ficar adstrita aos casos em que se dá o litígio", ${ }^{14}$ pois “há

10 Ver, nesse sentido, FERREIRA MENDES, Gilmar. Jurisdição constitucional: o controle abstrato de normas no Brasil e na Alemanha. 3. ed. São Paulo: Saraiva, 1999. p. 131-132 e nota de rodapé $\mathrm{n}^{\circ} 37$.

11 De acordo com Athos Gusmão Carneiro: "os atos praticados no exercício da jurisdição voluntária são atos judiciais, porque praticados por juízes; mas não são atos jurisdicionais, pois ao praticá-los o juiz não está aplicando o direito com vista a eliminar um conflito de interesses, mas sim com o propósito de influir em um negócio privado ou em uma situação jurídica. O juiz, no exercício da jurisdição voluntária, pratica atos subjetivamente judiciais, mas substancialmente administrativos" (CARNEIRO. Jurisdição e... p. 34). Embora a afirmação tenha um peso bastante significativo para a doutrina dominante, ainda assim é restrita, hajam vista os argumentos de Salvatore Satta, Rafael de Pina, Amilcar de Castro e Marcos Afonso Borges, partidários de uma conceituação mais ampla da jurisdição (citados por CARNEIRO, op. cit. p. 33), e defendendo ser a jurisdição voluntária verdadeira jurisdição por tratar-se de poder-dever que o judiciário deverá exercer toda vez que se manifestar acerca do que the é levado a apreciar, resolvendo a situação exposta, quer seja ela litigiosa ou não. Daí não ser necessária a existência de um conflito de interesses para que a lei seja aplicada com o objetivo de eliminar o litígio, bastando a necessária presença do judiciário para resolver aquilo que as partes ou interessados não podem resolver por si mesmos. Em outras palavras, a presença de um "terzietá", ou terceiro imparcial, é necessária para fazer a mediação entre a norma abstrata e seus efeitos concretos.

12 Ver: PRATA. Jurisdição... p. 16.

13 Ver: PORTO, Sérgio Gilberto. Jurisdição voluntária: atividade administrativa ou jurisdicional? Revista Jurídica, São Paulo, v. 31, n. 104, p. 90-95, mar./abr. 1984. p. 92-93.

14 Ver: MARANINCHI, Maria Luiza Ahrends. Natureza jurídica da jurisdição voluntária. Estudos Jurídicos, São Leopoldo, v. 19, n. 45, p. 45-67, jan./ abr. 1986. p. 51. 
determinadas categorias de interesses não conflitantes, especiais, as quais não podem prescindir da intervenção judicial". ${ }^{15}$ Assim, parece-me ser insuficiente toda e qualquer conceituação de jurisdição, que restringe este poder estatal à composição de conflitos, mediante aplicação da lei ao caso concreto. Com certeza, esta é sua faceta mais visível, mas não se pode descuidar que, na administração da justiça e do bem-comum, as funções do Estado também se relacionam e se combinam. Daí que, mais ponderado, Enrico Allorio preferiu uma saída mais estratégica, ao afirmar que se deve definir o instituto com base em seus efeitos, portanto, se resulta coisa julgada é jurisdição, se não resulta não é. $\mathrm{Na}$ verdade, refere que o emprego da forma do processo declarativo, mais a coisa julgada como seu resultado, definem a jurisdicionalidade do processo. ${ }^{16}$ Embora também passível de crítica, ${ }^{17}$ a tese tem inegavelmente uma virtude, e nesse ponto incontestável, que pelo menos o efeito declaratório substancialmente considerado na decisão (apto a produzir coisa julgada), e se juris dictio é dizer o direito, é sinal inequívoco de existência de jurisdição. A moderna doutrina, no entanto, acolhe a tese de que a jurisdição voluntária se constitui em atividade tipicamente jurisdicional, especialmente pela presença de um "terzietà", ou seja, do juiz estranho e imparcial a decidir sobre a causa que lhe é proposta. ${ }^{18} \mathrm{~A}$ presença subjetiva de integrante do Poder Judiciário e da atividade que lhe é rotineira, qual seja a da verificação de legalidade dos atos, conduz, com maior facilidade, à aceitação de um critério de forma de controle constitucional, constituído pela natureza do órgão de controle.

Nesse sentido, as ações diretas no controle de constitucionalidade aproximam-se, coincidentemente, na busca do efeito antes referido, ou seja, visam a declarar a existência ou não de vício da norma ou ato normativo atacado em tese, a fim de lhes atribuir conseqüências moduláveis no tempo e no espaço. $E$ isso ocorrerá sempre, no intuito de manter a higidez da

15 Ibidem.

16 ALLORIO, Enrico. Saggio polemico sulla giurisdizione volontaria. Rivista Trimestrale di Diritto e Procedura Civile, Milano, v. 2, p. 487-529, 1948. p. 510-516. Segundo Ovídio A. Baptista da Silva: "a doutrina que identifica jurisdição com coisa julgada tem mais adeptos no Brasil do que se imagina", identificando-a em Frederico Marques, Arruda Alvin, A. A . Lopes da Costa, Grinover-Dinamarco-Cintra e Kasuo Watanabe (SILVA, Ovídio Baptista da. Curso de processo civil. Porto Alegre: Fabris, 1987. v.1. p. 23).

17 Com relação às objeções levantadas à posição de Allorio, ver SILVA. Curso....p. 23).

18 Ver: PORTO Jurisdição... p. 95. 
Constituição e dos princípios e garantias nela estabelecidos. Porém, neste contexto, ao contrário da linha seguida pelos processualistas clássicos, não é possível se dar o mesmo tratamento das ações processuais comuns, ou de jurisdição contenciosa que a elas se relaciona, ao menos inicialmente, às ações diretas do controle de constitucionalidade, por não serem elas portadoras do conjunto de características que identificam sua exata pertinência a esse campo específico da jurisdição. Se não, vejamos! Costuma-se, em doutrina, cotejar os elementos diferenciadores entre a atividade jurisdicional e a atividade administrativa. Tem-se, portanto e simplificadamente, relembrando o quadro comparativo elaborado por Sérgio Gilberto Porto, que: 1) a atividade jurisdicional: depende da iniciativa da parte; o juiz faz atuar a lei; pressupõe uma lide, pois existem partes com interesses conflitantes; é uma atividade substitutiva; há um processo; resulta coisa julgada material; presença de um terceiro imparcial (terzietà); satisfaz interesse de outro; e 2) a atividade administrativa: normalmente não depende de qualquer requerimento; o administrador age conforme a lei; não pressupõe uma lide, pois existem apenas interessados; é uma atividade originária, há simplesmente um procedimento; não resulta coisa julgada; não há terceiro imparcial, satisfaz interesse próprio.
Desse cotejo, prossegue Sérgio Gilberto Porto, ressaltariam as seguintes divergências:

a) haveria diversidade de escopo entre a jurisdição contenciosa $e$ a voluntária, pois enquanto a primeira tem caráter repressivo, a segunda tem caráter preventivo; b) enquanto a iurisdição contenciosa é uma atividade declarativa de direitos, a voluntária se destina à formação de atos e negócios jurídicos, tendo, portanto, função constitutiva, estranha à natureza da jurisdição; c) na iurisdição voluntária não há litígio, nem contraditório, portanto não existem partes, mas apenas interessados, ao passo que na contenciosa existem partes, litigio e contraditório; d) os atos de jurisdição voluntária não produzem coisa iulgada material, ao passo que os atos de jurisdição contenciosa produzem coisa julgada material; e) finalmente que a jurisdição voluntária seria simples administração pública de interesses privados. ${ }^{19}$

As ações diretas não contemplam a existência de partes, pelo menos no sentido do processo comum. Há um requerente, mas não necessariamente um requerido. Sempre se teve a idéia, no Brasil, de que o Procurador-Geral da República e, atualmente, todos os legitimados constitucionalmente para propor ações diretas, são substitutos processuais, no exercício de uma atividade do interesse público, ou seja,

19 PORTO Jurisdição... p. 94. 
atuam como representantes da sociedade. ${ }^{20} \mathrm{E}$, completando a relação processual, num simulacro de partes, ou de interesses opostos, antes da Constituição Federal de 1988, apresentava-se a mesma figura do Procurador-Geral da República, substituído que foi pelo Advogado-Geral da União, atualmente, com o mister de representar os interesses da União, em juízo. Faz acreditar, portanto, que as ações diretas são ações públicas movidas pela sociedade contra a União, o que não é verdade. A propósito da representação, conforme aduz Arthur de Castilho Neto, "construiu a Suprema Corte o entendimento que é ela uma ação sem réu, simplesmente porque não há estado jurídico a modificar, isto porque a lei ou ato constitucional não adquiriu eficácia". ${ }^{21}$ São elas ações públicas de que o próprio Estado se vale (como poder-dever decorrente da própria Constituição), através de seus órgãos ou entes delegados, para expurgar ou adequar no ordenamento jurídico, normas ou atos normativos de constitucionalidade duvidosa. Semelhança pode ser buscada no processo penal que, segundo informa Hélio Tornaghi, ${ }^{22}$ no que tange à ação penal pública, o titular da ação é o próprio Estado, onde o Ministério Público é apenas um órgão dele, seguindo, de regra, o princípio da oficialidade. ${ }^{23}$ Além disso, tanto as ações diretas, em virtude de sua natureza e finalidade, quanto a ação penal pública, não são suscetíveis de desistência. ${ }^{24}$

Interessante salientar que a legislação brasileira já considerou, como modalidade de ação pública, a ação de ofício, movida pelo juiz ou autoridade policial. No saber de Tornaghi, nesses casos "não há propriamente ação, mas

20 Nesse sentido, conferir em FERREIRA MENDES. Jurisdição...p. 61. Por outro lado, outra versão pode ser encontrada. Assim: "a titularidade dessa ação especialíssima foi deferida pelas sucessivas disposições constitucionais unicamente ao Chefe do Ministério Público Federal, tendo por finalidades específicas manter o equilíbrio entre os Poderes Políticos do Estado e preservar sua instituição" (Repr. 1.161 - Questão de Ordem - rel. Min. Néri da Silveira, RTJ 113/22).

21 CASTILHO NETO, Arthur de. Reflexões críticas sobre a ação direta de constitucionalidade no Supremo Tribunal Federal. Revista da Procuradoria-Geral da República, São Paulo, n.. 2, p. 11-39, jan./mar. de 1993.p. 13.

22 TORNAGHI, Hélio Bastos. Instituições de processo penal. São Paulo: Saraiva, 1977. v.2. p. 317 et seq.

23 Nas demais ações penais, a própria lei penal concede legitimidade concorrente ou privativa ao ofendido (mas, por evidente, o interesse privado, aqui, deve-se revelar por proteção dos direitos privativos da personalidade do ofendido).

24 Ver arts. $5^{\circ}$ e 16 da Lei n ${ }^{\circ} 9.868$, de 10 de novembro de 1999. 
procedimento judicial independente de ação. Mas a lei fala em ação. É o que se infere do disposto nos arts. $17 \mathrm{da}$ Lei das Contravenções Penais e 26 do Código de Processo Penal." 25 Muito embora, por certo, o Código brasileiro seguisse o princípio ne procedat iudex ex officio, é possível demonstrar pelo exposto, que o uso dos conceitos de processo sofre, no tempo e no espaço, mutações que não permitiram a criação de uma teoria pura infensa a críticas, terminando por polemizar a matéria jurisdicional na sua exata compreensão, sem que se pudesse encontrar critério definitivo que a afastasse da atividade administrativa. ${ }^{26}$

Por outro lado, conforme já foi dito acima, as ações diretas têm função preventiva (eis que previnem futuras lides), não há litígio ou interesses subjetivos contrapostos ou contraditório, como antes se afirmava com veemência, principalmente com relação à ação declaratória de constitucio- nalidade, e agora menos (no que tange à inexistência de contraditório), pela introdução de providências de caráter pluralista, pela nova lei que regulamenta o processo e julgamento da ação direta de inconstitucionalidade e da ação declaratória de constitucionalidade, permitindo que outros titulares do direito de propositura da ação direta possam manifestar-se e requerer, positivando a figura do amicus curiae, e ensejando ao Tribunal o conhecimento pleno dos diversos aspectos envolvidos na questão, com a investigação integrada de elementos fáticos e jurídicos. ${ }^{27}$

\section{CONCLUSÃO}

De fato, elementos da jurisdição voluntária estão presentes no início da ação direta. Ocorre que, para os efeitos da coisa julgada da declaração de inconstitucionalidade/constitucionalidade, impossível de ser obtida pela via da jurisdição voluntária, ${ }^{28}$ faz-se

25 TORNAGHI, op. cit. p. 318.

26 Observe-se a afirmação de José Maria Rosa Tesheiner, com relação ao processo penal inquisitório: "...já não existe no Brasil (Constituição Federal, art. 129, I). Se existisse, caberia falar de uma 'função de administração da justiça', sem caráter jurisdicional" (TESHEINER, José Maria. Jurisdição voluntária. Rio de Janeiro: Aide, 1992. p. 25).

27 Ver: FERREIRA MENDES, Gilmar. Processo e julgamento da ação direta de inconstitucionalidade e da ação declaratória de constitucionalidade perante o Supremo Tribunal Federal: uma proposta de Projeto de Lei. Cadernos de Direito Tributário e Finanças Públicas, São Paulo, v. 6, n.. 23, p. 10-23, abr./jun. de 1998. p. 10-11.

28 Para Galeno Lacerda, "a diferença fundamental entre jurisdição e administração reside na eficácia do ato. $\mathrm{O}$ ato jurisdicional, ao aplicar a lei, impõe um vínculo por si só eficaz às partes e ao próprio juiz. A eficácia lhe é imanente, porque pertence à sua própria natureza. O ato administrativo não possui essa eficácia absoluta, pois sempre poderá ser submetido à jurisdição. Por isto, dele jamais nascerá a preclusão ou a coisa julgada" (LACERDA, Galeno. Despacho Saneador. Porto Alegre: La Salle, 1953.p. 104). 
necessária sua conversão em contenciosa. De outra parte, conforme nos revela Galeno Lacerda:

Onde houver, portanto, julgamento de questão, ai estaremos em presença de ato jurisdicional. Isto significa que a iurisdição também, pode se introduzir em procedimento de natureza administrativa, como os da impropriamente chamada "jurisdição" voluntária, sempre que, neles, se suscitar qualquer questão que requeira juizo, isto é, iulgamento para dirimir controvérsia. Neste caso, o procedimento se transforma de inter volentes em inter nolentes, fato que faz nascer automaticamente a jurisdição, porque tornada presente a causa, que é a lide, o conflito, embora sobre aspecto secundário como o meramente processual. ${ }^{29}$

Aceitando-se a ocorrência da conversibilidade, em qual momento será possível a sua verificação? Creio que o momento é o da decisão sobre a questão constitucional. À decisão serão emprestados os efeitos necessários da coisa julgada erga omnes e vinculante, temperando-se os demais efeitos (ex tunc, ex nunc ou pro futuro) de acordo com o alcance às situações concretas da vida, mitigando-se excessiva rigidez.

Os elementos de jurisdição voluntária e contenciosa, somados a uma atividade "legislativa" pelo Poder Judiciário, numa combinação de substância e forma, ${ }^{30}$ induzem à crença de tratar-se o ato procedimental que origina o controle pela via de ação direta, como decorrente do próprio poder soberano do Estado, onde, na doutrina Kelseniana, ele se confunde com a ordem jurídica. ${ }^{31}$ A manutenção e funcionalidade, ou melhor, da garantia da ordem necessita da unidade das funções do Estado, embora o exercício

29 LACERDA. Comentários... p. 23. Maria Berenice Dias vê, na posição sustentada, onde se procura identificação da atividade jurisdicional apreciadora da lide, "um apego, ainda que não revelado, à teoria civilista da ação, restando por restringir o campo de atividade do Poder Judiciário" (DIAS, Maria Berenice. Juridição voluntária e coisa julgada. Estudos Jurídicos, São Leopoldo, v. 21, n. 49, p. 53-72, maio/ago, de 1987. p. 59). A referida desembargadora do Tribunal de Justiça do Estado do Rio Grande do Sul defende o reconhecimento da jurisdição do procedimento voluntário e, de outra banda, conclui pela ocorrência de coisa julgada neste tipo de procedimento.

30 Sobre as possíveis combinações heterogêneas entre elementos próprios das diversas funções soberanas do Estado, ver: GODACCI-PISANELLI, G. Analisi delle funzioni sovrane. Milano: Giuffrè, 1946. p. 79-92.

31 Sobre o assunto, ver: GALEOTTI, Sergio. Introduzione alla teoria dei controlli costituzionali. Milano:. Giuffrè, 1963. p. 93-101, onde faz específica referência sobre a relação do controle e as funções soberanas, demonstrando não ser ele uma "quarta função estatal", mas presente em cada uma delas na sua relação horizontal e aos específicos atos de suas respectivas competências. 
da fiscalização ou competência, na prática, possa ser confiada, consti-

\section{REFERÊNCIAS}

ALLORIO, Enrico. Saggio polemico sulla giurisdizione volontaria. Rivista trimestrale di Diritto e Procedura Civile, Milano, v. 2, p. 487-529, 1948.

CANAS, Vitalino. Os processos de fiscalização da constitucionalidade e da legalidade pelo Tribunal Constitucional: natureza e princípios estruturantes. Coimbra: Coimbra 1986.

CAPPELLETTI, Mauro. Pronunce di rigetto nel processo costituzionale delle libertà e cosa giudicata. Rivista di Diritto Processuale, Padova, v. 11, n.1, p.135-166, 1956.

CARNEIRO, Athos Gusmão. Jurisdição e competência. 2. ed. São Paulo: Saraiva, 1983.

CASTILHO NETO, Arthur de. Reflexões críticas sobre a ação direta de constitucionalidade no Supremo Tribunal Federal. Revista da Procuradoria-Geral da República, SãoPaulo,n.2,p. 11-39, jan./mar. 1993.

DIAS, Maria Berenice. Juridição voluntária e coisa julgada. Revista Estudos Jurídicos, São Leopoldo, v. 21, n. 49, p. 53-72, maio/ago. 1987.

FABRÍCIO, Adroaldo Furtado. As novas necessidades do processo civil e os poderes do juiz. Estudos tucionalmente, a um de seus poderes; no caso brasileiro, ao Poder Judiciário.

Jurídicos, São Leopoldo, v. 25, n. 64, p. 57-63, maio/ago. 1992.

FERREIRA MENDES, Gilmar. Jurisdição constitucional: o controle abstrato de normas no Brasil e na Alemanha. 3. ed. São Paulo: Saraiva, 1999.

. Processo e julgamento da ação direta de inconstitucionalidade e da ação declaratória de constitucionalidade perante o Supremo Tribunal Federal: uma proposta de Projeto de Lei. Cadernos de Direito Tributário e Finanças Públicas, São Paulo, v. 6, n. 23, p. 10-23, abr.jun. de 1998.

GALEOTTI, Sérgio. Introduzione alla teoria dei controlli costituzionali. Milano: Giuffrè, 1963.

GODACCI-PISANELLI, G. Analisi delle funzioni sovrane. Milano: Giuffrè, 1946.

LACERDA, Galeno. Comentários ao código de processo civil; lei $\mathrm{n}{ }^{\circ}$ 5.869 , de 11.01.73. Rio de Janeiro: Forense, 1981. v.8, t.1.

- Despacho saneador. Porto Alegre: La Salle, 1953.

MANCUSO, Rodolfo de Camargo. Manual do consumidor em juizo. 2.ed. São Paulo: Saraiva. 1998.

MARANINCHI, Maria Luiza Ahrends. Natureza jurídica da jurisdição voluntária. Estudos 
Jurídicos, São Leopoldo, v. 19, n.. SILVA, Ovídio A. Baptista da. Curso 45, p. 45-67, jan./ abr. 1986. de processo civil. Porto Alegre:

PORTO, Sérgio Gilberto. Jurisdição voluntária: atividade administrativa ou jurisdicional? Revista Juridica, São Paulo, v. 31, n. 104, p. 90-95, mar./abr. 1984. Fabris, 1987. v.1

TESHEINER, José Maria Rosa. Jurisdição voluntária. Rio de Janeiro: Aide, 1992.

TORNAGHI, Hélio Bastos. Instituições

PRATA, Edson. Jurisdição voluntária. São Paulo: Leud, 1979. de processo penal. São Paulo: Saraiva, 1977.v.2. 



\title{
A proteção internacional do patrimônio cultural ${ }^{*}$
}

\author{
James L. Bischoff ${ }^{\star *}$
}

\section{INTRODUÇÃO}

\section{A) A ameaça ao patrimônio cultural}

A Convenção da UNIDROIT sobre Bens Culturais Furtados ou Ilicitamente Exportados de 1995, o mais atual dos acordos multilaterais que abrangem o tema do patrimônio cultural, apresenta a seguinte definição de "bens culturais": "Entende-se como bens culturais... aqueles bens que, a título religioso ou profano, se revestem (sic) de uma importância para a arqueologia, a pré-história, a história, a literatura, a arte ou a ciência...." O conceito

\footnotetext{
* Trabalho apresentado na disciplina Direito das Relações Internacionais, ministrada pela professora doutora Cláudia Lima Marques, no Curso de Graduação em Ciências Jurídicas e Sociais da Faculdade de Direito da Universidade Federal do Rio Grande do Sul.

** Aluno do Convênio CAPES/FIPSE entre a Universidade Federal do Rio Grande do Sul e a University of Texas at Austin, durante os meses de janeiro a agosto de 2003. Estudante de Direito (J.D.) da University of Texas School of Law e Mestrando (M.A.) em Estudos LatinoAmericanos pela University of Texas Lozano Long Institute of Latin American Studies (LLILAS). Formado em História e Letras Hispânicas pela University of Kentucky. O autor agradece à professora doutora Cláudia Lima Marques, pela colaboração na publicação do presente artigo, e à acadêmica de Direito da UFRGS, Antonia Espíndola Longoni Klee, pelas sugestões lingüísticas e revisão do texto.
}

1 Convenção da UNIDROIT sobre Bens Culturais Furtados ou Ilicitamente Exportados, celebrada em Roma, no dia 24 de junho de 1995, art. $2^{\circ}$ [daqui para diante UNIDROIT 1995]. A Convenção da UNIDROIT foi aprovada no Brasil pelo Decreto Legislativo n. 4, de 21 de janeiro de 1999; foi promulgada, com o texto integral em português, pelo Decreto n. 3.116, de 14 de setembro de 1999. Vide também Stephanie O. Forbes, Securing the Future of Our Past: Current Efforts to Protect Cultural Property, 9 TranSNAT'L LaW 235, 239-40 (1996). 
do patrimônio cultural, então, é bastante extenso: inclui não somente a arte, os artefatos e as antigüidades, mas também os monumentos e edifícios históricos, as ruínas e os navios naufragados, os objetos e locais religiosos e os artefatos contemporâneos de povos indígenas. ${ }^{2}$

Há inumeráveis razões para se proteger e se preservar o patrimônio cultural. Por um lado, algumas expressões culturais, especialmente os monumentos e outras edificações, têm grande valor como depositários do conhecimento e testemunhos da experiência humana; o patrimônio cultural é um retrato da origem e da evolução humana. Por outro lado, o patrimônio cultural tem valor pelo que expressa em termos estéticos, históricos e religiosos; isto é, possui uma importância intrínseca, pois a sua existência nos dá satisfação. Outrossim, os bens culturais que pertencem a um grupo em particular fomentam a sua dignidade, uma vez que promovem a auto-identificação e a autocompreensão; ajudam-lhe a definir a sua singularidade como povo e, para alguns grupos étnicos, são garantidores de força e segurança. ${ }^{3}$

Entretanto, apesar do enriquecimento de nossa vida coletiva que provém da proteção e da preservação dos bens culturais, a segurança e a integridade de tais bens têm sido continuamente comprometidas por diversas atividades humanas. A mais destrutiva não deve surpreender: a guerra tem sido responsável por uma quantidade incalculável de perdas de bens culturais, estes últimos sendo vítimas tanto de incursões e bombardeios, quanto da pilhagem que sempre acompanha os ambientes de conflito e

2 O patrimônio cultural brasileiro, de acordo com a Constituição de 1988, é constituído pelos "bens de natureza material e imaterial, tomados individualmente ou em conjunto, portadores de referência à identidade, à ação, à memória dos diferentes grupos da sociedade brasileira, nos quais se incluem: $a$ ) as formas de expressão; $b$ ) os modos de criar, fazer e viver; $c$ ) as criações científicas; $d$ ) as obras, objetos, documentos, edificações e demais espaços destinados às manifestações artístico-culturais; $e$ ) os conjuntos urbanos e sítios de valor histórico, paisagístico, artístico, arqueológico, paleontológico, ecológico e científico." Constituição Federal da República Federativa do Brasil, promulgada em 5 de outubro de 1988, art. 216. Vide também Helli Alves de Oliveira, Responsabilidade pelos danos ao patrimônio cultural, REVISTA FORENSE, vOL.49, p. 319 (1992), para informação geral sobre o regime brasileiro de proteção do patrimônio cultural.

3 Por exemplo, a escultura Afo-A-Kom, de uma tribo da República de Camarões, dá força e segurança à tribo, mas só quando está fisicamente presente. Vide infra, nota 98 . Vide também Lakshman Guruswamy, Jason C. Roberts and Catina Drywater, Protecting the Cultural and Natural Heritage: Finding Common Ground, 34 TULSA L.J. 713, 716-17 (1999). 
desordem. ${ }^{4}$ Outra formidável atividade que ameaça a segurança do patrimônio cultural é economicamente motivada: o tráfico dos bens culturais furtados ou ilicitamente exportados constitui uma das indústrias mais lucrativas do mundo. ${ }^{5}$ Dentre os protagonistas deste comércio, figuram os seguintes sujeitos: os inescrupulosos e avarentos comerciantes de arte; os colecionadores e os museus nos países importadores, que muitas vezes não sabem do status ilícito dos bens; os "soldados de fortuna" (huaqueros), que violam sítios arqueológicos à procura de algo vendável; e os paupérrimos e desesperados habitantes dos "países fontes", que se submetem a vender os seus tesouros culturais a preços vergonhosamente baixos. ${ }^{6}$ Tanto o comércio desenfreado dos bens culturais, como $o$ aniquilamento ou pilhagem na guerra, privam-nos de uma parte essencial de nossa existência humana e destroem dados científicos do nosso passado comum.

\section{B) A estrutura do artigo}

Para combater a destruição, a deterioração e a descontextualização dos bens culturais, a comunidade internacional tem construído uma variedade de mecanismos jurídicos que buscam criar uma ampla rede de proteção para o patrimônio cultural. A Parte II expõe os principais instrumentos do direito internacional que tratam da salvaguarda dos bens culturais: a Parte II (A) delineia o desenvolvimento histórico das normas protetoras aplicáveis durante a guerra, e a Parte II (B) discute os aspectos centrais do regime criado para tempos de paz. As Partes III e IV abordam, respectivamente, as principais fraquezas da atual rede de instrumentos de proteção e algumas idéias recentemente propostas para o seu melhoramento.

4 Vide, e.g., Joanne Mariner, Liberation and Looting in Iraq, FINDLAW's LEGAL COMMENTARY, Apr. 14, 2003, em http://writ.news.findlaw.com/mariner/20030414.html.

5 Vide Forbes, supra nota 3, p. 238. Vide também Jennifer H. Lehman, The Continued Struggle with Stolen Cultural Property: The Hague Convention, the UNESCO Convention, and the UNIDROIT Draft Convention, 14 ARIZ. J. INT'L \& Comp. L. 527, 528 (1997).

6 Por exemplo, o mercado privado obviamente teve poder o bastante para incentivar os camponeses comuns do Mali a colher e vender quase todas as terracotas preciosas do país. Estas terracotas atualmente formam parte de várias coleções européias, perdendo-se assim o contexto cultural das peças, em conjunto com qualquer oportunidade da grande maioria dos descendentes dos autores das obras de desfrutar daquela parte do seu patrimônio histórico. Vide Lehman, supra nota 7, p. 529. 


\section{O MARCO JURÍDICO INTERNACIONAL PARA A PROTEÇÃO DO PATRIMÔNIO CULTURAL}

A) O desenvolvimento histórico da proibição de danos ao patrimônio cultural durante tempos de guerra

1. O desenvolvimento até a Segunda Guerra

a) A regra antiga: pilhagem permitida

Através da História, a pilhagem indiscriminada e sistemática de obras de arte vinculava-se inextricavelmente ao conceito da guerra; a exibição pública dos "troféus" saqueados de povos vencidos já se tinha tornado um costume para os romanos no transcurso do século IV a.C. Além disso, alguns conflitos armados tiveram como motivo singular a aquisição de bens culturais; por exemplo, o ataque contra Praga, ordenado pela Rainha Cristina da Suíça, em 1648, teve como propósito a captura da coleção de arte do Imperador Rodolfo. ${ }^{7}$

\section{b) A mudança da atitude internacional quanto à pilha- gem durante o século XIX}

Logo no princípio do século XIX, porém, a atitude internacional quanto a certos atos de pilhagem dos bens culturais na guerra começou a mudar. Uma característica notória das campanhas napoleônicas foi a apropriação dos bens culturais dos povos europeus vencidos, a fim de enriquecer o novo Musée Napoléon (hoje Musée du Louvre) em Paris; os termos nos acordos de paz assinados por Napoleão sempre incluíam a entrega de obras de arte para a França, uma prática considerada particularmente insultante e ofensiva pelas vítimas. ${ }^{8}$ Quando as Forças Aliadas lograram vencer Napoleão, ordenaram a repatriação (parcial, pelo menos) dos bens apropriados pelos franceses. Durante a mesma época, surgiu um longo e vigoroso debate na Europa, sobre a legalidade e a moralidade da remoção dos chamados "Mármores de Elgin" e sua subseqüente compra pelo Governo inglês. Os Mármores, originalmente pertencentes à Acrópole de Antenas e que por séculos estavam sob o controle do Império Otomano, tinham sido apropriados pelo militar inglês Lorde Elgin. ${ }^{9}$

O segundo período de prolongada discussão internacional sobre a permissão do saque e dos danos ao patrimônio cultural durante a guerra iniciouse na Guerra de Secessão NorteAmericana, com o afamado Código

7 Victoria A. Birov, Prize or Plunder?: The Pillage of Works of Art and the International Law of War, 30 N.Y.U. J. INT'L L. \& PoL. 201, 205 (1997-98).

8 Id. pp. 205-06.

9 John Henry Merryman, The Free International Movement of Cultural Property, 31 N.Y.U. J. INT'L L. \& PoL. 1, 1-2 (1998) [daqui para diante Merryman Free Movement]. 
Lieber de $1863 .{ }^{10}$ O Código, que visava a regular o comportamento das tropas americanas nas suas campanhas militares, contém três artigos que são a gênese do direito internacional humanitário sobre o patrimônio cultural;" $\mathrm{o}$ artigo 35 é o mais ilustrativo deles, proporcionando um status de proteção às obras de arte e às bibliotecas: " $A s$ clássicas obras de arte, as bibliotecas, as coleções científicas ou instrumentos precisos - tais como os telescópios astronômicos -, assim como hospitais, devem ser assegurados contra todos os danos evitáveis, mesmo quando dentro de locais fortificados durante o sitio ou bombardeio."
Os três artigos do Código Lieber serviram como base para a ulterior codificação do direito da guerra, inclusive das regras protetivas dos bens culturais. Assim, o Código é considerado a inspiração jurídica dos Regulamentos de Haia de 1907 e da Convenção de Haia de $1954 .^{12}$

c) O desenvolvimento da
proteção no século $X X$ até a Segunda Guerra

Os Regulamentos de Haia de 1907 contêm as principais regras internacionais sobre o patrimônio cultural do período antes da promulgação da Convenção de $1954 .{ }^{13}$ Um congresso

10 John Henry Merryman, Two Ways of Thinking About Cultural Property, 80 AM. J. INT'L L. 831, 833 (1986) [daqui para diante Merryman Two Ways].

11 Francis Lieber, Instructions for the Government of Armies of the United States in the Field, reimpressa em The Miscellaneous Writings OF Francis Lieber 247 [daqui para diante Código Lieber], arts. 34-36. O texto dos artigos 34-36 aparece a seguir: Art. 34: "As a general rule, the property belonging to churches, to hospitals, or other establishments of an exclusively charitable character, to establishments of education, or foundations for the promotion of knowledge, whether public schools, universities, academies of learning or observatories, museums of the fine arts, or of a scientific character - such property is not to be considered public property ... but it may be taxed or used when the public service may require it." Art. 35: "Classical works of art, libraries, scientific collections, or precise instruments, such as astronomical telescopes, as well as hospitals, must be secured against all avoidable injury, even when they are contained in fortified places whilst besieged or bombarded." Art. 36: "If such works of art, libraries, collections, or instruments belonging to a hostile nation or government can be removed without injury, the ruler of the conquering state or nation may order them to be seized and removed for the benefit of the said nation. The ultimate ownership is to be settled by the ensuing treaty of peace. In no case shall they be sold or given away, if captured by the armies of the United States, nor shall they ever be privately appropriated, or wantonly destroyed or injured."

12 Merryman Free Movement, supra nota 11, p. 3.

13 Regulations to the Convention Concerning Laws and Customs of War on Land, Oct. 18 , 1907, arts. 27, 56, 36 Stat. 2277 [daqui para diante Haia IV]; Convention Concerning Bombardment by Naval Forces in Time of War, Oct. 18, 1907, art. 5, 36 Stat. 2351 [daqui para diante Haia IX]. 
em Haia em 1907, convocado conjuntamente pela Rússia e pelos Estados Unidos, resultou na produção de uma série de regras internacionais para a conduta de guerra. ${ }^{14} \mathrm{O}$ artigo $56 \mathrm{da}$ IV Convenção (sobre as leis e os costumes de guerra terrestre) e o artigo $5^{\circ}$ da IX Convenção (sobre os bombardeios navais) estabelecem o dever dos habitantes das povoações sitiadas ou atacadas de protegerem as edificações dedicadas à religião, à arte e à ciência, através da indicação da presença de tais edificações com sinais distintivos e visíveis. ${ }^{15}$ Aliás, a IV Convenção proíbe a destruição da propriedade do inimigo, a não ser que tal destruição seja imperativamente necessária, e proíbe qualquer confisco de obras de arte. ${ }^{16}$ De acordo com a IV Convenção, os indivíduos responsáveis por ofensas contra a propriedade cultural deveriam ser punidos pelas autoridades de suas nações de origem. ${ }^{17}$
Até depois do final da Segunda Guerra Mundial, a IV Convenção dè Haia de 1907 continuava sendo a principal legislação internacional, regulando o comportamento dos beligerantes. ${ }^{18}$ Os Regulamentos são muito extensos, com mecanismos mínimos de execução. Mas graças a esta generalidade, um número suficiente de Estados já aceitou seus dispositivos para que pudessem vir a ser considerados costume internacional. ${ }^{19}$ Infelizmente, no entanto, estas convenções não foram capazes de prevenir a devastação massiva de catedrais, igrejas, museus e bibliotecas que decorreu da Primeira Guerra Mundial. ${ }^{20}$

Na década de 1930, em virtude da enorme destruição ocasionada pela Primeira Guerra, a comunidade internacional começava a dar mais atenção à criação de uma convenção visando exclusivamente à proteção do patrimônio cultural durante a guerra. ${ }^{21} \mathrm{Em}$

14 Merryman Two Ways, supra nota 12, p. 834-35.

15 Haia IV, supra nota 16, art. 56; Haia IX, supra nota 16 , art. $5^{\circ}$.

16 Haia IV, supra nota 16, art. 56. O artigo 56 dispõe o seguinte: "The property of municipalities, that of institutions dedicated to religion, charity and education, the arts and sciences, even when State property, shall be treated as private property. All seizure of, destruction or willful damage done to institutions of this character, historic monuments, works of art and science is forbidden, and should be made the subject of legal proceedings." 17 Id.

18 Merryman Two Ways, supra nota 12, p. 835.

19 David A. Meyer, The 1954 Hague Cultural Property Convention and its Emergence into Customary International Law, 11 B.U. INT'L L.J. 349, 354 (1993).

20 Birov, supra nota 9, p. 208-09.

21 Merryman Two Ways, supra nota 12, p. 835. 
1935, os países da América promulgaram a primeira destas convenções internacionais, comumente conhecida como Pacto Roerich. ${ }^{22}$ O Pacto determinava que as partes beligerantes tratassem os bens culturais "com respeito e proteção". ${ }^{23}$ Aliás, em 1939, os governos da Bélgica, da Espanha, dos Estados Unidos, da Grécia e da Holanda, através da Liga das Nações, promulgaram a minuta de uma Convenção Internacional para a Proteção dos Monumentos e as Obras de Arte em Tempos de Guerra. Não obstante, a iminente eclosão da Segunda Guerra Mundial, e o conceito nazista de "guerra total", somados às conseguintes ofensas sistemáticas contra os bens culturais, tornaram vãos quaisquer esforços contemporâneos ou anteriores para proteger o patrimônio cultural. ${ }^{24}$

\section{A Segunda Guerra e o \\ Tribunal de Nuremberg}

A Alemanha nazista efetuou o mais completo e sistemático saque de arte da História; Hitler já tinha promulgado um decreto em 1942, autorizando o confisco dos bens culturais dos judeus, assim como dos museus e das bibliotecas dos territórios ocupados. No final da Segunda Guerra, o Einsatzstab Rosenberg, agência encarregada do saque dos territórios vencidos, já tinha pilhado em torno de vinte e duas mil obras de arte da Europa Ocidental e devastado inúmeras coleções na União Soviética, dentre elas o Museu de Leon Tolstoy. ${ }^{25}$

O Tribunal de Nuremberg impulsionou a evolução da proteção internacional do patrimônio cultural, com o julgamento e a condenação de Alfred Rosenberg, o dirigente do Einsatzstab; Rosenberg foi enforcado por, entre outras, ofensas contra a propriedade cultural. ${ }^{26}$ Outros réus foram julgados por tribunais nacionais; um tribunal polonês, por exemplo, condenou o nazista Wilhelm Ernest Palazieux pela pilhagem de bens culturais poloneses. ${ }^{27}$ Os julgamentos que ocorreram em Nuremberg e nos tribunais nacionais, depois da Segunda Guerra, estabeleceram um precedente que seria muito influente: a partir de

22 Treaty on the Protection of Artistic and Scientific Institutions and Monuments (Roerich Pact), Apr. 15, 1935, 49 Stat. 3267, TS No. 899, 167 LNTS 279.

23 Id. art. 52.

24 Vide Merryman Two Ways, supra nota 12, p. 835.

25 Trial of the Major War Criminals Before the International Military Tribunal, Nuremberg, 14 November 1945 - 1 October 1946, International Military Tribunal, pp. 294, 259 (Nuremberg, 1948) [daqui para diante Nuremberg]. Vide também Birov, supra nota 9, pp. 210-11.

26 Nuremberg, supra nota 28, p. 296.

27 Birov, supra nota 9, p. 211. 
então, os indivíduós podiam ser responsabilizados penalmente pelo saque e pela destruição dos bens culturais. $^{28}$

\section{A Convenção de Haia de $\mathbf{1 9 5 4}$}

A destruição massiva que resultou dos bombardeios e dos saques realizados durante a Segunda Guerra Mundial acarretou a elaboração da Convenção para a Proteção de Bens Culturais em Caso de Conflito Armado de $1954 .{ }^{29}$ O primeiro acordo transcontinental visando exclusivamente à proteção do patrimônio cultural, a Convenção de Haia proíbe a pilhagem e a destruição da propriedade cultural na ausência de uma imperativa necessidade militar. ${ }^{30}$ A rationale por trás da criação da Convenção aparece na Exposição de Motivos: "Convencidas de que os danos causados aos bens culturais pertencentes a qualquer povo constituem um prejuizo ao patrimônio

28 Vide, e.g., Convenção para a Proteção de Bens Culturais em Caso de Conflito Armado, assinada na Conferência Internacional reunida em Haia, de 21 de abril a 12 de maio de 1954 , art. 28 [daqui para diante Haia 1954]: "As Altas Partes Contratantes comprometem-se a tomar, no quadro de seus sistemas de direito penal, todas as medidas necessárias para descobrir e castigar com sanções penais ou disciplinares as pessoas, qualquer que seja a nacionalidade das mesmas que tenham cometido ou ordenado que se cometesse uma infração à presente Convenção." Vide também Estatuto do Tribunal Penal Internacional para a ex-lugoslávia, adotado em 25 de maio de 1993, pela Resolução 827 do Conselho de Segurança, disponivel em http://www.un.org/icty/legaldoc/index.htm, art. $3^{\circ}(\mathrm{d})$. Vide também Birov, supra nota 9, p. 211.

29 Haia 1954, supra nota 31 ü A Convenção de Haia foi aprovada no Brasil, com o texto integral em português, pelo Decreto Legislativo n. 32, de 1956; foi promulgada pelo Decreto n. 44.851, de 11 de novembro de 1958.

30 Haia 1954, supra nota 31 , art. $4^{\circ}$ (1). Os três principais parágrafos dispondo sobre os deveres dos Estados-partes seguem: Art. $4^{\circ}$ (1): “As Altas Partes Contratantes comprometem-se a respeitar os bens culturais situados, tanto em seu próprio território, quanto no território das outras Altas Partes Contratantes, abstendo-se de utilizar esses bens, seus sistemas de proteção e suas redondezas para fins que possam expor tais bens à destruição ou deterioração em casos de conflito armado e privando-se de todo ato de hostilidade para com esses bens." Art. $4^{\circ}$ (2): "As obrigações definidas no parágrafo primeiro do presente artigo só poderão deixar de ser cumpridas quando uma necessidade militar impedir de maneira imperativa o seu cumprimento." (ênfase acrescentada) Art. $4^{\circ}$ (3): "As Altas Partes Contratantes comprometem-se, outrossim, a proibir, a impedir e a fazer cessar, quando necessário, qualquer ato de roubo, de pilhagem e de apropriação indevida de bens culturais, qualquer que seja a forma de que venham revestidos esses atos, e, igualmente, todos os atos de vandalismo para com os bens mencionados. Comprometem-se também a não requisitar bens culturais móveis situados no território de outra Alta Parte Contratante." 
cultural de toda a humanidade, dado que cada povo traz a sua própria contribuição à cultura mundial...."

A Convenção de Haia proporciona uma proteção bem mais abrangente do que as precedentes. Embora se restrinja somente às ações das forças armadas durante a guerra, aplica-se a todos os conflitos armados e às ocupações bélicas de qualquer natureza, mesmo que seja um conflito puramente interno. ${ }^{32}$ Aliás, a Convenção fornece uma definição bastante ampla de "bens culturais", incluindo os monumentos de arquitetura, as obras de arte, os manuscritos, os livros de interesse histórico, os museus, as grandes bibliotecas, os depósitos de arquivos, os sítios arqueológicos e os edifícios históricos. ${ }^{33}$

A Convenção estabelece dois deveres principais para os Estados- partes cumprirem. Em primeiro lugar, as partes são obrigadas a respeitar os bens culturais situados tanto em seu próprio território, quanto no território do inimigo; não é permitido usar tais bens para fins que possam expô-los à destruição, que inclui o bombardeio e a requisição. ${ }^{34}$ Além disso, as partes contratantes têm a responsabilidade de proteger os bens; isto é, de proibir e de impedir que ocorra "qualquer ato de roubo, de pilhagem e de apropriação indevida de bens culturais", inclusive os atos de vandalismo. ${ }^{35} \mathrm{O}$ Protocolo da Convenção aplica-se aos territórios ocupados, obrigando as forças no controle a impedir a exportação dos bens culturais. ${ }^{36}$

Seguindo o precedente estabelecido pelo Tribunal de Nuremberg, a Convenção prevê um tipo de sanção para o descumprimento de seus dispositivos: o

\section{Id., Exposição de Motivos.}

32 Id. arts. $18^{\circ}(1), 18^{\circ}(2)$ e $19^{\circ}(1)$. O texto destes artigos segue: Art. $18^{\circ}$ (1): "Com exceção das disposições que devem entrar em vigor em tempo de paz, a presente Convenção será aplicada em caso de guerra declarada, ou de qualquer outro conflito armado que possa surgir entre duas ou mais das Altas Partes Contratantes, mesmo quando qualquer delas não reconheça o estado de guerra." Art. $18^{\circ}$ (2): "A Convenção será aplicada igualmente em todos os casos de ocupação inteira ou parcial do território de uma Alta Parte Contratante, mesmo quando essa ocupação não encontrar nenhuma resistência militar." Art. $19^{\circ}$ (1): "Em caso de conflito armado que não tenha caráter internacional e que tenha surgido no território de uma das Altas Partes Contratantes, cada uma das Partes em conflito ficará obrigada a aplicar, pelo menos, as disposições desta Convenção relativas ao respeito dos bens culturais."

$33 I d$ arts. $1^{\circ}$ (a)-(c).

34 Id. $\operatorname{art} .4^{\circ}(1)$.

35 Id. $\operatorname{art} .4^{\circ}(3)$.

36 Protocol for the Protection of Cultural Property in the Event of Armed Conflict, May 14, 1954, 249 U.N.T.S. 358 (1954), §§ 1-3. 
castigo com sanções penais de quaisquer pessoas de qualquer nacionalidade "que tenham cometido ou ordenado que se cometesse uma infração" ao tratado. ${ }^{37}$ Esta linguagem parece autorizar e até obrigar os países em cujo território se encontram violadores a processar penalmente estas pessoas. ${ }^{38}$

A ampla proteção proporcionada pela Convenção de 1954 aos bens culturais, no entanto, é limitada em um importante aspecto: o artigo $4^{\circ}(2)$ prescreve que as obrigações de salvaguardar os bens culturais "poderão deixar de ser cumpridas quando uma necessidade militar impedir de maneira imperativa o seu cumprimento". ${ }^{39}$ Isto significa dizer que a necessidade militar pode justificar a destruição dos bens culturais que normalmente seriam protegidos. Um exemplo clássico é o bombardeio de uma igreja que se encontrava ao lado de uma fábrica de munições. Ainda que a Convenção não defina as fronteiras da "necessidade militar" - o que tem gerado muita polêmica desde 1954 -, um dispositivo análogo do Código Lieber ilumina o debate: " $A$ necessidade militar... consiste na necessidade de todas as medidas que são indispensáveis para assegurar os fins da guerra..." "40 A exceção da necessidade militar, discutida em mais detalhes abaixo, constitui, talvez, a maior fraqueza da Convenção de Haia.

A Convenção de Haia de 1954 e seu Protocolo continuam sendo os únicos instrumentos mundiais dedicados exclusivamente à proteção dos bens culturais durante o conflito armado. ${ }^{41}$ Em março de 2003, eram 105 Estadospartes ao tratado. ${ }^{42}$

\section{As convenções de Genebra $e$ seus protocolos}

As Convenções de Genebra de 1949 , principais instrumentos estabelecendo as regras que regulam a condução da guerra em geral, não

37 Haia 1954, supra nota 30, art. 28.

38 Merryman Two Ways, supra nota 12, p. 836.

39 Haia 1954 , supra nota 31 , art. $4^{\circ}(2)$.

40 Código Lieber, supra nota 13, art. 14. O artigo 14 dispõe o seguinte: "Military necessity, as understood by modern civilized nations, consists in the necessity of those measures which are indispensable for securing the ends of war, and which are lawful according to the modern law and usages of war."

41 Birov, supra nota 9, p. 218.

42 Vide UNESCO, Convention and First Protocol for the Protection of Cultural Property in the Event of Armed Conflict (The Hague, 14 May 1954), List of the 105 States Parties, em http://www.unesco.org/ culture/laws/hague/html_eng/page9.shtml. 
contêm dispositivos específicos sobre a proteção da propriedade cultural. Em 1978, no entanto, quando a comunidade internacional se reuniu para renovar e atualizar as Convenções de Genebra, os delegados se detiveram especificamente no tema da preservação dos bens culturais. ${ }^{43}$ O princípio fundamental que ao final foi resguardado nos Protocolos é o seguinte: os beligerantes devem distinguir entre os objetos civis e os objetos militares, e devem dirigir suas ações militares só contra estes últimos. ${ }^{44}$ Em termos específicos, os Protocolos proíbem "quaisquer atos de hostilidade cometidos contra os monumentos históricos, as obras de arte ou o patrimônio cultural ou espiritual dos povos. "45 Embora os Protocolos de Genebra não trouxessem inovações ao corpo jurídico internacional protetor dos bens culturais, ajudaram a ampliar e fortalecer o princípio segundo o qual o desrespeito ao patrimônio cultural constitui um crime de guerra. ${ }^{46}$

\section{Os estatutos dos tribunais penais internacionais}

Apesar do novo marco normativo do pós-guerra proibir os ataques contra os bens culturais, a destruição do patrimônio cultural, durante a prolongada guerra na ex-Iugoslávia, assumiu uma forma particularmente brutal: as campanhas sérvias de limpeza étnica incluíam como tática essencial a destruição e a pilhagem dos objetos e dos monumentos culturais dos povos alvos, visando assim a apagar qualquer lembrança histórica destas comunidades. ${ }^{47}$ O Conselho de Segurança da ONU, quando constituiu o Tribunal Penal Internacional para a exIugoslávia, incluiu os crimes de pilhagem e de destruição dos bens culturais no artigo $3^{\circ}(\mathrm{d})$ do Estatuto; dentre as violações das leis e dos costumes de guerra se encontram "o confisco, a destruição ou o dano intencional às instituições dedicadas à religião, à caridade e à educação, às artes e às ciências, aos monu-

\section{Birov, supra nota 9, p. 219.}

44 Protocol Additional to the Geneva Conventions of 12 August 1949, and Relating to the Protection of Victims of International Armed Conflicts (Protocol I), opened for signature Dec. 12, 1977, art. 56, 1125 U.N.T.S. 3 [daqui para diante Protocolo I de 1977]; Protocol Additional to the Geneva Conventions of 12 August 1949, and Relating to the Protection of Victims of Non-International Armed Conflicts (Protocol II), opened for signature Dec. 12, 1977, art. 16, 1125 U.N.T.S. 609 [daqui para diante Protocolo II de 1977].

45 Protocolo I, supra nota 47, art. 56; Protocolo II, supra nota 47, art. 16.

46 Birov, supra nota 9, p. 220.

47 Id. 
mentos históricos e às obras de arte e ciência "48 No caso "Bósnia Herzegovina", atualmente tramitando perante a Câmara de Primeira Instância, os réus Radovan Karadzic e Ratko Mladic estão sendo processados, entre outros crimes, pela destruição a instituições dedicadas à religião, sob o artigo $3^{\circ}$ (d) do Estatuto..$^{49}$ O Estatuto do novo Tribunal Penal Internacional também reconhece os ataques contra o patrimônio cultural como crime de guerra. ${ }^{50}$

\section{b) O desenvolvimento histórico da proibição de danos ao patrimônio cultural durante tempos de paz \\ O processo da construção de um regime jurídico internacional que visa a}

proteger o patrimônio cultural em tempos de paz desenvolveu-se independentemente do processo análogo para tempos de guerra, e é muito mais recente, começando a sério apenas em 1970, com a promulgação da Convenção da UNESCO. ${ }^{51} \mathrm{~A}$ diferença central entre os dois regimes é a de que os instrumentos para tempos de guerra aplicam-se somente à conduta das forças armadas, enquanto os instrumentos para tempos de paz também regulam a conduta de agentes privados. Outra diferença fundamental é a de que os instrumentos para tempos de paz se concentram principalmente no comércio dos bens culturais, enquanto os instrumentos para tempos de guerra também protegem a sua integridade física.

48 Estatuto do Tribunal Penal Internacional para a ex-Iugoslávia, supra nota 31 , art. $3^{\circ}$ (d) (tradução livre). $\mathrm{O}$ artigo $3^{\circ}$ (d) dispõe: "The International Tribunal shall have the power to prosecute persons violating the laws or customs of war. Such violations shall include, but not be limited to: ... (d) seizure of, destruction or wilful damage done to institutions dedicated to religion, charity and education, the arts and sciences, historic monuments and works of art and science..."

49 Vide Indictment, Prosecutor v. Kradzic e Mladic, ICTY Case No. IT-95-5-I, Count 6, disponível em $\mathrm{http} / / \mathrm{www} . u n . o r g / i c t y /$ indictment/english/kar-ii950724e.htm.

50 Estatuto de Roma do Tribunal Penal Internacional, aprovado em 17 de julho de 1998, art. $8^{\circ}(2)$. O artigo $8^{\circ}(2)$ dispõe: "A los efectos del presente Estatuto, se entiende por 'crímenes de guerra' ... (b) violaciones graves de las leyes y usos aplicables en los conflictos armados internacionales dentro del marco establecido de derecho internacional, a saber, cualquiera de los actos siguientes: (ix) [d]irigir intencionalmente ataques contra edificios dedicados a la religión, la educación, las artes, las ciencias o la beneficencia, los monumentos históricos ...." O Estatuto de Roma foi aprovado no Brasil pelo Decreto Legislativo n. 112, de 2002. 51 Convenção sobre as Medidas a Serem Adotadas para Proibir e Impedir a Importação, Exportação e Transferência de Propriedade Ilícita dos Bens Culturais, aprovada pela XVI Sessão da Conferência Geral da Organização das Nações Unidas para a Educação, a Ciência e a Cultura (UNESCO), realizada em Paris, de 12 de outubro a 14 de novembro de 1970 [daqui para diante UNESCO 1970]. A Convenção foi aprovada no Brasil, com o texto integral em português, pelo Decreto Legislativo n. 71, de 1972. Vide também Birov, supra nota 9, p. 221. 
1. A Convenção da UNESCO de 1970

O primeiro e principal instrumento internacional que visa a proteger os bens culturais em tempos de paz é a Convenção da UNESCO sobre as
Medidas a Serem Adotadas para Proibir e Impedir a Importação, Exportação e Transferência de Propriedade Ilícita dos Bens Culturais de 1970.52 A Convenção proíbe o contrabando de bens culturais furtados ou ilegalmente exportados. ${ }^{53}$

52 Id. Os instrumentos predecessores da Convenção da UNESCO são os seguintes: Resolução XIV, Proteção dos Monumentos Móveis, do $7^{\circ}$ Congresso Internacional de Estados Americanos de 1933; três minutas de convenções internacionais preparadas pela Liga das Nações em 1933, 1936 e 1939; e a Recomendação da UNESCO sobre as Medidas para Proibir e Impedir a Exportação, Importação e Transferência de Propriedade Ilícita dos Bens Culturais de 1964. Merryman Two Ways, supra nota 12, 842. Vide também Roger W. Mastalir, A Proposal for Protecting the "Cultural" and "Property" Aspects of Cultural Property Under International Law, 16 FoRDHAM INT'L L.J. 1033, 1053 (1992-93).

53 UNESCO 1970, supra nota 54, art. $3^{\circ}$ A definição dos bens culturais da Convenção da UNESCO é bem mais ampla do que a da Convenção de Haia de 1954. A definição se encontra no artigo $1^{\circ}$ : "Para os fins da presente Convenção, a expressão 'bens culturais' significa quaisquer bens que, por motivos religiosos ou profanos, tenham sido expressamente designados por cada Estado como de importância para a arqueologia, a pré-história, a história, a literatura, a arte ou a ciência e que pertençam às seguintes categorias:

a) as coleções e exemplares raros de zoologia, botânica, mineralogia e anatomia, e objetos de interesse paleontológico;

b) os bens relacionados com a história, inclusive a história da ciência e da tecnologia, com a história militar e social, com a vida dos grandes estadistas, pensadores, cientistas e artistas nacionais e com os acontecimentos de importância nacional;

c) o produto de escavações arqueologias (tanto as autoridades quanto as clandestinas) ou de descobertas arqueologias;

d) elementos procedentes do desmembramento de monumentos artísticos ou históricos e de lugares de interesse arqueológico;

e) antigüidades de mais de cem anos, tais como inscrições, moedas e selos gravados;

f) objetos de interesse etnológico;

g) os bens de interesse artístico, tais como:

(i) quadros, pinturas e desenhos feitos inteiramente a mão sobre qualquer suporte e em qualquer material (com exclusão dos desenhos industriais e dos artigos manufaturados a mão);

(ii) produções originais de arte estatuária e de escultura em qualquer material;

(iii) gravuras, estampas e litografias originais;

(iv) conjuntos e montagens artísticas em qualquer material;

h) manuscritos raros e incunábulos, livros, documentos e publicações antigos de interesse especial (histórico, artístico, científico, literário, etc.), isolados ou em coleções;

i) selos postais, fiscais ou análogos, isolados ou em coleções;

j) arquivos, inclusive os fonográficos, fotográficos e cinematográficos;

k) peças de mobília de mais de cem anos e instrumentos musicais antigos." 
Qualquer exportação ou transferência de propriedade que contraria as leis do país de origem denomina-se "ilícita" sob o artigo $3^{\circ} ; 54$ os Estadospartes se comprometem a prevenir a importação de tais bens e a ajudar a sua repatriação. ${ }^{55}$ Para esses fins, a Convenção estabelece mecanismos para que um Estado-parte possa entrar em pactos bilaterais para reconhecer e executar as leis nacionais de outro Estado-parte. ${ }^{56}$ As partes também se comprometem a tomar as medidas necessárias para impedir que os museus nacionais adquiram bens culturais ilegalmente exportados. ${ }^{57}$

A rationale que inspirou a Convenção encontra-se na sua Exposição de Motivos: "Considerando que os bens culturais constituem um dos elementos básicos da civilização e da cultura dos povos, e que seu verdadeiro valor só pode ser apreciado quando se conhecem, com a maior precisão, sua origem, sua história e seu meio ambiente.... ",58 Os autores do tratado preocupavam-se majoritariamente com a difundida remoção dos bens culturais de países de poucos recursos econômicos para um pequeno grupo de países ricos aquisitivos, para ocuparem seus museus e suas coleções privadas. ${ }^{59}$ Outra preocupação importante era com a descontextualização da propriedade cultural: as escavações clandestinas privam de informações arqueológicas e etnológicas tanto o objeto furtado, quanto o lugar de onde foi tirado; estas informações teriam sido preservadas, caso a escavação tivesse sido supervisionada e documentada. ${ }^{60}$

Em julho de 2003, a Convenção da UNESCO de 1970 contava com a participação de 100 Estados-partes. Dentre eles, a maior parte são países fontes de bens culturais; até muito recentemente, unicamente os Estados Unidos, o Canadá e a Austrália podiam ser considerados países importadores de bens culturais. Esta falta de participação ativa na Convenção, por parte de muitos países importadores, inclusive o Japão e toda a Europa Ocidental, tem constituído uma das maiores fraquezas do tratado, tema discutido em mais detalhes abaixo. ${ }^{61}$

$54 \mathrm{Id}$ art. $3^{\circ}$.

$55 \mathrm{Id}$ art. $2^{\circ}(2)$.

$56 I d$. arts. $9^{\circ}, 13$ e 15.

$57 \mathrm{Id}$. art. $7^{\circ}(1)$.

58 ld., Exposição de Motivos.

59 Mastalir, supra nota 55, p. 1054.

60 Merryman Two Ways, supra nota 12, p. 843.

61 Forbes, supra nota 3, p. 240. 
2. A Convenção da UNESCO de 1972

A Convenção da UNESCO Relativa à Proteção do Patrimônio Mundial, Cultural e Natural foi adotada em 1972, para suplementar a Convenção da UNESCO de $1970 .{ }^{62}$ Estabelece um sistema de cooperação internacional para apoiar as partes, especialmente aquelas de recursos limitados, a conservar e identificar o seu patrimônio cultural e natural. ${ }^{63}$ Ademais, determina a criação de um inventário internacional dos bens do patrimônio cultural e natural de especial importância. ${ }^{64}$

\section{A Convenção da UNIDROIT de 1995}

A Convenção da UNIDROIT sobre Bens Culturais Furtados ou Ilicitamente Exportados, promulgada pelo Instituto Internacional para a Unificação do Direito Privado, em 1995, busca adiantar o propósito da Convenção da UNESCO de 1970, de regular o comércio transnacional de bens culturais. ${ }^{65}$ Os autores da Convenção reconheciam a continuidade e a persistência do tráfico ilegal e a pilhagem de sítios arqueológicos, por causa da ineficácia da Convenção da UNESCO, e resolveram assim fortalecer o regime de proteção. ${ }^{66}$

A Convenção da UNIDROIT estabelece uma via jurídica para a efetiva restituição, a partir da data da sua entrada em vigor, ${ }^{67}$ dos bens culturais ilegalmente exportados, através do mecanismo da carta rogatória. O tribunal de um Estado-parte pode requerer a um tribunal de outro Estado-parte o retorno de bens culturais ilicitamente exportados de seu território; ${ }^{68}$ o requerente deve estabelecer que tal exportação representou um prejuízo significativo à conservação material do bem, à sua integridade, ao seu uso tradicional ou ritual por parte de uma comunidade autóctone ou tribal, ou que o bem possui uma "importância cultural significativa" para o país. ${ }^{69}$

62 Convenção Relativa à Proteção do Patrimônio Mundial, Cultural e Natural, aprovado pela Conferência Geral da UNESCO, em sua XVII sessão, realizada em Paris, de 17 de outubro a 21 de novembro de 1972. A Convenção foi aprovada no Brasil, com o texto integral em português, pelo Decreto Legislativo n. 74, de 1977.

$63 \mathrm{Id}$. art. $5^{\circ}$.

64 Id. art. 11.

65 UNIDROIT 1995, supra nota 3, art. $1^{\circ}$ (a)-(b). Guruswamy, supra nota 5, p. 727.

66 Marilyn E. Phelan, The UNIDROIT Convention on Stolen or Illegally Exported Cultural Objects Confirms a Separate Property Status for Cultural Treasures, 5 VILL. SPORTs \& ENT. L.J. 31, 36-37 (1998). Vide também UNIDROIT 1995, supra nota 3, Exposição de Motivos. 67 Id. art. $10(1)$.

68 Id. art. $5^{\circ}(1)$.

$69 I d$ art. $5^{\circ}(3)(\mathrm{a})-(\mathrm{d})$. 
A obrigação do possuidor de bens furtados, ao invés do possuidor de bens meramente exportados ilegalmente, é mais clara e direta: "O possuidor de um bem cultural furtado deve restituilo. " 70 De acordo com o artigo $3^{\circ}(2)$, um bem cultural obtido através de escavações ilícitas, tanto como um bem licitamente obtido através de escavações, mas ilicitamente retido, considerase furtado. ${ }^{71}$ Além disso, enquanto a proteção conferida pela Convenção da UNESCO limita-se aos bens furtados que fazem parte do inventário de um museu ou de um monumento público, ${ }^{72}$ a Convenção da UNIDROIT estende a sua proteção a qualquer furto de bens culturais. Portanto, os bens furtados de particulares ou de coleções privadas, embora não tenham nenhum registro oficial, podem ser reclamados pelos seus proprietários originais. $^{73}$

Outra inovação importante da Convenção da UNIDROIT é a introdução da possibilidade de indenização para o comprador de boa-fé. ${ }^{74}$ Esta foi uma concessão aos países romanogermânicos, cujas leis reconhecem o direito de titularidade para o sujeito que comprou um objeto sem saber que fora furtado. ${ }^{75}$ Deste modo, enquanto o mandado da restituição dos bens furtados permaneça absoluto, ${ }^{76} \mathrm{o}$ artigo $4^{\circ}$ confere o pagamento de uma indenização eqüitativa ao possuidor que não sabia, ou não devia razoavelmente saber que o bem era furtado, e que pode provar "ter procedido às diligências cabiveis no momento da aquisição. "77 As partes têm que fazer "esforços razoáveis" para que a pessoa que transferiu o bem ao possuidor - seja o saqueador, o contrabandista ou um intermediário - pague a indenização; ${ }^{78}$ se não conseguirem achar pelo menos um dos autores conscientes do delito, o solicitante terá que arcar com o custo da indenização. ${ }^{79}$

Conforme $o$ artigo 12, a Convenção entrou em vigor no dia $1^{\circ}$ de julho de 1998. ${ }^{80}$ Em julho de 2003, dezoito países, na sua maioria países

70 Id. art. $3^{\circ}(1)$.

71 Id. art. $3^{\circ}(2)$.

72 UNESCO 1970, supra nota 54 , art. $7^{\circ}$ (b)(i).

73 Vide Forbes, supra nota 3, p. 246-47.

74 Guruswamy, supra nota 5, p. 728.

75 Forbes, supra nota 3, p. 247.

76 UNIDROIT 1995, supra nota 3 , art. $3^{\circ}(1)$.

$77 \mathrm{Id}$. art. $4^{\circ}(1)$.

78 Id. art. $4^{\circ}(2)$.

79 Id. art. $4^{\circ}(3)$.

80 Id. art. 12; Guruswamy, supra nota 5, p. 727. 
exportadores de bens culturais, já a tinham ratificado. ${ }^{81}$

\section{A INSUFICIENTE PROTEÇÃO DO PATRIMÔNIO CULTURAL PELO REGIME INTERNACIONAL}

Apesar da enorme ampliação, a partir do fim da Segunda Guerra Mundial, da rede de instrumentos jurídicos internacionais que visam a salvaguardar os bens culturais, dois fatos recentes bastam para evidenciar a contínua ineficácia do regime de proteção. Na ex-Iugoslávia, durante a década de 1990, os dispositivos da Convenção de Haia foram deliberada, sistemática e flagrantemente violados durante o que chegou a ser uma guerra cultural. Além disso, apesar da multiplicidade de esforços, desde 1970, para frear o tráfico ilícito de bens culturais, o comércio destes, furtados ou ilegalmente exportados, constitui uma das indústrias mais vantajosas no mundo contemporâneo, superado em termos de lucro só pelo narcotráfico. ${ }^{82}$ Esta Parte discutirá os aspectos dos três tratados internacionais principais, a Convenção de Haia de 1954, a
Convenção da UNESCO de 1970 e a Convenção da UNIDROIT de 1995, que têm permitido ou provocado a permanência da fragilidade do regime.

\section{A) A ineficácia da Convenção de Haia de 1954}

A fraqueza mais evidente da Convenção de Haia de 1954 é a qualificação da proteção pelo conceito da necessidade militar; uma imperativa necessidade militar justifica a destruição de bens culturais que normalmente desfrutariam de proteção. ${ }^{83} \mathrm{Em}$ primeiro lugar, como a Convenção não tem nenhum dispositivo que defina "necessidade militar", ou que estipule as circunstâncias que justificariam a invocação da doutrina, os comandantes militares freqüentemente substituem a palavra "necessidade" pela palavra "conveniência", uma vez que se encontram no campo de batalha. Por dar o direito de definir ao comandante (homem que talvez não consiga apreciar a significância de certos sítios culturais, ou que não tenha tempo suficiente para tomar uma decisão racional), a Convenção, assim, fica sujeita à arbitrariedade em sua interpretação. ${ }^{84}$ Ademais, na prática, os comandantes

81 Em julho de 2003, a Convenção contava com dezoito Estados-partes: Lituânia, Paraguai, Romênia, Peru, Hungria, Bolívia, Finlândia, Itália, Croácia, Camboja, Portugal, China, Equador, Brasil, El Salvador, Argentina, Noruega e Espanha. Vide http://www.unidroit.org/ english/implement/i-95.htm para a lista de Estados-partes e a data de ratificação ou adesão de cada um.

82 Forbes, supra nota 3, p. 238.

83 Haia 1954 , art. $4^{\circ}(2)$.

84 Birov, supra nota 9, p. 243-44. 
consideram outros valores, como a proteção à vida e à saúde das suas tropas, acima da proteção do patrimônio cultural, validando tal hierarquia com a invocação da "necessidade". ${ }^{85}$ Assim, "o patrimônio cultural de toda a humanidade" é posto à mercê dos interesses paroquiais de certos beligerantes. ${ }^{86}$

Outro aspecto que diminui a eficácia da Convenção de Haia é a falta de sanções autônomas e automáticas para os que transgridem os seus dispositivos; não existe nenhum organismo internacional independente para executar o tratado e punir os infratores. A única menção a sanções é encontrada no artigo 28 , que estabelece o dever de cada país de processar penalmente os violadores que se encontrem no seu território. ${ }^{87}$ Ademais, o número de Estados-partes da Convenção, apesar das quase cinco décadas de sua existência, é relativamente baixo; dentre os membros permanentes do Conselho de Segurança da ONU, apenas a França e a Rússia já ratificaram a Convenção de Haia. ${ }^{88}$

\section{B) A ineficácia da Convenção da UNESCO de 1970}

O maior defeito da Convenção da UNESCO, já mencionado acima, tem sido a falta de participação no tratado, até muito recentemente, por parte da maioria dos países importadores de bens

85 Merryman Two Ways, supra nota 12, p. 838. Enquanto os comandantes militares, quando têm que decidir entre a destruição de um monumento cultural e a segurança das suas tropas, quase invariavelmente optam por destruir o monumento, a atitude de Sir Harold Nicolson é interessante: "Não estou entre aqueles que sentem que os sítios religiosos têm mais importância do que as vidas humanas ...; nem hesitaria, se eu fosse comandante militar, a destruir algum prédio de significação puramente histórica se eu achasse que assim poderia assegurar uma vantagem tática ou diminuir o perigo para os meus homens. As obras de enorme valor artístico, no entanto, estão em uma categoria completamente diferente. Acho que é absolutamente desejável que tais obras sejam preservadas da destruição, mesmo que a sua preservação envolva o sacrifício de vidas humanas. Certamente eu estaria preparado para tomar um tiro na cabeça se tivesse certeza de que por tal sacrifício eu poderia preservar os afrescos de Giotto; de igual forma, não hesitaria por um instante ... a salvar a Catedral de São Marcos, mesmo sabendo que assim asseguraria a morte dos meus filhos... Minha atitude se governaria por um principio que é, sem dúvida, incontroverso. O insubstituível é mais importante do que o substituível, e a perda até da vida humana mais valiosa é ultimamente menos desastrosa do que a perda de algo que em nenhuma circunstância pode ser criado de novo." Id. p. 840 (tradução livre).

86 Vide Haia 1954, supra nota 31, Exposição de Motivos.

$87 \mathrm{Id}$. art. 28.

88 Birov, supra nota 9, p. 228. Os Estados Unidos se recusaram a ratificar o tratado porque, dentre outras razões, limitaria as suas opções, se eclodisse uma guerra nuclear. Id. 
culturais. ${ }^{89}$ Os Estados importadores que não ratificaram citam várias razões por sua oposição ao tratado. Em primeiro lugar, diversos países da União Européia alegam que a Convenção é incompatível com certos regulamentos de mercado da Comunidade Européia. Ademais, muitos temem que, por ratificar o tratado, seriam pressionados a repatriar os bens culturais previamente adquiridos, que por muito tempo estão expostos tranqüilamente nos seus museus. Depois de séculos de guerras nas quais o saque era perfeitamente permitido e até encorajado, as coleções européias de bens culturais estrangeiros não são insignificantes. Outrossim, parece haver uma certa falta de incentivo para os Estados ricos se ligarem ao tratado, porque já estabeleceram seus próprios sistemas efetivos para a proteção dos seus bens culturais nacionais. ${ }^{90}$ Até 1997, das grandes economias de mercado, somente os Estados Unidos, o Canadá e a Austrália tinham ratificado a Convenção; ${ }^{91}$ há nova razão para o otimismo, no entanto, com as recentes ratificações da França, do Japão e do Reino Unido. ${ }^{92}$

Sob a Convenção da UNESCO, apenas o Estado é dotado com a capacidade de designar quais dos bens culturais no seu território receberão a proteção conferida pelo tratado..$^{93}$ Este enfoque exclusivo no vínculo entre $o$ Estado e o patrimônio cultural nega aos povos indígenas e a outros grupos étnicos a habilidade de designar os bens com os quais eles se associam ou que consideram sagrados..$^{94}$ Como resulta-

89 Guruswamy, supra nota 5, p. 726-27; vide também Lehman, supra nota 7, p. 540. A Convenção foi implementada nos Estados Unidos pela Convention on Cultural Property, 19 U.S.C. S 2601 e no Canadá pela Cultural Property Export and Import Act, S.C., ch. 50, S 31(2) (1975).

90 Jason C. Roberts, The Protection of Indigenous Populations' Cultural Property in Peru, Mexico and the United States, 4 Tulsa J. Comp. \& InT'L L. 327, 336, 338 (1997).

91 Guruswamy, supra nota 5, p. 726-27. A Convenção foi implementada nos Estados Unidos pela Convention on Cultural Property, 19 U.S.C. S 2601 e no Canadá pela Cultural Property Export and Import Act, S.C., ch. 50, S 31(2) (1975).

92 Vide UNESCO, Convention on the Means of Prohibiting and Preventing the Illicit Import, Export and Transfer of Ownership of Cultural Property (Paris, 14 November 1970), List of the 100 States Parties as of 27 June 2003, em http://www.unesco.org/culture/laws/ 1970/html_eng/page3.shtml. A França ratificou a Convenção em 1997; o Reino Unido e o Japão a ratificaram em 2002. A Alemanha ainda não a ratificou.

93 UNESCO 1970, supra nota 54, art. $1^{\circ}$ : "Para os fins da presente Convenção, a expressão 'bens culturais' significa quaisquer bens que, por motivos religiosos ou profanos, tenham sido expressamente designados por cada Estado como de importância para a arqueologia, a pré-história, a história, a literatura, a arte ou a ciência..." (ênfase minha).

94 Ana Sljivic, Why Do You Think It's Yours? An Exposition of the Jurisprudence Underlying the Debate Between Cultural Nationalism and Cultural Internationalism, 31 GEO. WASH. J. INT'L L. \& ECON. 393, 398-99 (1997-98). Vide também Mastalir, supra nota 55, p. 1042. 
do, tem havido uma incompleta designação dos bens culturais, porque muitos países, deliberadamente ou por simples desatenção, ignoram o patrimônio cultural de suas comunidades indígenas. De igual maneira, a Convenção também nega à comunidade internacional o direito de designar os objetos merecedores de proteção. ${ }^{95}$

Um grupo de juristas, liderados pelo professor norte-americano John Merryman, tem feito outro tipo de crítica à Convenção da UNESCO: o tratado, por promover o que Merryman chama de "nacionalismo cultural", provoca uma situação na qual grandes quantidades de objetos com valor cultural mundial são "destrutivamente retidas" pelo país de origem..$^{96} \mathrm{O}$ Peru, por exemplo, retém uma abundância de bens culturais que não conserva adequadamente, nem exibe; se tais objetos fossem transferidos para um país com maiores recursos econômicos, poder-se-iam aproveitar dos museus e dos colecionadores que soubessem respeitá-los. Desta maneira, poderiam ser mais bem preservados e estudados, assim como vistos por maiores e mais diversos públicos; tal difusão, na qual os bens se tornam "embaixadores culturais", exibiria para o mundo as riquezas das culturas peruanas. ${ }^{97}$ Merryman sustenta que a melhor maneira para os bens culturais chegarem aos lugares mais capazes de os proteger é através do mercado; aqueles que estão dispostos a pagar o preço mais alto farão o necessário para preservar o seu investimento. A Convenção da UNESCO e as leis nacionais "cobiçosas" (ou egoístas) que ela encoraja, no entanto, opõem-se ao

95 Guruswamy, supra nota 5, p. 727-28.

96 Merryman Two Ways, supra nota 12, p. 846. Há, naturalmente, um grupo de juristas que se opõem a Merryman e aos outros "internacionalistas culturais", liderado por Roger Mastalir. Estes nacionalistas culturais apresentam vários argumentos, os principais dos quais aparecem a seguir, do ponto de vista dos direitos humanos para refutar as hipóteses dos internacionalistas: (1) quando há uma afinidade dos bens culturais com um grupo, aquele patrimônio cultural define e alimenta o grupo (e.g., a escultura Afo-A-Kom, de uma tribo da República de Camarões, dá força e segurança à tribo, mas só quando está fisicamente presente); (2) a importância cultural dos bens se diminui ou se destrói, e a cultura de onde provém se enfraquece, se os bens são afastados do seu contexto cultural; (3) portanto, os bens culturais devem ser estritamente inalienáveis para assegurar não só o valor dos mesmos, mas também a dignidade do grupo que lhes deu a sua origem: os elementos constitutivos de um grupo não se devem tornar bens fungíveis. Claro que esta linha de argumento tem maior força, quando os bens culturais podem ser reclamados por determinados e ainda existentes grupos étnicos dentro do país. Vide Mastalir, supra nota 55, p. 1046, 1062-63; vide também Sljivic, supra nota 97, p. 402; vide também John Moustakas, Group Rights In Cultural Property: Justifying Strict Inalienability, 74 CORNELL L. REv. 1179, 1205(1989).

97 Merryman Two Ways, supra nota 12, p. 846. Vide também Slijivic, supra nota 97, p. 415. 
mercado e, portanto, submetem os bens culturais ao descuido. ${ }^{98}$

\section{C) As perspectivas para a Convenção da UNIDROIT de 1995}

O período curto, durante o qual tem vigorado a Convenção da UNIDROIT, dificulta qualquer avaliação da sua eficácia na prevenção do tráfico ilícito de bens culturais. Não obstante, alguns aspectos do tratado permitem alguns prognósticos dos obstáculos com os quais o tratado terá que lidar.

Em primeiro lugar, parece haver uma persistência na oposição dos Estados importadores de bens culturais à ratificação do tratado. Embora alguns países da Europa Ocidental (a Itália, a Finlândia, a Noruega, a Espanha e Portugal) sejam partes da Convenção da UNIDROIT, o novo tratado ainda não conta com a participação do restante da Europa Ocidental, do Japão, dos Estados Unidos, do Canadá e da Austrália. ${ }^{99}$ Uma razão subjacente a tal oposição poderia ser a mesma que incentivou a falta de adesão de tantos países importadores à Convenção da
UNESCO: os países ricos já têm seus próprios sistemas eficazes para proteger os bens culturais nacionais. Afortunadamente, um dos argumentos em oposição à Convenção da UNESCO, segundo o qual os países não querem ser forçados a repatriar bens culturais adquiridos há muito tempo, não tem a mesma força nos debates sobre a ratificação da Convenção da UNIDROIT: os autores desta convenção, bem conscientes dos temores dos países importadores, estabeleceram uma série de prazos prescricionais dentro dos quais uma ação tem que ser iniciada. ${ }^{100}$

Outra grande dificuldade enfren-tada por este tratado emana da clássica dicotomia entre os países da common law e os países de tradição jurídica romanogermânica. Como se discutia acima, houve um debate entre os delegados durante o congresso que aprovou o texto da Convenção: os países romanogermânicos queriam proteger o comprador de boa-fé dos objetos furtados, enquanto os países da common law queriam uma regra de restituição absoluta dos bens ao proprietário original. ${ }^{101}$ O dispositiva que resultou deste debate

98 Merryman Two Ways, supra nota 12, p. 849.

99 Vide supra, nota 84 para a lista de Estados-partes da Convenção da UNIDROIT.

100 A Convenção estabelece três prazos de prescrição: (1) um prazo de três anos a partir do momento em que o solicitante toma conhecimento do lugar onde se encontra o bem cultural e da identidade do possuidor (art. $3^{\circ}(3)$ ); (2) um prazo máximo de cinqüenta anos a partir do momento do furto (art. $\left.3^{\circ}(3)\right)$; e (3) uma exceção para os bens que são essenciais para o patrimônio cultural de um Estado; em tal caso não há prazo de prescrição (art. $\left.3^{\circ}(4)\right)$. UNIDROIT 1995, supra nota 3, art. $3^{\circ}$ (3)-(4).

101 Vide Forbes, supra nota 3, p. 237. 
plenamente favorece os países da common law: "O possuidor de um bem cultural furtado deve restituilo. "102 Portanto, embora haja uma concessão no tratado, proporcionando uma indenização ao comprador de boafé, o artigo $3^{\circ}(1)$ poderia ainda ser inaceitável para aqueles países romano-germânicos que receiam que tal regra acarretaria incerteza nas relações comerciais. ${ }^{103}$

\section{PROPOSTAS PARA O MELHORAMENTO DO REGIME}

Em vista das múltiplas debilidades do regime atual de proteção internacional do patrimônio cultural, vários autores têm sugerido novas soluções para reforçá-lo, tanto durante os conflitos armados, quanto no âmbito do comércio e da preservação dos bens culturais em tempos de paz.

\section{A) Propostas para melhorar o regime de proteção do patri- mônio cultural durante a guerra}

Para o patrimônio cultural receber a proteção máxima possível, a exceção da necessidade militar tem que ser eliminada ou, pelo menos, circunscrita. Para conseguir tal circunscrição, um dispositivo deve ser acrescentado à Convenção de Haia de 1954, definindo com clareza os limites do termo e incorporando o princípio da proporcionalidade. ${ }^{104}$ Além disso, a decisão de quais situações concretas se constituem de necessidade militar deve ser tirada das mãos do "comandante militar" comum e colocada sob a competência exclusiva das autoridades mais altas.

Também, Charles McConney propõe a criação de uma unidade permanente dentro das forças de manutenção da paz da ONU, para proteger os monumentos e outros bens culturais durante os conflitos armados. ${ }^{105}$

102 UNIDROIT 1995, supra nota 3, art. $3^{\circ}$ (1).

103 Vide Forbes, supra nota 3, p. 237.

104 Durante a guerra, quando as forças de uma parte atacam um objetivo militar e há danos colaterais (isto é, civis feridos ou mortos ou danos a objetos não-militares), invoca-se o princípio da proporcionalidade. Conforme sua formulação no Protocolo I de 1977, os ataques são proibidos, se ocasionarem incidentalmente mortos e feridos entre a população civil, ou danos a bens de caráter civil, ou ambas as coisas, que seriam excessivos com relação à vantagem militar concreta e direta prevista. Desta forma, o princípio da proporcionalidade cria uma obrigação permanente para os comandantes militares compararem os resultados do ataque com a vantagem prevista. Horst Fischer, Principle of Proportionality, CRIMES OF WAR (Roy Gutman \& David Rieff eds., 1999). Vide também Protocolo I, supra nota 47, art. $5^{\circ}$ (b).

105 Charles E. McConney, Draft Proposal for the Creation of A Permanent Monuments, Fine Arts and Archives Unit Within the U.N. Peacekeeping Forces (1992), reimpressa em Patrick J. Boylan, Review of THE CONVENTION FOR THE PRotection of CUltural Property IN the Event of ARMed Conflict (1993), p. 200. 
Esta unidade seguiria o modelo das unidades M.F.A.\& A. (Monuments, Fine Arts \& Archives) da Segunda Guerra Mundial, que as Forças Aliadas estabeleceram em locais vulneráveis para impedir que as catedrais, os museus, as coleções de arte e os prédios históricos fossem saqueados. Da mesma maneira, as forças de paz da ONU poderiam assegurar zonas neutras em áreas de particular importância cultural. ${ }^{106}$

\section{B) Propostas para melhorar o regime de proteção dos bens culturais em tempos de paz}

Uma sugestão para robustecer o regime de proteção do patrimônio cultural em tempos de paz é a criação de um tribunal com competência específica para resolver os conflitos sobre o comércio dos bens culturais. ${ }^{107}$ Ann Prunty sustenta que o tribunal deve possuir o poder jurisdicional para acolher e determinar os conflitos sob as Convenções da UNESCO e da UNIDROIT, e quaisquer acordos bilaterais que existam entre as partes.
Após a entrega dos argumentos escritos de cada parte e uma audiência oral, o tribunal produziria um parecer escrito, explicando o seu raciocínio, assim contribuindo, com cada caso, para a criação de um crescente corpo de jurisprudência. ${ }^{108}$

Uma das principais críticas que John Merryman lança ao nacionalismo cultural é a de que os países fontes não têm a infraestrutura apropriada para preservar os bens culturais que se encontram no seu território. ${ }^{109}$ Roger Mastalir concebe uma solução análoga àquela que foi empregada para combater a destruição da camada de ozônio. Ao perceberem que as normas aplicáveis eram impossíveis de serem cumpridas pelos países subdesenvolvidos, os países desenvolvidos resolveram proporcionar a assistência necessária, através de transferência de tecnologia, de conhecimento técnico e de recursos econômicos. De igual maneira, sustenta Mastalir, poder-se-ia implementar um sistema de transferência de tecnologia para assegurar a

106 Id. p. 201. Vide também Birov, supra nota 9, p. 246.

107 A Convenção da UNESCO de 1970 trata o assunto da resolução de conflitos em apenas um dispositivo. O artigo 17 (5) dispõe o seguinte: "Mediante solicitação de, pelo menos, dois Estados-partes na presente Convenção que se achem envolvidos em uma controvérsia a respeito de sua implementação, a UNESCO poderá oferecer seus bons ofícios a fim de que seja alcançada uma composição entre eles." UNESCO 1970, supra nota 53, art. 17 (5). A Convenção não antecipa nenhum outro procedimento ou mecanismo para resolver os conflitos.

108 Vide Ann P. Prunty, Toward Establishing an International Tribunal for the Settlement of Cultural Property Disputes: How to Keep Greece from Losing Its Marbles, 72 Geo. L. J. 1155, 1167-82(1984).

109 Merryman Two Ways, supra nota 12, p. 846. 
proteção física dos bens culturais e promover a sua maior exibição ao público. ${ }^{110}$ Os países desenvolvidos teriam um incentivo para ajudar, por causa da resultante distribuição de bens culturais por meio de intercâmbios, empréstimos de longo prazo e exibições cooperativas. "'

Catherine Vernon recomenda outra solução para proteger os bens culturais ameaçados de furto, destruição ou deterioração, na forma de um direito de intervenção preventiva, por parte de organizações internacionais ou grupos de Estados, na soberania territorial dos países; ${ }^{112}$ os contornos de tal direito seriam modelados pela Convenção das Nações Unidas sobre o Direito do Mar. ${ }^{113}$ Esta convenção designa os objetos arqueológicos subaquáticos além do mar territorial de cada país como parte do patrimônio cultural da humanidade; a comunidade internacional goza de pleno acesso para estudar e proteger esses objetos. ${ }^{114}$ Alguns autores propõem uma expansão deste direito, na forma de uma nova norma que conceda autoridade limitada à comunidade internacional de intervir para preservar os sítios arqueológicos subaquáticos de particular importância, embora estes se encontrem dentro do mar territorial. ${ }^{115}$ Assim, ainda que o Estado costeiro mantenha o controle preferencial sobre aquela parte do mar, ele não seria exclusivo.

Por analogia, Vernon promove a extensão desta noção aos bens culturais na superfície terrestre. O Estado no qual os bens se situam permaneceria com seus direitos territoriais, sujeitos a um direito superior de intervenção da comunidade internacional, se não proteger suficientemente aqueles objetos que formam parte imprescindível do patrimônio cultural da humanidade. Esta classe de jurisdição extraterritorial se justificaria, já que a proteção inadequada dos bens culturais de valor

110 Mastalir, supra nota 55, p. 1074-77.

111 Id. p. 1081-82.

112 Vide M. Catherine Vernon, Common Cultural Property: The Search For Rights Of Protective Intervention, 26 CASE W. RES. J. INT'L L. 435, 440-45, 471-75 (1994).

113 Vide Convenção das Nações Unidas sobre o Direito do Mar, concluído em Montego Bay, Jamaica, em 10 de dezembro de 1982, U.N. Doc. A/CONF.62/122 (1982). A Convenção foi aprovada no Brasil pelo Decreto Legislativo n. 5, de 1987.

$114 \mathrm{O}$ artigo 149 dispõe: "[A]ll objects of an archaeological and historical nature found in the Area [beyond the twelve-mile national jurisdiction of coastal states] shall be preserved or disposed of for the benefit of mankind as a whole, particular regard being paid to the preferential rights of the States or Country of origin, or the State of cultural origin, or the State of historical and archaeological origin." Id art. 149. O mar territorial se estende por doze milhas náuticas da costa. Id arts. $3^{\circ}-4^{\circ}$.

115 Vernon, supra nota 115, p. 474. 
universal prejudica o interesse que todos os demais têm nesses bens. ${ }^{116}$

\section{CONCLUSÃO}

É preciso ser realista e reconhecer o triste fato de que alguns infratores das regras que visam a proteger o patrimônio cultural, apesar da natureza fundamental destas ou de qualquer universalidade que possam ter atingido, recusar-se-ão a cumprir tais normas, porque o proveito que tiram do continuado descumprimento é grande demais. No âmbito da guerra, embora os princípios subjacentes da Convenção de Haia já alcançassem o status de costume, o tratado ainda não era capaz de impedir a enorme aniquilação de bens culturais que o mundo testemunhou na década de 1990. ${ }^{117}$ Um dos obstáculos deveria ser óbvio: como disse o diretor de um museu na Bósnia, depois de tentar salvar algumas obras de arte de zonas de guerra sob controle sérvio, "ninguém se preocupa com a arte quando as pessoas estão morrendo". ${ }^{118}$ Isto é, as regras jurídicas raramente adiantam em ambientes de destruição sem limite, especialmente quando um dos objetivos centrais dos beligerantes é justamente apagar a identidade cultural do inimigo. Aliás, no contexto das transferências transnacionais dos bens culturais em tempos de paz, a enorme lucratividade do mercado encoraja o tráfico ilícito, dificultando assim qualquer tentativa jurídica de regular o comércio da propriedade cultural.

Mas apesar dos obstáculos que têm enfrentado os esforços internacionais para salvaguardar o patrimônio cultural, também há diversos fatores que estimulam o otimismo. Um destes fatores é o de que, atualmente, depois de decorridos noventa e um anos de adiantamentos jurídicos, desde os Regulamentos de Haia de 1907, até o Estatuto de Roma de 1998, o patrimônio cultural desfruta de uma posição inabalável naquilo que nos dedicamos a defender como comunidade global. Talvez o legado mais duradouro dos instrumentos jurídicos para tempos de guerra seja o desenvolvimento do conceito da responsabilidade penal individual e universal por ofensas cometidas contra o patrimônio cultural, que parece estar dando resultados positivos. ${ }^{119} \mathrm{Na}$ área da proteção durante tempos de paz, embora talvez

116 Id. p. 474-75.

117 Vide Meyer, supra nota 22, p. 351.

118 Birov, supra nota 9, p. 240. Esta hierarquia de facto aplica-se também aos comandantes militares; como mencionado acima, quase invariavelmente colocarão a segurança das suas tropas acima da proteção dos bens culturais, validando quaisquer danos aos bens com a invocação do conceito da necessidade militar. Merryman Two Ways, supra nota 12, p. 838. 119 Vide infra notas 50-53 acima, com texto correspondente. 
seja cedo demais para elogiar ou criticar a efetividade da Convenção da UNIDROIT, a recente onda de ratificações da Convenção da UNESCO de 1970, por parte de alguns dos países de

\section{BIBLIOGRAFIA}

\section{A) Artigos}

BIROV, Victoria A., Prize or Plunder?: The Pillage of Works of Art and the International Law of War, 30 New York UNIVERSITY JourNaL of International LaW \& Policy 201 (1997-98).

FISCHER, Horst, Principle of Proportionality, CRIMES OF WAR (Roy Gutman \& David Rieff eds., 1999).

FORBES, Stephanie O., Securing the Future of Our Past: Current Efforts to Protect Cultural Property, 9 TRANSNAT'L LaW 235 (1996).

GURUSWAMY, Lakshman, Jason C. Roberts and Catina Drywater, Protecting the Cultural and Natural Heritage: Finding Common Ground, 34 Tulsa LaW JouRnal 713 (1999).

LEHMAN, Jennifer H., The Continued Struggle with Stolen Cultural Property: The Hague Convention, the UNESCO Convention, and the UNIDROIT Draft Convention, 14 ARIZONA JOURNAL OF INTERNATIONAL \& Comparative Law 527 (1997). mercado mais significativos, pode assinalar, depois de tantas décadas de divergência, um novo consenso internacional quanto à repugnância do comércio ilícito dos bens culturais. ${ }^{120}$

MARINER, Joanne, Liberation and Looting in Iraq, FindLaW's LeGal Commentary, Apr. 14, 2003, em http://writ.news.findlaw.com/mariner/20030414.html.

MASTALIR, Roger W., A Proposal for Protecting the "Cultural" and "Property" Aspects of Cultural Property Under International Law, 16 FORDHAM INTERNATIONAL LaW JOURNaL 1033 (1992-93).

MERRYMAN, John Henry, Two Ways of Thinking About Cultural Property, 80 AMERICAN JOURNAL OF INTERNATIONAL LAW 831 (1986).

MERRYMAN, John Henry, The Free International Movement of Cultural Property, 31 NEW YORK UNIVERSITY JOURNAL OF INTERNATIONAL LaW \& Policy 1 (1998).

MEYER, David A., The 1954 Hague Cultural Property Convention and its Emergence into Customary International Law, 11 BostoN UNIVERSITY INTERNATIONAL LAW JOURNAL 349 (1993).

MOUSTAKAS, John, Group Rights In Cultural Property: Justifying

${ }^{120}$ Vide infra nota 95 acima, com texto correspondente. 
Strict Inalienability, 74 CORNELL

LAW REVIEW 1179 (1989).

OLIVEIRA, Helli Alves de, Responsabilidade pelos danos ao patrimônio cultural, 319 REVISTA FORENSE 49 (1992).

PHELAN, Marilyn E., The UNIDROIT Convention on Stolen or Illegally Exported Cultural Objects Confirms a Separate Property Status for Cultural Treasures, 5 Villanova Sports \& ENTERTAINMENT LAW JOURNAL 31 (1998).

PRUNTY, Ann P., Toward Establishing an International Tribunal for the Settlement of Cultural Property Disputes: How to Keep Greece from Losing Its Marbles, 72 GEORGETOWN LAW JoURNAL 1155 (1984).

ROBERTS, Jason C., The Protection of Indigenous Populations' Cultural Property in Peru, Mexico and the United States, 4 TULSA JOURNAL OF COMPARATIVE \& INTERNATIONAL LAW 327 (1997).

SLIJIVIC, Ana, Why Do You Think It's Yours? An Exposition of the Jurisprudence Underlying the Debate Between Cultural Nationalism and Cultural Internationalism, 31 GEORGE WASHINGTON JOURNAL OF INTERNATIONAL LAW \& ECONOMICS 393 (1997-98).

VERNON, M. Catherine, Common Cultural Property: The Search for Rights of Protective Intervention, 26 Case Western Reserve Journal of INTERNATIONAL LAW 435 (1994).

\section{B) Tratados internacionais}

Regulations to the Convention Concerning Laws and Customs of War on Land, Oct. 18, 1907, 36 Stat. 2277. Convention Concerning Bombardment by Naval Forces in Time of War, Oct. 18, 1907, Stat. 2351.

Treaty on the Protection of Artistic and Scientific Institutions and Monuments (Roerich Pact), Apr. 15, 1935, 49 Stat. 3267 , TS No. 899,167 LNTS 279.

Convenção para a Proteção de Bens Culturais em Caso de Conflito Armado, assinada na Conferência Internacional reunida em Haia, de 21 de abril a 12 de maio de 1954 .

Protocol for the Protection of Cultural Property in the Event of Armed Conflict, May 14, 1954, 249 U.N.T.S. 358 (1954).

Convenção Relativa à Proteção do Patrimônio Mundial, Cultural e Natural, aprovado pela Conferência Geral da UNESCO, em sua XVII sessão, realizada em Paris, de 17 de outubro a 21 de novembro de 1972. Convenção sobre as Medidas a Serem Adotadas para Proibir e Impedir a Importação, Exportação e Transferência de Propriedade Ilícita dos Bens Culturais, aprovada pela XVI Sessão da Conferência Geral da Organização das Nações Unidas para a Educação, a Ciência e a Cultura (UNESCO), realizada em Paris, de 12 de outubro a 14 de novembro de 1970.

Protocol Additional to the Geneva Conventions of 12 August 1949, and 
Relating to the Protection of Victims of International Armed Conflicts (Protocol I), opened for signature Dec. 12, 1977, 1125 U.N.T.S. 3.

Protocol Additional to the Geneva Conventions of 12 August 1949, and Relating to the Protection of Victims of Non-International Armed Conflicts (Protocol II), opened for signature Dec. 12, 1977, 1125 U.N.T.S. 609.

Convenção das Nações Unidas sobre o Direito do Mar, concluído em Montego Bay, Jamaica, em 10 de dezembro de 1982, U.N. Doc. A/ CONF. 62/122 (1982).

Convenção da UNIDROIT sobre Bens Culturais Furtados ou Ilicitamente Exportados, celebrada em Roma, no dia 24 de junho de 1995.

Estatuto de Roma do Tribunal Penal Internacional, aprovado em $17 \mathrm{de}$ julho de 1998.

\section{C) Outras fontes}

LIEBER, Francis, Instructions for the Government of Armies of the United States in the Field, reimpressa em THE MiscellaneOUS
Writings of Francis Lieber 247. Trial of the Major War Criminals Before the International Military Tribunal, Nuremberg, 14 November 1945 1 October 1946, International Military Tribunal, (Nuremberg, 1948).

Constituição da República Federativa do Brasil, promulgada em 5 de outubro de 1988, art. 216.

MCCONNEY, Charles E., Draft Proposal for the Creation of A Permanent Monuments, Fine Arts and Archives Unit Within the U.N. Peacekeeping Forces (1992), reimpressa em Patrick J. Boylan, ReView of THE CONVENTION FOR tHE Protection of Cultural Property in the Event of Armed Conflict (1993).

Estatuto do Tribunal Penal Internacional para a ex-Iugoslávia, adotado 25.05 .93 pela Resolução 827 do Conselho de Segurança, disponível em http://www.un.org/icty/legaldoc/ index.htm.

Indictment, Prosecutor v. Kradzic e Mladic, ICTY Case No. IT-95-5-I, Count 6, disponivel em http:// www.un.org/icty/indictment/ english/kar-ii950724e.htm. 


\title{
A moralidade administrativa - história de um conceito*
}

\author{
José Guilherme Giacomuzzi ${ }^{\text {** }}$
}

A $\mathrm{CF} / 88$ previu a moralidade administrativa em dois artigos. No art. $5^{\circ}$, LXXIII (quando fala da ação popular), e no art. 37 (quando trata dos princípios da administração pública). Das Constituições que influenciaram de alguma forma a nossa (Alemanha, Portugal, França, Espanha, Itália), nenhuma - e isto me parece digno de nota - trouxe o nome 'moralidade administrativa', nem consta que algum país desenvolvido a contenha. Há, no entanto, notícia de que a Constituição da Colômbia se refere à moralidade administrativa.

É curioso, ou até sintomático, que, passados 14 anos da edição da $\mathrm{CF} / 88$, nenhum jusfilósofo brasileiro tenha-se atrevido ainda a tratar, seja em artigo de doutrina, seja em livro, de forma consistente e preocupada, do tema 'moralidade administrativa', que, à primeira vista, pode dar muito pano para manga, visto que o tema da separação entre Direito e Moral foi, é e talvez sempre será $o$ tema da Filosofia do Direito. Tércio Ferraz Jr. tangenciou tão-somente o assunto recentemente, ${ }^{1}$ mas não disse nada de muito novo. É bem verdade que quase todos os que trataram da matéria, em livros ou artigos, tentaram sempre conferir um colorido filosófico ao tema - como que por

\footnotetext{
* Conferência proferida pelo autor na aula final de formatura dos alunos da Escola Superior do Ministério Público do Rio Grande do Sul, em Porto Alegre, dia 13-11-2002. O texto foi revisado pelo autor para o fim único de inserir as indicações bibliográficas nas notas de rodapé.

** Mestre em Direito Público pela UFRGS, promotor de Justiça no RS, professor da PUC-RS. 1 FERRAZ JÚNIOR, Tércio. Ética Administrativa em um país em desenvolvimento. Cadernos de Direito Constitucional e Ciência Política. São Paulo, v. 22, p. 38-43, jan./ mar. 1998.
} 
obrigação de fazê-lo -, mas, e digo isto com o máximo respeito e já confessando também a minha incapacidade para uma abordagem filosófica, não é menos verdade que impera sobremodo um desconfortável senso comum na doutrina pátria quando se trata de abordar o assunto da vinculação entre Moral e Direito sob o aspecto da moralidade administrativa. Os autores não saem das rasteiras vinculações entre moral e direito, encontráveis em todos os manuais acadêmicos de introdução ao estudo do tema. Os doutrinadores lembram amiúde o caráter interno da moral, que se contraporia ao aspecto externo do Direito, numa evidente - e por vezes expressa influência da concepção de doutrina da moralidade kantiana. Nada muito além disso.

Não há - eu ao menos não conheço - nem mesmo qualquer escrito vinculando a moralidade administrativa com, v.g., a Moral dos Clássicos (aqui considerados como tais Aristóteles e Santo Tomás de Aquino), ou sobre a Moral Religiosa (Cristã, Protestante ou outra), ou sobre a Moral moderna do pós-Kantismo, ou, mais próximo de nós, da chamada pós-modernidade (seja ela o que for), onde está inserido o Estado atual, que, segundo a nossa $\mathrm{CF} / 88$, deve obedecer à moralidade administrativa $\mathrm{e}$ agir de acordo com ela. A única exceção nesse oásis é uma obra que saiu há pouco nas livrarias, da professora desta casa, a procuradora da República Márcia Noll Barboza, obra que, só por ser inédita sob esse aspecto de imbricar Moral e Direito, já merece referência e leitura. ${ }^{2}$ É uma gota no deserto. No entanto, e renovando o respeito, depois de ver-lhe prometido o céu na primeira parte, de pouco mais de 40 páginas, do estudo (no qual a autora diz que abordará a moralidade administrativa à luz da noção da "moral crítica", analisando o que entende importante das doutrinas filosóficas ou jusfilosóficas dos alemães Habermas e Alexy), o leitor se pergunta ao final se na obra não faltam um ou dois capítulos, e o livro volta aos mesmos lugares-comuns antes mencionados, data venia.

Não, não vou eu tratar aqui de uma concepção jusfilosófica da moral administrativa. A isso faltam-me tempo e, sobretudo, conhecimento. Pretendo pisar em terreno mais firme, o dogmático, e demonstrar, ao final, que, ao contrário do que se tem dito e escrito, a moralidade administrativa prevista na $\mathrm{CF} / 88$ não representa, ao menos aquela que veio inscrita no art. $5^{\circ}$, inc. LXXIII, $\mathrm{CF} / 88$, nenhuma novidade de conteúdo. A "outra" moralidade-outro conteúdo, em verdade - parece ser, em termos de 'novidade', bem mais significativa. Ambas, no entanto, são extremamente importantes.

2 BARBOZA, Márcia Noll. O princípio da moralidade administrativa: uma abordagem do seu significado e suas potencialidades à luz da noção de moral crítica. Porto Alegre: Livraria do Advogado, 2002. 
Já se vê dessa rápida introdução que entendo haver dois conteúdos diferentes para as mencionadas "moralidades" - a do art. $5^{\circ}$ e a do art. 37 . Estou distinguindo as coisas, sem separá-las, como sempre lembra Miguel Reale.

Vou dividir então esta exposição em duas partes - falarei do conteúdo da moralidade do art. $5^{\circ}$ num primeiro momento, e da do art. 37 depois -, adiantando que a primeira parte é necessariamente maior que a segunda, porque naquela, a primeira, deverei tratar de desconstruir o mito segundo o qual temos na $\mathrm{CF} / 88$ alguma "novidade", o que me parece ser inteiramente falso. E vou tratar de fazer essa desconstrução não por simples intenção iconoclasta - o que seria irresponsável -, mas porque entendo que ela é necessária para que se extraia da moralidade do art. $5^{\circ}$ um conteúdo mais racional e mais rastreável, uma vez que hoje vivemos no terreno da incerteza. Nessa primeira e maior parte vou frisar sobretudo o aspecto histórico da moralidade administrativa, e é justo por isso que chamei o título desta breve exposição de "A moralidade administrativa - história de um conceito.", nome aliás que foi sugerido pela prof $\mathrm{f}^{\mathrm{a}} \mathrm{dr}^{\mathrm{a}}$ Judith Martins-Costa, que compunha a banca examinadora quando da minha defesa de dissertação de mestrado em dezembro/2000 na UFRGS. Mas não quero aqui, como dizia, só desconstruir a história do instituto, mas sim reconstruí-la, porque entendo que isso é absolutamente essencial, bastando ver a discrepância da jurisprudência que tem sido proferida na matéria. A moralidade é vinculada ora à legalidade, ora à igualdade, ora ao interesse público, ora ao desvio de poder, ora à proporcionalidade. ${ }^{3}$ É tudo e nada ao mesmo tempo.

Essa história que pretendo aqui brevemente resumir, se bem entendida e bem contada (reconstruída), evitará que cometamos alguns equívocos de interpretação (ao menos histórica) sobre o que significa, afinal, essa tão falada 'novidade'. A importância da história muitas vezes negligenciada, principalmente por nós brasileiros, decididamente um povo sem memória, e não só no Direito - é, nesta matéria, repito, fundamental, e mesmo indispensável.

Começo a primeira parte - e a história da moralidade administrativa, portanto.

1. Tem sabor de lugar-comum a afirmação de que a noção de "moralidade administrativa" nasceu na França, no início do século passado, com a obra de Maurice Hauriou. Hauriou (1856-1929) era professor em Toulouse e construiu a famosa escola do Poder Público, em oposição à Escola do Serviço Público, esta fundada pelo seu contemporâneo de Bordeaux, Léon

3 Sobre isso, GIACOMUZZI, José Guilherme. Introdução. In: A moralidade administrativa e a boa-fé da administração pública: o conteúdo dogmático da moralidade administrativa. São Paulo: Malheiros, 2002. 
Duguit. ${ }^{4}$ Hauriou foi um dos grandes juspublicistas franceses, um de seus mais influentes juristas, e sua mais conhecida contribuição foi ter elaborado a teoria da instituição, a qual não tenho tempo de abordar. ${ }^{5} \mathrm{O}$ que nos importa no pensamento de Hauriou é justo a sua original menção à moralidade administrativa, que é lembrada por todos os autores pátrios e estrangeiros. Até aqui nenhuma impropriedade ou novidade na doutrina brasileira. Hauriou foi mesmo o pioneiro. Mas esse é também um dos poucos acertos de boa parte da doutrina pátria do pós-88, que parece acreditar ter bebido do melhor vinho francềs, mas que é em verdade de duvidosa procedência-e não se deu conta disso.

Explico: a confusão nasceu já em 1964, bem antes da CF/88 portanto, quando o festejado e penso que ainda hoje o mais citado administrativista brasileiro, Hely Lopes Meirelles, já falava em moralidade administrativa na sua obra clássica (está na p. 58-9 da $1^{\text {" }}$ edição do seu Direito Administrativo Brasileiro). Hely já adotara então e sem reservas as posições de um advogado português, Antônio José Brandão (o vinho de duvidosa procedência que falei acima), cujo artigo, intitulado "Moralidade
Administrativa", foi citado por Hely e foi, depois disso e desde então, lido, relido e repetido acriticamente pela maioria de todos os que escrevemos sobre o tema. O artigo de Brandão foi originalmente publicado em 1947 no Boletim do Ministério da Justiça de Lisboal e copiado na nossa Revista de Direito Administrativo (RDA), volume 25 , de 1951, por meio da qual foi divulgado entre nós. Não conheço um autor brasileiro sequer que tenha lido a fonte portuguesa. Essa lembrança, que pode parecer um capricho, um triglicerídio como costumo dizer, tem sua razão de ser. É que as idéias contidas nesse artigo - todas encampadas pelo prof. Hely - têm sido direta ou indiretamente citadas na doutrina brasileira $\mathrm{e}-\mathrm{o}$ que é pior - na jurisprudência (que as cita via obra do professor Hely), constituindo-se, neste segundo momento, em fonte do Direito. Qual o mal disso? Ou, mais diretamente, qual o mal em citarse indiretamente o português Brandão? Ou, mais importante, que idéias tão errôneas ele nos legou?

Por partes. Nesse artigo da RDA, Antônio Brandão lança uma série de idéias e supostamente transcreve uma série de frases dos maiores discípulos franceses de Hauriou sobre o tema.

4 Sobre o assunto, ver MELLERAY, Fabrice. École de Bordeaux, école de service public et école duguiste. Proposition de distinction. Revue du Droit Public, Paris, n. 6, p. 1887-1905, nov./dez. 2001. Entre nós, ver, sobre a contraposição das escolas, MEDAUAR, Odete. Serviço Público. Revista de Direito Administrativo, Rio de Janeiro, v. 189, p. 100-113, jul./ set. 1992.

5 Ver GIACOMUZZI, op. cit., p. 90-102. 
Daqueles que teriam desenvolvido a idéia da moralidade. Mas o artigo da RDA não traz qualquer indicação bibliográfica. As citações, portanto, estão soltas no ar: não se sabe de onde vêm. Mas isso é só forma, poder-se-ia objetar. Talvez, não fosse um trabalho a ser publicado em uma revista científica. O problema maior, no entanto, está no conteúdo: o artigo é de uma retórica impressionantemente vazia.

No artigo de Brandão estão frases mais ou menos como: "a moralidade administrativa não se confunde com a moralidade comum", ou "a moralidade administrativa corresponde às regras internas da administração", ou ainda "a moralidade administrativa é a boa administração." Não consigo, para usar uma expressão do meu orientador, prof. dr. Luís Afonso Heck, "agarrar o fio vermelho do ponto". Ou, como gosta de dizer a prof ${ }^{a}$. dr $r^{\mathrm{a}}$. Judith, lembrando Pontes de Miranda, não consigo ver onde isso "morde a vida". E é assim, por tabela e de segunda mão, que nós temos lido os franceses, pais da idéia de moralidade administrativa.

Essa idéia de boa administração levou alguns brasileiros a dizer que "boa" é a "melhor" administração," e que a partir daí estariam ainda mais estreitadas as portas da discricionariedade administrativa, porque o juiz poderia controlar todo e qualquer ato administrativo, anulando-o, desde que não fosse "o melhor".

Quero chamar atenção a esse ponto com outras palavras: o importante aqui é notar que, pós-88, salvo raras exceções, como citações em regra desconexas de frases do próprio Hauriou, muito do que se tem dito entre nós brasileiros (os únicos 'privilegiados' a terem a moralidade administrativa no texto constitucional) sobre a doutrina francesa da época na qual nasceu o conceito de moralidade administrativa foi tirado do mencionado artigo de Antônio Brandão, artigo que tem, no entanto, repito, mais carências que virtudes. $\mathrm{O}$ artigo de Brandão pareceme mais uma colcha de retalhos - e retalhos que não sei de onde vêm.

Os autores mais citados por Brandão como sendo os discípulos de Hauriou que mais teriam levado adiante a idéia da moralidade administrativa são Lacharrière e Henri Welter. Posso afirmar com uma certa dose de certeza que a obra do primeiro ninguém entre nós leu, e eu estou dentre eles. ${ }^{8}$ A obra do segundo, que de acordo com Brandão seria - e nisso ele está certo

6 BRANDÃO, Antonio. Moralidade adminstrativa. Revista de Direito Administrativo, Rio de Janeiro, n. 25, p. 454-467, jul./set. 1951 p. 457-460.

7 Assim DELGADO, José Augusto. O princípio da moralidade administrativa na CF/88. Revista dos Tribunais, São Paulo, v.81, p. 680-739, jun. 1992.

8 A obra citada por Brandão é Le Contrôle Hierarchique de l'Administration dans la Forme Jurisdictionnelle, RDA 25/459. 
- a mais elaborada construção sobre a moralidade administrativa, não existe mais, hoje, nem na França. ${ }^{9}$ Depois de 1988, então, posso afirmar, com a mesma dose de certeza, que ela não foi consultada pela doutrina, apesar de alguns a citarem em pé de página, o que é no mínimo estranho. Até o início do ano 2000, um exemplar dessa obra de importância histórica ao menos para nós brasileiros existia, precioso, escondido numa livraria de antigüidades jurídicas bem perto do Panthéon em Paris. O nome da Livraria: A Memória do Direito (La Mémoire du Droit). Sugestivo nome.

Depois de três anos que passei atrás da relíquia, no intuito de tentar melhor compreender a moralidade administrativa, cheguei em meados de 2000 atrasado para comprá-la. Esse único e último exemplar havia sido adquirido havia quatro meses. Mas nada se dá por acaso na história, até na compra de livros. A obra, que foi esquecida no país de origem - e já veremos o porquê -, foi comprada por um advogado brasileiro, de São Paulo. Um erudito e educado senhor, que me fez a gentileza de emprestá-la. Tenho dúvidas de que tal obra tenha algum dia sido lida no Brasil que não pelo decano dos nossos administrativistas, o professor Caio Tácito (que soube muito bem interpretá-la - e eu não precisaria nem lembrar isso).
São exatas 513 páginas de uma tentativa hercúlea - que depois se viu fracassada - em independizar, na França, o conceito de moralidade administrativa. A obra data de 1929 , ano da morte de Hauriou. Ela é importante por vários aspectos, mas eu só vou salientar um: ela representa o ápice da doutrina francesa da moralidade administrativa, mas dela o português Brandão só cita uma frase, $\mathrm{e}$ ainda pela metade. A frase é a seguinte: "A moralidade administrativa, que nos propomos estudar, não se confunde com a moralidade comum; ela é composta por regras da boa administração, ou seja: pelo conjunto de regras finais e disciplinares suscitadas, não só pela distinção entre o bem e o mal, mas também pela idéia geral de administração e pela idéia de função administrativa." 10

Essa frase foi repetida dezenas de vezes na doutrina brasileira - e também na jurisprudência - como sendo a chave-mestra de um segredo. É peculiar - ia dizendo perigoso - a facilidade com que ela é encaixada em qualquer contexto fático ou mesmo jurídico. Só por isso a estou citando. É difícil, no entanto, excluir o que não caiba dentro dela, porque ela é de resto absolutamente oca e vazia de conteúdo. Numa palavra: a bela frase abriga quaisquer vontades e todos os arbítrios.

9 WELTER, Henri Le contrôle jurisdictionnel de la moralité administrative: étude de doctrine et de jurisprudence. Paris: Recueil Sirey, 1929.

10 Ibidem, p. 77. 
A frase, no entanto, continua assim: "De resto, o termo pouco importa, o todo é de se entender sobre os principios." Não há qualquer razão para a omissão dessa continuação, que faz toda a diferença, diferença essa que o prof. Caio Tácito já havia notado, mesmo sem citar esse providencial corte do texto. ${ }^{12}$

Faço breve retrospectiva histórica até aqui: com base em um único artigo - de valor científico quase nenhum -, nossa doutrina, desde antes de 1988 (relembro que Hely já escrevia em 1964) tem por base histórica do instituto da moralidade a obra de um português que pinçou, pela metade e fora do contexto, uma única frase da principal obra do melhor autor do país onde o tema - a nós inédito enquanto texto - havia nascido e se desenvolvido.

Bebíamos, e nos regozijávamos, do vinho "francês" que nos serviam. Não nos foi dado conferir nem o rótulo, quanto mais o conteúdo.

Mas o que fez Welter? Sabedor de que o Conselho de Estado francês só poderia - como até hoje - perscrutar a legalidade do ato administrativo, buscou, com base no seu mestre Hauriou, uma "forma" segundo a qual se pudesse controlar o ato administrativo aparentemente legal, mas desviado na sua finalidade. $\mathrm{E}$ aqui o ponto: foi ao tratar do desvio de finalidade que Hauriou, sem muito desenvolvimento, costumava referir-se à moralidade administrativa na sua vasta obra.

Não vou tratar do desvio de finalidade aqui. Esse instituto é por demais conhecido de todos os que têm, como nós, uma matriz francesa do direito administrativo. Só lembro que ele nasceu na França, com o caso Lesbats, de 1864 , e é fruto da lenta e gradual elaboração do Conselho de Estado. $\mathrm{O}$ conceito do desvio de poder ganhou o mundo e chegou, como não poderia deixar de ser, ao Brasil, o que se deu, positivado, na Lei de Ação Popular, em 1965. É a Lei 4.717. O desvio de finalidade, diz a letra 'e' do parágrafo único do art. $2^{\circ}$ da lei: "[...] se verifica quando o agente pratica o ato visando a fim diverso daquele previsto, explícita ou implicitamente, na regra de competência". Numa palavra: o desvio de finalidade quer controlar os móveis do agir da autoridade administrativa. Essa definição tem a simplicidade e a pureza exigida dos textos legislativos e resume quase cem anos do que se entendeu na França por desvio de poder. E é o que se entende até hoje, bastando para isso consultar os livros sobre o assunto. ${ }^{13}$ O mais autorizado administrativista francês de hoje, René Chapus, trata da moralidade administrativa somente e

11 Ibidem, p.77: "Du reste, le mot importe peu, le tout est de s'entendre sur les principles'. 12 TÁCITO, Caio. Direito administrativo. São Paulo: Saraiva, 1975, p.71.

13 Por todos, cito CHAPUS, René. Droit administratifgénéral. 15. ed. Paris: Montchrestien, 2001, v. 1, p.1048-55. 
justo quando fala no desvio de finalidade, como que em reverência a Hauriou, e cita uma série de decisões judiciais. Chega a dizer que o desvio de poder é uma condenação moral da administração, aduzindo o seguinte, verbis: "O Conselho de Estado provou relativamente cedo a necessidade de exercer o que Hauriou pôde caracterizar como um controle da moralidade." E cita, em seguida, o Caso Lesbats. ${ }^{14}$

Pois bem. Na França, de onde veio a idéia de moralidade administrativa, ela vingou sob outro nome. Moralidade administrativa veio a chamar-se desvio de poder, e continua assim. Maria Sylvia Di Pietro apreendeu muito bem isso e traz o melhor resumo entre nós dessa rápida evolução que tratei de fazer aqui. ${ }^{15}$ Aliás, antes da $\mathrm{CF} / 88$, isso era muito bem compreendido. Cretella Jr. foi o primeiro a tratar, em monografia, do tema do desvio de finalidade, e lá se referiu à moralidade administrativa, dando a ela a importância devida. ${ }^{16}$

Foi aparecer o nome "moralidade administrativa" na $C F / 88$ para que a casa se desarrumasse - e estou aqui no plano das idéias. Nem vou descer aos fatos da vida, que nos mostrou e nos mostra diuturnamente atos administrativos eivados de desvio de finalidade (imorais, segundo Hauriou, portanto) e que continuamos, mesmo com a previsão constitucional, sem conseguir frear.

Inúmeras tentativas doutrinárias de se dar um colorido autônomo a essa nova 'moralidade administrativa' apareceram na doutrina brasileira, sempre com o intuito de distingui-la da legalidade. Aqui, é bem verdade, pode caber o mundo, e novamente não tenho tempo nem competência para tratar do assunto. Cuidei no livro de criticamente analisar as que me pareciam mais razoáveis. ${ }^{17}$ Todas elas acabam ou dizendo o que a LAP já diz, ou referindo, implícita ou explicitamente, que a moralidade administrativa é um sobreprincípio de Direito, mais importante que o da legalidade, englobador de vários outros: razoabilidade, proporcionalidade, interesse público, igualdade. A moralidade é tudo, então, e nada. Além de arbitrário, por revelar a compreensão muito pessoal do Direito, penso que o raciocínio acaba desmerecendo os demais princípios, sobremodo o mais forte e importante deles, o da legalidade.

Alguns viram na moralidade administrativa, então, a tábua de

14 Ibidem, p. 1049.

15 DI PIETRO, Maria Sylvia. Discricionariedade administrativa na constituição de 1988. São Paulo: Atlas, 1991, p. 103.

16 CRETELLA JÚNIOR., José. Do desvio de poder. São Paulo: Revista dos Tribunais, 1964 , p. 45-46.

17 Ver GIACOMUZZI, A moralidade..., p. 141-179. 
salvação da nossa sociedade. Tudo estaria resolvido como que num passe de mágica. Aliás essa visão "abracadabra" do Direito tem sido muito difundida entre alguns novos hermeneutas brasileiros, que interpretam o Direito como se não tivessem existido milênios de estudo sério antes deles e que vêem na $\mathrm{CF}$ tudo o que querem. E eles, homens de bom coração, querem muito. Basta a eles que o juiz aplique o Direito com sabedoria, valendo-se da igualdade, da razoabilidade, da proporcionalidade, e outros conceitos indeterminados. Perigosa ingenuidade.

A jurisprudência que se seguiu à $\mathrm{CF} / 88$ revela a nebulosidade e a falta de critérios racionais para apreender o real significado da moralidade administrativa. Eu começo o livro deliberadamente citando algumas dessas decisões. E pincei, claro que de propósito, algumas decisões não unânimes, nas quais se encontram as mais variadas citações sobre Moral e Direito. Aquelas frases lidas acima estão quase sempre presentes. Elas se encaixam em qualquer lugar.

Já que falei de história, e história do Brasil, seja-me permitido comparar o significado dessas palavras com o que Sérgio Buarque de Holanda dizia de boa parte da intelectualidade brasileira do século XIX, no seu monumental Raizes do Brasil: "todo o nosso pensamento dessa época revela a mesma fragilidade, a mesma inconsistência íntima, a mesma indiferença, no fundo, ao conjunto social; qualquer pretexto estético serve-lhe de conteúdo. Pode aplicar-se a ele o que disse da filosofia Junqueira Freire, em sua autobiografia: Era uma linguagem igualmente luxuriosa para dizer a mesma coisa. Nada de verdadeiro, tudo de belo, mais arte do que ciência; mais cúpula que alicerce."18

Pois bem, ao contrário da maioria, não vejo na moralidade administrativa do art. $5^{\circ}$ qualquer novidade, a não ser a sua constitucionalização - e isso já é extremamente importante, por razões evidentes que me dispenso de comentar. Nem vejo nela a panacéia aos males da nossa administração pública. Sigo a advertência de Menezes Cordeiro: não se peça à moral o que ela não pode dar. ${ }^{19}$

Penso que o conteúdo dessa moralidade é o mesmo que sempre existiu e é ele que nós devemos perseguir e combater. Não há, repito, enquanto conteúdo, qualquer novidade aqui. Desde sempre a moralidade administrativa foi protegida entre nós, e mormente depois da LAP. Só não veio com este nome. $\mathrm{O}$ nome usado pelos feitores dessa lei - aliás uma das melhores leis que temos, muito ao sabor

18 HOLANDA, Sérgio Buarque de. Raizes do Brasil. 26. ed. São Paulo: Companhia das Letras, 2002, p. 162-163.

19 MENEZES CORDEIRO, António Manuel da Rocha e. Da boa-fé no direito civil. Coimbra: Almedina, 1997, p. 1.174. 
da excelência dos juristas que a redigiram, e vou lembrar somente um, Seabra Fagundes ${ }^{20}$ - era o nome utilizado à época pelo mundo todo: desvio de finalidade. Basta que consultemos a exposição de motivos da Lei - que a nossa doutrina, embriagada do vinho "francês", também não leu, talvez porque não tenha sido publicada. Lá estão inúmeras citações sobre a defesa da moralidade administrativa, da moral da administração. ${ }^{21}$ A LAP queria protegê-la também, da mesma forma que a CF o fez. Só que não usou o nome. Aqui entraria bem a observação de Clóvis do Couto e Silva segundo a qual há uma inexplicável relutância dos juízes brasileiros a aplicar normas não positivadas.

Mas voltando. Como se chega à conclusão que expus? É preciso que se perquira a nossa doutrina; que se bebam os nossos vinhos. Autores brasileiros já tratavam, embora timidamente, da matéria, antes da CF/ 88. Faziam-no em regra ao cuidar do desvio de finalidade. Já citei Cretella Jr. e aduzo agora José de Castro Nunes, que cuidou do assunto já em 1937 ao falar do mandado de segurança, instrumento jurídico apto na época a desfazer ato inconstitucional ou ilegal. No controle dessa legalidade estaria o excesso de poder, e aí apareceria a moralidade administrativa, também controlável. $^{22}$

Depois dele, foi Manoel de Oliveira Franco Sobrinho quem tratou do tema, em 1974. Curioso é que se tem lido mais a obra pós-88, intitulada $O$ Princípio Constitucional da Moralidade Administrativa, escrita em 1993, sem que se consulte a primeira obra: $O$ Controle da Moralidade Administrativa, de 1974. Aqui o professor paranaense trata vagarosamente da questão da moralidade, mas em nenhum momento fala que a moral contém o Direito. Ele sustenta justo o contrário. Ele diz, nas páginas 103-4 da obra: "A legalidade, como princípio, incorpora a moralidade". Em verdade, ele não se afasta em muito do desvio de poder, e chega a dizer, na página 40 , que o elemento teleológico do ato administrativo é o que mais se afina com a posição moral da ação estatal. E, em diversas outras passagens deixa claro que o que ele entende por moralidade administrativa é a legalidade material - e não meramente formal - do ato administrativo. Não é por coincidência que hoje a doutrina francesa já tenha fechado a questão no seguinte ponto: o controle da legalidade do ato pode-se dar de duas formas: legalidade externa (incompe-

20 Ver FAGUNDES, Miguel Seabra. Da ação popular. Revista de Direito Administrativo, Rio de Janeiro, n. 6, p. 1-19, out. 1946.

21 Conferir em GIACOMUZZI, A moralidade..., p. 125-128.

22 Conferir em GIACOMUZZI, A moralidade..., p. 119-120. 
tência, vício de procedimento e vício de forma), e ilegalidade interna (vício de conteúdo, de motivos e de intenção-aqui a moralidade e o desvio de finalidade). ${ }^{23}$

Isso foi, de certa forma, o que fez ver Henri Welter - que, em suma, chamou de moralidade administrativa todos as hipóteses de ilegalidade interna do ato administrativo. E, entre nós, com outras palavras, fez Diogo Moreira Neto. ${ }^{24}$

Pois bem. A história do nosso Direito Administrativo mostra que sempre demos à moralidade tratamento jurídico de acordo com o que ela vinha recebendo em todo o mundo. Por que veio aparecer na $\mathrm{CF} / 88$ então?

Aqui eu não posso mais que arriscar um palpite. Não tenho como provar isso, pois. Mas nossa memória nos faz lembrar que saímos, à época, de mais de 20 anos de ditadura. Os ventos da ética sopravam não somente no Brasil, mas no mundo todo, e não somente no Direito. Lembro que em 1996, na Califórnia, Amartya Sen, um indiano, que veio depois a ser um dos dois únicos não-americanos a ganhar o prêmio Nobel de economia, proferiu uma série de conferências sobre "Ética e Economia", que vieram a ser traduzidas ao português e estão publicadas em um livro. ${ }^{25}$ Lá, Amartya Sen dizia que já era hora de a economia se aproximar da ética. Muitos talvez hoje, observando o nosso mundo desigual, possam concluir que esse conselho não foi ouvido.

A Ética estava na pauta do dia. Queríamos um Estado ético, uma Administração moral, o combate à corrupção. Se vasculharmos os anais da Assembléia Constituinte, veremos que a moral estava sempre presente ao debate. Perderiam os Constituintes a oportunidade de fazer constar da nossa Constituição a palavra que todos queriam pronunciar e ouvir? Não perderam.

No meu entendimento, então, a moralidade administrativa do art. $5^{\circ}$ é a legalidade interna do ato. O que devemos é tentar controlá-la, e isso já será muito. Sabe-se que este vício, o do desvio de finalidade, é o mais oculto dos vícios. O mais difícil de provar. Sabemos que o cidadão brasileiro deve ser mais atuante, e aqui poderíamos discutir inclusive a legitimidade de o próprio Ministério Público intentar ações populares, o que entendo possível, lembrando que esse entendimento não tem nada de novo, uma vez que a prof ${ }^{\mathrm{a}}$. Ada Grinover já o defende há muito. ${ }^{26}$

23 Cito novamente, por todos, CHAPUS, Droit administratif.., p. 1.019-1.055.

24 Conferir MOREIRA NETO. Diogo de Figueiredo. Moralidade Administrativa: do conceito à efetivação. Revista de Direito Aadministrativo, Rio de Janeiro, v. 190, p. 1-44, out./nov. 1992. 25 SEN, Amartya. Ética e economia. São Paulo: Companhia das Letras, 1999.

26 GRINOVER, Ada Pelegrini. Uma nova modalidade de legitimação à ação popular: possibilidade de conexão, continência e litispendência. Cadernos de Direito Constitucional e Ciência Política, v. 19,p. 53-56, abr.jun. 1997, p.53. 
2. E o que dizer da moralidade do art. 37? Aqui começa a segunda parte.

Ela também tem uma história, que está imbricada com a do art. $5^{\circ}$. Também por isso eu disse antes que iria distinguilas, sem separá-las.

Pois bem. No artigo 37, entendo que a principal - não a única - função da moralidade administrativa é veicular ao Direito Público o princípio da boa-fé, que vem do Direito Privado. A boa-fé objetiva principalmente, porque a subjetiva está consubstanciada na improbidade administrativa, prevista no $\S 4^{\circ}$ do mesmo art. $37 .{ }^{27}$

Também há uma razão histórica para assim entender. E aqui, novamente ao contrário do que diz Antônio Brandão $0^{28}$ e outros, não foi em meados da década de 20 do século passado que Hauriou falou pela primeira vez em moralidade administrativa, mas sim em 1903, quando escreveu, em parceria com Guillaume de Bezin, um artigo sobre "A declaração de vontade no Direito Administrativo francês," ${ }^{29}$ a qual ele sustentava ser idêntica à do ato jurídico alemão.

Em síntese ao que nos interessa. Hauriou tratou da moralidade pela primeira vez aí, justo quando referiu que a moralidade deveria cumprir, no Direito Administrativo francês, o papel que a boa-fé dos $\S \S 157$ e 242 cumpriam no Código Civil alemão (BGB). Aqui a origem, e aqui a ligação que proponho.

Aprendi com o meu amigo Jorge Cesa Ferreira da Silva que nem mesmo os cultores do BGB sabiam qual seria o alcance dessa cláusula geral de boafé. ${ }^{30}$ Vemos hoje que foi vasto. Não vejo razão para não se adotar, com seus necessários matizes, as contribuições da boa-fé objetiva do Direito Privado aos domínios do Direito Público.

A moralidade administrativa veiculada pelo art. 37 significa principalmente, pois, a boa-fé, ou a proteção da confiança, no Direito Público. Isso não é pouco, ao contrário do que se tem dito. Não estou confinando a moralidade à boa-fé e à proteção da confiança. Quem diz isso só pode ter uma estreita visão da boa-fé objetiva, que tem várias funções no Direito Privado, tão bem tratadas por Wieacker, no seu livro sobre $O$ principio geral da boa-fé. Mais: somos nós, aqui, verdadeiramente privilegiados, porque temos os livros de Menezes Cordeiro e Judith Martins-

27 Desenvolvi o conteúdo da moralidade do art. 37 na segunda parte de: GIACOMUZZI, A moralidade..., p. 189-309.

28 BRANDÃO, Moralidade..., p. 457.

29 HAURIOU, Maurice; BEZIN, Guillaume. La déclaration de volonté dans le droit administratif français. Revue Trimestrielle de Droit Civil, v. 2, n. 3, p.543-586. jul./set. 1903. 30 FERREIRA DA SILVA. Jorge Cesa. A admissibilidade do conceito de violação positiva do contrato no Direito brasileiro. Rio de Janeiro: Renovar, 2002, p. 47 
Costa $^{31}$ a tratar do tema, para citar os melhores. No campo do Direito Público, ainda que em menor número os escritos, vale lembrar a recente publicação de Edilson Pereira Nobre Júnior ${ }^{32}$ e também as traduções do meu orientador, prof. Heck, de algumas palestras de um grande administrativista alemão, Harmut Maurer, sobre o tema. ${ }^{33}$

$\mathrm{O}$ que se pode esperar do Estado ante o princípio da moralidade do art. 37 é muito, portanto. Mas, como lá no art. $5^{\circ}$, aqui no art. 37 ela não representa a panacéia de todos os males. Mas pode ajudar-nos a construir um país mais igualitário.

Ainda "dentro" desta moralidade do art. 37 está a improbidade administrativa, como referi antes, mas sobre o tema da improbidade eu precisaria de outro convite do meu amigo Anízio, e não posso dele tratar aqui.

Alguém poderá objetar que parece não ter qualquer valor ter sido positivada moralidade administrativa na $\mathrm{CF} / 88$. Não é assim, entretanto. Fico aqui com as palavras do meu querido professor Almiro do Couto e Silva, que me honrou com o prefácio ao meu trabalho - que, sempre digo, vale mais que o livro:

Por ter função pedagógica, orientadora e, ao mesmo tempo, alimentadora do culto aos valores contidos nos direitos fundamentais e nos princípios por vezes chamados de estruturantes do Estado brasileiro, que se qualifica como Democrático de Direito, é que a Constituição de 1988 insiste, repete, reitera e torna, por vezes, a insistir, repetir e reiterar preceitos já implicitamente contidos na constelação de normas que formam o nosso sistema constitucional. Há coisas que só pela repetição se aprende ou que, como nas preces, só pela repetição cremos que se tornam eficazes. Que assim seja.

Seja-me permitido terminar com a leitura de dois trechos do trabalho, que entendo resumirem o esforço que empreendi.

Na epígrafe está a conhecida passagem de Leẃis Carrol, num dos Livros de Alice, Através do Espelho:

"Não sei o que você quer dizer com glória" - disse Alice. Humpty Dumpty sorriu, superior. "Claro que você não saberá, até que eu lhe diga: significa que há uma bela e arrasadora contenda o esperando." "Mas glória não significa isso", objetou Alice. "Quando uso uma palavra - disse Humpty Dumpty, ela significa aquilo que quero dizer, nem mais nem menos". "A questão $\dot{e}$-disse Alice-se você pode fazer uma palavra significar tantas coisas diferentes." "A questão é, respondeu Dumpty, quem manda-e isto étudo."

31 MENEZES CORDEIRO, Da boa-fé.... Ver MARTINS-COSTA, Judith. A boa-féno direito privado. São Paulo: Revista dos Tribunais, 1999.

32 NOBRE JÚNIOR., Edilson Pereira. O principio da boa-fé e sua aplicação no Direito administrativo brasileiro. Porto Alegre: Fabris, 2002.

33 MAURER. Harmut. Elementos de direito adminstrativo alemão. Porto Alegre: Fabris, 2000. 
O último parágrafo do livro diz:

Olhos na epigrafe da Introdução desta obra, troque-se, em imaginação, a palavra glória por moralidade administrativa. O operador do Direito deve pretender que jamais vingue, nem expresso, nem camuflado, o pensamento de Humpty Dumpty, e trabalhar para isso.

Falei em história, e não posso terminar essa exposição sem relembrar que esta Escola também tem uma história, da qual todos fazemos parte. Tenho um pouco de mim aqui dentro. Meu pai, ao lado de outros tantos, foi um de seus fundadores e o seu segundo diretor. Eu era criança. Estou um pouco em casa aqui. Mais em casa hoje do que antes, porque o diretor, hoje, desta Escola és tu, meu amigo Anízio - e é essa a única razão de eu estar aqui

\section{REFERÊNCIAS}

BARBOZA, Márcia Noll. O princípio da moralidade administrativa: uma abordagem do seu significado e suas potencialidades à luz da noção de moral crítica. Porto Alegre: Livraria do Advogado, 2002.

BRANDÃO, Antônio José. Moralidade Administrativa. Revista de Direito Administrativo, Rio de Janeiro, v. 25, p. 454-467, jul./set. 1951.

CHAPUS, René. Droit administratif général. 15. ed. Paris: Montchrestien, 2001.v. 1. agora, com a honra de ser o palestrante desta aula final. Sei bem que eu não merecia tanto, e que a amizade às vezes exagera na bondade. E quero dizer, em nome de todos, mesmo sem procuração, que és já um dos grandes, se não o maior, dos diretores desta Escola Superior. Em tão pouco tempo, fizeste tanto, com tanto empenho. Somos todos testemunhas disso, e eu, uma testemunha especial - e o registro é mais que necessário. O que estás a fazer na direção desta Casa não pode jamais ser esquecido. Estás dando seguimento e reforçando um trabalho de outros que te antecederam. O que tentei fazer aqui foi mostrar a importância da história, mas aquela da moralidade administrativa, nesta aula final, para a qual agradeço, novamente, comovido, o convite.

Muito obrigado.

CRETELLA JÚNIOR., José. Do desvio de poder. São Paulo: Revista dos Tribunais, 1964.

DELGADO, José Augusto. O princípio da moralidade administrativa na $\mathrm{CF} /$ 88. Revista dos Tribunais, São Paulo, v. 680, p. 34-46. jun. 1992.

DI PIETRO, Maria Sylvia. Discricionariedade administrativa na constituição de 1988. São Paulo: Atlas, 1991. FAGUNDES, Miguel Seabra. Da ação popular. Revista de Direito Administrativo, Rio de Janeiro, v. 6, p. 1-19, out. 1946.

FERRAZ JÚNIOR, Ética Administrativa em um país em 
desenvolvimento. Cadernos de Direito Constitucional e Ciência Política. São Paulo, v. 22, p. 38-43, jan./mar. 1998.

FERREIRA DA SILVA. Jorge Cesa. $A$ admissibilidade do conceito de violação positiva do contrato no direito brasileiro. Rio de Janeiro: Renovar, 2002.

GIACOMUZZI, José Guilherme. A moralidade administrativa e a boa-fé da administração pública: o conteúdo dogmático da moralidade administrativa. São Paulo: Malheiros, 2002.

GRINOVER, Ada Pelegrini. Uma nova modalidade de legitimação à ação popular: possibilidade de conexão, continência e litispendência. Cadernos de Direito Constitucional e Ciência Politica, São Paulo, v. 19, p. 53-56, abr./jun. 1997.

HAURIOU, Maurice; BEZIN, Guillaume. La déclaration de volonté dans le droit administratif français. Revue Trimestrielle de Droit Civil, v.2, n. 3, p. 543-586, jul./set. 1903. HOLANDA, Sérgio Buarque de. Raizes do Brasil. 26. ed. São Paulo: Companhia das Letras, 2002.

MARTINS-COSTA, Judith. A boa-fé no direito privado. São Paulo: Revista dos Tribunais, 1999.
MAURER. Harmut. Elementos de direito adminstrativo alemão. Porto Alegre: Fabris, 2000.

MEDAUAR, Odete. Serviço Público. $R D A$, Rio de Janeiro, v. 189, p.100113, jul./set. 1992.

MELLERAY, Fabrice. École de Bordeaux, école de service public et école duguiste. Proposition de distinction. Revue du Droit Public, Paris, n. 6, p. 1887-1905, nov./dez. 2001. MENEZES CORDEIRO, António Manuel da Rocha e. Da boa-fé no direito civil. Coimbra: Almedina, 1997. MOREIRA NETO, Diogo de Figueiredo. Moralidade Administrativa: do conceito à efetivação. Revista de Direito Administrativo, Rio de Janeiro, v. 190, p. 1-44, out./nov. 1992. NOBRE JÚNIOR, Edilson Pereira. $O$ principio da boa-fé e sua aplicação no direito administrativo brasileiro. Porto Alegre: Fabris, 2002. SEN, Amartya. Ética e Economia. São Paulo: Companhia das Letras, 1999. TÁCITO, Caio. Direito Administrativo. São Paulo: Saraiva, 1975. WELTER, Henri. Le contrôle iurisdictionnel de la moralité administrative: étude de doctrine et de jurisprudence. Paris: Recueil Sirey, 1929. 



\title{
João Leitão de Abreu, o juiz e a política*
}

\author{
José Néri da Silveira**
}

1. O honroso convite que me formularam os ilustres professores Eduardo Carrion e Plínio de Oliveira Corrêa, respectivamente diretor e vicediretor desta Faculdade, ao ensejo das comemorações de seu centenário, para falar sobre João Leitão de Abreu, o juiz e a política, põe-me, por primeiro, emocionado, diante da escada da saudade. Dela disse Ruy Cirne Lima, inspirado em Mário Quintana: "De poesia é feita a escada de Mário Quintana, à qual tanto se assemelha uma vida que se corta: nem fundamento no chão, nem patamar ao topo. Essa é a escada da saudade, na qual, de algum modo, se retrata o impulso à transcendência e ao infinito, que, todos, escondemos dentro de nós, - o impulso que, a todos, nos une, para além da morte, sempre, dentro da vida". Esse contraste do real que parece suspenso no irreal, e assim com a aparência do nada, desfaz-se, todavia, pelo mistério da fé, ao nos infundir o saber consolador de que a vida não termina com a morte, senão meramente se transforma. Esse conflito interior, que de certo modo sempre nos perturba, aflige-nos mais intensamente, quando a existência que se muda é a vida de um amigo. Tal como sobem as preces, alteiam-se, por essa escada, diante de nós, ao rumo do infinito, épocas, fatos, reminiscências, sentimentos os mais nobres da alma, inclusive o da gratidão, como se

\footnotetext{
* Palestra proferida no Ciclo de Conferências sobre a "Influência da Faculdade de Direito da UFRGS na Política e nas Letras Jurídicas", promovido no período de abril a julho de 1999.

** Ministro do Supremo Tribunal Federal, aposentado; professor convidado da Faculdade de Direito da UFRGS.
} 
envoltos, todos, na flagrância mais pura e delicada das flores, que se cultivam com carinho no mais indevassável recanto do coração.

Bem podeis avaliar, senhor diretor, senhores professores, caríssimos alunos, as reminiscências que este instante me traz, lembrando a extraordinária figura de João Leitão de Abreu, amigo de quase quarenta anos, numa amizade que nunca conheceu rusga ou contrariedade, iniciada em 1953, no antigo Conselho do Serviço Público deste Estado, e consolidada em longa convivência proveniente do exercício do magistério, nesta Faculdade e na Faculdade de Direito da Pontifícia Universidade Católica, nos anos 60, na mesma disciplina de Introdução à Ciência do Direito, sendo ele titular e eu o assistente; do trabalho conjunto na elaboração, que exigiu tempo e longas reflexões, por designação governamental, do projeto de adaptação da Carta sul-riograndense de 1947 ao modelo federal de 1967 e, por último, já em Brasília, na condição de membros do Tribunal Superior Eleitoral, na segunda parte da década de 1970. Quis, por fim, o Senhor de nossas vidas e de nossos destinos, em seus insondáveis desígnios, que houvesse eu, em 1981, de ter assento, no Supremo Tribunal Federal, precisamente, na cátedra que, por sete anos, fora ilustrada e honrada pelo ministro João Leitão de Abreu.

2. Nasceu, a 6 de julho de 1913, João Leitão de Abreu, em Cachoeira do Sul, RS, às margens do rio Jacuí, filho de Jary Carvalho de Abreu e de dona Ana Leitão de Abreu. Desde suas origens, gozou de notabilidade a cidade natal de João Leitão de Abreu, hoje conhecida, carinhosamente, como "Princesa do Jacuí". Terra de escaramuças entre castelhanos e portugueses, no século XVIII; elevada à categoria de vila, com a denominação de Vila Nova de São João da Cachoeira, por alvará de Dom João VI, de 26.4.1819, instalada a 5 de agosto de 1820 , como o sexto município da Capitania de São Pedro; por duas vezes, visitada por Dom Pedro II (1846 e 1865); com ativa participação na Revolução Farroupilha, de 1835 a 1845 , e filhos militares destacados, também, na Guerra do Paraguai. Dela saíram, no século passado e neste, ilustres poetas, jornalistas, políticos, juristas e magistrados. Com tantos vultos eminentes e de longa história, Cachoeira estendeu sua glória até a cúpula do Poder Judiciário brasileiro, com a nomeação de seu ilustre filho e jurista - João Leitão de Abreu - para o cargo de ministro do Supremo Tribunal Federal a 24 de maio de 1974, empossado a 17 de junho do mesmo ano como o $240^{\circ}$ membro do Augusto Tribunal, onde alcançou a VicePresidência, em fevereiro de 1981, havendo, antes, sido, também, ministro do Tribunal Superior Eleitoral (1976), seu vice-presidente, a 7.11.1977, e presidente, eleito em novembro de 1978, sucedendo o saudoso ministro José Geraldo Rodrigues Alckmin. 
3. Atingir o cume do Poder Judiciário, onde as liberdades e os direitos dos cidadãos, a Federação e a República encontram o último reduto de defesa institucional, bem assim exercer eleva-das funções ministeriais no Poder Executivo, não foi, entretanto, jornada sem sacrifícios para João Leitão de Abreu.

De sua formação e da juventude, dá-nos testemunho seguro, por todos os títulos, o ilustre general Aurélio de Lyra Tavares, membro da Academia Brasileira de Letras e seu cunhado, recentemente falecido, em artigo que publicou a 27 de novembro de 1992, no Jornal do Commercio do Rio de Janeiro, referindo-se às homenagens póstumas que foram prestadas a Leitão de Abreu:

O que me parece de maior significação, nessas justas e marcantes homenagens, é que elas exaltam a vida, que eu pude conhecer em passagens muito dificeis, como seu cunhado e amigo, por bem saber que ele se realizou, desde cedo, menino de família pobre, além de numerosa, sem nunca ter tido, por isso mesmo, ensino pago. Ele superou todos os problemas, graças ao interesse e ao desvelo do pai, conseguindo o seu acesso ao Seminário de São Leopoldo. Por falta de vocação, apenas lá ficaria alguns anos, que the foram preciosos, pelo quanto aprendeu, nas matérias que estudou, com grande rendimento do ensino no regime de internato.

Para bem compreender, efetivamente, o ambiente de formação de João Leitão de Abreu, é preciso anotar que o Colégio Conceição de São Leopoldo, fundado em 1869 , sob a orientação dos padres da Companhia de Jesus, representou, na segunda metade do século XIX e até seu fechamento em 1912, a instituição de maior importância na formação dos jovens rio-grandenses, com extraordinário reflexo na cultura gaúcha. Em 3.2.1900, obtinha, como raridade da época, pelo Decreto $n^{\circ}$ 3.580 , "o caráter e os direitos de Ginásio equiparado ao Ginásio Nacional Dom Pedro II do Rio de Janeiro." Por ele passaram alunos que haveriam de ser nomes destacados do episcopado e da política sulinos, como Dom Octaviano Pereira de Albuquerque, Dom João Becker, Dom Vicente Scherer, e os drs. Oswaldo Aranha, Vidal de Oliveira Ramos, Nereu Ramos, João Neves da Fontoura, Vitor e Adolfo Konder, Luiz Englert, Germano Hasslocher e Alberto Pasqualini, dentre tantos outros. Não obstante todos os elogios da época, inclusive da Princesa Isabel e do Conde D'Eu, considerado pelo embaixador da Alemanha, dr. Klaus, estabelecimento "que podia competir com as instituições congêneres da Europa", o Colégio Conceição cerrou as portas, em virtude da Lei Rivadávia, de 5.4.1911, que extinguiu todas as equiparações ao Ginásio Nacional Dom Pedro Il. Dom João Becker, então já à frente da arquidiocese de Porto Alegre, de imediato, entretanto, com extraordinária visão e inspiração, confiou aos Jesuítas do Conceição, a educação e a instrução dos seminaristas, tanto do clero regular, 
como do clero secular, da Arquidiocese. E a 20 de maio de 1913, em lugar do histórico Colégio Conceição, quase sem solução de continuidade e guardando o mesmo espírito, surge o Seminário Provincial de São Leopoldo, para onde afluíram, de todas as dioceses do Estado, jovens destinados à preparação para o sacramento da ordem, quer no Seminário Menor, para os cursos ginasial e colegial, quer no Seminário Maior, como estudantes de Filosofia e Teologia.

Foi em ambiente de internato qual esse, - de rígida disciplina, de reflexão, de cursos ministrados com a seriedade que tanto caracteriza os jesuítas como educadores, no estudo de latim, grego, alemão, inglês e francês, história, filosofia e religião, dentre outras matérias -, que o então jovem João Leitão de Abreu iniciou e, por alguns anos, desenvolveu sua formação humanística, filosófica e literária, de tão acentuada influência em sua ação como pensador, juiz e político.

Permanecendo em Cachoeira do Sul, aí exerceu o jornalismo, como anotou Lyra Tavares, ao escrever: "Recordo-me, sempre, das noitadas na redação do Jornal do Povo, fundado pelo seu avô, Virgílio Carvalho de Abreu, onde eu o acompanhava, todas as quartas e sábados, durante o preparo das edições das quintas-feiras e domingos". Segundo os registros, por volta de 1930 , tornou-se redator do Jornal do Povo. E, ainda, testemunha o ilustre general Lyra Tavares: "Aos dezoito anos, ele prestou o serviço militar no Tiro de Guerra 254 de
Cachoeira do Sul, onde soube escolher e cultivar boas amizades, entre as quais eu partilhava, especialmente, a do advogado Orlando da Cunha Carlos". Desde jovem, portanto, João Leitão de Abreu foi atento aos problemas políticos e sociais e aos debates ideológicos de sua época. Da atuação como redator do Jornal do Povo de sua terra, resultou-lhe, certa feita, inclusive, detenção pela polícia política do início do Estado Novo.

4. Transferindo-se para Porto Alegre, na década de 1940, ingressa João Leitão de Abreu, por concurso público, no serviço estadual, exercendo, aí, relevantes funções, como as de técnico de administração do Departamento do Serviço Público, em 1946; de diretorgeral da Secretaria de Educação e Cultura, quando dessa Pasta era titular o então deputado Eloy José da Rocha, em 1947; e a partir de 5 de maio 1949, por concurso público, tornou-se um dos cinco Conselheiros do Departamento do Serviço Público, depois, Conselho do Serviço Público, onde alcançou merecido e justo renome como administrativista, pelo brilho de suas produções, consubstanciadas em doutíssimos pareceres que emitia no exercício de tão importante múnus, até hoje fonte de indispensável e preciosa consulta, quais magníficos repositórios doutrinários, aos que se dedicam aos estudos jurídicoadministrativos.

De outra parte, havendo colado grau como bacharel em Ciências Jurídicas e Sociais, em 1946, nesta Faculdade, já 
no ano seguinte, com a advocacia, passou a desempenhar, em caráter voluntário, atividade de auxiliar de ensino, junto à cadeira de Direito Administrativo e Ciência da Administração, da mesma Faculdade, sendo regularmente admitido, em 1949, nessa função docente, estando a cátedra então provida pelo hoje também inolvidável professor Ruy Cirne Lima. professor de Direito Administrativo, na Faculdade de Direito da Pontifícia Universidade Católica do Rio Grande do Sul, desde 1952, ao vagar a cátedra de Introdução à Ciência do Direito, nesta Faculdade, veio a ser, nela, investido, a $1^{\circ}$ de março de 1954, concorrendo, posteriormente, ao provimento definitivo, com a tese " $\mathrm{A}$ Validade da Ordem Jurídica", escrita no início de 1964. Em 1955, assumiu a mesma disciplina na Faculdade de Direito da Universidade Pontifícia. De ambas tornou-se professor titular. Membro do Instituto de Administração da Universidade Federal do Rio Grande do Sul, em 1960, passou a dirigir o Instituto de Interpretação Emílio Betti, desta Faculdade de Direito, em 1962. Desse período são dois esplêndidos trabalhos doutrinários: A Discrição Administrativa (1949), com o qual conquistou o Prêmio Alcides Cruz, e $D a$ Prescrição em Direito Administrativo (1961). Da mesma época, é sua publicação sobre Função Social do Imposto.

5. Foi, entretanto, em momento de grave crise na política rio-grandense, em 1964, que o governador Ildo Meneghetti, recompondo o secretariado, convidou o então Conselheiro e professor João Leitão de Abreu, num apelo que se fez irrecusável a seu espírito de serviço à causa pública, para a chefia da Casa Civil do Governo do Estado, ao mesmo tempo em que o professor Ruy Cirne Lima ocupava a Secretaria da Fazenda e o então deputado e professor Paulo Brossard de Souza Pinto assumia a Secretaria do Interior e Justiça. Não tardou e nova função de índole política, já agora no âmbito federal, era confiada ao ilustre jurista. Investido no cargo de ministro da Justiça o senador gaúcho e professor desta Faculdade, dr. Mem de Sá, em 1966, veio a exercer Leitão de Abreu as funções de chefe de Gabinete daquela pasta. Retornando ao Estado, o novo governador, ao assumir em 1967 , convida o professor João Leitão de Abreu a integrar a Comissão designada pelo chefe do Poder Executivo para elaborar o projeto de adaptação da Constituição do Estado do Rio Grande do Sul, nos termos do art. 188 da Carta Federal de 1967. Vencidos os longos debates que então se travaram, no seio da Comissão, como relator do projeto, apresentou trabalho, acompanhado de "exposição de motivos", que constituem peças primorosas, pela técnica e precisão de conceitos, as quais foram levadas ao conhecimento do Supremo Tribunal Federal, na representação do procurador-geral da República Décio Miranda, contra dezenas de dispositivos da Carta gaúcha adaptada, eis que pretendeu elaborá-la, diferentemente, a Assembléia Legislativa, ensejando a 
reação do chefe do Executivo, em trabalho de rico conteúdo doutrinário, da lavra, ainda uma vez, do advogado João Leitão de Abreu (Rp 749-RS).

Convidado a assumir as elevadas funções de ministro de Estado para os Assuntos do Gabinete Civil da Presidência da República, em outubro de 1969, o professor João Leitão de Abreu dirigiu-se, pela derradeira vez, a seus alunos de Introdução à Ciência do Direito, em ambas as Faculdades de Porto Alegre, onde brilhantemente professava, com uma mensagem, - bem o recordo, embora quase trinta anos passados -, que traduzia a grandeza d'alma de um mestre autêntico, cujas palavras brotavam do íntimo do coração, mas os olhos tinham já a expressão da saudade. Era, em verdade, uma despedida, que a todos emocionou, e os fatos definitivamente confirmaram-na.

6. Vocação de pensador, vocação de jurista, com domínio seguro do direito e de sua técnica, inteligência ágil, percuciente, arquitetônica e luminosa na compreensão dos problemas humanos e sociais, espírito capaz de vislumbrar, ao primeiro intuito, o aspecto essencial das questões, energia inquebrantável, servo fidelíssimo do dever, coração em que pulsava o amor perene do justo, enfim, sacerdote de todas as virtudes, assim sempre foi João Leitão de Abreu, no Rio Grande como no Supremo Tribunal Federal, no Tribunal Superior Eleitoral como nos mais altos Conselhos da República. Em dois períodos, na condição de chefe do Gabinete Civil da Presidência da República (de 30.10.1969 a 15.3.1974, no governo do presidente Emílio Médici, e de 12.8.1981 a 15.3.1985, no governo do presidente João Figueiredo), em momentos difíceis da vida política nacional, marcante foi sua atuação de homem público austero, integro, respeitado, lúcido, coordenador eficiente e atento dos atos de governo e permanentemente preocupado com os exclusivos e superiores interesses da Pátria.

A ação de João Leitão de Abreu, em todos os cargos exercidos, no Governo como na Magistratura, guardou fidelidade constante às linhas fundamentais de seu pensamento formado nas fontes mais puras do humanismo cristão.

7. Assim, ao proferir a aula magna da Universidade Federal do Rio de Janeiro, em março de 1973, quando exercia as funções de ministro de Estado para os Assuntos da Casa Civil da Presidência da República, teve ensejo de afirmar:

Na idéia da suma importância que, na ordem espiritual, se assina ao homem, no postulado da sua eminente dignidade, no principio da sua vinculação a comandos éticos de caráter superior, imperativos inextirpáveis do seu ser, nesses velhos dogmas, cuja força magnética se conserva integra, está ainda, porém, ofundamento em que hão de assentar os esforços para restaurar a paz no inquieto coração do homeme suscitar, na ordem social, a harmonia de que se há mister. Argüições graves e 
veementes se levantam, por certo, de todos os lados, aos padrões de comportamento ético da humanidade, pregando-se, para corrigi-los, a necessidade de ampla revolução espiritual. Essas increpações nãose dirigem, porém, no fundo, à inteligência ética ou à correção dos cânones morais, porém à própria alma humana, que, na sua fraqueza, no seu egoismo, enfim, na avidez dos seus apetites, continua, como ainda hoje diria São Paulo, a não fazer o bem que quer e a fazer o mal que não quer. O descumprimento da regra ética não lhe retira, porém, a validade que permanece integra na sua retidão, ainda que a desobediencia seja total e permanente, ainda que a rebeldia seja deste, daquele ou de todos os sujeitos morais. Diz-se, a esse respeito, que o Sermão da Montanha não perderia, como lei moral, a sua validade inabalável, ainda que jamais tivesse sido cumprido.

Em escrito vindo a lume em março de 1968, sob o título A Guerra Perpétua, depois de analisar com acuidade os diversos aspectos do estado, atual ou iminente, de beligerância entre os povos e as tentativas frustradas, até agora, de sua superação, bem assim os extraordinários progressos científicos do homem na conquista do mundo sideral, em contraste com a estacionária situação no plano dos comportamentos éticos, anota, sempre no rumo de um humanismo autêntico:

O problema da paz não se prenuncia, por conseguinte, como solucionável em termos simplesmente racionais.
A impotência das construções lógicas ou teóricas para exercer, no universo político-social, o seu império sobre a ordem prática está, contudo, em violento contraste com a miraculosa leficácia para elas reveladas no que concerne ao dominio da natureza. Para vencer, pois, o impulso vital, ou seja, a lei do seu comportamento instintivo, necessita o homem, de acordo com a lição bergsoniana, realizar um salto para fora da natureza, pois que somente assim poderá chegar ao amor da humanidade, sem o qual se construirá sobre a areia o castelo da paz. Embora lesse milagre só se repute factivel pela via sobrenatural da caridade, o certo é que no momento em que o homem, deixando de ser prisioneiro da terra, assume, por obra da ciência, o status de cidadão do universo, deve ele encontrar, nesse feito, especial estímulo para intentar o prodigio de superar-se também no que diz respeito ao comportamento ético, sacudindo de si as cadeias da legalidade natural, a fim de criar condições para que em cada coração pulse a virtude unitiva do amor por.quantos possuem rosto humano.

Não foi diferente seu discurso, em O Gosto Impetuoso da Justiça, em 1979, quando escreveu:

Se a batalha da inteligência tem que ser vencida, não o será, pois, somente com o saber teórico, unicamente com o saber teórico, simplesmente com o saber geral, sistemático ou arquitetônico, porém com tudo isso acrescido de outro saber, o saber pensar, isto é, com a sagesse, que todos preconizam, com a sabedoria. Não apenas, contudo, como acentua Miguel Reale, lebrando Dante, com a sabedoria, mas 
com o uso amoroso da sabedoria, uno amoroso uso di sapienza. Aprofundando a sentença dantesca, o nosso grande pensador juridico sublinha que l'uso amoroso de que ai se fala, não é o amor abstrato, mas o amor concreto da habitualidade. Quando Dante, logo após, define o direito como o uso amoroso da justiça, sublinha Miguel Reale que o poeta não se refere à iustiça como algo estático e simétrico, mas à justiça como exigência de ação, a todo o instante e a toda a hora, à iustiça como presença do próximo, considerado este, não como abstração longínqua, mas como concreção da mão que está perto de nós, mão para a qual nós estendemos a nossa.

\section{E prossegue:}

Não basta, por conseguinte, prestar homenagem verbal à justiça exaltandolhe o esplendor conceitual. É possivel que, sob essa perspectiva tenha, também, a face mais bela do que a estrela da manhã. Porém é na justiça concreta, atuante, viva, fecunda, eficaz, que está, juntamente com o mistério dessa virtude peregrina, a sua autêntica beleza. Não é, portanto, somente como ser de razão que a justiça pode servir ao estabelecimento da paz social e politica, mas principalmente, como sentimento indefinivel e irrefreável que, brotando do mais intimo da alma humana, é capaz de inculcar em cada um, como já dizia, no alvorecer do século, Winston Churchill, falando como Home Secretary, a crença inabalável de que, no coração de cada homem, existe um tesouro.

Noutra oportunidade, discorrendo, ainda, sobre a justiça, observou:
Não é, no entanto, por defeito de limpidez conceitual que a idéia do iusto deixa de implantar-se na sociedade por forma satisfatória, a fim de proporcionar a felicidade, hoje não unicamente sonhada, mas exigida com veemência crescente. Não é, na verdade, porque a noção da justiça se mostra indeter-minada ou indefinida que a sua aplicação à realidade social se torna insegura ou claudicante.

$O$ defeito de perfeição que se vislumbra no justo não provém, pois, necessariamente, do seu conceito, mas dos defeitos imanentes aos passos do agir humano, quando viciados pelo imperialismo truculento dos interesses indivi-duais. A imperfeição, no que respeita à justiça, não será sempre, assim, de sua idéia, porém do sistema positivo que se constrói a sombra dessa noção peregrina, ou da forma pela qual esse complexo normativo pode vir a aplicar-se.

Sobre o mesmo tema, eterno e inexcedível, em discurso a bacharelandos, acentuou o ministro Leitão de Abreu:

Para bem cumprirdes a vossa missão, é impreterivel tenhais aquilo que já se chamou o gosto impetuoso da iustiça, que, no entanto, só se tornará operante, plenamente operante, se vos dispuserdes a seguir, com intransigência, a palavra de Camus, segundo a qual cumpre sejamos justos nós mesmos, se quisermos instituições iustas. Não percais, além disso, por um momento sequer, a consciencia, assim do peso de vossa responsabilidade, como da imensidão da vossa força, na condição de oficiantes do justo, porquanto, se é certo, como proclama 
orador norte-americano, que um homem com Deus é maioria, menos verdade não será que um homem com a justiça é igualmente a maioria.

8. A admirável fidelidade de João Leitão de Abreu aos princípios de formação humanística manifesta-se, quer em sua visão da justiça, quer em sua compreensão do fenômeno político. Ao assumir, pela segunda vez, a chefia do Gabinete Civil da Presidência da República, em agosto de 1981, no discurso de posse, referindo-se à crise que assoberba o mundo de hoje, afirmou:

Essa crise, entretanto, somente seria incontornável, se os homens tivessem perdido a capacidade de pensar de modo novo e de agir também de modo novo, à maneira de que, vai para cerca de um século, luminosamente preconizava Lincoln.

Haveria, em outras palavras, razões para medo, medo pânico, se os anos de pensamento criativo também houvessem acabado, se a razão, notadamente a razão vital, tivesse caido em letargo. A verdade, no entanto, a feliz verdade, é que assim como, segundo a lição bíblica, o ouvido não se cansa de ouvir e o olho não se cansa de ver, assim também o pensamento não se cansa de pensar. Mas, salvadoramente, não se cansa de pensar também um pensamento inovador, aquele pensamento que, na ordem especulativa, transforma as grandes concepções do mundo e do homem; no plano cientifico, aprofunda e alarga o conhecimento da natureza; na esfera da atividade prática, resolve os problemas vitais e soluciona as questões sociais e políticas.

Malgrado, pois, as turbulências, de caráter por assim dizer cósmico, que assolam o mundo moderno, não será exagero dizer que a humanidade possui imenso cabedal de recursos, de natureza intelectual, para vencer as dificuldades da hora presente. Se vivemos assim, como se tem observado, numa época social rápida, de crises, numa época de esperanças e de grandeza. Maior seria essa esperança, certamente, se a inteligência moral e política acompanhasse os progressos da inteligência especulativa, científica e técnica. É inegável, porém, que, não obstante a debilidade ainda denotada pela inteligência prática, a sociedade faz uso, em grau cada vez maior, daquilo que já se chamou uma das maiores descobertas da humanidade, ou seja, a descoberta, na ordem política e social, do compromisso.'

Nessa linha, em 1984, escreveu:

Não é de hoje que as idéias governam o mundo. Porém, jamais o seu poder foi tamanho como hoje. As idéias, que comandam a história, não são de muitos, nem são puramente politicas. Porquanto as idéias políticas, ao menos as fundamentais, provêm de achados filosóficos. Donde concluir um dos maiores pensadores jurídicos da nossa época que a luta partidária representa ao mesmo tempo uma grande discussão filosófica e que as grandes mudanças políticas são

1 Correio Brasiliense, 13 ago. 1981, p. 4. 
preparadas ou acompanhadas pela filosofia do direito. Daí apregoar, em termos categóricos: No princípio era a filosofia do direito; no fim, a revolução.

Agente da filosofia, a politica aumenta de importância. A tal ponto que se atribui a Jaspers considerar as questóes politicas demasiado sérias para serem deixadas somente aos politicos - juizo que aumenta a responsabilidade do politico, na medida em que lhe pede engenho de certo modo universal. ${ }^{2}$

9. Revelando, ainda uma vez, sua visão humanística da realidade jurídica, que não se pode entender como um mero universo de normatividade positiva ou como um conjunto de construções simplesmente normológicas, João Leitão de Abreu, em 1965, em ensaio sobre A Função Política do Judiciário, observou:

A beleza arquitetônica das construções e o prazer estético das elegâncias teóricas, doutrinárias ou hermenêticas não podem, de maneira alguma, levar o juiz a esquecer o caráter prático ou político da sua função. Se perdesse de vista os fins pragmáticos, a que o seu oficio deve servir, para deixar-se hipnotizar pela contemplação das estruturas lógicas do direito, reproduzir-se-ia, em relação ao juiz, aquilo que Wells, em um dos seus contos, narra de um principe indu. Morrendo-lhe, mordida de serpente, a mulher que adorava, consagrou ele a vida a construir-lhe um monumento, que, sob a denominação de "Pérola do Amor", pretendia fosse o mais belo do mundo. Todo feito de mármore puro, elevam-se em torno do sarcófago, pendendo da abóbada, que o recobria, jóias raras e preciosas. Ao cabo de anos, comple-tando-se, enfim, o monumento, con-templou-o o príncipe com satisfação. $O$ orgulho que experimentava pela beleza suprema do templo fez que sentisse haver ali algo, de somenos importância, que rompia o equilibrio artístico da sua criação. Repentinamente tomou consciência de que a pequena coisa em desarmonia com o desenho não era senão o próprio sarcófago, onde jazia o corpo da bemamada. Não tendo mão em si, voltouse, então, para os ope-rários e, apontando para o sarcófago, bradou: "Levem isto daqui".

Referindo-se, nesse sentido, em fevereiro de 1979, na posse do ministro Antônio Neder, na Presidência do STF, às repercussões das profundas mudanças que se operam, "irreprimível e perturbadoramente", na estrutura da sociedade e nas feições do Estado, notadamente, a partir da Segunda Guerra que assolou o mundo, Leitão de Abreu, ao examinar esse grave tema, no âmbito do cosmo jurídico, assevera que um dos característicos do nosso tempo está em que o direito, pela primeira vez, participa da angústia histórica, explicando:

Manifestação veemente dessa angústia é o processo que se move, em

2 Jornal do Brasil, 23 set. 1984, p. 5. 
todos os quadrantes, contra os chamados métodos ou elementos de interpretação. A tônica desse trabalho critico consiste, de um lado, em que a lei é importante para criar ou revelar todo o direito; de outro, que ao juiz cabe participar, em grau eminente, quando menos, no descobrimento do juridico. A um pensar cerrado, lógico-formal, silogístico, conceitual, agrilhoado ao direito objetivo, opõe-se - teórica, complementar e praticamente -, o pensamento aberto, a análise das questões de direito como problemas que, na sua peculiaridade, requerem o tratamento devido, em nome da iustiça, ao homem vivo, o homem concreto, mergulhado na solidão existencial. A regra de direito é formulada, portanto, em principio, dentro de certa margem de possibilidade, com pretensóes de probabilidade e não de modo exato, matematizante. Funda-se a lei em juizos de valor, que não estão reservados, contudo, exclusivamente, à autoridade legislativa, porquanto a função estimativa ou axiológica penetra e empapa todos os graus de produção do direito. Logo, o processo de individualização ou concretização da norma, se não exclui a dedução lógica, não se esgota em operações dessa natureza. No tocante à interpretação, será necessariamente, no que concerne à lei, um discurso sobre um discurso; porém, um discurso cuja inteligência é fixada, de modo terminante, na ordem judicial, pela sensibilidade ou inspiração individual do intérprete. Exprime-se essa idéia, quando, em direito continental europeu, se ensina que o problema medular da jurisprudência não é a correção formal das deduções, porém a prudente eleição das premissas, operação que não é regida pela lógica formal, mas por juizos de valor. Não intimidam, também, nos Estados Unidos, as regras da lógica, onde um dos maiores dos seus constitucionalistas assevera não haver razão para temê-las, uma vez que o tribunal pode escolher as premissas do silogismo judicial.

Aludindo, pouco tempo depois, ao universo do magistrado como região constantemente visitada pela angústia, em homenagem da Corte, ao ministro Bilac Pinto, acentuou Leitão de Abreu:

Plácido e tranqüilo seria o mundo do magistrado se fosse ele sempre a oficina silenciosa das construções silogísticas. Para isso, fora necessário, porém, que a norma juridica saísse perfeita, completa, acabada, sem falhas ou imprecisões das mãos do legislador, que, onisciente, tudo previsse, tudo deixasse precisa e exatamente disciplinado. Obra humana, à lei se aplica, entretanto, de certa forma, aquilo que do mundo humano, em termos gerais, se diz, ou seja, que nele nada começa jamais absolutamente $e$ nada jamais se completa. A formação do direito pelo legislador não exaure ou tranca, portanto, o processo da sua criação, que prossegue, forçosa e inevitavelmente, pelo trabalho iudiciário. Como a lei deve exprimir, qualquer que seja o processo de sua elaboração, exigência popular, vivana consciência da coletividade, o intérprete do comando legislativo há de buscar, na realidade social, que deu nascimento à norma jurídica, 
elementos para, por via hermenêtica, desenvolver-lhe o sentido.

O tema da angústia no mundo do direito, Leitão de Abreu retoma-o em trabalho que publicou no Jornal do Brasil, edição de 23.9.1984, sobre o mestre de todos nós, Ruy Cirne Lima, logo após a sua morte:

Dominando a ciência jurídica Ruy Cirne Lima conhecia o mundo do direito como poucos. Jurisconsulto acabado, conhecedor emérito dos direitos, comum e canônico, à maneira dos mestres germânicos não se deixava envolver inteiramente pelo complexo normativo, pelos ditados das fontes do direito positivo. Admitia que, pela primeira vez, o direito participava do drama humano, da angústia histórica. Entendia, porém, que isso era exato somente em relação ao direito positivo. Porque a angústia iurídica sempre acompanhou os que, como ele, postu-lavam a existência de um direito su-perior, suprapositivo. Neste se encon-trava para ele a pedra de toque pela qual cumpria aferir a legitimidade do direito humano, bem como a fonte de inspiração para modelar ou corrigir o direito empírico.

Depois de registrar, nessa linha, com ênfase, que a atividade jurisdicional não se pode reduzir a mera atividade jurídica, emparedado o juiz nos limites da lógica formal, esgotando-se a jurisdictio em simples reverências aos enunciados da lei, anota:

Como acontece, porém, com outras espécies de veneração, a que assim se presta à lei lhe é devotada apenas em efigie, por isso que, na realidade, os seus ministros, no exercicio legítimo da sua função, nunca se cingiram, no aplicá-la, a realizar operações de caráter simplesmente lógico-formal. A verdade é que, em todos os tempos, o juiz, para dar resposta às exigências da utilidade comum, sempre se deixou guiar por juizos de valor. Auscultando, em face da dramaticidade inerente ao caso concreto, as pulsações da vida social, o juiz, guardando as palavras da lei, presta-se com certa margem de liberdade na sua aplicação. A índole política da função judiciária não se acusa, via de regra, em períodos de estabilidade, nos quais a lei não se haja divorciado, quanto à sua ratio, das correntes políticas, em cujo seio o con-teúdo legislativo germinou e adquiriu forma. Nos periodos de crise, porém, durante os quais se infiltram no sistema jurídico, sob a pressão ou da algazarra das ruas, ou de nova filosofia politico-social, princípios novos, cria-se, para o órgão judiciário, a melindrosa tarefa de conciliar o passado com o presente, sem infidelidade ao seu nobre mister.

Ressalta desses excertos do pensamento de João Leitão de Abreu correspondência pontual a uma verdade que deve estar, de forma constante, na consciência do magistrado, de qualquer grau: o juiz, como órgão de um dos poderes do Estado, há de ter presente o caráter prático do grave ofício de julgar e, desse modo, embora seguro, como se faz mister, nos exercícios lógico-formais, nas construções teóricas e nas doutrinas hermenêuticas, importa, 
entretanto, não expor suas decisões, em nenhum momento, ao perigo da ausência do real, certo de ser na perspectiva desse, que cabe desenvolver o raciocínio judiciário, orientado, permanentemente, por fatores de índole axiológica e atento, em cada tempo, às exigências do bem comum que lhe incumbe também construir.

10. Em seus trabalhos, acerca da Juris-prudência, aqui entendida na acepção de "ciência do direito positivo", e da Filosofia do Direito, - a partir de precisa discriminação metodológica -, João Leitão de Abreu tratou do fenômeno jurídico, com nítida distinção do que compõe o objeto da ciência do direito positivo e o que se constitui no ofício da especulação filosófica, embora os dois domínios acabem por convergir no entendimento unitário do direito.

$\mathrm{Na}$ visualização, destarte, da universalidade do direito, anota o ministro Leitão de Abreu, em sua obra A Validade da Ordem Jurídica:

5. A validade do direito é, assim, problema que se pode propor segundo critérios diferentes. Tantos serão esses critérios, quantos ângulos pelos quais se possa considerar o fenômeno jurídico.

Posto que seja possivel arrolar série numerosa de critérios, que presidem ao exame do direito, o certo é, contudo, que, desprezadas particularidades secundárias de cada um, podem eles ser reduzidos, na sua substância, a três posições fundamentais: a lógicaformal, a sociológica e a filosófica. Essa tripartição é tradicional, achando-se consagrada, senão explicita, ao menos implicitamente, na maneira como são versados, em geral, os problemas jurídicos.

Negando aceitação à doutrina segundo a qual a validade do direito é noção só aplicável a estruturas normativas, porque traz como consequiência "admitir como só objeto possível do conhecimento jurídico conjunto de normas", "que se reputem válidas", circunscrevendo-se, destarte, a tarefa do juris-ta "à execução de operações lógico-formais a respeito do complexo normativo", anota o ministro Leitão de Abreu:

Não é bastante, contudo, no concernente ao direito positivo, que as normas se tenham formado de acordo com os critérios estabelecidos no ordenamento a que pertencem. É necessário, ainda, que este, em certa medida, corresponda aos comportamentos reais dos individuos. Requerse, por isso, o que se chama de tensão entre a ordem jurídica e os próprios fatos ou realidade social, de tal sorte que haja um mínimo de conformidade entre o sistema normativo e os comportamentos adotados em razão dele.

Em página magistral acerca dos limites do conhecimento científico do direito e da ação do jurista, em sua obra básica, escreveu:

Ainda que se não aceite, integralmente, a tese kelseniana de que a ciencia do direito se exaure no conhecimento das normas, que compõem o direito positivo ou na 
descrição do processo pelo qual estas se engendram, cumpre se reconheça que a atividade científica do jurista não pode prescindir da consideração de normas que já se achem em vigor. Não estão essas normas desligadas, por certo, da realidade social, achando-se, ao revés, em conexão incindivel com esta. É imperioso, desta sorte, que, no exame cientifico do direito, se atente, a um tempo, para o complexo normativo e para os comportamentos sociais a que o sistema jurídico se refere. Quando a atenção recai, não pode esta, de outra parte, enquanto objeto da ciência do direito, deixar de ser referida ao conjunto normológico, consistente nas proposições jurídicas em vigor.

Questão melindrosa é a que entende com a determinação do nexo entre o sistema normativo e os elementos que a ele, indissoluvelmente, estão ligados. Entre as soluções que se apontam para o problema, figura a da teoria dialética, segundo a qual a relação entre a norma e a realidade social é nexo de implicação, estabelecido de tal sorte que não se poderia conceber uma sem a outra. As teorias, se assim se pode dizer, dimensionalistas do direito nele discernem diversos momentos que, por abstração, podem ser vistos na sua individualidade própria, mas que, para se integra-rem no conhecimento iurídico, se relacionam entre si polar ou dialetica-mente, formando o todo sobre o qual incide a atividade cognitiva do jurisconsulto.

Depois de aludir, entre nós, nesse sentido, o pensamento de Miguel Reale, para quem o direito se apresenta sob estrutura tridimensional, decorrente da integração nele, em moldes dialéticos, de norma, fato e valor, acrescenta João Leitão de Abreu:

Malgrado as reservas que ai se enunciam quanto ao unilateralismo da doutrina normativista no determinar o objeto da ciência do direito, consentese, todavia, em que o jurisconsulto há de atentar, como momento culminante da sua atividade, para a norma jurídica ou para o complexo normativo. Está implicito, nessa doutrina, que não cabe à ciência do direito criar a norma iurídica, se bem que lhe compita, diante dos elementos axiológicos que integram a estrutura do direito positivo, a explicitação do sentido que às proposições normativas são imanentes. No desenvolver ou explicar o sentido da norma, em face do momento axiológico, é natural que o jurista se deixe seduzir, contudo, pela tentação de modificar-lhe o conteúdo, transmudando-se, então, de fato, em criador do direito. A medida em que tudo isso pode acontecer é revelada, de modo eloqüente, pelas modernas doutrinas, acerca da hermenêutica jurídica, onde se sustenta que a interpretação começa por um juizo de valor a respeito da solução que merece a hipótese em exame. Significa isso que o fundamental, na exegese do direito, a teor dessa doutrina, é o momento axiológico, que, impondo-se à inteligência da norma, dá lugar, no fundo, à insuflação nela de sentido novo, se o aceito até então não se coadunar com as exigências deontológicas, que o caso concreto suscite.

Examinando, longamente, na obra citada, a ordem jurídica, também, na 
perspectiva filosófica, registra o saudoso ministro Leitão de Abreu, em certo passo:

O tratamento filosófico dos problemas jurídicos implica, pois, atitude, na qual se julga se o direito positivo corresponde, ou não, ao arquétipo ou modelo, a que se deve ajustar. Se a discrepância entre a idéia do direito e aquilo que o direito é na sua positividade ou facticidade torna insuportável a ordem juridica em vigor, haverá lugar para que se the negue validade. Não se limita, porém, a apreciação filosófica a essa manifestação de caráter negativo. Definida, em proporções deontológicas, a feição que se deve imprimir ao direito positivo, cumpre ao jurista, enquanto filósofo, apostar-se na transformação deste, a fim de aproximar, pelos meios ao seu alcance, a ordem jurídica dos valores a que esta deve subordinar-se. Se não é possivel, vor meios lógicos, passar do ser para o dever ser, da realidade para o valor, é possivel, contudo, referir o ser aos valores e promover, pela atração que o valioso exerce sobre o existente, a compatibilidade de um com o outro.

Reveste-se, desse modo, de importância científica a obra de João Leitão de Abreu sobre $A$ Validade da Ordem Jurídica, notadamente, pelo tratamento dispensado a matérias como o controle em abstrato da constitucionalidade das leis e a eficácia da norma inválida, o princípio da efetividade, a operatividade do fato na criação do direito e a teoria do fato normativo, bem assim o amplo estudo acerca das doutrinas da "jurisprudência analítica", da "jurispru- dência sociológica" e da "jurisprudência sobre as teorias da justiça", a par de outras questões teóricas da maior significação no estágio presente da ciência do direito. A atualidade dessa obra esgotada está a indicar a inequívoca conveniência de uma nova edição, ao ensejo de seu $35^{\circ}$ aniversário, ocorrido neste ano, para torná-la, de tal maneira, acessível aos estudiosos da teoria do direito.

Em 1976, o ministro Leitão de Abreu publicou, ainda, valioso e erudito ensaio sobre "Lei Natural e Lei Jurídica", inserido no livro Estudos de Direito Público em Homenagem a Aliomar Baleeiro, onde retoma o exame de algumas questões versadas em $A$ Validade da Ordem Jurídica.

11. A visão segura da política e do constitucionalismo moderno de Leitão de Abreu está, também, expressa em reflexões significativas e de densidade conceitual em dois outros importantes ensaios. O primeiro, publicado em janeiro de 1969, sob o título $A$ Crise da Constituição, onde examinou a realidade européia pós-guerra e, em especial, a Carta francesa de 1958, acentuado:

A crise constitucional que assinala os tempos modernos, como decorrência das transformações sociais ora em pleno desenvolvimento, é particularmente aguda naquilo que entende com a posição do Poder Legislativo entre os órgãos do Estado. A sua antiga e incontestável preeminência, como fonte de toda a autoridade, cede o passo, de modo sempre mais acentuado, à preeminência do Poder 
Executivo, diante da concentração de atribuições que se lhe deferem para desempenhar as tarefas capitais do governo.

\section{E acrescenta:}

A crise constitucional, que se abate sobre o universo político, nada mais é do que um dos aspectos ou reflexos $d a$ crise das idéias, que aflige, no seu conjunto, o universo cultural. A perplexidade que atormenta o espírito humano, diante do caráter problemático assumido, em todos os setores, por doutrinas e teorias, que se afiguravam diáfanas, certas $e$ inabaláveis, assalta igualmente a inteligência prática dos políticos e iuristas, diante da rebelião dos fatos contra esquemas e categorias constitucionais, que se reputavam definitivos, visto corresponderem a ditados da própria razão. A crise da Constituição, que esse estado de perplexidade revela, não resulta, entretanto, unicamente, dos escombros a que foi reduzida a antiga ordem constitucional. $O$ núcleo verdadeiro da crise está em que não se cristalizaram ainda principios novos que se substituam aos velhos postulados constitucionais.

O outro estudo, de 1978, elaborouse em torno da Constituição dos Estados Unidos da América do Norte de 1778, então comemorando seu bicentenário. Em análise rica de informações e reflexões, apreciou a origem, as crises institucionais superadas, o poder de emenda, a interpretação da Corte Suprema, a iudicial review, as transformações do direito constitucional americano, as conseqüências da I Guerra Mundial, as constituições da Europa, o controle concentrado de constitucionalidade das leis e o sistema americano com sua feição interpretativa peculiar, suas vinculações ao espírito do common law, a noção da recta ratio judicial, que se invoca como critério de razoabilidade da norma. Registrou, nesse erudito ensaio, o ministro Leitão de Abreu:

A história do venerável documento, que rege a vida política norteamericana, longe de possuir a placidez, que a sua duração poderá sugerir, é pontilhada de angústias, perigos e querelas. A sua história, em suma, é uma história de crises; e precisamente na virtude que exibe para dominar crises está a sua grande, a sua inapreciável contribuição para o constitucionalismo, mormente o contemporâneo que vê na judicial review fórmula impreterível para garantir ao sistema constitucional a estabilidade que dele se requer.

12. Evidenciam, de outra parte, a correspondência da ação do ministro Leitão de Abreu, como juiz, as linhas de seu pensamento, votos que proferiu no Supremo Tribunal Federal, tão bem registrados nas palavras do então advogado José Paulo Supúlveda Pertence, hoje ilustre ministro daquela Corte, na homenagem de despedida, por motivo de sua aposentadoria, em sessão de 30 de setembro de 1981:

"Recordem-se os seus votos a respeito da inviolabilidade parlamentar, ainda na 
vigência da redação original do art. 32 da Carta de 69, que assegurando-a nominalmente, dela excluía, no entanto, além dos crimes contra a segurança nacional, as acusações de calúnia, injúria e difamação. Quer ao sustentar a irresponsabilidade penal de um congressista por ofensa a outro, que "não transcenderia do âmbito das questões interna corporis do Parlamento, resolúveis dentro dos seus muros, por via disciplinar" (Apn 222) quer ao rejeitar denúncia contra deputado acusado de ofensa a autoridades administrativas, que traduziriam "opinião manifestada por parlamentar no desempenho de função inerente ao mandato" (Apn 240), lutou, com brilho e pertinácia excepcionais, o ministro Leitão de Abreu: tentou contra a confessada clareza da norma, que se reduzisse a exceção "aos limites mais rigorosos que o texto constitucional, explicado liberalmente, possa admitir, para evitar que a regra da imunidade, solenemente garantida, se convertesse - dizia - no que já se chamou a sombra de uma sombra, pois que, dessa prerrogativa constitucional, em última análise, pouco mais sobraria do que o galanteio de homenagem puramente verbal."

$\mathrm{Na}$ mesma linha das liberdades políticas, tornou-se célebre a sua manifestação, igualmente minoritária, pela inconstitucionalidade da LC 5/70, no ponto em que faz inelegível não só o condenado, mas o cidadão apenas denunciado por determinados crimes. O voto, de impressionante grandeza, extraí, da norma que assegura, além dos especificados, os direitos e garantias implícitos nos princípios do regime, a consagração positiva da presunção de inocência, nos termos da Declaração Universal dos Direitos do Homem, para daí deduzir a ilegitimidade constitucional da lei questionada. Responde à contradita de que a presunção de inocência estaria desmentida pela admissão da prisão provisória que "não vale argumentar com normas do direito comum para estabelecer limites a princípios fundamentais." "Em lugar de argumentar da lei ordinária para a norma fundamental, a fim de limitar-lhe o sentido e a eficácia" - redargue - "o que cumpre é argumentar dos princípios estabelecidos na declaração de direitos para os preceitos de lei ordinária, para subordinar estes últimos aos primeiros".

O mesmo raciocínio - da prevalência da substância e da força de expansão dos princípios fundamentais de segurança da liberdade - retorna, mais ou menos explicitamente, em numerosos votos seus. Particularmente naqueles em que, versando questões aparentemente rotineiras de processo penal comum, o ministro Leitão de Abreu prestou testemunho de aguda sensibilidade para a democratização dos direitos humanos, fazendo-os descer dos páramos dos direitos políticos para a planície da violência cotidiana da repressão penal comum sobre o homem indefeso das multidões anônimas.

Os exemplos seriam incontáveis. Recorde-se o papel decisivo do nosso homenageado, aqui vitorioso, na interpretação da L. 5.941, para firmar como direito subjetivo, não como mero arbítrio do juiz, a liberdade provisória do réu primário e de bons antecedentes. 
Releia-se o seu voto vencido pela extensão do direito de apelar em liberdade ao réu anteriormente preso em flagrante ou preventivamente, quando não subsistam, à sentença condenatória, motivos que imponham a manutenção do encarceramento (RHC 53.603). É, sem favor, um trabalho magistral - dificilmente superável no direito brasileiro - seja a respeito do caráter estritamente cautelar de todas as modalidades de prisão provisória, seja no tocante à natureza restrita do poder discricionário da autoridade judicial, insuscetível de equiparação ao conferido à autoridade administrativa.

$\mathrm{Na}$ mesma área, e com o mesmo sentido profundamente liberal que identificou a sua judicatura, refiram-se ainda - sempre derivados do princípio constitucional da ampla defesa, contra textos legais de sabor restritivo -, os votos do ministro Leitão de Abreu, sobre o caráter absoluto da nuiidade oriunda da ausência do réu preso à instrução do processo (HC 54.543); ou sobre a obrigatoriedade, para o defensor dativo, da apelação contra sentença condenatória (RHC 57.091), orientação depois alterada pela maioria do eg. plenário.

Na mesma oportunidade, o ministro Rafael Mayer, falando em nome da Corte, observou: Momentos da atividade judicante devem ser ressaltados, exponenciais de sua arte de julgar, caracterizados sempre pelo equilíbrio e segurança, e pelo suporte cultural, mas também registráveis pela marcante $\mathrm{e}$ definida posição a respeito de temas de singular relevo no direito aplicado.
Dedicado e exato, no exame de todos os casos a seu encargo, acrescem sempre os seus cuidados de juiz, quando os temas tocavam os magnos postulados de ordem constitucional, maiores dentre os magnos temas desta Casa.

São decerto destacáveis, como expressões de alta doutrina, alguns dos seus votos, em memoráveis julgamentos da Corte, no período em que se cumpriu a sua judicatura, temas que são representativos dessa linha de preocupações e de teses que emergem harmo-nicamente do sedimento de sua ciência jurídica.

Contribuição erudita, como a qualificou o eminente ministro Thompson Flores, está, por exemplo, no voto do ministro Leitão de Abreu, proferido nos debates em torno do conceito de ato do governo local, para o pressuposto do recurso extraordinário pela letra "c", a saber se compreensivo tão-somente dos atos normativos e não dos individuais. Em análise comparativa com símile norte-americano, concluiu pela abrangência maior do conceito brasileiro, mas afastando, de modo flexível a obrigatoriedade de conhecimento que é inerente a essa via recursal, "quando se tratar de ato individual cuja prática não ponha em risco, de modo significativo, a preeminência do Direito federal. (RE 80.896).

Ao declarar-se a inconstitucionalidade de lei regulamentadora da profissão de corretores de imóveis, o seu voto enfocou, de modo singular, o critério de razoabilidade a utilizar na hermenêutica do direito constitucional, para 
aferir se a lei ordinária "se manteve dentro de limites próprios, conve-nientes ou apropriados ao fim que teve em vista a Carta Política." Sob pena de constituir letra morta o direito individual ao livre exercício da profissão, os re-quisitos que o legislador the ponha devem ser compatíveis com o critério de razoabilidade, contrariado, no caso, de modo invalidante $\left(\mathrm{Rp} \mathrm{n}^{\circ} 930\right)$ com o que dava destaque a um critério prestante.

Apenas chegado a esta Corte, o ilustre ministro, com a clarividência de abordagem dos temas constitucionais e de direito administrativo, contribuiu com o seu voto, de maneira decisiva, para o deslinde de questão, que vinha debatida, de há muito, a que diz respeito a imunidade tributária do IBC no tocante às operações de revenda do café adquirido aos produtores. Ressalta, desse voto, de larga erudição, o rigor lógico em estabelecer a fina e precisa discriminação entre finalidade essencial e não essencial dos entes menores, índice da imunidade recíproca que lhes é extensiva pelo texto constitucional (MS 19.097).

Em se tornando relator, na Representação $n^{\circ} 921$, o ministro Leitão de Abreu, enfatiza um dos temas de sua predileção, o da hermenêutica constitucional, para tirar a consequiência do decisum. É que, invocando precedentes do corpus juris secundum, entendeu que, embora não vinculantes da Corte a interpretação administrativa ou judiciária precedente, cumpre, na determinação do sentido de uma norma ambígua, recorrer a subsídio de caráter extrínseco consistente na averiguação da exegese de tal norma dada ao tempo de sua adoção, e daí por diante, por aqueles cujo dever tem sido de interpretá-la, executá-la e aplicá-la na prática, cabendo emprestar-lhe grande peso ( $R p$ 921).

Deteve-se, demoradamente, nos conceitos constitucionais do direito tributário, numa pertinente e completa distinção entre taxa e contribuições especiais, postas em face dos elementos conotativos do imposto. Nessa análise dos dados configurantes da taxa florestal do Estado de Minas Gerais, permitiu que os identificasse com o fato gerador do ICM, o que fez o Tribunal, seguindo o seu entendimento, declarar-lhe a inconstitucionalidade (RE 78.600).

Como bem anotou o eminente ministro Rafael Mayer, "esse registro, como um perfil, contém apenas alguns índices representativos da escala de sua atividade judicante, impossível de condensar, na oportunidade, quer pelo número das manifestações, quer pela diversidade das proposições", acrescentando:

"Possível, no entanto, é obter, pela análise do seu trabalho de sete anos, nesta Corte, a confirmação e a consequiência dos conceitos e valores pelos quais, culturalmente, se guiou e formou, agora aprofundados e desdobrados a uma nova luz, ao crivo desse grave encargo de julgar. Em seus votos, na verdade, repercutem, ao revérbero dos fatos e das situações concretas, os princípios cristalizados de sua experiência jurídica, sob nova dimensão." 
E conclui:

"Assim, ao longo das formulações de uma cultura solidamente construída, de um seguro raciocínio silogisticamente discorrido, de ampla apreensão intelectual do complexo mundo das realidades, das normas e dos valores, nos sucessivos planos de sua atividade intelectual e jurídica, o ministro Leitão de Abreu realiza aquela coerência das diversidades no todo de um universo intelectual e moral, aquela unidade espiritual e dinâmica, que faz a marca indelével de uma presença."

O ministro João Leitão de Abreu foi, em vida, agraciado com todas as condecorações do Poder Executivo e do Poder Judiciário da República, inclusive a Ordem Nacional do Mérito, no grau "Grã Cruz", e com a mais alta insígnia de seu Estado natal, a comenda "Ponche Verde", bem assim com medaIhas e condecorações de Estados da Federação e de governos de nações amigas.

Em 1943, ainda estudante de Direito, João Leitão de Abreu casou com sua prima, D. Iracema Pessoa de Abreu. Nasceram dessa união feliz, que viu quase meio século passar, quatro filhas: Corina, Patrícia, Alice e Paula.

$\mathrm{Na}$ simplicidade de sua vida, austera e honrada, de inexcedível espírito público e amor ao bem comum, vocação constante ao serviço generoso, João Leitão de Abreu soube, admiravelmente, decifrar o enigma do poder, entendendo-o sempre, e assim o exercendo, não como um direito, que se atribua a alguém, mas como um instrumento posto a um fim que toca imediatamente ao serviço de todos. Nunca o atormentou a ambição do poder; jamais o seduziu o fascínio da riqueza. Nele não havia a tentação do parecer simplesmente, sem a responsabilidade do ser.

Sua morte, a 13 de novembro de 1992, entristeceu a Nação, quanto a sua amantíssima e dedicada família e a seus amigos. Os meios de comunicação reservaram-lhe significativos espaços $\mathrm{e}$ o chefe de Estado decretou luto oficial, numa justa homenagem de reverência a quem, no Executivo e no Judiciário, por longos anos, soube viver, com absoluta integridade, o verdadeiro mistério do poder, cuja essência deve ser o amor, a dádiva generosa de si, ao serviço de todos, sem outra lei que não a da bondade.

Estou certo de que sua vida há de ser lembrada pelos pósteros, com justiça, - conforme hoje já o faz esta Faculdade, nas comemorações de seu centenário -, como chefe de família exemplar, homem público integérrimo, professor, pensador e insigne magistrado, mas, acima de tudo isso, pela verdadeira bondade que, de fato, informava todos os seus gestos e inspirava o pensamento mesmo, pois é pela bondade que o homem se faz mais chegado à sabedoria, mais voltado para a eternidade que para o tempo. 


\title{
Os impactos da existência de diversos mecanismos de solução de controvérsias na aplicação do Direito Internacional Ambiental ${ }^{*}$
}

\author{
Maitê de Souza Schmitz ${ }^{\star \star}$
}

\section{INTRODUÇÃO}

Atualmente, há mais de treze tribunais internacionais permanentes, além de pelo menos outros seis mecanismos de solução de controvérsias que operam em âmbito mundial. Apesar do considerável número de tais instituições, nunca se chegou a desenvolver, no Direito Internacional Público, um sistema compulsório de regras concernentes à concorrência de jurisdição de órgãos internacionais. Especificamente quando se trata da proteção ao meio ambiente, as disparidades entre as decisões de diferentes sistemas de solução de controvérsias demonstram a necessidade de alguma modificação no cenário internacional, a fim de melhor enfrentar as questões ambientais.

O presente artigo, desta forma, tratará dos impactos que a pluralidade de tribunais internacionais e outros mecanismos de solução de controvérsias exerce na aplicação do Direito Internacional Ambiental. Na Parte I, será apresentada a maneira através da qual diferentes tribunais e mecanismos

\footnotetext{
* Artigo apresentado como trabalho final para a disciplina de Direito Internacional Ambiental, ministrada pelo profesșor Stephen Kass, e cursada na Pace University, em 2003.

** Estudante do último ano de Direito na Universidade Federal do Rio Grande do Sul (UFRGS), também estudou na Pace University (New York), durante o segundo semestre de 2003, com uma bolsa da CAPES. A autora gostaria de agradecer à profa. dra. Cláudia Lima Marques pelo seu papel fundamental na concretização desse intercâmbio, pelo seu constante apoio, bem como pela oportunidade dada aos participantes de dividir com a comunidade acadêmica alguns dos resultados dessa experiência. Gostaria de agradecer, também, à CAPES pela oportunidade, ao prof. Kass pela ajuda e orientação, e à profa. dra. Catherine Tinker por todo o apoio dado durante o semestre em Nova Iorque.
} 
de solução de controvérsias (como a Corte Internacional de Justiça, os painéis da Organização Mundial de Comércio, as cortes de direitos humanos e os sistemas de solução de disputas do NAFTA e do MERCOSUL) lidam com a questão do meio ambiente.

Após comparar o tratamento dado ao meio ambiente por tais órgãos, verificando como as suas decisões enfrentam as questões de direito ambiental, a Parte II examinará as soluções já propostas para o problema do conflito de jurisdição desses órgãos internacionais, e se tais idéias seriam ou não viáveis. Finalmente, serão sugeridas algumas possibilidades de mudança no cenário internacional, para que seja melhor promovida a proteção ambiental. Nesse sentido, a melhor forma de atingir o referido fim-de melhor proteger o meio ambiente - seria através de mecanismos diplomáticos, com o foco na cooperação entre os Estados. Após, se, como última alternativa, as partes buscarem um mecanismo jurisdicional, a Corte Internacional de Justiça, atuando como órgão revisor, seria a instituição mais apropriada para decidir as questões ambientais.

\section{AS DIVERSAS MANEIRAS ENCONTRADAS PELOS ÓRGÃOS INTERNACIONAIS PARA TRATAR DA PROTEÇÃO AO MEIO AMBIENTE}

\section{A) A Corte Internacional de Justiça e as Cortes de Direitos Humanos \\ 1. A Corte Internacional de Justiça}

A Corte Internacional de Justiça (CIJ), o principal órgão jurídico das Nações Unidas,' não só tem jurisdição e competência ratione materiae para decidir disputas sobre questões ambientais, ${ }^{2}$ mas também é comumente incentivada a assim agir por significativa parcela da doutrina. ${ }^{3}$ Todavia, mesmo considerando o parco número de casos que são, via de regra, analisados pela $\mathrm{CIJ},{ }^{4}$ as questões ambientais são com pouquíssima frequiência levantadas, e

1 Carta da Organização das Naçôes Unidas, art. 92.

2 Veja Robert Jennings, The Role of the ICJ in the Development of International Environment Protection Law, 22 ENvTL. Pol. \& L. 312, 313 (1992).

3 Veja por exemplo World Commission on Environment and Development, Our Common Future 334 (1987); Catherine Tinker, "Environmental Security" in the United Nations: not a matter for the Security Council, 59 TENN. L. Rev. 787, 801 (1992).

4 Em média, a CIJ elabora, anualmente, cerca de duas a três decisões ou ordens. Veja Mark W. Janis, The Law of The Sea Tribunal, in International Courts For The Twenty-First Century 248 (Mark W. Janis ed. 1992) (fazendo uma análise comparativa entre o Tribunal Internacional de Direito do Mar e a CIJ). 
ainda mais raramente consideradas nas suas decisões.

Costuma-se citar o Caso Corfu Channel $^{5}$ como a primeira decisão da CIJ estabelecendo uma regra que poderia, posteriormente, vir a ser utilizada em casos envolvendo questões ambientais. ${ }^{6}$ Nesse caso, atribuiu-se responsabilidade ao Estado por sua falha em avisar aos demais acerca de um perigo iminente, bem como estabeleceu-se o dever do Estado de divulgar informações cujo desconhecimento possa acarretar efeitos danosos a outros países. Assim, entendeu-se, por analogia, que tais regras viriam a incluir os casos de poluição e riscos ambientais transfronteiriços. ${ }^{7}$ Embora tenha importância histórica, o caso Corfu Channel está longe de exercer um relevante papel no âmbito da proteção internacional do meio ambiente. Além de a palavra "meio ambiente" não ter sido mencionada em nenhuma parte da decisão, o resultado do caso foi obtido consideravelmente antes do desenvolvimento do direito internacional ambiental.
Os casos Nuclear Tests ${ }^{8}$ consistiram na primeira oportunidade que a CIJ teve de, efetivamente, abordar questões ambientais. O pedido da Austrália adotou uma tese similar à de "invasão" como base para determinar a responsabilidade da França, alegando que o depósito de material radioativo em seu território violaria sua soberania territorial. ${ }^{\circ}$ Embora a CIJ tenha determinado, preliminarmente, que a França deveria "evitar testes nucleares que causassem o depósito de material radioativo", ${ }^{10}$ não houve decisão de mérito, com base na declaração da França de que ela cessaria com os testes nucleares. ${ }^{11}$

Similarmente, no Case Concerning Phosphate Lands in Nauru, a CIJ novamente se restringiu à discussão quanto à admissibilidade, não tendo abordado a questão da proteção ambiental em sua decisão. ${ }^{12}$ A reabilitação das reservas de fosfato em Nauru, desgastada por ação da Austrália, foi reduzida a questões concernentes a, além de admissibilidade, responsabili-

5 Corfu Channel (UK v. Alb.), 1949 I.C.J. 4 (Apr. 9).

6 Ian Brownle, Principles of Public International Law 274 (Oxford 2003).

7 Ved P. Nanda \& George Rock Pring, International Environmental Law and Policy for the 21 st Century 73 (Ardsley ed. 2003).

8 Nuclear Tests (Australia v. Fr), 1973 I.C.J. 99 (Interim Protection Order of June 22); Nuclear Tests (N.Z. v. Fr.), 1973 I.C.J. 135 (Interim Protection Order of June 22).

9 Argument of Mr. Byers, Nuclear Tests (Australia v. France), 1973 I.C.J. Pleadings 479-90. 10 Nuclear Tests (Australia v. Fr), 1973 I.C.J. 99 (Interim Protection Order of June 22); Nuclear Tests (N. Z. v. Fr.), 1973 I.C.J. 135 (Interim Protection Order of June 22).

11 Nuclear Tests (Australia v. France), 1974 I.C.J. 253 (Dec. 20); Nuclear Tests (N. Z. v. Fr.), 1974 I.C.J. 457 (Dec. 20).

12 Case Concerning Phosphate Lands in Nauru (Nauru v. Australia), 1992 I.C.J. 240 (June 26). 
dade internacional e regime de exprotetorados da ONU. ${ }^{13}$ A opinião dissidente do vice-presidente, porém, destacou a importância da proteção ambiental no desenvolvimento ou na exploração dos recursos naturais. ${ }^{14}$

No Request for an Examination of Situation in Accordance with Paragraph 63 of Court's Judgment of 20 December 1974 in Nuclear Tests (Nova Zelândia v. França), ${ }^{15}$ a Nova Zelândia levantou diversos princípios ambientais para fundamentar seu pedido. Argumentando que o direito costumeiro evoluiu a ponto de compreender novos padrões e procedimentos de Direito Internacional Ambiental, a Nova Zelândia fundamentou no princípio da precaução o seu pedido de que a França deveria ter realizado um estudo de impacto ambiental dos testes nucleares em questão, antes de ter começado a levá-los a efeito. ${ }^{16}$ A Corte, novamente, não adentrou no mérito da questão, uma vez que considerou que o caso não se enquadrava nas hipóteses do Parágrafo 63 do julgamento anterior. ${ }^{17}$ Não obstante, a CIJ reconheceu a "obrigação de respeitar e proteger o meio ambiente". ${ }^{18}$ Outrossim, na sua opinião dissidente, o juiz Weeramantry destaca alguns princípios de direito ambiental mencionados pela Nova Zelândia, como o princípio da equiidade intergeracional (principle of intergenerational equity), ${ }^{19}$ o princípio

13 Ian Brownlie, Principles of Public International Law 274 (Oxford 6. ed.2003).

14 Case Concerning Phosphate Lands in Nauru (Nauru v. Australia), 1992 I.C.J. 240, 324-25 (June 26) (dissenting opinion of Judge Oda).

15 Request for an Examination of Situation in Accordance with Paragraph 63 of Court's Judgment of 20 December 1974 in Nuclear Tests (New Zealand v. France), 1995 I.C.J. 288 (Sep. 22).

16 A Nova Zelândia argumentava que, de acordo com o princípio da precaução, ao Estado que desejasse iniciar conduta potencialmente danosa ao meio ambiente recairia o ônus de provar que suas atividades não causariam contaminação ("the burden of proof fell on a State wishing to engage in potentially damaging environmental conduct to show in advance that its activities would not cause contamination"). Id. p. 298.

17 Id p. 307.

18 Id. p. 306.

19 O juiz Weeramantry, ao enfrentar a questão dos direitos intergeracionais, considerou o princípio da eqüidade intergeracional como um "princípio em desenvolvimento do direito ambiental contemporâneo" ("developing principle of contemporary environmental law"), e citou a afirmação de Lauterpacht de que "se um dano tal qual o alegado fosse causado ao meio ambiente por pessoas da Idade da Pedra, ele estaria ainda hoje entre nós" ("if damage of the kind alleged had been inflicted on the environment by the people of the Stone Age, it would be with us today"). Request for an Examination of Situation in Accordance with Paragraph 63 of Court's Judgment of 20 December 1974 in Nuclear Tests (New Zealand v. France) 1995 I.C.J. 288, 341 (Sep. 22) (dissenting opinion of Judge Weeramantry). 
da precaução (precautionary principle) ${ }^{20}$ e o reconhecimento, em geral, da necessidade de realização de estudos de impacto ambiental. ${ }^{21}$

Em uma Opinião Consultiva decidida em 1996, a CIJ teve a oportunidade de analisar algumas normas e princípios ambientais no âmbito do Direito Internacional. Em Legality of the Threat or Use of Nuclear Weapons, a Corte afirmou que os Estados têm um dever geral de garantir que atividades realizadas na esfera de sua jurisdição e controle respeitarão o meio ambiente não apenas de outros Estados, mas também de áreas fora do controle estatal. ${ }^{22}$

Mais recentemente, no caso Kasikili/Sedudu Island, o juiz Weeramantry apresentou outra opinião dissidente, expressando sua preocupação com relação aos aspectos ligados ao meio ambiente. No presente caso, a única referência ao meio ambiente feita na opinião majoritária foi para determinar que tanto os barcos de
Botswana quanto os da Namíbia que navegassem nos canais das Ilhas Kasikili/Sedudu poderiam estar sujeitos a regulamentações ambientais. ${ }^{23} \mathrm{O}$ que o juiz Weeramantry criticou, entretanto, foi o método adotado pela Corte para delimitar a fronteira: ao invés da divisão geométrica adotada pela maioria, o julgamento deveria ter levado em consideração "os interesses do ecossistema e da diversidade biológica", num esforço para preservar a reserva natural localizada na área em disputa. ${ }^{24}$

Finalmente, a CIJ tem, atualmente, uma oportunidade de versar diretamente sobre a proteção do meio ambiente, no julgamento adicional do Case Concerning the GabcikovoNagymaros Project. ${ }^{25}$ Tal controvérsia entre a Hungria e a Eslováquia permanece na lista de casos a serem decididos pela CIJ, embora já tenha sido analisado previamente pela Corte em 1997. ${ }^{26}$ Muitos consideram o Gabcikovo-Nagymaros Project o primeiro caso contencioso no qual a CIJ

20 Em suas palavras: "um princípio que está sendo cada vez mais defendido como parte do direito internacional do meio ambiente" ("a principle which is gaining increasing support as part of the international law of the environment"). Id. p. 342 .

21 Id. p. 344.

22 Legality of the Threat or Use of Nuclear Weapons (United Nations), 1996 I.C.J. 226, 241-2 (Jul. 08). 23 Case Concerning Kasikili/Sedudu Island (Botswana v. Namibia), 1999 I.C.J. 1045, 1107 (Dec. 13).

24 Case Concerning Kasikili/Sedudu Island (Botswana v. Namibia), 1999 I.C.J. 1045, 1184 (Dec. 13) (dissenting opinion of Judge Weeramantry).

25 International Court of Justice, Press Release 98/28, Sept 3 1998, disponível em http://www.icj-cij.org/icjwww/idocket/ihs/ihsframe.htm 26 Gabcikovo-Nagymaros Project (Hung. v. Slovakia), 1997 I.C.J. 7 (Sep. 25). 
claramente levantou questões ambientais em seu julgamento. ${ }^{27}$ De fato, a Corte procurou estabelecer um conceito para desenvolvimento sustentável,,$^{28} \mathrm{o}$ qual, embora não tenha sido considerado como um princípio pela $\mathrm{CIJ}$, foi tido como um fator para guiar a futura operação da usina de Gabcikovo. ${ }^{29}$ Contudo, o referido julgamento se concentrou quase totalmente no direito dos tratados, e em tópicos de responsabilidade do Estado em geral, ${ }^{30}$ não tendo reservado a devida atenção às questões ambientais apresentadas. Eis porque tal caso foi duramente criticado, haja vista sua falha em discutir diversos aspectos atuais do direito internacional ambiental. ${ }^{31}$ Ademais, na comprovação do "estado de necessidade ecológico" (state of ecological necessity), ${ }^{32}$ alegado pela Hungria como fator que a levou ao descumprimento do tratado com a Eslováquia, a CIJ estabeleceu o mesmo padrão elevado que exige na determinação do estado de necessidade tradicional. Com isso, a Corte deixou de considerar o princípio da precaução, ao menos nos casos de acordos e tratados já existentes. ${ }^{33}$

\section{As Cortes de Direitos \\ Humanos}

O juiz da CIJ Weeramantry, em um de seus votos, enfatizou a visão antropocêntrica na proteção ao meio ambiente, este considerado como précondição para a fruição de diversos direitos humanos, como o direito à

27 Afshin A-Khavari \& Donald R. Rothwell, The ICJ and the Danube Case: a missed opportunity for International Environmental Law?, 22 MeLB. U. L. REv. 507, 508 (1998).

28 Como notou a Corte, "a necessidade de conciliar o desenvolvimento econômico com a proteção do meio ambiente está expressa com propriedade no conceito de desenvolvimento sustentável" ("the need to reconcile economic development with protection of the environment is aptly expressed in the concept of sustainable development"). GabcikovoNagymaros Project (Hung. v. Slovakia) 1997 I.C.J. 7, 78 (Sep 25).

29 Id. p. 75-76.

30 Ian Brownle, Principles of Public International Law 274 (Oxford 6 ed. 2003).

31 Erika L. Preiss, The International Obligation to Conduct an Environmental Impact Assessment: the ICJ case concerning the Gabcikovo-Nagimarus Project, 7 N.Y.U. ENvTL. L. J. 307,308 (1999).

32 O Estado que levanta a hipótese de estado de necessidade deve provar que o ato, justificado por um interesse essencial do Estado ameaçado por um "perigo grave e iminente", era a "única forma" de garantir seus interesses, e não "prejudicava seriamente um interesse essencial" de outro Estado. Finalmente, o autor do ato não deve ter contribuído para causar o estado de necessidade. Gabcikovo-Nagymaros Project (Hung. v. Slovakia) 1997 I.C.J. 7, 40 (Sep. 25).

33 Ida L. Bostian. Flushing the Danube: the World Court's Decision Concerning the Gabcikovo Dam, 9 CoLO. J. INT'L ENvTL. L. \& PoL'y 401, 425 (Summer 1998). 
saúde e à vida. ${ }^{34}$ Esse é, normalmente, o enfoque adotado pelas Cortes de Direitos Humanos quando lidam com questões ambientais.

A Corte Européia de Direitos Humanos (CEDH) mencionou pela primeira vez a questão do meio ambiente no caso Powell \& Rayner v. Reino Unido, no qual ela procedeu ao balanço entre a necessidade da existência de um aeroporto e a poluição sonora por ele causada ao peticionário, tendo finalmente decidido pela manutenção do aeroporto. ${ }^{35}$ No ano seguinte, em um novo exercício de ponderação, a CEDH colocou novamente os aspectos ambientais em segundo plano, considerando, desse modo, que as restrições impostas pela Suécia à propriedade do peticionário (devido a normas de proteção ambiental) consistiam numa violação ao seu direito de propriedade. ${ }^{36}$

A preocupação quanto aos efeitos da poluição ao meio ambiente sobre o bem-estar da pessoa foi tema do caso Lopez Ostra v. Espanha: a CEDH determinou o pagamento de indenização ao peticionário pela violação, causada por danos ambientais, ao seu direito à privacidade. ${ }^{37}$ Do mesmo modo, no Guerra \& Outros v. Itália, ${ }^{38}$ a CEDH considerou que a Itália descumpriu suas obrigações ao deixar de garantir o direito à vida e à privacidade dos peticionários, entendendo que um alto grau de poluição ambiental pode afetar o bemestar do indivíduo, tendo conseqüências adversas em sua vida familiar e particular. ${ }^{39}$ Ainda, a CEDH entendeu que a Itália deveria ter informado às

34 Gabcikovo-Nagymaros Project (Hung. v. Slovakia), 1997 I.C.J. 7, 206 (Sep. 25) (dissenting opinion of Judge Weeramantry).

35 Powell \& Rayner v. United Kingdom, 12 Eur. Ct. H. R. 355, 369 (ser. A) (1990).

36 Fredin v. Sweden, 192 Eur. Ct. H.R. (Ser. A), 6 (1991).

37 Lopez Ostra v. Spain, App. No. 16798/90, 20 Eur. Ct. H.R. 277 (1994).

38 Guerra \& Others v. Italy, App. No. 14967/89, 26 Eur. Ct. H.R. 357, 367-83 (1998).

39 "In addition, in its report of 8 December 1988, a committee of technical experts appointed by the Manfredonia District Council said in particular that because of the factory's geographical position, emissions from it into the atmosphere were often channelled towards Manfredonia (see paragraphs 14-16 above). The direct effect of the toxic emissions on the applicants' right to respect for their private and family life means that Article 8 is applicable. The Court considers that Italy cannot be said to have "interfered" with the applicants' private or family life; they complained not of an act by the State but of its failure to act. However, although the object of Article 8 is essentially that of protecting the individual against arbitrary interference by the public authorities, it does not merely compel the State to abstain from such interference: in addition to this primarily negative undertaking, there may be positive obligations inherent in effective respect for private or family life (see the Airey v. Ireland judgment of 9 October 1979 , Series A no. 32, p. 17, § 32)." Guerra \& Others v. Italy, App. No. 14967/89, 26 Eur. Ct. H.R. 357, 367-83 (1998). Parágrafos 57-58. 
pessoas sobre os riscos de morar em local com tais problemas ambientais. Esse caso foi posteriormente diferenciado do McGinley \& Eagan v. Reino Unido, no qual os peticionários também requeriam a responsabilidade do Estado pelo descumprimento da obrigação de informá-los sobre os efeitos de testes nucleares que estavam sendo realizados na Christmas Island, onde os peticionários serviam às forças armadas. A Corte reiterou a ratio de Guerra \& Outros, embora tenha concluído que o Reino Unido forneceu as informações disponíveis, não tendo, portanto, violado as suas obrigações. ${ }^{40}$

A Corte Interamericana de Direitos Humanos nunca tratou diretamente com questões de proteção ambiental. A Comissão de Direitos Humanos, entretanto, já discutiu aspectos relacionados ao meio ambiente, ainda que tangencialmente, quando lidou com casos ligados aos direitos dos povos indígenas. ${ }^{41}$
B) Os painéis de solução de controvérsias do GATT/ OMC, do MERCOSUL e do NAFTA

\section{GATT/OMC}

Os fundamentos das decisões dos casos sob o Acordo Geral sobre Tarifas e Comércio (General Agreement on Tariffs and Trade - GATT) ${ }^{42}$ e sob a Organização Mundial do Comércio (OMC) tradicionalmente conflitaram com o direito internacional ambiental. ${ }^{43}$ As normas materiais do GATT/OMC não incluem os instrumentos internacionais voltados à proteção ambiental, os quais não fazem parte do GATT ou dos seus acordos. ${ }^{44}$ A maior parte das controvérsias surge devido a medidas de proteção ambiental adotadas por um Estado, ${ }^{45}$ as quais podem ser questionadas com base na cláusula da nação mais favorecida, ${ }^{46}$ na do tratamento nacional, ${ }^{47}$ ou nas proibições de restrições quantitativas a

40 McGinley \& Eagan v. United Kingdom, 27 Eur. Hum. Rts. Rep. 1 (1998).

41 See generally, Inara K. Scott, The Inter-American System of Human Rights: an Effective Means of Environmental Protection?, 19 VA. ENVTL. L.J. 197 (2000).

42 General Agreement on Tariffs and Trade, Oct. 30, 1947,61 Stat. A-11, T.I.A.S. 1700, 55 U.N.T.S. 194.

43 Virginia Dailey, Sustainable Development: Reevaluating the Trade vs. Turtles Conflict at the WTO, 9 J. TRANSNAT'L \& POL'Y $331,333$.

44 Lakshman D. Guruswamy, Should UNCLOS or GATT/WTO decide trade and environment disputes?, 7 MinN. J. Global TRADE 287, 288.

45 Para uma explicação geral sobre medidas comerciais empregadas para atingir propósitos ambientais, veja Charnovitz, The Environment v. Trade Rules: defogging the debate, 23 ENVTL. L. 475 (1993).

46 GATT art. I(1).

47 GATT art. III. 
importações. ${ }^{48}$ Dessarte, o que mais se discute é se as medidas adotadas pelos Estados estariam incluídas no rol de exceções listadas no artigo XX do GATT. ${ }^{49}$

Uma análise das decisões do GATT/ OMC demonstram que o meio ambiente tem um papel secundário, quando este conflita com interesses comerciais. $\mathrm{O}$ GATT com freqüência vedava ou restringia medidas comerciais empregadas para atingir propósitos ambientais, especialmente a proteção de recursos globais em comum (global common resources).$^{50}$ No caso Canadá-Herring and Salmon,,$^{51}$ por exemplo, o painel do GATT concluiu que a proibição de exportação, pelo Canadá, de certos tipos de salmão e arenque, devido à forma de conservação, não só violava o artigo $\mathrm{XI},{ }^{52}$ mas também não se incluía no rol de exceções do artigo XX (g) do GATT. ${ }^{53}$

Alguns anos após, o Painel do GATT teve a oportunidade de decidir duas vezes acerca da proibição de importação de atum, pelos Estados Unidos, de Estados que não seguissem as determinações contidas no Marine Mammal Protecion Act. ${ }^{54}$ A primeira decisão ${ }^{55}$ foi favorável ao pedido do México, concluindo que as proibições dos Estados Unidos eram restrições quantitativas (art. XI), e não se justificavam pelas exceções nem do artigo XX (b), nem do artigo XX (g) do GATT. ${ }^{56} \mathrm{~A}$ segunda objeção às restrições impostas pelos Estados

48 GATT art. XI.

49 GATT art. XX. Afirma, em parte: "[s]ubject to the requirement that such measures are not applied in a manner which would constitute a means of arbitrary or unjustifiable discrimination between countries where the same conditions prevail, or a disguised restriction on international trade, nothing in this Agreement shall be construed to prevent the adoption or enforcement by any contracting party of measures (...) (b) necessary to protect human, animal or plant life or health; $(. .).(\mathrm{g})$ relating to the conservation of exhaustible natural resources if such measures are made effective in conjunction with restrictions on domestic production or consumption".

50 Jeffrey L. Dunoff, Institutional Misfits: the GATT, the ICJ\& Trade-environment Disputes, 15 MiCH. J. INT'L L. 1043, 1053 (Summer 1994).

51 GATT Dispute Panel Report on Canada-Unprocessed Salmon and Herring, GATT B.I.S.D (35th Supp.) at 90 (1989).

52 ld. Parágrafo. 4.3

53 Id. Parágrafo. 5.1

54 16 U.S.C. $\S \S 1361-1362,1371-1384,1401-1407$ (1994 \& Supp.1995). The Marine Mammal Protection Act foi aprovado em 1972.

55 GATT Dispute Panel Report on United States Restrictions on Import of Tuna, 30 I.L.M. 1594 (1991).

56 Id. Parágrafo 6.2. O Painel concluiu que as medidas dos Estados Unidos não eram nem necessárias, nem primariamente direcionadas à conservação dos recursos naturais. Id. Parágrafos. 5.28, 5.33. 
Unidos foi trazida por países europeus que não barravam as importações de atum oriundas de Estados sujeitos à proibição direta dos Estados Unidos (e que, portanto, também eram prejudicados consoante o Marine Mammal Protection Act).${ }^{57} \mathrm{O}$ Painel modificou a decisão anterior no que tange à interpretação do artigo XX (b) e (g) do GATT. $^{58}$ Mesmo assim, o Painel não só rejeitou pela segunda vez a aplicação do artigo XX (g), ${ }^{59}$ mas também optou por não considerar documentos internacionais de direito ambiental na interpretação dos dispositivos do GATT. ${ }^{60}$

No âmbito da OMC, o caso Reformulated Gasoline representou outra objeção às regulamentações ambientais dos Estados Unidos. ${ }^{61}$ Nesse caso, o Órgão de Apelação, revertendo a justificativa do Painel, concluiu que as medidas impostas pelos Estados Unidos não preenchiam os requisitos do chapeau do artigo $\mathrm{XX}$ e, portanto, consistiam numa discriminação injustificada, bem como uma restrição velada ao comércio internacional. ${ }^{62}$ Similarmente, no caso Shrimp-Turtle, a proibição dos Estados Unidos à importação de camarão pescado através de métodos danosos a tartarugas marinhas foi também analisada segundo o chapeau do artigo $X X .{ }^{63}$ Nesse sentido, a decisão, favorável à Índia, à Malásia, ao Paquistão e à Tailândia, teve a mesma conclusão do caso Reformulated Gasoline ${ }^{64}$ Entretanto, esse caso foi considerado um avanço nas decisões da OMC acerca de proteção ambiental, ${ }^{65}$

57 GATT Dispute Panel Report on United States Restrictions on Import of Tuna, 33 I.L.M. 842(1994).

58 O Painel adotou um novo enfoque, segundo o qual as exceções contidas no art. XX (b) e (g) poderiam ser aplicáveis para a conservação de recursos naturais não-renováveis localizados aquém do território da parte. Id. Parágrafos. 5.10.

59 Id. Parágrafo 5.24.

60 ld. Parágrafos 5.18-5.20.

61 WTO Report of the Panel in United States - Standards for Reformulated and Conventional Gasoline (Treatment of Imported Gasoline and Like Products of National Origin), 35 I.L.M.274 (1996). 62 Id. p. 632-33.

63 United States-Import Prohibition of Certain Shrimp and Shrimp Products, WT/DS58R, May 15, 1998, reformado pelo Appellate Body Report, WT/DS58/AB/R, Oct. 12, 1998, disponivel em WTO Dispute Settlement (visited Feb. 22, 1999) < http://www.wto.org/wto/ dispute/distab.htm>. Parágrafos 116-119, 186-187.

64 Id. O Órgão de Apelação concluiu que a restrição no acesso ao mercado norte-americano baseada somente na adoção de determinadas políticas por governos estrangeiros consistiria em discriminação injustificada. Id. Parágrafos 7.25, 7.26, 7.49, 7.62.

65 Ved P. NANDA \& George Rock PRING, International Environmental Law and Policy for the 21st Century. 413 (Ardsley ed. 2003). 
não somente porque reconheceu a importância da proteção ambiental, mas também porque estabeleceu "um novo padrão de revisão de medidas comerciais que visem à proteção de recursos ambientais globais". ${ }^{66}$

\section{MERCOSUL e NAFTA}

\section{Mercosul}

As fontes nas quais o Tribunal Arbitral do MERCOSUL pode basear suas decisões consistem em tratados e documentos subseqüentes (ordenamento jurídico do Mercosul), e princípios gerais do Direito Internacional, bem como, mediante autorização das partes, em eqüidade. ${ }^{67}$ Diferentemente do NAFTA, porém, o MERCOSUL não tem um acordo específico que seja diretamente voltado à proteção ambiental. Embora expressamente mencionada no preâmbulo do Tratado de Assunção, ${ }^{68}$ a proteção do meio ambiente ainda se restringe ao campo da declaração de princípios, carecendo da força necessária para ser aplicado. ${ }^{69}$ Outrossim, a afirmação contida no preâmbulo não consiste sequer em um objetivo, mas sim em uma preocupação com relação ao desenvolvimento de uma área de livre comércio, já que as regulamentações ambientais poderiam acabar por restringir o comércio entre as partes. ${ }^{70}$

A lógica que considera o meio ambiente como um elemento secundário ${ }^{71}$ e que, portanto, visa a proteger o

66 Patricia Isela Hansen. Transparency, Standards of Review, and the Use of Trade Measures to Protect the Global Environment, 39 VA. J. INT'L L. 1017, 1057 (Summer 1999). 67 Protocolo de Brasília para a Solução de Controvérsias, MERCOSUL/CMC/DEC. N 01/ 1991 art. 19.

68 O Preâmbulo do Tratado de Assunção assim estabelece: "Considerando que a ampliação das atuais dimensões de seus mercados nacionais, através da integração constitui condição fundamental para acelerar seus processos de desenvolvimento econômico com justiça social; Entendendo que esse objetivo deve ser alcançado mediante o aproveitamento mais eficaz dos recursos disponíveis, a preservação do meio ambiente, o melhoramento das interconexões físicas, a coordenação de políticas macroeconômicas da complementação dos diferentes setores da economia, com base nos princípios de gradualidade, flexibilidade e equilíbrio". Tratado para a Constituição de um Mercado Comum Entre a República Argentina, a República Federativa do Brasil, a República do Paraguai e a República Oriental do Uruguai (Assunção, 26/03/1991).

69 Guillermo Malm Green. Environmental Issues and MERCOSUR, in Free Trade Area for the Americas. 184 (Joseph A. McKinney \& Melissa Essary eds. 1995).

70 JuAn Novara. Integracion Economica, Comercio Internacional y Medio Ambiente: Ensenanzas para el MERCOSUR. 98, 110 (1994).

71 Jonathan S. Blum, The FTAA and the Fast Track to Forgetting the Environment: a comparison of the NAFTA and the MERCOSUR Environmental Models as Examples for the Hemisphere. 35 TEX. INT'L L.J. 435. 
sistema comercial das conseqüências advindas de um meio ambiente adverso (e não o contrário), ${ }^{72}$ também está refletida nos dois únicos casos decididos pelo Tribunal Arbitral que lidam, ainda que indiretamente, com questões ambientais. ${ }^{73} \mathrm{O}$ primeiro caso é o Laudo VI do Tribunal Arbitral do MERCOSUL, de 2002, que decidiu sobre a controvérsia apresentada pelo Uruguai ao Brasil sobre a "Proibição de Importação de Pneumáticos Remoldados Procedentes do Uruguai". No presente caso, o Uruguai contestava a Portaria $\mathrm{N}^{\circ} 8 / 00$, de 25 de setembro de 2000, da Secretaria de Comércio Exterior do Ministério de Desenvolvimento, Indústria e Comércio Exterior (SECEX) do Brasil, a qual "dispôs a não concessão de licenças de importação de pneumáticos recauchutados e usados, classificados na posição 4012 da Nomenclatura Comum do MERCOSUL (NCM), seja para consumo ou uso como matéria-prima". O Uruguai alegava que tal restrição imposta às importações de pneumáticos remoldados constituía-se numa nova barreira ao comércio, contrária aos propósitos do MERCOSUL. O Brasil aduziu, por sua vez, que um pneumático remoldado não poderia ser considerado como um pneumático novo, uma vez que apenas $30 \%$ dele seria composto de material novo. Além disso, por ser impossível reformar novamente tais pneumáticos, após sua vida útil, eles acabariam se transformando, ao final, num "resíduo indesejável". ${ }^{74} \mathrm{O}$ Tribunal Arbitral entendeu que a regulamentação do governo brasileiro que proibia a importação de pneumáticos remoldados do Uruguai era incompatível com a normativa MERCOSUL, pois consistia numa medida restritiva ao comércio recíproco existente. Conseqüentemente, determinou-se que o Brasil deveria adaptar sua legislação interna em consideração à referida incompatibilidade. ${ }^{75}$

O segundo caso consiste no Laudo VII do Tribunal Arbitral, de 2002, o qual decidiu sobre a controvérsia apresen-

72 Leila Devia, La Politica Ambiental en el Marco del Tratado de Asuncion, in MERCOSUR y MEdio AmBiente 27, 29-30 (Ediciones Ciudad Argentina.ed. 1996).

73 Tal número é significativo, já que o Tribunal Arbitral só decidiu, até o presente momento, nove casos. Além disso, o mecanismo de solução de controvérsias do MERCOSUL não prevê casos específicos de direito ambiental. See, David Lopez, Dispute Resolution Under MERCOSUR from 1991 to 1996: Implications for the Formation of a Free Trade Area of the Americas, 3 NAFTA: L. \& Bus. Rev. Am. 3, 20 (1997).

74 Laudo do Tribunal Arbitral ad Hoc do MERCOSULConstituído para Entender da Controvérsia Apresentada pela República Oriental do Uruguai à República Federativa do Brasil sobre "Proibição de Importação de Pneumáticos Remoldados (Remolded) Procedentes do Uruguai" (Uruguai v. Brasil), 2000, disponivel em http:// www.mercosur.org.uy/portugues/snor/normativa/laudos.htm\#neumaticos. 
tada pela Argentina ao Brasil sobre "obstáculos à entrada de produtos fitossanitários argentinos no mercado brasileiro" e a "não incorporação das Resoluções GMC N $\mathrm{GM}^{\circ}$ 48/96, 87/96, 149/ 96, 156/96 e 71/98, o que impede sua entrada em vigência no MERCOSUL." A Argentina reclamava dos obstáculos derivados da imposição de restrições originárias de registro para os produtos fitossanitários, resultando numa barreira à importação de produtos da Argentina. ${ }^{76} \mathrm{O}$ Brasil, por sua vez, argumentou que o tratado de Assunção não proibia a adoção de medidas unilaterais necessárias para a proteção da saúde, do meio ambiente e da segurança da população. Alegou, ademais, que o sistema de registro para produtos fitossanitários existente no Brasil não era discriminatório, já que era aplicado igualmente tanto para as indústrias nacionais quanto para as estrangeiras. ${ }^{77} \mathrm{O}$ Tribunal Arbitral, entretanto, concluiu que o Brasil estava violando seu dever de promover a livre circulação de mercadorias no
MERCOSUL, pois considerou que a restrição supracitada era por demais ampla, ao invés de ser direcionada para produtos determinados. Assim sendo, o Tribunal Arbitral determinou que o Brasil deveria incorporar a seu ordenamento jurídico interno as Resoluções GMC No 48/96, 87/96, 149/96, 156/96 e $71 / 98$, e, caso fosse necessário, "adotar as medidas e ditar as normas jurídicas internas que garantam a efetiva aplicação destas normas". ${ }^{78}$

\section{NAFTA}

O preâmbulo do Tratado de Livre Comércio da América do Norte (North American Free Trade Agreement NAFTA) se refere expressamente ao meio ambiente, estabelecendo como metas promover o desenvolvimento sustentável, bem como reforçar a elaboração e a aplicação de leis e regulamentos em matéria ambiental. ${ }^{79}$ As instituições referentes ao meio ambiente do NAFTA foram consideradas mais "sofisticadas" do que aquelas do MERCUSUL, ${ }^{80}$ enquanto

76 Laudo Arbitral do Tribunal Arbitral "ad Hoc" do Mercosul Constituído para Decidir sobre a Controvérsia Apresentada pela República Argentina à República Federativa do Brasil sobre "Obstáculos à entrada de produtos fitossanitários argentinos no mercado brasileiro. Não incorporação das Resoluções GMC No 48/96, 87/96, 149/96, 156/96 e 71/98, o que impede sua entrada em vigência no MERCOSUL", 2002, disponivel em http:// www.mercosur.org.uy/portugues/snor/normativa/laudos.htm\#fitosanitario.

77 Id.

78 Id.

79 North American Free Trade Agreement, 32 I.L.M. 297.

80 Pedro Villegas. Nature beyond the nation state symposium: the environmental challenge of the common market in South America: REMA under MERCOSUR, 29 GOLDEN GATE U.L. REv. 445 (Spring 1999). 
os dispositivos do NAFTA foram tidos como mais "favoráveis ao meio ambiente" do que as regras da OMC. ${ }^{81}$

O NAFTA contém três mecanismos de solução de controvérsia: o Capítulo XI (arbitragem internacional para os casos em que investidores estrangeiros reclamem de violações às disposições do NAFTA referentes a investimentos), ${ }^{82}$ o Capítulo XIX (solução de controvérsias em matéria de anti-dumping e direitos compensatórios) ${ }^{83}$ e o Capítulo XX (interpretação, aplicação ou violação do NAFTA) ${ }^{84}$ Os dispositivos mais controvertidos do NAFTA são os procedimentos do Capítulo XI, os quais levantaram diversas preocupações ambientais. ${ }^{85} \mathrm{O}$ temor de que o artigo 1110 do NAFTA possa ser utilizado para forçar governos a pagar indenizações pela aplicação de regulamentações ambientais aumentou após a decisão Metalclad, ${ }^{86}$ na qual o México foi condenado a indenizar a Metalclad em US\$16.685.000. Isso porque entendeuse que a negativa do Município de Guadalcazar (no México) em conceder licença municipal para a construção de um depósito permanente (aterro sanitário) de resíduos perigosos, tendo como justificativa a proteção ambiental, consistia em falha do México em fornecer à Metalclad tratamento justo e eqüitativo. ${ }^{87}$ Atualmente, há, ainda pendentes, cerca de onze casos

81 Greg Block. Trade and environment in the western hemisphere: expanding the North American Agreement on Environmental Cooperation into the Americas, 33 ENVTL. L. 501 (Summer 2003).

82 NAFTA art. 1116(1). Veja por todos, Daniel M. Price. An Overview of the NAFTA Investment Chapter: Substantive Rules and Investor-State Dispute Settlement, 27 INT'L LAW. 727, 731-2 (1993).

83 NAFTA arts. 1901-11.

84 NAFTA arts. 2001-22. Veja por todos, Gary N. Horlick \& F. Amanda DeBusk, Dispute Resolution Under NAFTA: Building on the U.S.-Canada FTA, GATT and ICSID, $10 \mathrm{~J}$. INT'L ARB. 51, 64 (1993).

85 Howard Mann \& Konrad von Moltke, International Institute for Sustainable Development, NAFTA's Chapter 11 and the Environment: Addressing the Impacts of the Investor-State Process on the Environment 1, 38 (1999), disponivel em http:// iisd.ca/pdf/nafta.pdf.

86 Vicki Been, The global fifth amendment? Nafta's investment protections and the misguided quest for an international "regulatory takings" doctrine, 78 N.Y.U. L. REv. 30, 33-34. A autora afirma que "disposições muito idênticas ao art. 1110 do NAFTA estão contidas em muitos dos 1500 tratados bilaterais de investimento, em vigor em todo o mundo" ("provisions nearly identical to NAFTA's article 1110 are contained in many of the 1500 bilateral investment treaties in effect around the world").

87 Metalclad v. United Mexican States, ICSID Case No. ARB(AF)/97/1 Final Award, p. 74 (Aug. 30, 2000), disponivel em http:// www.state.gov/s/1/c3752.htm. 
estabelecidos consoante o capítulo XI, em que são questionadas regulamentações ambientais e de uso da terra. ${ }^{88}$

Em outro caso, a proibição, imposta pelo Canadá, de importação e venda de MMT, uma substância tóxica, foi questionada por uma companhia norteamericana. ${ }^{89} \mathrm{O}$ Canadá aceitou fazer um acordo nesse caso, mas, caso tivesse seguido adiante na contenda, a sua atitude seria provavelmente considerada como uma violação do artigo 1105 do NAFTA, referente ao dever de tratamento justo e eqüitativo. ${ }^{90}$ Do mesmo modo, no caso S.D. Myers, o Tribunal, seguindo praticamente a mesma lógica do Metalclad, considerou que a proibição de exportação de resíduos de

88 Notice of Arbitration and Statement of Claim Under the Arbitration Rules of the United Nations Commission on International Trade Law and the North American Free Trade Agreement (Frank v. United Mexican States) (Aug. 5, 2002), disponivel em http://www.dfait- maeci.gc.ca/tna-nac/NoticeofArbitration l.pdf; Notice of Arbitration and Statement of Claim (Canfor Corp. v. United States) (July 9, 2002), disponivel em http:// www.state.gov/documents/organization/13203.pdf; Notice of Intent to Submit a Claim to Arbitration Under Section B of Chapter 11 of the North American Free Trade Agreement (Doman Indus. Ltd. v. United States) (May 1, 2002), disponivel em ht tp://www.international-economic-law.org/US\%20 Notices/ Doman\%20Notice\%C20of\% 20Intent.pdf; Submission to Arbitration (GAMI Investment, Inc. v. United Mexican States) (Apr. 9, 2002), disponivel em http:// www.state.gov/documents/organization/11848.pdf; Notice of Intent to Commence Arbitration Pursuant to Chapter XI of the North American Free Trade Agreement (Calmark Commercial Dev., Inc. v. United Mexican States) (Jan. 11, 2002), disponivel em http://www.international-economic-law.org/Mexicans/ Calmark_Redacted_NOI.pdf; Notice of Intent to Submit a Claim to Arbitration Under Section B of Chapter Eleven of the North American Free Trade Agreement (Crompton Corp. v. Canada) (Nov. 6, 2001), disponivel em http://www.dfait-maeci.gc.ca/tna-nac/ ComptonCorp.pdf; Notice of Arbitration Under the Rules Governing the Additional Facility for the Administration of Proceedings by the International Centre for Settlement of Investment Disputes and the North American Free Trade Agreement (Fireman's Fund v. United Mexican States) (Oct. 30, 2001), disponivel em http:// www.dfait-maeci.gc.ca/tna- nac/documents/Fireman_Notice.pdf; Notice of Arbitration (Adams v. United Mexican States) (Feb. 16, 2001), http://www.international-economiclaw.org/Mexicans/Adams\%20et\%C20al\%C20and\%C20Mexico\%C20\%20$\% 20$ Notice $\% 20$ of $\% 20$ Arbitration.PDF; Notice of Arbitration (Karpa v. United Mexican States) (Apr. 30, 1999), at http://www.state.gov/documents/organization/3995.pdf; Notice of Claim (Loewen Group, Inc. v. United States) (Oct. 30, 1998), disponivel em http://www.state.gov/documents/organization/3922.pdf.

89 Ethyl Corporation v. Canada, 38 I.L.M. 708.

90 David A. Gantz, Potential Conflicts Between Investor Rights and Environmental Regulation Under NAFTA's Chapter 11, 33 GeO. WASh. INT'L L. REv. 651, 665-666 (2001). 
PCB pelo Canadá consistia em violação ao artigo 1105 do NAFTA, rejeitando, portanto, a alegação do Canadá de que tal medida visava ao cumprimento de diversos acordos internacionais de proteção ao meio ambiente. ${ }^{9 !}$

As controvérsias estabelecidas sob o capítulo XIX também podem afetar a proteção do meio ambiente, ainda que indiretamente. No caso In the matter of cross-border trucking services, por exemplo, o Painel concluiu que a suspensão da análise dos pedidos de licença para operação nos Estados Unidos para os caminhões pertencentes a prestadores de serviço do México violava as obrigações contidas no Anexo I (reservas a medidas de livrecomércio já existentes ou a comprometimentos de liberalização), no artigo 1202 (tratamento nacional a serviços transfonteiriços), e artigo 1203 (tratamento da nação mais favorecida para serviços transfronteiriços) do NAFTA. Os Estados Unidos alegaram que a medida se justificava pela falta de segurança dos caminhões provenientes do México, mencionando, ainda, pelo menos dois acidentes que envolviam caminhões do México (em um deles, os freios não funcionavam adequadamente e os pneus apresentavam alto desgaste) e que resultaram em derrame de materiais perigosos. O Painel rejeitou os argumentos dos Estados Unidos, alegando que "as inadequações do sistema de regulamentação do México não forneciam base jurídica suficiente para os Estados Unidos manterem a moratória". ${ }^{22}$

Finalmente, a Comissão para a Cooperação Ambiental (Commission for Environmental Cooperation), criada pelo Acordo de Cooperação Ambiental da América do Norte (North American Agreement on Environmental Cooperation), tem como principal foco a aplicação das regulamentações ambientais. ${ }^{93}$ Os mecanismos de solução de controvérsia estão previstos nos artigos 13, 14, 15 e 22 a 36 . Até o presente momento, poucos casos foram decididos com base nos dispositivos do artigo $13,{ }^{94}$ os quais se destinam a controvérsias outras que aquelas originadas pela falha do Estado em aplicar as leis ambientais. Por outro

91 S.D. Myers, Inc. v. Canada Partial Award, PP. 136, 667 (Nov. 13, 2000), disponivel em http://www.naftaclaims.com.

92 In the Matter of Cross-Border Trucking Services (USA-Mex), February 6 (2001), 12. 93 Isso se deve à pouca aplicação dos padrões e regulamentos ambientais no México. Kal Raustiala, International "Enforcement of Enforcement" Under the North American Agreement on Environmental Cooperation, 36 VA. J. INT'L L. 721, 723, 728-29(1996). 94 Ignacia Moreno et al. Free Trade and the Environment: The NAFTA, the NAAEC, and Implications for the Future, 12 TUL. ENvTL. L.J. 405, 431 (1999). 
lado, até o ano de 2000, mais de vinte reclamações foram entregues, com base nos procedimentos dos artigos 14 e 15.95 A Comissão pode, ao final, elaborar um "relatório dos fatos" (factual record), isto é, um relatório preparado por especialistas independentes, sem caráter vinculativo. ${ }^{96}$

Finalmente, os mecanismos de solução de controvérsia dos artigos 22 e 36 somente podem ser usados caso um estado persistentemente falhe na aplicação de suas normas ambientais. ${ }^{97} \mathrm{O}$ primeiro passo é a consulta entre as partes envolvidas e, caso não se chegue a um consenso, o procedimento seguinte é a arbitragem. ${ }^{98}$ Até o presente momento, nenhuma arbitragem foi iniciada, e muitos vêem tais artigos como letra morta, já que as partes ficariam "relutantes em partir para um procedimento judicial para solucionar controvérsias internacionais envolvendo o meio ambiente". ${ }^{99}$

\section{A JURISDIÇÃO CONCORRENTE DE TRIBUNAIS INTERNA- CIONAIS E A PROTEÇÃO AO MEIO AMBIENTE}

\section{A) Mecanismos de solução de controvérsias internacionais}

1. Classificação dos mecanismos de solução de controvérsias

Um litígio internacional pode se dar entre Estados (ou entre Estados e organizações intergovernamentais ou, ainda, entre elas próprias), sendo regido pelo Direito Internacional Público; entre pessoas físicas ou jurídicas, de direito público ou privado, submetidas a sistemas jurídicos nacionais distintos; ou entre pessoas físicas ou jurídicas de direito interno dos Estados, de um lado, e Estados, de outro. No segundo caso, a solução pode ser judicial, sendo regida pelo Direito Internacional Privado, ou extrajudicial. O último caso, por fim, pode ter solução perante o Poder

95 Jonathan S. Blum. The FTAA and the Fast Track to Forgetting the Environment: a comparison of the NAFTA and the MERCOSUR Environmental Models as Examples for the Hemisphere. 35 TEX. INT'L L.J. 435, 453 (Summer 2000).

96 North American Agreement on Environmental Cooperation, Sep. 13, 1993, 32 I.L.M. 1480,1490 art. 15.

$97 \mathrm{Id}$. arts. 22-36.

98 Jonathan S. Blum, The FTAA and the Fast Track to Forgetting the Environment: a comparison of the NAFTA and the MERCOSUR Environmental Models as Examples for the Hemisphere. 35 TEX. INT'L L.J. 435.453 (Summer 2000).

99 John Knox. A new approach to compliance with international environmental law: the Submissions procedure of the NAFTA environmental commission, 28 ECOLOGY L.Q. 1 (2001). 
Judiciário do Estado envolvido ou, no âmbito do Direito Internacional Público, ter uma solução em instituições especializadas. ${ }^{100}$

Os modelos de sistemas para solução de controvérsias entre Estados podem ser classificados em dois padrões: ${ }^{101}$ o tradicional, de alcance maior e em que prevalece uma finalidade política, e o econômico, de menor alcance e com finalidade fundamentalmente econômica. O primeiro estabelece oficialmente como regra de direito internacional a solução pacífica de disputas, a qual pode ser estabelecida em acordo (resultante de negociações, bons ofícios, mediação, conciliação ou comissão de inquérito) ou em sentença internacional (arbitragem ou tribunal internacional). Já o segundo padrão prima pelo cumprimento de normas livremente acordadas pelas partes sobre seu comércio exterior, sendo apenas secundária a finalidade de assegurar paz resguardando a soberania. O modelo é mais flexível, com regras complexas e não decorrentes de procedimentos jurídicos. Pode envolver consultas, negociações e arbitragem, tendo como exemplos os sistemas de solução de controvérsias do GATT (hoje OMC), do NAFTA e do Mercosul. ${ }^{102}$

Ainda, os mecanismos de solução de controvérsias no Direito Internacional Público podem ser divididos em duas categorias: mecanismos diplomáticos (métodos não-jurisdicionais) e mecanismos jurisdicionais. Os primeiros não possuem foro especializado e independente, sendo instrumentalizados por negociação direta, sistemas de

100 SOARES, Guido F.S. Solução e prevenção de litígios internacionais: tipologia e características atuais. in MERCADANTE, Araminta de Azevedo; MAGALHÃES, José Carlos (coord.). Solução e Prevenção de Litígios Internacionais - Volume II. São Paulo: NECIN-CAPES; Porto Alegre: Livraria do Advogado, 1999. p. 15-16.

101 Guido Soares, porém, entende sem relevância a distinção entre, de um lado, litígios de natureza política ou jurídica e, de outro, de natureza econômica, por entender que, embora esses últimos tenham um encaminhamento com maior precisão e eficácia, tal se deve não pela natureza do assunto tratado, mas sim da natureza da regulamentação das relações interestatais nas organizações que prevêem tais mecanismos de solução de controvérsia. (Solução e prevenção de litígios internacionais: tipologia e características atuais. in MERCADANTE, Araminta de Azevedo; MAGALHÃES, José Carlos (coord.). Solução e Prevenção de Litígios Internacionais - Volume II. São Paulo: NECIN-CAPES; Porto Alegre: Livraria do Advogado, 1999. p. 14). Independentemente da importância de tal distinção, é fato que ela existe, seja baseada na natureza do assunto discutido, seja com base na relação interestatal verificada.

102 BAPTISTA, Luíz Olavo. Sistemas para Solução de Divergências nas Instituições de Integração e o Mercosul. in MERCADANTE, Araminta de Azevedo; MAGALHÃES, José Carlos (coord.). Solução e Prevenção de Litígios Internacionais - Volume II. São Paulo: NECIN-CAPES; Porto Alegre: Livraria do Advogado, 1999. p.441-453. 
consultas, intervenção de um terceiro (mediador ou conciliador) e painéis de especialistas. Buscam não necessariamente a recomposição da ordem jurídica violada, mas sim a composição de interesse das partes conflitantes. Já nos mecanismos jurisdicionais, que visam a uma solução baseada em uma regra de Direito, há necessariamente a intervenção de um terceiro alheio ao conflito, seja ele um árbitro (arbitragem) ou um juiz (corte de justiça). ${ }^{103}$

\section{Conflitos de jurisdição entre} mecanismos de solução de controvérsias internacionais: as normas reguladoras de conflito (competitionregulating norms)

A discussão acerca da "proliferação" de mecanismos internacionais de solução de controvérsias não é tão recente como pode parecer à primeira vista, e mesmo em períodos mais antigos do Direito Internacional, a doutrina já demonstrava alguma preocupação com relação ao tema. ${ }^{104} \mathrm{~A}$ fim de regulamentar a escolha do órgão decisório, dois modelos foram adotados: a cláusula de exclusão jurisdicional (vedando o litígio em outros órgãos), que tanto pode conter dispositivos flexíveis quanto inflexíveis (dependendo da capacidade da parte de afastar a jurisdição de um determinado órgão), e a jurisdição nãoexclusiva (permitindo a eleição do foro pelas partes), que inclui a organização jurisdicional paralela e a residual (dependendo do nível de precedência que o mecanismo em questão tem sobre as demais jurisdições concorrentes). ${ }^{105}$

A OMC, por exemplo, apresenta um dispositivo de jurisdição exclusiva inflexível, ${ }^{106}$ pois o artigo 23 do Entendimento Relativo às Normas e Procedimentos pelos quais se rege a Solução de Diferenças que forma parte do acordo sobre a OMC veda a apresentação de casos sobre os acordos da OMC em qualquer outro órgão que não aquele estabelecido pelo próprio acordo sobre a OMC. ${ }^{107}$

Ao contrário, o dispositivo de solução de controvérsias contido na Convenção das Nações Unidas sobre o Direito do Mar (United Nations Convention on the Law of the Sea UNCLOS) ${ }^{108}$ consiste em uma cláusula

103 FRANCESCHINI DA ROSA, Luis Fernando. Mercosul e função judicial: realidade e superação. São Paulo: LTr, 1997. p. 35.

104 Veja por todos. Charney, Jonathan I. Is international law threatened by multiple international tribunals? Recueil des Cours, Volume 271 (1998), pp. 101-382.

105 Yuval Shany. The Competing Jurisdiction of International Courts and Tribunals. 180 (Oxford ed. 2003).

$106 \mathrm{ld}$, at 183 .

107 Entendimento Relativo às Normas e Procedimentos pelos quais se rege a Solução de Diferenças que forma parte do Acordo sobre a OMC, art. 23.

108 United Nations Convention on the Law of the Sea of 10 December 1982. 
de jurisdição não-exclusiva residual, ${ }^{109}$ pois o artigo 282 da referida Convenção não só permite que a disputa seja apresentada em outra jurisdição, mas também impede a aplicação dos mecanismos presentes na UNCLOS caso as partes tenham concordado, através de acordo geral, regional ou bilateral, que suas controvérsias sejam submetidas a outro procedimento que gere decisão dotada de caráter vinculante. ${ }^{110}$

Portanto, em um caso no qual tanto o mecanismo de solução de controvérsias do GATT/OMC quanto o Tribunal Internacional de Direito do Mar (Tribunal do Mar) tenham "jurisdição", aquele teria precedência, segundo o modelo apresentado. Entretanto, essa posição não é pacífica, uma vez que a "cláusula de não-derrogação" expressa no artigo 311(3) da UNCLOS ${ }^{111}$ é considerada suficiente para tornar "inválida" norma conflitante de tratado posterior (como no caso do GATT/ OMC). ${ }^{112}$ Assim, independentemente da existência de mecanismos de solução de controvérsias do GATT/OMC, o Tribunal do Mar ainda permaneceria com jurisdição. ${ }^{113}$

A questão fica mais complexa quando a jurisdição da CIJ concorre com a determinada pela UNCLOS. A CIJ apresenta uma jurisdição nãoexclusiva paralela, isto é, ao mesmo tempo que seu estatuto permite o recurso a outros mecanismos de solução de controvérsias, ele (diferentemente da UNCLOS) não se sujeita a tais mecanismos. ${ }^{114}$ Isso significa dizer que, ainda que seja possível a escolha de outro foro, a CIJ

109 Yuval Shany. The Competing Jurisdiction of International Courts and Tribunals. 201-02 (Oxford ed. 2003).

110 UNCLOS, art. 282. "If the States Parties which are parties to a dispute concerning the interpretation or application of this Convention have agreed, through a general, regional or bilateral agreement or otherwise, that such dispute shall, at the request of any party to the dispute, be submitted to a procedure that entails a binding decision, that procedure shall apply in lieu of the procedures provided for in this Part, unless the parties to the dispute otherwise agree."

111 UNCLOS, art. 311 , o qual impede as partes de estabelecer acordos futuros que se mostrem incompativeis com a natureza da UNCLOS ou que, de alguma outra forma, derrogue seus princípios básicos.

112 Veja Lakshman D. Guruswamy, Should UNCLOS or GATT/WTO decide trade and environment disputes?, 7 MINN. J. GLOBAL TRADE 287, 305-6. (argumentando que o GATT/ OMC não é o foro apropriado para as controvérsias envolvendo o meio ambiente, por não reconhecer "a proteção ambiental marítima como princípio básico" - "it does not recognize maritime environmental protection as a basic principle").

$113 \mathrm{Id}$. at 305-6.

114 Veja U.N. Charter arts. 33, 95. Veja também Yuval Shany. The Competing Jurisdiction of International Courts and Tribunals. 195-96 (Oxford ed. 2003). 
não deixa de ter jurisdição, nem impede o recurso posterior aos seus procedimentos jurisdicionais. Considerando que tanto a CIJ quanto o Tribunal do Mar têm jurisdição para decidir sobre a interpretação ou aplicação da UNCLOS, muitos viam a criação do Tribunal do Mar com reservas. ${ }^{115}$ Nessa situação de conflito, porém, os dispositivos da UNCLOS e do Estatuto da CIJ poderão esclarecer alguns pontos quanto aos casos de jurisdição concorrente. Por exemplo, como a declaração a que se refere o artigo 36 (2) do Estatuto da CIJ pode ser considerada como um "acordo" para o propósito do artigo 282 da UNCLOS, o Tribunal do Mar não teria jurisdição. ${ }^{116}$

A CEDH, por sua vez, é considerada como detentora de uma jurisdição exclusiva flexível, porquanto o artigo 55 da Convenção Européia de Direitos Humanos estabelece a jurisdição compulsória da CEDH, a qual só pode ser afastada mediante acordo especial realizado entre as partes. ${ }^{117}$ Finalmente, os procedimentos do NAFTA são considerados um "meiotermo" entre os dois modelos supracitados, permitindo uma eleição restrita do foro. ${ }^{118}$ Prevendo os possíveis conflitos entre o NAFTA e o GATT/OMC, os autores do projeto do NAFTA buscaram coordenar a jurisdição de ambos os órgãos ao estabelecer, no artigo 2005, que, no caso de uma disputa que se enquadrasse na jurisdição de ambos, a parte autora poderia escolher onde litigar. ${ }^{119}$ Similarmente, o MERCOSUL recentemente adotou o Protocolo de Olivos, o qual contém uma previsão semelhante

115 Veja por todos, Shigeru Oda. Some Reflections on the Dispute Settlement Clauses in the United Nations Convention on the Law of the Sea, in ESSAYS IN INTERNATIONAL LAW IN HONOR OF Judge MANFRED LACHS 645, 649 (J. Makarcyzyk ed. 1984). O Juiz da CIJ afirma que o desenvolvimento uniforme de uma jurisprudência internacional seria melhor atingido com o fortalecimento da CIJ, e não com a dispersão da função judicial internacional em vários órgãos esparsos ("the rule of law based upon the uniform development of jurisprudence will be best secured by way of strengthening the role of the International Court of Justice, not by dispersing the judicial funcion of the international community among various scattered organs").

116 Veja Tullio Treves. Conflicts Between the International Tribunal for the Law of the Sea and the International Court of Justice, 31 N.Y.U. J. INT'L L. \& PoL. 809, 812 (Summer 1999). O autor em seguida observa que essa regra é aplicável somente para as controvérsias surgidas conforme a Parte XV da Convenção, reconhecendo que, no caso de uma disputa baseada na Parte XI da UNCLOS, um real conflito de jurisdição pode surgir. See id. at 813-21.

117 Yuval Shany. The Competing Jurisdiction of International Courts and Tribunals. 188-191 (Oxford ed. 2003).

118 Id., 208-209.

119 NAFTA, art. 2005. 
à do NAFTA, permitindo ao autor escolher entre o mecanismo de solução de controvérsias do MERCOSUL e o da OMC (ou outro mecanismo de solução de controvérsias relacionado ao comércio). ${ }^{120}$

B) Possíveis soluções para a questão das disputas ambientais submetidas a múltiplas jurisdições

1. A criação de um Tribunal

Internacional do Meio Ambiente: seria uma solução?

Como visto antes, muitas disputas que tocam na questão da proteção ambiental são discutidas em órgãos especializados em outros assuntos específicos, como comércio ou direitos humanos. Isso não significa afirmar que o meio ambiente não tem relação com o comércio, ${ }^{121}$ ou que inexiste ligação entre os direitos humanos e a proteção ambiental, ${ }^{122}$ mas significa, sim, dizer que não há atualmente nenhum tribunal especificamente criado para lidar com questões ambientais.

Por esse motivo, muitos propuseram a criação de um Tribunal Internacional Ambiental para lidar especificamente com disputas de direito ambiental. ${ }^{123}$ Entretanto, essa proposta apresenta um problema similar ao apontado em diversos casos decididos por mecanismos de solução de controvérsias ligados ao comércio: em um órgão especializado, um assunto seria, em última instância, subordinado ao outro, tornando, portanto, mais difícil uma abordagem mais equilibrada entre interesses conflitantes. ${ }^{124}$

\section{Fortalecendo a Corte Inter-} nacional de Justiça como meio de garantir uma proteção ambiental mais efetiva

A CIJ apresenta uma vantagem, uma vez que as fontes que a mesma utiliza para basear seus julgamentos incluem,

120 Protocolo de Olivos para a Solução de Controvérsias no Mercosul, 18 Fev. 2002, art. 1(2). Veja por todos, Eduardo Biacchi Gomes. Protocolo de Olivos: alterações no sistema de soluções de controvérsias do Mercosul e perspectivas, 42 Revista de Direito Constitucional e Internacional 78-88 (Jan./Mar. 2003).

121 Veja Report of the Committee on Trade and Environment, WT/CTE/1, Nov. 12, 1996, e anos seguintes, disponivel em www.wto.org; mas veja também David W. Leebron, Symposium: The Boundaries of the WTO: Linkages, 96 A.J.I.L 5 (Jan. 2002).

122 John Lee, The Underlying Legal Theory to Support a Well-Defined Human Right to a Healthy Environment as a Principle of Customary International Law, 25 COLUM. J. ENvTL. L. 283 (2000); Gabcikovo-Nagymaros Project (Hung. v. Slovakia), 1997 I.C.J. 7, 206 (Sep. 25) (dissenting opinion of Judge Weeramantry).

123 Veja por todos, ElLEN Hey. Reflections on an international environmental court (Kluwer Law International ed. 2000).

124 Jeffrey L. Dunoff. Institutional Misfits: the GATT, the ICJ \& Trade-environment Disputes, 15 Mich. J. INT'L L. 1043, 1108 (Summer 1994). 
com o mesmo status, tanto normas de direito ambiental quanto as demais normas de direito internacional. A utilização, entretanto, de mecanismos jurisdicionais para casos de direito internacional ambiental não parece ser a opção mais indicada, principalmente no caso da CIJ.

Primeiramente, a ausência de jurisdição compulsória da CIJ, o baixo número de vezes em que os estados confiam as suas disputas à corte, associados ao tempo relativamente longo que se leva até uma decisão, torna questionável a efetividade de tal instituição para as questões ambientais. Outrossim, não há consenso quanto a dois pontos fundamentais, quais sejam: os modos de reparação que podem ser buscados em caso de danos ambientais; e quais entes teriam legitimidade para fazer isso. Finalmente, a impossibilidade de haver mais participação pública nas decisões da CIJ também poderia afetar negativamente o objetivo da proteção ambiental, uma vez que a sociedade civil tem um papel ativo na busca da proteção ao meio ambiente. ${ }^{125}$

\section{CONCLUSÃO}

Um estudo da ONU compara as questões ambientais com problemas de trânsito: é mais útil instalar semáforos, estabelecer regras de tráfego e outros meios de controle do que colocar tais medidas em segundo plano para se concentrar na responsabilização de cada motorista pelos danos causados aos demais. ${ }^{126} \mathrm{Da}$ mesma forma, a proteção ambiental é melhor atingida através da cooperação entre os Estados, e não com mecanismos jurisdicionais, que dificilmente preveniriam danos ambientais, mas sim se concentrariam na reparação de danos passados. ${ }^{127}$

Entretanto, a cooperação entre os Estados pode ainda assim se mostrar insuficiente para enfrentar todos os aspectos da proteção ao meio ambiente. Nesses casos, se não for obtida a cooperação, e caso não se chegue a nenhum consenso, somente então, o mecanismo jurisdicional deveria ser buscado. Pela análise das decisões de diferentes organismos, é possível concluir que aquele que melhor versa sobre as questões ambientais seria a CIJ. É inegável que nos casos em que a CIJ teve a oportunidade de lidar com princípios do direito internacional ambiental, ela focou-se nas "áreas específicas do direito internacional que não se relacionavam com o meio

125 Para uma análise mais aprofundada de tais argumentos, veja Jeffrey L. Dunoff, Institutional Misfits: the GATT, the ICJ \& Trade-environment Disputes, 15 Mich. J. INT'L L. 1043, 1085-1106(Summer 1994).

126 UNITAR. International Co-operation for Pollution Control, Research Reports 9, 25 (1972).

127 Para mais argumentos nesse sentido, veja Franz Xaver Perrez. Cooperative Sovereignty - From Independence to Interdependence in the Structure of International Environmental Law (Kluwer Law International ed. 2000), 255-283. 
ambiente em si". ${ }^{128}$ Entretanto, o crescente número de casos da $\mathrm{CIJ}$ fazendo referência a princípios de direito internacional ambiental, juntamente com os pedidos das partes levantando tais argumentos, as diversas opiniões separadas ou dissidentes de juizes defendendo especificamente uma maior preocupação com o meio ambiente, e a criação de um Chamber para Questões Ambientais, constituem fatores relevantes para considerar a $\mathrm{CIJ}$ o foro apropriado para as disputas ambientais.

Contudo, alguns obstáculos permanecem. Como visto, a jurisdição da CIJ, além de voluntária, é não-exclusiva. Portanto, ela não pode impedir as partes de procurar outros tribunais ou órgãos para a solução de sua controvérsia. Além disso, o conflito de jurisdições permaneceria como um entrave na busca de uniformidade e certeza nas decisões internacionais.

Sendo assim, uma possibilidade para enfrentar tais limitações seria o estabelecimento de um órgão geral e permanente de apelação - e a CIJ poderia desempenhar esse papel. ${ }^{129}$ Para isso, algumas mudanças se fariam necessárias: as regras atinentes à legitimidade (locus standi), por exemplo, deveriam ser reformuladas para se enquadrar aos propósitos de um órgão geral (ou "universal") de apelação.

Embora isso possa parecer relativamente idealista no presente momento, essa estrutura é viável, e melhoraria o sistema internacional de mecanismos jurisdicionais de solução de controvérsias, o que, em última análise, afetaria positivamente as disputas envolvendo questões ambientais. Analogamente, embora nas décadas passadas a responsabilidade internacional do indivíduo, juntamente com o estabelecimento de um Tribunal Penal Internacional, fossem consideradas soluções utópicas, tais medidas são hoje uma realidade no campo do Direito Internacional. Do mesmo modo, o estabelecimento de um órgão de apelação internacional, permanente e geral, poderia - e deveria - se tornar uma realidade no futuro desenvolvi-mento do Direito Internacional.

128 Ian Brownlie. Principles of Public International Law. 274 (Oxford 6. ed. 2003).

129 Para mais opiniões favoráveis a essa proposta, veja Charney, Jonathan I. Is international law threatened by multiple international tribunals?, Recueil des Cours, Volume 271 (1998), p. 101-382; Yuval SHANY. The Competing Jurisdiction of International Courts and Tribunals, 272-73 (Oxford ed. 2003). 


\title{
Relato de Emilio Betti sobre a visita à Universidade do Rio Grande do Sul ${ }^{*}$
}

\author{
Marco Fridolin Sommer Santos ${ }^{\star \star}$
}

\section{APRESENTAÇÃO}

O presente artigo, de autoria de Emílio Betti, foi encontrado em razão da pesquisa que realizei para o Curso de Pós-Graduação em Direito da UFSC entre 2001 e 2002 na Faculdade de Direito da Universidade La Sapienza de Roma, na condição de bolsista da CAPES. Na verdade, estava em busca de um escrito clássico na literatura italiana sobre acidentes do trabalho (tema da minha tese de doutorado), publicado por Guido Fusinato na Rivista Italiana per le Scienze Giuridiche em 1887. Nas pesquisas que realizo, tenho por hábito não me limitar às citações bibliográficas contidas noutras obras. Por este motivo, sempre que posso, costumo simplesmente "bisbilhotar" revistas jurídicas especializadas "para ver o que é que tem". Assim, não satisfeito de já ter encontrado o texto de Guido Fusinato, continuei "folheando" os demais volumes da mesma revista, até o momento em que, para minha surpresa, deparei-me com um artigo de Emílio Betti, cujo título se referia a uma instituição que me é por demais familiar: "Relazione sulla visita alla Universidade do Rio Grande do Sul".

A vinda de Emilio Betti à Faculdade de Direito da URGS, tida como a primeira de um professor europeu à nossa instituição, foi um fato marcante nos idos de 1958. No átrio da Faculdade de Direito, na parede situada à direita de quem entra no prédio, pode-se notar a existência de uma placa de bronze afixada em sua homenagem com os

\footnotetext{
* Artigo publicado originariamente sob o título "Relazione sulla visita alla Universidade do Rio Grande do Sul" na Rivista Italiana per le Scienze Giuridiche, Giuffrè, 1957-1958, p. 435-445. Tradução de Marco Fridolin Sommer Santos.

** Professor da Faculdade de Direito da UFRGS; doutor em Direito pela UFSC.
} 
dizeres "Aqui lecionou Emilio Betti outubro de 1958”. Na sala da Direção, pode-se vê-lo em uma fotografia, ladeado por quatro professores da Faculdade: da esquerda para a direita nela figuram os professores Francisco Simch, Ruy Cirne Lima, Elpidio Ferreira Paes, Emílio Betti e Armando Câmara. Apesar disso, as referências atuais sobre o que efetivamente se passou nesse importante momento para a história da nossa Faculdade se perderam no tempo. A publicação desse relato de Emílio Betti na Revista da Faculdade de Direito, quase meio século após a sua visita à Universidade do Rio Grande do Sul, reacende a nossa memória, trazendo a lume um depoimento singular, que desvanece a todos aqueles que integram esta centenária instituição. Da sua leitura percebe-se quão importantes foram as suas contribuições, cujos reflexos podem ser percebidos nos dias atuais. Esse artigo, é um escrito apaixonado, que não poupa elogios aos nossos conterrâneos. Elaborado para ser lido por seus concidadãos italianos, o texto, mais do que um simples relato, é uma declaração de apreço e admiração pela cultura jurídica brasileira. Seu estilo, leve e abrangente, é um espelho onde nós nos podemos enxergar com olhos alheios e amigos.

\section{- I -}

Hoje em dia, vários fatores concorrem para tornar o Brasil um centro de atração cultural, e centro de atração também para outros países da América Latina: em primeiro lugar, o reconhecimento da superioridade da ciência como tal (e, portanto, de seus seguidores) em relação a qualquer ideologia política; e, ao mesmo tempo, o reconhecimento da superioridade da autoridade civil em relação àquela militar. Esta última é demonstrada de forma eloqüente pela história política do Brasil, cujo desenvolvimento segue um caminho claramente oposto àquele dos países de língua espanhola: nesses, estando o domínio nas mãos das autoridades militares, produziu-se, após a independência, uma fragmentação em tantos ordenamentos estatais quantos foram os chefes militares à frente de revoltas e agitações políticas. O Brasil, ao contrário, com a conquista da independência em 1822, reservou o domínio político à legítima autoridade civil (a cujas mãos esse foi reconduzido mesmo depois de agitações sustentadas pelo poder militar) e pôde assim conservar intacta a sua unidade política, apesar da imensa extensão territorial e da variedade de raças que compõem a sua população. Nada mais instrutivo acerca da sua atual constituição demográfica do que a formação de tais raças e de seus cruzamentos, que produzem, na costa ou nos planaltos do interior, diferentes tipos de mestiços mulato, curiboca, cafuso, jagunço, sertanejo - cuja gênese é descrita por Euclides da Cunha em um genial estudo sociológico e histórico. ${ }^{1}$ Raças e cruzamentos, longe de dar lugar a

1 [Os Sertões, $24^{\mathrm{a}}$ ed. 1956, 61ss.; 82s.; 99s.]. 
permanentes divisões e conflitos (como hoje na América do Norte), atingiram uma fusão harmônica e uma convivência pacífica na superior e absorvente unidade nacional, reforçada, no centro e ao sul do país, pela imigração italiana e alemã. Fusão e convivência essas que, mesmo na paridade jurídica das raças, reconhecem e valorizam as suas diferenças de capacidade produtiva e construtiva, sem padronizá-las e reduzilas a um nível uniforme forçado (como na América do Norte).

No que concerne à superioridade reconhecida à ciência e ao ensino independentemente das ideologias políticas e de suas conseqüentes mudanças, não é menos instrutivo o confronto com outros países da América Latina, em particular com a Argentina. Na Argentina, agitações que provocam mudança no regime político interrompem a continuidade, explicando o porquê das repercussões nocivas na vida econômica e cultural do país: a mudança de regime induz à expulsão de funcionários do regime anterior, bem como a destituição dos professores de categorias superiores. Ora, tal problema, que põe em risco a certeza das relações de direito público e perturba a tranqüilidade da convivência civil, certamente não favorece o desenvolvimento autônomo da cultura superior, que deveria, por sua própria natureza, ser independente de determinadas influências. E este fenômeno é talvez uma (e não a última) das razões pelas quais a Argentina, nos últimos tempos, tem decaído da posição de nação-guia das repúblicas da América Latina, posição que o Brasil parece ser chamado a ocupar por uma série de fatores, dentre os quais a estabilidade de seus ordenamentos. A esse respeito, deve-se notar que na passagem da primeira constituição republicana, de 1889, para a segunda, que é de 1934 e é influenciada pelas idéias de MirkineGützewich, e para a terceira, de 1946, as inovações trazidas para reforçar ora o poder central da União, ora a autonomia dos Estados, não são tão profundas quanto possa parecer a quem se prenda literalmente ao texto, mas antes conservam uma linha de continuidade.

\section{- II -}

Passando a examinar o comportamento dos docentes de direito na Universidade do Rio Grande do Sul, seja na Faculdade de Porto Alegre, seja naquela de Pelotas (da qual limito-me a recordar Bruno de Mendonça Lima, Mario Ferreira de Medeiros, Gilda Mayer Russomano), deve-se dizer que, ao ouvi-los falar, percebe-se, junto a uma abertura intelectual não influenciada por preferências e cautelas apriorísticas, uma decidida disposição inata de interesse e simpatia para com a ciência jurídica italiana, a qual eles todos consideram parte indispensável da própria educação e cultura jurídicas. Esse comportamento geral confere aos juristas italianos no Brasil (vivos ou mortos) uma proeminência verdadeiramente singular, da qual mais adiante 
serão reveladas as razões. É verdade que muitas obras jurídicas francesas e alemãs, ao lado daquelas italianas, foram traduzidas para o espanhol (que no Brasil é correntemente compreendido); mas uma exposição catedrática dessas obras por seus autores não seria tão facilmente entendida, enquanto uma exposição clara e distinta em italiano o seria, graças a uma maior afinidade entre as línguas e a um maior conhecimento do italiano (em relação ao francês ou alemão) como língua escrita entre as pessoas cultas. No que tange ao inglês, embora largamente conhecido, uma essencial diferença na forma dos ordenamentos, das fontes, da jurisprudência e dos institutos impede a difusão do interesse em conhecer o direito anglo-americano. Quanto, ainda, ao ensino de docentes portugueses ou espanhóis, teria certamente a vantagem da pronta (ou mais rápida) comprensão; mas parece lícita a dúvida de que esses docentes possuam, em geral, junto aos colegas brasileiros, ao menos no campo das ciências jurídicas, o mesmo ascendente prestígio jurídico dos docentes italianos. E, de qualquer forma, uma cordial colaboração com eles é sempre possível.

\section{- III -}

Acerca da eficácia de penetração com que pode contar o ensino em língua italiana (salvo sempre o melhor, que, para a maioria dos docentes, seria o ensino em português pelos docentes italianos), limitando-se o exame às matérias jurídicas (mas deve-se lembrar que também para outras ciências morais não é muito diferente), um confronto entre as experiências do subscrito em ambientes culturais diversos pode ser instrutivo, a partir do momento em que encontrou-se frente à tarefa de estabelecer um diálogo com os alunos: diálogo sempre indispensável, se a aula deve atingir 'o êxito didático a que almeja, como colaboração que é essencialmente colóquio (ainda que mudo).

1. Na Alemanha, dada a familiaridade com a língua alemã, ele pôde, na qualidade de Gastprofessor em Frankfurt M., Bohn, Hamburg e Marburg, ministrar cursos que contavam corì a presença de um certo (ainda que exíguo) número de freqüentadores; cursos que, em virtude da continuidade, estavam aptos a contribuir verdadeiramente para a informação e formação mental dos freqüentadores. ${ }^{2}$ Ao contrário, as conferências únicas (Vorträge) por vezes proferidas em várias universidades alemãs não puderam mais do que influenciar minimamente os ouvintes, e serviram mais para promover uma troca de idéias entre os presentes, especialmente quando foram seguidas por discussões (como ocorreu por último em Heidelberg, em junho passado). $\mathrm{Na}$

2 Cf. meu relatório em Studi in on. di Pacchioni, 1939, e na Nuova riv. di dir. comerc., 1953 II, 12; 1955, II, p. 74. 
verdade, a conferência única, rigorosamente limitada a uma duração de 50 minutos, quando não é proferida, livre de termos prefixados, no âmbito de um seminário, dá ao docente convidado a dolorosa impressão de um leito de Procusto que o separa com obstáculos intransponíveis do público discente, o qual torna-se inatingível para o estrangeiro, ainda que este domine o idioma local.

2. No Egito, a dificuldade encontrada ao estabelecer comunicação com os discentes, ainda que sejam doutorandos e, portanto, providos de uma relativa preparação geral, é acrescida de uma dupla circunstância: em primeiro lugar, ter que falar em uma língua diferente da sua (o francês) e a eles não totalmente familiar (o que explica os insistentes pedidos de ter acesso imediato às notas escritas da exposição oral), e ter também que pressupor o conhecimento de certas noções preliminares que as diferenças de mentalidade e preparação tornam menos facilmente acessíveis e familiares mesmo para os alunos dotados de suficiente inteligência e de bom critério jurídico (como são, em média, os doutorandos egípcios). Isso não torna essa experiência didática menos interessante, mas com certeza mais difícil.

3. No Brasil, as condições nas quais o docente é chamado a estabelecer contato com os alunos são bem melhores do que nos outros dois países. Acima de tudo, a afinidade entre as línguas e as culturas confere a uma exposição suficientemente clara em língua italiana muitas chances de ser imediatamente entendida pelos professores e pela elite dos alunos. Mas a afinidade e a notoriedade da língua escrita ainda assim não seriam fatores decisivos se não existisse um outro fator que não se encontra em outros países, nos quais um inigualável "complexo de superioridade" reduz o interesse e paralisa a predisposição a compreender um patrimônio de pensamento estrangeiro, alheio à tradição nacional (Alemanha, França, países anglosaxões). Este outro fator, em si só decisivo, que opera no Brasil, é dado por uma admirável abertura de horizonte espiritual que induz a uma predisposição natural a entender as contribuições trazidas à ciência por estudiosos estrangeiros, e uma atitude de humildade que é alheia a qualquer preconceito chauvinista. Assim, ocorre este fato extraordinário: enquanto nos citados países nórdicos as contribuições trazidas pela ciência italiana em várias áreas das ciências morais - em particular no campo do direito civil são pouco ou nada conhecidas, e, de qualquer forma, não são utilizadas e valorizadas como merecem, no Brasil, ao contrário, figuram em primeiro lugar no ranking dos conhecimentos que se tem da literatura científica estrangeira, e os próprios docentes brasileiros - não bloqueados, como no norte, por preconceitos e complexos de superioridade - acorrem para escutá-las, prontos a converter-se em humildes alunos 
ansiosos por aprender e aprofundar os próprios conhecimentos. Mesmo esta precedência reconhecida às contribuições da ciência italiana tem razões profundas, que não se limitam à afinidade entre as línguas e - no campo do direito civil - à afinidade dos institutos: não passa despercebido aos colegas brasileiros o valor que aquelas contribuições possuem no momento em que se posicionam em relação às contribuições de outros países, examinando e utilizando-os. Tratados franceses e alemães sobre direito civil ou direito processual civil informam os leitores apenas sobre o estado da ciência na França ou na Alemanha; já os tratados italianos avançam o olhar para além das fronteiras da doutrina e da tradição italianas, avaliando as contribuições estrangeiras da mesma maneira com que avaliam as suas próprias. É sintomático, a este propósito, o grande sucesso que obteve na Sorbonne, na primavera de 1949 , um jurista da América Latina, Eduardo Couture, falando sobre as novas teorias elaboradas pela ciência processualística da Itália e da Alemanha: ora, ele trazia aos franceses uma mensagem sobre o trabalho científico que se concretizava à porta das suas casas: trabalho que esses, fechados em seus antolhos chauvinistas, nem mesmo conheciam. Ora, é exatamente essa maior abertura de horizonte que os juristas brasileiros apreciam na ciência italiana, porque sentem-na similar à sua própria orientação espiritual.

\section{- IV -}

Mas não se acredite que o docente italiano chamado a ensinar no Brasil possa limitar-se a simplesmente repetir as doutrinas expostas em seus próprios livros. Seria um erro, como de resto é errado o preconceito vulgar que reconhece como dever do professor a distribuição de um saber definitivamente adquirido, sem levar em conta o grupo de alunos que está em sua frente. Se a aula é um feito de colaboração, ou seja, é essencialmente um colóquio, é claro que deve ser orientada de acordo com o grupo de alunos e é difereciada de acordo com as suas atitudes e disposições particulares. Cada novo grupo de alunos coloca o docente frente a uma nova experiência didática que, exigindo uma comunicação renovada, requer dele um novo exame de consciência científico, em vista da escolha dos assuntos a serem tratados e do rumo a ser tomado na exposição. Quando, em particular, a matéria a ser tratada implica uma comparação entre culturas ou ordenamentos diferentes, é óbvio que o termo de confronto é buscado no tipo ou gênero mais próximo à experiência e ao conhecimento dos alunos. Assim, a nova experiência didática interage necessariamente na auto-educação do docente, estimulandoo a controlar e revisar esquemas e categorias tradicionais, o que não poderá não exercer um efeito benéfico sobre o conjunto de sua preparação, no sentido de estimulá-lo a vencer quaisquer formas de inércia e de 
angústia mental e a superar aquele provincianismo de espírito que sempre ameaça o docente habituado a falar sempre ao mesmo público; de modo que a experiência nova resulta sumamente educativa para o próprio docente (algo que o próprio subscrito pôde constatar inclusive nesta recente ocasião).

\section{$-\mathrm{V}-$}

No Brasil, em particular, o professor italiano de matérias jurídicas não deve esquecer-se do férvido movimento de preparação legislativa que levou à codificação do direito privado durante o século XIX nos vários países da América Latina. É de 1850 o excelente código de comércio brasileiro, cujo centenário foi celebrado com três volumes de escritos muito instrutivos. É de 1855 o apreciável código civil do Chile, redigido pelo jurista venezuelano Andres Bello. É de 1858 a "consolidação das leis civis" elaborada para o Brasil por Augusto Teixeira de Freitas; de 1859-66 a elaboração, desenhada pelo mesmo genial jurista brasileiro, de um monumental esboço de código civil para o Brasil em 5016 artigos, obra insigne de sabedoria legislativa. É de 1871 o código civil argentino, no qual o esboço de Teixeira de Freitas foi tão amplamente aproveitado que pode ser considerado a sua principal fonte. A propósito da influência exercida por Teixeira de Freitas com seu esboço e com as diretivas metódicas apontadas na "introdução às leis civis do Brasil" anteposta à citada "consolidação", basta considerar, para ter-se uma idéia, que a "consolidação" reflete-se, além do código argentino, nos códigos uruguaio e suíço. ${ }^{3}$ e constituiu a principal fonte das inovações mais tarde introduzidas no código brasileiro de $1916 .{ }^{4} \mathrm{O}$ docente que estuda a evolução do direito privado no Brasil logo vê desmentida a ilação que lhe poderia ser sugerida do fato de que esta tinha como ponto de partida o direito português: ou seja, que em coerência com tal origem, o movimento tendente à codificação se encontrasse, no Brasil, ante à perspectiva de um desenvolvimento diferente daquele assumido nos outros estados da América Latina, que antes de conseguir a independência eram todos colônias espanholas (o Brasil tornou-se um império independente em 1822, e uma república federal com congresso legislativo nacional em 1889). Ao contrário, também no Brasil, como no Chile e na Argentina, o movimento legislativo inspirou-se mais na teoria geral do direito privado do que nas tradições nacionais lusitanas, ainda que estas continuassem a formar uma série de institutos. Expondo os deveres da codificação na citada "Introdução às leis civis no Brasil", bem como traçando as linhas gerais do futuro código no referido esboço, Teixeira de Freitas remonta

3 PONTES DE MIRANDA. Fontes e evolução do direito civil. p. 112.

4 Ibidem, p. 119, p. 497 et seq. 
sobretudo à tradição dos pandectistas em voga naquele tempo, começando por Savigny ("o imenso Savigny", como o chama). Apesar de alguns deploráveis dissídios com ministros brasileiros da justiça entre 1867 e 1872 provocarem o fracasso da conversão do esboço em código, ainda assim o projeto foi de decisiva influência para a elaboração preparatória do novo código civil. A redação deste foi confiada a Clóvis Beviláqua, professor de legislação comparada na Universidade do Recife, e foi composta em seis meses graças ao fato de que a precedente maturação e justificativa doutrinal delineadas por Teixeira de Freitas poupava ao sucèssor o trabalho, geralmente ingrato, de envolver-se em discussões de dogmática jurídica. Por outro lado, em virtude de uma técnica excelente, o novo código apresentava formulações concisas, que reduziram os artigos para 1867 (dos quais 26 destinados aos direitos autorais). E mesmo aí o que atrai a atenção e o interesse do estudioso europeu está no ideal, visivelmente almejado, de oferecer uma disciplina jurídica de valor universal, que responda ao progresso da legislação e da doutrina junto aos povos civis: ideal este que esclarece o ecletismo e a tendência a selecionar o melhor, sem preconceitos, onde quer que esteja.

$O$ ideal de um direito moderno virtualmente dotado de um valor universal, que foi inspirado, nos codificadores, pela sua preparação pandectista e que hoje continua a animar os intérpretes, enquanto de um lado dá razão à simpatia nutrida por eles pela ciência jurídica italiana, de outro induz a refletir sobre o árduo dever que espera o professor italiano que queira manterse ao mesmo nível do fervor das idéias que primeiro levaram à codificação e depois animaram a interpretação dos códigos. Sentindo-se em meio a espíritos fraternos como em meio a amigos que o conhecem há muito tempo, ele deve responder ao calor da acolhida com outro tanto de empenho e coração.

\section{- VI -}

Falando sobre como o subscrito desenvolveu sua missão e sobre as condições que favoreceram o seu cumprimento, deve ele honestamente confessar que, do direito brasileiro hoje em vigor ou em preparação, conhecia muito pouco além do código civil de 1916 e do anteprojeto de código de obrigações redigido entre 1937 e 1940 por uma comissão de três juristas do Rio de Janeiro (Orozimbo Nonato, Philadelpho de Azevedo, Hahnemann Guimarães) que o apresentou em 24 de janeiro de 1941; mas a cortesia dos colegas porto-alegrenses logo deixou-o em condições de preencher esta lacuna. Como principais termos de referência na comparação com o código italiano ele tem também presentes o código civil português (com as recentes exegeses de Galvão Telles e de Silva Vaz Serra para a matéria das obrigações) e o espanhol, e também os códigos civis do Chile, da Argentina e do Uruguai. No programa do curso, com previsão de 15 aulas, o subscrito havia indicado 
três ordens de problemas a tratar: a) a primeira concernente à interpretação da lei e dos atos jurídicos; b) outra referente à autonomia privada como fato social destinado a funções sociais diferenciadas, a ser explanada através de uma análise do negócio jurídico e de seus critérios de tratamento; c) a última referente às relações obrigacionais, concebidas como instrumentos destinados a atuar no plano social entre sujeitos de mesmo grau na cooperação entre os homens.

Apesar do esforço de síntese do subscrito nas exposições, os vários pontos deste programa puderam ser desenvolvidos apenas em parte nas 15 aulas e nos cinco debates que pôde realizar entre 10 de outubro e 3 de novembro (note-se que a oitava aula, ocorrida em 22 de outubro, foi dedicada ao direito processual), embora a atenção e o vivo interesse dos ouvintes encorajassem o docente a falar durante uma hora e meia (das 10 às 11:30h da manhã) - circunstância digna de destaque pela sintomática antítese que esta nova experiência didática assinala em relação a experiências análogas em universidades alemãs. Fazendo um balanço, pode-se honestamente concluir que o breve curso teve um sucesso inegável; mas é necessário dizer imediatamente que o sucesso deveu-se à viva participação dos ouvintes e, particularmente, ao incomparável encorajamento dado ao docente pelo fato de que, entre os ouvintes, estavam na primeira fila os próprios docentes da Faculdade de Direito, desde José Salgado Martins a Armando de Azevedo, a Galeno Lacerda; de Hernani Estrella a Ruy Cirne Lima, a Elpidio Paes, e assim sucessivamente. A aula tornava-se assim um vivo colóquio, se não com os alunos (com os quais as conversas explicativas não tiveram, por vários motivos, o desenvolvimento que seria desejável), ao menos com os colegas juristas, e dava lugar a trocas de idéias, as quais o docente aproveitava tanto quanto os próprios "alunos". Experiência verdadeiramente extraordinária, que o presidente Salgado Martins exaltou com palavras comovidas durante uma fala aos estudantes em 31 de outubro, recordando, entre outras coisas, que "... todos se transformaram em seus discípulos, acompanhando, numa eclosão de alegria espiritual, a exposição do mestre, sempre segura e brilhante, sobre velhos e novos problemas do direito civil". Na férvida troca de idéias que precedia e seguia as aulas e se acentuava nos debates, $o$ subscrito conheceu obras notáveis desconhecidas ou mal conhecidas (ao menos para ele), como tratados de teoria hermenêutica, ${ }^{5}$ ou tratados de direito internacional privado. ${ }^{6}$

5 SANTOS, Carlos Maximiliano Pereira dos. Hermenêutica e aplicação do direito. 1925, 6a ed. 1957; RECASENS SICHES. Filos. de la interpretacion del derecho, 1956.

6 Pontes de Miranda, 1935-36; Werner Goldschmidt, 1952; Quintin Alfonsin, 1955; ou de teoria geral do direito [ex.: Miguel Reale, Teoria tridimensional do direito; R. Cirne Lima, Preparação à dogmática jurídica, 2a ed. 1958]. 
Por sua vez, ele encontrou nos colegas porto-alegrenses pronta e inteligente compreensão de vários ensinamentos concernentes à problemática da autonomia privada e das obrigações, e ficou feliz em constatar como aos colegas não escapassem o pano de fundo e o valor ético de certas idéias condutoras (como a da exigência de reconhecimento no mundo social, ou da auto-responsabilidade, ou da cooperação entre sujeitos independentes). Mas o subscrito ficou particularmente satisfeito em constatar com quanta inteligência e íntima adesão era acolhida a teoria geral da interpretação, a qual delineou não somente em Porto Alegre, mas - a convite dos colegas das respectivas Faculdades jurídicas - no dia 6 de outubro em São Paulo (onde conheceu pessoalmente Miguel Reale, Alfredo Buzaid, Gama e Silva, Alexandre Correia, antes conhecidos apenas pelo nome), em 25 de outubro em Pelotas, em 7 de novembro em Montevidéu $^{7}$ : nesses centros universitários renovaram-se cordiais manifestações de fraternidade à qual os colegas estavam predispostos por simpatia ao nosso país. (Frente a tais manifestações, o subscrito não deixou de acentuar que as considerava dirigidas não a sua modesta pessoa, que servia como intermediária, mas à grande comunhão de pessoas que é a nação italiana em sua milenária missão de civilidade). Por último, foi muito sintomático, e ao mesmo tempo motivo de alto conforto para o subscrito, o propósito que o prof. Ruy Cirne Lima manifestou espontaneamente no dia da partida ao confirmar a intenção de traduzir para o português o livro sobre a Interpretazione della legge e degli atti giuridici e de colocar em prática as premissas para constituir, no futuro, na órbita da Faculdade de Direito de Porto Alegre, um instituto de teoria da interpretação análogo àquele existente na Università di Roma.

\section{- VII -}

Balanço encorajador, portanto, o do breve curso de direito civil comparado ministrado em Porto Alegre; mas encorajador sobretudo por mérito dos próprios juristas anfitriões, graças à sua abertura de espírito e fraternidade de coração. Mas este relatório seria demasiado falho se não destacasse zonas de luz e sombra, perspectivas mais e menos favoráveis. O reitor Eliseu Paglioli, oriundo de família cremonese, confidenciava francamente ao subscrito que a Universidade do Rio Grande do Sul, por ele administrada, aspira a tornar próprios professores italianos, prezados pelo seu valor didático (na Faculdade de Filosofia já leciona como titular de Literatura Italiana o prof. Angelo Ricci; na Faculdade de Medicina leciona

7 Onde renovou o agradável contato, já feito em Roma, com o professor J. Sanchez Fontans e conheceu pessoalmente os colegas Mezzera Alvarez, A. Gelsi-Bidart, H. E. Gatti, Q. Alfonsin, Ant. Prunell e outros. 
como professor adjunto de anatomia o sardo prof. Paolo Contu). É opinião difusa (confirmada pelo escultor Caringi e pelo compatriota dr. Renzo Rosa) que, dentre os imigrantes, os italianos são melhor aceitos, seja pela maior flexibilidade e inteligência, que os torna mais facilmente assimiláveis (enquanto, p.ex., os imigrantes alemães conservam o uso da língua materna até além da quarta geração), seja pela sua proverbial laboriosidade, que lhes atribui uma função de equilíbrio na economia do país. O prof. Waldemar Ferreira me recordava o imenso benefício trazido à agricultura brasileira pelo afluxo de colonos italianos de 1870 em diante, após a libertação dos escravos negros, que ameaçou destruir a economia agrária brasileira. É um sentimento bastante difuso (confirmado por mais de um colega de Porto Alegre) que entre o Brasil e os Estados Unidos da América não subsista justamente aquela íntima e profunda afinidade cultural que é, ao contrário, vivamente sentida em relação aos países ibéricos e à Itália, pelo que, apesar da tendência a se tratar a América do Sul como "zona de influência" dos EUA, não é de se supor ou temer uma difusão no Brasil da concepção utilitarista que se denomina american way of life, nem uma expansão dos EUA, exceto em determinados setores da vida econômica dependentes do capital norteamericano. É, ao contrário, opinião firmemente enraizada nos mais iluminados espíritos brasileiros que a
Itália deva - como expressou-se Waldemar Ferreira em um colóquio "retomar sua missão cultural" em relação aos países da América Latina, particularmente o Brasil, tão enriquecido e potencializado pela imigração italiana, especialmente em Estados como o Rio Grande do Sul: exigência esta que foi repetidamente afirmada pelos brasileiros durante a apreciada visita do presidente Gronchi.

Mas quando se verificam quais as realizações, ou quais os meios de atuação que correspondem a perspectivas tão promissoras para a cultura italiana no Brasil, encontra-se entre umas e outras uma desproporção impressionante.

Ressalte-se, acima de tudo, uma iniciativa altamente benemérita e digna do máximo apoio: o Colégio de Aplicação anexo à cátedra de Literatura Italiana na Faculdade de Filosofia de Porto Alegre. Trata-se de uma escola modelo na qual o aluno é acompanhado com cuidado minucioso nas primeiras manifestações de sua inteligência e capacidade social. As professoras entram em contato com os pais das crianças para compreender seu ambiente familiar e para poder inferir de que cuidados (mesmo físicos) e de que orientação moral elas necessitam no processo educativo.

São admiráveis o zelo e o espírito de dedicação materna com que as senhoras professoras amorosamente seguem cada aluno no intento de classificá-lo com critérios estritamente 
pedagógicos, tendo em vista um tratamento diferenciado. Contudo, devese dizer, faltam a essa nobre iniciativa os meios de atuação adequados, a começar por locais confortáveis, visto que a escola está, no momento, alojada em simples barracões de madeira. Animadas por um espírito de vivaz italianidade e cheias de uma fé comovente, as professoras têm condições de mostrar o ótimo resultado atingido com seus esforços, e coerentemente solicitaram meios educativos, livros, discos, filmes e tudo de mais moderno que haja em funcionamento nas escolas pedagógicas italianas, de modo a poder realizar melhor sua árdua tarefa. Tanta fé não deve ser desiludida. Quão vivaz é a chama de italianidade e de amor pela pátria mãe que anima o espírito e a paciente atividade que estes nossos compatriotas desenvolvem na luta cotidiana contra dificuldades de clima, de ambiente, de isolamento! Mas o senso de comovida bravura com que nos enche esse nobre exemplo não deve limitar-se a estéreis expressões de solidariedade ideal: deve antes traduzirse em apoio operante, com trocas de idéias e ajuda material de caráter contínuo. Só assim uns e outros poderão sentir-se solidários uns com os outros, camaradas em uma batalha comum.

Uma outra iniciativa, que infelizmente parou em 1954 por falta de recursos, mas que mereceria ser retomada com meios adequados, é aquela de um instituto italiano de cultura em Porto Alegre. Se existe no exterior um centro de italianidade para o qual um instituto de cultura italiana deveria constituir um indispensável instrumento de irradiação (e ainda mais quanto mais docentes italianos afluirão, como é de se esperar), este centro é Porto Alegre, tendo presente a presença de italianos em todo o Rio Grande do Sul, de Caxias a Passo Fundo, de Garibaldi a Pelotas. Dessa exigência estava bem consciente o prof. Angelo Ricci, que tomou uma iniciativa neste sentido; mas não veio nenhuma ajuda, nenhum apoio efetivo por parte das autoridades competentes, de forma que o simulacro de instituto, após poucos anos de vida, desapareceu. Outras tentativas foram feitas, sempre sem nenhuma ajuda das autoridades competentes; assim, em Pelotas foi constituída, por iniciativa do vice-cônsul dr. Luigi Scattolin, uma "associazione italo-brasiliana", mas com subsídios voluntários dos participantes, que lhe asseguram apenas uma existência precária. Esta carência é tão lamentável quanto é fácil deduzir, de um confronto com a política cultural de outros governos ou com critérios seguidos pelo nosso próprio em outras sedes, que os meios disponíveis, quando há vontade verdadeira, se encontram. Assim, o governo alemão, quando tratou-se de fundar em Porto Alegre um instituto de cultura, destinou para tal 15 mil marcos, ou seja, mais de dois milhões de liras. $\mathrm{Na}$ fronteira do Estado do Rio Grande do Sul, na cidade de Montevidéu - onde a cultura italiana faz frente, não sei com 
que chances de sucesso, à temível concorrência da cultura espanhola e francesa (que em Porto Alegre, ao contrário, não exercem uma influência particular) - existe um instituto italiano de cultura provido de uma verba anual de mais de cinco milhões de liras: verba respeitável, ainda que três quintos dela sejam atualmente absorvidos pela despesa com o aluguel da sede. Análoga reflexão comparativa vale também para o centro italiano de estudos na Argentina, que tem sede em Buenos Aires, Charcas 1149. Por que um centro de crescente importância, como o é indubitavelmente Porto Alegre, continua hoje a ser negligenciado? $\mathrm{O}$ fato de que na distante São Paulo exista um instituto de cultura italiana não elimina certamente a incongruência para quem conheça as tendências autonomistas do Rio Grande do Sul e-como diz Euclides da Cunha, Os Sertões, 77 - "este espírito de revolta, eloqüentíssimo, que ruge em todas as páginas da história do sul". É tempo de reparar aquela que, no estado atual de evolução histórica do Brasil, parece uma sensível omissão de uma grande possibilidade.

\section{- VIII -}

No ambiente cultural que tem seu fulcro na Universidade do Rio Grande do Sul, portanto, as exigências a satisfazer para uma política que pretenda promover a difusão da cultura italiana são múltiplas e variadas. Em primeiro lugar, dever-se-ia enviar livros mais adequados, escolhidos com muita atenção; e, para baratear o envio, as tarifas postais entre Brasil e Itália deveriam ser modificadas. Além disso, deveriam ser enviados professores convictos do valor da própria missão: homens superiores às mesquinhas ambições pessoais e aptos a uma tarefa árdua, que requer empenho e coração. Objetivos parciais deveriam ficar em segundo plano; por exemplo, o fato de que em Montevidéu exista uma boa biblioteca de direito comparado não justifica a proposta (que me foi referida) de lá concentrar nossos esforços: em Montevidéu a cultura italiana sofreria sempre a preponderância das culturas espanhola e francesa. Os acordos culturais firmados no Rio de Janeiro em 6 de setembro de 1958, cuja importância foi sublinhada pela visita do presidente Gronchi, que os subscreveu, trazem indubitavelmente uma premissa que justifica as mais altas esperanças; mas para haver atuação prática é preciso um regulamento executivo elaborado entre os dois estados: regulamento que é ponderado com muito cuidado, com consciência das exigências a satisfazer e com a firme decisão de superar as dificuldades de qualquer espécie que se opõem à realização dos objetivos prefixados. Tais dificuldades podem e devem ser vencidas com a convicção da importância da aposta em jogo. Assim, por exemplo, devem ser baixadas medidas para que a posição jurídica e a carreira dos docentes que serão enviados em missão não sejam prejudicadas em nada; disciplinas 
restritivas e incongruentes em relação aos mesmos devem ser extintas, para que o seu empenho seja encorajado e favorecido. ${ }^{8} \mathrm{O}$ conhecimento das respectivas línguas - premissa indispensável para uma maior influência do ensino - deveria ser aprofundado e largamente difundido, e o acesso aos cursos de aperfeiçoamento seria facilitado de todas as formas possíveis. Trata-se, para a Itália, de retomar sua missão de civilidade em um grande país que, por sua história e constituição, predispõe-se a acolher o benefício da cultura italiana; em um grande país que lhe oferece imensas perspectivas e possibilidades de expansão e oferece aos seus docentes uma oportunidade verdadeiramente única de valorizar ao máximo o seu magistério. Trata-se de uma missão para a qual os próprios docentes devem ser preparados sob o aspecto moral e intelectual: para isso, é necessário que eles se libertem dos grilhões de uma especialização mesquinha e dos hábitos de um provincianismo tacanho que mortificam seus espíritos e restringem seus horizontes de estudiosos e educadores.

O subscrito fica à disposição das autoridades competentes para qualquer esclarecimento mais oportuno sobre as informações dadas e as exigências afirmadas. E, de sua parte, está firmemente decidido a prosseguir a obra de colaboração iniciada (com a destinação de 56 mil cruzeiros para a aquisição de livros para várias instituições) e a manter as promessas de intercâmbio feitas aos colegas brasileiros.

8 Seria fácil, p. ex., estabelecer com uma medida legislativa que os professores enviados em missão e, portanto, tornados funcionários do Ministério dos Assuntos Exteriores possam, em seu retorno, reassumir seus lugares como funcionários do Ministério da Educação. 


\title{
O dano extrapatrimonial, a crueldade contra os animais e a dignidade da pessoa humana em face da autorização anual da caça amadorista no Rio Grande do Sul
}

\author{
Patricia Azevedo da Silveira* \\ Que me perdoe a deusa Artêmis, mas Têmis há ainda de fazer justiça! \\ "[...] mas saibamos lutar contra o horror, uma vez que [...] uma das finalidades \\ planetárias é a resistência contra a crueldade do mundo". \\ (MORIN, Edgar; KERN, Anne Brigitte. Terra-pátria. Porto Alegre: Sulina, 2002, p. 168).
}

\section{UM TIRO NO ESCURO: DA} METODOLOGIA CIENTÍFICA

Em 3 de janeiro de 1967, ou seja, há 37 anos, entrou em vigor a Lei 5.197, que dispõe sobre a proteção da fauna e dá outras providências. Em seu artigo $1^{\circ}$, é vedada a caça. Essa é a regra. O parágrafo $1^{\circ}$ desse artigo dispõe que, se peculiaridades regionais comporta-rem o exercício da caça, a permissão será estabelecida em ato regulamen-tador do Poder Público federal.
Tecnicamente, não podemos falar em permissão no caso da caça amadorista, senão em autorização, em função da sua natureza jurídica. Permissão é cabível quando há interesse concorrente da Administração Pública, como é o caso da caça de controle. ${ }^{1}$ Inclusive há confusão entre ato regulamentador, de efeitos gerais e abstratos, com a permissão de efeitos concretos. $^{2}$

O Rio Grande do Sul, através da Lei 10.056 , de 10 de janeiro de 1994 ,

* Doutoranda (UFRGS), professora de Direito Ambiental do Curso de Especialização em Direito Ambiental da UFRGS/MPRS/Instituto o Direito por um Planeta Verde (RS).

1 Nesse sentido, MACHADO, P. Direito ambiental brasileiro. 7. ed. São Paulo: Malheiros, 1998 , p. 657.

2 MOREIRA NETO, 1997 apud Ibidem. 
regulamentada pelo Decreto n. 35.194 , de 18 de abril de 1994, permite a caça amadorista, o que não significa dizer que há direito adquirido à caça, senão que existem interesses. $\mathrm{O}$ ato que promove a liberação da caça amadorista tecnicamente é a autorização, ato discricionário, porém nunca arbitrário.

Anualmente, vem sendo autorizada a caça amadorista (de campo e de banhado) no Rio Grande do Sul, aliás, único Estado em que tal prática é permitida. Fundação Zoobotânica, pesquisadores da UFRGS e CEMAVE são órgãos importantes na discussão da metodologia de pesquisa dos animais a serem abatidos. Com base nos dados coletados, a caça amadorista é autorizada anualmente no Rio Grande do Sul. Órgãos estaduais realizavam o estudo, em princípio a FEPAM, e, a partir de 1994, com o decreto estadual n. 35.194/ 94, a Fundação Zoobotânica. Embora sejamos contrários à realização da caça amadorista, tal prática é um exemplo interessante de realização do federalismo cooperativo.

Ocorre que a caça amadorista no Rio Grande do Sul, na prática, tornouse um assunto de pesquisadores das ciências naturais, cujas hipóteses de investigação, senão os seus resultados, padecem de inúmeros problemas (isso já foi por eles reconhecido em audiências públicas sobre tal matéria, vide autos do processo n. 20037000332014/ $8^{\mathrm{a}}$ Vara Federal Cível de Porto Alegre- Justiça Federal) seja em função da metodologia, seja em função da escassez de verbas, de forma que seus resultados não podem ser considerados como dotados de uma validade universal. Titulação ou local de trabalho podem conferir legitimidade a um trabalho científico, mas nunca a priori conferem a um resultado de uma pesquisa validade universal. Tanto isso é verdade que, no ano de 2003 , o CEMAVE confrontou metodologia empregada pela Fundação Zoobotânica. Tal incerteza viola o princípio da precaução, vetorial em matéria ambiental.

O Brasil ratificou a Declaração do Rio de 1992. O princípio 15 trata da precaução, nesses termos definida:

PRINCÍPIO 15 - Com o fim de proteger $o$ meio ambiente, o principio da precaução deverá ser amplamente observado pelos Estados, de acordo com as suas capacidades. Quando houver ameaça de danos graves ou irreversiveis, a ausência de certeza científica não será utilizada como razão para o adiamento de medidas economicamente viáveis para prevenir a degradação ambiental.

Podemos vislumbrá-lo na Constituição de 1988 , no artigo $225, \S 1^{\circ}$, inc. IV:

$\S 1^{\circ}$ - Para assegurar a efetividade desse direito, incumbe ao Poder Público: $I V$ - exigir, na forma da lei, para [...] atividade potencialmente causadora de significativa degradação do meio ambiente, estudo prévio de impacto ambiental, a que se dará publicidade.

Em nome justamente do princípio da precaução, que pleiteamos, no mínimo, 
a moratória da caça amadorista no ano corrente, uma vez que a estiagem provocou alterações significativas no ecossistema, comprometendo a safra de inúmeros cultivos (v. reportagem que apresenta dados da produtividade em função dos efeitos da seca, levantados pela Ascar/ Emater/RS, intitulada Crescem prejuízos causados pela seca e Estado amplia medidas. ${ }^{3}$ Quais são os efeitos da estiagem sobre a diversidade biológica aqui existente?

Há outras perguntas que não querem calar:

a) Quantos animais, habitualmente relacionados na lista de animais autorizados à caça, não foram atingidos ou mortos pela seca? Isso não afetará o processo de nidificação das espécies nos campos e banhados, duramente atingidos?

b) Quais os efeitos da utilização dos organismos geneticamente modificados nas plantações sobre os animais silvestres?

c) Qual o efeito da seca sobre os agrotóxicos misturados à terra e suas implicações sobre os animais habitualmente autorizados à caça amadorista?

d) Qual o efeito dos sons dos tiros disparados à reprodução e sobrevivência de outras espécies não autorizadas que estejam ou não ameaçadas de extinção?

e) Qual a implicação dos sons dos tiros nas áreas de corredores ecológicos, em unidades de conservação, mosaicos ou zonas de amortecimento (v. conceitos na Lei 9.985 , de 18 de julho de 2000, que institui o Sistema Nacional de Unidades de Conservação da Natureza e dá outras providências)? Não estaríamos diante da prática da crueldade contra os animais, repudiada pela Constituição Republicana Brasileira (art. $225,1^{\circ}$, inc. VII) e pela Lei dos Crimes Ambientais (art. 32, $\S 1^{\circ}$, da Lei 9.605/98)? Cremos que sim.

O Decreto 24.645 , em seu artigo $3^{\circ}$, apresenta exemplificativamente o que se consideram maus-tratos. Helita Barreira Custódio apresenta uma conceituação genérica e abrangente. ${ }^{4}$ Diz ela que crueldade contra os animais "é toda ação ou omissão dolosa ou culposa (ato ilícito), em locais públicos ou privados, mediante matança cruel pela caça abusiva [...]". Poderíamos acrescentar a seguinte idéia em relação à concepção de crueldade contra os animais, qual seja, "é toda ação ou omissão dolosa ou culposa (ato ilícito), em locais públicos ou privados [...]" e mediante a matança facilitada por questões climáticas que diminuam ou impeçam a capacidade de eles fugirem, mediante a matança cruel pela caça abusiva, etc.

São muitas perguntas sem respostas, insuficientes para legitimarem a saciedade e o prazer de um número cada vez mais reduzido de caçadores lega-

3 CRESCEM prejuízos causados pela seca e Estado amplia medidas. Correio do Povo, 17 abr. 2004, capa e p. 14.

4 CUSTÓDIO, 1997 apud DIAS, Edna. A tutela jurídica dos animais. Belo Horizonte: Mandamentos, 2000, p. 156 et seq. 
lizados (hoje em torno de um mil e duzentos caçadores) em detrimento da sociedade, violando-se flagrantemente o princípio da igualdade material (art. $5^{\circ}$, caput, da Constituição Republicana de 1988), senão causando dano moral àqueles que não querem mais tal prática em nosso Estado.

Note-se que estudo da dinâmica das espécies não é feito, ensejando a potencialidade de um dano ambiental, que pode ser inclusive irreversível. $\mathrm{O}$ estudo feito anualmente constitui um relatório de pesquisa e monitoramento da fauna cinegética. E ponto final. Não se trata de um estudo prévio de impacto ambiental. Isso inclusive tem implicações na publicização do ato, não atendendo às condições preconizadas no artigo 85, II, do Código Estadual do Meio Ambiente do Rio Grande do Sul, e sim no parágrafo único do artigo 84 .

É indispensável para que a comunidade se faça representar dignamente um espaço físico maior para a apresentação do relatório, sobretudo, porque cada vez mais a população tornar-se-á esclarecida sobre o assunto, não se restringindo o mesmo a caça-dores, como o era inicialmente. O sistema de áudio deve ser mais eficiente, assim como a disponibilização da degravação das fitas da audiência pública, em consonância ao princípio da eficiência que rege a Administração Pública (art. 37 da CF/88). Por outro lado, é indispensável que ONGs que não sejam favoráveis à caça amadorista sejam convidadas a participar do grupo de discussão multidisciplinar, senão para acompanhar os trabalhos em postos de contagem.

\section{DO BOM SELVAGEM HOBBESIANO}

A metodologia empregada pelos órgãos governamentais competentes parece não considerar o processo em todas as suas fases, atendo-se àquilo que foi apresentado nos procedimentos, quando, em verdade, inúmeros fatos passam à margem da fiscalização ora existente.

Todos nós sabemos que existem inúmeros caçadores ilegais e mesmo caçadores legalizados que não preenchem os requisitos do bom selvagem hobbesiano, ou melhor dito, não configuram o caçador "consciente". Um curso preparatório, pressuposto à condição de caçador legalizado, não confere de per si o atributo de um caçador dito "consciente"; veja-se o exemplo do processo de avaliação dos condutores de veículos automotores no Brasil.

O artigo $6^{\circ}$ da Lei de "proteção" à fauna dispõe in verbis:

Art. $6^{\circ}$ - O Poder Público estimulará: a) a formação e o funcionamento de clubes e sociedades amadoristas de caça e de tiro ao vôo, objetivando alcançar o espirito associativista para a prática desse esporte. [...] [destaques nossos].

A redação do presente artigo repousa sobre uma base antropocêntrica, e hoje são invocadas bases de desenvolvimento biocêntricas, ou antropocêntricas alargadas. Vicente 
Cappella ${ }^{5}$ indica no biocentrismo uma clara tendência de formulação de juízos de reconhecimento e proteção de uma posição de autonomia do patrimônio natural, importando o reconhecimento de um verdadeiro status de dignidade intrinsica à natureza, que condiciona a imposição de comportamentos de prudência do elemento humano inserido $n a$ comunidade biótica [itálico no original].

No entendimento de Celso Fiorillo ${ }^{6}$ "a caça amadorista tem fundamento jurídico no direito social ao lazer". Estaríamos diante de uma antinomia jurídica, na medida em que, de outro lado, temos o direito ao meio ambiente equilibrado, proclamado no artigo 225 . Poderíamos considerar como direito social ao lazer uma prática que promove a destruição ou que pode causar o desequilíbrio da diversidade biológica? Não, a caça amadorista vai de encontro ao direito ao meio ambiente equilibrado.

Por outro lado, no texto constitucional de 1967, não havia a afirmação da dignidade humana como um dos fundamentos do Estado Democrático de Direito. Isso é novidade da atual constituição (art. $1^{\circ}$, III). Dessa forma, podemos afirmar que a consideração da caça amadorista como um esporte viola a dignidade humana, pois sacia um sentimento de destruição no homem e fere moralmente aqueles que não admitem tal prática - e não são poucos. Não podemos considerar tal prática como atividade moralmente válida, sobretudo em função do artigo 225 e parágrafos da Constituição Brasileira de 1988. Houve uma mudança de paradigma definido não pelo legislador ordinário, mas pelo Poder Constituinte.

Em 1967, o contexto cultural era outro. $\mathrm{E}$ isso teve reflexos profundos na elaboração da lei de um modo geral. A constituição de 1967 não prevê o direito ao meio ambiente equilibrado; a realidade fática era a da ditatura com todas as suas implicações, inclusive com a ode às armas, o que se verifica no artigo $6^{\circ}$, "a", da lei supra mencionada.

O Clube de Roma dispõe que:

[...] todo e qualquer privilégio, seja de um indivíduo ou de uma nação, deve sempre ser acompanhado de uma responsabilidade correspondente, [...] as chances de uma mudança positiva se encontram nas motivações e nos valores que determinam o nosso comportamento.?

Se houver efetivamente contaminação do solo pelo chumbo, quem paga por isso? Os caçadores? Claro que não, é o Estado. Quem será responsável pelo cemitério de cartuchos lançados aos banhados e campos, formando verdadeiro resíduo sólido sem

5 CAPPELA, V. 1997 apud LEITE, José Rubens Morato; AYALA, Patryck. Direito ambiental na sociedade de risco. Rio de Janeiro: Forense Universitária, 2002, p. 85.

6 FIORILLO, C. Curso de Direito Ambiental Brasileiro. 4. ed. São Paulo: Saraiva, 2003, p. 105. 7 KING, A.; SCHNEIDER, B., 1991 apud WEIL, Pierre. A nova ética. 2. ed. Rio de Janeiro, 1993, p. 79. 
tratamento? Os caçadores? Claro que não, será o Estado. Podemos inclusive afirmar que a prática da caça amadorista causa um ônus às municipalidades, na medida em que resíduos sólidos são efetivamente lançados nos banhados e nos campos. É visível a distorção no sistema da responsabilidade provocada pela ameaça potencial de dano (risco) ou dano ambiental efetivo, pois o artigo $4^{\circ}$, inc. VII, da Lei $6.938 / 81$, estabelece a responsabilidade do poluidor e do predador de recuperar e/ou indenizar pela utilização de recursos ambientais com fins econômicos (princípio do poluidor-pagador). E se não houver fim econômico, como é o caso da caça amadora (senão seria profissional)? É claro que continua sendo dos caçadores em face da responsabilidade civil objetiva em matéria ambiental, adotada no direito brasileiro. Por outro lado, sabemos que é muito difícil concretizarmos práticas dotadas de risco zero, porém o fundamento central do presente artigo jurídico é a ocorrência de dano extrapatrimonial e violação da dignidade humana.

\section{DA FIC E DOS VÍCIOS DE FORMA E DE FINALIDADE}

O procedimento administrativo existente opera com base nas FIC (ficha individual de controle de caça), documento no qual o caçador declara o núme- ro de animais abatidos e o município da caçada. Ora, para que tenhamos uma dimensão mais abalizada da pressão de caça é indispensável a menção do distrito, senão da propriedade rural em que tal prática foi realizada. A reformulação da FIC não implica violação do princípio da separação dos poderes, esculpido no artigo $2^{\circ}$ da Constituição Federal, nem a margem de discricionariedade na formulação de certos atos administrativos. Ocorre que, no presente caso, certos elementos desse ato administrativo apresentam defeito em relação à finalidade. Ele resta comprometido, uma vez que se "finalidade é o resultado que a Administração quer alcançar com a prática do ato," e a FIC não revela a dimensão real quantitativa das espécies abatidas, nem as áreas de pressão de caça, as presentes e futuras conclusões restarão comprometidas (esfera da motivação) e, por conseqüência, estaremos diante de um desvio de finalidade, pois atenderemos não ao interesse público, mas sim a interesses particulares.

No presente ato, não basta apenas a forma escrita. A forma mais rigorosa, dotada de outras especificações necessárias à compreensão do processo da caça, atende aos direitos difusos e à salvaguarda de um bioma (art. 225, § $1^{\circ}$, inc. I, da Constituição Republicana de 1988), bem como à proteção da fauna de práticas que coloquem em risco sua função ecológica (art. 225, § $1^{\circ}$, VII, da Constituição Republicana de 
1988). Uma forma mais rígida deve ser preconizada em atendimento aos direitos de terceira geração, no presente caso, o direito ao meio ambiente equilibrado, e não apenas em relação aos direitos individuais. A reformulação da FIC atende ao direito à informação ambiental (art. $5^{\circ}$, XIV, da Constituição Brasileira de 1988), que pode ser vislumbrado tanto sob uma perspectiva individual como transindividual.

Não basta informar; um ato administrativo deve informar bem, o que não é verificável aqui, conforme já expusemos, comprometendo a motivação do ato administrativo, portanto, a forma, já que se atém à realidade parcial do fenômeno.

\section{DA EQÜIDADE \\ INTERGERACIONAL, DA DIGNIDADE HUMANA E DO DANO EXTRAPATRIMONIAL}

Lembra Fritjof Capra $^{9}$ que a criação de "comunidades sustentáveis - isto é, ambientes sociais e culturais onde podemos satisfazer as nossas necessidades e aspirações sem diminuir as chances das gerações futuras" é o grande desafio de nosso tempo. Conforme dispõem Ayala e Leite: ${ }^{10}$

Na formulação dessa nova composição ética, reconhece-se que a comunidade moral é substancialmente ampliada, não só no espaço, recebendo novos atores (não sujeitos), sob a direção de uma nova compreensão sobre as relações, mas sobretudo modificada a partir da admissão de que todos os homens são iguais também no tempo. O direito à existência é, notadamente, espécie de direito cuja compreensão de seu conteúdo integral não pode se esgotar a um termo determinado ou de possivel determinação.

Eis a eqüidade intergeracional que também é uma forma de consagração da dignidade humana.

A ONG (organização não governamental) União pela Vida tomou a iniciativa de coletar assinaturas de pessoas contrárias à caça amadorista no Rio Grande do Sul., recebendo apoio, posteriormente, de outras entidades. De outubro de 2003 até a presente data, já foram coletadas mais de dez mil assinaturas. São aproximadamente mil e duzentos caçadores licenciados no Rio Grande do Sul versus mais de dez mil pessoas que se opõem a tal prática. Imagine-se um contexto de maior contingente de colaboradores, maior divulgação, quantas não seriam as pessoas que assinariam o abaixoassinado em prol da proibição definitiva da caça amadorista? Aliás, o abaixoassinado foi inclusive veiculado na internet (disponível no site http:// www.protetoresvoluntarios.dpi.com.br). Como manter-se tal privilégio sem

9 CAPRA, Fritjof. A teia da vida. São Paulo: Cultrix, 1996, p. 6.

10 AYALA, P.; LEITE, J. Direito ambiental na sociedade derisco. Rio de Janeiro: Forense, 2002, p. 89. 
efetivamente delimitarem-se aos caçadores inúmeras responsabilidades que, efetivamente, não lhes são atribuídas?

Neste ano, estamos diante de um fato novo: a coleta de mais de dez mil assinaturas contrárias à caça amadora no Rio Grande do Sul. Há elementos suficientes que demonstram a violação da dignidade humana, assim como a ocorrência de dano extrapatrimonial, nos termos do artigo $1^{\circ}$, I, em face desta prática. Tal prazer, a caça amadora, fere flagrantemente a consciência ambiental que muitos já adquiriram.

"Dano moral é aquele que, direta ou indiretamente, a pessoa física ou jurídica, bem assim a coletividade, sofre no aspecto não econômico dos seus bens jurídicos." $11 \mathrm{O}$ direito ao meio ambiente equilibrado constitui um direito instrumental à realização dos direitos de personalidade. Afirma José Rubens Morato Leite ${ }^{12}$ que o direito de personalidade é uma cláusula aberta, "considerando que o elenco de algumas figuras de danos extrapatrimoniais transcritos no citado dispositivo constitucional [art. $5^{\circ}$, inciso X, da Constituição Brasileira de 1988] são meramente exemplificativas".

Ascensão, ${ }^{13}$ ao discutir o direito de personalidade, assevera que a dignidade da pessoa humana implica que a cada homem sejam atribuidos direitos, por ela justificados e impostos, que assegurem esta dignidade na vida social. Estes direitos devem representar um mínimo que crie o espaço no qual cada homem poderá desenvolver sua personalidade.

Lembre-se que "o meio ambiente ecologicamente equilibrado é um dos bens e valores indispensáveis à personalidade humana, considerado essencial à sadia qualidade de vida, portanto, à dignidade social." 14 A respeito dos direitos de personalidade, reza o artigo 12 do novo Código Civil que "pode-se exigir que cesse a ameaça, ou lesão, a direito da personalidade, e reclamar perdas e danos, sem prejuízo de outras sanções previstas em lei”. No presente caso, há ameaça de lesão a direitos de personalidade transindividuais, de maneira que estão presentes o fumus boni juris e o periculum in mora.

O STF já teve oportunidade de manifestar-se a respeito da crueldade em outro caso. Ele julgou procedente o recurso extraordinário ajuizado por várias associações civis. ${ }^{15}$ No voto do ministro José Néri da Silveira,

11 FRANÇA, Rubens. Reparação do dano moral. Revista dos Tribunais, SãoPaulo, n. 631, 1988,p. 31. 12 LEITE, José Rubens Morato. Dano ambiental: do individual ao coletivo extrapatrimonial. São Paulo: Revista dos Tribunais, 2000, p. 290.

13 ASCENSÃO, 1997 apud LEITE, J. Dano ambiental: do individual ao coletivo extrapatrimonial. São Paulo: Revista dos Tribunais, 2000, p. 287.

14 Ibidem, p. 288.

15 BRASIL. RE- 153531/SC. Relator: Min. Francisco Rezek. Relator Acórdão Min. Marco Aurélio. DJ 13 mar. 98, p. 00013. 
encontramos menção à vedação de tal prática por constituir violação da dignidade da pessoa humana.

Como sustenta Edna Cardoso, ${ }^{16}$

A caça por esporte é também conhecida como caça amadora (amador, segundo Aurélio Buarque de Holanda, significa aquele que faz por prazer). Este é, pois, o grande objetivo para o esporte de caça feito pelos ricos. Quer seja um caro safári, quer seja uma temporada de caça, o propósito é o mesmo: perseguir ematar animais por divertimento. É um negócio fantástico também para o supridores de armas, munições, roupas e outros equipamentos de caça. [Acrescentemos também: fabricantes de balas, no Brasil; há a empresa de economia mista $C B C$, que tem como principal acionista o Exército - inserção nossa].

Qualquer que seja a razão alegada, a caça é uma atividade inaceitável e, também, de dificil controle, se considerarmos a incompetência, a falta de estrutura e a burocracia dos órgãos fiscalizadores.

A dignidade daqueles que não desejam tal prática pode vir a ser duramente abalada, caso venha a ser liberada a temporada de caça amadorista. A caça amadorista não pode ser mais utilizada como medida paleativa ao desaparecimento dos biomas, em geral causados pelo avanço da agricultura.

Diante da dignidade humana, tal prática, não pode ser mais considerada como medida de conservação (palavra que, aliás, compõe irônica e contraditoriamente o nome de algumas agremiações de caça e/ou seus estatutos).

Crê Leonardo Boff ${ }^{17}$ que dar centralidade ao cuidado não significa deixar de trabalhar e intervir no mundo. Significa renunciar à vontade de poder que reduz tudo a objetos, desconectados da subjetividade humana". [...] Significa respeitar a comunhão que todas as coisas entretêm entre si e conosco. Significa colocar o interesse coletivo da sociedade, da comunidade biótica e terrenal acima dos interesses exclusivamente humanos".

Por que não se estimular o turismo ecológico, fundado, por exemplo, na observação de animais silvestres? O Brasil possui um grande potencial turístico. Segundo Antônio Brasil Pinto, o patrimônio turístico como bem público de uso comum do povo, torna possível sua tutela através dos mecanismos da ação civil pública. ${ }^{18}$ Para ele, ${ }^{19} \mathrm{o}$ verdadeiro interesse público é o interesse público primário, o bem geral, o interesse de toda a coletividade" [grifo nosso] - e não de um segmento, no caso o dos caçadores.

Crê, ainda, o referido doutrinador ${ }^{20}$

16CARDOSO, Edna. A tutelajurídica dos animais. Belo Horizonte: Mandamentos, 2000, p. 106. 17 BOFF, L. Saber cuidar... p. 102.

18 PINTO, A. Turismo emeio ambiente: aspectos jurídicos. 3. ed. Campinas: Papirus, 2000, p. 183. 19 Ibidem, p. 140.

20 Ibidem, p. 184. 
que em função da potencialidade ecológica das localidades que abrigam os animais habitualmente elencados como passíveis de caça neste Estado, cabe exigir relatório de impacto turístico e paisagístico, uma vez que a intervenção pleiteada pode representar risco à vocação turística de uma localidade, tanto para interesse geral nacional, como para o estadual, municipal ou municipal localizado, é conduta legalmente válida e enquadrável nas formas de proteção alinhadas no artigo $216, \S 1^{\circ}$, da Constituição Federal de 1988.

$\mathrm{E}$ isso não vem sendo avaliado nos estudos feitos anualmente em caráter preliminar à autorização.

De forma geral, podemos depreender nesta questão quatro visões: a holística, a ecológica, a jurídica e a científica:

a) a visão holística determina que a caça amadorista seja analisada em seus elementos internos, tentando-se compreender a interdependência de suas partes, daí compreenderemos que a autorização da caça no Rio Grande do Sul dá-se com base em uma visão antropocêntrica da relação homemnatureza;

b) a visão ecológica promoverá, por exemplo, discussão a respeito da manutenção da diversidade ecológica e equilíbrio dos ecossistemas, entre eles reflexão sobre biomas característicos do Rio Grande do Sul;

c) a visão científica repousa sobre a discussão das metodologias que justificam e legitimam a liberação da caça que anualmente ocorre em nosso Estado; embora demonstrem a interdisciplinaridade da questão ambiental, mostra-nos o quão reféns podemos ficar de outras áreas que não a jurídica;

d) a visão jurídica remete-nos ao reconhecimento da violação da dignidade humana com a manutenção desta prática, à constatação da ocorrência de dano moral ambiental, e a um estudo comparativo das bases valorativas que ensejaram a promulgação da lei supra mencionada, promulgada em 1967, e das bases valorativas hoje vigentes em função da atual constituição brasileira.

\section{DO TEMPO DAS ARMAS AO DIREITO AO MEIO \\ AMBIENTE EQUILIBRADO: DA NÃO RECEPÇÃO DO CÓDIGO DE CAÇA PELA ORDEM CONSTITUCIONAL VIGENTE}

A questão da não recepção da lei de "proteção" à fauna tem a ver com os fundamentos acima invocados, no que diz respeito às bases valorativas que modelam a presente constituição. A presente lei é da década de sessenta, outro contexto histórico, outro contexto normativo. Em face desse entendimento, sequer precisaríamos discutir a precariedade do ato administrativo que autoriza a caça amadorista anualmente no Rio Grande do Sul. 
Segundo Edna Dias, ${ }^{21}$

embora o inciso VII do art. 24 da Constituição Federal conceda competência concorrente à União, aos Estados e ao Distrito Federal para legislar sobre o assunto, sabemos que a caça (amadora [...]) coloca em risco a fauna já extinção, submete os animais a [sic] crueldade, provoca a extinção das espécies e compromete o remanescente patrimônio genético.

Há neste caso, portanto, conforme seu entendimento, com o qual concordamos, violação do artigo 225 , parágrafos I, II, III e VII.

Em relação à inconstitucionalidade da lei de proteção à fauna, acrescenta a tal idéia a violação da dignidade humana Érika Bechara ${ }^{22}$ que

a caça esportiva, ainda que não ocasione danos ambientais, é inconstitucional, mesmo porque não é exatamente o temor de extinção dos recursos faunísticos que torna essa prática repugnante $[. .$.$] , mas sim as$ razões que levam à sua prática, ou seja, a sua razão de existir.

Para ela ${ }^{23}$,

a morte dos bichos, às vezes inevitável, deve ser motivada por fatores mais relevantes, ou seja, por fatores que revelem que esta atitude é indispensável à sobrevivência humana. Fora disso, o animal estará sendo submetido, desnecessariamente, a um mal e, este quadro, para o Texto Maior, importa em tratamento cruel, nos exatos termos do art. $225, \S 1^{\circ}$, inciso VII, in fine.

São razoáveis e pertinentes as idéias esposadas pelas doutrinadoras supra mencionadas. Qualquer outra interpretação viola os princípios da razoabilidade e segurança jurídica.

\section{CONCLUSÕES}

1. A autorização da caça amadorista funda-se em metodologia que apresenta inúmeros problemas, entre eles, técnicos, operacionais, financeiros, violando o princípio da precaução.

2. A lei de "proteção" à fauna, datada de 1967, não foi recepcionada pela atual Constituição Brasileira de 1988, nos termos do artigo $1^{\circ}$, III e artigo. 225, § $1^{\circ}$, I, II, III e VII.

3. A realização da caça amadorista no RS constitui violação da dignidade humana e prática de crueldade contra os animais, não somente daqueles que são habitualmente arrolados na portaria, mas aqueles que são ou podem ser incomodados por tal prática.

4. A caça amadorista não constitui o melhor instrumento para inibir a progressão das monoculturas no Brasil ou mesmo para conservar os banhados.

21 DIAS, Edna. A tutela jurídica dos animais. Belo Horizonte: Mandamentos, 2000, p. 107.

22 BECHARA, Érika. A proteção da fauna sob a ótica constitucional. São Paulo: Juarez de Oliveira, 2003, p. 113.

23 Ibidem, p. 113. 
Não sabemos precisar se, por conterem chumbo, os cartuchos lançados contaminam o solo e o lençol freático.

5. O Poder Público deveria incentivar, isto sim, o turismo de observação de animais, em consonância com a legislação ambiental em vigor, sobretudo a Lei do SNUC.

6. É fundamental o papel de ONGs na conscientização da população a respeito da necessária proteção do meio ambiente, assim como na concreção do direito à informação ambiental.

7. A coleta de assinaturas ao longo desses últimos meses revela o quão distante está a Administração Pública, senão os legisladores, do verdadeiro clamor social.

\section{REFERÊNCIAS}

AYALA, P.; LEITE, J. Direito ambiental na sociedade de risco. Rio de Janeiro: Forense, 2002.

BECHARA, Érika. A proteção da fauna sob a ótica constitucional. São Paulo: Juarez de Oliveira, 2003. BOFF, L. Saber cuidar... 7. ed. Petrópolis: Vozes, 2001.

CAPRA, Fritjof. A Teia da vida. São Paulo: Cultrix, 1996.

CRESCEM prejuízos causados pela seca e Estado amplia medidas. Correio do Povo, 17 abr. 2004.

DI PIETRO, Maria Sylvia. Direito administrativo. 13. ed. São Paulo: Atlas.

DIAS, Edna. A tutela jurídica dos animais. Belo Horizonte: Mandamentos, 2000.

FIORILLO, C. Curso de direito ambiental Brasileiro. 4. ed. São Paulo: Saraiva, 2003.
8. A autorização da caça amadorista no RS provoca a lesão de direitos de personalidade transindividuais, gerando dano moral ambiental.

9. É fundamental o exercício do direito à informação ambiental, com uma maior publicização dos procedimentos adotados pelo Poder Público, para efetivo conhecimento da matéria por parte da população.

10. Em vez de estimular a criação de clubes de tiro, como está na lei da fauna da década de 60 , é fundamental que o Estado, isso sim, concretize a lei de educação ambiental, quem sabe, um mecanismo para evitar a médio e a longo prazo o surgimento de novos caçadores.

FRANÇA, Rubens. Reparação do dano moral. Revista dos Tribunais, São Paulo, v. 631, 1988.

LEITE, J. Dano ambiental: do individual ao coletivo extrapatrimonial. São Paulo: Revista dos Tribunais, 2000.

MACHADO, P. Direito ambiental brasileiro. 7. ed. São Paulo: Malheiros, 1998. MEDAUAR, Odete (Org.) Coletânea de legislação de direito ambiental: Constituição Federal. São Paulo: Revista dos Tribunais, 2004.

PINTO, A. Turismo e meio ambiente: aspectos jurídicos. 3. ed. Campinas: Papirus, 2000.

SERRES; Michel. O contrato natural. Rio de Janeiro: Nova Fronteira, 1990. WEIL, Pierre. A nova ética. Rio de Janeiro, 2. ed. 1993. 


\title{
Ney Messias e o ensino do processo penal ${ }^{*}$
}

\author{
Plinio de Oliveira Corrêa ${ }^{\star \star}$
}

Em 1932, o professor Ney Messias escreveu um poema, donde se destaca esta passagem:

Quando a cadencia de meu passo incerto

Passar no último pouso da existência; Quando eu sentir morrer minha consciência

Como um grito perdido no deserto;

Quando eu for qual átomo esquecido Na profundeza caótica do nada,

Não haverá sinal de mim na estrada

Porque eu passei sem ser apercebido.

Felizmente, enganou-se o ilustre professor ao fazer essa previsão, quando tinha apenas 19 anos de idade. Senão vejamos:
Os bacharéis de 1969 imprimiram para sempre no bronze de uma placa fixada no saguão desta Casa, esta homenagem ao seu paraninfo:

E quando ele se calou, nosso coração continuou a ouvir [...]

Daí em diante seguiram-se incontáveis louvores, seja do Poder Público, designando o seu nome para uma rua desta Capital; sejam as publicações jurídicas que lhe foram dedicadas, como A Provocação Jurisdicional e a Legitimidade da Prisão no Direito Brasileiro; seja a edição póstuma de sua obra literária $O$ Construtor de Mistérios; seja a

* Ney Messias e o Ensino do Processo Penal foi o tema abordado pelo prof. Plínio de Oliveira Corrêa, em 21.06.99, no Ciclo de Conferências sobre a "Influência da Faculdade de Direito da UFRGS na Política e nas Letras Jurídicas", que a Gestão do Centenário da "Casa de Thompson Flores e André da Rocha" promoveu no período de 05.04.99 a 19.07.99, tendo por local o Salão Nobre da Faculdade de Direito.

** Professor adjunto e diretor da Faculdade de Direito da UFRGS, gestão 2000/04. 
transferência das distinções de paraninfo à sua memória $\left(80^{\mathrm{a}}\right.$ Turma de Bacharéis em Direito da UFRGS); sejam os inúmeros artigos e reportagens de juristas, de políticos, de jornalistas e de literatos, todos enaltecendo suas virtudes e suas qualidades, como nestes depoimentos:

- Do poeta Mário Quintana:

Ney Messias foi um homem de luta e de sonhos na tentativa de salvar o mundo. Ele rejuvenescia a gente.

- Do jornalista Janer Cristaldo:

De certa forma, agradeço não ter tido a oportunidade de conhecê-lo pessoalmente. De longe, vislumbro melhor sua grandeza. Estamos diante de um homem da estirpe de Nietzsche e de Pessoa. Eestes seres, por discretos que pretendam ser, não conseguem passar desapercebidos.

- Do jurista Paulo Brossard:

O Ney não tinha talento, tinha talentos, e em tudo era eximio e original, ainda que nenhuma preocupação tivesse em sê-lo; havia coisas que só ele era capaz de dizer ou de fazer, coisas que a ninguém poderiam ocorrer, nele brotavam com a espontaneidade do dia que nasce. Não havia outro Ney. Ney era um só.

Por isto mesmo aqueles que não o conheceram não podem ter idéia do homem que deixaram de conhecer. Por muitos que fossem os seus talentos, $o$ homem ainda era melhor. Terno como uma criança, bravo até a temeridade, generoso, compreensivo, era a correção em pessoa. Leal, franco, bom. As suas qualidades de coração e de caráter eram tão vivas, que eu chego a esquecer- me das cintilações da sua inteligência. Todos os dias, à hora certa, estávamos juntos e fruíamos o Ney - o Ney das crônicas, o Ney poeta, o Ney professor, o Ney galhofeiro, o Ney humorista, o Ney cavalheiro. Certo dia, depois de anos de convívio diário ele se foi. Ficamos todos engasgados. Mas continuamos a falar nele, porque ele continuava conosco.

- E, Mário de Almeida Lima, o sintetizou nesta parábola:

O Ney era tão genial que seria capaz de abraçar a Torre Eiffel e trazê-la para o Brasil, dando em troca apenas uma estatueta de canela de burro, por ele esculpida, acomodando a ira do general De Gaulle.

E neste momento solene anunciamos, para breve, mais uma publicação em sua homenagem, que vai conservar viva sua lembrança para o próximo milênio: Ação Penal Originária - Procedimentos, que já circula de forma incipiente junto à PósGraduação em Ciências Penais.

Esse curso, a propósito, houve por bem instituir no seu Regimento o que segue (artigo 79):

[...] será conferida a Medalha Professor Ney Messias ao docente que tiver destacada atuação no Curso de Especialização em Ciências Penais e demonstrar excepcional dedicação ao estudo e à pesquisa no campo das ciências criminais.

E, em 1995, o docente que primeiro recebeu este título, por decisão 
unânime dos especializandos, registrou esta dedicatória em edição especial de obra que publicara:

Dedicamos este livro à $1^{a}$ turma do Curso de Especialização em Ciências Penais da Faculdade de Direito da Universidade Federal do Rio Grande do Sul, agradecendo a homenagem contida na outorga da Medalha Professor Ney Messias, cuja honra estamos repartindo com os demais professores do curso.

E a parte que nos toca nesta divisão, desejamos transferir à memória do imortal Jurista que dignificou a Cultura, o Magistério e as Letras Jurídicas - o próprio professor Ney Messias.

Anteriormente, a turma de 1965 já o escolhera como paraninfo, cuja solenidade de formatura marcou época pelos corajosos pronunciamentos em favor do Estado de Direito e da Ordem Democrática, incluindo o significado político do lema: Cedam as Armas à Toga.

Agora, passados quase trinta anos do seu falecimento, os nossos corações continuam a ouvi-lo [...], pois espíritos especiais e privilegiados não passam desapercebidos pela estrada da vida, e seu exemplo e seus ensinamentos costumam se perpetuar, estendendo-se para muito além do horizonte do tempo...

E dentre os nomes ilustres que fizeram a história deste templo, onde se ministra o Evangelho do Direito, o de Ney Messias é, certamente, o mais fácil e o mais difícil de se discorrer. Sua personalidade foi tão marcante e tão retilínea, tão límpida e tão transparente, tão humana e tão cativante, tão rica e tão múltipla em profundidade e extensão cultural que, se de um lado facilita, de outro dificulta ao expositor.

Essa foi a explicação dada por diversos convidados, que agradecendo ao honroso convite, alegaram a impossibilidade de tratar dos inúmeros "Neys" em tão curto espaço de tempo.

Então - e por exclusão - é que esta "missão impossível" coube a quem apenas teve o privilégio de ter sido seu discípulo, seu paraninfado, seu amigo pessoal, seu colega de escritório, seu assistente na cátedra e modesto continuador de suas brilhantes aulas de processo penal.

E mesmo diante das dificuldades apontadas, vamos iniciar dizendo que o nosso homenageado nasceu a 24 de setembro de 1913, em São João Baptista do Quarahy, neste Estado; viveu em Uruguaiana, Santa Maria e Porto Alegre, onde faleceu em 23 de janeiro de 1970. Foi casado com Dona Ondina Dornelles Messias, de cuja união resultou o nascimento de dois filhos: Sérgio Dornelles Messias, conceituado médico psicanalista, e Gladys Messias de Figueiredo, dedicada professora de Letras; Bacharelou-se em Direito e Filosofia por esta Universidade; cursou a Escola Superior de Guerra no Rio de Janeiro; foi advogado militante; escritor exímio; jornalista atuante e diretor de jornal; chefe do departamento jurídico do Clube, que mais venceu gre-nais e que mais conquistou campeonatos gaúchos de futebol; membro do 
Conselho Penitenciário do Estado; procurador do Estado do Rio Grande do Sul; primeiro diretor da Caixa de Assistência da Ordem dos Advogados do Brasil, neste Estado; professor catedrático de Direito Processual Penal nesta Faculdade, onde exerceu o magistério jurídico no período de 31 de março de 1951 a 23 de janeiro de 1970.

Além de penetrar pelos largos horizontes do Direito e da Filosofia, fez estudos de Sociologia e de Política, de Psicologia e de Psicanálise, de Astronomia, de Astrologia e das Ciências Holísticas, atualmente tão difundidas pela globalização e no âmbito da paranormalidade. Também não ficou indiferente à pintura, à composição, à arte $\mathrm{e}$ à escultura, tendo deixado trabalhos memoráveis. Enfim, brilhou em tudo e encantou a todos, esbanjando talentos, humanismo e lições de ética em cada uma dessas áreas do conhecimento.

Mas foi, sobretudo, um político de escol, que criticava construtivamente os políticos, especialmente aqueles, cujos partidos, vencendo ou perdendo as eleições, estavam sempre no poder; foi um cidadão ativo e atuante, que exerceu a cidadania em sua plenitude, não hesitando jamais em se opor à prepotência dos poderosos, resistindo ao império das leis injustas, dos seus intérpretes e aplicadores; enfim, foi um advogado modelar e um professor sábio e independente, que assumia posições corajosas, visando o aperfeiçoamento da Ordem Jurídica, como instrumento para atingir o Bem Comum, esse Bem
Comum, assim concebido por João XXIII e pelo nosso professor Câmara: - o primeiro, o definia como o conjunto de condições sociais que possibilitam e favorecem o desenvolvimento integral da personalidade; e o segundo, o conceituava como o conjunto de situações ou condições de vida, individual e social, que assegura a realização dos fins humanos.

Mas, retomando o tema pontual deste evento, cabe acentuar que desde a sua criação até 1963 , o curso de bacharelado desta Faculdade teve apenas uma única cadeira de Processo Penal, a qual, na época, estivera sob a responsabilidade docente do professor Francisco José Simch Júnior. A partir daí foi instituída a segunda Cadeira desta disciplina, que ficou sob a regência e titularidade do nosso homenageado, que até então era assistente do prof. Simch.

Qual foi, então, o perfil dado pelo professor Messias ao ensino do Processo Penal, aqui ministrado?

A par das Lições de Processo Penal, condensadas neste volume único que estamos destinando à nossa Biblioteca, e que representam o resgate de uma parte de suas aulas, - desejamos destacar, neste momento, outras notas doutrinárias e complementares, assim resumidas:

\section{O ensino analítico, sistema- tizado e comparativo}

Cabe referir, desde logo, a projeção metodológica encetada pelo mestre, 
que, inovando os métodos tradicionais, não se fixava apenas neste ou naquele tema, isoladamente, mas sim de forma dinâmica, comparativa e globalizante.

Assim, como que adotando a filosofia orteguiana, partia do essencial e magistralmente enveredava por todas as circunstâncias pontuais, relacionando a matéria, comparativamente, com as demais províncias do ordenamento jurídico.

Em outras palavras, partia dos institutos consagrados pelo Direito Positivo e ia sistematizando o estudo do Processo Penal com os demais ramos não só da Teoria Geral do Processo, mas também da Teoria Geral do Direito e, ainda, correlacionando com as conquistas inseridas nas declarações de direitos das diferentes épocas, bem como conjugando as últimas conclusões dos conclaves jurídicos nacionais e as recomendações doutrinárias dos congressos internacionais da ciência do Direito.

E não parava aí, prosseguia na análise interligando a abordagem didática da matéria com as outras ciências afins, circunscritas ao seu objeto finalístico: o ser humano, situado não num mundo imaginário e ilusório, mas plantado na concretude das relações interpessoais e devidamente sintonizado com a realidade e com o convívio no meio ambiente.

Examinava a crise do Judiciário e, particularmente, do processo penal, como resultante do processo social em crise, sendo oportuno recordar esta passagem:
É assim, no processo de desidentificação social, que o estudante se transforma em operário, que o sacerdote vira guerrilheiro, que o filósofo vem a ser pregador de comicios, que o militar invade a área civil, que o artista, à força de buscar em si o outro, transfigura-se no agente publicitário da indústria com a sua incrivel pop-arte. Dai para as deformações da cultura, da pintura, da poesia, do direito, do magistério, da magistratura, dafilosofia e do bom senso, o passo é curto, dolorosamente curto. Confuisão total, guerra total, desajustamento total.

Com esta metodologia, procurava buscar não só a ontologia da norma, mas a sua deontologia jurídica para que o intérprete pudesse apreender o seu espírito e projetar a sua correta interpretação no tempo e no espaço.

Este estilo inovador de ensinar e de se fazer entender, que só ele conseguiu imprimir nesta Casa, era fruto de sua privilegiada inteligência e de seu sólido e profundo preparo cultural, dominando vários ramos das Ciências Humanas e fazendo com que todos ficassem como que hipnotizados com o legado de suas exposições, que, ao final, culminavam, muitas vezes, em aplausos prolongados para um novo e sempre esperado recomeçar...

\section{A provocação jurisdicional}

Quando, em suas aulas, tratava dos Sistemas Processuais - que são as grandes avenidas pelas quais passa e 
se define a filosofia do processo - o professor se posicionava pelo Sistema Acusatório, em franca oposição ao Sistema Inquisitório.

Com efeito, dentro dessa orientação doutrinária, ao elencar os postulados informadores do processo penal, destacava o princípio da provocação jurisdicional, pelo qual o juiz somente pode agir se for provocado e, ainda, nos limites da imputação e do pedido, evitando, desta forma, decisão ultra, citra e extra petita. Com isto preservava a imparcialidade do magistrado, assim concebida por Bettiol:

A história do processo penal é a história de uma luta orientada para a conquista de um juiz imparcial, que atua a nivel distinto e superior ao das partes.

E, quando analisava, por exemplo, o conteúdo dos artigos 26 e 531 do Código de Processo Penal, bem como da Lei N. $.^{\circ} 4.611 / 65$, que, nos casos de contravenção penal, lesão corporal culposa e homicídio culposo, permitiam ao juiz instaurar o processo - acusando e julgando ao mesmo tempo - o nosso Ney foi, certamente, a voz que primeiro levantou apontando a incongruência desta posição, diante dos ensinamentos doutrinários, especialmente, de Búlgaro e de Büllow, que consideravam o processo como actus trium personarum: o autor que acusa, o réu que se defende e o juiz que julga.

Além desta direta permissibilidade legal ex-officio, o nosso Código ainda permite que, indiretamente, o juiz tome a iniciativa acusatória, como se constata pelos preceitos dos artigos $28,383,384$ e $\S$ único, e $408 \S \S 4^{\circ}$ e $5^{\circ}$, do aludido diploma.

Todos estes dispositivos legais, que ainda hoje integram o nosso código, representam um retrocesso ao odioso inquisitorialismo, onde o acusado só tem o direito de não ter direito algum.

E suavizava a crítica, com estas palavras:

No processo jurisdicional é indispensável a divisão de tarefas. Um é o que acusa, outro éo que defende, e um terceiro é o que julga, isso para não aludir às tarefas complementares como a do perito. Não pode o juiz acusar, nem élicito ao acusador defender, enquanto o patrocínio da defesa impede, obviamente, que o defensor acuse. Técnica, ética e logicamente, o processo se desenvolve através da especialização de funções, ou mediante a fidelidade dos agentes à tarefa que se propõem exercer. Em suma, no processo cada um é o que é: princípio de identidade que não pode ser desatendido sem que se torne perigosa e instável a ordem processual.

E, ao finalizar, invocava este histórico preceito do artigo 110 do Código de Processo Penal do Rio Grande do Sul:

Os (juizes e os) tribunais não podem ex-officio promover a ação penal.

No âmbito do Direito Comparado, tanto interno quanto externo, este diploma rio-grandense é 
o único que consagra claramente o princípio da provocação jurisdicional e que, somente agora, a Constituinte de 1988 instituiu o preceito do artigo 129, inciso I, da nossa lei maior, que sepultou, definitivamente, o inquisitorialismo judiciário no sistema processual penal brasileiro.

\section{Postulação por um código votado pelo poder legislativo e a crítica ao anteprojeto Tornaghi}

Dentre muitas preocupações do mestre com o ensino do Processo Penal, cabe destacar o fato de que até então (e continua) não possuíamos um Código de Processo Penal que tivesse passado pelo Poder Legislativo.

Todos os diplomas resultaram de ato exclusivo do Poder Executivo. Foi assim com o Código de Processo Criminal de 1832, bem como com as reformas de 1841 e de 1871. Com o advento da Constituição de 1891, se implantou no país o princípio da descentralização processual, permitindo que os Estados legislassem sobre Direito Processual. E o Rio Grande do Sul foi o Estado que promulgou o $1^{\circ}$ Código Estadual de Processo Penal, em 1898, seguindo-se, em regra, os demais Estados da Federação.

Com a Revolução de 1930 adveio a Constituição de 1934, que restabeleceu o princípio da unidade processual, concentrando na União, como ocorre até hoje, o poder de legislar sobre Direito Processual.

Assim, em 1941, foi promulgado pelo Poder Executivo o atual Código de
Processo Penal. Três anos antes, em 1938, foi editado o Código de Justiça Militar, revogado, em 1969, pelo vigente Código de Processo Penal Militar, instituído pelos três ministros militares, da época, que assumiram o poder central face a enfermidade do presidente Costa e Silva, e o fizeram, ainda, com base nos atos institucionais $n .^{\circ} 5$ e $n^{\circ} 16$.

Tal situação sempre mereceu as mais acirradas críticas do professor Messias, que defendia uma reforma sistematizada do nosso atual diploma, mas através do Poder Legislativo e mediante o encaminhamento ao Congresso $\mathrm{Na}$ cional de um projeto de lei que consultasse as aspirações do mundo jurídico e atendesse à evolução científica do Direito Processual.

Por solicitação do sr. João Mangabeira, ministro da Justiça, veio, então, em 1963, o anteprojeto de código elaborado pelo professor Hélio Bastos Tornaghi que, inobstante a autoridade e o renome do seu autor, pecava por excesso de conceitos e definições dos institutos, esquecendo que tal mister deveria ser obra da doutrina e não de um código, destinado a regular objetivamente as inúmeras e complexas situações jurídicas dentro do processo.

Este pecado original - conceitualismo e excesso de definições - logo foi percebido e apontado pela crítica aguda do nosso professor, cabendo ressaltar, entre tantos outros, os seguintes dispositivos do anteprojeto:

- O artigo 43, dava a definição oficial de relação processual; 
- $O$ artigo 82, definia o que se deveria entender por pressupostos processuais;

- Os artigos 177 a 183 e 196, conceituavam fato, ato e negócio processual, bem como ato discricionário e ilegalidade;

- Os artigos 300 e 308 , apresentavam uma noção do que se deveria entender por documento e indícios. $\mathrm{E}$ assim por diante.

Esta crítica procedente ao anteprojeto Tornaghi generalizou-se, e após 1964 foi definitivamente afastado pelo regime autoritário, sendo substituído pelo anteprojeto do professor José Frederico Marques, que, depois de revisado, foi encaminhado primeiramente à Câmara dos Deputados e transformado no Projeto de Lei N $.^{\circ} 633 / 75$.

Este projeto, após receber emendas e sugestões do mundo jurídico brasileiro, foi aprovado por unanimidade na Câmara dos Deputados e, quando já tramitava no Senado Federal sob o $n .^{\circ}$ $05 / 78$, foi retirado, inexplicavelmente, pelo Poder Executivo para estudo, e continua até hoje sendo estudado pelo esquecimento oficial.

Seguindo a mesma orientação do Projeto N. ${ }^{\circ} 633$, em 1979 o deputado Sérgio Murilo, que havia presidido a Comissão Especial que estudou o preterido projeto, o reapresentou sob N ${ }^{\circ}$ 1.268 , mas o mesmo foi arquivado na legislatura seguinte.

Em 1983, através da Mensagem Presidencial N. ${ }^{\circ} 241$, o Governo encaminhou outro projeto de código, conservando as linhas mestras dos dois projetos originais, que tomou o N. ${ }^{\circ} 1.655$, sendo abandonado mais uma vez.

Em 1994 o Poder Executivo ensaiou outra tentativa, remetendo ao Congresso Nacional um pacote de 17 projetos, visando a reformas parciais do atual código que, transcorrido algum tempo e com exceção de um deles, também foram relegados por inconstitucionais, naquilo que o próprio Governo alterou da proposta elaborada por uma comissão de juristas.

E assim é que continuamos com o vetusto e cada vez mais assistemático Código, editado pelo Poder Executivo há mais de meio século, sem que fosse ouvida a postulação do professor Messias, bradando por uma lei processual penal que resultasse do óbvio, isto é, uma lei votada pelo Poder Legislativo.

Neste particular, a indevida intromissão do Executivo e a inexplicável omissão do Legislativo, têm sido agravadas pela indiferença da doutrina, retratada nesta constatação de Carnelutti, lembrada, aliás, nas lições do nosso homenageado:

Era uma vez três irmãs que tinham em comum, pelo menos, um de seus progenitores: chamavam-se ciência do direito penal, ciência do processo penal e ciência do processo civil. Ocorreu que a segunda, em comparação com as outras duas, que eram mais belas e prósperas, teve uma infância e uma adolescência infelizes. Com a ciência do direito penal coubelhe dividir durante muito tempo a mesma habitação; e aquela reteve para si o bom e o melhor.. 
Com a ciência do processo civil tem ocorrido situação semelhante, uma vez que noventa por cento do progresso do processo penal é mera adaptação do processo civil, (devido ao comodismo dos processualistas penais)...

Enfim (é doloroso reconhecer que) a ciência do processo penal, isto é, a nossa Cinderela, tem se contentado com os vestidos jogados fora por suas irmãs mais afortunadas...

Por isso, a geração que hoje é responsável pelos destinos desta Faculdade centenária, vai implementar as idéias do professor Ney Messias - concentrando-as num novo anteprojeto a ser elaborado juntamente com os órgãos representativos da Sociedade Jurídica Rio-grandense-Ordem dos Advogados, Instituto dos Advogados, Associações dos Juízes, do Ministério Público, dos Defensores Públicos e dos Delegados de Polícia-e, depois, encaminhá-lo ao Poder Legislativo Federal através do concurso de todos os componentes da bancada gaúcha no Congresso Nacional.

Oxalá possamos contar, brevemente, com um Código de Processo Penal que não só seja votado pelo Poder Legislativo, mas também satisfaça às aspirações e aos anseios da comunidade jurídica brasileira, como desejava o nosso ilustre homenageado.

\section{Teoria da ação penal}

Outra significativa contribuição do professor Messias diz respeito à teoria da ação e, particularmente, à ação penal, publicando, em 1951, estudo coincidente com as conclusões aceitas pela doutrina contemporânea.

Com efeito, ao que se sabe foi o jurisconsulto Celso, no Digesto (D. $44,7,51)$ e nas Institutas (I. 14,6, $2^{\mathrm{a}}$ parte), quem primeiro definiu a ação como o direito de exigir em juízo aquilo que lhe é devido (actio nihil aliud est quam jus persequendi in judicio quod sibi debetur).

Por mais de quatorze séculos o tema ficou intocável, como um dogma indiscutível e indiscutido.

No fim da Idade Média, porém, o jurista Hottomamus pretendeu acrescentar ao texto uma pequena glosa; o mesmo aconteceu com Savigny, no século passado. Embora estas tentativas não tivessem logrado êxito, a preocupação destes autores serviu para despertar a discussão dos estudiosos da Ciência do Direito, cabendo referir a célebre polêmica entre Windscheid e Muther a respeito da actio romana, em meados do século passado, que trouxe importante contribuição para a independência do Direito Processual. Na mesma época e nesta direção, merece registro a contribuição do professor recifense Francisco de Paula Batista.

A partir daí foram surgindo novas teorias à margem da milenar concepção civilista, como: a do direito concreto de agir, de Wach; a do direito potestativo, de Chiovenda; a do direito abstrato, de Degenkolb e Plósz; a eclética, do nosso professor Galeno; a do direito cívico constitucional, de Couture; e a das 
condições da ação civil, referidas por Chiovenda, mas adaptadas magistralmente por Liebman.

Pois bem, neste conflito doutrinário sobre a natureza jurídica da ação, o professor Messias, simplificando toda essa infindável discussão, publicou, há meio século, um estudo intitulado Direito subjetivo e conceito da ação penal, concluindo que a ação nada mais era do que o direito à provocação jurisdicional, isto é, o direito subjetivo à prestação judicial pela sentença, que, só recentemente, a evolução científica do Direito Processual chegou ao mesmo entendimento.

Graças à orientação do mestre, desenvolvemos estudo complementar sobre a teoria da ação penal, mais propriamente a respeito de sua qualificação distintiva, isto é, as condições para o seu exercício, divididas, sistematicamente, em condições gerais, especiais e formais.

\section{Constituição dos tribunais}

A mesma isenção que deve informar o objeto interno do processo, na investigação do tema penal, deve orientar externa e institucionalmente a constituição dos órgãos jurisdicionais, na distribuição da Justiça, sejam eles juízos monocráticos, sejam eles juízos colegiados, pois, como ensinava o prof. Messias:

O interesse interno ao objeto principal do processo é tipicamente parcial. É calorosamente parcial. Parcial é a acusação; parcial é a defesa. E a imparcialidade do juiz, esta postura de eqüidistância, é algo absolutamente necessário para que, das parcialidades da acusação e da defesa, vença aquela que está marcada por um interesse legitimo. Isto é fazer justiça segundo uma programação oficial, segundo um desejo, uma opção especialíssima do grupo social, revelada na legislação. Um juiz pode ser sábio, mas se ele, ainda que remotamente, tiver determinados interesses coincidentes com os interesses que estão discutindo, ele corre o risco da parcialidade.

No que diz respeito à constituição dos membros integrantes dos nossos tribunais, o professor defendia a tese que deveria obedecer à seguinte composição:

- 1/3 dos juízes, advindo da magistratura, - 1/3, provindo do Ministério Público,

$-1 / 3$, indicado pela Ordem dos Advogados.

Tal constituição deveria resultar da escolha exclusiva dos três órgãos representativos, sem qualquer interferência política, que lhe retira a independência e restringe a confiança dos jurisdicionados.

Com esta composição de pesos e contrapesos, certamente, acabaria não só com o polêmico controle da Magistratura, mas com os apadrinhamentos político-partidários, numa escandalosa deturpação da filosofia franciscana do é dando que se recebe.

\section{Teleologia do processo}

Outra questão doutrinária interessante, levantada pelo mestre, consiste na indagação teleológica do processo. 
É evidente - ensinava - que encon-tramos no processo fins múltiplos e, conseqüentemente, resultados múltiplos, desde que plural é o seu objeto: a cada objeto corresponde um fim especifico; cada objeto, de sua vez, chegará ao resultado correspondente.

Cabe observar - continuava - que a atividade processual, como obra humana, corre o risco de não atingir a sua finalidade substancial. Tal risco é conseqüente, primeiro, da própria imperfeição do trabalho humano. Convém atentar para o fato de que o processo é uma técnica de investigação usada por sujeitos que, embora todos os graus de especialização de que são por-tadores, não podem atingir o ideal de perfeição. Assim, a imperfeição do sujeito se manifesta na imperfeição da técnica, que é inseparável do sujeito.

Além disso, a técnica do processo está juridicamente limitada por princípios de respeito à dignidade humana. A coação fisica pela dor, a coação moral pelas ameaças e pelo medo, os métodos científicos de inspeção psicológica ou psico-biológica (tais os aventados pela aplicação do detector de mentiras, a ministração de drogas como a escopolamina, o emprego de artificios na devassa do foro intimo como a hipnose e outras formas de catarsis psicológica) são meios de investigação $e$ de apuração da verdade processual como técnicas inaceitáveis e imorais. Com todas essas limitações, a técnica de investigação processual corre o risco do erro, que a lei procura conjurar mediante a possibilidade de reexame da decisão pelo recurso a um juizo de segundo grau e, até mesmo, pela revisão criminal.

Resta claro, agora, o motivo pelo qual se fala em fim e em resultado do processo.
A diferença, pois, entre fim e resultado está na distância que existe entre o ideal e a possibilidade de atingi-lo.

Com efeito, quando todos pareciam satisfeitos com a resposta de que o fim do processo é a sentença justa, o nosso professor aprofundou a análise, destacando que, no caso, havia necessidade de se distinguir, de um lado, a teleologia do processo e, de outro, a axiologia da jurisdição. E dizia - a jurisdição tem por finalidade a sentença justa, ou seja, a sentença justa é o fim do Poder Jurisdicional.

Agora, se a jurisdição é exercida através do processo, isto não quer dizer que processo e jurisdição sejam a mesma coisa, nem significa que tenham a mesma meta finalística, especialmente porque são institutos distintos, embora o processo absorva a jurisdição.

Assim, o objetivo do processo não pode ser o mesmo do Poder Jurisdicional. E arrematava - é indiscutível que o fim idealístico e axiológico da jurisdição é a sentença justa. Mas o fim do processo é anterior a essa, ou seja, consiste em ressuscitar a hipótese delitiva (através de depoimentos, acareações, perícias, etc.), fornecendo ao juiz os meios e os elementos necessários para que a jurisdição possa atingir o seu fim último, isto é, a sentença justa.

Se o juiz, que é o titular do Poder Jurisdicional, fosse Deus (que a tudo vê e a tudo ouve), não haveria necessidade de processo, pois aplicaria a sanção justa, tão logo ocorresse o fato delituoso. 
Mas, como o juiz não é Deus nem testemunha (e se o fosse seria ouvido como tal) necessita, primeiro e através do processo, ouvir testemunhas, ordenar perícias e demais diligências, para depois, então, decidir com justiça.

Desta forma, o processo atinge o seu fim, quando o juiz dá início à atividade jurisdicional, elaborando a sentença. É por isso, que somente depois de encerrada a instrução processual e feitas as alegações finais pelas partes, que os autos são conclusos ao juiz para a sentença, isto é, para que a jurisdição atinja o seu ideal com a sentença justa.

\section{Direito de resistência e de rebeldia}

Inobstante esta Casa tenha nascido sob o manto político da filosofia positivista, que pregava submissão à ordem legal, os continuadores e depositários desta tradição cultural souberam consolidar a sua independência de qualquer outra influência que não fosse o livre compromisso com a Ciência do Direito, fazendo jus ao nome com o qual batizaram esta Instituição de "Faculdade Livre de Direito".

E não poderia ser de outra forma, pois o povo gaúcho é o mais politizado deste país, e por isso mesmo não suporta conviver com leis iníquas e muito menos com governos despóticos.

Para tanto, não vamos recordar atitudes pessoais, embora heróicas, como a do consagrado professor
Francisco Brochado da Rocha, que iniciou a revolta vitoriosa de 1930 , tendo sido ferido gravemente.

Nem vamos rememorar, em nível estadual, a bravura dos revolucionários de 1893 e de 1923, na busca de ideais que, a final, foram alcançados, respectivamente, com os Pactos de Pelotas e de Pedras Altas.

Mas vamos sublinhar, isto sim, apenas três fatos nacionais e históricos, que definem a índole libertária desta brava gente que, quando unida em torno das mesmas idéias, sempre venceu a todos os obstáculos:

- a Revolução Farroupilha de 1835, que levou esta Província às últimas consequências, chegando até a proclamação da República do Piratini, cuja pacificação só ocorreu depois de dez anos de luta, com o Tratado do Ponche Verde.

- a Revolução de 1930, que remodelou os costumes e a fisionomia política desta Nação;

- o Movimento da Legalidade de 1961, em respeito à Constituição e à vontade livre e democrática do eleitorado brasileiro.

Pois bem, esse direito de resistência e de rebeldia - pregado por Santo Tomás na Summa Teológica, no século XIII; difundido por John Locke, no século XVII; proclamado pela Declaração dos Direitos do Homem e do Cidadão em 1789 (art. II); valorizado pela melhor doutrina contemporânea; aceito pelas constituições modernas, como a alemã (art.20) e a portuguesa 
(art.21); e, antes de tudo isso, conclamado pela Magna Carta de 15.06.1215, que (revogada por Inocêncio III a 24.08.1215) foi reconquistada, palmo a palmo, em lutas que se seguiram por oito décadas - esse direito de resistência e de rebeldia era um dos temas não só preferidos mas apregoados pelo mestre diante da promulgação de leis injustas, da prepotência dos poderosos e do uso indevido do Poder Público.

Por isso, inspirado em Voltaire e prevenindo o uso do direito de resistência, sintetizava a ação do Estado de Direito nesta mensagem:

É preciso que a ordem juridica amarre as mãos dos governantes para fazer o mal e as deixe livres para realizar o bem.

Como se vê, não há qualquer semelhança com a doutrina inconseqüente do sí hay gobierno soy contra. Não. Aqui há critérios definidos e motivações lícitas e racionais.

Com efeito, quando a lei ou seus agentes atentarem contra as garantias dos cidadãos ou contra os direitos individuais, a resistência e a rebeldia se transformam em deveres dos mesmos cidadãos e indivíduos. Ou, para ser mais preciso ao que foi escrito na Declaração de Direitos (art.II), que resultou da Revolução Francesa:

Quando os governantes violam os direitos do povo, a resistência é para o povo e paracada um em particular, omais sagrado e o mais indispensável dos deveres.
E essa rebeldia, nos seus e nos nossos dias, deve ser traduzida não só pela arma poderosa do voto, mas também pela constante participação em todas as atividades políticas, que circundam as relações humanas na sociedade.

E aqui nesta Faculdade ninguém melhor do que Ney Messias simbolizou a excelência dessa altivez e independência, ou seja, de obediência à lei, enquanto ela for legítima, enquanto atender ao bem comum, enquanto consultar aos interesses maiores do povo.

E lembrando Pontes de Miranda, sublinhava que os atentados à vida e à propriedade eram menos perigosos e prejudiciais ao bem geral do que a menor violência ou coação à liberdade física do indivíduo. Matar um cidadão, confiscar seus bens ou destruí-los, sem acusação e sem processo seria ato de insigne despotismo; mas, a notoriedade do delito levaria ao seio de todo o povo o grito de alarma contra a tirania iminente...

Ao passo que o encarceramento de uma pessoa é arma menos pública e notória, ninguém percebe, ou poucos poderão dela ter notícia. Oprime-se às escuras, nas prisões, no interior dos edifícios, nos porões e nos recantos secretos. É violência silenciosa, invisível, ignorada, secreta e incontrolável. Portanto, mais grave e mais perigosa do que qualquer outra.

Eis porque - acentuava - o primeiro mandamento da cidadania consiste em se ter consciência de que o desrespeito aos direitos de um cidadão representa o desrespeito aos direitos de todos os cidadãos. 
E as notas continuam...

Mas já é hora de encerrar para dar lugar à próxima palestra. Por isso,

- Considerando que o Homem, segundo Aristóteles, é um ser social e político por natureza, e da conscientização dessa vocação depende a sobrevi-vência e a evolução da sociedade;

- Levando em consideração a mesma fonte de sabedoria, que, referindo respeitável corrente filosófica, considera a vida consagrada à política como a única digna do homem;

- Considerando as lições de vida que apreendemos do professor Messias, pela sua palavra e pelo seu exemplo;

- Considerando, ainda, o muito do pouco que dele conhecemos, e tentando interpretar e projetar o seu pensamento, pedimos venia para registrar nos Anais deste Evento Histórico/ Cultural, ao ensejo do Centenário desta Faculdade, uma pequena mensagem dirigida à nossa juventude:

Jovens de todas as idades!

Participem ativamente da política, como ciência e como arte do bem comum, pois só assim se poderá garantir o bem social e individual de cada um; só assim se poderá salvar o nosso País da grave crise em que se encontra, e que é fruto da omissão de muitos, que permitem a poucos desgovernar esta nação, à custa do sofrimento, da insegurança, da miséria e do abandono do povo brasileiro.

Esta é a velha e cada vez mais nova fórmula de cidadania e de resistência, participando incessantemente de todas as atividades relacionadas com o nós, com o eu e com as circunstâncias de cada cidadão.

Assim - no segundo centenário desta Casa - o Brasil será, seguramente, a primeira potência mundial sob as bênçãos do Criador e sob a égide da Democracia, do Direito, da Justiça e da Liberdade. 


\section{$\mathbf{V M +}$}

editoração eletrônica

513222.5044

vmm.ez@terra.com.br

Composto especialmente para a Editora Meridional, em Times New Roman, corpo $11 / 13,9$, sobre o papel offset $75 \mathrm{~g}$ e impresso na

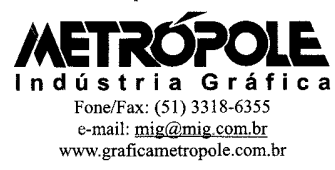




\section{Revista da Faculdade de Direito UFRGS}

Av. João Pessoa, n. 80 - CEP 90.040-000 - Porto Alegre/RS - Brasil

Tel: (51) $3316.3118 / 3316.3128 / 3316.3555 / 3316.3464$

\section{REPRESENTANTES}

ACRE

M.M. Paim Representações e Comércio - F: (68) 224-3432

AMAZONAS

Travessia Editora e Livraria Ltda. - F: (92) 633-6565

Editora Vozes Ltda. 61 - F: (92) 232-5777

BAHIA/SERGIPE

LDM Livraria e Distribuidora Multicampi Ltda. - F: (71) 329-0326

CEARA

Cavalo Marinho Editora Distribuidora e Livraria Ltda. - F: (85) 3223-0321

Livraria Marques Mariano Ltda. - F: (85) 223-4336

DISTRITO FEDERAL

J. Quinderé Distribuidora de Livros Ltda. - F: (61) 347-8461

GOIÁS

Araújo e Dias Ltda. - F: (62) 212-8022

Editora Vozes Ltda. 27 - F: (62) 225-3077

MINAS GERAIS

Alpha Distribuidora de Livros Ltda. - F: (31) 3497-9179

PARA

Ponto e Virgula Comércio Ltda. - (91) 4006-6650

PARAÍBA

Ufpb - Universidade Federal da Paraíba - Casa do Livro - (83) 216-7327

PARANÁ

Livrarias Brooklin Ltda. - F: (41) 3029-3738

PERNAMBUCO

Editora Vozes Ltda. 10 - F: (81) 3423-4100

RIO DE JANEIRO

Prefácio Distribuidora de Livros Ltda. - F: (21) 2508-9797

Susanne Bach Comércio de Livros Ltda. - F: (21) 2539-3590

RIO GRANDE DO NORTE

Potylivros Distribuidora Ltda. - (84) 211-2001

RIO GRANDE DO SUL

Multilivro Distribuidora e Livraria Ltda. - F: (51) 3223-7363

SANTA CATARINA

Livraria Livros \& Livros Ltda. - F: (48) 3028-6244

Unisul - F: (48) 621-3009

Midas Distribuidora e Representações Ltda. - F: (47) 433-0536

SÃO PAULO

Batatais Comércio e Represent. de Livros Ltda. - F: (11) 3266-3097

EDUSP - Editora Universidade de São Paulo - F: (11) 3091-4409

Empório do Livro Ed. e Livraria Ltda. - F: (11) 3255-1447

Lerlivros Distribuidora Ltda. Potyguar - F: (11) 3661-1776

TOCANTINS

S.G.Vieira - Livraria Palmas Cultural - F: (63) 215-3123

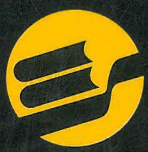

Editora Sulina

www.editorasulina.com.br

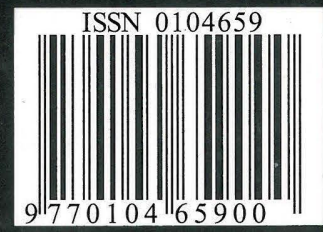

